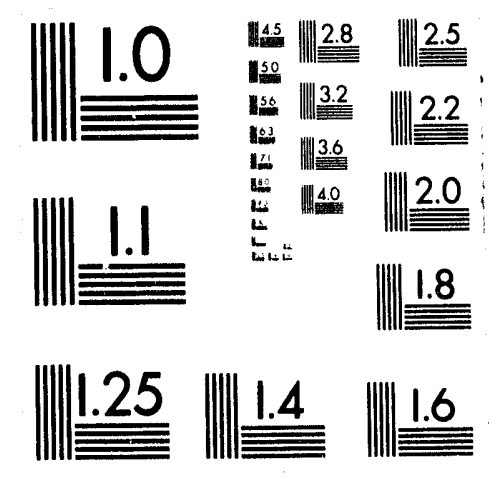



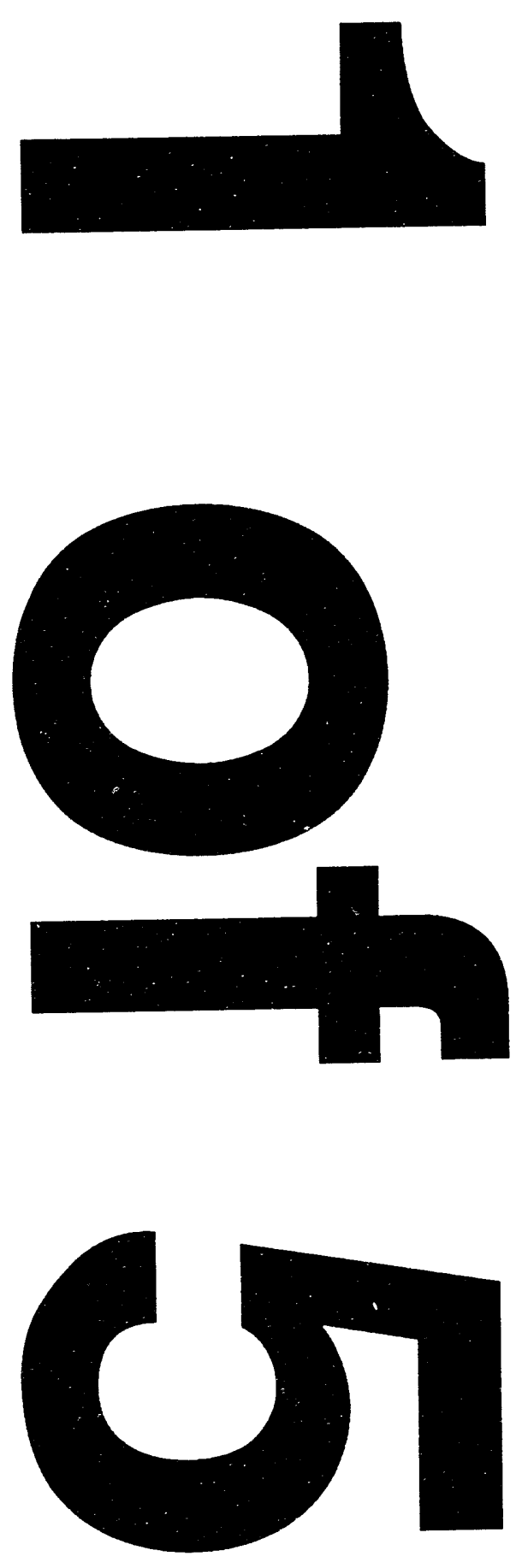


\title{
HISTORIC LAND USE AND CARBON ESTIMATES FOR SOUTH AND SOUTHEAST ASIA: 1880-1980
}

\author{
Contributed by \\ John F. Richards \\ and \\ Elizabeth P. Flint \\ Department of History \\ Duke University \\ Durham, North Carolina
}

Edited by Richard C. Daniels ${ }^{1}$

Carbon Dioxide Information Analysis Center

Environmental Sciences Division

Publication No. 4174

Date Published: January 1994

Prepared for the

Global Change Research Program

Environmental Sciences Division

Office of Health and Environmental Research

U.S. Department of Energy

Budget Activity Number KP 0500000

Prepared by the

Carbon Dioxide Information Analysis Center

OAK RIDGE NATIONAL LABORATORY

Oak Ridge, Tennessee 37831-6335

managed by

MARTIN MARIETTA ENERGY SYSTEMS, INC.

for the

U.S. DEPARTMENT OF ENERGY

under contract DE-AC05-84OR21400

${ }^{1}$ Energy, Environment and Resources Center, The University of Tennessee, Knoxville, Tennessee.

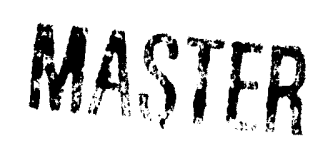

DIETRIBUTION OF THIS DOCUMENT IS UNLMMITED 


\section{TABLE OF CONTENTS}

\section{Page}

LIST OF FIGURES $\ldots \ldots \ldots \ldots \ldots \ldots \ldots \ldots \ldots \ldots \ldots$ vii

LIST OF TABLES $\ldots \ldots \ldots \ldots \ldots \ldots \ldots \ldots \ldots \ldots \ldots \ldots \ldots \ldots \ldots \ldots$

ABSTRACT $\ldots \ldots \ldots \ldots \ldots \ldots \ldots \ldots \ldots \ldots \ldots \ldots \ldots \ldots \ldots \ldots \ldots \ldots \ldots$

PART 1: INFORMATION ABOUT THE DATA PACKAGE $\ldots \ldots \ldots \ldots \ldots 1$

1. NAME OF THE NUMERIC DATA PACKAGE $\ldots \ldots \ldots \ldots \ldots \ldots$

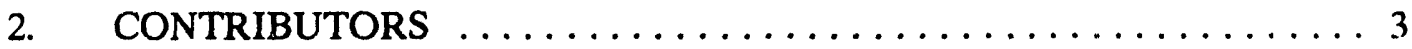

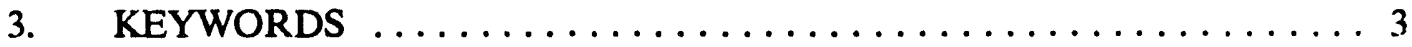

4. BACKGROUND INFORMATION $\ldots \ldots \ldots \ldots \ldots \ldots \ldots \ldots$

5. APPLICATIONS FOR THE DATA $\ldots \ldots \ldots \ldots \ldots \ldots \ldots$

6. COMPILATION OF THE DATA BASE $\ldots \ldots \ldots \ldots \ldots$

7. REGIONAL GEOGRAPHY AND CLIMATE ............. 17

7.1 LAND USE RECORDS $\ldots \ldots \ldots \ldots \ldots \ldots \ldots \ldots \ldots \ldots \ldots$

7.2 LAND USE CATEGORIES $\ldots \ldots \ldots \ldots \ldots \ldots \ldots \ldots \ldots \ldots$

7.3 ORGANIZATION OF LAND USE DATA

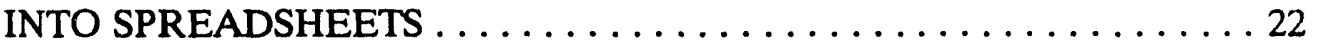

7.4 CHANGES IN LAND USE $\ldots \ldots \ldots \ldots \ldots \ldots \ldots \ldots \ldots \ldots \ldots \ldots \ldots \ldots$

8. CARBON STOCK IN LIVE VEGETATION $\ldots \ldots \ldots \ldots \ldots \ldots \ldots$

8.1 ESTIMATING CHANGES IN CARBON $\ldots \ldots \ldots \ldots \ldots \ldots$

8.2 MODELING OF CARBON CONTENT . . . . . . . . . . . . 29

8.3 ORGANIZATION OF CARBON DATA

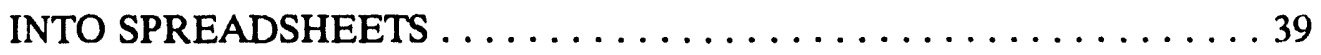

8.4 CHANGES IN CARBON $\ldots \ldots \ldots \ldots \ldots \ldots \ldots \ldots \ldots \ldots \ldots \ldots$ 
TABLE OF CONTENTS (Continued)

9. LIMITATIONS AND RESTRICTIONS OF THE DATA $\ldots \ldots \ldots \ldots 41$

10. DATA CHECKS PERFORMED BY CDIAC $\ldots \ldots \ldots \ldots \ldots \ldots . \ldots 3$

11. HOW TO OBTAIN THE DATA AND DOCUMENTATION $\ldots \ldots \ldots 44$

12. REFERENCES AND DATA SOURCES $\ldots \ldots \ldots \ldots \ldots \ldots \ldots, \ldots 5$

12.1 LITERATURE CITED $\ldots \ldots \ldots \ldots \ldots \ldots \ldots \ldots \ldots \ldots, 45$

12.2 PRIMARY DATA SOURCES $\ldots \ldots \ldots \ldots \ldots \ldots \ldots \ldots \ldots \ldots \ldots \ldots \ldots \ldots$

12.3 MAPS (ZONE BOUNDARIES) $\ldots \ldots \ldots \ldots \ldots \ldots \ldots \ldots \ldots \ldots \ldots$

PART 2: INFORMATION ABOUT THE COMPUTERIZED

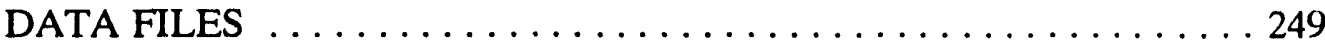

13. CONTENTS OF THE COMPUTERIZED DATA FILES $\ldots \ldots \ldots \ldots 251$

14. DESCRIPTIVE FILE ON THE MAGNETIC MEDIA . . . . . . . . . . . 267

15. LISTING OF THE FORTRAN DATA

RETRIEVAL PROGRAMS $\ldots \ldots \ldots \ldots \ldots \ldots \ldots \ldots \ldots \ldots \ldots \ldots$

16. LISTING OF THE SAS ${ }^{\mathrm{TM}}$ DATA

RETRIEVAL PROGRAMS $\ldots \ldots \ldots \ldots \ldots \ldots \ldots \ldots \ldots \ldots \ldots \ldots \ldots \ldots$

17. PARTIAL LISTINGS OF THE FLAT ASCII

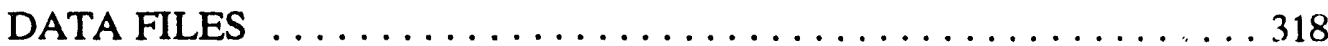

18. VERIFICATION OF DATA TRANSPORT:

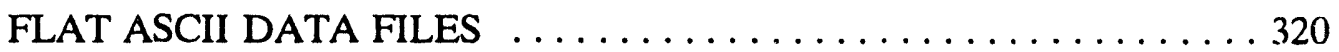

19. VERIFICATION OF DATA TRANSPORT:

LOTUS $1-2-3^{\text {TM }}$ SPREADSHEET FILES $\ldots \ldots \ldots \ldots \ldots \ldots \ldots \ldots . \ldots \ldots 21$

20. VERIFICATION OF DATA TRANSPORT:

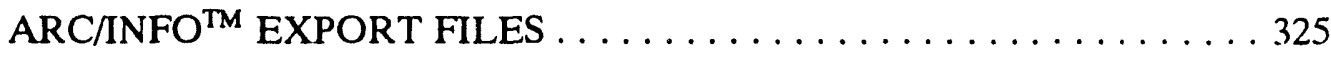




\section{TABLE OF CONTENTS (Continued)}

APPENDIX A: PRINTOUTS OF THE STEP 2 (LAND USE)

LOTUS $1-2-3^{\text {TM }}$ SPREADSHEETS FOR 13

COUNTRIES (TOTALS) $\ldots \ldots \ldots \ldots \ldots \ldots \ldots \ldots \ldots \ldots \ldots \ldots \ldots \ldots \ldots$

APPENDIX B: LISTING OF THE FACTORS (S, F, AND A)

USED IN CALCULATING THE DEGRADATION

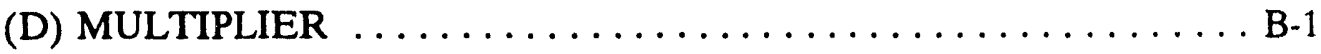

APPENDIX C: PRINTOUTS OF THE STEP 3 (CARBON)

LOTUS $1-2-3^{\mathrm{TM}}$ SPREADSHEETS FOR 13

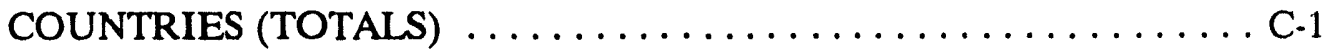

APPENDIX D: EXPLANATORY LOTUS 1-2-3 ${ }^{\mathrm{TM}}$ SPREADSHEETS

PROVIDED BY THE PRIMARY INVESTIGATORS .......... D-1

APPENDIX E: REPRINT OF PERTINENT LITERATURE . . . . . . . . E E-1

Historical analysis of changes in land use and carbon

stock of vegetation in south and southeast Asia,

By Elizabeth P. Flint and John F. Richards. $1991 \ldots \ldots \ldots \ldots \ldots \ldots$ E-3

ARC/INFO ${ }^{\mathrm{TM}}$ is a registered trademark of the Environmental Systems Research Institute (ESRI), Inc., Redlands, CA 92372.

SAS $^{\mathrm{TM}}$ is a registered trademark of the SAS Institute, Inc., Cary, NC 27511-8000.

Lotus $1-2-3^{\mathrm{TM}}$ is a registered trademark of Lotus Development Corporation, Cambridge, MA 02142. 


\section{LIST OF FIGURES}

Figure

Page

1. Map of South and Southeast Asia identifying the 13 countries with data in this data base $\ldots \ldots \ldots \ldots \ldots \ldots \ldots$

2a. Map of the identification numbers of the ecological zones contained within India and Sri Lanka

2b. Map of the identification numbers of the ecological zones contained within Bangladesh and Myanmar (Burma) ..... 12

2c. Map of the identification numbers of the ecological zones contained within Thailand, Cambodia, Laos, and Vietnam ........................... 13

2d. Map of the identification numbers of the ecological zones contained within Malaysia, Singapore, and Brunei . . . . . 14

2e. Map of the identification numbers of the ecological zones contained within the Philippines.

2f. Map of the identification numbers of the ecological zones contained within Indonesia

3. Flow chart summarizing the construction and aggregation of the spreadsheets used to calculate the land use and carbon data for a single ecological zone $\ldots \ldots \ldots \ldots \ldots \ldots$

4. Estimated degradation values as determined by applying

Eq. (4) 34 


\section{LIST OF TABLES}

Table

Page

1. Listing of the 94 ecological zones contained within

South and Southeast Asia . . . . . . . . . . . . . . 7

2. Total area in each land use class and total population

and livestock numbers for the 13 countries in South and Southeast Asia (i.e., India, Sri Lanka, Bangladesh, Myanmar, Thailand, Laos, Kampuchea, Vietnam, Malaysia, Brunei, Singapore, Indonesia, and the Philippines) . . . . . . 25

3. Total biomass and yield predictions by the United Nations

Food and Agricultural Organization for selected tropical and subtropical crops growing in a field under optimal

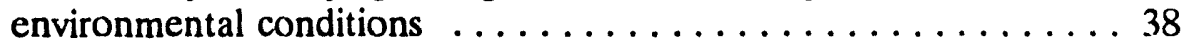

4. Mean carbon content in $\mathrm{Mg}$ /ha (above and below ground) for each land use class, at each of five dates, for all eight land use categories $\ldots \ldots \ldots \ldots \ldots \ldots \ldots \ldots \ldots$

5. Total carbon content of live vegetation estimated by class (values are $\times 10^{3} \mathrm{Mg}$ ) for each year for the 13 countries in South and Southeast Asia

6. Variable formats for LANDCARB.ASC (File 2) . . . . . . 269

7. Variable formats for FLAGS.ASC (File 5) . . . . . . . . 279

8. System used to rank the quality of the data utilized in determining the amount of cultivated and settled land in each ecological zone. Values range from 0 to 10,10 being the best (variable AG_FLG) . . . . . 280

9. System used to rank the quality of the data utilized in determining the amount of land in all land use classes except cultivated and built-up/settled land in each ecological zone. Values range from 0 to 10 , 10 being the best (variable NON_FLG) $\ldots \ldots \ldots \ldots \ldots . \ldots 28$ 
10. System used to rank the quality of the human population data in each ecological zone. Values range from 0 to 10,10 being the best (variable HP_FLG)

11. System used to rank the quality of the livestock

population data in each ecological zone. Values range

from 0 to 10,10 being the best (variable LP_FLG)

12. Variable formats for FACTORS.ASC (File 8) . . . . . . . . 289

13. Sample of the vector format used for SEA_CTRY.ASC

(File 11) and SEA_ZONE.ASC (File 12) ........... 294

14. Display of a portion of the land use and carbon

data in spreadsheet 100LUC.WK1

15. Display of a portion of the data accuracy flags in spreadsheet FLAGS.WK1.

16. Display of a portion of the $\mathrm{M}, \mathrm{E}, \mathrm{D}$, and $\mathrm{N}$ data in spreadsheet FACTORS.WK1.

17. Variable formats for SEA_LAND.E00 (File 30) . . . . . . 300

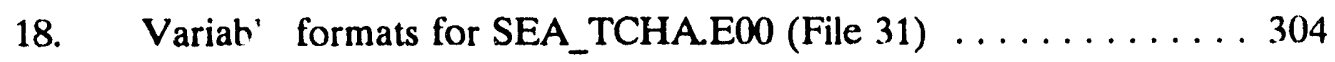

19. Vari: ule formats for SEA_CARB.E00 (File 32) . . . . . 306

20. File characteristics of the five flat ASCII

data files provided with this numeric data package $\ldots \ldots \ldots . \ldots 320$

21. File characteristics of the 90 Lotus $1-2-3^{\mathrm{TM}}$

WK1 spreadsheets provided with this numeric data

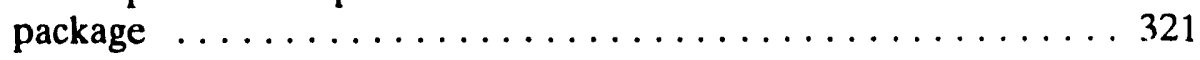

22. File characteristics of the three ARC/INFO ${ }^{\mathrm{TM}} \mathrm{E} 00$

export files provided with this numeric data package . . . . . . . 325 


\begin{abstract}
Richards, J.F. and E.P. Flint. 1993. Historic Land Use and Carbon Estimates for South and Southeast Asia: 1880-1980. ORNL/CDIAC-61, NDP-46, Oak Ridge National Laboratory, Oak Ridge, Tennessee. 404 pp.
\end{abstract}

This document describes the contents of a digital data base containing estimates of land use change and the carbon content of vegetation for South and Southeast Asia for the years $1880,1920,1950,1970$, and 1980 . These data were originally collected for climate modelers, so they could reduce the uncertainty associated with the magnitude and time course of historical land use change and of carbon release. For this data base, South and Southeast Asia is defined as encompassing nearly $8 \times 10^{6} \mathrm{~km}^{2}$ of the earth's land surface and includes the countries of India, Sri Lanka, Bangladesh, Myanmar (Burma), Thailand, Laos, Kampuchea (Cambodia), Vietnam, Malaysia, Brunei, Singapore, Indonesia, and the Philippines.

The most important chance in land use over the 100 year period was the conversion of $107 \times 10^{6}$ ha of forest/woodland to categories with lower biomass. Land thus transformed accounted for $13.5 \%$ of the total area of the study region. The estimated total carbon content of live vegetation in South and Southeast Asia has dropped progressively, from $59 \times 10^{9} \mathrm{Mg}$ in 1880 to $27 \times 10^{9} \mathrm{Mg}$ in 1980 . Throughout the study period, the carbon stock in forests was greater than the carbon content in all other categories combined, although its share of the total declined progressively from $81 \%$ in 1880 to $73 \%$ in 1980.

The data base itself was developed in Lotus $1-2-3^{\mathrm{TM}}$ using a sequential bookkeeping model. The source data were obtained at the local and regional level for each country from official agricultural and economic statistics (e.g., the United Nations Food and Agriculture Organization); from historical geographic and demographic texts, reports, and articles; and from any other available source. Because of boundary changes through time and disparities between the validity, availability, and scale of the data for each country, the data were aggregated into 94 ecological zones. The resulting data base contains land use and carbon information for 94 ecological zones and national totals for 13 countries.

These data are available as a Numeric Data Package (NDP) from the Carbon Dioxide Information Analysis Center. The NDP consists of this document and a set of data files consisting of ninety Lotus $1-2-3^{\mathrm{TM}}$ files, three $\mathrm{ARC} / \mathrm{INFO}^{\mathrm{TM}}$ export files, and five flat ASCII data files (provided to extend the use of the data to non-Lotus $1-2-3^{\mathrm{TM}}$ and nonARC/INFO ${ }^{\text {TM }}$ users). The documentation contains information on the methods used in calculating each variable, detailed descriptions of file contents and formats, and a discussion of the sources, restrictions, and limitations of the data. The data files are available on a variety of media and through the INTERNET. The ARC/INFO ${ }^{\mathrm{TM}}$ files contain digitized outlines of each nation and zone within the data base. Also provided are FORTRAN and SAS ${ }^{\text {TM }}$ retrieval programs for use with the flat ASCII data files and a descriptive file that explains the contents and format of each data file.

ARC/INFO ${ }^{\mathrm{TM}}$ is a registered trademark of the Environmental Systems Research Institute (ESRI), Inc., Redlands, CA 92372.

$\mathrm{SAS}^{\mathrm{TM}}$ is a registered trademark of the SAS Institute, Inc., Cary, NC 27511-8000.

Lotus $1-2-3^{\mathrm{TM}}$ is a registered trademark of Lotus Development Corporation, Cambridge, MA 02142. 
PART 1

INFORMATION ABOUT THE DATA PACKAGE 


\section{NAME OF THE NUMERIC DATA PACKAGE}

\section{HISTORIC LAND USE AND CARBON ESTIMATES FOR \\ SOUTH AND SOUTHEAST ASIA: $1880-1980$}

\section{CONTRIBUTORS}

\author{
John F. Richards \\ Department of History \\ Duke University \\ Durham, NC 27708 \\ U.S.A.
}

\author{
Elizabeth P. Flint \\ Department of History \\ Duke University \\ Durham, NC 27708 \\ U.S.A.
}

\section{KEYWORDS}

Agricultural expansion, biomass, carbon release, climate change, deforestation, environmental history, land use change, livestock, population, wetland clearance, Bangladesh, Brunei, India, Indonesia, Kampuchea (Cambodia), Laos, Malaysia, Myanmar (Burma), Philippines, Singapore, Sri Lanka, Thailand, Vietnam.

\section{BACKGROUND INFORMATION}

The irreversible nature of human induced climate change and the possible adverse impacts these changes may have on the Earth's ecological and economic systems make the task of developing an all-inclusive general circulation model (GCM) with predictive capabilities essential if we are to develop mitigation strategies for the future. Currently, GCMs estimate that an increase of 1.5 to $4.2^{\circ} \mathrm{C}$ in the average global surface air temperature will occur with a doubling (from preindustrial levels) of the concentration of greenhouse gases in the atmosphere (Dale et al. 1991). Based on extrapolations from currently available atmospheric $\mathrm{CO}_{2}$ concentration data (Keeling and Whorf 1991), this doubling is expected to occur by the year 2160 .

To more accurately predict the effects of long-term increases in the number and concentration of greenhouse gases on climate, GCMs will be required to predict the timing and magnitude of past and future increases in atmospheric $\mathrm{CO}_{2}$ concentrations, as well as the concentration of methane, nitrous oxide, water vapor, and a host of anthropogenic gases, based on an understanding of all the major processes leading to the release (sources) or storage (sinks) of these gases over time.

The development of a GCM that can predict regional trends in climate will be problematic until a well-documented understanding of the past, present, and possible future usage of fossil fuels and land is achieved. Such an understanding is only possible with the concerted effort of many investigators from a diverse set of disciplines. The perspectives of ecologists, biologists, historians, geographers, foresters, mathematicians, physicists, and others are needed if a multifaceted examination of the causes and consequences of land use change and human population growth on the world's climate is to be obtained.

Reductions in the amount of carbon stored in terrestrial ecosystems are partially 
responsible for the increase in the concentration of atmospheric $\mathrm{CO}_{2}$ that has occurred since 1850 (Bacastow and Keeling 1981, WMO 1981, Woodwell et al. 1978, Bolin 1978). For example, terrestrial vegetation is estimated to have contained over $900 \mathrm{Pg}$ of carbon before any land clearing occurred on Earth (Olson et al. 1985). In 1982 Olson and Watts estimated the amount of carbon sequestered in vegetation to be about $560 \mathrm{Pg}$. The decline in the amount of carbon sequestered in vegetation has been associated with the rapid increase in human population that began during the industrial revolution (Woodwell and Houghton 1977). This population growth created demands for food and forest products that could only be fulfilled through the clearing and conversion of large tracts of forest to agricultural and other uses. This land use conversion impacted the concentration of atmospheric $\mathrm{CO}_{2}$, because forests originally contained about $90 \%$ of the carbon stored in terrestrial vegetation (Dale et al. 1991).

Land use data and carbon estimates for South and Southeast Asia were collected and analyzed by John F. Richards and Elizabeth P. Flint (Department of History, Duke University, Durham, North Carolina) between 1983-1993. This data base was collected to help reduce the uncertainty associated with the release of carbon into the atmosphere caused by land use change. Results and conclusions drawn by the researchers using these data are described in detail in Effects of Land-use Change on Atmospheric $\mathrm{CO}_{2}$ Concentrations: South and Southeast Asia as a Case Study, published by Springer-Verlag in 1993 (Dale 1993). Discussion of earlier results may be found in Richards et al. (1983, 1985) and Flint and Richards (1991).

Their research was supported by a series of contracts and grants from the U.S. Department of Energy (presently under the direction of program manager Roger $\mathrm{C}$. Dahlman). All funding was part of a long-term, multidisciplinary research initiative to examine the impacts of land-use change in tropical regions of the world on global atmospheric $\mathrm{CO}_{2}$ concentrations. The contracts and grants that supported the construction of this data base include the following: Department of Energy, Office of Basic Energy Sciences, subcontract 19X-43361C under contract DE-AC05-84OR21400 to Oak Ridge National Laboratory (1983-1988); Department of Energy, Office of Energy Research, subcontract 19X-SB828C under contract DE-AC05-84OR21400 to Oak Ridge National Laboratory (1988-1990); Department of Energy, Office of Energy Research, Basic Energy Sciences, Carbon Dioxide Research grant DE-FG05-90ER61082 (1990-1991); Department of Energy, Office of Health and Environmental Research, Environmental Sciences Division, Global Carbon Cycle Research Program grant DE-FG05-90ER61082 (1991-1994). Additional long-term support was provided by the Smithsonian Institute, Office of Fellowships and Grants, Foreign Currency Program (1984-1992; program manager Francine Berkowitz). 


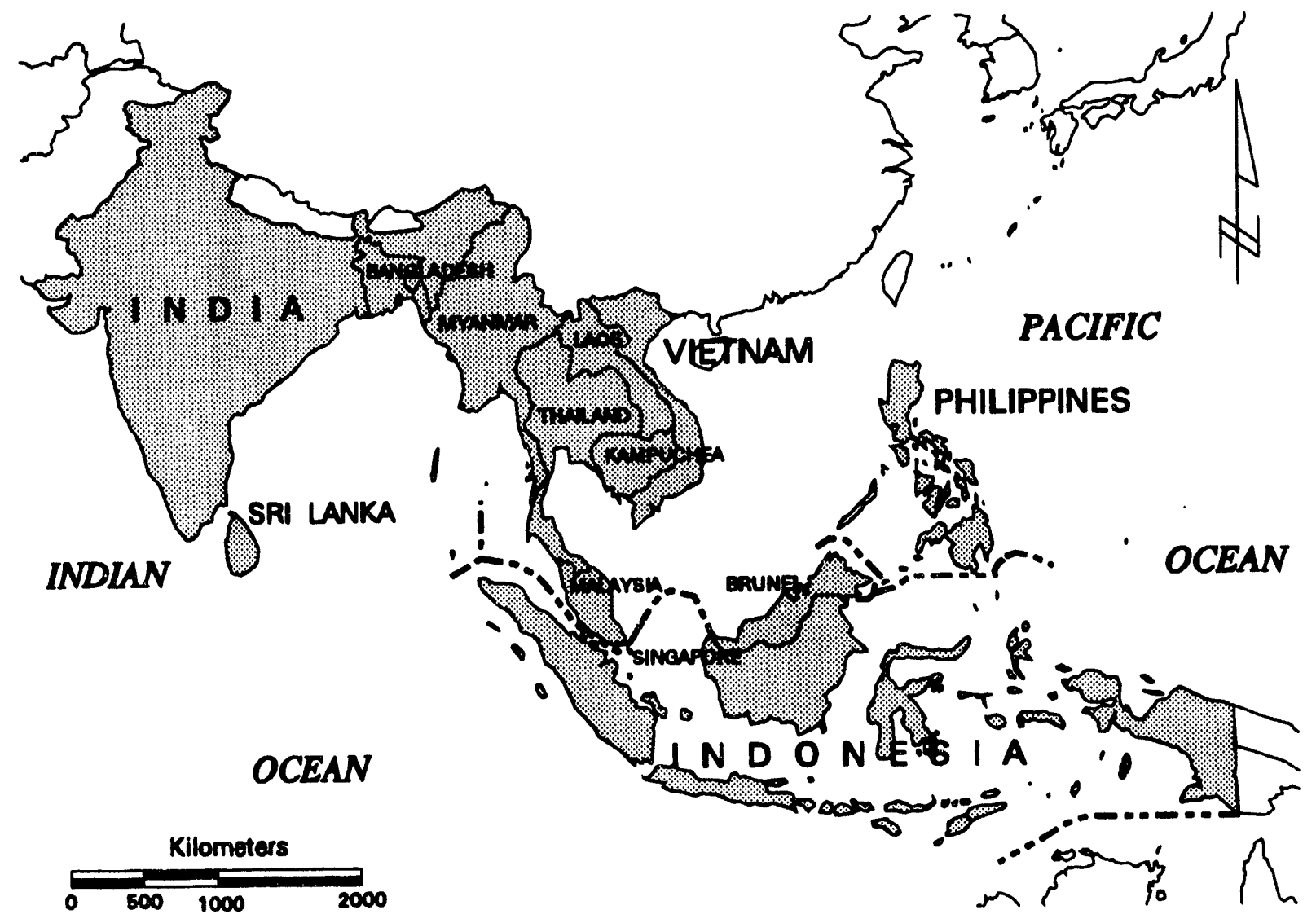

Figure 1. Map of South and Southeast Asia identifying the $\mathbf{1 3}$ countries with data in this data base 


\section{APPLICATIONS FOR THE DATA}

This data base contains a historical record of the conversion of land from natural or partially modified vegetation (high biomass) to agricultural or other low biomass activities (e.g., pasture) for South and Southeast Asia in the years 1880, 1920, 1950, 1970, and 1980. For purposes of this Numeric Data Package (NDP), South and Southeast Asia covers $7.9 \times$ $10^{6} \mathrm{~km}^{2}$ of the world's surface and includes the countries of India, Sri Lanka, Bangladesh, Myanmar (Burma), Thailand, Laos, Kampuchea (Cambodia), Vietnam, Malaysia, Brunei, Singapore, Indonesia, and the Philippines (Figure 1). The data base also includes information on human and livestock populations in each country and ecological zone for the bench mark years mentioned above. [A ecological zone is defined as an area consisting of one or more adjacent political units (e.g., districts) that have been grouped together based on socioecological similarities.] Thus, these data may be used by demographers, historians, geographers, or other researchers interested in the relationship between land cover change, land degradation, and anthropogenic activities.

\section{COMPILATION OF THE DATA BASE}

The data base itself was developed in Lotus $1-2-3^{\mathrm{TM}}$ using a sequential bookkeeping model; the source data were obtained at national, regional, and local scales for each country. Two general bodies of information were used to obtain bounds on the vegetation change component in relation to known carbon dioxide sources and sinks. The primary sources of information were historical and geographical documents from colonial records, accounts of economic and trade activities, national yearbooks, and descriptive materials of forests and their conversion, as well as the more recent statistics of the International Institute of Agriculture (IIA) in Rome and the United Nations Food and Agriculture Organization (FAO). The second body of background information was obtained from a review of research dealing with the field sampling of plant mass and the calculation of the carbon content of several different vegetation types (e.g., Brown and Lugo 1989, Negi et al. 1988). These carbon studies were used to estimate the mean carbon content per ha for the general land use classes used in this data base. Uncertainties in these values remain, but an important advantage of this approach is the possibility of modeling the differences that would result from alternative assumptions on the carbon content of a given land cover class. As additional/better data become available, the "average" carbon content of each vegetation type used herein may change. In that case, the new values may be applied to the land use data to obtain new carbon estimates.

The primary sources of uncertainty in this data base are (1) the decade-by-decade decline in biomass in live vegetation (i.e., land cover change) has not been well documented and (2) the average per ha carbon content of each ecosystem, used in predicting the total carbon content of vegetation, varies between studies. Boundary changes through time and disparities between the validity, availability, and scale of the data for each country has also introduced error into this data base. It was these data limitations that made it necessary to aggregate the available information from national administrative units into 94 ecological zones, where an ecological zone is defined as an area consisting of one or more contiguous political units (e.g., districts) that have been grouped together based on socio-ecological similarities. The names and locations of these zones are listed in Table 1 and are shown in Figure 2a through $2 \mathrm{f}$. The zone identification numbers shown in Table 1 are used in all data files (ARC/INFO $^{\mathrm{TM}}$, Lotus $1-2-3^{\mathrm{TM}}$, and flat ASCII) as the primary sort and identification key. 
Table 1. Listing of the 94 ecological zones contained within South and Southeast Asia.

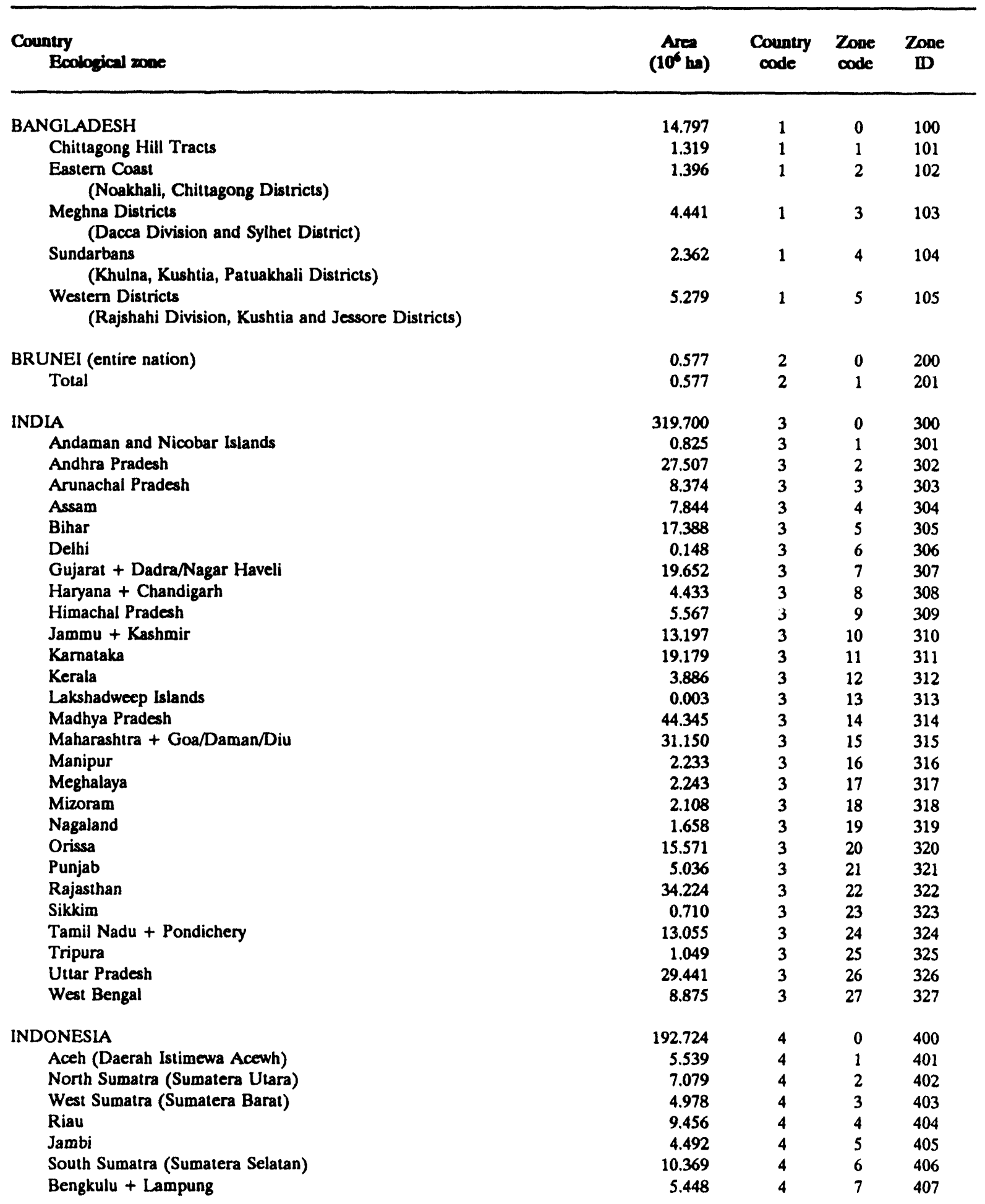


Table 1. (Continued)

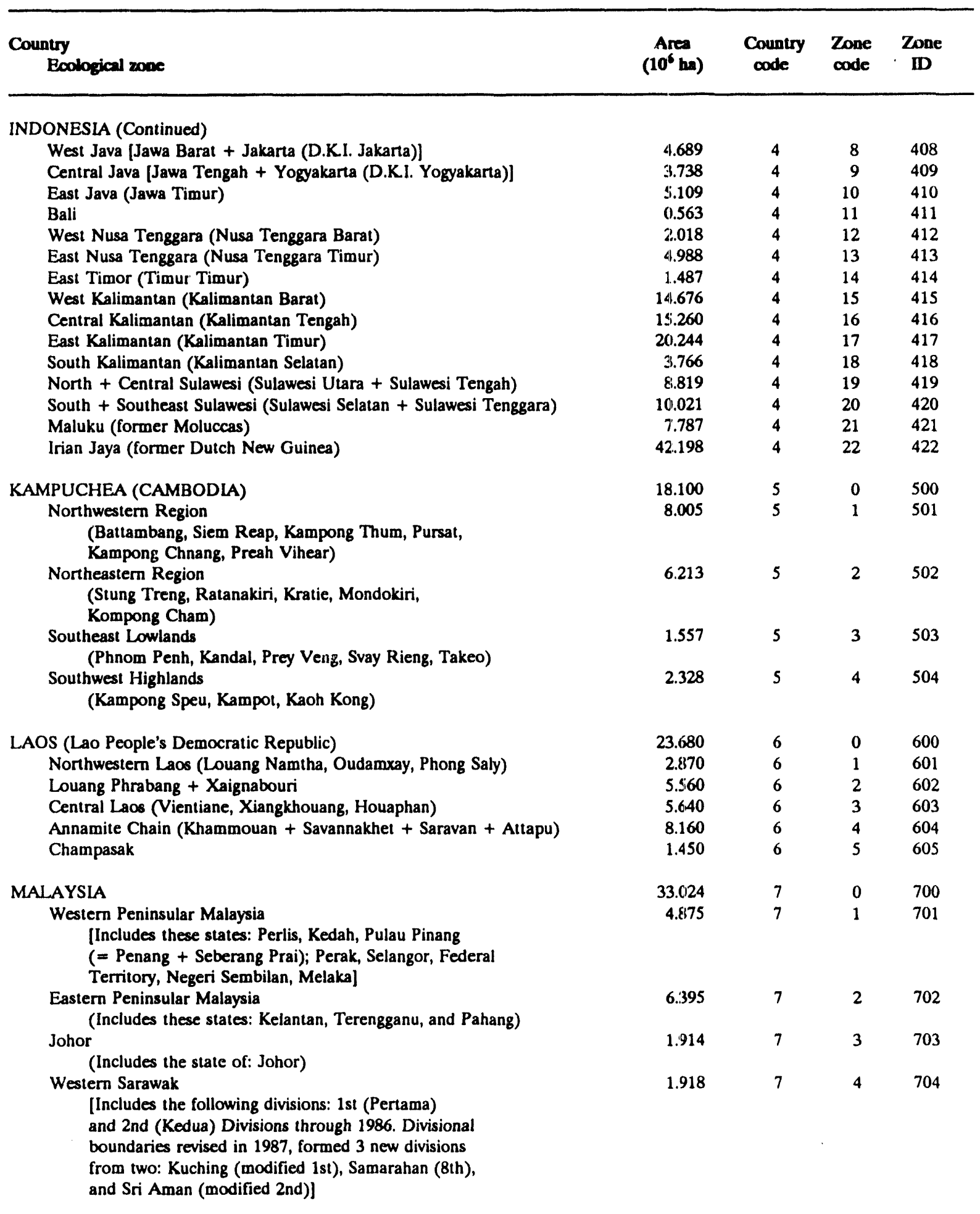




\section{Table 1. (Continued)}

\begin{tabular}{|c|c|c|c|c|}
\hline $\begin{array}{l}\text { Country } \\
\text { Ecological zone }\end{array}$ & $\begin{array}{c}\text { Area } \\
\left(10^{6} \mathrm{ha}\right)\end{array}$ & $\begin{array}{l}\text { Country } \\
\text { code }\end{array}$ & $\begin{array}{l}\text { Zone } \\
\text { code }\end{array}$ & $\begin{array}{l}\text { Zone } \\
\text { ID }\end{array}$ \\
\hline MALAYSLA (Continued) & & & & \\
\hline $\begin{array}{l}\text { Central Sarawak } \\
\text { [Includes the following divisions: 3rd Division } \\
\text { (before } 1972 / 73 \text { ), then subdivided into 3rd (Ketiga), } \\
\text { 6th (Keenam) \& 7th (Ketujuh) Divisions. These divisions } \\
\text { were renamed in } 1987 \text { as follows: 3rd (Ketiga) = Sibu; } \\
\text { 6th (Keenam) = Sarikei; 7th (Ketujuh) }=\text { Kapit] }\end{array}$ & 5.854 & 7 & 5 & 705 \\
\hline $\begin{array}{l}\text { Eastern Sarawak } \\
\text { [4th (Keempat) and 5th (Kelima) Divisions through } 1986 . \\
\text { In Aug. } 1986 \text { the } 4 \text { th (Keempat) Division was subdivided } \\
\text { into } 2 \text { new divisions: Miri (modified 4th) and Bintulu (9th). } \\
\text { In Aug. } 1986 \text { the Sth (Kelima) Division was renamed as Limbang.] }\end{array}$ & 4.673 & 7 & 6 & 706 \\
\hline Sabah [Total state] & 7.394 & 7 & 7 & 707 \\
\hline MYANMAR (BURMA) & 67.657 & 8 & 0 & 800 \\
\hline Chin + Arakan (Rakhine) States & 7.280 & 8 & 1 & 801 \\
\hline Northern Myanmar (Kachin State, Sagaing Division) & 18.367 & 8 & 2 & 802 \\
\hline Dry Zone (Magwe + Mandalay Divisions) & 8.184 & 8 & 3 & 803 \\
\hline Shan, Karen, + Kayah States & 19.791 & 8 & 4 & 804 \\
\hline Delta (Irrawaddy + Pegu + Rangoon Divisions) & 8.471 & 8 & 5 & 805 \\
\hline Peninsular (Mon State, Tenasserim Division) & 5.564 & 8 & 6 & 806 \\
\hline PHILIPPINES & 30.000 & 9 & 0 & 900 \\
\hline $\begin{array}{l}\text { Luzon } \\
\text { (Regions 1, 2, 3, } 5 \text { and portions of Region 4, includes } \\
\text { Luzon, Mindoro, Masbate) }\end{array}$ & 12.650 & 9 & 1 & 901 \\
\hline $\begin{array}{l}\text { Palawan } \\
\text { (The rest of Region 4, includes Palawan) }\end{array}$ & 1.490 & 9 & 2 & 902 \\
\hline $\begin{array}{l}\text { Visayas } \\
\text { (Regions 6, 7, and 8, includes Panay, Negros, Cebu, } \\
\text { Bohol, Leyte, Samar) }\end{array}$ & 5.661 & 9 & 3 & 903 \\
\hline $\begin{array}{l}\text { Mindanao } \\
\text { (Regions 9, 10,11, and 12, includes Northern, Southern, } \\
\text { Eastern, \& Western Mindanao) }\end{array}$ & 10.200 & 9 & 4 & 904 \\
\hline SINGAPORE (entire nation) & 0.062 & 10 & 0 & 1000 \\
\hline Total & 0.062 & 10 & 1 & 1001 \\
\hline SRI LANKA & 6.561 & 11 & 0 & 1100 \\
\hline $\begin{array}{l}\text { Wet Zone } \\
\text { [Western Provinces (Gampaha, Kalutara, Colombo Districts) } \\
\text { Central Provinces (Matale, Kandy, Nuwara Eliya Districts) } \\
\text { Sabaragamuwa Provinces (Kegalla, Ratnapura Districts) } \\
+ \text { Galle, Matara, and Badulla Districts] }\end{array}$ & 2.012 & 11 & 1 & 1101 \\
\hline $\begin{array}{l}\text { Dry Zone } \\
\text { [Northwestern Provinces (Kurunegala, Puttalam Districts), } \\
\text { Northern Provinces (Jaffna, Mullaitivu, Mannar, Vavuniya } \\
\text { Districts), North Central Provinces (Anuradhapura, } \\
\text { Polonnaruva Districts), Eastern Provinces (Trincomalee, } \\
\text { Batticaloa, Amparai Districts) + Monaragala and Hambantota } \\
\text { Districts] }\end{array}$ & 4.549 & 11 & 2 & 1102 \\
\hline
\end{tabular}


Table 1. (Continued)

\begin{tabular}{|c|c|c|c|c|}
\hline $\begin{array}{l}\text { Country } \\
\text { Eoological zone }\end{array}$ & $\underset{\left(10^{6} \mathrm{ha}\right)}{\operatorname{Ares}}$ & $\begin{array}{l}\text { Country } \\
\text { code }\end{array}$ & $\begin{array}{l}\text { Zone } \\
\text { code }\end{array}$ & Zone \\
\hline THAILAND & 51.311 & 12 & $\mathbf{0}$ & 1200 \\
\hline Northern Region & 16.964 & 12 & 1 & 1201 \\
\hline Northeastern Region & 16.885 & 12 & 2 & 1202 \\
\hline Central Plain & 10.390 & 12 & 3 & 1203 \\
\hline Southern Region & 7.072 & 12 & 4 & 1204 \\
\hline VIETNAM & 33.169 & 13 & 0 & 1300 \\
\hline $\begin{array}{l}\text { Northwest Highlands } \\
\text { (Lai Chau, Son La, Hoang Lien Son, Ha Tuyen, } \\
\text { Bac Thai, Cao Bang) }\end{array}$ & 8.312 & 13 & 1 & 1301 \\
\hline $\begin{array}{l}\text { Tonkin Delta } \\
\text { (Vinh Phu, Ha Son Banh, Hanoi, Ha Bac, Hai Hung, } \\
\text { Ha Nam Ninh, Thai Binh, Haiphong, Quang Ninh) }\end{array}$ & 3.260 & 13 & 2 & 1302 \\
\hline $\begin{array}{l}\text { North Central Coast } \\
\text { (Thanh Hoa, Nghe Tinh, Binh Tri Thien, } \\
\text { Quang Nam/Da Nang) }\end{array}$ & 6.395 & 13 & 3 & 1303 \\
\hline $\begin{array}{l}\text { Central Highlands } \\
\text { (Gia Lai-Cong Tum, Dac Lac, Lam Dong) }\end{array}$ & 5.535 & 13 & 4 & 1304 \\
\hline $\begin{array}{l}\text { South Central Coast } \\
\text { (Nghia Binh, Phu Khanh, Thuan Hai) }\end{array}$ & 3.510 & 13 & 5 & 1305 \\
\hline $\begin{array}{l}\text { Mekong Delta } \\
\text { (Ho Chi Minh City, Song Be, Dong Nai, Tay Ninh, } \\
\text { Long An, Tien Giang, Ben Tre, Cuu Long, Dong Thap, } \\
\text { An Giang, Hau Giang, Kien Giang, Minh Hai) }\end{array}$ & 6.157 & 13 & 6 & 1306 \\
\hline
\end{tabular}




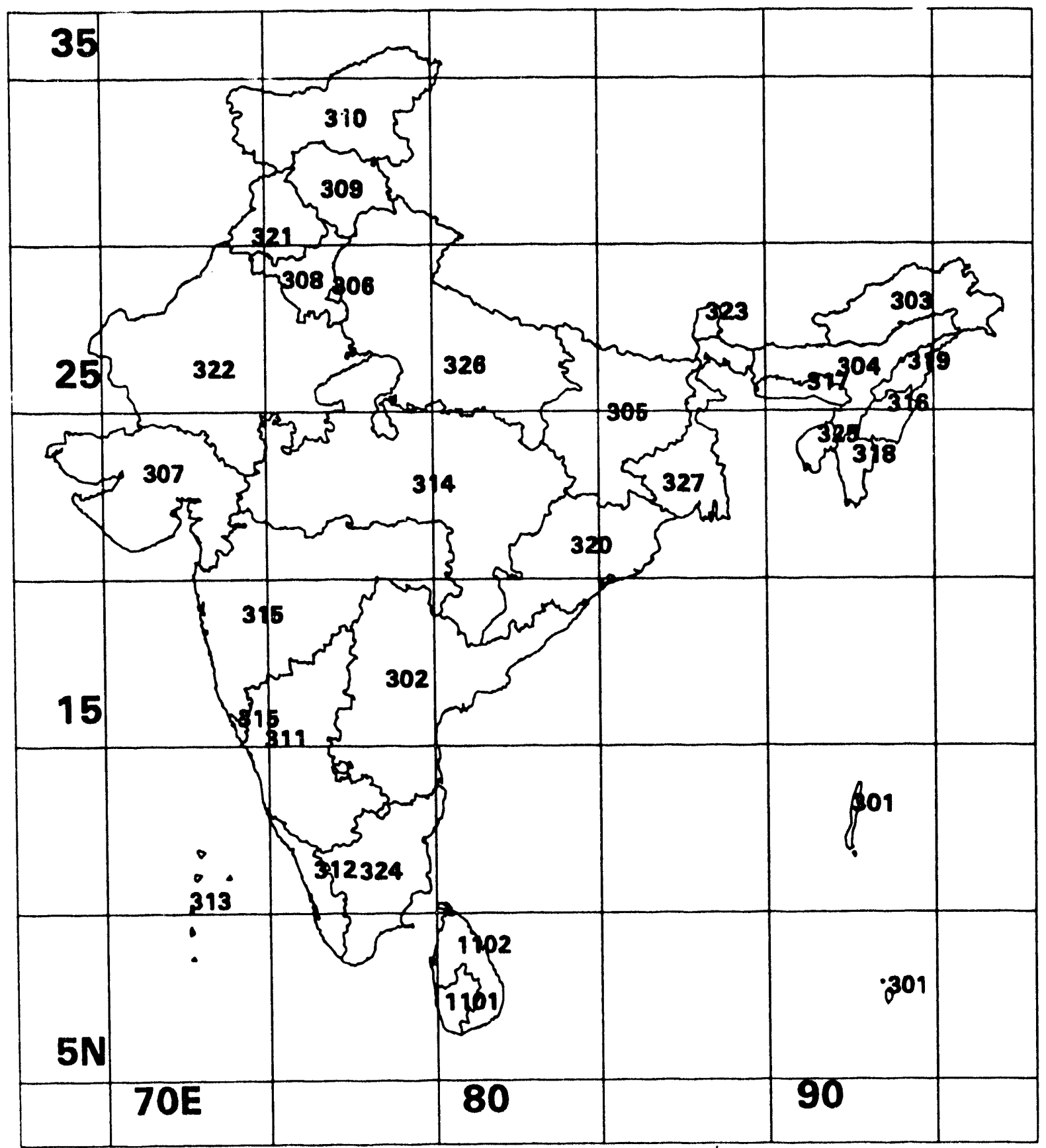

Figure 2a. Map of the identification numbers of the ecological zones contained within India and Sri Lanka. 


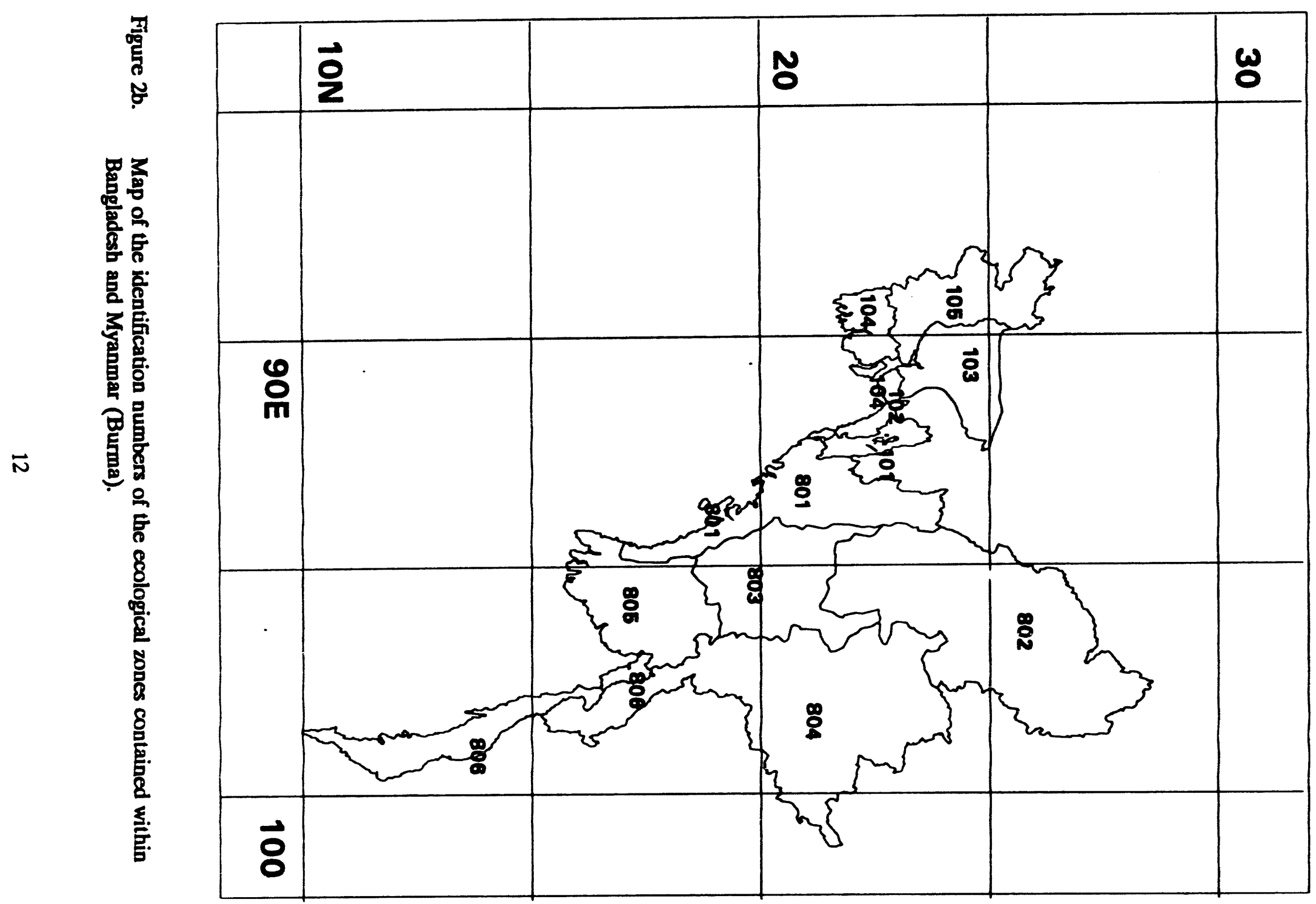




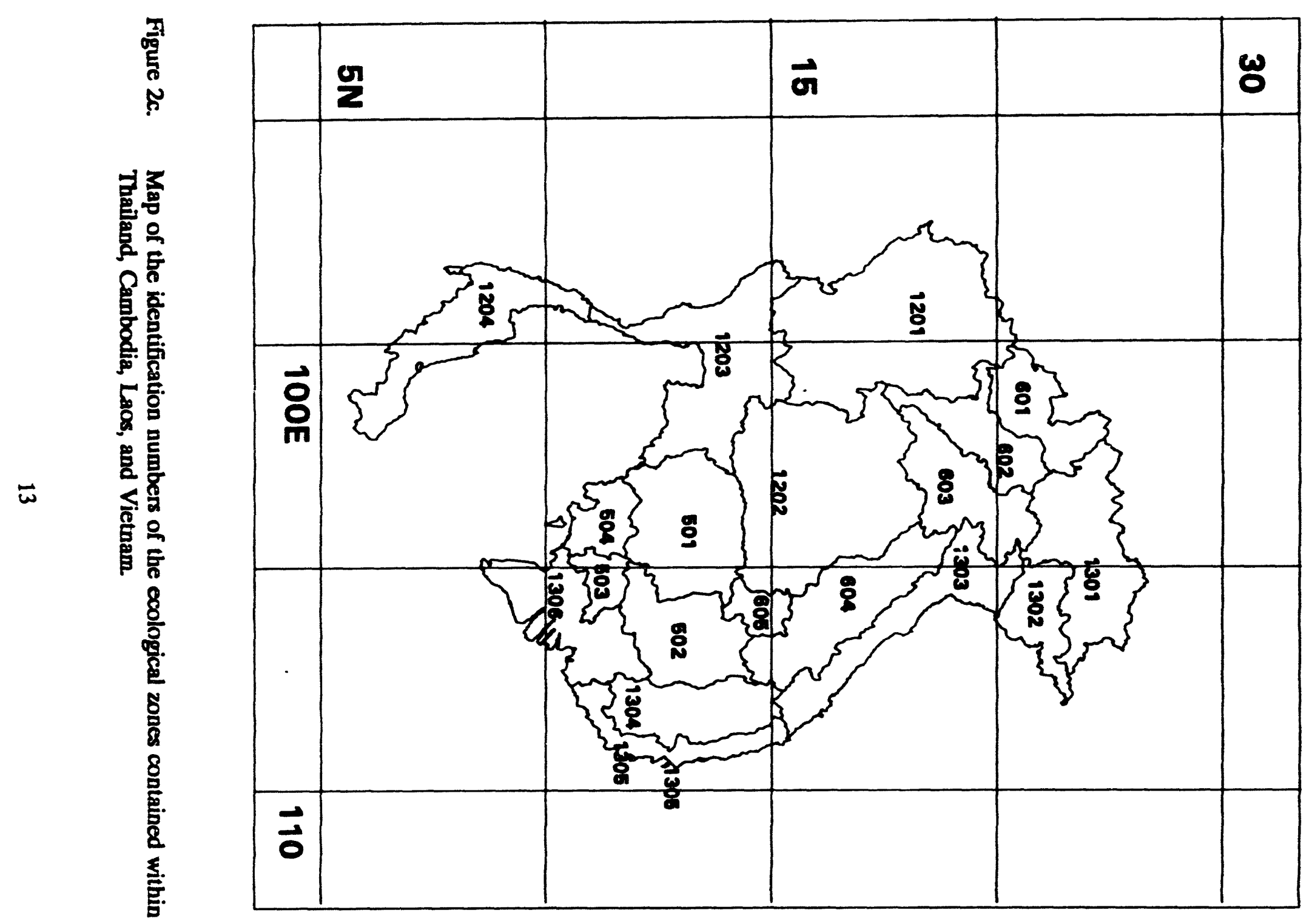




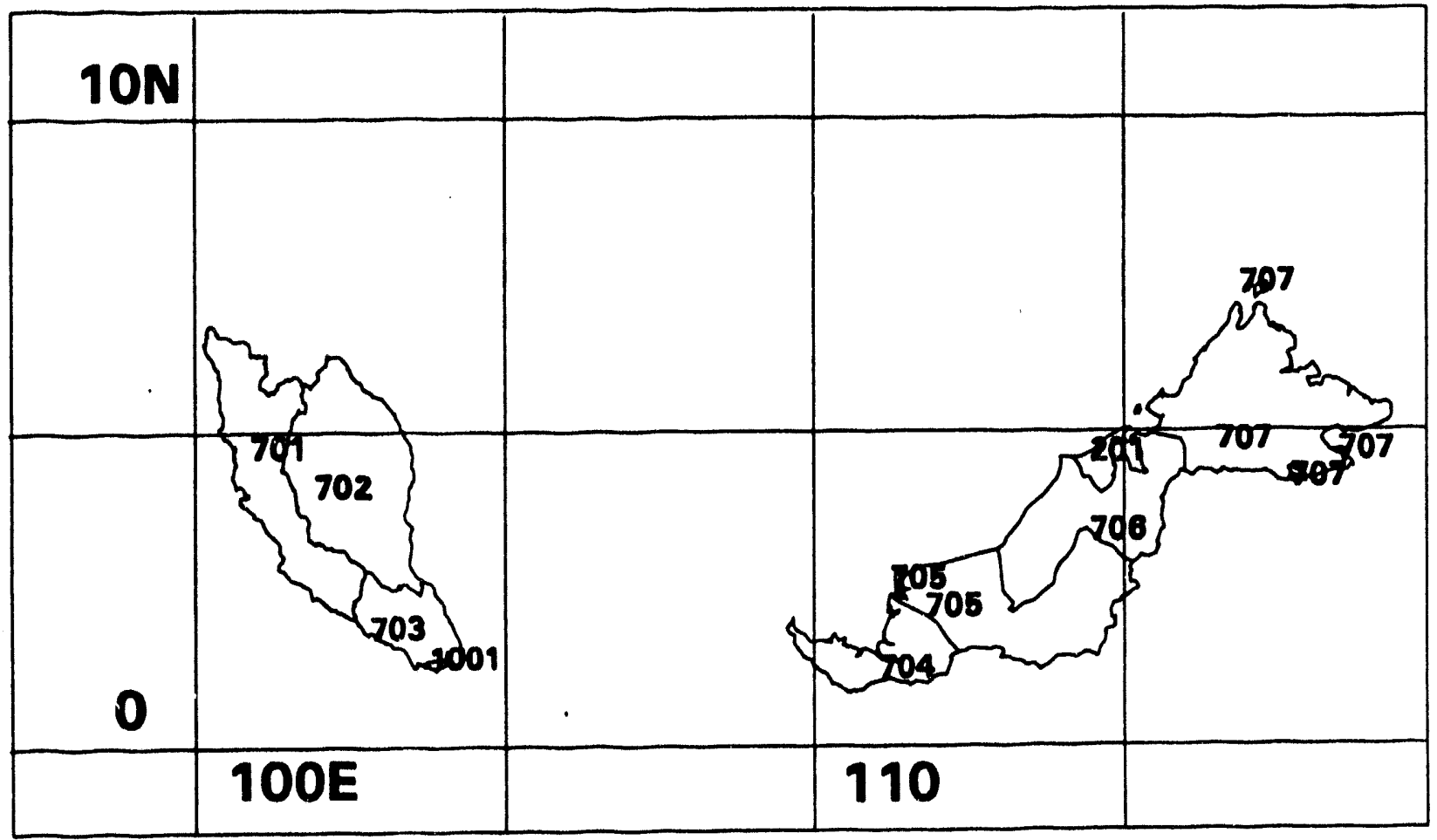

Figure 2d. Map of the identification numbers of the ecological zones contained within Malaysia, Singapore, and Brunei. 


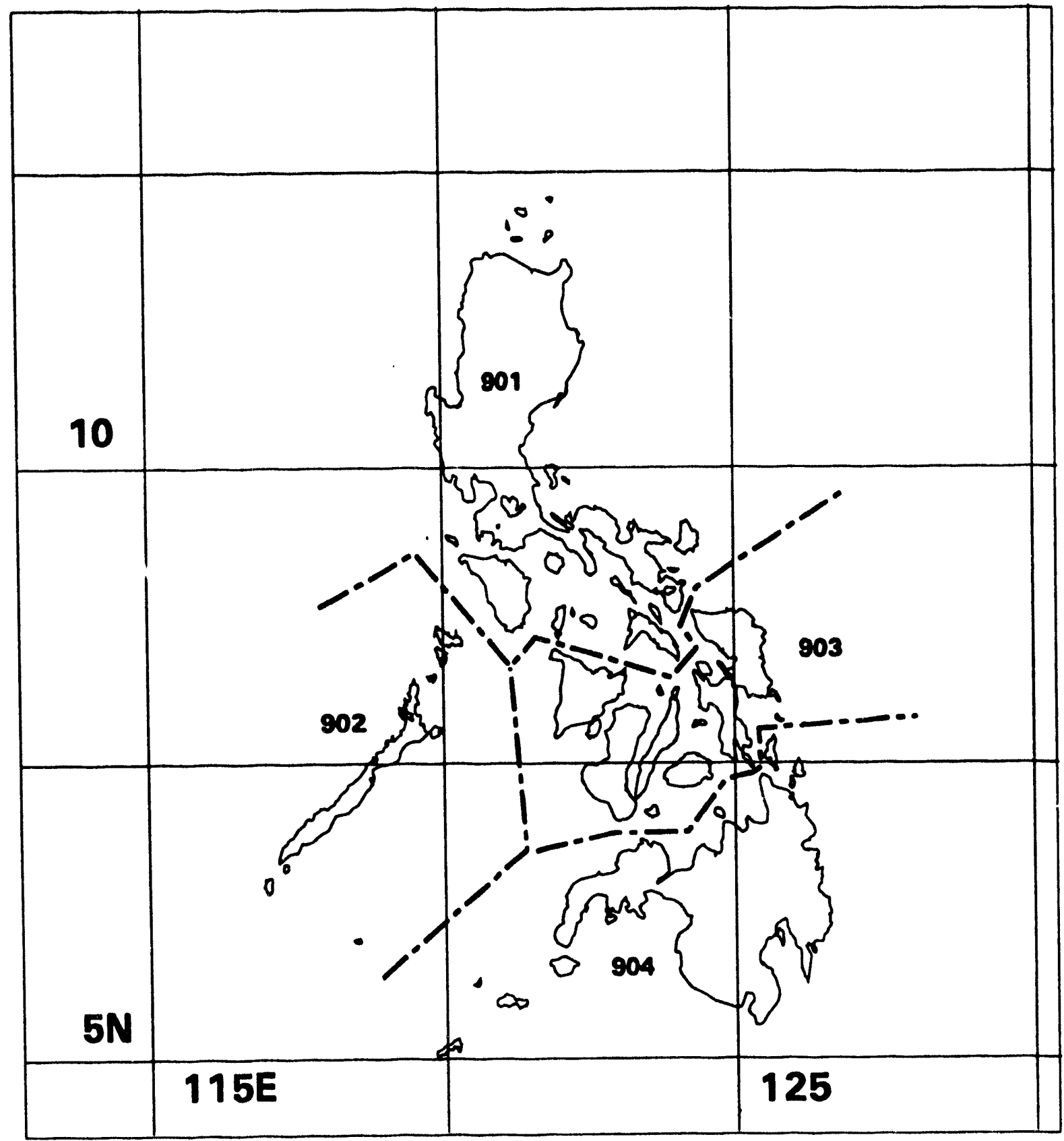

Figure 2e. Map of the identification numbers of the ecological zones contained within the Philippines. 


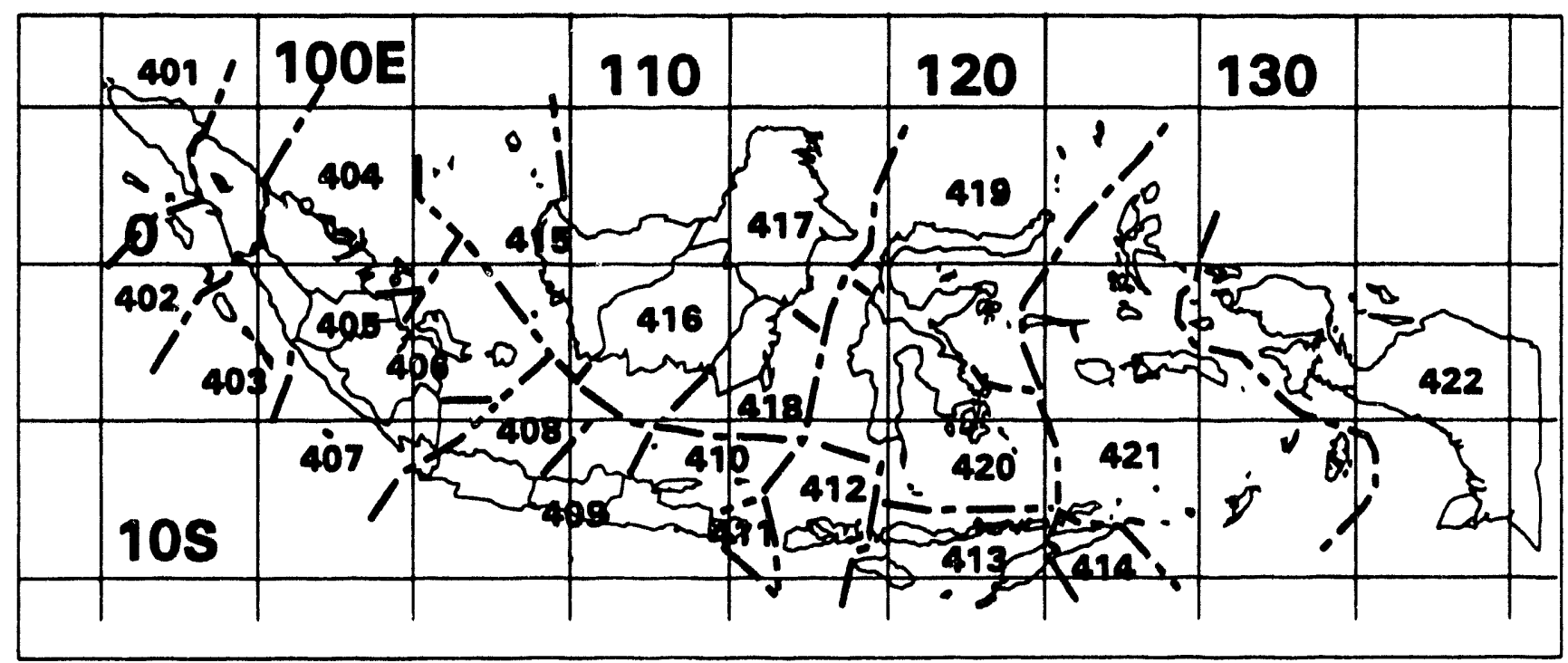

Figure 2f. Map of the identification numbers of the ecological zones contained within Indonesia. 


\section{REGIONAL GEOGRAPHY AND CLIMATE}

A dominant feature in the climate of South and Southeast Asia is the Asiatic monsoon, which is characterized by a strong seasonal variation in the direction of summer and winter winds. In continental South and Southeast Asia moisture-laden southwesterly winds prevail in summer, causing up to $88 \%$ of the year's total precipitation to fall between June and September. Precipitation in Insular Southeast Asia, particularly near the Equator, is modified by the Intertropical Convergence Zone and, as a result, has less seasonal variation (Yoshino 1984).

The topography of the study region varies from coastal lowlands to interior mountain peaks exceeding $6000 \mathrm{~m}$. This varying topography, when combined with variations in wind direction, introduces significant variability in the annual distribution of precipitation within the region. Areas with high annual precipitation $(>1500 \mathrm{~mm})$ show a tendency toward more even distributions of rainfali. Unlike precipitation, temperatures in South and Southeast Asia generally do not limit plant growth (FAO 1980). Mean annual temperatures range from 22 to $28^{\circ} \mathrm{C}$ over most of the study region (Ramdas 1974, Oldeman and Frere 1982) with a temperature regime that grades from tropical to subtropical as latitudes increase. Elevation exerts a similar influence on temperature, with mean maxima and minima decreasing by about $0.6^{\circ} \mathrm{C}$ per $100 \mathrm{~m}$ increase in elevation.

The amplitude of diurnal and seasonal temperatures varies with latitude and distance from the ocean (Donner 1987). In the more northerly and continental portions of the study area, seasonal variations in mean temperature of $13^{\circ} \mathrm{C}$ or more can occur (Ramdas 1974). In areas with higher elevations, alpine-type climates occur. In contrast, the climate of Insular Southeast Asia is characterized by seasonal variations in temperature of only 1 to $3^{\circ} \mathrm{C}$ (Oldeman and Frere 1982).

Variations in precipitation, temperature, topography, elevation, and soil types within the region encourage a wide range of natural vegetation types. The lowland vegetation of South and Southeast Asia includes large areas of wetland forest (tidal, peat swamp, and freshwater swamp), tropical humid forest, tropical moist-to-dry deciduous forest, and some tropical thorn forest. Higher elevations in northerly latitudes support wet-to-dry subtropical or temperate mountain forest types, including both broad-leafed and coniferous associations, in addition, sites at higher elevations support a variety of subalpine and alpine vegetation.

\subsection{LAND USE RECORDS}

Most of South and Southeast Asia was under the political control of the European colonial powers by 1880 . This control was weakened during World War II and ended shortly there after when India, Bangladesh, Sri Lanka, Myanmar (Burma), Brunei, Singapore, and Malaysia (all part of the British Empire) were granted independence. Indonesia gained independence in 1949 from the Netherlands (East Timor, a colony of Portugal, was annexed by Indonesia in 1976); and Vietnam, Kampuchea (Cambodia), and Laos were ruled by France as Indochina (Forest 1980). Spain ruled the Philippines until the United States succeeded them at the end of the Spanish-American War in 1901. Not all of the territories in these countries were directly governed, as colonial powers tended to concentrate their attention on densely populated and productive lowlands. Less accessible upland territories were often administered by semiautonomous local rulers. Thailand escaped colonization by the European powers altogether, although it was forced to transfer sovereignty of some contested coastal 
territories to both Britain and France.

Colonial governments tended to rely on direct or indirect taxation of agricultural land as a major source of income (Blyn 1966, Randhawa 1983, Reynolds 1927, Chai 1964, Jackson 1968, Lee 1965, Furnivall 1944, Osborne 1969, Boomgaard 1990). The government of British India, for example, taxed agricultural land annually at a rate proportional to its economic productivity (Asthana and Srivastava 1965). British India conducted extensive cadastral surveys and maintained long-term land use records for most of the area under its direct control (Bansil 1984). Some of the semi-independent South Asian states also recorded agricultural information for revenue purposes (e.g., Chaudhuri 1903). In much of British India, the colonial government revised its land revenue assessments every few decades. After resurveying land and recording changes in revenue obligations and details of land tenure, the local administration issued extensive settlement reports ${ }^{1}$ (usually at the subdistrict or district level) that contained detailed land use statistics plus information on local physiography, soils, vegetation, agriculture, and forestry. This information was used to explain and justify the proposed land tax structures that were included in these reports (e.g., Jack 1915).

The authors of settlement reports often contributed to the district gazetteer. This compendium of geographical, historical, economic, and ethnographic information was prepared according to a provincially standardized format and periodically updated. Gazetteers published for larger political units (Provinces) were compilations of the district gazetteers. The central colonial government of India summarized the entire body of gazetteer data in the 26-volume Imperial Gazetteer of India (India 1907-1909), a major source of statistical and descriptive information for the turn of the century. The completeness of these land use records varied with the directness of British colonial control (Heath 1951). Generally, the most comprehensive statistics were generated in densely populated and agriculturally productive regions. The same tendency was carried to an extreme by the governments of the Netherlands East Indies and French Indochina. For example, in Indonesia the Dutch kept excellent records for Java, home to at least $70 \%$ of the colony's people and almost all of its irrigated rice cultivation, whereas little attention was paid to crop production in the remaining $93 \%$ of the country until the 1920s (Boomgaard 1990). Similarly, the French maintained excellent land records in Cochin-China, Tonkin, and Annam but documented Laos and Cambodia with less precision (Henry 1932).

Taxation of agricultural land was less important to the Thai monarchy than to adjacent colonial governments (Ingram 1971), but its relative contribution to national revenue was sufficient to provide incentive for the annual compilation of agricultural statistics starting in 1905 (Wilson 1983).

With the end of World War II and the gradual end of colonial rule in South and Southeast Asia, the newly independent countries of this region tended to maintain the same statistical and land use classification systems as used by the colonial powers. In addition, the goal of national economic development and central planning, encouraged by multinational agencies such as the FAO, inspired several national efforts at data compilation. New states were urged by international organizations to obtain detailed land use surveys by contracting with private North American and European companies. The resulting aerial and cadastral

${ }^{1}$ In the Presidency of Bengal (roughly equivalent to modern Bangladesh, West Bengal, Bihar, and part of Assam), a permanent assessment had been established late in the 18th century and periodic settlement reports were not issued. However, "final" settlement reports were issued for most districts in the late 19 th and early 20 th centuries. 
surveys, such as that carried out by Hunting Survey Corporation in 1961 for Sri Lanka, were invaluable in compiling this data base (Hunting Survey Corp. Ltd. 1962).

By 1880 ownership of most forest lands in the study region were vested in the state, whether that government was the direct creation of the British, French, Spanish, or Dutch, a semiautonomous protectorate, or an independent entity such as Siam [Conservator of Forests (Siam) 1904, Cubitt 1920, Dutch East Indies 1902, 1923, Forest Research Institute (India) 1961]. An outcome of the state ownership of forests was that each government hired professional foresters to manage and survey its forests for the stated purpose of maximizing the long-term yield of timber and other renewable resources (Brandis 1897, Ribbentrop 1900, Menon 1976, Samapuddhi 1966, Kumar 1986, Feeny 1988, Boomgaard 1988, Kummer 1991). The first forests surveyed were those that contained significant quantities of merchantable timber that were immediately accessible. The quality of forestry data improved throughout the century as developments in technology and transportation increased the number of commercially exploitable species, the amount of accessible forest, and the quantity of timber that could be removed (Gaertner et al. 1963).

The rapid population growth experienced within South and Southeast Asia created a demand for food and increased export income. This population pressure mandated the continued clearing of forests. These demands conflicted with the new countries' long-term goal of self-sufficiency that mandated the conservation of forest resources. Moreover, forest preservation was a prerequisite for the proper management of watersheds to reduce soil erosion and downstream flooding (Richards et al. 1985, Kumar 1986, Boomgaard 1988). To resolve the conflicts over these issues, national governments needed reliable surveys and assessments of the quantity and quality of forest lands. Economic and political interests thus provided a strong incentive for the collection of information on the extent and condition of the forests in all but the most inaccessible territories. Professionally qualified forest officers began to carry out these tasks and to develop methods for reporting the condition of forests under their care.

Geographically specific information on population numbers and distribution (of both humans and livestock) is critical to the understanding of trends in land use. The obvious political utility of such information provided an incentive for officials to conduct population and agricultural censuses. As in the case of forest and agricultural statistics, the first areas of South and Southeast Asia to have censuses were the densely populated agricultural lowlands in each country (Jahdav et al. 1972, Wilson 1983, Boomgaard 1990). The coverage and accuracy of the census data improved as the various states consolidated political control over their territories. Both primary and secondary references on the demographic history of each country have been consulted in the construction of this data base (e.g., Sungsawan 1985, Jones $1953,1962 a, 1962 b, 1966)$. Censuses of livestock in the study region were initiated considerably later than those of population [e.g., India (Republic) 1954, 1972]; because of this, most of the livestock data prior to 1950 were obtained from secondary data sources. The secondary sources were consulted to obtain estimates of the number and type of livestock within each ecological zone. The livestock data were collected for this data base because livestock information provides an important indicator of the amount of vegetation degradation to be expected within the forests and wetlands of each ecological zone. Livestock are defined for this NDP as including any four-footed domesticated stock animal (e.g., cattle, water buffalo, pigs, goats, sheep, and equines).

When analyzed and compared with other data sources, it is possible to use the official data discussed above to estimate long-term land use changes and population and livestock compositions. Admittedly, historical data contain errors of omission due to incomplete 
coverage in the early years of data collection. This is especially true in areas under shifting cultivation or areas of less-formalized administrative jurisdiction. Definitions of land use categories changed abruptly, often with only cryptic notice in the published compilations, to reflect changing official concerns and policies. Official biases, corruption, and ignorance also skewed reporting of land use data, with overly optimistic reports from forestry departments often inflating the areas reported under canopied forest. (This implies that the quality of the statistical data has very little to do with the age of the information, but is directly related to the priorities of the political regime in power at the time of data collection.)

When these biases are understood within the changing context of time and place, the official data series reveal long-term trends in land use; some have been published in an unbroken format as far back as the 1880s (Bansil 1984). In general, government agencies throughout the region engaged in an ongoing effort to improve the quality of their reported data because each nation was deeply interested in enumerating productive assets, especially land under crops or in forest. Systematic cadastral surveys based on trigonometric grids were routinely used by many of the colonial states in South and Southeast Asia as taxation revenues often rested on such information. Thus, the technical means for obtaining and displaying land use data improved over time as the newly created countries, anxious to be seen as modern states, became leaders in compiling and disseminating land use and population information.

Maps of vegetation and land cover that document actual vegetative cover and land use for several areas (e.g., Kuchler 1968, Gaussen et al. 1971, Whitmore 1984, Laumonier et al. $1983,1986 \mathrm{a}, 1986 \mathrm{~b})$ were extremely helpful in interpreting tabular data. Two reports on tropical forest resources (FAO 1976, 1981) used a common format to summarize contemporary forest areas for each country in the study region. These reports were partly based on information gathered using remote sensing technology. Similar sources published for individual countries have also been employed in the creation of this data base (e.g., Wong 1969, 1973, 1979, World Bank 1977).

The profusion of descriptive and quantitative sources permitted cross-checks and adjustments to the official land use data. Over the course of time, scientists and academically trained government officials have carried out hundreds of studies relating to land use and population in the region. These books, articles, reports, and case studies were utilized in deriving (where necessary) and cross-checking the land use, population, and livestock information contained from official data sources. The primary data sources utilized in the creation of this data base are listed in Section 12.2. Though too numerous to cite here, the secondary data sources are partially referenced in Hall et al. (1988) and Flint and Richards (1989). These two documents [available from the Carbon Dioxide Information Analysis Center (CDIAC)] contain geographically indexed bibliographies with references to over 5,000 published botanical, agricultural, ecological, geographical, and historical studies of the region. 


\subsection{LAND USE CATEGORIES}

Land use statistics were gathered from the available published compilations of official data at various scales (colony, country, state, district, province, or other administrative unit), and preliminary compilations were made using each nation's original classification system. As these systems were structured to meet political rather than ecological needs, their categories do not necessarily reflect the actual vegetation cover or carbon content (biomass) of a given area. Furthermore, the official statistics available for the various geographical entities in South and Southeast Asia are not directly comparable with each other, nor with land use classifications used in other parts of the world. Therefore, a set of eight carbon-based land use classes were developed, and the land use data were converted from their original classifications into this system. The eight carbon-based land use categories are defined as follows:

(1) Net cultivated area, is subdivided into two subcategories: land planted in temporary crops (annuals such as rice) and land planted in permanent crops (perennials such as rubber).

(2) Settled/built-up area, includes all land under settlements, roads, railways, mines, etc.

(3) Forest/woodland, includes all forms of continuous natural dry land forests or timber plantations with $40 \%$ or greater crown closure. To increase the accuracy of carbon estimates, information was compiled on the area of land in the major forest types within each zone (e.g., tropical moist forest, tropical dry forest, temperate broad-leafed forest, and coniferous forest).

(4) Interrupted woods, includes vegetation with an arboreal component with a crown closure below $40 \%$. To increase the accuracy of carbon estimates, information was compiled on the area of land in several subcategories (e.g., thorn woodland, degraded or scrub forest, tree savanna, and vegetation types with biomass significantly lower than that of closed forest.) This class is similar, but not identical to, the category of the same name used by Olson et al. (1983).

(5) Grass/shrub complex, includes grasslands, forb communities, and shrub land.

(6) Barren/sparsely vegetated, includes tundra, desert, semidesert scrub land, and all non-vegetated lands.

(7) Wetlands, includes all lands subject to inundation by either fresh or salt water and has been divided into two subcategories: nonforested and forested wetland.

(8) Surface water, comprises areas permanently under water (including land in reservoirs). 
Although these eight land use classes are called land use categories, this classification system is really a hybrid of land use, land cover, and vegetation terminology. In view of the extent of human impact on the region, this approach is acceptable because the so-called "natural vegetation" of the region is currently restricted to land that has been consciously allocated to conservation, forestry, and rangeland or has a potential productivity so low that there is no economic incentive to modify its vegetation cover.

\subsection{ORGANIZATION OF LAND USE DATA INTO SPREADSHEETS}

This land use data base is based on information taken from subnational administrative units and aggregated upward to the ecological zone and national level. The fact that substantial boundary changes occurred at virtually every level of political organization during the century covered has necessitated compromise in the choice of the spatial unit to use for this data base. In the largest country, India, basic data were obtained at the third administrative level down to the district. The same approach was used in Bangladesh and Sri Lanka. In Malaysia data were collected at the level of the state (in Peninsular Malaysia and Sabah) and the division (in Sarawak), whereas data were gathered at the division and state level for Myanmar (Burma). In Indonesia and the Philippines data were obtained at the province level. The scarcity of pre-1920 data for Thailand dictated the use of the four traditional geographic regions as units of data collection, whereas in Vietnam, Kampuchea (Cambodia), and Laos (formally Indochina) data was initially obtained at the province level. For the two smallest countries, Singapore and Brunei, data were collected at the national level only.

The large size variation between administrative units and the differences in nomenclature for the various units in each country led to the designation of a neutral term for our basic spatial unit of analysis. Data from contiguous administrative units were combined, as necessary, to create 94 "ecological zones" in 13 countries. The administrative units combined into a single ecological zone contain similar vegetation types and topography and are subject to comparable climatic regimes.

The time series of land use data presented in this NDP consists of the total area in each land use category in each ecological zone for the years 1880, 1920, 1950, 1970, and 1980. In developing this series, the data consulted have not been limited to sources covering only these dates. Information from intervening years was used to extrapolate missing data values and for error checking.

To estimate the area in each land use category at successive points in time a multistep sequence of Lotus spreadsheets were used. Flint and Richards (1991) described this process in detail for data generated by the colonial government of British India and the nations that inherited and continued its system of land records (a reprint of Flint and Richards 1991 is provided in Appendix E). Variants of this procedure were developed to deal with differences in the structure of land use data in countries where the format of official statistics were different from that used by the Indian revenue bureaucracy. Common to all versions is the use of the sequential multistep procedure depicted in Figure 3.

Step 1 involved the collection and preliminary processing of data for a single administrative unit, where the name (i.e., province, state, or district) and size of the unit varied by country. The form of the spreadsheet used for this step depended on the number and kind of land use categories found in the official records. Because of the large number of 
these files and the wide variation in file layout and file size imposed by dissimilar official terminology, these spreadsheets are not distributed with this data base.

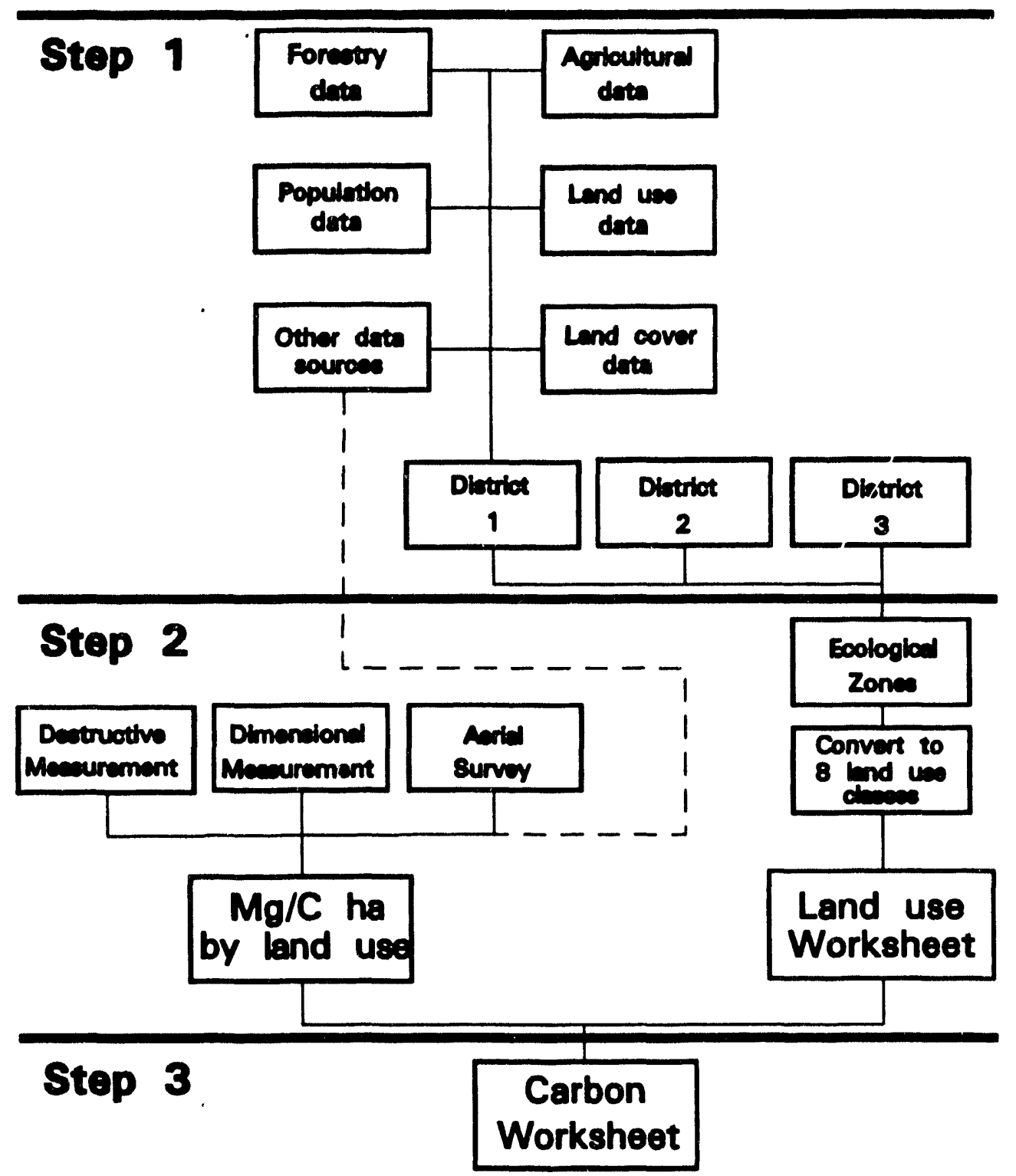

Figure 3. Flow chart summarizing the construction and aggregation of the spreadsheets used to calculate the land use and carbon data for a single ecological zone. 
Spreadsheets generated during Step 1 contained rows designating with each land use category (according to the official terminology used by the particular country under study) and columns headed by the years of available data. The rows directly beneath the land use data were reserved for data on human and livestock populations for the years 1880-1980. Wherever possible, data drawn from statistical publications was entered directly into the Step 1 spreadsheets. The area in the target year is entered directly from the source for each land use category, except in categories dealing with temporarily cropped and fallow land. In cases where an annual series of areas (in each land use class) were available, the mean value for several years bracketing the target date were calculated instead of relying on a single value. Use of the mean value reduced the possibility of introducing distortion into the time series by depending on data from a single year. When data were missing from official statistical compilations, data were obtained from other sources. For a listing of the primary data sources, sorted alphabetical by country, see Section 12.2 .

Once all the data were entered, algorithms contained within the spreadsheets converted areas into metric units and adjusted for small boundary changes. (Large boundary changes were evaluated on a case-by-case basis and may have entailed the simultaneous restructuring of two or three Step 1 spreadsheets.) The output of each Step 1 spreadshect was a time series of data in which the entire area of an administrative unit was allocated to the appropriate official land use categories for each date in the analysis. When the administrative unit treated in Step 1 was congruent with a single ecological zone, this output was entered directly into a Step 2 spreadsheet. For regions composed of more than one administrative unit, the areas for all units in the ecological zone, in each category, and for each date, were summed to produced a composite spreadsheet, which became the input into Step 2.

The Step 2 spreadsheet translated land use data for a single ecological zone from the official categories (which may vary by country and date) of the Step 1 spreadsheets into the uniformly applicable carbon-based system of land use classes described in Section 7.1. This conversion process required informed evaluation of the reliability and quality of the official statistics that were used in Step 1. Critical to the successful completion of Step 2 was an understanding of the limitations of the original official data. To assist the user in this regard, a set of 75 Lotus $1-2-3^{\mathrm{TM}}$ spreadsheets are included with this NDP. These spreadsheets describe the assumptions used in each country and zone when converting the original data into the eight uniform land use classes. Appendix D provides a short description of each of these files. Due to the highly varied format and subjective nature of these spreadsheets, they have not been quality assured by CDIAC and are provided in the same form as they were received in from the primary investigators. As such, any questions regarding the contents of these Lotus $1-2-3^{\mathrm{TM}}$ files should be directed to the primary investigators.

When creating the land use spreadsheets for each ecological zone, it was necessary to keep in mind the caveat that official land use records, for a variety of political and economic reasons, may misrepresent actual vegetative cover. For example, in India the legal definition of forest is not congruent with any generally accepted botanical or ecological definition of the term, as all areas officially identified as "forest lands" under any section of the Indian Forest Act are included in official land use statistics under the category of forest, even if an area is not covered by trees (Vohra 1985; see also Lal 1989, Bansil 1984). Similar considerations hold for Bangladesh (Rashid 1977). For this reason the land area of each official category was allocated to the eight carbon-based land cover classes only after consulting a multi-disciplinary bibliography of corroborative material. [Primary data sources utilized in the creation of this data base are listed in Section 12.2. Secondary data sources are referenced in Hall et al. (1988), Flint and Richards (1989, 1993), and Richards and Flint (1993).] 
The Step 2 spreadsheets structured the allocation procedure by assigning percentages of the total area in each official land use category to each of the eight carbon-based land use classes. Allocation percentages were entered into the Step 2 spreadsheets to simplify the review and revision of estimated values when new data became available. These percentages were multiplied by the summed official areas for the entire ecological zone to generate the estimated total area in each carbon-based land use category for each time period. Zone spreadsheets (i.e., the Step 2 spreadsheets distributed with this NDP) were then aggregated to obtain area totals for the each country.

All Step 2 spreadsheets are identical in structure and format across all zones, time periods, and countries, thus permitting the intercomparison of land use change over time. Printouts of the Step 2 spreadsheet for each country (aggregations of the zone spreadsheets in each country) are contained within Appendix A.

Table 2. Total area in each land use class and population and livestock numbers for the 13 countries in South and Southeast Asia (i.e., India, Sri Lanka, Bangladesh, Myanmar, Thailand, Laos, Kampuchea, Vietnam, Malaysia, Brunei, Singaporc, Indonesia, and the Philippines).

\begin{tabular}{lrrrrr}
\hline Land use class & 1880 & 1920 & 1950 & 1970 & 1980 \\
\hline & & & & & \\
\hline NET CULTIVATED AREA & 124,754 & 148,968 & 178,037 & 213,470 & 232,616 \\
$\quad$ Temporary crops & 117,229 & 137,432 & 161,867 & 192,023 & 205,243 \\
$\quad$ Permanent crops & 7,569 & 11,590 & 16,244 & 21,485 & 27,271 \\
SETTLED/BUILT-UP & 4,789 & 6,140 & 9,022 & 12,973 & 16,251 \\
FOREST/WOODLAND & 317,266 & 293,454 & 264,532 & 233,623 & 210,346 \\
INTERRUPTED WOODS & 109,594 & 102,273 & 99,680 & 99,578 & 95,596 \\
WETLANDS & 53,626 & 48,045 & 42,701 & 38,528 & 34,258 \\
$\quad$ Forested wetlands & 44,925 & 40,257 & 36,039 & 32,568 & 29,071 \\
$\quad$ Nonforested wetlands & 8,700 & 7,788 & 6,662 & 5,960 & 5,187 \\
GRASS/SHRUB COMPLEXES & 123,195 & 135,304 & 141,543 & 139,639 & 147,841 \\
BARREN/SPARSELY VEGETATED & 41,080 & 40,215 & 38,975 & 36,536 & 37,366 \\
SURFACE WATER & 17,121 & 17,027 & 16,936 & 17,107 & 17,151 \\
TOTAL LAND AREA & 791,425 & 791,425 & 791,425 & 791,425 & 791,425 \\
TOTAL FOREST COVER & 473,193 & 437,390 & 401,584 & 367,337 & 336,676 \\
TOTAL POPULATION & 310,487 & 396,121 & 584,040 & 900,641 & $1,128,373$ \\
TOTAL LIVESTOCK & 223,498 & 273,279 & 359,782 & 470,452 & 511,519 \\
& & & & & \\
\hline
\end{tabular}

Note: Areas are in $10^{3}$ ha.

Note: Populations are in thousands. 


\subsection{CHANGES IN LAND USE}

Changes in the area of land in each carbon-based land use class for the entire study region in $1880,1920,1950,1970$, and 1980 are summarized in Table 2 . As mentioned previously, the most important change in land use is deforestation -the conversion of $107 \times$ $10^{6}$ ha of land classified as forest in 1880 to categories bearing vegetation of lower biomass by 1980. Land thus transformed accounted for $13.5 \%$ of the total area of the study region.

Reduction in wetlands, althought proportionately more severe than that in forests, amounted to only $2.4 \%$ of the total area of the study region. Most lands classified as wetlands, especially in Southeast Asia, originally contained forest rather than herbaceous vegetation (Whitmore 1984, Kumar 1986, Williams 1965, Champion 1936, Arhabirama et al. 1988, Davis 1964). Accordingly, the loss of area in the wetlands class can be seen as a special case of deforestation. Overall, over $123 \times 10^{6}$ ha of land in the forested/woodland and forested wetland classes have been converted to one of the low-biomass categories (e.g., grassland) by 1980.

\section{CARBON STOCK IN LIVE VEGETATION}

The Step 2 spreadsheets contain historical land use data for 94 ecological zones and 13 countries in South and Southeast Asia. When compiling the land use data for each zone, the dominant type of forest and agricultural use was determined. Information was compiled from all available studies of patch, landscape, and ecosystem level biomass (e.g., Dagar 1987. Gupta and Mishra 1978, Brown and Lugo 1984) pertinent to the zone. Together with population density data for humans and livestock at each date, this information was used to estimate the amount of carbon per ha of live vegetation within each land use class at each point in time. By multiplying the average carbon values estimated for each land use type for each ecological zone by the amount of land within each land use class, the total amount of carbon stored within live vegetation in each zone and land use class was calculated for the Step 3 (carbon) spreadsheets (see Figure 3).

This section describes the processes used to derive the carbon estimates for each ecological zone within South and Southeast Asia. These data have been used to estimate the net change in the amount of carbon sequestered in vegetation over time, but they are particularly useful as input to geographically referenced global carbon models that link human activities to biological and geochemical processes. The following subsections describe the methods and equations used to determine the carbon pool for each land cover class (8), for each country (13), and each ecological zone (94).

\subsection{ESTIMATING CHANGES IN CARBON}

The equation used to calculate the total amount of carbon sequestered in live vegetation for each ecological zone for 1880, 1920, 1950, 1970, and 1980 is as follows:

$$
\operatorname{TCS}_{i}=\sum_{j=1}^{N} L_{j i} A_{j i}
$$


where the total carbon stock of vegetation at time $i\left(\right.$ TCS $\left._{i}\right)$ is calculated based on $L_{j i}$, which is the total carbon (above- and below-ground) in vegetation type $j$ at time $i, A_{j i}$ is the area in vegetation of type $j$ at time $i$, and $N$ is the total number of land use categories within the zone. If $\mathrm{TCS}_{1+1}<\mathrm{TCS}_{i}$, then the difference between the two values represents the amount of carbon lost from live vegetation during the interval $(i+1)-i$. Otherwise, the difference represents the amount of carbon sequestered by vegetation during the given interval.

This equation utilized data from the land use spreadsheets to obtain estimates carbon content for each land use category. It permitted the estimation of the relative importance of changing land use on the amount of carbon sequestered in vegetation through the use of several equations. The output of these equations was used to produce the Step 3 spreadsheets which contain carbon estimates for each ecological zone and country. The equations standardized the methods used in obtaining estimates of the total carbon content of live vegetation per ha $(\mathrm{CPH})$ in each land use category, for each date.

It is important to note that the equations used in the creation of the carbon estimates cannot provide a detailed time course of carbon release or partition carbon into different decay pools. However, their structure does permit an evaluation of the relative importance of biomass as a carbon reservoir in each land use category. Ultimately, the carbon estimates are dependent on biomass estimates that were derived using a variety of methods by several different investigators. These methods are discussed below.

The first of these methods estimated biomass based on dimensional measurements taken during forest inventories. Methods for estimating total above-ground biomass (TAGB) from information contained in stand or stock tables constructed during forest inventories have been applied to about $22 \times 10^{6}$ ha of tropical forests in the study area (Brown et al. 1991). Species-variable multipliers were applied to measurements of commercially useful standing timber to determine the total volume, or biomass, of the forests being inventoried. In the inventories utilized by Brown et al. (1991), TAGB for tropical moist forests $(n=206)$ ranged from below $50 \mathrm{Mg} \mathrm{C} /$ ha to over $500 \mathrm{Mg} \mathrm{C} / \mathrm{ha}$, with a mean value of $225 \mathrm{Mg} \mathrm{C} / \mathrm{ha}$. In tropical dry forests TAGB ranged from $50 \mathrm{Mg} \mathrm{C} / \mathrm{ha}$ to $200 \mathrm{Mg} \mathrm{C} / \mathrm{ha}$, with a mean of $82 \mathrm{Mg} \mathrm{C} / \mathrm{ha}$.

Based on data and methodology of Brown et al. $(1991,1992)$ and Gillespie et al. (1992), Iverson et al. (1993) developed a map of the maximum potential forest biomass (i.e., climax vegetation undisturbed by anthropogenic activities) for South and mainland Southeast Asia. This map was used to estimate the maximum potential above-ground biomass for all portions of the study region covered by the map (including peninsular Malaysia). For those locations not covered by the Iverson et al. biomass map, the methods described below were used (as appropriate) to derive an estimate of TAGB.

The second method for determining the biomass of live vegetation is based on the use of aerial surveys of forest cover (Tiwari and Singh 1987). Estimates of TAGB based on air photos and survey data have been made for forests in Himalayan Uttar Pradesh, India (Tiwari et al. 1985). Tiwari et al. (1985) mapped five crown cover classes for several forest types and then selected test sites that were representative of all combinations of forest type and crown cover. At each test site, the girths of trees greater than $10 \mathrm{~cm}$ was recorded for all species and ground-based measurements of the crown cover were taken. This information was used to construct an empirically based regression model that related TAGB, basal cover, and crown cover for several tree species. By applying these equations to composite air photos it is possible to estimate TAGB for a given tree stand.

The third method, direct biomass measurement, requires the destructive harvest of natural forest vegetation. Biomass estimates obtained by this method are available for India, Thailand, Kampuchea, Malaysia, and Indonesia. Estimates of TAGB range from less than 35 
$\mathrm{Mg} \mathrm{C} / \mathrm{ha}$ for severely degraded tropical dry forests to almost $700 \mathrm{Mg} \mathrm{C} / \mathrm{ha}$ in relatively undisturbed tropical rain forests. TAGB tends to increase with mean annual precipitation within the 0.5 to $2 \mathrm{~m} / \mathrm{yr}$ range.

Biomass data obtained by this method must be treated with caution, because most of the destructive studies were conducted in or near major educational or forestry institutions (implying that the samples were taken from protected refuges) and the number of trees actually harvested in each study was relatively small. This is important because sample size has been shown to affect the accuracy of tropical forest biomass estimates (Negi et al. 1988). Nevertheless, the collective body of destructive-harvest research is an essential guide to the potential range of TAGB per ha as it provides information on the expansion factor that must be used to convert TAGB to an estimate of total below-ground and above-ground carbon for a given land cover class.

The fourth, or last method, is designed to be utilized in areas with nonwoody vegetation. In this method all above ground vegetation for a plot of land (usually less than 1 ha) is harvested, dried, and weighed to determine the TAGB for the given plant species or community. This technique, when used on bamboo stands, has found TAGB's of 41, 179, and $154 \mathrm{Mg} \mathrm{C}$ ha for Myanmar bamboo in dry, moist, and wet locations, respectively, and TAGB of $272 \mathrm{Mg} \mathrm{C} / \mathrm{ha}$ in a 15-year old plantation of Dendrocalamus strictus in Utter Pradesh, India (Seth et al. 1963). In studies conducted in Thailand, by Ogawa et al. (1961), a TAGB of 104 $\mathrm{Mg} \mathrm{C}$ ha was reported for a riverside thicket of Anundo donax, and Ruangpranit (1981) found a TAGB biomass of only $2.7 \mathrm{Mg}$ C/ha for Arundinaria pusilla.

Most biomass measurements of nonwoody vegetation are for grasslands. In South and Southeast Asia, grass and shrub biomass has been found to vary seasonally, with peak values for above-ground biomass in the study area ranging from 0.1 in the dry season to $40 \mathrm{Mg} \mathrm{C} / \mathrm{ha}$ in the wet. Peak total biomass for grass/shrub vegetation for South and Southeast Asia can reach $45 \mathrm{Mg} \mathrm{C} / \mathrm{ha}$, with the proportion allocated to below-ground biomass ranging from almost nil to $95 \%$. Root system biomass in grassland is affected by the proportion of annua: and perennial species; the amplitude of the seasonal fluctuation in rainfall and temperature; and the degree of disturbance from fire, grazing, or trampling (Yadava and Singh 1977, Melkania and Singh 1989).

Most published measurements of herbaceous wetland biomass are from India (i.e., Vyas et al. 1990). These data indicate that the peak above-ground biomass is $5 \mathrm{Mg} \mathrm{C} / \mathrm{ha}$ or below in most herbaceous wetland vegetation, but values as high as $100 \mathrm{Mg} \mathrm{C} /$ ha have been reported. Like grasslands, herbaceous wetland communities may allocate considerable proportions of their total biomass to root systems (up to $50 \%$ ).

The estimates of biomass per ha discussed in the preceding paragraphs may or may not accurately describe the status of the vegetation prior to 1880 . Human activities, especially in the more densely populated areas of the study area, have depleted the standing stock of forests and woodlands. In extreme cases, these disturbances have caused the forests to be transformed into discontinuous forest, grass/shrub communities, or in severe cases, into barren or sparsely vegetated land. In most cases, however, the mean biomass within the forest has been reduced by overgrazing, the rimoval of firewood, and repeated fires. 


\subsection{MODELING OF CARBON CONTENT}

The procedure for making time- and area-specific estimates of the mean above-ground and below-ground carbon per ha (CPH) for each ecological category is based on the following assumptions.

(1) There is a maximum limit to the biomass and carbon content per ha attainable by any vegetation type, where the variable $M$ is the maximum carbon content per unit area for a sizeable stand of totally undisturbed vegetation growing under optimal environmental conditions. $M$, expressed in $\mathrm{Mg}$ of carbon per ha, includes both above- and below-ground carbon in live vegetation. High values of $\mathbf{M}$ are possible in closed forest communities in which the canopy species have the potential to achieve both great height and girth.

(2) At the scale of this analysis, mean forest carbon stock does not achieve or even approach $M$ for any given vegetation class because of environmental factors that limit the development/retention of vegetation biomass.

Accordingly, the actual carbon stock of a given vegetation class is calculated as the product of its potential maximum carbon stock $(\mathrm{M})$ and two fractional multipliers which quantify the estimated reduction of $M$ by environmental limitations (E) and degraclation (D). This equation is represented as follows:

$$
\mathrm{CPH}=\mathrm{M} \times \mathrm{E} \times \mathrm{D}
$$

Within the tropics and subtropics, the amount of carbon sequestered in woody vegetation is positively correlated with precipitation and temperature. Accordingly, as prerequisites for estimating $\mathrm{M}$ for the closed forest class for a given ecological zone, the proportional representation of different climatic regions within each zone must be determined, and the potential climax vegetation by zone must be allocated to the major vegetation categories for which biomass information is available (e.g., tropical dry forest, tropical moist forest or coniferous forest).

\subsubsection{Maximum Carbon Stock for each Land Use Category}

In this data base, the $M$ value for each major vegetation class was fixed at values comparable with the carbon stock of large stands of mature trees grown under optimal conditions. The same $M$ values were applied to zones with comparable macroclimates, vegetation structures, and floristics. The highest $M$ values, 350 to $375 \mathrm{Mg} \mathrm{C/ha}$, were assigned only to locations where climate, soil, and topography are optimal for the development of either tropical dipterocarp forest or Himalayan coniferous forest over a large percentage of the total closed forest class in a given ecological zone. $M$ values of $300 \mathrm{Mg} \mathrm{C} /$ ha are more typical for tropical rain forest and coniferous forest; and $300 \mathrm{Mg} \mathrm{C} / \mathrm{ha}$ is frequently used for tropical moist forest where precipitation is more seasonal; 250 and $200 \mathrm{Mg} \mathrm{C} / \mathrm{ha}$ was typically 
chosen for $\mathrm{M}$ in zones dominated by tropical mesic deciduous forest and tropical dry forest, respectively.

The $M$ value for the interrupted wood class is estimated as $1 / 4$ to $1 / 3$ of the $M$ value for closed forest in the same zone. The rationale for this decision is as follows. Forty per cent crown cover is used as the lower boundary of the Forest/woodland (closed forest) class, and the upper boundary of the Interrupted woods (discontinuous forest) class. Despite that $40 \%$ upper boundary, the average crown cover in the Interrupted woods category is considerably lower-about $10 \%$. Forest volume and biomass are approximately proportional to crown closure, except in stands with relatively open canopies, where the expansion factor relating TAGB and CPH is greater (Brown et al. 1991). The limited data available indicate that forests in the 0 to $20 \%$ crown closure category typically have about $25 \%$, and forests in the 20 to $40 \%$ crown closure category may have up to $50 \%$, of the biomass of the same forest type in the 80 to 100\% crown closure category (Tiwari and Singh 1987, Flint and Richards 1993). As a result, it is assumed that mean carbon content of vegetation in the interrupted woodland class is equivalent to 25 or $33 \%$ of the value for forest/woodland in the same zone. The higher value is used only in zones where climatic factors and popuiation densities permit rapid regrowth of woody species after disturbance.

The $\mathrm{M}$ value for the wetlands class is a weighted average, by area, for both the woody and herbaceous vegetation within the wetlands. Published results indicate that welland forest biomass is generally lower than that of tropical moist forest (Brown et al. 1991). Therefore, $M$ for wetland forests is assumed to be $75 \%$ of the closed forest value used for the same zone, except where available data suggest another ratio. The maximum $M$ for herbaceous wetlands is $80 \mathrm{Mg} \mathrm{C} / \mathrm{ha}$, which is near the top of the range of observed biomass estimates for the bestdeveloped stand of tall emergent macrophytes.

The $M$ value for the grass/shrub class represents the maximum biomass in those systems where significant annual fluctuations in the standing crop occur. Accumulation of carbon in live nonwoody vegetation is not as strongly associated with the amount and seasonality of precipitation as in the closed forest class; so a single $\mathrm{M}$ value of $15 \mathrm{Mg} \mathrm{C} / \mathrm{ha}$ is applied to these zones, except where available data suggest another value. Reduced values of $M$ are used for zones in which development of most of the grass/shrub vegetation is clearly constrained by low precipitation or temperatures.

Much of the land in the barren/sparsely vegetated class bears some plant cover. Even desert and alpine vegetation can achieve a peak biomass of several $\mathrm{Mg} \mathrm{C}$ /ha when the below. ground component is included (Melkania and Tandon 1985). Accordingly, these systems are assigned an $\mathrm{M}$ value of 0 to $5 \mathrm{Mg} \mathrm{C}$ /ha based on the climatic factors (i.e., precipitation, mean temperature, and annual temperature range) that were used in determining $E$.

\subsubsection{Environmental Limitation Multiplier}

The environmental limitation multiplier (E) expresses the degree to which abiotic factors (e.g., soil types, hydrology, topography, and local climatic variations) constrain the maximum potential carbon content $(\mathrm{M})$ in each category of vegetation. The value of $E$ may be as high as 1 in cases where all factors are favorable to plant growth or as low as 0 where adverse environmental factors prevent the growth of vegetation.

One source utilized for scaling the $E$ value is the extensive forestry literature relating forest yield to site quality. Site quality can be defined as the capability of the physical environment of a site to produce a crop of a given species. Site quality effectively integrates 
the limitations of vegetation growth imposed by local climatic, edaphic, and physiographic factors. Operationally, it is usually determined on the basis of one or more measurements of stand height (i.e., above-ground biomass).

The effects of both site quality and stand age on biomass can be quantified for each species by expressing all biomass values in a yield table as percentages of the biomass of a mature stand in the top-quality class. It is then possible to compare the percentages expressing the effect of site quality and stand age on biomass across species. Yield tables that predict the volume of fully stocked monospecific stands as a function of age fur each site quality class, are available for a number of important Asian tree species. These tables reveal the range of volumes expected for commercial forests based on several environmental factors. Yield tables seldom provide estimates of biomass, but the few that do confirm the close correlation between forest biomass and forest volume. Using the methodology of Brown and Lugo (1984) and Brown et al. (1989, 1991, 1992), the potential biomass values associated with each site quality class can be extrapolated from the volume data in yield tables, and then scaled up from TAGB to total biomass (i.e., above- and below-ground biomass). The general method used to estimate TAGB is to first estimate the stem biomass [stem biomass = bole volume (from yield tables) $\times$ specific gravity of wood (for the given species)] and to then apply an expansion factor to convert stem biomass to total biomass. The expansion factor may be calculated from biomass partitioning data, available for some species for stands of known age, or the generalized factors developed by Brown et al. $(1989,1992)$ may be used.

Within the South Asian convention, quality I forests are of the highest quality and quality IV are the lowest. The following trends have been observed for both broad-leafed and coniferous species (Flint and Richards 1993). The biomass in quality II stands is 20 to $40 \%$ less than that of quality I stands. Quality III stands have 40 to $60 \%$ and quality IV stands 60 to $80 \%$ less biomass than quality I stands. (In Java the Roman numerals are used in the reverse order for teak forests; in Indonesia the finest locations are classified as site quality VI, and poorest and most noncommercial are site quality I.) Top-quality trees rarely cover more than a few percent of a sizeable forest tract, with the mean site quality of the best statecontrolled forests seldom reaching quality II (Chakraborty 1972) and quality III veing more typical (Sinha 1962, Dwivedi 1980).

The environmental limitation multiplier $\mathrm{E}$ represents the mean "site quality" of all forest/woodland or interrupted woodland within a given ecological zone. The maximum biomass $\mathrm{M}$ can only be attained by forests growing undisturbed for centuries under optimal conditions (i.e., $\mathrm{E}=1$ ). Site-related limitations usually reduce the average forest biomass to $75 \%$ or less of the maximum value of $\mathrm{M}$, even in forests dominated by commercially valuable species. Mean volume and biomass per ha for forests judged to be noncommercial tend to be lower than that of commercial forests. Accordingly, values for E are 0.75 or less for the forest/woodland and interrupted woodland categories in nearly all zones.

Wetlands include both woody and herbaceous vegetation. $E$ is determined for the woody component using methods comparable to those described in the preceding paragraphs for the forest/woodland class. A separate estimate of $E$ was made for nonwoody wetlands and an area-weighted average of the two values taken.

Generally, a single value of $E$ is assigned to all land use classes dominated by nonwoody vegetation. $E$ is estimated based on direct assessment of annual means and seasonal patterns of precipitation and temperature, along with variations in these factors generated by topographic relief (Melkania and Tandon 1988). Edaphic and hydrological factors known to affect biomass were also considered in the estimation of $E$ for nonwoody vegetation.

For the 100 years covered in this data base, $\mathrm{E}$ is assumed to have remained constant 
for each land use class and zone. This assumption is made as no known major shifts in climate have been noted over this period and biotic conditions (e.g., soil chemistry) have also remained relatively constant.

\subsection{Calculation of $\mathrm{M} \times \mathrm{E}$}

For all ecological zones covered by the biomass map of Iverson et al. (1993), the total above-ground biomass has already been calculated and was determined directly from the map. $\mathrm{CPH}$ is calculated as $50 \%$ of mean mapped TAGB for each zone, and an expansion factor, varying by forest type, is added to this value to account for the below-ground storage of carbon by vegetation.

For zones not included on the map, $\mathrm{M} \times \mathrm{E}$ has been estimated as follows. $\mathrm{M}$ was determined from the sources described in Sections 8.2.1 and 8.2.2. Extrapolations of E were then made from location-specific site quality information for several common gregarious tree species (Champion 1933, Dwivedi 1980). Site quality descriptions in older literature were used to assign $\mathrm{E}$ values for forests that no longer exist.

If published site quality data was unobtainable, as is often the case with mixed-species forests, other information is used to estimate E. For example, because site quality is strongly correlated with canopy height, it may be used as a proxy to assess the limitations placed by abiotic factors on the accumulation of carbon in vegetation. Alternatively, predictions of forest yield, with documented growth data, may be extrapolated from one zone to adjacent zones that have similar climate, topography, and soils. This comparison method was used with Peninsular Malaysia (as the control) to develop estimates of E for Sarawak, Sabah, Indonesia, and the Philippines.

\subsubsection{Degradation Multiplier}

In Eq. 2 the degradation multiplier (D) expresses the reduction of carbon content in vegetation in a given land use class resulting from the direct and indirect removal of biomass

by human activities and livestock. It is assumed that $\mathrm{D}$ operates on existing vegetation (i.e., on the actual communities whose carbon content in an undisturbed state is $M \times E$ ). $D$ is expressed as a decimal fraction which, like $\mathrm{E}$, can range in value from 0 to 1 . $\mathrm{D}$ is equal to 1 only if the human population of a zone exerts so little impact on vegetation that its biomass per ha remains equal to that of virgin forest. The value of $D$ decreases toward zero as human population increases.

To develop a method for estimating $D$, the processes by which human populations remove biomass and the linkage between population density, livestock density, and location and distance to market must be understood. Based on this understanding, a conceptual model can be developed that will predict the value of $\mathrm{D}$ as a function of human and livestock population density and other socioeconomic factors (e.g., timber production). Some general physical and economic constraints apply to all biomass removal processes. Per capita forest removal rates are high as long as supply is high, and decrease as the resource is depleted. Under conditions of scarcity, the real cost of an item will increase and people will change their pattern of resource use by resource substitution. Given this sequence of events, the mean per capita biomass removal should decrease as population density increases.

The removal of biomass will tend to be localized to forests/woodlands located near 
populated areas (or transportation networks), rather than being evenly distributed (Brown et al. 1993, Dawning et al. 1993). Because of this tendency, even sparse populations are likely to remove more biomass from accessible forests than these forests can replace. This biomass removai is not balanced by an increase in biomass in the inaccessible forests because the carbon stock of vegetation in these forests is already in a state of equilibrium. Therefore, even small human populations within an ecological zone can significantly reduce a zone's mean carbon stock.

The primary reasons for biomass removal in South and Southeast Asia involve the distinction between using the forest as a source of energy or materials for the maintenance of subsistence economies versus the removal of biomass to fulfill external demands (i.e., export activities). Within the category of subsistence biomass removal, a further subdivision is needed. The process of biomass removal required to maintain shifting agriculture (the burning of forests to clear a swidden plot) is distinctively different from those required by sedentary agriculture (the collection of firewood, poles, and fodder).

Case studies of biomass removal by Asian communities have been conducted for each of the three modes of agriculture production (Gadgil 1991). Based on this and other studies (see Flint and Richards 1993) ranges of $D$ have been estimated for the forest/woodland category. $\mathrm{D}$ will vary based on the type of agriculture dominating in given region. For example, the degradation factor for subsistence sedentary agriculture ranges from 0.3 to 0.5 , with subsistence shifting agriculture with $>10$ years fallow period having D's of 0.2 to 0.3 . In areas were forest products are exported, D ranges from 0.3 to 0.9 .

\subsubsection{Model of Forest Degradation}

The conceptual model used in the calculation of $D$ for Eq. 2 relates forest degradation to human population and other variables. In the simplest case,

(1) all biomass removals are driven by subsistence requirements of the local population (no biomass export),

(2) all biomass requirements are supplied by the resources available within the boundaries of a given ecological zones (no biomass import), and

(3) subsistence requirements for forest products are independent of population density (constant per capita demand),

Under these circumstances, an inverse relationship between the density of a zone's population and the live biomass of its forests is expected and can be expressed as follows:

$$
D=1 /(1+P)
$$

where $P$ represents the human population density per ha in a zone. Eq. 3 causes the value of $\mathrm{D}$ to vary between one, at zero population density, and zero, at infinite population density. 
This form of model omits the influence of socioeconomic variables that can individually or collectively alter the nature of the relationship between $\mathrm{D}$ and $\mathrm{P}$ by modifying the assumptions stated above. It does not explain residual variations caused by any factor that may cause the subsistence requirement for forest biomass to become dependent on population density or by any factor that promotes the export (or import) of biomass across zone boundaries.

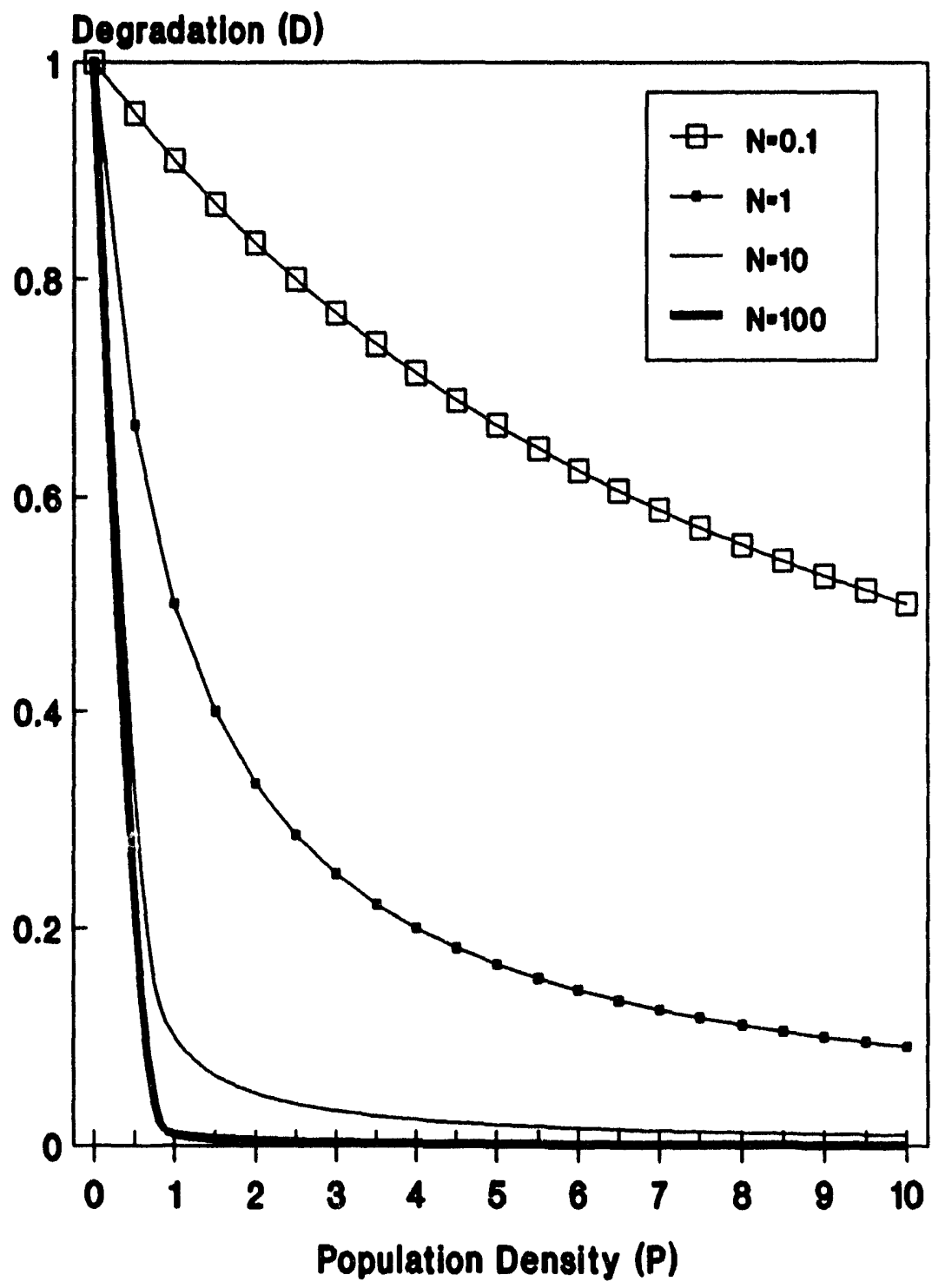

Figure 4. Estimated degradation values as determined by applying Eq. 4 for four $\mathbf{N}$ values. 
Effects of these factors were modeled by constructing a product $(\mathrm{N})$ of the following three factors, S, F, and A and rewriting Eq. 3 as follows:

$$
D=1 /[1+(\mathbf{N} \times \mathbf{P})]
$$

where $\mathrm{N}$ is the product of $\mathrm{S}$, the degree to which the agricultural system in a zone is dominated by shifting cultivation versus other components of a zone's agricultural sector; $F$, the degree to which a zone is a net exporter or importer of forest products; and $A$, the degree to which a zone is a net exporter or importer of agricultural products. Figure 4 shows the variations in $D$ that occur with four different $N$ values. Note that when $N=1$, Eq. 4 reduces to Eq. 3.

The value of $S$ can vary from a minimum value of 1 (where shifting cultivation is absent) to a maximum of 10 (where shifting cultivation is dominant). The value of $\mathrm{S}$ can be estimated from the relative proportions of net sown area in a zone occupied by swidden (shifting cultivation) versus sedentary cropland. The following criteria were used to assign values of $\mathbf{S}$ to each zone for each year.

\begin{tabular}{cc}
\hline $\begin{array}{l}\text { Percentage of crop area, } \\
\text { or total production, in } \\
\text { swidden cropland }\end{array}$ & $\begin{array}{l}\text { Estimated } \\
\text { value of } \\
\mathrm{S}\end{array}$ \\
\hline 0 & 1.0 \\
$1-10$ & $1.0-1.5$ \\
$11-20$ & $1.5-2.0$ \\
$21-30$ & $2.1-3.0$ \\
$31-40$ & $3.1-4.0$ \\
$41-50$ & $4.1-5.0$ \\
$51-60$ & $5.1-6.0$ \\
$61-70$ & $6.1-7.0$ \\
$71-80$ & $7.1-8.0$ \\
$81-90$ & $8.1-9.0$ \\
$91-100$ & $9.1-10$ \\
\hline
\end{tabular}

If information on crop area and production is unavailable for a zone at a given date, the value of $\mathrm{S}$ may also be estimated from the percentage of the total agricultural population of a zone that practices shifting cultivation, as determined from censuses or descriptive material. The value of S may also be based on estimates for other zones or other dates with comparable agricultural systems. Because of the importance of $S$, this factor has been weighted by giving it a range from 1 to 10 (unlike $\mathrm{F}$ and $\mathrm{A}$, below) so that it provides $\sim 50 \%$ of the calculated $\mathrm{N}$ value.

The value of $\mathrm{F}$ may range from a minimum of zero to a maximum of five. The value is 
set at 1 if the forestry sector output within a zone is equivalent to its subsistence demand, with no significant cross border movement of biomass. The maximum value of 5 is assigned to zones where most of the forestry sector output is exported. For zones in which forest sector production is equal to or greater than the internal demand, the value of $F$ can be approximated as follows:

\begin{tabular}{cc}
$\begin{array}{l}\text { Exports as a percentage } \\
\text { of total forestry production }\end{array}$ & $\begin{array}{l}\text { Estimated } \\
\text { value of } F\end{array}$ \\
\hline 0 & 1.0 \\
$1-25$ & $1.1-2.0$ \\
$26-50$ & $2.1-3.0$ \\
$51-75$ & $3.1-4.0$ \\
$>75$ & $4.1-5.0$ \\
\hline
\end{tabular}

F may also take on fractional values between one and zero. This occurs in zones that are net importers of forest materials. The fractional values are determined based on the equation, $\mathrm{F}=1-\mathrm{I}$, where $\mathrm{I}$ is the percent of a zones forest biomass consumption that is imported.

Like $F$, the value of $A$ may range from zero to five. A value of 1 is used if all crop production is locally used for subsistence, with minimal exports or imports. In zones that produce significant quantities of export crops, the value of $A$ increases as the relative importance of the export sector increases up to a limit of 5 , according to the same criteria as used for factor $F$. The dedication of a zone's entire agricultural output to export (i.e., $A=5$ ) would leave the zone unable to feed even a small population; consequently, A seldom exceeds 2 . In cases where imports exceed local production, fractional values are used. The fractional values are determined based on the equation, $A=1-I$, where $I$ is the percentage of a zone's total food demand that is imported.

\subsubsection{Application of the Model (Woody Vegetation)}

For each of the 94 ecological zones at each date, the value of each of the three factors (S, F, and $\mathrm{A}$ ) were estimated and $\mathrm{N}$ calculated. The calculated $\mathrm{N}$, in combination with $P$ (population density), was then used with Eq. 4 to calculate the value of $D$ for woody vegetation. This value of $D$ was then combined in Eq. 2 with the product of $M \times E$ (previously estimated according to the procedures summarized in Section 8.2.3), in order to calculate the estimated carbon stock per ha for each category of woody vegetation in each zone at each date. Except in cases where unusually detailed information was available, the same values of $\mathrm{D}$ were applied to the forest/woodland, interrupted woods, and to the woody subcategory of the wetland vegetation class in each zone.

The estimated total carbon stock for woody vegetation was cross-checked to ensure that the values were reasonably consistent with national level carbon-stock extrapolations from FAO forest volume statistics. The estimated carbon stocks for all zones within a nation were 
also cross-checked against available comparable data on forest productivity at the national level. (These data are generally available only for 1980.) In cases where the values of $D$ differed considerably from published information, we tested the effects of alternative estimates of $S, F$, and $A$ on the zonal carbon stock and adjusted our estimated $N$ to fit the available empirical data. Because of the subjective nature of $S, F$, and $A$, these factor values have not been provided in a digital format; however, they are listed in Appendix B.

\subsection{Application of the Model (Nonwoody Vegetation)}

Equation 3 (Section 8.2.5) was used to obtain the degradation values for nonwoody vegetation. (Equation 4 was not used due to the absence of sufficient information to justify the inclusion of the $\mathrm{S}, \mathrm{F}$, and $\mathrm{A}$ factors). In its original form, as applied to forest vegetation, Eq. 3 defined the value of $P$ as the density of the human population (in persons per ha). However, use of Eq. 3 to calculate the value of $D$ for nonwoody vegetation required an alternative definition of $P$ because several discrete processes actually contribute to the degradation of rangeland. Among them are the removal of above-ground biomass by grazing; damage to plants and the soil by trampling; and the deliberate burning of grasslands by pastoralist seeking to improve the forage quality. The total impact of these activities are directly related to livestock and human population densities within a zone (Dabadghao and Shankarnarayan 1973).

Thus, in South Asia the value of $P$, and by extension D, applied to the grass/shrub complexes, barren/sparse vegetation, and the herbaceous portion of the wetland class was estimated as a function of livestock density, since in South Asia livestock outnumber people by over 2 to 1 in lands available for grazing (i.e., land available for grazing = closed forest + discontinuous forest + grass/shrubs + wetlands + barren/sparse). In Southeast Asia, P was calculated as the sum of the human and livestock densities in each zone. Cultivated areas were omitted from the livestock density calculation because this land is unavailable for grazing due to the multicrop rotations used in most of Asia. Thus, the only difference in the application of Eq. 3 between South and Southeast Asia is that the density of livestock (L) was substituted for $P$ in South Asia and in Southeast Asia livestock and population densities were combined.

Having already estimated the value of $\mathrm{M} \times \mathrm{E}$ according to the procedures summarized in Section 8.2.3, Eq. 2 was used to calculate the estimated carbon stock per ha for the nonwoody vegetation for all zones, at all dates, and within each nation. To allow future caseby-case modification of the estimated $\mathrm{Mg}$ of carbon per ha for each land cover class; the $\mathrm{M}$, $E, D$, and $N$ values used for each ecological zone have been provided in digital form with this NDP.

\subsubsection{Estimation of the Carbon in Built-up and Cultivated Areas}

Human settlements in the study area are seldom completely devoid of vegetation, but few studies have been published concerning the biomass of vegetation in settled areas.

Therefore, $4 \mathrm{Mg} \mathrm{C} / \mathrm{ha}$ has been selected as the maximum $\mathrm{M}$ value for carbon in settled and built-up areas. Such a value is intended as an average for a heterogeneous land use mosaic. Environmental multipliers for the settled/built-up land use class are directly related to rainfall. As for other categories, degradation multipliers were assigned on the basis of population 
density on the assumption that the mean biomass of vegetaion in settled areas will decline with an increase in the population density (as described for nonwooded vegetation).

The carbon content of live vegetation in monospecific crop stands cycles annually from a very low value to a maximum value just prior to harvesting. Standardized estimates of crop carbon content were calculated on the basis of the peak biomass of the crops. The peak biomass of each crop varies based on the crop species (Table 3). The biomass values shown in Table 3 were obtained under optimal environmental conditions. In South and Southeast Asia, biomass rarely reaches even $50 \%$ of this theoretical maximum. Therefore, to estimate the mean carbon content of temporary cropland in a zone, it was necessary to identify the major crops within a zone, estimate the proportional area planted in each, and determine the E value for the zone. This information was used to calculate a weighted mean crop biomass for each zone.

Table 3. Total biomass and yield predictions by the United Nations Food and Agricultural Organization for selected tropical and subtropical crops growing in a field under optimal environmental conditions.

\begin{tabular}{|c|c|c|c|}
\hline $\begin{array}{l}\text { Crop } \\
\text { type }\end{array}$ & $\begin{array}{l}\text { Total biomass } \\
(\mathrm{Mg} / \mathrm{ha})\end{array}$ & $\begin{array}{l}\text { Crop yield } \\
(\mathrm{Mg} / \mathrm{ha})\end{array}$ & $\begin{array}{l}\text { Yield as \% } \\
\text { of biomass }\end{array}$ \\
\hline \multicolumn{4}{|l|}{ Cereals } \\
\hline Rice & 17.6 & 5.3 & 30 \\
\hline Spring wheat & 14.3 & 5.7 & 40 \\
\hline Winter wheat & 12.3 & 4.9 & 40 \\
\hline Maize & 21.0 & 7.3 & 35 \\
\hline Sorghum & 20.6 & 5.1 & 25 \\
\hline Pearl millet & 15.3 & 3.8 & 25 \\
\hline \multicolumn{4}{|l|}{ Legumes } \\
\hline $\begin{array}{l}\text { Soybean } \\
\text { Phaseolus }\end{array}$ & 11.5 & 3.4 & 30 \\
\hline beans & 11.5 & 3.4 & 30 \\
\hline \multicolumn{4}{|l|}{ Root crops } \\
\hline White potato & 15.7 & 9.4 & 60 \\
\hline Sweet potato & 18.6 & 10.2 & 55 \\
\hline Cassava & 24.8 & 13.6 & 55 \\
\hline \multicolumn{4}{|l|}{ Fiber crops } \\
\hline Cotton & 15.9 & 1.1 & 7 \\
\hline
\end{tabular}

(Source: FAO, 1980) 
Permanent crop biomass is higher than that of temporary crops. The area planted in permanent crops with a potentially high biomass (e.g., rubber) expanded dramatically during the twentieth century in many of the countries in the region (Aiken et al. 1982, Donner 1987). Biomass estimates for perennial crops in these zones were based on date-specific information, as the biomass for a given stand increases with age, on the relative proportions of different species, and the relative areas planted with mature and immature trees. Combining such information with published biomass measurements on immature and mature stands of imiportant perennial crops (Flint and Richards 1993), mean values of $\mathrm{CPH}$ in $\mathrm{Mg}$ /ha were estimated for the permanent crop areas of each zone at each date.

\subsection{ORGANIZATION OF CARBON DATA INTO SPREADSHEETS}

In Section 8.2 the methods used to obtain estimates of the mean above-ground and below-ground CPII for each of the seven land use categories have been described (the carbon in live vegetation in the eighth class, surface water, was assumed to be $0.1 \mathrm{Mg} / \mathrm{ha}$ ). For cach zone, the Step 3 spreadsheet of the bookkeeping model generated estimates of the total carbon conicnt of live vegetation in each category at each date, by multiplying the area of land in the category by the appropriate date-specific CPH value. Total carbon sequestered in live vegetation of a zone at each date was then calculated by summing the carbon contents of all categories, as in Eq. 1. Printouts of the national total spreadsheets produced by aggregating the Step 3 zone spreadsheets are contained within Appendix C.

Table 4. Mean carbon content in $\mathrm{Mg}$ C/ha (above and below ground) for each land use class, at each of five dates, for all eight land use categories.

\begin{tabular}{lrrrrr}
\hline & 1880 & 1920 & 1950 & 1970 & 1980 \\
\hline & & & & & \\
\hline & 5.29 & 6.05 & 7.59 & 8.57 & 8.62 \\
NET CULTIVATED AREA & 4.35 & 4.54 & 4.61 & 4.83 & 5.14 \\
$\quad$ Temporary crops & 19.80 & 23.99 & 37.26 & 41.97 & 34.91 \\
$\quad$ Permanent crops & 3.43 & 3.47 & 3.38 & 3.31 & 3.16 \\
SETTLED/BUILT-UP & 151.15 & 137.79 & 121.40 & 104.27 & 92.84 \\
FOREST/WOODLAND & 34.18 & 31.06 & 27.35 & 24.08 & 21.36 \\
INTERRUPTED WOODS & 113.11 & 104.10 & 92.97 & 79.65 & 76.98 \\
WETLANDS & 131.29 & 120.93 & 107.53 & 92.22 & 81.88 \\
$\quad$ Forested wetlands & 19.27 & 17.13 & 14.19 & 10.97 & 9.90 \\
$\quad$ Nonforested wetlands & 7.62 & 7.32 & 6.64 & 6.05 & 5.81 \\
GRASS/SHRUB COMPLEXES & 0.92 & 0.88 & 0.78 & 0.66 & 0.62 \\
BARREN/SPARSELY VEGETATED & 0.10 & 0.10 & 0.10 & 0.10 & 0.10 \\
SURFACE WATER & & & & & \\
\hline
\end{tabular}


To give a notion of the amount of carbon that is sequestered in live vegetation in each land use class, Table 4 was developed. Table 4 shows the mean carbon content per ha for each land use class for the entire 13-country study region. The downward trend in carbon content in all categories of natural vegetation is attributable to increased environmental degradation from the rapid increase in human and livestock population that has occurred since the 1900s.

\subsection{CHANGES IN CARBON}

The estimated total carbon content of live vegetation in South and Southeast Asia has dropped progressively from $59 \times 10^{9} \mathrm{Mg}$ in 1880 to $27 \times 10^{9} \mathrm{Mg}$ in 1980 (Table 5) -almost half of the initial 1880 value. The amount of carbon in live vegetation decreased by $8.9 \times 10^{9}$ $\mathrm{Mg}$ for the 1880-1920 time period and by $8.6 \times 10^{9}$ in the 1950-1980 time period. Throughout the 100 year study period, the carbon stock of the closed forest vegetation class was greater than the carbon content in all other categories combined, although its share of the total (for each time period) declined progressively from $81 \%$ in 1880 to $73 \%$ in 1980 . This decline is due to a reduction in forest area, from $41 \%$ to $27 \%$ of the region, and the reduction in the mean carbon stock of the remaining forests (from degradation) from 151 to $93 \mathrm{Mg}$ ha (Flint and Richards 1993).

Table 5. Total carbon content of live vegetation estimated by class (values are $\times 10^{3}$ Mg) for each year for the $\mathbf{1 3}$ countriea in South and Southeast Asia.

\begin{tabular}{|c|c|c|c|c|c|}
\hline Land use class & 1880 & 1920 & 1950 & 1970 & 1980 \\
\hline NET CULTIVATED AREA & 659,435 & 901,698 & $1,351,325$ & $1,828,431$ & $2,006,009$ \\
\hline Temporary crops & 509,604 & 623,596 & 746,159 & 926,788 & $1,054,088$ \\
\hline Permanent crops & 149,830 & 278,103 & 605,165 & 901,643 & 951,926 \\
\hline SETTLED/BUILT-UP' & 16,444 & 21,316 & 30,537 & 42,948 & 51,393 \\
\hline FOREST/WOODLAND & $47,956,365$ & $40,434,080$ & $32,113,177$ & $24,360,071$ & $19,529,263$ \\
\hline INTERRUPTED WOODS & $3,745,869$ & $3,176,301$ & $2,726,151$ & $2,397,609$ & $2,042,347$ \\
\hline WETLANDS & $6,065,796$ & $5,001,497$ & $3,969,971$ & $3,068,683$ & $2,431,672$ \\
\hline Forested wetlands & $5,898,142$ & $4,868,098$ & $3,875,422$ & $3,003,297$ & $2,380,296$ \\
\hline Nonforested wetlands & 167,655 & 133,398 & 94,549 & 65,386 & 51,373 \\
\hline GRASS/SHRUBB COMPLEXES & 939,334 & 989,871 & 940,519 & 844,446 & 859,292 \\
\hline BARREN/SPARSELY VEGETAT & TED37,637 & 35,485 & 30,549 & 23,950 & 23,000 \\
\hline SURFACE WATER & 1,712 & 1,703 & 1,694 & 1,711 & 1,715 \\
\hline TOTAL C & $59,422,587$ & $50,561,951$ & $41,163,921$ & $32,567,842$ & $26,944,694$ \\
\hline TOTAL C IN FOREST COVER & $57,610,3^{\prime} 75$ & $48,478,478$ & $38,714,749$ & $29,760,976$ & $23,951,908$ \\
\hline
\end{tabular}


In conclusion, the carbon sequestered in forest/woodland vegetation has been reduced by $28.4 \times 10^{9} \mathrm{Mg}$ between 1880 and 1980 , whereas the amount of carbon lost from interrupted woods, wetlands, and grass/shrub lands was $1.7,3.6$, and $0.1 \times 10^{9} \mathrm{Mg}$, respectively. The reduction in carbon stored in live vegetation was caused by two factors: the transfer of land from high biomass to low biomass classes (e.g., from the expansion of agriculture) and (2) a reduction in the mean biomass of each class (i.e., from degradation).

\section{LIMITATIONS AND RESTRICTIONS OF THE DATA}

The following paragraphs recap the limitations and caveats that should be considered when this data base is utilized. Failure to consider these limitations could result in erroneous interpretations of the data.

(1) The land use data contained within this NDP are base primarily on historical land use and census records collected by multinational organizations and local, regional, and national governments within the study area. The accuracy of these data vary by decade and location because of variations in the classification systems and methods used by each government to collect the data. Thus, the land use information contained within this data base may contain errors brought forward from the original data sources.

(2) To reduce the impacts of errors in the source data, mean values for each land use class were calculated (when possible) based on the available data for years bracketing the year of interest. For example, if the year of interest is 1920 and data were available for 1916 and 1922, the data value for 1920 in the data base would represent the weighted mean of these two years. Because of this averaging process the land use values contained herein should be seen as 10 year averages centered on the given date.

(3) The carbon data in this data base were developed utilizing several equations. It is important to recognize that these carbon data do not provide a detailed time course of carbon release or partition carbon into different decay pools, instead these equations were designed to allow an evaluation of the relative importance of each land use category as a carbon reservoir to be made.

(4) Ultimately, the accuracy of the carbon estimates are dependent not only on the assumptions explicitly stated in the description of the model, but also on the assumption that the available estimates of biomass and carbon content of South and Southeast Asian vegetation made by different investigators can be evaluated in a comparative framework, despite the variety of methods used to develop these estimates. 
(5) The carbon estimates for $\mathbf{1 8 8 0}$ for the closed forest class are relatively low when compared with the maximum potential carbon content for climax forests (i.e., $\mathrm{M} \times \mathrm{E}$ ). For example, the average carbon value in 1880 was $99 \mathrm{Mg} / \mathrm{ha}$ for South Asia, $116 \mathrm{Mg} / \mathrm{ha}$ for Mainland Southeast Asia, and $178 \mathrm{Mg} / \mathrm{ha}$ for Insular Southeast Asia. Estimated carbon values in the wetland class for the same date and region are somewhat lower, and estimated values for the discontinuous forest class, lower still. The carbon estimates reflect the longterm removal of forest biomass before 1880 by nonindustrialized populations with modest per capita demands, and do not reflect the amount of carbon that would have been sequestered in live vegetation in an undisturbed (i.e., climax) landscape.

(6) Critical to the successful conversion of the historical land use and land cover data into the eight land use classes utilized in this NDP is an understanding of the inherent limitations of the source data. To assist the user in understanding these limitations, a set of 75 Lotus $1-2-3^{\mathrm{TM}}$ spreadsheets have been provided with this NDP. These spreadsheets describe how the original data sources for each country were translated. Appendix D provides a short description of each of these files. Because of the highly varied format of these spreadsheets, they have not been quality assured by CDIAC and are included in this NDP in the same form as they were received from the primary investigators. 


\section{DATA CHECKS PERFORMED BY CDIAC}

An important part of the data packaging process at the CDIAC is the quality assurance $(\mathrm{QA})$ of the data before its distribution. The QA process is an important component in the value-added concept of assuring accurate, usable information for researchers. The complete QA of a data set can be a time consuming process, since data received by CDIAC are rarely in condition for immediate distribution, regardless of source. The following summarizes the QA checks performed on the various data groups presented in this document.

1. The land use data in the Step 2 spreadsheets, for each of the 94 ecological zones, were compared with the Step 1 spreadsheets to ensure that no errors occurred during the aggregation process.

2. The carbon data, for each of the 94 ecological zones, were recalculated (based on the $M, E$, and D values) and compared with the carbon data contained within the Step 3 spreadsheets.

3. The maximum, minimum, and mean values were generated for all land use and carbon variables and checked for reasonableness.

4. The total land area in each country, along with the human population figures for 1970 and 1980, were compared against a data source with land and population data for 1974-75 (Berry et al. 1978). If significant differences were found between the values in this NDP and the Berry data, values were recalculated and corrected if necessary.

5. The data values for each data variable were graphed to check for outliers and identify discrepancies. Any questionable data were recalculated and corrected as necessary. 


\title{
11. HOW TO OBTAIN THE PACKAGE
}

This document describes the historical land use and carbon data collected by Dr. John Richards and Dr. Elizabeth Flint for the U.S. Department of Energy's Global Climate Change Research Program. This data may be used with a vector or raster geographic information system (GIS) or non-GIS data base systems. The computerized data are available on 9-track magnetic tapes, Exabyte $8 \mathrm{~mm}$ tapes, QIC $1 / 4$ tape cartridges, IBM DOS-compatible floppy diskettes ( $3.5^{\mathrm{n}}$ or $5.25^{\mathrm{n}}$ diskettes), and through an anonymous File Transfer Protocol (FTP) service from CDIAC. Requests for magnetic media should include any specific instructions required by the user and/or the user's local computer system. Requests for this data package should be addressed to:

\author{
Carbon Dioxide Information Analysis Center \\ Oak Ridge National Laboratory \\ Post Office Box 2008 \\ Oak Ridge, Tennessee 37831-6335 \\ U.S.A. \\ Telephone: (615) 574-0390 \\ FAX: (615) 574-2232

\section{BITNET: CDP@ORNLSTC \\ INTERNET: CDP@STC10.CTD.ORNL.GOV \\ OMNET: CDIAC}

The data files may be acquired via INTERNET from CDIAC's anonymous FTP service as follows:

- $\quad$ FTP to CDIAC.ESD.ORNL.GOV (128.219.24.36).

- Enter "ftp" as the user id.

- $\quad$ Enter your electronic mail address as the password (e.g., BIRDT@ORNL.GOV).

- Change to the directory "cd pub/ndp046".

- $\quad$ Set ftp to get ASCII files by using the FTP "ascii" command.

- Acquire the ASCII data files by using the FTP "mget ".asc" command.

- $\quad$ Acquire the ASCII FORTRAN files by using the FTP "mget *.for" command.

- $\quad$ Acquire the ASCII SAS ${ }^{\mathrm{TM}}$ files by using the FTP "mget *.sas" command.

- $\quad$ Set ftp to get binary files by using the FTP "binary" command.

- Acquire the binary Lotus 1-2-3 ${ }^{\mathrm{TM}}$ data files by using the FTP "mget *.wk1" command.

- $\quad$ Acquire the binary ARC/NFO ${ }^{\mathrm{TM}}$ export files by using the FTP "mget *.e00" command.

- $\quad$ Exit the system by using the FTP "quit" command.

- Contact CDIAC by phone, FAX, or electronic mail to order a hard copy of this documentation. 


\section{REFERENCES AND DATA SOURCES}

\subsection{LTTERATURE CITED}

Aiken, S.R., Leigh, C.H., Leinbach, T.R., and M.R. Moss. 1982. Development and Environment in Peninsular Malaysia. McGraw-Hill Int. Book Co., Singapore.

Arhabirama, A., Phantumvanit, D., Elkington, J., and P. Ingkasuwan. 1988. Thailand: Natural Resources Profile. Oxford University Press, Oxford.

Asthana, B.N. and S.S. Srivastava. 1965. Applied Statistics of India. Chaitanya Publications House, Allahabad.

Bacastow, R. and C. Keeling. 1981. Atmospheric carbon dioxide concentrations and the observed airborne fraction. SCOPE 16:103-112.

Berry, L., DeVorsey, L., Fisher, J.S., Hoy, D.R., Johnson, D.L., Pannell, C.W., Thiede, R.L., and J.F. Williams. 1978. Geography and Development: $A$ World Regional Approach. Macmillan Publishing Company, New York.

Bansil, P.C. 1984. Agricultural Statistics in India: A Guide. Oxford and IBH Publishing Company, New Delhi.

Blyn, G. 1966. Agricultural Trends in India, 1891-1947: Output, Availability, and Productivity. University of Pennsylvania Press, Philadelphia.

Bolin, B. 1978. Changes of land biota and their importance for the carbon cycle. Science 196:613-615.

Boomgaard, P. 1988. Forests and forestry in colonial Java, 1677-1942, pp. 59-87 In Changing Tropical Forests: Historical Perspectives on Todays Challenges in Asia, Australasia, and Oceania, Dargavel, J., Nixon, K., and N. Semple (eds.) Centre for Resources and Environmental Studies, Australian National University, Canberra.

Boomgaard, P. (ed.) 1990. Changing Economy in Indonesia: A Selection of Statistical Source Material from the Early 19th Century up to 1940, Volume 10: Foodcrops and Arable Lands, Java 1815-1942. Martinus Nijhoff, The Hague.

Brandis, D. 1897. Indian Forestry. Oriental University Institute, Woking.

Brown, S., and A.E. Lugo. 1984. Biomass of tropical forests: a new estimate based on forest volumes. Science 223:1290-1293.

Brown, S., Gillespie, A.J., and A.E. Lugo. 1989. Biomass estimation methods for tropical forests with applications to forest inventory data. Forest Science 35:881-902. 
Brown, S., Gillespie, A.J., and A.E. Lugo. 1991. Biomass of tropical forests of south and southeast Asia. Canadian J. Forest Research 21:111-117

Brown, S. and L. Iverson. 1992. Biomass estimates for tropical forests. World Resource Review 4:366-384.

Brown, S., Iverson, L., and A.E. Lugo. 1993. Land use and biomass changes of forests in Peninsular Malaysia from 1972 to 1982: a GIS approach, pp. 117-143 In Effects of Land Use Change on Atmospheric $\mathrm{CO}_{2}$ Concentrations: South and Southeast Asia as a Case Study, Dale, V.H. (ed.) Springer-Verlag, New York.

Chai, H.-C. 1964. The Development of British Malaya 1896-1909. Oxford University Press, Kuala Lampur.

Chakraborty, R.N. 1972. First Working Plan for Udaipur Forest Division, Tripura, for the Years 1971-1972 to 1980-1981. Tripura Government Press, Agartala.

Champion, H.G. 1933. Regeneration and management of Sal (Shorea robusta). Indian Forest Records (Silviculture) 3:1-159.

Champion, H.G. 1936. A preliminary survey of the forest types of India and Burma. Indian Forest Records 1:1-279.

Chaudhuri, H.N. 1903. The Cooch Behar State and its Land Revenue Settlements. Cooch Behar State Press, Cooch Behar.

Conservator of Forests, Siam, 1904. Forestry in Siam, pp. 173-181 In The Kingdom of Siam, A.C. Carter (ed.) G.P. Putnam's Sons and Knickerbocker Press, New York.

Cubitt, G.E.S. 1920. Forestry in the Malay Peninsula. A Statement Prepared for the British Empire Forestry Conference, London, 1920. Malay States Government Printing Office, Kuala Lumpur.

Dabadghao, P.M. and K.A. Shankarnarayan. 1973. The Grass Cover of India. Indian Council for Agriculture Research, New Dehli.

Dagar, J.C. 1987. Species composition and plant biomass of an ungrazed and a grazed grassland at Ujjain, India. Tropical Ecology 28:208-215.

Dale, V.H. (ed.) 1993. Effects of Land Use Change on Atmospheric $\mathrm{CO}_{2}$ Concentrations: South and Southeast Asia as a Case Study. Springer-Verlag, New York.

Davis, J.H. 1964. The forests of Burma. Sarracenia 8:1-41.

Dawning, S.L., Iverson, L.R., and S. Brown. 1993. Rates and patterns of deforestation in the Philippines: application of geographic information system analysis. Forest Ecology and Management 57:1-16. 
Donner, W. 1987. Land Use and Environment in Indonesia. University of Hawaii Press, Honolulu, HI.

Dutch East Indies. 1902. Verslag van den Dienst van het Boschwezen over het jaar 1901. 2 Vols., Forest Service of the Dutch East Indies, Landsdrukkerij, Batavia.

Dutch East Indies. 1923. Verslag van den Dienst van het Boschewezen in Nederlansch-Indie over het jarr 1920. Forest Service of the Dutch East Indies, Landsdrukkerij, Weltevreden.

Dwivedi, A.P. 1980. Forestry in India. Jugal Kishore and Company, Dehra Dun.

Feeny, D. 1988. Agricultural expansion and forest depletion in Thailand, 1900-1975, pp. 281287 In World Deforestation in the Twentieth Century, Richards, J.F. and R.P. Tucker (eds.) Policy Studies, Duke Press, Durham, NC.

Flint, E.P. and J.F. Richards. 1989. Bibliography on Tropical Forests and the Global Carbon Cycle, Volume 2, South Asia. ORNL/CDIAC-24/V2, Oak Ridge National Laboratory, U.S. Department of Energy, Oak Ridge, TN.

Flint, E.P. and J.F. Richards. 1991. Historical analysis of changes in land use and carbon stock of vegetation in south and southeast Asia. Canadian J. Forest Research 21:91-110.

Flint, E.P. and J.F. Richards. 1993. Trends in carbon content of vegetation in South and Southeast Asia associated with changes in land use, pp. 201-299 In Effects of Land-use Change on Atmospheric $\mathrm{CO}_{2}$ Concentrations: South and Southeast Asia as a Case Study, Dale, V.H. (ed.) Springer-Verlag, New York.

FAO. 1976. Forest Resources in the Asia and Far East Region. United Nations, FAO, Rome.

FAO. 1980. Report on the Agro-Ecological Zone Project. Volume 4, Results for Southeast Asia. World Soil Resources Report 48/4, FAO, Rome.

FAO. 1981. Forest Resources of Tropical Asia. Tropical Forest Assessment Project, FAO, Rome.

Forest, A. 1980. Le Cambodge et la colonization franciase. Library Editions, L'Harmattan, Paris.

Forest Research Institute (India). 1961. 100 Years of Indian Forestry, 1861-1961. 2 Vols., Editorial Committee for Forest Centenary Publications, Manager of Publications, Dehli.

Furnivall, J.S. 1944. Netherlands India: A Study of Plural Economy. Cambridge University Press, Cambridge, MA.

Gadgil, M. 1991. Deforestation: problems and prospects, pp. 13-85 In History of Forestry in India, Rawat, A.S. (ed.) Indus Publishers, New Delhi. 
Gaertner, E.J.G. and G.K. Beuschel. 1963. Report to the Government of Thailand: Forest Inventory of the Northeastern Region. FAO Expanded Technical Assistance Program, Report 1692, FAO, Rome.

Gaussen, H., Legris, P., Blasco, F., Delacourt, A., Meher-Homji, V.M., and J.P. Troy. 1971. International Map of the Vegetation and of Environmental Conditions, Wainganga. Indian Council for Agricultural Research, Pondichery.

Gillespie, A.J.R., Brown, S., and A.E. Lugo. 1992. Tropical forest biomass estimation from truncated stand tables. Forest Ecology and Management 48:69-87.

Gupta, S.R. and G.P. Mishra. 1978. Relationships between phytosociological attributes and aboveground biomass in grassland communities. Geobios 5:105-107.

Hall, C.A.S., Brown, S., O’Hara, F.M., Bogdonoff, P.B., Barshaw, D., Kaufman, E., and S. Underhill. 1988. Bibliography on Tropical Rain Forests and the Global Carbon Cycle. Volume 1, An Introduction to the Literature. ORNL/CDIAC-24/V1, Oak Ridge National Laboratory, U.S. Department of Energy, Oak Ridge, TN.

Heath, R.G. 1951. Malayan Agricultural Statistics 1949. Bulletins, Economic Series No. 15, Div. of Agriculture, Federation of Malaya, Kuala Lampur.

Henry, Y. 1932. Economie agricole de l'indochine. Govt. General de l'indochine, Hanoi.

Hunting Survey Corp. Ltd. 1962. Air Surveys of Sri Lanka. Ceylon Forestry Dept., Govt. Press, Colombo.

India (Republic). 1954. Indian Livestock Census 1951. Directorate of Economics and Statistics, Manager of Publications, Delhi.

India (Republic). 1972. Indian Livestock Census 1966. Directorate of Economics and Statistics, Manager of Publications, Delhi.

India. 1907-1909. The Imperial Gazetteer of India (New Edition). 26 Vols., Govt. of India, Clarendon Press, Oxford.

Ingram, J.C. 1971. Economic Change in Thailand 1850-1970. Stanford University Press, Stanford, CA.

Iverson, L.R., Brown, S., Prasad, A., Mitasova, H., Gillespie, A.J.R., and A.E. Lugo. 1993. Use of GIS for estimating potential and actual forest biomass for continental South and Southeast Asia, pp. 67-116 In Effects of Land-use Change on Atmospheric $\mathrm{CO}_{2}$ Concentrations: South and Southeast Asia as a Case Study, Dale, V.H. (ed.) Springer-Verlag, New York.

Jack, J.C. 1915. Final Report on the Survey and Settlement Operations in the Bakargnj District, 1900 to 1908. Bengal Secretariat Book Dept., Calcutta. 
Jackson, J.C. 1968. Sarawak: A Geographic Survey of a Developing State. University of London Press, London.

Jahdav, C.G., Singh, C., Prakash, A., and B.K. Roy-Burman. 1972. Bibliography of Census Publications in India. Manager of Publications, Delhi.

Jones, L.W. 1953. Report on the Census of Population held on 4th June 1951 in North Borneo. Crown Agents, London.

Jones, L.W. 1962a. Colony of North Borneo. Report on the Census of Population taken on 10th August 1960. Govt. Printing Office, Kuching.

jones, L.W. 1962b. Colony of Sarawak. Report on the Census of Population taken on 15th June 1960. Govt. Printing Office, Kuching.

Jones, L.W. 1966. The Population of Borneo: A Study of the Peoples of Sarawak, Sabah, and Brunei. University of London, The Athlone Press, London.

Keeling, C.D. and T.P. Wharf. 1991. Atmospheric $\mathrm{CO}_{2}-$ Modern Record, Mauna Loa, pp. $12-$ 15 In Trends' 91: A Compendium of Data on Global Change, T.A. Boden, R.J. Sepanski, and F.W. Stoss (eds.) ORNL/CDIAC-46, Carbon Dioxide Information Analysis Center, Oak Ridge National Laboratory, Oak Ridge, TN.

Kuchle, A.W. (ed.) 1968. International Bibliography of Vegetation Maps. Volume 3, U.S.S.R., Asia, and Australia. Library Series No. 29, University of Kansas, Lawrence, KS.

Kumar, R. 1986. The Forest Resources of Malaysia: Their Economics and Development. Oxford University Press, Oxford.

Kummer, D.M. 1991. Deforestation in the Postwar Philippines. University of Chicago Press, Chicago, IL.

Lal, J.B. 1989. India's Forests: Myth and Reality. Natraj Publishers, Dehra Dun.

Laumonier, Y., Gadrinah, A, and Purnajadja. 1983. Sumatra Sud. Map, 1:5,000,000, Institut de la carte Internationale du Tapis Vegetal, SEAMEO-BIOTROP, Toulouse.

Laumonier, Y., Purnajadja, and Setiabudhi. 1986a. Sumatra Centre. Map, 1:5,000,000, Institut de la carte Internationale du Tapis Vegetal, SEAMEO-BIOTROP, Toulouse.

Laumonier, Y., Purnajadja, and Setiabudhi. 1986b. Sumatra Nord. Map, 1:5,000,000, Institut de la carte Internationale du Tapis Vegetal, SEAMEO-BIOTROP, Toulouse.

Lee, Y.L., 1965. Agriculture in Sarawak. J. Tropical Geography 21:21-29.

Melkania, N.P. and J.S. Singh. 1989. Ecology of Indian grasslands, In Perspectives in Ecology, Singh, J.S. and B. Gopal (eds.) Jagmander Book Agency, New Dehli. 
Melkania, N.P. and J.P. Tandon. 1985. Dry matter yield, and strategies for regeneration of pastures in central Himalaya, pp. 399-409 In Environmental Regeneration in Himalaya: Concepts and Strategies, Singh, J.S. (ed.) Central Himalayan Environmental Association, Gyanodaya Prakashan, Naini Tal.

Melkania, N.P. and J.P. Tandon. 1988. Investigations on the natural grasslands, their degradation and regeneration in Kumaon Himalayas, pp. 137-167 In Himalayas: Ecology and Environment, Chadha, S.K. (ed.) Mittal Publications, Delhi.

Menon, K.P.V. 1976. History and Development of Forestry and Forest Industries in Malaysia ( $A$ Bibliography). Forest Research Institute, Kepong, Selangor.

Negi, J.D., Sharma, S.C., and D.C. Sharma. 1988. Comparative assessment of methods for estimating biomass in forest ecosystems. Indian Forester 114:136-144.

Ogawa, H., Yoda, K, and T. Kira. 1961. A preliminary survey on the vegetation of Thailand, pp. 21-157 In Nature and Life in Southeast Asia. Vol. I, Fauna and Flora Research Society, Kyoto.

Oldeman, L.R. and M. Frere. 1982. Technical Report on a Study of the Agroclimatology of the Humid Tropics of Southeast Asia. FAO/UNESCO/WMP Interagency Project on Climatology, FAO, Rome.

Olson, J.S., Garrels, R.M., Berner, R.A., Armentano, T.V., Dyer, M.I., and D.H. Yaalon. 1985. The natural carbon cycle, In Atmospheric Carbon Diaxide and the Global Carbon Cycle, Trabalka, J.R. (ed.) DOE/ER-0239, U.S. Department of Energy, Washington, DC.

Olson, J.S. and J.A. Watts. 1982. Major world ecosystem complexes (Map), In Carbon Dioxide Review: 1982, Clark, W.C. (ed.) Oxford University Press, New York.

Olson, J.S., Watts, J.A., and L.J. Allison. 1983. Carbon in Live Vegetation of Major World Ecosystems. TR004, DOE/NBB-0037, U.S. Department of Energy, Office of Energy Research, Carbon Dioxide Research Division, Washington, DC.

Osborne, M.E. 1969. The French Presence in Cochinchina and Cambodia. Cornell University Press, Ithaca, NY.

Ramdas, L.A. 1974. Weather and climatic patterns, pp. 99-134 In Ecology and Biogeography of India, Mani, M.S. (ed.) Dr. W. Junk Publishers, The Hague.

Randhawa, M.S. 1983. A History of Agriculture in India, Volume III. Indian Council on Agricultural Research, New Dehli.

Rashid, H. 1977. Geography of Bangladesh. Bangladesh University Press, Dacca. 
Reynolds, H.O. 1927. Land records and agricultural statistics, pp. 12-15 In Agriculture in Burma: A Collection of Papers Written by Government Officials for the Royal Commission on Agriculture, 1926-1928. Govt. Printing and Stationery, Rangoon.

Ribbentrop, B. 1900. Forestry in India. Govt. Printing Office, Calcutta.

Richards, J.H., Olson, J.S., and R.M. Rotty. 1983. Development of a Data Base for Carbon Dioxide Releases Resulting from Conversion of Land to Agricultural Uses. ORNL/TM-8801, Environmental Sciences Division, Oak Ridge National Laboratory, Oak Ridge, TN.

Richards, J.F., Haynes, E.S., and J.R. Hagen. 1985. Changes in the land and human productivity in northern India, 1870-1980. Agricultural History 59:523-547.

Richards, J.F. and E.P. Flint. 1993. A century of land use change in South and Southeast Asia, In Effects of Land-use Changr un Atmospheric $\mathrm{CO}_{2}$ Concentrations: South and Southeast Asia as a Case Study, Dale, V.H. (ed.) Springer-Verlag, New York.

Samapuddhi, K. 1966. Forestry Development in Thailand. Royal Forestry Dept., Bangkok.

Seth, S.K., Kaul, O.N., and A.C. Gupta. 1962. Some observations on nutrient cycling and return of nutrients in plantations at New Forest. Indian Forester 89:90-102.

Sinha, J.N. 1962. Fourth Revised Working Plan for the Reserved and Protected Forests of Saranda Division, Bihar, 1956-57 to 1975-76. Secretariat Press Bihar, Patna.

Sungsawan, S. 1985. A Study on the Causes of Deforestation in Northeast Thailand. M.S. Thesis, Dept. of Economics, Thammasart University, Bangkok.

Tiwari, A.K., Saxena, A.K., and J.S. Singh. 1985. Inventory of forest biomass for Indian Central Himalaya, pp. 236-247 In Environmental Regeneration in Himalaya: Concepts and Strategies, Singh, J.S. (ed.) Central Himalaya Environmental Association, Gyanodaya Prakashan, Naini Tal.

Tiwari, A.K. and J.S. Singh. 1987. Analysis of forest land-use and vegetation in a part of Central Himalaya, using aerial photographs. Environmental Conservation 14:233-244.

Vohra, B.B. 1985. Why India's forests have been cut down. Ecologist 15:50-51.

Vyas, L.N., Sharma, K.P., Sankhla, S.K., and B. Gopal. 1990. Primary production and energetics, pp. 149-175 In Ecology and Management of Aquatic Vegetation in the Indian Subcontinent, Gopal, B. (ed.) Kluwer Academic Publishers, Dordrecht.

Whitmore, T.C. 1984. Tropical Rain Forests of the Far East. Clarendon Press, Oxford.

Williams, L. 1965. Vegetation of Southeast Asia: Studies of Forest Types 1963-1965. Crops Research Div., Agricultural Research Service, U.S. Dept. of Agriculture, Washington, DC. 
Wilson, C.M. 1983. Thailand: A Handbook of Historical Statistics. G.K. Hall and Company, Boston, MA.

Wong, I.F.T. 1969. Land Use Report of Johor. Land Use Section, Soil Sciences Div., Research Branch, Dept. of Agriculture, Kuala Lumpur.

Wong, I.F.T. 1973. The Present Land Use of Sabah, 1970. Sabah Present Land Use Report Number 5, Dept. of Agriculture, Kuala Lumpur.

Wong, I.F.T. 1979. The Present Land Use of Peninsular Malaysia. Ministry of Agriculture, Peninsular Malaysia, Kuala Lumpur.

Woodwell, G.M. and R.A. Houghton. 1977. Biotic influences on the world carbon budget, In Global Chemical Cycles and Their Alterations by Man, Stumm, W. (ed.) Dahlem Konferenzen, Berlin.

Woodwell, G.M., Whittaker, R.H., Reiners, W.A., Likens, G.E., Delwiche, C.C., and D.B. Botkins. 1978. The biota and world carbon budget. Science 199:141-146.

World Bank. 1977. Final Report: Land Use Map Component, Burma Umbrella Project. BUR/74/026, Economic Resources Div., Agriculture and Rural Development Dept., Washington, DC.

Yadava, P.S. and J.S. Singh. 1977. Grassland Vegetation: Its Structure, Function, Utilization, and Management. Vol. II, Today and Tomorrow's Printers, New Dehli.

Yoshino, M.M. 1984. Climate and Agricultural Land Use in Monsoon Asia. University of Tokyo Press, Tokyo. 


\subsection{PRIMARY DATA SOURCES}

\subsubsection{Bangladesh}

Ahmad, N. 1959. The Sundarban forests of East Pakistan -A resource appraisal. Oriental Geographer 3:1-18.

Ahmad, N 1963. The landscape of the Dacca urban area. Oriental Geographer 7:1-18.

Ahmad, N. 1965. Population in Pakistan. Govt. of Pakistan Dept. Films and Publications, Karachi. Ahmad, N. 1976. A New Economic Geography of Bangladesh. Vikas Publ. House, New Delhi.

Ahmed, Mazind Din. 1954. Timber resources and exploitation in Kassalong Reserve, Chittagong Hill Tracts Division. Pakistan J. Forestry 4:189-95.

Ahmed, M. 1987. Bangladesh: how forest exploitation is leading to disaster. Ecologist 17:168-169.

Ahmed, N. 1990. Temporal changes in agricultural land use in Bangladesh, pp. 87-95 In Environmental Aspects of Agricultural Development in Bangladesh, S. Huq, A.A. Rahman, and G.R. Conway (eds.) University Press Lid., Dhaka.

Ali, Mohammad Akram. 1962. Jhum control in the Chittagong Hill Tracts. Pakistan J. Forestry 12:217-19.

Allen, B.C. (comp.) 1905. Assam District Gazetteers. Vol. 2, Sylhet, Caledonian Steam Printing Works, Calcutta.

Allen, Charles. 1900. Chittagong Survey and Settlement Report. Bengal Secretariat Book Depot, Calcutta.

Ascoli, F.D. 1917. Final Report on Survey and Settlement of Dacca District. Govt. Press, Calcutta.

Assam (India). 1915. Assam District Gazetteers. Supplement to Vol. 2, Sylhet, The Assam Secretariat Press, Shillong.

Atiqullah, M. and F. Karim Khan. 1965. Growth of Dacca City: Population and Area (1608-1981). Science Research Project, Dept. of Statistics, University of Dacca, Dacca.

Bangladesh Bureau of Statistics. 1972-1974. Statistical Digest of Bangladesh (annual, 1970/71-1973). Bangladesh Bureau of Statistics, Statistics Div., Ministry of Planning, Dacca.

Bangladesh Bureau of Statistics. 1976-1991. Statistical Pocket Book of Bangladesh (annual, 1975-1990). Bangladesh Bureau of Statistics, Statistics Div., Ministry of Planning, Dacca.

Bangladesh Bureau of Statistics. 1976-1991. Statistical Yearbook of Bangladesh (annual, 1975-1990). Bangladesh Bureau of Statistics, Statistics Div., Ministry of Planning, Dacca. 
Bangladesh Bureau of Statistics. 1976. Population Census of Bangladesh 1974 (one volume for each district). District Census Reports Series, Bangladesh Bureau of Statistics, Dacca.

Bangladesh Bureau of Statistics. 1980. The Yearbook of Agricultural Statistics of Bangladesh 1979-80. Bangladesh Bureau of Statistics, Dacca.

Bangladesh Bureau of Statistics. 1983. District Statistics, 1983 Series (one volume for each district). Bangladesh Bureau Statistics, Dacca.

Bangladesh Census Commission. 1975. Bangladesh Census of Population 1974. Bulletin-2. Assistant Controller-in-Charge, Bangladesh Forms and Publications Office, Dacca.

Bangladesh Dept. of Forestry. 1974. Progress Report 1966-72 by the Department of Forestry of the People's Republic of Bangladesh Prepared for the Tenth Commonwealth Forestry Conference 1974. Dept. of Forestry, Dacca.

Bangladesh Forests Directorate. 1974-1983. Annual Progress Report of Forest Administration in Bangladesh for the Year 1973-74 to 1979-1980. Supt., Bangladesh Govt. Press, Dhaka.

Bangladesh Ministry of Agriculture. 1973. Bangladesh Agriculture in Statistics. Agro-Economic Research Section, Dacca.

Bangladesh Ministry of Cabinet Affairs. 1971-1981. Bangladesh District Gazetteers Series (one volume per district; continuation of East Pakistan District Gazetteers series begun in 1970 by East Pakistan Govt.). Govt. Press, Dacca.

Basu, P.N. 1896. Survey and Settlement of the Dakhin Shahbajpur Estates in the District of Bakerganj, 1889-1895. Bengal Secretariat Book Depot, Calcutta.

Basu, P.N. 1900. Survey and Settlement Report of Tushkhali in the District of Bakarganj, 1894-1898. Bengal Secretariat Book Depot, Calcutta.

Bell, F.O. 1942. Final Report of the Survey and Settlement Operations for the District Dinajpur. Govt. Press, Calcutta.

Bengal. 1908-1923. Bengal District Gazetteers, L.S.S. O'Malley (ed.) Separate volumes for: Khulna (1908), Nadia (1910), Jessore (1912), Faridpur (1913), Rajshahi (1916), Mymensingh (1917), Bakarganj (1918), Pabna (1923), Faridpur (rev., 1925). Bengal Secretariat Book Depot, Calcutta.

Bengal. 1913-1915. Bengal District Gazetteer, B series (Statistics for 1900/1901 to 1910/1911, one volume for each district in Bengal or Eastem Bengal and Assam series). Bengal Secretariat Book Depot, Calcutta.

Bengal. 1923. Bengal District Gazetteer, B series (Statistics for 1910/1911 to 1920/1921, one volume for each district in Bengal Presidency). Bengal Secretariat Book Depot, Calcutta. 
Bengal. 1933. Bengal District Gazetteer, B series (Statistics for 1920/1921 to 1930/1931, one volume for each district in Bengal Presidency). Bengal Secretariat Book Depot. Calcutta.

Bengal Dept. of Land Records and Agriculture. 1892. Report on the Season and Crops of Bengal, 1890-91. Secretariat Press, Calcutta.

Bengal Forest Dept. 1932. Annual Progress Report on Forest Administration in the Presidency of Bengal for the Year 1931-32. Bengal Secretariat Book Depot, Calcutta.

Bertocci, P.J. 1984. Resource development and ethnic conflict: the case of Chittagong Hill Tracts of Bangladesh. pp. 345-361 In Tribal Cultures in Bangladesh, M.S. Qureshi (ed.) Institute of Bangladesh Studies, Rajshahi University, Rajshahi.

Beveridge, H. 1876. The District of Bakergonj, Its History and Statistics. Govt. Press, Calcutta.

Beveridge, H. 1876. Were the Sundarbans inhabited in ancient times? J. Asiatic Society Bengal 10:12-24.

Briscoe, J. 1979. Energy use and social structure in a Bangladesh village. Population and Development Review 5:615-642.

Browne, J.F. 1866. General Report on the Tippera District. Govt. Press, Calcutta.

Candler, E. 1907. The Sundarbans. Blackwood Magazine (London/ No. 182 (August):20-35.

Champion, H.G., S.K. Seth, and G.M. Khattak. 1965. Forest Types of Pakistan. Pakistan Forest Institute, Peshawar.

Champion, H.G., S.K. Seth, and G.M. Khattak. 1968. Manual of Silviculture for Pakistan. Pakistan Forest Institute, Peshawar.

Chatterjee, S.P. 1949. Bengal in Maps: A Geographical Analysis of Resource Distribution in West Bengal and Eastern Pakistan. Orient Longmans Ltd., Calcutta.

Clarke, C.B. 1896. The Sundarbans of Bengal. Geographical J. 8:32-49.

Clay, A.L. 1867. Report on Dacca District. Star Press, Calcutta.

Coffey, T.M. 1940. The Chittagong Hill Tracts Forest Division. Indian For. 66:19-28.

Comming, J.G. 1899. Survey and Settlement of the Chakla Roshnabad Estate in the Districts of Tippera and Noakhali, 1892-99. Govt. Press, Calcutta.

Cowan, J.M. 1928. The flora of the Chakaria Sundarbans. Rec. Botanical Surv. India 11:197-225.

Das, D.K. 1968. The vegetation of Sylhet forests. Pakistan J. Forestry 18:307-16. 
Das, G.C. 1903. Report on the Inam Settlement of Sylhet. Assam Secretariat Printing Office, Shillong.

Datta, R.C. 1906. Survey and Settlement of Pattikara in the District of Tippera. Govt. Press, Calcutta.

Dey, S.C. 1899. Survey and Settlement Report of Joypurhat, Bogra. Govt. Press, Calcutta

Eastem Bengal and Assam. 1908-1912. Eastern Bengal and Assam District Gazetteers. Separate volumes for: Chittagong (1908), Chittagong Hill Tracts (1909), Bogra (1910), Tippera (1910), Rangpur (1911), Noakhali (1911), Dacca (1912), Dinajpur (1912). Bengal Secretariat Book Depot, Calcutta.

Eastem Bengal and Assam (India) Dept. of Agriculture. 1901. Report on the Season and Crops of Eastern Bengal, 1907-08. Govt. Press, Shillong.

East Pakistan. 1770. East Pakistan District Gazetteers. Separate volumes for Chittagong, Sylhet, Dacca Govt. Press, Dacca.

East Pakistan Bureau of Statistics. 1965. Abstract of Agricultural Statistics of East Pakistan (Land and Crop Statistics) for 1947-48 to 1958-59. Vol. I, East Pakistan Govt. Press, Dacca.

East Pakistan Bureau of Statistics. 1971. Abstract of Agricultural Statistics of East Pakistan 1966. Vol. 2, East Pakistan Bur. Stat., Dacca.

Fawcus, L.R. 1927. Final Report on the Survey and Settlement Operations in the District of Khulna 1920-1926. Govt. Press, Calcutta.

Forestal Forestry and Engineering Intemational Ltd. 1966. Soil and Land Use Survey, 1964-66, Chittagong Hill Tracts, East Pakistan. Forestal, Dacca.

Gastrell, J.C. 1868. Geographical and Statistical Report of the Districts of Jessore, Faridpur and Bakarganj. Govt. Press, Calcutta.

Ghani, Q. 1955. The cultivation of rubber in East Pakistan. Pakistan J. Forestry 5:178-82.

Ghulam Rabbani, A.K.M. and associates. 1984. Bangladesh Population Census 1981: Analytical Findings and National Tables. Bangladesh Bureau of Statistics, Dhaka.

Ghulam Rabbani, A.K.M. and M. Hussain. 1979. Bangladesh Population Census in Retrospect: Sub-national and Inter-district Comparisons of 1961 and 1974 Census. Bangladesh Bureau of Statistics, Dacca.

Hedayetullah, S. 1958. The study of tropical vegetation with particular reference to Pakistan, pp. 144-153 In Studies of Tropical Vegetation: Proceedings of the Kandy Symposium. UNESCO, Paris. 
Howes, M. and M.A. Jabbar. 1986. Rural Fuel Shortages in Bangladesh: The Evidence from Four Villages. Discussion Paper 213, Institute of Development Studies, University of Sussex, Sussex.

Howlader, N.I. 1971. Coastal afforestation in Noakhali District. Pakistan J. Forestry 21:179-82.

Hunter, W.W. 1875-76. A Statistical Account of Bengal: Vols. 1, 2, 5, 6, 7, 8, 9. Trubner and Co., London.

Hunter, W.W. 1879. A Statistical Account of Assam. Vol. 2, District of Goalpara (including the Eastem Dwars), the Garo Hills, the Naga Hills, the Khasi and Jaintia Hills, Sylhet and Cachar. Trubner and Co., London.

Huq, M. 1953. Final Report on the Revisional Survey Settlement Operations in the District of Bakerganj, 1940-42 and 1945-52 and Khulna Sundarbans 1947-50. Govt. Press, Dacca.

Husain, T. 1959. Fuel Wood in Pakistan. Forestry Occasional Paper No. 7, Food and Agriculture Organization of the United Nations, Rome.

Hussain, M. 1987. Bangladesh energy resources and renewable energy prospects. Energy 12:369-374.

Hutchinson, R.H.S. 1906. An Account of the Chittagong Hill Tracts. Bengal Secretariat Book Depot, Calcutta.

India Dept. Commercial Intelligence and Statistics. 1933. Agricultural Statistics of India for the Year 1930-31. 2 vols, Directorate of Economics and Statistics, Manager of Publications, Delhi.

India Dept. Commercial Intelligence and Statistics. 1945. Agricultural Statistics of India for the Year 1938-1939. Manager of Publications, Delhi.

India Dept. Revenue and Agriculture. 1886-1891. Returns of Agricultural Statistics for British India (annual, 1884/85 to 1889/1890). Superintendent, Govt. Printing, Calcutta.

India Dept. Revenue and Agriculture. 1902. Agricultural Statistics of India for the Years 1896-97 to 1900-01. 2 vols., Office of the Superintendent of Govt. Printing, Calcutta.

India Dept. Revenue and Agriculture. 1904. Agricultural Statistics of India for the Years 1898-99 to 1902-03. 2 vols., Office of the Superintendent of Govt. Printing, Calcutta.

India Dept. Revenue and Agriculture. 1913. Agricultural Statistics of India for the Years 1906-07 to 1910-11. 2 vols., Office of the Superintendent of Govt. Printing, Calcutta.

India Dept. Revenue and Agriculture. 1915. Quinquennial Review of Forest Administration in British India for the Period 1909-10 to 1913-14, to Which is Appended the Annual Return of Forest Statistics for the Year 1913-1914. Govt. Monotype Press, Simla. 
India Dept. Revenue and Agriculture. 1920. Quinquennial Review of Forest Administration in British India for the Period 1914-15 to 1918-19, to Which is Appended the Annual Return of Forest Statistics for the Year 1918-19. Govt. Monotype Press, Simla.

India Dept. Statistics. 1896. Agricultural Statistics of British India for the Years 1890-91 to 1894-95. Superintendent, Govt. Printing, Calcutta.

India Dept. Statistics. 1921, 1922. Agricultural Statistics of India, 1919-20 and 1920-21. Superintendent, Govt. Printing, Calcutta.

India Forest Dept. 1915. Quinquennial Review of Forest Administration in British India for the Period 1909 to 1914 to which is Appended the Annual Return of Forest Statistics for the year 1913-14. Govt. Monotype Press, Simla.

India Forest Dept. 1921. Annual Return of Statistics Relating to Forest Administration in British India for the Year 1919-20. Govt. Monotype Press, Simla.

India Forest Dept. 1922. Annual Return of Statistics Relating to Forest Administration in British India for the Year 1920-21. Superintendent Govt. Printing, Calcutta.

India Inspector General of Forests. 1906. Review of Forest Administration in British India for the Year 1904-1905. Maps, Office of the Superintendent of Govt. Printing, Calcutta.

India Inspector General of Forests. 1907, 1908. Review of Forest Administration in British India for the Year, 1905-1906, 1906-1907. Superintendent Govt. Printing, Calcutta.

India Inspector General of Forests. 1910. Review of Forest Administration in British India for the Year 1907-1908. Superintendent Govt. Printing, Calcutta.

Ishaq, S.M. 1959. A Study of the Fuel Wood Problem in Pakistan. Pakistan Forest Institute, Peshawar.

Ishaque, H.S.M. 1946. Agricultural Statistics by Plot to Plot Enumeration in Bengal 1944-45. Supt. Govt. Printing, Bengal Govt. Press, Alipore.

Islam, M.A., M.M. Miah, N. Islam, M.F. Huq, M.A. Taher, M. Hossain, Q.N. Islam, and A.K.M. Nasimuzzaman. 1981. Bangladesh in Maps. University of Dacca, Dacca.

Islam, M.N. 1984. Energy and rural development: critical assessment of the Bangladesh situation, pp. 43-88 In Rural Energy to Meet Development Needs: Asian Village Approaches, M. N. Islam, R. Morse, and H. Soesastro (eds.) Westview Press, Boulder, CO. 
Jack, J.C. 1915. Final Report on the Survey and Settlement Operations in the Bakarganj District. 1900 to 1908. Bengal Secretariat Book Depot. Calcutta.

Johnson, B.L.C. 1975. Bangladesh. Harper and Row, New York.

Kabir, M. 1981. Regional Variations in the Growth of Population in Bangladesh. Occasional Paper 3, Centre for Population Studies, Jahangimagar University, Dacca.

Kennes, W., J.K. Parikh, and H. Stolwijk. 1984. Energy from biomass by socio-economic groups -A case study of Bangladesh. Biomass 4:209-234.

Khan, F.K. 1960. Agricultural origins in East Pakistan and adjoining areas. Oriental Geographer 4:47-57.

Khan, F.K. and A.L. Khisha. 1970. Shifting cultivation in East Pakistan. Oriental Geographer 14:22-43.

Khattak, G.M. 1979. History of forest management in Bangladesh. Pakistan J. Forestry 29:121-128.

Kindersly, J.B. 1933. Final Survey and Settlement Report of Chittagong District. Govt. Press, Calcutta.

Lewin, T.H. 1869. The Hill Tracts of Chittagong and the Dwellers Therein. Orphan Press, Calcutta.

MacPherson, D. 1930. Final Report on the Survey and Settlement Operations in the Districts of Pabna and Bogra, 1920-1929. Bengal Secretariat Book Depot, Calcutta.

Momen, M.A. 1925. Final Report on the Survey and Settlement Operations in the District of Jessore. Govt. Press, Calcutta.

Mozumder, S.Z. 1981. The energy situation in Bangladesh and a strategy for future development. Energy 6:809-816.

Mozumder, S.Z. 1983. Energy efficiency and conservation in Bangladesh. Energy 8:69-72.

Mukerjee, R. 1938. The Changing Face of Bengal: A Study in Riverain Economy. Calcutta University Press, Calcutta.

Mukherjee, A.K. 1917. Report on the Survey and Settlement Operations of the Makimpur Estate of Jessore, 1909-1916. Govt. Press, Calcutta.

Mukherjee, S.C. 1928. Supplement to the Final Report on the Survey and Settlement Operations in the District of Khulna, 1926-27. Govt. Press, Calcutta. 
Pakistan Central Statistical Office. 1968. 20 Years of Pakistan in Statistics, 1947-1967. Economic Affairs Div., Manager of Publications, Karachi.

Pakistan Central Statistical Office. 1970. Pakistan Statistical Yearbook 1968. Economic Affairs Div., Manager of Publications, Karachi.

Pakistan Dept. Agricultural Economics and Statistics. 1962. Land and Crop Statistics of Pakistan. Manager of Publications, Karachi.

Pakistan Ministry of Agriculture and Works (Planning Unit). 1970. Agricultural Statistics of Pakistan. Pakistan Press, Karachi.

Pakistan Office of Census Commissioner. 1961. Population Census of Pakistan 1961. Census Bulletin No. 2. Sex, Urban-Rural, Religion, Non-Pakistanis. Final Release by Thanas in East Pakistan and Tehsils in West Pakistan. Manager of Publications, Karachi.

Pakistan Office of Census Commissioner. 1964. Population Census of Pakistan 1961, District Census Reports (one volume per district; series includes all districts of both East and West Pakistan as then constituted). Manager of Publications, Karachi.

Parikh, J.K. 1982. Perspectives on rural energy: demand, supply and constraints, pp. 57-76 In National Energy Planning and Management in Developing Countries, H. Neu and D. Bain (eds.) D. Reidel Publ. Co., Dordrecht, Netherlands.

Parikh, J.K. 1985. Modeling energy and agriculture interactions: I. A rural energy systems model. Energy 7:793-804.

Parikh, J.K. 1988. Bangladesh: agriculture, biomass, and environment, pp. 331-364 In Sustainable Development in Agriculture, J.K. Parikh (ed.) Martinus Nijhoff Publishers/Kluwer Academic Publishers Group, Dordrecht, Netherlands.

Parikh, J.K. and G. Kromer. 1985. Modeling energy and agriculture interactions: II. Food-fodder-fuel-fertilizer relationships for biomass in Bangladesh. Energy 10:805-817.

Paul, B.K. 1983. Demographic Regionalization of Bangladesh. Occasional Paper 9, Centre for Population Studies, Jahangimagar University, Dhaka.

Prance, B.C. 1916. Final Report on the Survey and Settlement Operations in the Riparian Area of District Tippera Conducted with Faridpur District Settlement, 1909-15. Govt. Press, Calcutta.

Pringle, I.M. and A.H. Kemm. 1928. Final Report on the Survey and Settlement Operations in the District of Nadia, 1918-1926. Govt. Press, Calcutta.

Rahman, M. Azizur and A.M.Z. Huq. 1980. Energy resources in Bangladesh -Problems and prospects, pp. 328-340 In Energy in the Developing World: The Real Energy Crisis, V. Smil and W.E. Knowland (eds.) Oxford University Press, Oxford. 
Rajput, A.B. 1963. The Tribes of the Chittagong Hill Tracts. Pakistan Publications, Karachi.

Rashid, H. 1977. Geography of Bangladesh. University Press, Dacca.

Sachse, F.A. 1920. Final Report on the Survey and Settlement Operations in the District of Mymensingh, 1908-1919. Bengal Secretariat Book Depot, Calcutta.

Seidensticker, J. and M.A. Hai. 1983. The Sundarbans Wildlife Management Plan: Conservation in the Bangladesh Coastal Zone. Int. Union Conserv. Nature and Nat. Resources, Gland, Switzerland.

Sen, K.S. 1893. Survey and Settlement Report of Sarail in the District Tippera. Govt. Press, Calcutta.

Sen, R.C. 1899. Final Report on the Survey and Settlement of the Tushkhali Government Estates in the District of Khulna, 1894-1898. Govt. Press, Calcutta.

Sen, R.C. 1916. Final Report on the Survey and Settlement Operations of the Faridpur District 1904-1914. Govt. Press, Calcutta.

Sen, R.C. 1916. Final Report on the Survey and Settlement of the Tushkhali Govt. Estates in the District of Bakergonj, 1912-1916. Bengal Secretariat Book Depot, Calcutta.

Sengupta, S.C. 1899. Final Report on the Survey and Settlement of the Tantibunia Estate in Khulna District, 1894-1898. Govt. Press, Calcutta.

Shamsuddin, M. and N. Rahman. 1980. Country paper of Bangladesh, pp. 74-76 In Proceedings of the Working Group Meeting on Efficiency and Conservation in the Use of Energy.

NR/ECUE/CRP.6, Energy Resources Development Series No. 22, UNESCAP, United Nations, New York.

Sherwill, J.L. 1868. Geographical and Statistical Account of Dinajpur District. Govt. Press, Calcutta.

Smart, G.R. 1866. Geographical and Statistical Report on the District of Tippera. Govt. Press, Calcutta.

Sopher, David. 1963. Population dislocation in the Chittagong Hills. Geographical Review 53:339.

Sopher, David. 1964. The swidden/wet rice transition in the Chittagong Hills. Ann. Assoc. American Geographers 54:96-109.

Stebbing, E.P. 1952. Chittagong fifty years ago. Pakistan J. Forestry 2:8-12. 
Task Force Bangladesh (M. Hossain, B.E.K. Jahangir, F.I. Chowdhury, A.U. Sarkar, S. Rahman, et al.). 1979. Population in Forestry Communities Practicing Shifting Cultivation: A Case Study of Bangladesh. Bangladesh Inst. Development Studies, Dacca.

Taylor, D.G. 1840. A Sketch of the Topography and Statistics of Dacca. Orphan Press, Calcutta.

Thomson, W.H. 1920. Final Report on the Survey and Settlement Operation in the District of Tippera, 1915-19. Govt. Press, Calcutta.

Vahid, S.A. 1952. Forestry and agriculture in Pakistan. Pakistan J. Forestry 2:13-31.

Wennergren, E.B., C.H. Anholt, and M.D. Whitaker. 1984. Agricultural Development in Bangladesh. Westview Press, Boulder, CO.

Westland, James. 1870. A Report on the District of Jessore and Its Antiquities, History and Commerce. Govt. Press, Calcutta.

Zahir-ud-Din, A.S.M. 1954. Aerial survey of Chittagong Hill Tracts forests. Pakistan J. Forestry 4:237-40. 


\subsubsection{Brunei}

Anderson, J.A.R. 1958. Studies of freshwater swamp forests of Sarawak and Brunei, pp. 195-96 In Study of Tropical Vegetation: Proceedings of the Kandy Symposium (19-21 March 1956).

UNESCO, Paris.

Anderson, J.A.R. 1957. The enumeration of 235 acres of dipterocarp forest in Brunei. Malayan For. 20:144-49.

Anderson, J.A.R. 1964. The structure and development of the peat swamps of Sarawak and Brunei. J. of Tropical Geography 18:7-16.

Anderson, J.A.R. 1983. The tropical peat swamps of Westem Malaysia, pp. 181-99 In Swamp, Bog, Fen and Moor: Regional Studies. A.J.P. Gore (ed.) Ecosystems of the World 4B, Elsevier Scientific Publ. Co., Amsterdam.

Ashton, P.S. 1964. Ecological Studies in the Mixed Dipterocarp Forests of Brunei State. Oxford For. Mem. No. 25, Clarendon Press, Oxford.

Ashton, P.S. 1964. Manual of the Dipterocarp Trees of Brunei States. Oxford University Press, Oxford.

Austin, M.P., P.S. Ashton, and P. Greig-Smith. 1972. The Application of Quantitative Methods to Vegetation Survey III. A Re-Examination of Rain Forest Data from Brunei. J. Ecology 60:305-24.

Browne, F.G. 1955. Forest Trees of Sarawak and Brunei. Sarawak Govt. Printer, Kuching.

Brunei. 1964-65. State of Brunei Annual Report: 1961-1963. Brunei Press Ltd., Kuala Belait.

Brunei. 1966-1973. State of Brunei Annual Report: 1964-1966, 1969, 1972. Govt. Printer, Kuala Belait.

Brunei State Secretariat Information Sector. 1978, 1983. State of Brunei Annual Report, 1977, 1982. Govt. Printing Dept., Kuala Belait.

Brunei Forest Dept. 1935-1939. Brunei Report on Forest Administration for the Year (annual, 1934-1938). Sarawak Govt. Printing Office, Kuching.

Brunei Forest Dept. 1954. Brunei Report on Forest Administration 1953. Govt. Printing Office, Kuching.

Brunei Forest Dept. 1955. State of Brunei Forestry Development Plan, 1954-1964. Govt. Printing Office, Kuching. 
Brinig, E.F. 1968. Some observations on the staius of heath forests in Sarawak and Brunei, pp. 451-56 In Proceedings of the Symposium on Recent Advances in Tropical Ecology, R. Misra and B. Gopal (eds.) International Society for Tropical Ecology, Varanasi.

Brinig, E.F. 1974. Ecological Studies in the Kerangas Forests of Sarawak and Brunei. Bomeo Literature Bureau for Sarawak Forest Dept., Kuching.

Chapman, V.J. 1977. Wet coastal formations of Indo-Malaysia and Papua-New Guinea, pp. 261-70 In Ecosystems of the World 1: Wet Coastal Ecosystems, V.J. Chapman (ed.) Elsevier Scientific Publ. Co., Amsterdam.

Christensen, Bo. 1983. Mangroves -what are they worth? Unasylva 35(139):2-15.

Flemmich, C.O. 1940. History of shifting cultivation in Brunei 1906-1939. Malayan For. 11:167-169.

Gilliland, H.B. 1960. A coniferous forest in Bomeo. Malayan For. 23:217-20.

Great Britain Colonial Office. 1907-1940. Annual Report on the State of Brunei for the Year, 1906-1938. Microfilm of Colonial Office records CO824/1-2, H.M.S.O., London.

Great Britain Colonial Office. 1934-1955. Economic Survey of the Colonial Empire, 1932, 1933, 1935, 1937, 1951. H.M.S.O., London.

Great Britain Colonial Office. 1949-1962. State of Brunei Annual Report for the Year: 1948-1962. H.M.S.O., London.

Harris, G.L. 1956. North Borneo, Brunei, Sarawak. Human Relations Area Files, New Haven, CT. Jacobs, M. 1974. Botanical panorama of the Malaysian Archipelago (vascular plants), pp. 263-94 In Natural Resources of Humid Tropical Asia (Natural Resources Research XII). UNESCO, Paris.

Lee, Y. 1973. Brunei. pp. 41-44 In World Atlas of Agriculture, Vol. 2. Asia and Oceania. Istituto Geografico de Agostini-Novara, Novara.

Malay States (Federated) Forest Dept. 1936-1941. Report on Forest Administration in Malaya, Including Brunei, for the Year, 1935-1940. Federated Malay States Govt. Press, Kuala Lumpur.

Noakes, J.K. 1950. The Colony of Sarawak and the British Protected State of Brunei. A Report of the 1947 Population Census. Govt. Printer, Kuching.

Smythies, B.E. 1956. Forests and forestry in Brunei. Malayan For. 19:19-24. 
Specht, R.L. and J.S. Womersley. 1979. Heathlands and related shrublands of Malaysia (with particular reference to Bomeo and New Guinea), pp. 321-88 In Heathlands and Related

Shrublands: Descriptive Studies, R.L. Specht (ed.) Ecosystems of the World 9A, Elsevier Scientific Publ. Co., Amsterdam.

Treacher, W.H. 1890. British Borneo: sketches of Brunei, Sarawak, Labuan and North Borneo. J. Straits Branch Royal Asiatic Society 21:19-121.

Whitmore, T.C. 1978. The forest ecosystems of Malaysia, Singapore and Brunei: description, functioning and research needs, pp. 641-53 In Tropical Forest Ecosystems: A State-of-Knowledge Report. UNESCO/UNEP/FAO, Paris.

Whitmore, T.C. 1984. Vegetation map of Malaysia at scale 1:5 million. J. Biogeography $11: 461-71$.

Whitmore, T.C. 1984. Tropical Forests of the Far East. 2nd edition, Clarendon Press, Oxford. 


\subsubsection{India}

Adams, A. 1899. The Western Rajputana States. A Medico-Topographical and General Account of Marwar, Sirohi, Jaisalmer. Junior Army and Navy Stores Ltd., London.

Adiceam, E. 1967. La canne a sucre au Pays Tamil (Sugarcane in the Agriculture of Tamil Nadu]. Trav. Sec. Sci. Tech. Tome IV, Fasc. 2, Institut Francais, Imprimerie de la Mission, Pondichery.

Agarwal, D.C. 1972. Agricultural Efficiency in Vindhya Pradesh. Registrar, University Indore, Indore.

Agarwala, V.P. 1989. Forests in India. 2nd edition, Oxford and IBH Publ. Co., New Delhi.

Ahmad, E. 1965. Bihar: a Physical, Economic and Regional Geography. Ranchi University. Ranchi, Bihar.

Aiyer, A.K. Yegna Narayan. 1980. Field Crops of India: With Special Reference to Karnataka. 7th edition, BAPPCO Publications, Bangalore.

Alam, M. 1987. Supply and demand of fuel wood in the domestic sector -the case of Hyderabad city, pp. 531-546 In Global Energy Interactions, R.K. Pachauri (ed.) Allied Publishers Private Ltd., Ahmedabad.

Alam, M., J. Dunkerley, and A.K. Reddy. 1985. Fuelwood use in the cities of the developing world: two case studies from India. Natural Resources Forum 9:205-213

Alam, M., J. Dunkerley, K.N. Gopi, W. Ramsay, and E. Davis. 1985. Fuelwood in Urban Markets: A Case Study of Hyderabad. Concept Publ. Co., New Delhi.

Allen, B.C. (ed.) 1905-1906. Eastern Bengal and Assam District Gazetteers. 11 vols. (last volume added in 1928), Pioneer Press, Allahabad.

Allen, B.C. (ed.) 1906. Provincial Gazetteer of Assam. Eastem Bengal and Assam Secretariat, Shillong.

Allen, B.C., E.A. Gait, C.G.H. Allen, and H.F. Howard (eds.) 1906. Gazetteer of Bengal and North East India. Assam Secretariat Press, Shillong. Reprinted 1979 by Mittal Publications, Delhi.

Anant Ram, R.B. and H.N. Raina. 1933. Census of India 1931. Jammu and Kashmir State. Vol. XXIV, Part I Report, Superintendent, The Ranbir Govt. Press, Jammu.

Andhra Pradesh (State). 1970-1983. Andhra Pradesh District Gazetteers. Director of Printing and Stationery, Hyderabad.

Andhra Pradesh Bureau of Economics and Statistics. 1962. Statistical Abstract of Andhra Pradesh 1962. Bureau of Economics and Statistics, Hyderabad. 
Andhra Pradesh Bureau of Economics and Statistics. 1973. Statistical Abstract of Andhra Pradesh 1971. Bureau of Economics and Statistics, Hyderabad.

Andhra Pradesh Bureau of Economics and Statistics. 1980-1987. Statistical Abstract of Andhra Pradesh (annual 1978-79, 1979-80, 1981, 1982, 1985). Bureau of Economics and Statistics, Hyderabad.

Andhra Pradesh Planning Atlas Project. 1980. Planning Atlas of Andhra Pradesh (Supplement). Govt. of India and Andhra Pradesh, Hyderabad.

Ansari, S.A. 1985. Some Aspects of the Geography of Manipur. B.R. Publ. Co., Delhi.

Arora, R.K. 1961. The forests of North Kanara district. J. Indian Bot. Soc. 40:187-200.

Arora, R.K. 1963. The forests of North Kanara district: III. evergreen type. J. Indian Bot. Soc. 42:38-60.

Arora, R.K. 1965. Ecological notes on the vegetation of Coorg district, Westem Ghats. Indian For. 91:722-742.

Arora, R.K. 1965. The vegetation of South Kanara district, Westem Ghats, India: I. General features and floristic composition of bioedaphic types. J. Indian Bot. Soc. 44:433-467.

Arora, R.K. 1966. The vegetation of South Kanara district, Westem Ghats, India. J. Indian Bot. Soc. 45:304-316.

Arora, R.K. 1967. The vegetation of South Kanara district, Westem Ghats, India. IV. Succession in plant communities. J. Indian Bot. Soc. 46:15-24.

Arunachal Pradesh (State). 1978-1990. Arunachal Pradesh District Gazetteers. 5 vols., Govt. Arunachal Pradesh, Shillong.

Arunachal Pradesh Dept. of Agriculture and Rural Development. (Agricultural Census Wing). 1979. State Report on Agricultural Census, 1976-77. Arunachal Pradesh Directorate of Agriculture and Rural Development, New Itanagar.

Arunachal Pradesh Director of Information and Public Relations. 1973. Arunachal 1947-72. Director of Information and Public Relations Arunachal Pradesh, Shillong.

Assam (State). 1967-1979. Assam District Gazetteers. 7 vols., Govt. of Assam, Gauhati. Assam Chief Conservator of Forests. 1964. Forests of Assam. Dhoomi Mal Ram Chand, New Delhi.

Assam Dept. of Economics and Statistics. 1970. Statistical Abstract of Assam, 1967-68. Govt. Press, Shillong. 
Assam Dept. of Economics and Statistics. 1972. Siatistical Handbook: Assam 1971. Dept. of Economics and Statistics, Govt. of Assam, Shillong.

Assam Directorate of Economics and Statistics. 1980. Statistical Abstract: Assam 1978. Govt. of Assam, Gauhati.

Assam Directorate of Economics and Statistics. 1981. Statistical Handbook: Assam 1980. Directorate of Economics and Statistics, Govt. of Assam, Gauhati.

Asthana, B.N. and S.S. Srivastava. 1965. Applied Statistics of India. Chaitanya Publ. House. Allahabad.

Atkinson, E.F.T. (ed.) 1874-1886. Statistical, Descriptive and Historical Account of the North-Western Provinces. 14 vols. + supplement, North Westem Provinces and Oudh Govt. Press, Allahabad.

Bailey, F. 1897. Forestry in India. The Scottish Geographical Magazine 13:572-90.

Baines, J.A. 1893. Census of British India 1891, General Report. Eyre and Spottiswoode, London.

Balfour, Edward. 1870. The Timber Trees, Timber and Fancy Woods, as also, the Forests, of India and of Eastern and Southern Asia. Higginbotham and Co., Madras. Reprinted 1983 by Bishen Singh Mahendra Pal Singh, Dehra Dun.

Baliga, B.S. 1957. Tanjore District Handbook. Superintendent, Govt. Press, Madras.

Bamber, C.J. 1910. Plants of the Punjab: A Descriptive Key to the Flora of the Punjab, North-west Frontier Province and Kashmir. Superintendent, Govt. Printing, Punjab, Lahore.

Banerjee, A. 1966. Indian forests through the ages, pp. 29-52 In West Bengal forests: Centenary Commemoration Vol. 1964. West Bengal Directorate of Forests, W. B. Divisional Forest Officer, Planning and Statistical Cell, Calcutta.

Banerjee, A.K. 1979. Local needs of small timber and fuel wood in India, pp. 92-103 In Forestry in National Development: Production Systems, Conservation, Foreign Trade and Aid, K.R. Shepherd and H.V. Richter (eds.) Development Studies Centre Monograph No. 7. Australian National University, Canberra.

Bansil, P.C. 1984. Agricultural Statistics in India: A Guide. 3rd edition, Oxford and IBH Publ. Co., New Delhi.

Bareh, H. 1974. Meghalaya. North-Eastem India News and Feature Service, Shillong.

Baria, R.L. 1933. Final Report of the First Revised Settlement of the Bharatpur Stait. State Press, Bharatpur. 
Basu, B.P. 1928. Destruction of forests in Chota Nagpur in Bihw and Orissa. Indian For. $54: 401-402$.

Beddome, R.H. 1876. The forests and flora of the Nilgiris. Indian For. 2:17-28.

Bengal (Presidency). 1905. Bengal District Gazetteers. Bengal B Series, Statistics for 1901-1902. 53 vols. (most but not all refer to Indian districts now in West Bengal, Bihar, Orissa, Tripura), Bengal Secretariat Book Depot, Calcutta.

Bengal (Presidency). 1913-1915. Bengal District Gazetteers. Bengal B Series, Statistics for 1900101-1910111. 33 vols. (most refer to Indian districts), Bengal Secretariat Book Depot, Calcutta.

Bengal (Presidency). 1923. Bengal District Gazetteers. Bengal B Series. Statistics for 1921/22-1930/31. 27 vols. (most refer to Indian districts), Bengal Secretariat Book Depot, Calcutta.

Bengal (Presidency). 1933. Bengal District Gazetteers. Bengal B Series. 27 vols., Secretariat Govt. Printing, Calcutta.

Bengal (Presidency) Forest Dept. 1932-1939. Annual Progress Report on Forest Administration in the Presidency of Bengal for the Year (annual, 1931-32 - 1937-38). Bengal Secretariat Book Depot, Calcutta.

Berry, A. 1984. Economic availability of forest resources in Northeastem India, pp. 95-103 In Resource Potentials of North-East India, Vol II: Living Resources, R.S. Tripathi (ed.) Meghalaya Science Society, Shillong.

Bharadwaj, O.P. 1961. The arid zone of India and Pakistan, pp. 143-174 In A History of Land Use in Arid Regions, L. Dudley Stamp (ed.) Paris.

Bhancha, F.R. 1958. Studies on the grasslands of the Westem Ghats. Indian J. Ecology 46:681-705.

Bharucha, F.R. and K.A. Shankamarayan. 1958. Effects of overgrazing on the grasslands of the Westem Ghats. Indian J. Ecology 39:152-153.

Bihar and Orissa (Govt.). 1913-1918. Bihar and Orissa District Gazetteers. Series B Statistics for 1900101 to 1910/11. 16 vols., Bihar Govt. Printing Press, Patna.

Bihar and Orissa (Govt.). 1917. Bihar and Orissa District Gazetteers. 2 vols. [Hazaribagh, (E. Lister, ed.); Ranchi, (M.G. Hallett, ed.)], Bihar Govt. Printing Press, Patna. 
Bihar and Orissa (Govt.). 1924-1933. Bihar and Orissa District Gazetteers. Cuttack (1933), Monghyr (1926), Palamau (1926), Paina (1924), Puri (1929), Sambalpur (1932), Saran (1930), Shahabad (1924). 8 vols., Bihar Govt. Printing Press, Patna.

Bihar (State). 1957-1970. Bthar State Gazetteers. 17 vols., Bihar Secretariat Press, Patna.

Bihar Chief Conservator of Forests. 1963. First Working Plan for the Forests of Deoghar Division in the Districts of Bhagalpur and Santal Parganas, 1956-57 to 1965-66. Secretariat Press, Patna.

Bihar Directorate of Statistics and Evaluation. 1965. Annual Season and Crop Report, 1960-61. Secretariat Press, Patna.

Bihar Directorate of Statistics and Evaluation. 1983. Bihar Statistical Handbook, 1980. Secretariat Press, Patna.

Bihar Forest Dept. 1967. Statistical Glimpses of Bihar Forests 1964-1965. Forest Research Div., Supt. Secretariat Press, Patna.

Biswas, K. 1933. The distribution of wild conifers in the Indian Empire. J. Indian Botanical Soc. 12:24-47.

Blasco, F. 1971. Montagnes du Sud de l'Inde. Trav. Sec. Sci. Tech. Tome X, Fasc. 1, Institut Francais, Pondichery and B.N.K. Press Pvt. Ltd., Madras.

Blasco, F. 1975. Les Mangroves de l'Inde. Trav. Sec. Sci. Tech. Tome XIV, Fasc. 1, Institut Francais, Pondichery.

Blyn, G. 1966. Agricultural Trends in India, 1891-1947: Output, Availability, and Productivity. University of Pennsylvania Press, Philadelphia, PA.

Bombay (Presidency) Gazetteers Dept. 1904-1907. Gazetteer of Bombay Presidency. Bombay B Series. 20 vols., Govt. Central Press, Bombay.

Bombay (Presidency) Gazetteers Dept. 1913-1914. Gazetteer of Bombay Presidency. Bombay B Series. 20 vols., Govt. Central Press, Bombay.

Bombay (Presidency) Gazetteers Dept. 1926-1928. Gazetteer of Bombay Presidency. Bombay B Series. 19 vols., Govt. Central Press, Bombay.

Bombay (State). 1953. Gazetteer of the Bombay State (Revised ed., general series.) Vol. A. Botany. Part 1. Medicinal Plants. Govt. Central Press, Bombay.

Bor, N.L. 1938. A sketch of the vegetation of the Aka Hills, Assam, an ecological study. Indian For. Rec. 1(4):1-221. 
Bor, N.L. 1942. The relict vegetation of the Shillong Plateau -Assam. Indian For. Rec. 3(6):152-195.

Bora, A.K. 1986. Pattern of Land Utilization in Assam. Manas Publications, Delhi.

Borthakur, D.N., A. Singh, R.P. Awasthi and R.N. Rai. 1978. Shifting cultivation in the Northem region, pp. 330-342 In National Seminar on Resources Development and the Environment in the Himalayan Region. India Dept. Sci. Tech., Nat. Committee on Environmental Planning and Co-Ordination, New Delhi.

Bose, S. 1967. Carrying Capacity of Land Under Shiffing Cultivation. Asiatic Society Monograph Series Vol. 12, Asiatic Society, Calcutta.

Bose, S.C. 1978. Geography of West Bengal. 2nd edition, National Book Trust, India, New Delhi.

Bourgeon, G. 1989. Explanatory Booklet on the Reconnaissance Soll Map of Forest Area, Western Karnataka and Goa. Trav. Sect. Sci. Tech. Hors. Ser. No. 20, Institut Francais, Pondichery.

Bowonder, B. 1982. Deforestation in India. Int. J. Environ. Stud. 18:223-236.

Brandis, D. 1883. On the distribution of forests in India. Indian For. 9:173-83.

Brandis, D. 1897. Indian Forestry. Oriental University Institute, Woking.

Brandis, D. and J.L. Stewart. 1874. The Forest Flora of North-West and Central India: A Handbook of the Indigenous Trees and Shrubs of Those Countries. Vol. 1. Reprinted 1972 by Bishen Singh Mahendra Pal Singh, Dehra Dun.

Brown, R. 1874. Statistical Account of the Native State of Manipur, and the Hill Territory Under Its Rule. Office of the Superintendent of Govt. Printing, Calcutta. Reprinted 1975 by K.M. Mittal, Sanskaran Prakashak, Delhi.

Buch, M.N. 1991. The Forests of Madhya Pradesh. Madhya Pradesh Madhyam, Bhopal.

Campbell, J.M. (ed.) 1877-1904. Gazetteer of the Bombay Presidency. 27 vols., Govt. Central Press, Bombay.

Carey, B.S. and H.N. Tuck. The Chin Hills: A History of the People, Our Dealings with Them, their Customs and Manners, and a Gazetteer of their Country. Reprinted 1976 by Firma KLM on behalf of Tribal Research Institute, Aizawl.

Central Provinces (India). 1904-1910. Central Provinces District Gazetteers. B Series. 21 vols., Various publishers. 
Central Provinces (India). 1906-1910. Central Provinces District Gazetteers. A Sertes. 23 vols. (R.V. Russell ed.), Vartous publishers.

Central Provinces (India). 1912-1917. Central Provinces District Gazetteers. B Serles. 22 vols., Various publishers.

Central Provinces (India). 1927-1930. Central Provinces District Gazetteers. B Series. 22 vols., Govt. Press, Nagpur.

Centre for Earth Science Studies. 1984. Resource Atlas of Kerala. Centre for Earth Science Studies, Trivandrum.

Centre for Science and Environment. 1982. The State of India's Environment 1982: A Citizens' Report. Centre for Science and Environment, New Delhi.

Centre for Science and Environment. 1985. The State of India's Environment, 1984-85: The Second Citizens' Report. Centre for Science and Environment, New Delhi.

Champion, H.G. 1936. A preliminary survey of the forest types of India and Burma. Indian Forest Records 1:1-279.

Champion, H.G. and F.C. Osmaston (eds.). 1962. E.P. Stebbing's "The Forests of India", Vol. IV. Being the History from 1925 to 1947 of the Forests now in Burma, India, and Pakistan. Oxford University Press, London.

Champion, H.G. and S.K. Seth. 1968. A Revised Survey of the Forest Types of India. Manager of Publications, Delhi.

Chandrasekharan, C. 1962. Forest types of Kerala State. In 4 parts, Indian For. 88: 473-480; 660-674; 731-747; and 837-847.

Chatterjee, S.N. 1984. Tripura, A Profile. Inter-India Publications, New Delhi.

Chatterjee, S.P. 1949. Bengal in Maps: A Geographical Analysis of Resource Distribution in West Bengal and Eastern Pakistan. Orient Longmans Ltd., Calcutta.

Chaturvedi, A.N. 1987. Firewood as main energy source in hills, pp. 60-65 In Himalayan Energy Systems, T.N. Dhar and P.N. Sharma (eds.) Gyanodaya Prakashan, Naini Tal.

Chaube, S.K. (ed.) 1985. The Himalayas: Profiles of Modernization and Adaptation. Sterling Publishers Pvt. Ltd., New Delhi.

Chaudhuri, A.B. and H.B. Naithani. 1985. Environment and Resources of Temperate and Tropical Forests of India. Intemational Book Distributors, Dehra Dun.

Chaudhuri, H.N. 1903. The Cooch Behar State and its Land Revenue Settlements. Cooch Behar State Press, Cooch Behar. 
Choudhury, K.C.R. 1951. Sikkim -The country and its forests. Indian For. 77: 676-683.

Chowdhury, A. and G. S. Sarwade. 1982. A simple approach for climatic classification of India. Tropical Ecology 23:234-46.

Chowdhury, B. 1964. Growth of Commercial Agriculture in Bengal (1757-1900). Vol. I. R.K. Maitra for Indian Studies Past and Present, Calcutta.

Clarke, C.B. 1890. On the plants of Kohima and Muneypore. J. Linnean Society 25:1-107.

Cole, B.L. Census of India 1931. Vol. XXVII, Rajputana Agency, Report and Tables, Saraswati Press, Meerut.

Conybeare, H.C.A. (ed.) 1878-1884. Statistical, Descriptive and Historical Account of the North-Western Provinces. 7 vols., North Western Provinces and Oudh Govt. Press, Allahabad.

Cowan, J.M. 1929. The forests of Kalimpong: an ecological account. Rec. Bot. Surv. India 12(1):1-74.

Cox, A.F. 1881. Manual of North Arcot District in the Madras Presidency. Madras Govt. Press, Madras.

Crole, C.S. 1879. The Chingleput: a Manual of a Madras district. Madras Govt. Press, Madras.

Dabadghao, P.M. and K.A. Shankamarayan. 1973. The Grass Cover of India. Indian Council for Agricultural Res., New Delhi.

Dalton, E.T. 1872. Descriptive Ethnology of Bengai. Superintendent, Govt. Printing, Calcutta.

Das, H.P. 1970. Geography of Assam. National Book Trust, New Delhi.

Das, J.N. 1989. Land System of Arunachal Pradesh. N.M. Tripathi Pvt. Ltd. for Indian Law Institute, Bombay.

Das, P. 1973. Changes in landuse pattem of Dehradun. Geogr. Rev. India 35:52-60.

Das Gupta, S.P. (ed.) 1976. Forest Atlas of India. Nat. Atlas Org., Dept. Science and Tech., New Delhi.

Das Gupta, S.P. (ed.) 1980. Atlas of Agricultural Resources of India. Nat. Atlas and Thematic Mapping Org., Dept. Science and Tech., New Delhi.

Datta, S.K. 1952. The forests of Tripura. Indian For. 78:68-80.

Datta Ray, B. (ed.) 1978. Social and Economic Profile of North-east India. B.R. Publ. Corp., New Delhi. 
Davis, K. 1951. The Population of India and Pakistan. Princeton University Press, Princeton, NJ.

Day, R.H. and I. Singh. 1977. Economic Development as an Adaptive Process: The Green

Revolution in the Indian Punjab. Cambridge University Press, Cambridge, MA.

Davis, A.W. 1894. Gazetteer of the North Lushai Hills, compiled under the orders of the Chief Commissioner of Assam. Assam Secretariat, Shillong.

De, R.N. 1932. Taungya in Garo Hills Division, Assam. Indian For. 58:93-99.

Deb, D.B. 1963. Bibliographical review on the botanical studies in Tripura. Bull. Bot. Surv. India 5:9-58.

Deb, D.B. Forest types studies in Manipur. Indian For. 86:94-111.

Deshpande, C.D. 1971. Geography of Maharashtra. National Book Trust, New Delhi.

Deshpande, S.H. 1973. Economy of Maharashtra (Shri M. Joag Felicitation Volume). Samaj Prabodhan Sanstha, Poona.

Dhawan, B.D. and Y. Satyanarayana. 1967. The role of firewood in the Indian economy. Indian J. Agric. Economics 22:169-173.

Dikshit, K.R. 1991. Environment, Forest Ecology and Man in the Western Ghats: The Case of Mahabaleshwar Plateau. Rawat Publications, New Delhi.

Dracup, A.H. and H.T. Sorley. 1933. Census of India 1931. Bombay Presidency. Vol. VIII, Part I Report, Govt. Central Press, Bombay.

Drake-Brockman, H.E. 1923. A Gazetteer of Eastern Rajputana, Comprising the Native States of Bharatpur, Dholpur and Karauli. Scottish Mission Industries Co. Ltd., Ajmer.

Dudgeon, W. 1920. A contribution to the ecology of the Upper Gangetic Plain. J. Indian Bot. Soc. 1:296-324.

Dun, E.W. 1886. Gazetteer of Manipur. Superintendent, Govt. Printing, Calcutta. Reprinted 1975 by Vivek Publ. House, Delhi.

Dutt, A.K., S.P. Chatterjee, and M.M. Geib. 1976. India in Maps. Kendall/Hunt Publ. Co. Dubuque, IA.

Dwivedi, R.C. 1987. Energy and environment with special reference to hills, pp. 31-40 In Himalayan Energy Systems, T.N. Dhar and P.N. Sharma (eds). Gyanodaya Prakashan, Naini Tal. 
Eardley-Wilmot, S. 1906. Review of Forest Administration in British India for the year 1903-1904 with a Quinquennial Summary. Office Supt. Govt. Printing, Calcutta.

Eardley-Wilmot, S. 1910. Forest Life and Sport in India. Edward Amold, London.

Elwin, V. 1961. Nagaland. P. Dutta for Research Dept., Adviser's Secretariat, Shillong.

Elwin, V. 1969. The Nagas in the Nineteenth Century. Oxford University Press, London.

Environmental Services Group. 1985. Tropical Moist Forests: A Reader. World Wildlife Fund, New Delhi.

Erskine, K.D. (comp.) 1908. Rajputana Gazetteers. The Mewar Residency. Vol. II-A, Scottish Mission Industries Co. Ltd., Ajmer.

Erskine, K.D. (comp.) 1908. Rajputana Gazetteers. The Mewar Residency, Statistical Tables. Vol. II-B, Scottish Mission Industries Co., Ltd., Ajmer.

Erskine, K.D. (comp.) 1908. Rajputana Gazetteers. The Western Rajputana States and Bikaner Agency, Statistical Tables. Vol. III-B, Pioneer Press, Allahabad.

Erskine, K.D. (comp.) 1909. Rajputana Gazetteers. The Western Rajputana States and Bikaner Agency. Vol. III-A, Pioneer Press, Allahabad.

Ethiraj, R. 1976. Plantations in Tamil Nadu. Sangam Publishers for Madras Inst. Development Studies, Madras.

Evans, F.B. (ed.) 1894-1915. Madras District Gazetteers. 24 vols., Superintendent Govt. Press, Madras.

Fanu, H. Le. 1883. A Manual of the Salem District in the Presidency of Madras. 2 vols., Madras Govt. Press, Madras.

Fazl-i-Ilahi, Sheikh. 1942. Census of India 1941. Delhi. Report and Tables. Vol. XVI, Manager of Publications, Delhi.

Fischer, C.E.C. 1922. A survey of the flora of the Anaimalai Hills in the Coimbatore district, Madras Presidency. Vol. 9, Part 1, Rec. Botanical Survey of India, Calcutta.

Forest Research Institute (India). 1961. 100 Years of Indian Forestry, 1861-1961. 2 vols, Editorial Committee for Forest Centenary Publications, Manager of Publications Civil Lines, Delhi.

Forest Research Institute and Colleges. 1970, 1972. Indian Forest Utilization. 2 vols, Manager of Publications, Delhi. 
Forsyth, J. 1920. The Highlands of Central India: Notes on their Forests and Wild Tribes, Natural History and Sports. E.P. Dutton and Co., New York.

Furer-Haimendorf, C.V. 1933. The Naked Nagas. Thacker Spink and Co., Calcutta.

Furer-Haimendorf, C.V. 1982. Tribes of India: the Struggle for Survival. Oxford University Press, Delhi.

Francis, W. 1904. Gazetteer of the Bellary district, Madras Presidency. Superintendent Govt. Press, Madras.

Francis, W. 1908. The Nilgiris. Superintendent Govt. Press, Madras.

Friel, R. (ed.) 1914-1915. Assam District Gazetteers. Supplementary Series. 10 vols., Assam Secretariat Press, Shillong.

Gage, A.T. 1901. A botanical tour in the south Lushai Hills. Rec. Botanical Society of India 1(13):331-404.

Gait, E.A. 1913. Census of India 1911. Vol. I, Part I, Report and Part II, Tables, Superintendent, Govt. Printing, Calcutta.

Gamble, J.S. 1875. The Darjeeling forests. Indian For. 1:73-99.

Gan-Chaudhuri, J. (ed.) 1980. Tripura, The Land and Its People. Leeladevi Publications, Delhi.

Ganguly, J.B. 1969. Economic Problems of the Jhumias of Tripura (A Socio-economic Study of the System of Shifting Cultivation in Transition). Bookland Pvt. Ltd., Calcutta.

Gangwar, A.K. and P.S. Ramakrishnan. 1987. Cropping and yield pattems under different land use systems of the Khasis at higher elevations of Meghalaya in north-eastem India. Intern. J. Ecology and Environ. Sci. 13:73-86.

Garstin, J.H. 1878. Manual of the District of South Arcot in the Madras Presidency. Asylum Press, Madras.

Gaussen, H., P. Legris, and M. Viart. 1961. Carte internationale du tapis vegetal et des conditions ecologiques a $1 / 1.000 .000$ / International Map of the Vegetation and of Environmental Conditions at 1/1,000,000. Cape Comorin. Institut Francais de Pondichery and Indian Council for Agric. Res., Pondichery.

Gaussen, H., P. Legris, and M. Viart. 1961. Carte internationale du tapis vegetal et des conditions ecologiques a 1/1.000.000 / International Map of the Vegetation and of Environmental Conditions at 1/1,000,000. Notice de la feuille Cape Comorin / Notes on the sheet Cape Comorin. Trav. Sect. Sci. Tech. Inst. Fr. Pondichery, Hors. Ser. No. 1, Institut Francais, Pondichery. 
Gaussen, H., P. Legris, and M. Viart. 1962. Carte internationale du tapis vegetal et des conditions ecologiques a 1/1.000.000 / International Map of the Vegetation and of Environmental Conditions at $1 / 1,000,000$. Madras. Institut Francais de Pondichery and Indian Council for Agric. Res., Pondichery.

Gaussen, H., P. Legris, and M. Viart. 1962. Carte internationale du tapis vegetal et des conditions ecologiques a I/1.000.000 / International Map of the Vegetation and of Environmental Conditions at 1/1,000,000. Notice de la feuille Madras / Notes on the sheet Madras. Trav. Sect. Sci. Tech. Inst. Fr. Pondichery, Hors. Ser., Institut Francais, Pondichery.

Gaussen, H., P. Legris, and M. Viart. 1963. Carte internationale du tapis vegetal et des conditions ecologiques a 1/1.000.000 / International Map of the Vegetation and of Environmental Conditions at $1 / 1,000,000$. Jagannath. Institut Francais de Pondichery and Indian Council for Agric. Res., Pondichery.

Gaussen, H., P. Legris, and M. Viart. 1964. Carte internationale du tapis vegetal et des conditions ecologiques a I/1.000.000 / International Map of the Vegetation and of Environmental Conditions at 1/1,000,000. Notice de la feuille Jagannath / Notes on the sheet Jagannath. Trav. Sect. Sci. Tech. Inst. Fr. Pondichery, Hors. Ser., Institut Francais, Pondichery.

Gaussen, H., P. Legris, M. Viart, V.M. Meher-Homji, and L. Labroue. 1965. Carte internationale du tapis vegetal et des conditions ecologiques a 1/1.000.000 / International Map of the Vegetation and of Environmental Conditions at 1/1,000,000. Mysore. Institut Francais de Pondichery and Indian Council for Agric. Res., Pondichery.

Gaussen, H., P. Legris, M. Viart, V.M. Meher-Homji, and L. Labroue. 1966. Carte internationale du tapis vegetal et des conditions ecologiques a 1/1.000.000 / International Map of the Vegetation and of Environmental Conditions at 1/1,000,000. Notice de la feuille Mysore / Notes on the sheet Mysore. Trav. Sect. Sci. Tech. Inst. Fr. Pondichery, Hors. Ser. No. 7, Institut Francais, Pondichery.

Gaussen, H., P. Legris, M. Viart, V.M. Meher-Homji, and L. Labroue. 1965. Carte internationale du tapis vegetal et des conditions ecologiques a 1/1.000.000 / International Map of the Vegetation and of Environmental Conditions at I/I,000,000. Bombay. Institut Francais de Pondichery and Indian Council for Agric. Res., Pondichery.

Gaussen, H., P. Legris, M. Viart, V.M. Meher-Homji, and L. Labroue. 1966. Carte internationale du tapis vegetal et des conditions ecologiques a 1/1.000.000 / International Map of the Vegetation and of Environmental Conditions at 1/1,000,000. Notice de la feuille Bombay / Notes on the sheet Bombay. Trav. Sect. Sci. Tech. Inst. Fr. Pondichery, Hors. Ser. No. 8, Institut Francais, Pondichery.

Gaussen, H., P. Legris, F. Blasco, V.M. Meher-Homji, J.P. Troy, and M. Viart. 1968. Carte inierinationale du tapis vegetal et des conditions ecologiques a 1/1.000.000 / International Map of the Vegetation and of Environmental Conditions at 1/1,000,000. Kathiawar. Institut Francais de Pondichery and Indian Council for Agric. Res., Pondichery. 
Gaussen, H., P. Legris, F. Blasco, V.M. Meher-Homji, and J.P. Troy. 1968. Carte internationale du tapis vegetal et des conditions ecologiques a 1/1.000.000 / International Map of the Vegetation and of Environmental Conditions at 1/1,000,000. Notice de la feuille Kathiawar / Notes on the sheet Kathiawar. Trav. Sect. Sci. Tech. Inst. Fr. Pondichery, Hors. Ser. No. 9, Institut Francais, Pondichery.

Gaussen, H., P. Legris, F. Blasco, V.M. Meher-Homji, and J.P. Troy. 1968. Carte internationale du tapis vegetal et des conditions ecologiques a 1/1.000.000 / International Map of the Vegetation and of Environmental Conditions at 1/1,000,000. Satpura Mountains. Indian Council Agric. Res. and Institut Francais de Pondichery, Pondichery.

Gaussen, H., P. Legris, F. Blasco, V.M. Meher-Homji, and J.P. Troy. 1968. Carte internationale du tapis vegetal et des conditions ecologiques a 1/1.000.000 / International Map of the Vegetation and of Environmental Conditions at 1/1,000,000. Notice de la feuille Satpura Mountains / Notes on the sheet Satpura Mountains. Inst. Fr. Pondichery, Hors. Ser. No. 10, Pondichery.

Gaussen, H., V.M. Meher-Homji, P. Legris, F. Blasco, A. Delacourt, R.K. Gupta, and J.P. Troy. 1971. Carte internationale du tapis vegetal et des conditions ecologiques a 1/1,000,000 / International Map of the Vegetation and of Environmental Conditions at 1/1,000,000. Rajasthan. Indian Council Agric. Res. and Institut Francais de Pondichery, Pondichery.

Gaussen, H., V.M. Meher-Homji, P. Legris, F. Blasco, A. Delacourt, R.K. Gupta, and J.P. Troy. 1972. Carte internationale du tapis vegetal et des conditions ecologiques a $1 / 1,000,000 /$ International Map of the Vegetation and of Environmental Conditions at 1/1,000,000. Notice de la feuille Rajasthan / [Notes on the sheet Rajasthan]. Trav. Sect. Sci. Tech. Inst. Fr. Pondichery, Hors. Ser. No. 12, Pondichery.

Gaussen, H., P. Legris, F. Blasco, A. Delacourt, V.M. Meher-Homji, and J.P. Troy. 1974. Carte internationale du tapis vegetal et des conditions ecologiques a 1/1.000.000 / International Map of the Vegetation and of Environmental Conditions at 1/1,000,000. Wainganga. Indian Council Agric. Res. and Institut Francais de Pondichery, Pondichery.

Gaussen, H., V.M. Meher-Homji, P. Legris, A. Delacourt, J.P. Troy, F. Blasco, and J. Fontanel. 1974. Carte internationale du tapis vegetal et des conditions ecologiques a 1/1.000.000 / International Map of the Vegetation and of Environmental Conditions at 1/1,000,000. Notice de la feuille Wainganga / Notes on the sheet Wainganga. Trav. Sect. Sci. Tech. Inst. Fr. Pondichery, Hors. Ser. No. 13, Pondichery.

Gaussen, H., V.M. Meher-Homji, F. Blasco, A. Delacourt, J. Fontanel, P. Legris, and J.P. Troy. 1973. Carte internationale du tapis vegetal et des conditions ecologiques a $1 / 1.000 .000 /$ International Map of the Vegetation and of Environmental Conditions at 1/1,000,000. Orissa. Indian Council Agric. Res. and Institut Francais de Pondichery, Pondichery. 
Gaussen, H., P. Legris, V.M. Meher-Homji, J. Fontanel, J.-P. Pascal, K. Chandrahasan, A. Delacourt, and J.P. Troy. 1975. Carte internationale du tapis vegetal et des conditions ecologiques a 1/1.000.000 / International Map of the Vegetation and of Environmental Conditions at 1/1,000,000. Notice de la feuille Orissa / [Notes on the sheet Orissa]. Trav. Sect. Sci. Tech. Inst. Fr. Pondichery, Hors. Ser. No. 14, Pondichery.

Gaussen, H., V.M. Meher-Homji, J. Fontanel, P. Legris, and J.-P. Pascal. 1978. Carte internationale du tapis vegetal et des conditions ecologiques a 1/1.000.000/International Map of the Vegetation and of Environmental Conditions at 1/1,000,000 scale. Allahabad. Indian Council Agric. Res. and Institut Francais de Pondichery, Pondichery.

Gaussen, H., V.M. Meher-Homji, J. Fontanel, P. Legris, and J.-P. Pascal. 1978. Carte internationale du tapis vegetal et des conditions ecologiques a 1/1.000.000/International Map of the Vegetation and of Environmental Conditions at 1/1,000,000 scale. Notes on the Sheet Allahabad. Trav. Sect. Sci. Tech. Inst. Fr. Pondichery, Hors. Ser. No. 15, Pondichery.

Gautam, N.C. and G.C. Chennaiah. 1985. Land-use and land-cover mapping and change detection in Tripura using satellite LANDSAT Data. Intern. J. Remote Sensing 6:517-528.

Gautam, N.C. and L.R.A. Narayan. 1982. Suggested National Land Use/Land Cover Classification System for India Using Remote Sensing Techniques. Pink Publ. House, Mathura.

George, P.S. 1979. Recent trends in production and productivity in Kerala agriculture, pp. 36-47 In Kerala Economy Since Independence, M.A. Oommen (ed.) Oxford and IBH Publishing Co., New Delhi.

George, P.S. 1979. The coconut economy of Kerala: an analysis of production trends and projections, pp. 48-61 In Kerala Economy Since Independence, M.A. Oommen (ed.) Oxford and IBH Publishing Co., New Delhi.

Ghosh, R.C. 1979. The socio-economic consequences and constraints to use of land and forest for energy and organics in India, pp. 36-47 In Biological and Sociological Basis for a Rational Use of Forest Resources for Energy and Organics: An International Workshop, S.G. Boyce (ed.) U.S. Dept. of Agriculture, Forest Service, Southeastem Forest Exp. Stn., Asheville, NC.

Gorrie, R.M. 1946. Soil and Water Conservation in the Punjab. Punjab Govt., Simla.

Goudge, J.E. 1903. Report on the Land Settlement of Almora District. Govt. Press, Allahabad.

Goswami, P.C. 1980. Problem of jhum control, pp. 48-61 In Tribal Economy of the Northeastern region, T. Mathew (ed.) Spectrum Publication, Gauhati, Assam.

Goswami, S. 1987. Fuelwood crisis in rural areas, pp. 109-116 In Ecology of Rural India, Vol. I, P. Singh (ed.) Ashish Publ. House, New Delhi.

Grant, C. (ed.) 1870. The Gazetteer of the Central Provinces of India. Education Society's Press. Bombay. Reprinted 1984 by Usha, New Delhi. 
Greig, G. 1879. The Banda forests. Indian For. 4:317-323.

Gribble, J.D.B. 1875. Manual of the District of Cuddapah in the Presidency of Madras. Govt. Press, Madras.

Griffith, W. 1847. Journals of Travels in Assam, Burma, Bootan, Afghanistan and the Neighboring Countries. (Posthumous papers bequeathed to East India Co. and arranged by John M'Clelland.) Bishop's College Press, Calcutta.

Griffith, W. 1848. Itinerary Notes of Plants Collected in the Khasyah and Bootan Mountains, 1837-38, in Affghanistan and Neighboring Countries. 1839 to 1841. (Posthumous papers bequeathed to East India Co. and arranged by John M'Clelland.) F.J. Bellamy, Calcutta.

Guhathakurta, P. 1974. A Study of the Forest Resources of Kalimpong Forest Division. Bulletin 58, Planning and Statistical Cell, Office of Chief Conservator of Forests, West Bengal, Calcutta.

Gujarat (State). 1961-1984. Gujarat State Gazetteers. 17 vols., Directorate of Govt. Printing, Stationery and Publications, Ahmedabad.

Gujarat Bureau of Economics and Statistics. 1982. Statistical Atlas of Gujarat. Resource Frofile. Vol. 1, Bureau of Economics and Statistics, Gandhinagar.

Gujarat Bureau of Economics and Statistics. 1984. Statistical Outline of Gujarat 1983. Bureau of Economics and Statistics, Gandhinagar.

Gujarat Directorate of Agriculture. 1980. Season and Crop Report of Gujarat State for the Year 1979-80. Govt. Central Press, Gandhinagar.

Gupta, N.S. and A. Singh. 1979. Agricultural Development of States in India. Vol. I, Seema Publications, New Delhi.

Gupta, R.K. 1983. The Living Himalayas, In Aspects of Environment and Resource Ecology of Garhwal. Vol. I, Today and Tomorrow's Printers and Publ., New Delhi.

Gupta, T.R. (ed.) 1978. Planning for the Growth of Rural Economy of the Punjab (Background Papers). Dept. Economics and Sociology, Punjab Agricultural University, Ludhiana.

Gune, V.T. (ed.) 1979. Gazetteer of the Union Territory Goa, Daman and Diu. Gazetteer Dept., Govt. of the Union Territory Goa, Daman and Diu, Panaji.

Habib, 1. 1982. An Atlas of the Mughal Empire: Political and Economic Maps with Detailed Notes, Bibliography and Index. Oxford University Press, Delhi.

Hamilton, W. 1820. Geographical, Statistical, and Historical Description of Hindostan and the Adjacent Countries. 2 vols, John Murray, London. 
Haridasan, K. and R.R. Rao. 1985. Forest Flora of Meghalaya. Ranunculaceae to Cornaceae. Vol 1, Bishen Singh Mahendra Pal Singh, Dehra Dun.

Haryana (State). 1970-1990. Haryana District Gazetteers. 10 vols., Haryana Gazetteers Organization, Chandigarh.

Haryana Dept. of Public Relations. 1971. Haryana District Handbooks (one volume per district). Lok Sampark Vibhag Hariyana, Chandigarh.

Haryana Economic and Statistical Organization. 1967-1977. Statistical Abstract (one volume per district). Economic and Statistical Adviser to Govt. of Haryana, Chandigarh.

Haryana Directorate of Land Records. 1970. Kritu Tatha Phasalon Ki Riporti (Season and Crop Report) 1969-70. Directorate of Land Records, Haryana, Chandigarh.

Haryana Economic and Statistical Organization, Planning Dept. 1968, 1971. Sankhyikiya Saransh Haryana [Statistical Abstract of Haryana] (annual 1967, 1970-71). Govt. of Haryana, Chandigarh.

Hayavadana Rao, C. (ed.) 1930. Mysore Gazetteer. 5 vols., Mysore Govt. Press, Bangalore.

Henderson, P.D. 1980. Energy resources, consumption, and supply in India, pp. 172-193 In Energy in the Developing World: The Real Energy Crisis, V. Smil and W.E. Knowland (eds.) Oxford University Press, Oxford.

Himachal Pradesh (State). 1964-1975. Himachal Pradesh District Gazetteers. 5 vols., Various publishers, Batala and Chandigarh.

Himachal Pradesh Dept. of Forest Farming and Environmental Conservation. 1980. H.P. Forest Statistics 1980. H.P. Dept. For. Farming and Environ. Conserv., Simla.

Himachal Pradesh Directorate of Economics and Statistics. 1970. Statistical Outline of Himachal Pradesh 1970. Directorate of Economics and Statistics, Simla.

Himachal Pradesh Directorate of Economics and Statistics. 1973. Symposium on Social and Economic Problems of Hilly Areas. Directorate of Economics and Statistics, Simla.

Himachal Pradesh Directorate of Economics and Statistics. 1980. Statistical Outline of Himachal Pradesh 1980. Directorate of Economics and Statistics, Simla.

Himachal Pradesh Planning Dept. 1970. Review of Economic Conditions and Development Activities in Himachal Pradesh. Directorate of Economics and Statistics, Simla.

Hobbs, F.B. 1986. Demographic Estimates, Projections and Selected Social Characteristics of the Population of India. Center for International Research, U.S. Bureau of the Census, Washington, DC.

Hooker, J.D. 1854. Himalayan Journals; or, Notes of a Naturalist in Bengal, the Sikkim and Nepal 
Himalayas, the Khasia Mountains. Republished and revised 1891 by Ward, Lock, Bowden and Co., London.

Hunter, W.W. (ed.) 1875-1877. A Statistical Account of Bengal. 20 vols., Trubner and Co., London.

Hunter, W.W. (ed.) 1879. A Statistical Account of Assam. 2 vols., Trubner and Co., London.

Husain, M. 1945. Census of India 1941. The Nizam's Dominions (Hyderabad State). Vol. XXI, Part I Report, Govt. Central Press, Hyderabad-Deccan.

Husain, M. 1988. Nagaland: Habitat, Society and Shifting Cultivation. Rima Publ. House, New Delhi.

Hutton, J.H. 1933. Census of India 1931. Vol. I, Part I and II, Imperial Tables. Manager of Publications, Delhi.

Hyderabad Bureau of Economics and Statistics. 1953. Statistical Abstract for Hyderabad State, 1952-53. Finance Dept., Bureau of Economics and Statistics, Hyderabad.

Ibbetson, D.C.J. 1884-1889. Punjab District Gazetteers. Vols. for Ambala, Amritsar, Delhi, Ferozepore, Gurdaspur, Gurgaon, Hissar, Hoshiarpur, Jullundur, Kangra (includes Kulu, Seraj, Lahul and Spiti), Kamal, Ludhiana, Rohtak, Simla. Various publishers, Lahore or Calcutta.

Ibbetson, D.C.J. 1889-1899. Punjab District Gazetteers. Vols. for Ambala, Amritsar, Ferozepore, Gurdaspur, Hissar, Kangra (inc. Kulu, Seraj, Lahul and Spiti), Karnal. The Civil and Military Gazette Press, Lahore.

India. 1907-1909. Imperial Gazetteer of India. 26 vols., Clarendon Press, Oxford.

India Dept. Commercial Intelligence and Statistics. 1933. Agricultural Statistics of India for the Year 1930-31. 2 vols, Directorate of Economics and Statistics, Manager of Publications, Delhi.

India Dept. Commercial Intelligence and Statistics. 1945. Agricultural Statistics of India for the Year 1938-1939. Manager of Publications, Delhi.

India Dept. Revenue and Agriculture. 1902. Agricultural Statistics of India for the Years I896-97 to 1900-01. 2 vols., Office of the Superintendent of Govt. Printing, Calcutta.

India Dept. Revenue and Agriculture. 1904. Agricultural Statistics of India for the Years 1898-99 to 1902-03. 2 vols., Office of the Superintendent of Govt. Printing, Calcutta.

India Dept. Revenue and Agriculture. 1913. Agricultural Statistics of India for the Years 1906-07 to 1910-11. 2 vols., Office of the Superintendent of Govt. Printing, Calcutta. 
India Dept. Revenue and Agriculture. 1915. Quinquennial Review of Forest Administration in British India for the Period 1909-10 to 1913-14, to Which is Appended the Annual Return of Forest Statistics for the Year 1913-1914. Govt. Monotype Press, Simla.

India Dept. Revenue and Agriculture. 1920. Quinquennial Review of Forest Administration in British India for the Period 1914-15 to 1918-19, to Which is Appended the Annual Return of Forest Statistics for the Year 1918-19. Govt. Monotype Press, Simla.

India Dept. Statistics. 1921, 1922. Agricultural Statistics of India for the Year (annuals, 1919-20 and 1920-21). 4 vols., Office of the Superintendent of Govt. Printing, Calcutta.

India Forest Dept. 1921. Annual Return of Statistics Relating to Forest Administration in British India for the Year 1919-20. Govt. Monotype Press, Simla.

India Forest Dept. 1922. Annual Return of Statistics Relating to Forest Administration in British India for the Year 1920-21. Superintendent Govt. Printing, Calcutta.

India Inspector General of Forests. 1906. Review of Forest Administration in British India for the Year 1904-1905. Maps, Office of the Superintendent of Govt. Printing, Calcutta.

India Inspector General of Forests. 1907, 1908. Review of Forest Administration in British India for the Year, 1905-1906, 1906-1907. Superintendent Govt. Printing, Calcutta.

India Inspector General of Forests. 1910. Review of Forest Administration in British India for the Year 1907-1908. Superintendent Govt. Printing, Calcutta.

India Quartermaster-General (India) Intelligence Branch. 1890. Gazetteer of Kashmir and Ladak. Superintendent Govt. Printing, Calcutta. Reprinted 1974 by Vivek Publishing Co., Delhi.

India (Republic) Census Commissioner. 1952-1955. Census of India 1951. Vol. I, Final Population Tables. Manager of Publications, Delhi.

India (Republic) Census Commissioner. 1952-1955. Census of India 1951. Vol. II, Uttar Pradesh. Superintendent of Printing, Allahabad.

India (Republic) Census Commissioner. 1952-1955. Census of India 1951. Vol. III, Madras and Coorg, Part I Report. Superintendent Govt. Press, Madras.

India (Republic) Census Commissioner. 1952-1955. Census of India 1951. Vol. IV, Bombay, Saurashtra and Kutch, Part I-A Report and Subsidiary Tables, Part II-A General Population Tables, Social and Cultural Tables and Summary Figures by Talukas and Petas. Govt. Central Press, Bombay.

India (Republic) Census Commissioner. 1952-1955. Census of India 1951. Vol. V, Bihar. Govt. Printer, Patna. 
India (Republic) Census Commissioner. 1952-1955. Census of India 1951. Vol. VI, West Bengal, Sikkim, and Chandernagore, Part I Report, Part II Tables. Govt. Press, Calcutta.

India (Republic) Census Commissioner. 1953. Census of India 1951. Vol. VII, Madhya Pradesh, Part I-A Report, Part I-B Subsidiary Tables/ Govt. Printing, Madhya Pradesh, Nagpur.

India (Republic) Census Commissioner. 1952-1955. Census of India 1951. Vol. VIII, Punjab, Bilaspur, and Delhi, Part I Report, Part II Tables. Govt. Press, Simla.

India (Republic) Census Commissioner. 1952-1955. Census of India 1951. Vol. IX, Hyderabad, Part I Report, Part II Tables. Govt. Press, Hyderabad.

India (Republic) Census Commissioner. 1952-1955. Census of India 1951. Vol. X, Rajasthan and Ajmer, Part I-A Report, Part I-B Subsidiary Tables, Part I-C Appendices. Govt. Press, Jodhpur.

India (Republic) Census Commissioner. 1952-1955. Census of India 1951. Vol. XI, Orissa, Part I Report, Part II-A Tables. Govt. Press, Cuttack.

India (Republic) Census Commissioner. 1952-1955. Census of India 1951. Vol. XII, Assam, Manipur and Tripura, Part I-A Report, Part I-B Subsidiary Tables. Municipal Printing Press, Bombay, for Superintendent of Census Operations, Shillong.

India (Republic) Census Commissioner. 1953. Census of India 1951. Vol. XIII, Travancore and Cochin, Part I-A Report, Part II Tables. Manager of Publications, Delhi.

India (Republic) Census Commissioner. 1953-1954. Census of India 1951. Vol. XIV, Mysore, Part I Report, Part II Tables. Govt. Press, Bangalore.

India (Republic) Census Commissioner. 1954-1957. Census of India 1951. Vol. XV, Madhya Bharat and Bhopal, Part I-A Report, Part I-B Subsidiary Tables. Govt. Central Press, Gwalior.

India (Republic) Census Commissioner. 1953. Census of India 1951. Vol. XVI, Vindhya Pradesh, Part I Report and Subsidiary Tables. Manager of Publications, Delhi.

India (Republic) Census Commissioner. 1955. Census of India 1951. Vol. XVII, Andaman and Nicobar Islands, Part I Report, Part II Tables. Manager of Publications, Delhi.

India (Republic) Central Forestry Commission. 1976. Forest Statistics. F.R.I. Press, Dehra Dun. 
Indla (Republic) Central Statistical Organization. 1961-1971. Statistical Abstract India 1961-1969. New Series Nos. 10-17, Dept. of Statistics, Cabinet Secretariat, Manager of Publications, Delhi.

India (Republic) Central Statistical Organization. 1972-1988. Statistical Abstract India (annual, 1972-1986). New Series Nos. 18-28, Dept. of Statistics, Ministry of Planning, Controller of Publications, Delhi.

India (Republic) Director of Census Operations. 1972-1981. Census of India 1971. District Census Handbooks No. 2 (Andhra Pradesh). Govt. Press, Hyderabad.

India (Republic) Director of Census Operations. 1972-1981. Census of India 1971. District Census Handbooks No. 3 (Assam). Govt. Press, Gauhati.

India (Republic) Director of Census Operations. 1972-1981. Census of India 1971. District Census Handbooks No. 4 (Bihar). Govt. Press, Patna.

India (Republic) Director of Census Operations. 1972-1981. Census of India 1971. District Census Handbooks No. 6 (Haryana). Govt. of Haryana, Chandigarh.

India (Republic) Director of Census Operations. 1972-1981. Census of India 1971. District Census Handbooks No. 7 (Himachal Pradesh). Govt. Press, Simla.

India (Republic) Director of Census Operations. 1972-1981. Census of India 1971. District Census Handbooks No. is (Jammu and Kashmir). Jammu and Kashmir Govt. Press, Srinagar.

India (Republic) Director of Census Operations. 1972-1981. Census of India 1971. District Census Handbooks No. 9 (Kerala). Govt. Press, Trivandnum.

India (Republic) Director of Census Operations. 1972-1981. Census of India 1971. District Census Handbooks No. 10 (Madhya Pradesh). Govt. Press, Bhopal.

India (Republic) Director of Census Operations. 1972-1981. Census of India 1971. District Census Handbooks No. 11 (Maharashtra). Govt. Press, Bombay.

India (Republic) Director of Census Operations. 1972-1981. Census of India 1971. District Census Handbooks No. 12 (Manipur). Govt. Press, Imphal.

India (Republic) Director of Census Operations. 1972-1981. Census of India 1971. District Census Handbooks No. 13 (Meghalaya). Govt. Press, Shillong.

India (Republic) Director of Census Operations. 1972-1981. Census of India 1971. District Census Handbooks No. 14 (Mysore). Govt. Press, Bangalore.

India (Republic) Director of Census Operations. 1972-1981. Census of Inaia 1971. District Census Handbooks No. 15 (Nagaland). Govt. Press, Kohima. 
India (Republic) Director of Census Operations. 1972-1981. Census of India 1971. District Census Handbooks No. 16 (Orissa). Orissa Govt. Press, Cuttack.

India (Republic) Director of Census Operations. 1972-1981. Census of India 1971. District Census Handbooks No. 17 (Punjab, Andaman and Nicobar Islands). Manager of Publications, Delhi.

India (Republic) Director of Census Operations. 1972-1981. Census of India 1971. District Census Handbooks No. 18 (Rajasthan). Govt. Press, Jaipur.

India (Republic) Director of Census Operations. 1972-1981. Census of India 1971. District Census Handbooks No. 18A (Sikkim). Govt. Press, Madras.

India (Republic) Director of Census Operations. 1972-1981. Census of India 1971. District Census Handbooks No. 19 (Tamil Nadu). Govt. Press, Madras.

India (Republic) Director of Census Operations. 1972-1981. Census of India 1971. District Census Handbooks No. 20 (Tripura). Govt. Press, Madras.

India (Republic) Director of Census Operations. 1972-1981. Census of India 1971. District Census Handbooks No. 21 (Uttar Pradesh). Govt. Press, Allahabad.

India (Republic) Director of Census Operations. 1972-1981. Census of India 1971. District Census Handbooks No. 22 (West Bengal). Govt. Press, Calcutta.

India (Republic) Director of Census Operations. 1972-1984. Census of India 1971. District Census Handbooks No. 24 (Arunachal Pradesh). Govt. Press, Gauhati.

India (Republic) Director of Census Operations. 1972-1981. Census of India 1971. District Census Handbooks No. 25 (Chandigarh). Govt. Press, Cinandigarh.

India (Republic) Director of Census Operations. 1972-1981. Census of India 1971. District Census Handbooks No. 26 (Dadra and Nagar Haveli). Govt. Press, Panaji.

India (Republic) Director of Census Operations. 1972-1981. Census of India 1971. District Census Handbooks No. 27 (Goa, Daman and Diu). Govt. Press, Panaji.

India (Republic) Director of Census Operations. 1972-1981. Census of India 1971. District Census Handbooks No. 28 (Gujarat). Govt. Press, Ahmedabad.

India (Republic) Director of Census Operations. 1972-1981. Census of India 1971. District Census Handbooks No. 30 (Pondichery). Govt. Press, Madras.

India (Republic) Director of Census Operations. 1979. Census of India 1971. Series 3 (Assam), Census Atlas. Controller of Publications, Delhi. 
India (Republic) Director of Census Operations. 1979. Census of India 1971. Series 6 (Haryana), Census Atlas. Controller of Publications, Delhi.

India (Republic) Director of Census Operations. 1979. Census of India 1971. Series 7 (Himachal Pradesh), Census Atlas. Controller of Publications, Delhi.

India (Republic) Director of Census Operations. 1979. Census of India 1971. Series 10 (Madhya Pradesh), Census Atlas. Controller of Publications, Delhi.

India (Republic). Director of Census Operations. 1981. Census of India 1971. Series 12. (Manipur), Census Atlas. Controller of Publications, Delhi.

India (Republic). Director of Census Operations. 1974. Census of India 1971. Series 15, (Nagaland), Administrative Atlas. Controller of Publications, Civil Lines, Delhi.

India (Republic) Director of Census Operations. 1974. Census of India 1971. Series 16, (Orissa), Administrative Atlas. Govt. Press, Cuttack.

India (Republic) Directorate of Economics and Statistics. 1954. Indian Livestock Census 1951. Manager of Publications, Delhi.

India (Republic) Directorate of Economics and Statistics. 1972. Indian Livestock Census 1966. Manager of Publications, Civil Lines, Delhi.

India (Republic) Directorate of Economics and Statistics. 1977. Indian Livestock Census 1972. Manager of Publications, Civil Lines, Delhi.

India (Republic) Directorate of Economics and Statistics. 1986. Area and Production of Principal Crops in India 1984-85. Dept. of Agriculture and Co-Operation, Ministry of Agriculture, Controller of Publications Civil Lines, Delhi.

India (Republic) Economic and Statistical Adviser to the Govt. of India. 1960. Indian Forest Statistics 1956-57 and 1957-58. Manager of Publications, Civil Lines, Delhi.

India (Republic) Fuelwood Study Committee. 1982. Report of the Fuelwood Study Committee. Planning Commission, Govt. of India, New Delhi.

India (Republic) Meteorological Dept. 1982. Climatological Atlas of India (scale 1:7,500,000). Part A Rainfall, India Meteorological Dept., New Delhi.

India (Republic) Ministry of Agriculture and Imigation. 1976. Indian Forest Statistics, 1966-67 to 1968-69. Directorate of Economics and Statistics, Controller of Publications, Civil Lines, New Delhi.

India (Republic) Ministry of Agriculture. 1970. Indian Agricultural Statistics, 1961-62 and 1962-63. Directorate of Economics and Statistics, Manager of Publications, Delhi. 


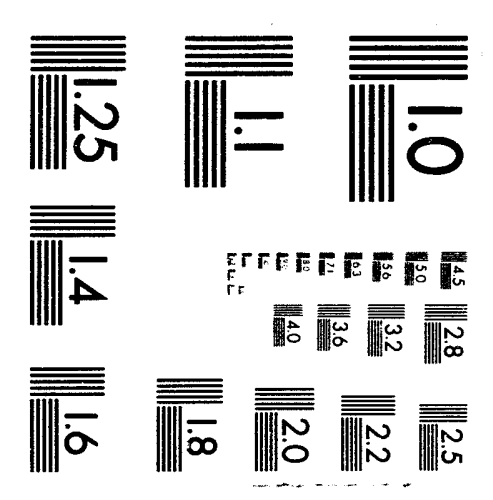



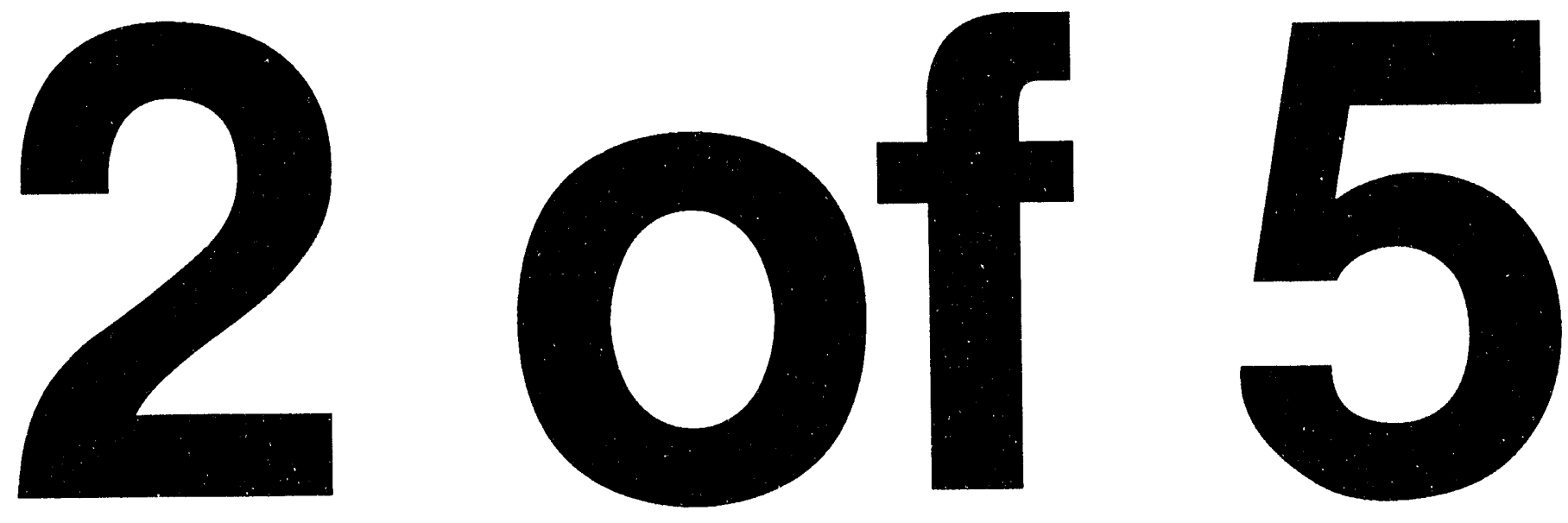
India (Republic) Ministry of Agriculture. 1981. Indian Agricultural Statistics, 1971-72 to 1973-74. Directorate of Economics and Statistics, Manager of Publications, Delhi.

India (Republic) Ministry of Agriculture. 1985. Indian Agricultural Statistics, 1974-75 to 1976-77. Directorate of Economics and Statistics, Controller of Publications Civil Lines, New Delhi.

India (Republic) Ministry of Agriculture. 1979. Indian Forest Statistics, 1960-61 to 1962-63. Directorate of Economics and Statistics, Controller of Publications, Civil Lines, New Delhi.

India (Republic) Ministry of Environment and Forests. 1989. The State of Forest Report, 1989. Forest Survey of India (Republic), Forest Research Institute, Dehra Dun.

India (Republic) Ministry of Environment and Forests. 1989. Wetlands, Mangroves and Biosphere Reserves: Proceedings of the Indo-US Workshop (New Delhi, 4-7 January, 1989). Ministry of Environment and Forests, New Delhi.

India (Republic) Ministry of Food and Agriculture. 1952. Indian Agricultural Statistics, 1949-50. Directorate of Economics and Statistics, Manager of Publications, Delhi.

India (Republic) National Atlas Organization. 1977. National Atlas of India. National Atlas Organization, Delhi.

India (Republic) National Commission on Agriculture. 1976. Report of the National Commission on Agriculture 1976, Part IV, Climate and Agriculture, and Part IX, Forestry. Controller of Publications, Delhi.

India (Republic) National Remote Sensing Agency. 1983. Mapping of Forest Cover in India from Satellite Imagery, 1972-75 and 1980-82. Summary Report, Govt. India Nat. Remote Sensing Agency, Hyderabad.

India (Republic) National Steering Committee on Fuels from Biomass. 1980. Production and Availability of Biomass: A State of the Art Report. Subgroup on Production and Availability of Biomass, Dept. Science and Technology, New Delhi.

India (Republic) Office of the Registrar General. 1972-1979. Census of India 197J. Series 1, Part I-A General Report, Part II-A General Population Tables (One volume per each state/union territory. Compiled by each states director or superintendent of census operations, and published individually within the state/territories level series as follows: Ser. 2. Andhra Pradesh; Ser. 3. Assam; Ser. 4. Bihar, Ser. 5. Gujarat; Ser. 6. Haryana; Ser. 7. Himachal Pradesh; Ser. 8. Jammu and Kashmir; Ser. 9. Kerala; Ser. 10. Madhya Pradesh; Ser. 11. Maharashtra; Ser 12. Manipur; Ser. 13. Meghalaya; Ser. 14. Mysore; Ser. 15. Nagaland; Ser. 16. Orissa; Ser. 17. Punjab; Ser. 18. Rajasthan; Ser. 18A. Sikkim; Ser. 19. Tamil Nadu; Ser. 20. Tripura; Ser. 21. Uttar Pradesh; Ser. 22. West Bengal; Ser. 23. Andaman and Nicobar Islands; Ser. 24. Arunachal Pradesh; Ser. 25. Chandigarh; Ser. 26. Dadra and Nagar Haveli; Ser. 27. Delhi; Ser. 28. Goa, Daman and Diu; Ser. 29. Laccadive, Amindivi and Minicoy Is.; Ser. 30. Pondichery.), Manager of Publications, Delhi. 
India (Republic) Office of the Registrar General. 1973. Census of India 1971, Indian Census Centenary Atias. Office of the Registrar General and Census Commissioner, Ministry of Home Affairs, New Delhi.

India (Republic) Office of the Registrar General and Census Commissioner. 1982. Census of India 1981, Series 1, India Final Population Totals. Paper 1 of 1982, Controller of Publications, Civil Lines, Delhi.

India (Republic) Scheduled Areas and Scheduled Tribes Commission. 1961. Report of the Scheduled Areas and Scheduled Tribes Commission. 2 vols., Manager of Publications Civil Lines, Delhi.

India (Republic) Superintendent of Census Operations. 1962. Census of India 1961. Vol. 1, Part I-A, India General Report. Manager of Publications, Civil Lines, Delhi.

India (Republic) Superintendent of Census Operations. 1964. Census of India 1961. Vol. IX, Part IX, Census Atlas (Madras). Govt. Press, New Delhi.

India (Republic) Superintendent of Census Operations. 1964. Census of India 1961. Vol. XII, Part IX, Census Atlas (Orissa). Govt. Press, New Delhi.

India (Republic) Superintendent of Census Operations. 1966. Census of India 1961. Vol. XIII, Part IX., Census Atlas (Punjab). Manager of Publications, Delhi.

India (Republic) Superintendent of Census Operations. 1967. Census of India 1961. Vol. VI, Part IX, Census Atlas (Jammu and Kashmir). Govt. Press, New Delhi.

India (Republic) Superintendent of Census Operations. 1967. Census of India 1961. Vol. VII, Part IX, Census Atlas (Kerala). Govt. Press, New Delhi.

India (Republic) Superintendent of Census Operations. 1968. Census of India 1961. Vol. IV, Part IX, Census Atlas (Bihar). Govt. Preis, New Delhi.

India (Republic) Superintendent of Census Operations. 1968. Certsus of India 1961. Vol. V, Part IX, Census Atlas (Gujarat). Govt. Press, New Delhi.

India (Republic) Superintendent of Census Operations. 1972. Census of India 1961. Vol. X, Part IX, Census Atlas (Maharashtra). Controller of Publications, Civil Lines, Delhi.

India (Republic) Superintendent of Census Operations. 1962-1974. Census of India 1961. District Census Handbooks Series XXVII (Andaman and Nicobar Islands). Vijaya Printing Press, Sehore.

India (Republic) Superintendent of Census Operations. 1962-1974. Census of India 1961. District Census Handbooks Series II (Andhra Pradesh). Manager of Publications, Delhi. 
India (Republic) Superintendent of Census Operations. 1962-1974. Census of India 1961. District Census Handbooks Series III (Assam). Manager of Publications, Delhi.

India (Republic) Superintendent of Census Operations. 1962-1974. Census of India 1961. District Census Handbooks Series IV (Bihar). Manager of Publications, Delhi.

India (Republic) Superintendent of Census Operations. 1962-1974. Census of India 1961. District Census Handbooks Series XVIII (Dadra and Nagar Haveli). Vijaya Printing Press, Sehore.

India (Republic) Superintendent of Census Operations. 1962-1974. Census of India 1961. District Census Handbooks Series XIX (Delhi). Manager of Publications, Delhi.

India (Republic) Superintendent of Census Operations. 1962-1974. Census of India 1961. District Census Handbooks Series XXVII (Goa, Daman and Diu). Vijaya Printing Press, Sehore.

India (Republic) Superintendent of Census Operations. 1962-1974. Census of India 1961. District Census Handbooks Series V (Gujarat). Manager of Publications, Delhi.

India (Republic) Superintendent of Census Operations. 1962-1974. Census of India 1961. District Census Handbooks Series VI (Jammu and Kashmir). Manager of Publications, Delhi.

India (Republic) Superintendent of Census Operations. 1962-1974. Census of India 1961. District Census Handbooks Series VII (Kerala). Manager of Publications, Delhi.

India (Republic) Superintendent of Census Operations. 1962-1974. Census of India 1961. District Census Handbooks Series XXI (Laccadive, Minicoy, and Amindivi Islands). Vijaya Printing Press, Sehore.

India (Republic) Superintendent of Census Operations. 1962-1974. Census of India 1961. District Census Handbooks Series VIII (Madhya Pradesh). Manager of Publications, Delhi.

India (Republic) Superintendent of Census Operations. 1962-1974. Census of India 1961. District Census Handbooks Series IX (Madras). Manager of Publications, Delhi.

India (Republic) Superintendent of Census Operations. 1962-1974. Census of India 1961. District Census Handbooks Series X (Maharashtra). Manager of Publications, Delhi.

India (Republic) Superintendent of Census Operations. 1962-1974. Census of India 1961. District Census Handbooks Series XXI (Manipur). Vijaya Printing Press, Sehore.

India (Republic) Superintendent of Census Operations. 1962-1974. Census of India 1961. District Census Handbooks Series XI (Mysore). Manager of Publications, Delhi.

India (Republic) Superintendent of Census Operations. 1962-1974. Census of India 1961. District $C$ nsus Handbooks Series XXIII (Nagaland). Govt. of India Press, Calcutta. 
India (Republic) Superintendent of Census Operations. 1962-1974. Census of India 1961. District Census Handbooks Series XXIV (North East Frontier Agency). Vijaya Printing Press, Sehore.

India (Republic) Superintendent of Census Operations. 1962-1974. Census of India 1961. District Census Handbooks Series XII (Orissa Pradesh). Manager of Publications, Delhi.

India (Republic) Superintendent of Census Operations. 1962-1974. Census of India 1961. District Census Handbooks Series XXV (Pondichery). Manager of Publications, Delhi.

India (Republic) Superintendent of Census Operations. 1962-1974. Census of India 1961. District Census Handbooks Series XIII (Punjab). Manager of Publications, Delhi.

India (Republic) Superintendent of Census Operations. 1962-1974. Census of India 1961. District Census Handbooks Series XIV (Rajasthan). Manager of Publications, Delhi.

India (Republic) Superintendent of Census Operations. 1962-1974. Census of India 1961. District Census Handbooks Series XXVI (Tripura). Govt. of India Press, Calcutta.

India (Republic) Superintendent of Census Operations. 1962-1974. Census of India 1961. District Census Handbooks Series XV (Uttar Pradesh). Manager of Publications, Delhi.

India (Republic) Superintendent of Census Operations. 1962-1974. Census of India 1961. District Census Handbooks Series XVI (West Bengal and Sikkim). Manager of Publications, Delhi.

India (Republic) Wastelands Survey and Reclamation Committee. 1960. Report on Location and Utilization of Wastelands in India. Part I, Punjab, Part II, West Bengal, Part III, Bihur, Part IV, Mysore, Part V, Andhra Pradesh, Part VI, Madhya Pradesh. Ministry of Food and Agriculture, Delhi.

India Revenue and Agricultural Dept. 1886-1890. Returns of Agricultural Statistics for British India for 1884-85 (annual, 1885-86 through 1889-90). Superintendent of Govt. Printing, Calcutta.

India Dept. Statistics. 1896. Agricultural Statistics of British India for the Years 1890-91 to 1894-95. Supt. Govt. Printing, Calcutta.

Innes, C.A. 1908. Malabar and Anjengo District Gazetteer. Govt. Press, Madras.

Ishaque, H.S.M. 1946. Agricultural Statistics by Plot to Plot Enumeration in Bengal 1944-45. Supt. Govt. Printing, Bengal Govt. Press, Alipore.

Iyengar, M. Venkatesh. 1932. Census of India 1931. Mysore State. Vol. XXV, Bangalore Govt. Press, Bangalore. 
Iyengar, S. Kesava. 1951. Rural Economic Enquiries in the Hyderabad State 1949-51. Govt. Press, Hyderabad-Deccan.

Jahdav, C.G., C. Singh, A. Prakash, and B.K. Roy Burman. 1972. Bibliography of Census Publications in India. Census Centenary Publication No. 5, Census of India 1971, Manager of Publications, Delhi.

Jammu and Kashmir Directorate of Economics and Statistics. 1971. Digest of Statistics: Jammu and Kashmir 1970-71. Govt. Press, Srinagar.

Jammu and Kashmir. 1969. A Digest of Forest Statistics. J and K Forest Record No.1 (2nd ed.), Srinagar.

Jayal, N.D. (ed.) 1989. Deforestation, Drought and Desertification: Perceptions of a Growing Ecological Crisis. Studies in Ecology and Sustainable Development, Indian National Trust for Art and Cultural Heritage, New Delhi.

Jenny, Hans and S. Raychaudhuri. 1960. Effect of Climate and Cultivation on Nitrogen and Organic Matter Reserves in Indian Soils. Indian Council of Agricultural Research, New Delhi.

Jha, D.D. 1986. Arunachal Pradesh (Rich Land and Poor People). Omsons Publications, New Delhi.

Jha, U.M. 1984. Irrigation and Agricultural Development. Deep and Deep Publications, New Delhi.

Johnstone, J. 1896. My Experiences in Manipur and the Naga Hills; with an Introduction Memoir. Sampson Low, London. Reprinted 1971 by Vivek Publ. House, Delhi.

Kachroo, P., B.L. Sapru, and U. Dhar. 1977. Flora of Ladakh: An Ecological and Taxonomical Appraisal. Bishen Singh Mahendra Pal Singh, Dehra Dun.

Kadambi, K. 1939. The montane evergreen forest, Bisale region. Indian For. 65:189-201.

Kadambi, K. 1941. The evergreen ghat rain forest, Agumbe-Kilandur zone. Indian For. 67:184-203.

Kadambi, K. 1942. The evergreen ghat rain forests of the Tunga and the Bhadra river sources. Indian For. 68:233-240; 305-312.

Kadambi, K. 1950. Evergreen, montane forests of the Westem Ghats of Hassan District, Mysore State. Indian For. 76:69-82; 121-132.

Kaith, D.C. 1936. Manipur forests. Indian For. 62:361-369; 409-414. 
Kanai, H. 1966. Phytogeography of Eastem Himalaya, with special reference to the relationship between Himalaya and Japan, pp. 13-38 In The Flora of Eastern Himalaya (Results of the Botanical Expedition to Eastern Himalaya Organized by the University of Tokyo 1960 and 1963), Hiroshi, H. (ed.) University Tokyo Press, Tokyo.

Kanjilal, U.N. and B.L. Gupta. 1928. Forest Flora of the Chakrata, Dehra Dun and Saharanpur Forest Divisions, Utter Pradesh. Central Publications Branch, Dehra Dun.

Kanjilal, U.N., P.C. Kanjilal, and A. Das. 1934-1938. Flor a of Assam. 5 vols., Govt. of Assam, Shillong.

Karan, P.P., S. Ijima, and G. Pauer. 1984. Sikkim Himalaya: Development in Mountain Environment. Monumenta Serindica No. 13, Institute for the Study of Languages and Cultures of Asia and Africa, Tokyo University Foreign Studies, Tokyo.

Kamataka (State). 1973-1990. Karnataka District Gazetteers. Vols. 11-20, Director of Printing, Stationery and Publications at the Govt. Press, Bangalore.

Karve, I. (ed.) 1968. Maharashtra State Gazetteers. Maharashtra -Land and Its People. General Series, Director, Govt. Printing, Stationery and Publications, Maharashtra State, Bombay.

Kaul, O.N. 1990. Forest biomass burning in India. Tata Energy Research Institute, New Delhi.

Kaul, P.N. 1961. Management of the forests of Jammu and Kashmir state. Indian For. 87:667-677.

Kaul, R.N. and K. Gurumurti. 1981. Forest energy in India: the state of the art. Indian For. 107:737-43.

Kaul, O.N. and D.C. Sharma. 1971. Forest types statistics. Indian For. 97:435-436.

Kawosa, M.A. 1988. Remote Sensing of the Himalaya. Natraj Publ., Dehra Dun.

Kayastha, S.L. 1964. The Himalayan Beas Basin: A Study in Habitat, Economy, Society. Banaras Hindu University, Varanasi.

Kelsall, John. 1872. Manual of the Bellary district, Madras Presidency. Asylum Press, Madras.

Kerala (State). 1960, 1959. An Economic Review. Govt. Press, Trivandrum.

Kerala (State). 1962-1986. Kerala District Gazetteers. Superintendent of Govt. Press, Trivandrum or Emakulam.

Kerala Agricultural Census Division. 1973. The Third Decennial World Census of Agriculture 1970-71: Report for Kerala State. 2 vo's., Govt. Press, Emakulam. 
Kerala Bureau of Economics and Statistics. 1975. Basic Statistics Relating to Kerala Economy 1956-67 to 1973-74. Govt. Press, Trivandrum.

Kerala Dept. Agriculture. 1973. Administration Report for the Year 1969-70. Govt. Press, Trivandrum.

Kerala Dept. Agriculture. 1983. Administration Report of the Dept. of Agriculture for the Year 1976-77. Govt. Press, Emakulam.

Kerala State Planning Board. 1972. Economic Review Kerala -1971. State Planning Board, Trivandrum.

Kerala State Planning Board. 1980-1982. Economic Review (annual, 1979-1981). State Planning Board, Trivandrum.

Khan, G.A. 1933. Census of India 1931. The Nizam's Dominions. Vol. XXIII, Part I Report, Govt. Press, Hyderabad-Deccan.

Khator, R. 1989. Forests: the People and the Government (An Analysis of the Forest Policy Performance in India). National Book Organization, New Delhi.

Khoshoo, T.N. 1984. Environmental Concerns and Strategies. Indian Environmental Society, New Delhi.

Khunteta, M.R. 1932. Census of India, Jaipur State, 1931. Part I, Report, Newul Kishore Press, Lucknow.

Kingdon-Ward, F. 49. Plant hunting in Manipur. J. Royal Horticultural Society 74:288-95; 334-40.

Koul, P.A. 1978. Geography of the Jammu and Kashmir State. Light and Life Publishers, New Delhi.

Krishna Rao, P.H. 1943. Census of India 1941, Vol. XXIII, Mysore. Part I Report, Superintendent Govt. Press, Bangalore.

Krishnaswamy, K.S. 1968. Thoughts on Indian Forestry. K.S. Krishnaswamy, Madras.

Kundu, A.K., D. Saha, and P. Nag (eds.) 1988. Resource Mapping at District Level. Monograph 8, National Atlas and Thematic Mapping Org., Calcutta.

Kunhamanm M. 1989. Development of Tribal Economy. Classical Publ. Co., New Delhi.

Kurien, C.T. 1981. Dynamics of Rural Transformation, A Study of Tamil Nadu: 1950-1975. Orient Longman Ltd., Madras. 
Labroue, L., P. Legris, and M. Viart. 1965. Bioclimats du sous-continent Indien. Trav. Sec. Sci. Tec. Tome 3, Fasc. 3, Institut Francais, Pondichery.

Laeequddin, M. 1937. Census of India 1931. Census of Mayurbhanj State. 2 vols., Caledonian Printing Co., Calcutta.

Lakshmana Rao, V. 1988. Economic Growth of Andhra Pradesh. Chugh Publications, Allahabad.

Lal, J.B. 1989. India's Forests: Myth and Reality. Natraj Publ., Dehra Dun.

Lal, M. 1974. Haryana: On High Road to Prosperity. Vikas Publ. House Ltd., Delhi.

Lal, P. and B.K. Das Gupta. 1979. Lower Siang People: A Study in Ecology and Society. Anthropological Survey of India, Calcutta.

LaTouche, J.D. 1875. Report on the Settlement of the Ajmere and Mhairwarra Districts. Foreign Dept. Press, Calcutta.

Lawrence, W.R. 1895. The Valley of Kashmir. Henry Frowde, London.

Lawrence, W.R. 1909. Kashmir and Jammu. Clarendon Press, Oxford.

Leach, G. 1985. Household energy in South Asia. Biomass 12:155-184.

Leach, G. 1987. Household Energy in South Asia. Elsevier Applied Science, New York.

LeFanu, H. 1883. Manual of the Salem District of the Madras Presidency. Madras Govt. Press, Madras.

Legris, P. 1963. La vegetation de l'Inde: Ecologie et Flore. Trav. Sect. Sci. Tech., Tome VI, Institut Francais, Imprimerie de la Mission, Pondichery.

Legris, P. and M. Viart. 1961. Bioclimates of South India and Ceylon. Trav. Sect. Sci. Tech., Tome III, Fasc. 2, Institut Francais, Imprimerie de la Mission, Pondichery.

Loffeier, M.E. 1989. Sylviculture et Sylvigenese en foret sempervirente du Coorg (Sud-ouest de l'Inde). Trav. Sect. Sci. Tech., Tome XXVI, Instituit Francais, Pondichery.

Logan, W. 1887. Malabar. 2 vols., Madras Govt. Press, Madras.

Luard, C.E. 1907-1912. Central India Gazetteers. 8 vols., Unnumbered series, Various publishers.

Luard, C.E. 1907. Central India Gazetteers. Rewa State Gazetteer. Vol. IV, Superintendent, Govt. Printing, Calcutta. 
Luard, C.E. 1908-1909. Central India Gazetteers. Gwalior State Gazetteer. Vol. I, Parts 1-4, Superintendent, Govt. Printing, Calcutta.

Luard, C.E. 1908. Central India Gazetteers. Indore State Gazetteer. Vol. II, Superintendent, Govt. Printing, Calcutta.

Luard, C.E. 1908. Central India Gazetteers. Bhopal State Gazetteer. Vol. III, Superintendent, Govt. Printing, Calcutta.

Luard, C.E. 1908. Central India Gazetteers. Malwa (Western States) Gazetteer. Vol. V, Parts A-B, British India Press, Byculla, Bombay.

Luard, C.E. 1908. Central India Gazetteers. Bundelkhand (Eastern States) Gazetteer. Vol. VI, Parts A-B, Newal Kishore Press, Lucknow.

Madhavan Unni, N.V., P.S. Roy, and V. Parthasarathy. 1985. Evaluation of LANDSAT and airborne multispectral data and aerial photographs for mapping forest features and phenomena in a part of the Godavari basin. Int. J. Remote Sensing 6:419-431.

Madhya Pradesh. 1958. Economic and Statistical Atlas of Madhya Pradesh. Directorate of Land Records, Gwalior.

Madhya Pradesh. 1965-1989. Madhya Pradesh District Gazetteers. 23 vols. (continuing series), Govt. Central Press, Bhopal.

Madhya Pradesh Directorate of Agriculture. 1979, 1982. Agricultural Statistics Madhya Pradesh (vols. for 1978, 1980). Directorate of Agriculture, Bhopal.

Madhya Pradesh Directorate of Land Records. 1965. Agro-Economic Atlas of Madhya Pradesh. Vol. I, Govt. Regional Press, Gwalior.

Madras (Presidency). 1894-1917. Madras District Gazetteers. 24 vols., Superintendent Govt. Press, Madras.

Madras (Presidency). 1904-1906. Madras District Gazetteers. Statistical Appendix Series. 22 vols., Superintendent Govt. Press, Madras.

Madras (Presidency). 1915. Madras District Gazetteers. Statistical Appendix Series. 24 vols., Superintendent Govt. Press, Madras.

Madras (Presidency). 1924. Statistical Atlas of the Madras Presidency. Superintendent Govt. Pruss, Madras.

Madras (Presidency). 1928-1938. Madras District Gazetteers. Statistical Appendix Series. 39 vols. (Some districts represented twice; 10 district volumes include supplemental text to earlier gazetteers in addition to the tables), Superintendent Govt. Press, Madras. 
Madras (State). 1963. A Statistical Atlas of the Madras State, Revised and Brought up to the end of 1960 (1950-51). Directorate of Statistics, Madras.

Madras (State) Record Office. 1957-1966. Madras District Gazetteers. Superintendent Govt. Press, Madras.

Madras Director of Statistics. 1963-1968. Annual Statistical Abstract for (the) Madras State (annual 1959-60 to 1964-65). Govt. of Madras, Madras.

Mahabale, T.S. 1987. Maharashira State Gazetteers. Botany. Part IV, Rev. edition, Gazetteer Dept., Bombay.

Mahapatra, L.K. 1983. India, pp. 13-82 In Swidden Cultivation in Asia: Content Analysis of the Existing Literature, A Stocktaking Exercise. UNESCO, Bangkok.

Maharashtra (State). 1960-1986. Maharashtra District Gazetteers. Gazetteers Dept., Govt. of Maharashtra, Bombay.

Maharashtra (State). 1961. Maharashtra State Gazetteers, Botany. Part III, Rev. edition, Manipur (State) District Gazetteers, Bombay.

Maharashtra Dept. of Agriculture. 1964. Season and Crop Report, Bombay State, 1959-60.

Director, Govt. Printing, Maharashtra State, Bombay.

Maharashtra Dept. of Agriculture. 1975. Season and Crop Report, Maharashtra State, 1970/71.

Director, Govt. Printing, Maharashtra State, Bombay.

Maharashtra Dept. of Agriculture. 1989. Season and Crop Report, Maharashtra State, $1981 / 82$.

Director, Govt. Printing, Maharashtra State, Bombay.

Maharashtra Directorate of Economics and Statistics. 1971-1975. Statistical Abstract of Maharashtra State (annual, 1968/69-1972/73). Govt. Press, Nagpur.

Maharashtra Directorate of Economics and Statistics. 1979, 1981. Handbook of Basic Statistics of Maharashtra State (annual, 1978-1980). Directorate of Economics and Statistics, Bombay.

Maharashtra Directorate of Economics and Statistics. 1983. Statistical Abstract of Maharashtra State for the Year 1978-79. Govt. Press, Nagpur.

Maharashtra Directorate of Economics and Statistics. 1988. Handbook of Basic Statistics of Maharashtra State 1988. Directorate of Economics and Statistics, Bombay.

Mahendra, A.K. and G.P. Maithani. 1986. Forest production in India vis-a-vis other Asian countries. Indian For. 112:1058-1066.

Maheshwari, P. and Umrao Singh. 1965. Dictionary of Economic Plants in india. Indian Council of Agricultural Research, New Delhi. 
Maithani, G.P., N.M. Misra, and A.K. Mahendra. 1986. Socio-economic factors associated with fuel consumption in rural areas (Vill. Karaundi). Indian For. 112:753-761.

Mamoria, C.B. 1975. Geography of India [Agricultural Geography]. Shiva Lal Agarwal and Co., Agra.

Mandal, R.B. 1982. Land Utilization: Theory and Practice. Concept Publ. Co., New Delhi.

Mani, M.S. (ed.) 1974. Ecology and Biogeography in India. Dr. W. Junk Publishers, The Hague.

Mani, M.S. 1978. Ecology and Phytogeography of High Altitude Plants of the Northwest Himalaya: Introduction to High Altitude Botany. Chapman and Hall, London.

Mannadiar, N.S. (ed.) 1977. Administration of the Union Territory of Lakshadweep, Kavaratti. Manual of the Administration of the Madras Presidency, In Illustration of the records of government and the yearly administration reports, C.D. Maclean (ed.) Reprinted by Asian Educational Services, New Delhi.

Marten, J.T. 1922. Census of India 1921, Final Figures Showing the Population of Each Province, District and State and the Distribution of the Population by Religion. Govt. Press, Simla.

Marten, J.T. 1924. Census of India 1921. Vol. I, Part I and II, Tables. Superintendent Govt. Printing, Calcutta.

Mateer, S. 1871. The Land of Charity: A Descriptive Account of Travancore and its People. John Snow and Co., London.

Mawthoh, P.R. 1976. The buming problems of shifting cultivation (jhumming) in Meghalaya, pp. 106-111 In Shifting Cultivation in North East India. North East India Council Soc. Sci. Res., Shillong.

McNeill, D., J.W.H. West, and C.B. Little. 1884. Gazetteer of Manipur, the Country between it and Ava, and Some of the Adjacent Hill-Tracts. Superintendent Govt. Printing, Calcutta.

Meher-Homji, V.M. 1963. Les bioclimats du sub-continent indien et leurs types analogues dans le monde. Travaux de la section scientifique et technique, Vol. 7, fasc. 1, Institut Francais, Pondichery.

Meher-Homji, V.M. 1963. Les bioclimats du sub-continent indien et leurs types analogues dans le monde (appendices). Travaux de la section scientifique et technique, Vol. 7, fasc. 2, Institut Francais, Pondichery.

Meher-Homji, V.M. 1971. Bio-climatic variability with special reference to India. Tropical Ecology 12:155-76.

Meher-Homji, V.M. 1984. A new classification of the phytogeographic zones of India. Indian J. Bot. 7:224-233. 
Meher-Homji, V.M., J. Fontanel, J.-P. Pascal, K. Chandrahasan, and A. Delacourt. 1978. Notes on the Sheet Allahabad. Trav. Sect. Sci. Tech. Inst. Fr. Pondichery, Hors Ser. 15, Institut Francais, Pondichery.

Melkania, N.P. and U. Melkania 1987. Man and environment in Himachal Pradesh, India, pp. 81-99 In Himachal Himalaya Ecology and Environment, S. K. Chadha (ed.) Today and Tomorrow's Printers and Publ., New Delhi.

Melkania, N.P. and J.S. Singh. 1989. Ecology of Indian grasslands, pp. 67-103 In Perspectives in Ecology, J.S. Singh and B. Gopal (eds.) Jagmander Book Agency, New Delhi.

Melkania, U. 1987. An energetics model for agro- and forest ecosystems in Himalaya, pp. 101-110 In Himalayan Energy Systems, T.N. Dhar and P.N. Sharma (eds.) Gyanodaya Prakashan, Naini Tal.

Mencher, J.P. 1978. Agriculture and Social Structure in Tamil Nadu: Past Origins, Present Transformations and Future Prospects. Allied Publishers Pvt. Ltd., New Delhi.

Menon, B.V.K. 1944. Census of India 1941. Vol. XIX, Cochin. Part I Report, Part II Tables, Superintendent, Cochin Govt. Press, Emakulam.

Menon, T.K. and Sankara. 1933. Census of India 1931. Vol. XXI, Cochin. Parts I Report, Part II, Tables, Superintendent, Cochin Govt. Press, Emakulam.

Mishra, B.K. and P.S. Ramakrishnan. 1981. The economic yield and energy efficiency of hill agro-ecosystems at higher elevations of Meghalaya in North-Eastern India. Acta Oecologica Oecol. Applic. 2:369-389.

Mishra, B.K. and P.S. Ramakrishnan. 1983. Secondary succession subsequent to slash and burn agriculture at higher elevations of north-east India: I. Species diversity, biomass and litter production. Acta Oecologica Oecol. Applic. 4:95-107.

Mishra, B.K. and P.S. Ramakrishnan. 1983. Secondary succession subsequent to slash and bum agriculture at higher elevations of north-east India: II. Nutrient cycling. Acta Oecologica Oecol. Applic. 4:237-245.

Misra, N., A.K. Mahendra, and A.Y. Ansari. 1988. Pilot survey of fuel consumption in rural areas, Part V. Indian For. 114:57-62.

Misra, R.P. 1973. Geography of Mysore. Director, National Book Trust, New Delhi.

Mitra, A. 1953. An Account of Land Management in West Bengal 1870-1950. Census of 1951, West Bengal Land and Land Revenue Dept., Supt. Govt. Printing, West Bengal Govt. Press, Alipore.

Mitra, A. 1963. Census of India 1961. Vol. I, Part II-A (ii), Union Primary Census Abstracts. Manager of Publications, Delhi. 
Mitra, A. and R.P. Sachdev, with G.C. Pant, N.S. Soam, and V.S. Gaihlaut. 1980. Population and Area of Cities Towns and Urban Agglomerations 1872-1971. An Indian Council of Social Science Research and Jawaharlal Nehru University study, Allied Publishers Pvt. Ltd., Bombay.

Mobbs, E.C. 1941. The early history of Indian forests, Indian For. 67 (1941):231-41.

Mohammad, N. 1978. Agricultural Land Use In India: A Case Study. M.C. Mittal, Delhi.

Mohanty, A.P. 1979. Forestry in Nagaland, pp. 223-225 In Man and Forest (A New Dimension in the Himalaya), K.M. Gupta and D. Bandhu (eds.) Today and Tomorrow's Printers and Publishers, New Delhi.

Moore, Lewis. 1878. Manual of the Trichinopoly district in the Presidency of Madras. Madras Govt. Press, Madras.

Morris, H. 1878. A Descriptive and Historical Account of the Godavery District. Madras Govt. Press, Madras.

Mukerjea, S.V. 1941. Census of India 1941. Baroda. Some Results of the Census of 1941 with Tables and Subsidiary Tables. Vol. XVII, Baroda State Press, Baroda.

Mukharji, S.C. (ed.) 1938. Bihar District Gazetteers. Central Parganas. Bihar Govt. Printing Press, Patna.

Murthy, R.S., L.R. Hirerekur, S.B. Deshpande, and B.V. Venkata Rao (eds.) 1982. Benchmark Soils of India: Morphology, Characteristics and Classification for Resource Management. National Bureau of Soil Survey and Land Use Planning (ICAR) in collaboration with the All India Soil and Land Use Survey (Govt. of India) Agricultural Universities and Soil Survey Organizations of the State Dept. of Agriculture, Bangalore.

Mysore (State). 1967-1971. Mysore State Gazetteers. Vols. 1-10, Govt. Press, Bangalore.

Mysore Resources and Economy Committee. 1962. Report of the Mysore Resources and Economy Committee. Govt. Press, Bangalore.

Mysore Dept. of Statistics. 1968. Mysore State in Maps 1966. Govt. Press, Bangalore.

Nadkarni, M.V., S.A. Pasha, and L.S. Prabhakar. 1989. The Political Economy of Forest Use and Management. Sage Publications, New Delhi.

Nagaland (State). 1970-1981. Nagaland District Gazetteers. 5 vols., Govt. of Nagaland, Kohima.

Nagam-Aiya, Y. 1906. The Travancore State Manual. 3 vols., Govt. Press, Trivandrum.

Nair, K.S.S., R. Gnanaharan, S. Kedharnath, S. Sankar, K.V. Bhat, A.R.R. Menon, and K.K. Ramachandra (eds.) 1986. Ecodevelopment of Western Ghats. Kerala Forest Research Institute, Peechi. 
Natarajan, B. 1985. Domestic Fuel Survey With Special Reference to Kerosene. 2 vols., National Council of Applied Economic Research, New Delhi.

Natarajan, B. 1981. Rural Energy Consumption in Southern India for Dept. of Environment, Govt. of India. Institute for Techno Economic Studies, Madras.

National Council of Applied Economic Research. 1959. Domestic Fuels in India. Asia Publ. House, Bombay.

National Council of Applied Economic Research. 1959. Techno-Economic Survey of Bihar. National Council of Applied Economic Research, New Delhi.

National Council of Applied Economic Research. 1960. Techno-Economic Survey of Madhya Pradesh. National Council of Applied Economic Research, New Delhi.

National Council of Applied Economic Research. 1961. Techno-Economic Survey of Himachal Pradesh. National Council of Applied Economic Research, New Delhi.

National Council of Applied Economic Research. 1961. Techno-Economic Survey of Madras. National Council of Applied Economic Research, New Delhi.

National Council of Applied Economic Research. 1961. Techno-Economic Survey of Manipur. National Council of Applied Econon.ic Research, New Delhi.

National Council of Applied Economic Research. 1961. Techno-economic Survey of Tripura. National Council of Applied Economic Research, New Delhi.

National Council of Applied Economic Research. 1962. Demand for Energy in Southern India. National Council of Applied Economic Research, New Delhi.

National Council of Applied Economic Research. 1962. Techno-Economic Survey of Andhra Pradesh. National Council of Applied Economic Research, New Delhi.

National Council of Applied Economic Research. 1962. Techno-Economic Survey of Assam. National Council of Applied Economic Research, New Delhi.

National Council of Applied Economic Research. 1962. Techno-Economic Survey of Kerala. National Council of Applied Economic Research, New Delhi.

National Council of Applied Economic Research. 1962. Techno-Economic Survey of Orissa. National Council of Applied Economic Research, New Delhi. 
National Council of Applied Economic Research. 1962. Techno-Economic Survey of Punjab. National Council of Applied Economic Research, New Delhi.

National Council of Applied Economic Research. 1963. Demand for Energy in Eastern India. Publications Div., National Council oi Applied Economic Research, New Delhi.

National Council of Applied Economic Research. 1963. Socio-economic Conditions of Primitive Tribes in Madhya Pradesh. Publications Div., National Council of Applied Economic Research, New Delhi.

National Council of Applied Economic Research. 1963. Techno-Economic Survey of Gujarat. National Council of Applied Economic Research, New Delhi.

National Council of Applied Economic Research. 1963. Techno-Economic Survey of Konkan Region, an Underdeveloped Area of Maharashtra. National Council of Applied Economic Research, New Delhi.

National Council of Applied Economic Research. 1963. Techno-Economic Survey of Maharashtra. National Council of Applied Economic Research, New Delhi.

National Council of Applied Economic Research. 1963. Techno-Economic Survey of Rajasthan. National Council of Applied Economic Research, New Delhi.

National Council of Applied Economic Research. 1964. Techno-Economic Survey of Goa, Daman and Diu. National Council of Applied Economic Research, New Delhi.

National Council of Applied Economic Research. 1965. Demand for Energy in Northern India. Publications Div., National Council of Applied Economic Research, New Delhi.

National Council of Applied Economic Research. 1965. Demand for Energy in Western India. Publications Div., National Council of Applied Economic Research, New Delhi.

National Council of Applied Economic Research. 1965. Domestic Fuel Consumption in Rural India. Publications Div., National Council of Applied Economic Research, New Delhi.

National Council of Applied Economic Research. 1965. Techno-Economic Survey of Pondichery. National Council of Applied Economic Research, New Delhi.

National Council of Applied Economic Research. 1965. Techno-Economic Survey of Uttar Pradesh. National Council of Applied Economic Research, New Delhi.

National Council of Applied Economic Research. 1966. Demand for Energy in India. Administrative Officer, National Council of Applied Economic Research, New Delhi.

National Council of Applied Economic Research. 1966. Survey of Hilly and Backward Areas of Punjab. National Council of Applied Economic Research, New Delhi. 
National Council of Applied Economic Research. 1967. Cropping Paitern in Madhya Pradesh. Administrative Officer, National Council of Applied Economic Research, New Delhi.

National Council of Applied Economic Research. 1967. Techno-Economic Survey of North East Frontier Agency. National Council of Applied Economic Research, New Delhi.

National Council of Applied Economic Research. 1969. Techno-Economic Survey of Jammu and Kashmir. National Council of Applied Economic Research, New Delhi.

National Council of Applied Economic Research. 1970. Techno-Economic Survey of Haryana. National Council of Applied Economic Research, New Delhi.

National Council of Applied Economic Research. 1973. Techno-Economic Survey of Delhi. National Council of Applied Economic Research, New Delhi.

National Council of Applied Economic Research. 1968. Techno-Economic Survey of Nagaland. National Council of Applied Economic Research, New Delhi.

Nayar, P.K.B. (ed.) 1972. Development of Kerala: Problems and Promises. Dept. Sociology, University Kerala, Trivandrum.

Negi, G.S. 1984. Landsat data in study of forest recession due to shifting cultivation -a case study in Garo Hills of Meghalaya. Indian J. Forestry 7:273-280.

Nelson, J.H. 1868. The Madurai Country: A Manual. Asylum Press, Madras.

Nayar, M.P. 1977. Changing pattems of the Indian flora. Bull. Botanical Survey India 19:145-55.

Negi, G.S. 1984. Landsat data in study of forest recession due to shifting cultivation -a case study in Garo Hills of Meghalaya. Indian J. Forestry 7:273-80.

Negi, S.S. 1983. Simulation of the firewood extraction process in the Himalaya, pp. 35-43 In Contributions to Himalayan Ecology, S.S. Negi (ed.) Bishen Singh Mahendra Pal Singh and Indian J. of Forestry, Dehra Dun.

Negi, S.S. 1989. Forest Types of India, Nepal and Bhutan. Periodical Export Book Agency, Delhi.

Negi, Y.S., L.R. Sharma, and J. Singh. 1986. Factors affecting fuel-w'ood consumption -A micro level study. Indian For. 112:737-741.

Nicholson, F.A. 1898. Madras District Manuals: Coimbatore. New edition, Superintendent Govt. Press, Madras.

Nicholson, J.W. 1926. The Forests Within Bihar and Orissa. Supt. Govt. Printing Bihar and Orissa, Patna. 
Nisanka, S.K. and M.K. Misra. 1990. Ecological study of an Indian village ecosystem: biomass production and consumption. Biomass 23:117-136; 165-178.

Odend'hal, S. 1972. Energetics of Indian cattle in their environment. Human Ecology 1:3-22.

O'Malley, L.S.S. (ed.) 1906-1925. Bengal District Gazetteers. 39 vols., Bengal Secretariat Book Depot, Calcutta.

Orissa (State). 1966-1986. Orissa District Gazetteers. 10 vols., Superintendent Orissa Govt. Press, Cuttack.

Orissa Agricultural Census Commissioner. 1970. Agricultural Census. Board of Revenue, Orissa, Cuttack.

Orissa Bureau of Statistics and Economics. 1964. A Report on the Sample Survey for Estimating Consumption of Domestic Fuels in Cuttack City. Bureau of Statistics and Economics, Cuttack, Orissa.

Orissa Bureau of Statistics and Economics. 1985. Economic Survey' of Orissa, 1983-84. Orissa Govt. Press, Cuttack.

Orissa Bureau of Statistics and Economics. 1975, 1983, 1985. Statistical Abstract of Orissa (annual, 1973, 1979, 1981). Bureau of Statistics and Economics, Bhubaneshwar.

Osmaston, A.E. 1927. A Forest Flora for Kumaon. Superintendent Govt. Press, United Provinces, Allahabad.

Padhi, G.S. 1982. Forestry in India: A Critical Study. Intemational Book Distributors, Dehra Dun.

Padhi, G.S. 1984. Forest Resources of Orissa. Udyog Printers for A.K. Padhi, Bhubaneshwar.

Padmanabha, P. 1982. Census of India 1981. Series 1, Final Population Totals. Paper 1 of 1982, Controller of Publications Civil Lines, Delhi.

Padmanabha, P. 1983. Census of India 1981. Series 1, Part II B(iii), Primary Census Abstract and Scheduled Tribes. Controller of Publications Civil Lines, Delhi.

Painuly, J.P. 1987. Household energy demand and energy supply potential in hill areas, pp. 219-229 In Himalayan Energy Systems, T.N. Dhar and P.N. Sharma (eds.) Gyanodaya Prakashan, Naini Tal.

Pakem, B., J.B. Bhattacharjee, B.B. Dutta, and B. Datta Ray (eds.) 1980. Shifting Cultivation in North East India. 2nd edition, North East India Council for Social Science Research, Shillong. 
Palande, M.R. 1959. Gazetteer of the Bombay State. Rev. edition, District Gazetteers, Dharwar.

Paliwal, G.S. (ed.) 1984. The Vegetational Wealth of the Himalayas. Puja Publishers, Delhi.

Panandikar, S.G. 1926. The Wealth and Welfare of the Bengal Delta. Calcutta University Press, Calcutta.

Pande, P.N. 1987. The nature of the energy problem and its remedies for the hill region in Uttar Pradesh, pp. 88-100 In Himalayan Energy Systems, T.N. Dhar and P.N. Sharma (eds.) Gyanodaya Prakashan, Naini Tal.

Pandey, B.B. 1986. Land and land use of a Himalayan tribe -"Adi" of Arunachal Pradesh, pp. 148-155 In Land Use Pattern in North-East India, B.B. Dutta (ed.) Gagan Publishers, Ludhiana, Punjab.

Pandey, U. and J.S. Singh. 1984. Energy-flow relationships between agro- and forest ecosystems in Central Himalaya. Environmental Conservation 11:45-53.

Pandeya, S.C., S.M. Pandeya, M.S. Murthy and K. Kuruvilla. 1967. Forest ecosystem: classification of forest vegetation with reference to forests in the river Narmada catchment area. $J$. Indian Botanical Society 46:412-417.

Pandit, S. 1965. Chandigarh. Sneh Pandit, Chandigarh.

Pant, G.B. 1922. Forest Problem in Kumaon (Forest Problems and National Uprisings in the Himalayan Region). Reprinted 1990 by Gyanodaya Prakashan, Nainital.

Paranjpye, V. 1990. High Dams on the Narmada: a Holistic Analysis of the River Valley Projects. Studies in Ecology and Sustainable Development 3, Indian National Ait Trust for Cultural Heritage, New Delhi.

Parkash, R. and L.S. Khanna. 1979. Theory and Practice of Silvicultural Systems. Intemational Book Distributors, Dehra Dun.

Parker, R.N. 1921. A Forest Flora for the Punjab with Hazara and Delhi. Superintendent Govt. Printing, Punjab, Lahore.

Parks, P.J. 1993. Economic reasons for forest land-use change: relevance to tropical deforestation and the carbon cycle, pp. 329-360 In Effects of Land Use Change on Atmospheric $\mathrm{CO}^{2}$ Concentrations: South and Southeast Asia as a Case Study, V.H. Dale (ed.) Springer-Verlag, New York.

Pascal, J.P. 1982. Bioclimates of the Western Ghats at 1/250,000. 2 sheets, Trav. Sec. Sci. Tech., Hors serie No. 17, Institut Francais, Pondichery. 
Pascal, J.P. 1986. Explanatory Booklet on the Forest Map of South India. Trav. Sec. Sc:. Tech., Hors serie No. 18, Institut Francais, Pondichery.

Pascal, J.P. 1988. Wet Evergreen Forests of the Western Ghats of South India: Ecology, Structure, Floristic Composition and Succession. Trav. Sec. Sci. Tech., Tome XX bis, Institut Francais, Pondichery.

Pascal, J.P., S. Shyam Sunder, and V.M. Meher-Homji. 1982a. Forest Map of South India, 1/250,000 scale, Sheet Mercara-Mysore. Trav. Sec. Sci. Tech., Hors serie No. 18a, Institut Francais, Pondichery.

Pascal, J.P., S. Shyam Sunder, and V.M. Meher-Homji. 1982b. Forest Map of South India, 1/250,000 scale, Sheet Shimoga. Trav. Sec. Sci. Tech., Hors serie No. 18b, Institut Francais, Pondichery.

Pascal, J.P., S. Shyam Sunder, and V.M. Meher-Homji. 1984. Forest Map of South India, 1/250,000 scale, Sheet Belgaum-Dharwar-Panaji. Trav. Sec. Sci. Tech., Hors serie No. 18c, Institut Francais, Pondichery.

Patel, G. 1977. Gujarat's Agriculture. Overseas Book Traders, Ahmedabad.

Patil, B.D. and P.S. Pathak, 1978. Grassland development in the Himalayas. pp. 204-215 In National Seminar on Resources Development and the Environment ir the Himalayan Region. India (Govt.), Dept. Sci. Tech. Nat. Committee Environ. Planning and Co-ordination, New Delhi.

Patro, S.N. and B.N. Mishra. 1987, Shifting cultivation: ecological implications, pp. 481-488 In Environmental Education for Conservation and Development, D. Bandhu and G. Berberet (eds.) Indian Environmental Soc., New Delhi.

Peal, S. E. 1883. The necessities for jhuming. Indian For. 9:243-46.

Pearson, R.S. 1913. On the Economic Value of Shorea robusta, Sal. Vol. 2, Part II, Indian Forest Memoirs, Superintendent Govt. Printing, Calcutta.

Pillai, N. Kunjan. 1932. Census of India 1931. Travancore. Vol. 18, Part 1, Report, Superintendent Govt. Press, Trivandrum.

Plowden, W.C. 1883. Report on the Census of British India Taken on the 17th February, 188I. Eyre and Spottiswoode, London.

Pouchepadass, J. 1990. The ecological history of the central Western Ghats in the modern period: a preliminary survey. Pondy Papers in Social Sciences 6, French Institute, Pondichery.

Powlett, P.W. 1878. Gazetteer of Ulwur. Trubner and Co., London. 
Punekar, S.D. and A.R. Golwalkar. 1973. Rural Change in Maharashtra: An Analytical Study of Change in Six Villages in Konkan. Popular Prakashan, Bombay.

Punjab. 1904-1909. Punjab District Gazetteers. B Series, Statistical Tables. Vols. for Ambala (1904), Ambala District and Kalsia State (1909), Amritsar (1904), Delhi (1904), Ferozepore District and Faridkot State (1908), Gurdaspur (1908), Gurgaon District and Pataudi State (1908), Hissar (1904), Hoshiarpur (1904), Jullundur District and Kapurthala State (1908), Kamal (1919), Kangra (1908), Ludhiana District and Maler Kotla Siate (1907), Rohtak District and Dujana State (1904), Simla (1909). The Civil and Military Gazette Press, Lahore.

Punjab. 1907-1909. Punjab States Gazetteers. B Series, Statistical Tables. Vols. for Chamba (1909), Mandi and Suket (1907), Patiala (1908), Phulkian States (1908), Sirmur (1907). The Civil and Military Gazette Press, Lahore.

Punjab. 1907-1926. Punjab District Gazetteers. Punjab A Series. Vols. for Ambala (1925), Amritsar (1914), Delhi (1913), Ferozepore (1916), Gurdaspur (1915), Gurgaon (1911), Hissar District and Loharu State (1907, 1916), Hoshiarpur (1905), Jullundur District and Kapurthala State (1908), Kamal (1919), Kangra (1926), Kangra (with Kulu and Saraj, Lahul and Spiti) (1918), Ludhiana District and Maler Kotla State (1907), Rohtak (1911), Simla (1908). Various publishers, Lahore.

Punjab. 1908-1939. Punjab States Gazetteers. Punjab A Series. Vols. for Chamba (1910), Dujana (1908), Kalsia (1908), Mandi (1920), Mandi and Suket (1908), Phulkian States (1909), Simla Hill States $(1911,1935)$, Sirmur $(1907,1939)$. Various publishers, Lahore.

Punjab. 1911-1919. Punjab District Gazetteers. B Series, Statistical Tables. Vols. for Ambala District and Kalsia State (1913), Amritsar (1913), Delhi (1913), Ferozepore District and Faridkot State (1913), Gurdaspur (1913), Gurgaon District and Pataudi State (1913), Hissar District and Loharu State (1912), Hoshiarpur (1913), Jullundur (1917), Jullundur District and Kapurthala State (1908), Kamal (1919), Kangra (1912), Ludhiana District and Maler Kotla State (1913), Rohtak District and Dujana State (1911, 1913, 1915), Simla (1913). Various publishers, Lahore.

Punjab. 1913-1917. Punjab States Gazetteers. B series, Statistical Tables. Vols. for Chamba (1913), Kaptrthala (1917), Mandi and Suket (1913), Phulkian States (1913), Sirmur (1913). Various publishers, Lahore.

Punjab. 1934-1937. Punjab District Gazetteers. B Series, Statistical Tables. Vols. for Ambala (1936), Amritsar (1934), Ferozepore (1935), Gurdaspur (1936), Gurgaon (1936), Hissar (1936), Hoshiarpur (1936), Jullundur (1935), Karnal (1936), Kangra (1935), Ludhiana (1935), Rohtak (1937), Simla (1936). Superintendent Govt. Printing, Punjab, Lahore.

Punjab. 1934-1937. Punjab States Gazetteers. B Series, Statistical Tables. Vols. for Bilaspur (1935), Chamba (1934), Dujana (1936), Faridkot (1935), Jind (1934), Kalsia (1935), Kapurthala (1934), Loharu (1937), Maler Kotla (1937), Mandi (1936), Nabha (1936), Pataudi (1937), Patiala (1937), Sirmur (1935), Suket (1927, 1934). Superintendent Govt. Printing, Punjab, Lahore. 
Punjab (State). 1970-1989. Punjab District Gazetteers. 10 vols., Revenue Dept. of Punjab, Chandigarh.

Punjab Forest Dept. 1900. Progress Report on Forest Administration in the Punjab for 1899-1900. The Civil and Military Gazette Press, Lahore.

Punjab Forest Dept. 1911. Progress Report on Forest Administration in the Punjab for the Year 1910-11. The Punjab Govt. Press, Lahore.

Punjab Forest Dept. 1920, 1921. Progress Report on Forest Administration in the Punjab for the Year 1919-20, 1920-21. Superintendent, Govt. Printing, Punjab, Lahore.

Punjab (State). 1870. Punjab Report of the Census of the Punjab Taken on 10th January 1868. Vol. 2, Indian Public Opinion Press, Lahore.

Punjab (State) Economic and Statistical Adviser to Govt. 1951. Agricultural Statistics of the Punjab, 1939-1950. Economic and Statistical Organization Publication No. 7, Economic and Statistical Adviser to Govt., Punjab, Simla.

Punjab (State) Economic and Statistical Organization. 1965. Statistical Atlas of Punjab. Economic and Statistical Adviser to Govt., Punjab, Chandigarh.

Punjab (State) Economic and Statistical Advisor to Govt. 1960. Statistical Abstract of Punjab 1959. Pub. No. 27, Economic and Statistical Organization, Govt. of Punjab, Chandigarh.

Punjab (State) Economic and Statistical Advisor to Govt. 1967. Statistical Abstract of Punjab 1966. Pub. No. 67, Economic and Statistical Organization, Govt. of Punjab, Chandigarh.

Punjab (State) Economic and Statistical Advisor to Govt. 1981. Statistical Abstract of Punjab 1980. Pub. No. 358, Economic and Statistical Organization, Govt. of Punjab, Chandigarh.

Puri, G.S. 1960. Indian Forest Ecology: A Comprehensive Survey of Vegetation and Its Environment in the Indian Subcontinent. 2 vols., Oxford Book and Stationery Co., New Delhi.

Puri, G.S., V.M. Meher-Homji, R.K. Gupta, and S. Puri. 1983. Forest Ecology: Phytogeography and Forest Conservation. 2nd edition, Vol. I, Oxford and IBH Publ. Co., New Delhi.

Puri, G.S., V.M. Meher-Homji, R.K. Gupta, and S. Puri. 1989. Forest Ecology: Plant Form, Diversity, Communities and Succession. 2nd edition, Vol. II, Oxford and IBH Publ. Co., New Delhi.

Puttaswamaiah, K. 1980. Economic Development of Karnataka: A Treatise in Continuity and Change. 2 vols., Oxford and IBH Publ. Co., New Delhi.

Rai, L. 1955. Forestry in Orissa. Indian For. 81:75-81. 
Raina. A.N. 1977. Geography of Jammu and Kashmir. National Book Trust, New Delhi.

Rajagopala Rao, N. (ed.) 1965. Land Utilization and Agriculture in North Kanara District. Kanara College Planning Forum, Kumta, Kamataka.

Rajasthan (State). 1962-1987. Rajasthan District Gazetteers. 26 vols., Govt. Central Press for Directorals of District Gazetteers, Jaipur.

Rajasthan Directorate of Economics and Statistics. 1980. Regional Statistics of Rajasthan 1961-1979. Directorate of Economics and Statistics, Jaipur.

Rajasthan Directorate of Economics and Statistics. 1962-1971. Statistical Abstract Rajasthan (annual, 1961-1970). Govt. Central Press, Jaipur.

Rajasthan Directorate of Economics and Statistics. 1987. Statistical Abstract Rajasthan 1984. Govt. Central Press, Jaipur.

Rajkhowa, S. 1961. The Upper Assam Dipterocarpus-Mesua forests and their regeneration. Indian For. 87:406-25.

Ramachandran Nair, A.K.K. (ed.) 1986. Kerala State Gazetteer. State Editor, Kerala Gazetteers, Trivandrum.

Ramakrishna Reddy, V. 1987. Economic History of Hyderabad State: Warangal Suba, 1911-1950. Gian Publ. House, Delhi.

Ramakrishnan, P.K. 1985. Conversion of rain forests in North Eastem India, pp. 69-84 In Environmental Regeneration in Himalaya - Concepts and Strategies, J.S. Singh (ed.) Central Himalayan Environment Association and Gyanodaya Prakashan, Nainital.

Ramakrishnan, P.S. 1985. Tribal man in the humid tropics of the North-east. Man in India 65:1-32.

Ramakrishnan. P.S. 1992. Shifting Agriculture and Sustainable Development. Man and the Biosphere Series, Vol. 10, UNESCO (Paris) and Parthenon Publ. Group, Park Ridge, NJ.

Ramakrishnan, P.S. and S.C. Ram. 1988. Vegetation, biomass and productivity of seral grasslands of Cherrapunji in north-east India. Vegetation 74:47-53.

Ramakrishnan, P.S. and O.P. Toky. 1983. Some aspects of environmental degradation in North-Eastem hill areas of India, pp. 149-156 In Studies in Eco-Development: Himalayas Mountains and Men, T. V. Singh and J. Kaur (eds.) Indian Print House, Lucknow.

Raman Rao, A.V. 1958. Economic Development of Andhra Pradesh (1766-1957). Popular Book Depot, Bombay.

Ramanadham, V.V. 1959. The Economy of Andhra Pradesh. Asia Publ. House, Bombay. 
Ramdas, L.A. 1974. Weather and climatic patterns, pp. 99-134 In Ecology and Biogeography in India, M.S. Mani (ed.) Dr. W. Junk Publishers, The Hague.

Ramesh, A. and P.S. Tiwari (eds.) 1983. Basic Resource Atlas of Tamil Nadu. Dept. Geography, University Madras, Madras.

Rampur (State). 1911. Rampur State Gazetteer. Superintendent Govt. Press, Allahabad.

Rampur (State). 1914. Supplementary Notes and Statistics to the Rampur State Gazetteer. Superintendent Govt. Press, Allahabad.

Randhawa, M.S. 1980. A History of Agriculture in India, Vol. I, Beginning to 12th Century. Indian Council Agriculture Res., New Delhi.

Randhawa, M.S. 1982. A History of Agriculture in India, Vol. II, Eighth to Eighteenth Century. Indian Council Agriculture Res., New Delhi.

Randhawa, M.S. 1983. A History of Agriculture in India, Vol. III, 1757-1947. Indian Council Agriculture Res., New Delhi.

Randhawa, Mi.S. 1986. A History of Agriculture in India, Vol. IV, 1947-1981. Indian Council of Agricultural Res., New Delhi.

Rang Lal. 1933. Census of India 1931, Gwalior State. Part I Report, Aligah Darbar Press, Gwalior.

Rao, G.V.K. 1987. Economic Development and Social Change in Karnataka. Prasarang, Gulbarga University, Gulbarga.

Rao, H. 1990. Rural Energy Crisis: A Diagnostic Analysis. S.B. Nangia for Ashish Publ. House, New Delhi.

Rao, R.R. 1977. Changing pattem in the Indian flora. Bull. Botanical Surv. India 19:156-66.

Rao, T.A. and A.R.K. Sastry. 1974. An outline of the coastal vegetation of India. Bull. Botanical Surv. India 16:101-15.

Ratnam, R. 1966. Agricultural Development in Madras State prior to 1900. New Century Book House Pvt. Ltd., Madras.

Rau, M.A. 1974. Vegetation and phytogeography of the Himalaya, pp. 247-280 In Ecology and Biogeography in India, M.S. Mani (ed.) Dr. W. Junk Publishers, The Hague.

Ravindranath, N.H. and R. Shailaja. 1986. Rural fuelwood crisis and energy options -a case study of Ungra village, pp. 73-80 In Rural Energy Crisis, S. Giriappa (ed.) Himalaya Publ. House, Bombay. 
Ravishankar, K. and B. Bowonder. 1981. An analysis of energy consumption in India. Natural Resources Forum 5:213-226.

Ray, A.C. 1972. Mizoram. Publications Div., Ministry of Information and Broadcasting, Govt. of India, New Delhi.

Ray, A.C. 1982. Mizoram. Dynamics of Change. Pearl Publishers, Calcutta.

Reddy, A.K.N. 1981. Biomass as an energy source, pp. 901-915 In Long-Term Energy Resources, R.F. Meyer and J.F. Olson (eds.) Vol. II, Pitman Publ. Inc., Boston, MA.

Reddy, A.K.N. and N.H. Ravindranath. 1987. Biomass, village energy and rural development, pp. 387-411 In Biomass: Regenerable Energy, D.O. Hall and R.P. Overend (eds.) John Wiley and Sons Ltd., Chichester.

Reid, A.S. 1893. Chin-Lushai Land. Including a Description of the Various Expeditions into the Chin-Lushai Hills and the Final Annexation of the Country. Reprinted 1976 by Firma KLM Pvt., Ltd., Calcutta, on behalf of Tribal Research Institute, Aizawl.

Revelle, R. 1976. Energy use in rural India. Science 192:969-975.

Revelle, R. 1980. Energy use in rural India, pp. 194-207 In Energy in the Developing World: The Real Energy Crisis, V. Smil and W.E. Knowland (eds.) Oxford University Press, Oxford.

Ribbentrop, B. 1900. Forestry in India. Office Supt. Govt. Printing, Calcutta.

Rice, B.L. 1876-1878. Mysore and Coorg: a Gazetteer. 3 vols., Bangalore.

Rice, B.L. 1897. Mysore, a Gazetteer Compiled for the Government. 2 vols., Rev. edition, Archibald and Constable. Westminster.

Rice, B.L. 1908. Imperial Gazetteer of India: Mysore and Coorg. Superintendent Govt. Press, Calcutta.

Richards, J.F. and E.P. Flint. 1990. Long-term transformations in the Sundarbans wetlands forests of Bengal. Agriculture and Human Values 7(2):17-33.

Richards, J.F., E.S. Haynes, and J.R. Hagen. 1985. Changes in the land and human productivity in northem India, 1870-1970. Agric. Hist. 59:523-547.

Richards, J.F., J.R. Hagen, and E.S. Haynes. 1985. Changes in land use in Bihar, Punjab, and Haryana, 1850-1970. Modern Asian Stud. 19:699-732.

Richter, G. 1870. Manual of Coorg: a Gazetteer of Natural Features of the Country and the Social and Political Condition of its Inhabitants. C. Stolz, Bangalore.

Risley, H.H. 1894. The Gazetteer of Sikhim. Bengal Secretariat Press, Calcutta. 
Risley, H.H. and E.A. Gait. 1903. Census of British India 1901. Vol. I, Part I and II, Tables, Office of the Superintendent of Govt. Printing, Calcutta.

Roy, P.S. and N.V. Madhavan Unni. 1980. The forest type classification and mapping of shifting cultivation areas using Landsat data in Mizoram, pp. 246-251 In Proceedings of the Seminar on Application of Photo-Interpretation and Remote Sensing Techniques for Natural Resources Survey and Environmental Analysis. Indian Soc. Photo-Interpretation and Remote Sensing, Dehra Dun.

Roy, P.S., R.N. Kaul, M.R. Sharma Roy, and S.S. Garbyal. 1985. Forest-type stratification and delineation of shifting cultivation areas in the eastern part of Arunachal Pradesh using LANDSAT MSS data. Int. I. Remote Sensing 6:411-418.

Roy-Burman, B.K. 1970. Demographic and socio-economic profiles of the Hill Areas of north-east India, In C'ensus of India, 1961. Office of the Registrar General, India Manager of Publications, New Delhi.

Sacchidananda, 1985. India -swidden cultivation among the Wancho of Arunachal Pradesh, pp. 173 In Swidden Cultivation in Asia, Vol. 3: Empirical Studies in Selected Swidden Communities: India, Indonesia, Malaysia, Philippines, Thailand. UNESCO, Bangkok.

Sacchidananda and K.N. Pathak. 1983. India, pp. 1-107 In Swidden Cultivation in Asia, Vol. 2: Country Profiles: India, Indonesia, Malaysia, Philippines, Thailand. UNESCO, Bangkok.

Sagar, S.R., L.P. Chandola, and M.Y. Ansari. 1981. Pilot survey of fuel consumption in rural areas: Part II and Part IV. Indian For. 107:486-491; 111:305-317.

Sagreiya, K. P. 1982. Forests and Forestry. 4th edition, National Book Trust New Delhi.

Sahu, N.C. 1986. Economics of Forest Resources (Problems and Policies in a Regional Economy). B.R. Publ. Co., New Delhi.

Saigal, O. 1978. Tripura: Its History and Culture. Concept Publ. Co., Delhi.

Saigal, O. 1990. Lakshadweep. National Book Trust, India, New Delhi.

Saikia, P.D. 1986. Crop production under shifting and settled cultivation in the hill areas of North East India, pp. 74-84 In Land Use Pattern in North-East India, B.B. Dutta (ed.) Gagan Publishers, Ludhiana, Punjab.

Sain, I. 1987. Transformation of Punjab Agriculture. B.R. Publ. Co., Delhi.

Saini, B.S. 1975. The Social and Economic History of the Punjab 1901-1939 (including Haryana and Himachal Pradesh). Ess Ess Publications, Delhi.

Sarma, P.K. 1991. Forest Resources and their Utilization in India (A Study of Assam). Mittal Publications, New Delhi. 
Satish Chandran, T.R. 1986. Energy consumption patterns in the rural sector, pp. 15-37 In Rural Energy Crisis, S. Giriappa (ed.) Himalaya Publ. House, Bombay.

Satsangi, P.S. and V. Gautam. 1984. Comparative analysis of rural energy pattems in selected village clusters of Uttar Pradesh, pp. 26-37 In Energy and Habitat: Town Planning and Building Design for Energy Conservation, V. Gupta (ed.) Wiley Eatem Ltd., New Delhi.

Saxena, G. 1990. The Forest Crisis. Natraj Publishers, Dehra Dun.

Saxena, S.K. 1972. The concept of ecosystem as exemplified by the vegetation of Westem Rajasthan. Vegetation 24:215-227.

Scholberg, H. 1970. The District Gazetteers of British India: A Bibliography. Bibliotheca Asiatica 3, Inter Documentation Co. AG. Zug, Switzerland.

Schwartzberg, J. (ed.) 1978. A Historical Atlas of South Asia. University Chicago Press, Chicago, IL.

Schweinfurth, U. 1957. Die horizontale und vertikale Verbreitung der Vegetation im Himalaya. Ferd. Dummlers Verlag, Bonn.

Sehgal, J.L, D.K. Mondal, and S. Vadivelu. 1990. Agro-Ecological Regions of India. National Bureau of Soil Survey and Land Use Planning, Nagpur.

Sen Gupta, J.N. 1939. Dipterocarpus (gurjan) forests in India, and their regeneration, pp. 61-164 In Indian Forest Records Silviculture, vol. 3, no. 4. Manager, Govt. of India Press, New Delhi.

Seth, S.K. and J.S.P. Yadav. 1960. Soils of the tropical moist evergreen forests of India. Indian For. 86:401-13.

Seth, S.K. 1954. Forests and forestry in Uttar Pradesh. Indian For. 80:851-860.

Shakespear, L.W. 1914. History of Upper Assam, Upper Burmah, and Northeastern Frontier. Macmillan, London.

Shafi, M. 1984. Agricultural Productivity and Regional Imbalances: A Study of Uttar Pradesh. Concept Publ. Co., New Delhi.

Shafi, M. and M. Raza. 1987. Dryland Agriculture in India. Rawat Publications, Jaipur.

Shah, G.L. 1978. Flora of Gujarat State. Part I, Sardar Patel University, Vallabh Vidyanagar.

Shah, S.L. and S. Pant. 1987. An assessment of wood fuel and biogas as potential sources of energy in future in hill districts of Uttar Pradesh, pp. 41-52 In Himalayan Energy Systems, T.N. Dhar and P.N. Sharma (eds.) Gyanodaya Prakashan, Naini Tal. 
Shankar, V. 1978. Ecology of the past and the present vegetation of the Indian desert, vegetational indicators and use of a score card for measuring desertification, pp. 269-283 In Glimpses of Ecology, J.S. Singh and B. Gopal (eds.) International Scientific Publications, Jaipur.

Sharjan, G. (ed.) 1987. Energy Use in Rural Gujarat. Oxford and IBH Publ. Co. Pvt. Ltd., New Delhi.

Sharma, A.N. and V. Laxmi. 1987. Fuel consumption pattern and the factors affecting consumption of fuel wood, pp. 53-59 In Himalayan Energy Systems, T.N. Dhar and P.N. Sharma (eds.) Gyanodaya Prakasan, Naini Tal.

Sharma, P.S. 1973. Agricultural Regionalization of India. New Heights Publishers and Distributors, Delhi.

Sharma, V.K. 1991. Remote Sensing for Land Resource Planning. Concept Publ. Co., New Delhi.

Sharma, Y.M.L. 1981. Non-commercial energy resources in Kamataka. Myforest 17:41-53.

Singh, Abha L. 1985. The Problem of Wastelands in India (with special reference to Uttar Pradesh). B.R. Publ. Co., New Delhi.

Singh, Anil K. and J. Singh. 1986. Deforestation in Uttar Pradesh: an environment threat, pp. 61-76 In Geography and Environment: Issues and Challenges, H.H. Singh (ed.) Concept Publ. Co., New Delhi.

Singh, Ashbindu. 1986. Change detection in the tropical forest environment of Northeastern India using Landsat, pp. 237-254 In Remote Sensing and Tropical Land Management, M.J. Eden and J.T. Parry (eds.) John Wiley and Sons, Ltd., Montreal.

Singh, Gopal. 1976. A Geography of India. 2nd edition, Atma Ram and Sons, Delhi.

Singh, Hari. 1983. Agrarian Scene in British Punjab. Vol. 1, People's Publ. House, New Delhi.

Singh, Jasbir. 1974. An Agricultural Atlas of India: A Geographical Analysis. Vishal Publications, Kurukshetra.

Singh, J.S. (ed.) 1985. Environmental Regeneration in Himalaya: Concepts and Strategies. Central Himalayan Environment Association and Gyanodaya Prakashan, Naini Tal.

Singh, J.S. and B. Gopal (eds.) 1978. Glimpses of Ecology (Professor R. Misra Commemoration Vol.). Intemational Scientific Publications, Jaipur.

Singh, J.S. and S.P. Singh. 1986. Forest vegetation of the Himalaya. Bot. Rev. 53:80-195. 
Singh, J.S., A.K. Tiwari, and A.K. Saxena. 1985. Himalayan forests: a net source of carbon for the atmosphere. Environ. Conserv. 12:67-69.

Singh, Prakash. 1972. Nagaland. National Book Trust, India, New Delhi.

Singh, R.P. 1974. Forest resources of Manipur. J. North-East India Geographical Society 6:26-38.

Singh, R.P. 1982. Geography of Manipur. National Book Trust, New Delhi.

Singh, R.P. and N.S. Davi. 1975. Meiteis of Manipur. A Study in Human Ecology. Geographical Review of India 37:53-61.

Singh, Racchpal. 1987. Farm Production in Rainfed Sub-Mountainous Punjab. V.R. Publ. Co., Delhi.

Singh, S.P. 1981. Fuelwood as energy source. Indian For. 107:785-794.

Singh, S.P. and J.S. Singh. 1989. Ecology of central Himalayan forests with special reference to sal forest ecosystem, pp. 193-232 In Perspectives in Ecology, J.S. Singh and B. Gopal (eds.) Jagmander Book Agency, New Delhi.

Singh, V. and M.S. Kairon. 1987. An Agricultural View of Haryana. B.R. Publ. Co., Delhi.

Sinha, B.N. 1981. Geography of Orissa. National Book Trust, India, New Delhi.

Sinha, B.N. (ed.) 1990. Ecosystem Degradation in India. Ashish Publ. House, New Delhi.

Sinha, J.N. 1962. Fourth Revised Working Plan for the Reserved and Protected Forests of Saranda Division, Bihar, 1956-57 to 1975-76. Supt. Secretariat Press Bihar, Patna.

Society of Scientists for Advancement of Agriculture. 1982. Agriculture in Andhra Pradesh. The Farmers' Welfare Trust and Society of Scientists for Advancement of Agriculture, Hyderabad.

Somasekhara, N. 1978. Planning and Development in Karnataka: Targets, Allocations and Perspectives. Geetha Book House Publishers, Mysore.

Somasekhara, N. 1985. Rural Energy: Flows, Inter-fuel Substitution and Development Profile of a Developing Country with Special Reference to India. Sterling Publishers Pvt. Ltd., New Delhi.

Sorley, H.T. and A.H. Dracup. 1933. Census of India 1931. Western India States Agency. Vol. X, Part I, Report and Statistical Tables. Govt. Central Press, Bombay.

Spate, O.H.K. 1954. India and Pakistan: A General and Regional Geography. Methuen and Co., Ltd., London.

Srinivasa Raghavaiyangar, S. 1893. Memorandum on the Progress of the Madras Presidency during the Last Forty Years of British Administration. Superintendent, Govt. Press, Madras. 
Stebbing, E.P. 1922. The Forests of India, Vol. I. John Lane, The Bodley Head Ltd., London.

Stebbing, E.P. 1923. The Forests of India, Vol. II: The Development of the Indian Forest Service. John Lane, The Bodley Head Ltd., London.

Stebbing, E.P. 1926. The Forests of India, Vol. III: The Progress of Conservancy and the Development of Research in Forestry 1901-1925. John Lane, The Bodley Head Ltd., London.

Stebbing, E.P. 1952. Forests, catchment areas and water supplies. Indian Forest Records (n.s.) Silviculture, 7, no. 4., pp. 253-421. Manager of Publications, Delhi.

Stracey, P.D. 1956. The development of forestry in Assam in the last 50 years. Indian For. $82: 433-443$.

Stracey, P.D. 1963. The forests of Nagaland. Indian For. 89:712-15.

Stracey, P.D. 1966. A note on Nagaland. J. Bombay Natural History Society 64:440-46.

Stuart, A.J. 1879. A Manual of the Tinnevelly district in the Presidency of Madras. Madras Govt. Press, Madras.

Sturrock, J. 1894. Madras District and Canara District Manual. Superintendent Govt. Press, Madras.

Subhash, C. and P.S. Satsangi. 1990. An integrated planning and implementation-strategy for rural energy systems. Energy 15:913-920.

Subrahmanyam, V.P. and C.V.S. Sastry. 1969. Climatic analogues for the dry regions of India. Tropical Ecology 10:34-44.

Subrahmanyam, V.P. and K. Karuna Kumar. 1977. Climatic analogues for the humid regions of India. Tropical Ecology 18:71-82.

Subrahmanyan, V.P. and H.S. Ram Mohan. 1984. Droughts and agricultural land use in India, Pakistan and Bangladesh, pp. 183-202 In Climate and Agricultural Land Use in Monsoon Asia, M.M. Yoshino (ed.) University Tokyo Press, Tokyo.

Sweazy, R.E. (ed.) 1938. Bihar District Gazetteers, Champaran. Bihar Govt. Press, Patna.

Tamil Nadu (state). 1972-1983. Tamil Nadu District Gazetteers (continues revised series of Madras District Gazetteers). Superintendent Govt. Press, Madras.

Tamil Nadu Director of Statistics. 1969, 1971. Annual Statistical Abstract for Tamil Nadu (annual, 1965-66-1966-67). Director of Stationery and Printing, Madras.

Tamil Nadu Director of Statistics. 1973. Annual Statistical Abstract for Tamil Nadu for 1967-68 and 1968-69 (Combined issue). Director of Stationery and Printing, Madras. 
Tamil Nadu Director of Statistics. 1975, 1976, 1978. Annual Statistical Abstract for Tamil Nadu (annual, 1969-70 and 1970-71). Director of Statistics, Madras.

Tamil Nadu Director of Statistics. 1976, 1978. Annual Statistical Abstract for Tamil Nadu (annual, 1971-72, 1972-73, 1973-74, 1978-79, 1980-81, 1981-82, 1982-83, and 1983-84). Director of Statistics, Madras.

Tampi, A. Narayanan. 1942. Census of India 1941. Travancore. Vol. XXV, Part I Report, Superintendent Govt. Press, Trivandrum.

Tata Energy Research Institute. 1986, 1987. TERI Energy Data Directory and Yearbook: TEDDY (annual, 1986 and 1987). Tata Energy Res. Inst., New Delhi.

Tayeng, J. 1985. Census of India 1981. Special Report on Jhum. Series-14 (Meghalaya). Paper I of 1983, Controller of Publications, Delhi.

Taylor, G.F. II. 1981. The forestry/agriculture interface: some lessons from Indian forest policy. Commonw. For. Rev. 60:45-52.

Tewari, A.K. 1966. Land utilization in Jaunsar Bewar. Deccan Geogr. 3/4:1-128.

Tewari, R.N. 1970. Agricultural Development and Population Growth (An Analysis of Regional Trends in Uttar Pradesh). Sultan Chand and Sons, Delhi.

Thaladi, S. 1986. Biomass energy potential in Andhra Pradesh, pp. 57-69 In Proceedings Bio-Energy Society Third Convention and Symposium 1986, Theme: Bioenergy Education, R.N. Sharma, O.P. Vimal. N.G. Hegde, and M. Madan (eds.) Bio-Energy Society of India, New Delhi.

Thangam, E.S. 1979. Forest development programme in Arunachal Pradesh -development strategy, pp. 215-222 In Man and Forest (A New Dimension in the Himalaya), K.M. Gupta and D. Bandhu (eds.) Today and Tomorrow's Printers and Publishers, New Delhi.

Thangam, E.S. 1982. Problems of shifting cultivation in north-eastern India, pp. 53-64 In Socio-economic Effects and Constraints in Tropical Forest Management, E.G. Hallsworth (ed.) John Wiley and Sons, Chichester.

Thangliana, C. 1978. Management of forests development strategy with reference to Mizoram, pp. 200-241 In Man and Forest (A New Dimension in the Himalaya), K.M. Gupta and D. Bandhu (eds.) Today and Tomorrow's Printers and Publishers, New Delhi.

Thapar, S.D. 1975. India's Forest Resources. Birla Inst. Scientific Economic Res. Div., New Delhi.

Thapliyal. U.P. (ed.) 1987. Gazetteer of Rural Delhi. Gazetteer Unit, Delhi Administration, Delhi.

Thingalaya, N.K. (ed.) 1968. Studies in Kanara Agriculture. Economic Research Dept., Syndicate Bank Ltd., Manipal, South Kanara. 
Thorat, S.S., S.D. Nimbalkar, and K.R. Kadam (eds.) 1976. Report of a Seminar on Agricultural Production and Productivity in Maharashtra State. V.K. Mahajan, Registrar, Mahatma Phule Agric. University, Rahuri.

Thurston, E. 1913. The Madras Presidency with Mysore, Coorg and the Associated States. Cambridge University Press, Cambridge, MA.

Tiwari, K.M. 1983. Social Forestry in India. Natraj, Dehra Dun.

Tiwari, P.S. 1973. Agricultural Atlas of Uttar Pradesh. G.B. Pant University Agriculture and Technology, Pantnagar.

Toky, O.P. and P.S. Ramakrishnan. 1981. Cropping and yields in agricultural systems of the northeastem hill region of India. Agro-Ecosystems 7:11-25.

Toky, O.P. and P.S. Ramakrishnan. 1984b. Litter decomposition related to secondary succession and species type under slash and burn agriculture (jhum) in North-Eastem India. Proc. Indian Acad. Sci. B50(1):57-65.

Toky, O.P. and P.S. Ramakrishnan. 1981. Cropping and yields in agricultura! systems of the north-eastem hill region of India. Agro-Ecosystems 7:11-25.

Toky, O.P. and P.S. Ramakrishnan. 1983. Secondary succession following slash and bum agriculture in North-Eastern India: I. biomass, litterfall and productivity. J. Ecology 71:735-45.

Toky, O.P. and P.S. Ramakrishnan. 1984. Forest wealth of the north-eastem India and its conservation, pp. 422-32 In The Vegetational Wealth of the Himalayas, G. S. Paliwal (ed.) Puja Publishers, Dehli.

Tomar, M.S. 1969. Identification of land use and forest cover types on aerial photographs. Indian For. 95:85-89.

Tribal Cultural Research and Training Institute. 1963. The Scheduled Tribes of Andhra Pradesh. Govt. Central Press, Hyderabad.

Tripura. 1963-1970. Annual Administration Report of the Union Territory of Tripura (annual, 1962-63, 1965-66, 1966-67, 1978-68). Superintendent, Govt. Printing, Tripura, Agartala.

Tripura. 1971-1985. Annual Administration Report (annual, 1968-1969 to 1974-1975). Superintendent, Govt. Printing, Agartala.

Tripura (India). 1975-1989. Tripura District Gazetteers. 5 vols., Educational Publications, Dept. of Education, Govt. of Tripura, Agartala.

Tripura Statistical Dept. 1964-1973. Statistical Abstract for Tripura (annual, 1962-1970). Statistical Dept., Govt. of Tripura, Agartala. 
Trivedi, R.K. 1931. Census of India 1931. Bhatnagar State. Part I State Census Report. Aligah Darbar Press, Gwalior.

Trivedi, S.N. 1986. Fuelwood production in India -an evaluation. Indian For. 112:279-287.

Troup, R.S. 1921. The Silviculture of Indian Trees. 3 Vols., Clarendon Press, Oxford.

Tucker, R.P. 1982. The forests of the Westem Himalayas: the legacy of British colonial administration. J. For. Hist. 26:112-123.

Tucker, R.P. 1983. The British colonial system and the forests of the Westem Himalayas, 1815-1914, pp. 146-166 and 199-202 In Global Deforestation and the Nineteenth-Century World Economy, R. Tucker and J.F. Richards (eds.) Duke Press Policy Studies, Durham, NC.

Tyagi, P.D. 1989. Fuel from Wastes and Weeds. Batra Book Service, New Delhi.

United Provinces of Agra and Oudh, India. 1903-1911. District Gazetteers of the United Provinces of Agra and Oudh, H.R. Nevill, E.R. Neave, L.K. Drake-Brockman, H.G. Walton (eds.) 48 vols., Superintendent Govt. Press, Allahabad.

United Provinces of Agra and Oudh, India. 1916-1921. District Gazetteers of the United Provinces of Agra and Oudh, B Series. 48 vols., Govt. Branch Press, Lucknow.

United Provinces of Agra and Oudh, India. 1924-1929. District Gazetteers of the United Provinces of Agra and Oudh, C Series. 48 vols., Govt. Branch Press, Lucknow.

United Provinces of Agra and Oudh, India. 1934-1936. District Gazetteers of the United Provinces of Agra and Oudh, D Series. 48 vols., Govt. Branch Press, Lucknow.

Upadhyaya, K.K. 1986. Development Problems and Prospects of Mizoram. Inter-India Publications, New Delhi.

Uttar Pradesh (State). 1959-1988. Uttar Pradesh District Gazetteers. 54 vols., Dept. of District Gazetteers, Govt. of Uttar Pradesh, Allahabad.

Uttar Pradesh Economics and Statistics Division. 1985, 1989. Statistical Diary Uttar Pradesh (annual, 1984-1988). Economics and Statistics Div., State Planning Institute, Allahabad.

Uttar Pradesh Forest Dept. 1961. The Centenary of Forest Administration in Uttar Pradesh 1861-1961, Souvenir. United Block Printers, Lucknow.

Uttar Pradesh Forest Dept. 1962, 1966. Annual Progress Report of Forest Administration in Uttar Pradesh for the Years 1957-58 (1963-1964). Superintendent, Printing and Stationery, Uttar Pradesh, Allahabad.

Veena, D.R. 1988. Rural Energy: Consumption, Problems and Prospects (A Replicable Model for India). Ashish Publ. House, New Delhi. 
Velu Pillai, T.K. 1940. The Travancore State Manual. 4 vols., Govt. Press, Trivandrum.

Venkasami Rau, D.B. 1883. Manual of the District of Tanjore in the Madras Presidency. Madras Govt. Press, Madras.

Venkatachar, C.S. 1933. Census of India 1931. Vol. XX, Central India Agency. Part I Report, Govt. Central Press, Nagpur.

Venugopal, K. and I. Natarajan. 1981. National Council of Applied Economic Research Report on Rural Energy Consumption in Northern India. Environment Research Committee. Dept. of Science and Technology, Saraswati Press, New Delhi.

Vohra, B.B. 1985. Why India's forests have been cut down. Ecologist 15:50-51.

Wadia, F.K. 1980. Control of shifting cultivation in the Northeastem region, pp. $40-47$ In Tribal Economy of the Northeastern Region, T. Mathew (ed.) Spectrum Publications, Gauhati, Assam.

Walter, C.K.M. 1879. Gazetteer of Mewar, Mallani and Jaisalmer. Scottish Mission Industries Co., Ltd., Ajmer.

Watt, G. 1888. The forests of Manipur. Indian For. 14:291-99; $338-44 ; 387-94$.

Watson, C.C. (comp.) 1904. Rajputana Gazetteers. Ajmer-Merwara. Vol. I-A and I-B, Scottish Mission Industries Co., Ltd., Ajmer.

Watson, J.W. 1878. Statistical Account of Dhrangadhra: Being the Dhrangadhra Contribution to the Kathiawar Portion of the Bombay Gazetteer. The Education Society's Press, Bombay.

Watson, J.W. 1879. Statistical Account of Nawanagar: Being the Nawanagar Contribution to the Kathiawar Portion of the Bombay Gazetteer. The Education Society's Press. Bombay.

Watson, J.W. 1879. Statistical Account of Porbandar: Being the Porbandar Contribution to the Kathiawar Portion of the Bombay Gazetteer. The Education Society's Press, Bombay.

Watson, J.W. 1883. Statistical Account of Bhavnagar: Being the Bhavnagar Contribution to the Kathiawar Portion of the Bombay Gazetteer. The Education Society's Press, Bombay.

West Bengal (State). 1965-1985. West Bengal District Gazetteers. 12 vols., State Editor, West Bengal District Gazetteers, Calcutta.

West Bengal Bureau of Applied Economics and Statistics. 1979. Statistical Abstract, West Bengal. 1976 and 1977 (Combined). No. 2 and 3, Govt. Printing, Calcutta.

West Bengal Bureau of Applied Economics and Statistics. 1980-19?3. Key Statistics of the District. One volume per district, Govt. Printing, Calcutta. 
West Bengal Dept. of Forests. 1966. West Bengal Forest Centenary Commemoration Volume. 1964. Dept. Forests, West Bengal, Calcutta.

West Bengal Dept. of Forests. 1982. Forestry in West Bengal -An Appraisal: 1977-78 and 1981-82. Dept. Forests, West Bengal, Calcutta.

West Bengal Forest Dept. Planning and Statistical Cell (Statistics). 1987. Wood Balance Study. West Bengal. Office of the Chief Conservator of Forests, Calcutta.

West Bengal Forest Directorate. 1983. West Bengal Forest Statistics 1983. Office of the Chief Conservator of Forests, West Bengal, Calcutta.

Whyte, R.O. 1957. The Grassland and Fodder Resources of India. Sci. Mon. No. 22. Indian Council Agric. Res., New Delhi.

Wreford, R.G. 1943. Census of India 194I. Vol. XXII, Jammu and Kashmir. Parts I and II Essay and Tables, Superintendent. The Ranbir Govt. Press. Jammu.

Yeatts, M.W.M. 1943. Census of India, 194I. Vol. I. Part I, Report and Tables, Manager of Publications, New Delhi.

Zimba, D.T. 1978. Geography of Meghalaya. 2nd edition, Zimba and Sons, Shillong. 


\subsubsection{Indonesia}

Blasco, F., Y. Laumonier, and Pumajaya. 1983. Tropical vegetation mapping: Sumatera. BIOTROP Bulletin in Tropical Biology No. 22, SEAMEO-BIOTROP, Bogor.

Boomgaard, P., 1988. Forests and forestry in colonial Java, 1677-1942. pp. $59-87$ In Changing Tropical Foresis: Historical Perspectives on Today's Challenges in Asia, Australasia and Oceania. J. Dargavel, K. Nixon, and N. Semple (eds.) Centre for Resources and Environmental Studies, Australian Nat. University, Canberra.

Boomgaard, P. (ed.) 1992. Changing Economy in Indonesia: A Selection of Statistical Source Material from the Early 19th Century up 10 1940. Vol. 10. Foodcrops and Arable Lands, Java 1815-1942. Martinus Nijhoff. The Hague.

Boomgaard, P. and A.J. Gooszen (eds.) 1990. Changing Economy in Indonesia: A Selection of Statistical Source Material from the Early 19th Century up to 1940. Vol. 11: Population Trends 1795-1942. Martinus Nijhoff. The Hague.

Carson. J. and Hidayat Andullah. 1976. Land Resources in East Indonesia. East Indonesia Regional Development Study No. 2. Rep. Indonesia, Min. Public Works and Electric Power, Directorate General of Housing. Building. Planning, and Urban Development. Directorate of City and Regional Planning, Jakarta.

Centre for Agricultural Publ. and Documentation. 1982. Indonesian Forestry Abstracts: Dutch Literature Until About 1960. Pudoc, Wageningen.

Daroesman, R. 1979. An economic survey of East Kalimantan. Bull. Indonesian Econ. Stud. 15(3):43-82.

Dick, H. 1980. The oil price subsidy, deforestation and equity. Bull. Indonesian Econ. Stud. 16(3):32-60.

Donner, W. 1987. Land Use and Environment in Indonesia. University of Hawaii Press, Honolulu, HI.

Dove, M.R. 1985. Swidden Agriculture in Indonesia: the Subsistence Strategies of the Kalimantan Kantu'. New Babylon Stud. Soc. Sci. No. 43, Mouton Publishers, Berlin.

Ellen, R.F. 1978. Nuaulu Setllement and Ecology: An Approach to the Environmental Relations of an Eastern Indonesian Community. Martinus Nijhoff. The Hague.

Fischer, K.M. and Y. Rasyid. 1977. Population and Social Structure, East Kalimantan Transmigration Area Development Project PTA 46/ATA 140. TAD-Report No. 8, HWWA-Institut fur Wirtschaftforschung-Hamburg, Hamburg.

Fumivall, J.S. 1944. Netherlands India: A Study of Plural Economy. Cambridge University Press, Cambridge, MA. 
Geertz, C. 1968. Agricultural Involution: The Process of Ecological Change in Indonesia. University Califomia Press, Berkeley, CA.

Gilis, M. 1988. Indonesia: public policies, resource management, and the tropical forest, pp. 43-113 In Public Policies and the Misuse of Forest Resources, R. Repetto and M. Gillis (eds.) Cambridge University Press, Cambridge, MA.

Goldammer, J.G. and B. Selbert. 1990. The impact of droughts and forest fires on the tropical lowland rain forest of East Kalimantan, pp. 11-31 In Fire in the Tropical Biota: Ecosystem Processes and Global Challenges, J.G. Goldammer (ed.) Ecological Studies 84, Springer-Verlag, Berlin.

Great Britain Naval Intelligence Division, Geographical Section. 1920. A Manual of Netherlands India (Dutch East Indies). I.D. 1209, H.M.S.O., London.

Hadi, S. and Y.B. Lung. 1988. Swidden cultivation among the Tunjung of East Kalimantan with particular emphasis on socio-economic factors. Sarawak Museum J. 39(60, N.S.):111-147.

Hadi, S., S. Hadi, and R. Hidayat. 1985. Indonesia -swidden cultivation in East Kalimantan (Kenyah and Buginese), pp. 74-149 In Swidden Cultivation in Asia, Vol. 3: Empirical Studies in Selected Swidden Communities: India, Indonesia, Malaysia, Philippines, Thailand. UNESCO Regional Office for Education in Asia and Pacific, Bangkok.

Hugo, G.J., T.H. Hull, V.J. Bull, and G.W. Jones. 1987. The Demographic Dimension in Indonesian Development. Oxford University Press, Singapore.

Hunink, R.B.M. and J.W. Stoffers. 1984. Mixed-and Forest Gardens on Central Java: An Analysis of Socio-economic Factors Influencing the Choice between Different Types of Land-use. Diskussiestukken van de vakgroep sociale geografie van ontwikkelingslanden Nr.b 29, Gengrafisch Instituut Rijksuniversitiet Utrecht, Utrecht.

Indonesia Directorate General of Forestry. 1967. Some Aspects of Forest Development in Indonesia. Indonesia Directorate General of Forestry Publ. No. 9. Directorate General of Forestry, Bogor.

Indonesia Biro Pusat Statistik. 1956. Statistik 195617 Agustus. Biro Pusat Statistik, Djakarta.

Indonesia Biro Pusat Statistik. 1960-1963. Statistical Pocket Book of Indonesia (annual, 1960-1963). Biro Pusat Statistik, Djakanta.

Indonesia Biro Pusat Statistik. 1962a. Sensus Penduduk 196/ Republik Indonesia (Population Census of Indonesia). Bim Pusat Statistik. Djakarta.

Indonesia Biro Pusat Statistik. 1969, 1971. Statistical Pocketbook of Indonesia (biennial, 1968/1969; 1970/1971). Biro Pusat Statistik, Djakarta. 
Indonesia Biro Pusat Statistik. 1975-1991. Statistik Indonesia (Statistical Yearbook of Indonesia) 1975, 1981, 1983, 1985, 1986, 1987, 1991. Biro Pusat Statistik, Jakarta.

Indonesia Biro Pusa Statistik. 1980, 1981. Buku Saku Statistik Indonesia (Statistical Pocketbook of Indonesia) 1979/80 and 1980/81. Biro Pusat Statistik, Jakarta.

Indonesia Biro Pusut Statistik. 1980. Survei Pertanian January-April 1979 (Agricultural Survey). Biro Pusat Statistik, Jakarta.

Indonesia Biro Pusat Statistik. 1983. Buku Saku Statistik Indonesia (Statistical Pocketbook of Indonesia) 1983. Biro Pusat Statistik, Jakarta.

Indonesia Biro Pusat Statistik. 1985. Penduduk Indonesia. Hasil Survel Penduduk Antar Sensus 1985 (Population of Indonesia, Results of the 1985 Intercensal Population Survey). Biro Pusat Statistik, Jakarta.

Indonesia Biro Sensus. 1963. Sensus Pertanian 1963 Republik Indonesia. Biro Sensus, Djakarta.

Indonesia Directorate General of Forestry. 1967. Some Aspects of Forest Development in Indonesia. Directorate General of Forestry, Bogor.

Indonesia Directorate General of Forestry. 1972. Forestry in Indonesia. Directorate General of Forestry, Bogor.

Indonesia Directorate General of Forestry. 1969, 1970. Perusahaan Kehutanan Negara (Perhutani) Statistik (annual 1969, 1970). B.P.U. Perhutani, Djakarta.

Indonesia Directorate General of Forestry. 1968. Statistik Kehutanan Indonesia 1968 (Indonesian Forest Statistics 1968). Sekretariat Direktorat Djendral Kehutanan, Djakarta.

Indonesia Directorate General of Forestry. 1973. Statistik Kehutanan Indonesia 1973 (Indonesian Forest Statistics 1973). B.P.U. Perhutani, Djakarta.

Indonesia Direktorat Tata Guna Tanah. 1980. Republik Indonesia penggunaan tanah. Direktorat Tata Guna Tanah, Jakarta.

Indonesia Forest Service. 1957. Forest Administration in Indonesia. Indonesia Forest Service, Bogor.

Indonesia Ministry of Agriculture and Manfred Woelke. 1986. Statistical Information on Indonesian Agriculture: Second Edition, 1968-1980. Market Information Project ATA 85/86, P.T. Intermasa for Indonesia Ministry of Agriculture and German Agency for Technical Cooperation, Jakarta.

Indonesia Survei Penduduk Antar Sensus. 1985. Penduduk Indonesia, Seri No. 5, Hasil Survei Penduduk Antar Sensus 1985 (Population of Indonesia, Series No. 5, Results of the 1985 Intercensal Population Survey). Govt. of Indonesia, Jakarta. 
Inoue, M. and A.M. Lahjle. 1990. Dynamics of swidden agriculture in East Kalimantan. Agroforestry Systems 12:269-284.

Jones, P.H. and A. Darsidi. 1976. Forestry in East Indonesia. Rep. Indonesia, Min. Public Works and Electric Power, Directorate General of Housing, Building, Planning, and Urban Development, Directorate of City and Regional Planning, Jakarta.

Kantor Statistik Jawa Timur (Statistical Office of Jawa Timur). 1981. Statistik Jawa Timur 1980 (East Java Statistics 1980). Kantor Statistik Jawa Timur, Surabaya.

Kantor Statistik Jawa Barat (Statistical Office of Jawa Barat). 1981. Statistik Jawa Timur 1980 (West Java Statistics 1980). Kantor Statistik Jawa Barat, Djakarta.

Kantor Statistik Bali (Statistical Office of Bali). 1981. Statistik Bali 1981 (Bali Statistics 1981). Kantor Statistik Bali, Bali.

Kantor Statistik Kalimantan Barat (Statistical Office of Kalimantan Barat). 1977. Kalimantan Barat Dalam Angka 1977 (West Kalimantan in Figures 1977). Kantor Statistik Kalimantan Barat, Pontianak.

Kantor Statistik Kalimantan Timur (Statistical Office of Kalimantan Timur). 1981. Kalimantan Timur Dalam Angka 1981 (East Kalimantan in Figures 1981). Kantor Statistik Kalimantan Timur, Samarinda.

Kantor Statistik Kalimantan Selatan (Statistical Office of Kalimantan Selatan). 1981. Kalimantan Selatan Dalam Angka 1981 (South Kalimantan in Figures 1981). Kantor Statistik Kalimantan Selatan, Samarinda.

Kantor Statistik Nusa Tenggara Barat (Statistical Office of Nusa Tenggara Barat). 1977. Nusa Tenggara Barat Dalam Angka 1977 (West Nusa Tenggara in Figures 1977). Kantor Statistik Nusa Tenggara, Barat.

Kantor Statistik Nusa Tenggara Timur (Statistical Office of Nusa Tenggara Timur). 1981. Nusa Tenggara Timur Dalam Angka 1981 (East Nusa Tenggara in Figures 1981). Kantor Statistik Nusa Tenggara, Timur.

Kantor Statistik Maluku (Statistical Office of Maluku). 1981. Maluku Dalam Angka 1981 (Moluccas in Figures 1981). Kantor Statistik, Maluku.

Kantor Statistik Propinsi D.I. Aceh (Statistical Office of Aceh Province). 1980. Aceh Dalam Angka 1980 (Aceh in Figures 1980). Kantor Statistik Propinsi Aceh, Sumatra.

Kantor Statistik Propinsi Jambi (Statistical Office of Jambi Province). 1979. Jambi Dalam Angka 1979 (Jambi in Figures 1979). Kantor Statistik Propinsi Jambi, Sumatra. 
Kantor Statistik Propinsi Sumatera Utara (Statistical Office of North Sumatra Province). 1979. Sumatera Utara Dalam Angka 1979 (North Sumatra in Figures 1979). Kantor Statistik Propinsi Sumatera, Utara.

Kantor Statistik Propinsi Sumatera Barat (Statistical Office of West Sumatra Province). 1979. Sumatera Barat Dalam Angka 1979 (West Sumatra in Figures 1979). Kantor Statistik Propinsi Sumatera, Barat.

Kantor Statistik Propinsi Riau (Statistical Office of Riau Province). 1981. Riau Dalam Angka 198I (Riau in Figures 1981). Kantor Statistik Propinsi Riau, Sumatra.

Kantor Statistik Propinsi Lampung (Statistical Office of Lampung Province). 1980. Lampung Dalam Angka 1980 (Lampung in Figures 1980). Kantor Statistik Propinsi Lampung, Sumatra.

Kantor Statistik Propinsi Bengkulu (Statistical Office of Bengkulu Province). 1981. Bengkulu Dalam Angka 1981 (Bengkulu in Figures 1981). Kantor Statistik Propinsi Jambi, Jambi, Sumatra.

Kartawinata, K. 1990. A review of natural vegetation studies in Malesia, with special reference to Indonesia, pp. 121-132 In The Plant Diversity of Malesia, P. Baas, K. Kalkman and R. Geesink (eds.) Kluwer Academic Publishers, Dordrecht.

Kartawinata, K. and A.P. Vayda. 1984. Forest conversion in East Kalimantan, Indonesia: The activities and impact of timber companies, shifting cultivators, migrant pepper-farmers, and others, pp. 98-126 In Ecology in Practice, Part I: Ecosystem Management, F. di Castri, F.W.G. Baker, and M. Hadley (eds.) Tycooly International Publ. Ltd., Dublin.

Kartawinata, K., T.C. Jessup, and A.P. Vayda. 1989. Exploitation in Southeast Asia, pp. 591-610 In Tropical Rain Forest Ecosystems: Biogeographical and Ecological Studies, H. Lieth and M.J.A. Werger (eds.) Ecosystems of the World 14B, Elsevier, Amsterdam.

Laumonier, Y., A. Gadrinab, and Pumajadja. 1983. Sumatra Sud. Map, 1:5,000,000. Institut de la Carte Internationale du Tapis Vegetal, SEAMEO-BIOTROP, Toulouse.

Laumonier, Y., Pumajadja, and Setiabudhi. 1986. Sumatra Centre. Map, 1:5,000,000. Institut de la Carte Internationale du Tapis Vegetal, SEAMEO-BIOTROP, Toulouse.

Laumonier, Y., Pumajadja, and Setiabudhi. 1986. Sumatra Nord. Map, 1:5,000,000. Institut de la Carte Internationale du Tapis Vegetal, SEAMEO-BIOTROP, Toulouse.

Leighton, M. and N. Wirawan. 1986. Catastrophic drought and fire in Bomeo tropical rain forest associated with the 1982-1983 El Nino Southem Oscillation event, pp. 75-102 In Tropical Rain Forests and the World Atmosphere, G.T. Prance (ed.) Westview Press, Inc., Boulder, CO.

Lindblad, J.T. 1985. Economic change in southeast Kalimantan 1880-1940. Bull. Indonesian Econ. Stud. 21(3):69-103.

MacDonald, L. and A. Shameen. 1984. Wound in the world. Asiaweek (July 13):34-49. 
Mackie, C. 1984. The lessons behind East Kalimantan's forest fires. Borneo Research Bulletin 16(2):63-74. Bomeo Res. Council, Williamsburg, VA.

Malingreau, J.-P., G. Stephens, and L. Fellows. 1985. Remote sensing of forest fires: Kalimantan and North Borneo in 1982-83. Ambio 14:314-321.

Manning, C. 1971. The timber boom: with special reference to East Kalimantan. Bull. Indonesian Econ. Stud. 7(3):30-60.

Manning, C. and M. Rumbiak. 1989. Irian Jaya: economic change, migrants, and indigenous welfare, pp. 76-106 In Unity and Diversity: Regional Economic Development in Indonesia since 1970, H. Hill (ed.) Oxford University Press, Singapore.

Mansvelt, W.M.F. and P. Creutzberg. 1975. Changing Economy in Indonesia: A Selection of Statistical Source Material from the Early 19th Century up to 1940, Vol. 1: Indonesia's Export Crops 1816-1940. Martinus Nijhoff, The Hague.

Mansvelt, W.M.F. and P. Creutzberg. 1978. Changing Economy in Indonesia: A Selection of Statistical Source Material from the Early 19th Century up to 1940, Vol. 4: Rice Prices. Martinus Nijhoff, The Hague.

McNicoll, G. 1970. Research in Indonesian Demography: A Bibliographic Essay. Paper No. 6, East-West Population Institute, Honolulu, HI.

Meijer, W. 1973. Devastation and regeneration of lowland dipterocarp forests in Southeast Asia. Bioscience 23:528-533.

Meijer, W. 1975. Indonesian Forests and Land Use Planning: Report on a Fact-finding Tour Aimed Toward a Co-ordinated Development of Forest Resources in Indonesia. University of Kentucky, Lexington, KY.

Metzner, J.K. 1977. Man and Environment in Eastern Timor: A Geogecological Analysis of the Baucau-Viqueque Area as a Possible Basis for Regional Planning. Australian National University, Canberra.

Metzner, J.K. 1982. Agriculture and Population Pressure in Sikka, Isle of Flores: A Contribution to the Study of the Stability of Agricultural Systems in the Wet and Dry Tropics. Development Studies Centre Monograph No. 28, Australian National University, Canberra.

Nederlandsch-Indie Central Kantoor voor de Statistiek, Departement van Economische Zaken. 1935. Indisch Verslag 1935. I. Statistisch Jaaroverzicht van Nederlandsch-indie over het Jaar 1934 (Netherlands Indies Report 1935. I. Statistical Abstract for the Year 1934). Landsdrukkerij, Batavia. 
Nederlandsch-Indie Centraal Kantoor voor de Statistiek, Departement van Economische Zaken. 1941. Indisch Verslag 1941. I. Statistisch Jaaroverzicht van Nederlandsch-indie over het Jaar 1940 (Netherlands Indies Report 1941. I. Statistical Abstract for the Year 1940). Landsdrukkerij, Batavia.

Nederlandsch-Indie Departement van Landbouw. 1906. Jaarboek van het Departement van Landbouw (Yearbook of the Department of Agriculture). G. Kolff and Co., Batavia.

Nederlandsch-Indie Departement van Landbouw, Nijverheid en Handel. 1915. Jaarboek van Landbouw, Nijverheid en Handel in Nederlandsch-Indie 1914 (Yearbook of Agriculture, Industry, and Commerce 1914). Landsdrukkerij, Batavia.

Nederlandsch-Indie Departement van Landbouw, Nijverheid en Handel, Centraal Kantoor voor de Statistiek in Nederlansch-Indie. 1924, 1925. Statistisch Jaaroverzicht van Nederlandsch-Indie vervolg van: Jaarcijfers voor het Koninkrijk der Nederlanden (Kolonien) Jaargang 1924 (1925) (Statistical Abstract for the Netherlands East-Indies). New series, Departement van Landbouw, Nijverheid en Handel, Batavia.

Nederlandsch-Indie Departement van Landbouw, Nijverheid en Handel, Centraal Kantoor voor de Statistiek in Nederlansch-Indie. 1929. Jaarboek van het Departement van Landbouw, Nijverheid en Handel en Nederlandsch-Indie 1929. Landsdrukkerij, Batavia.

Nederlandsch-Indie Departement van Ekonomische Zaken. 1936. Volkstellung 1930 (Census of 1930 in the Netherlands Indies). 8 vols., Landsdrukkerij, Batavia.

Netherlands East Indies Dept. of Agriculture, Industry and Commerce. 1916. Yearbook of the Netherlands East Indies 1916. Sub-department of Commerce and Industry, Albrecht and Co., Weltevreden.

Netherlands East Indies Dept. of Agriculture, Industry and Commerce. 1920. Yearbook of the Netherlands East Indies. Sub-department of Commerce, Albrecht and Co., Weltevreden.

Netherlands East Indies Dept. of Agriculture, Industry and Comerce. 1924. Handbook of the Netherlands East Indies, Edition 1924. Div. of Commerce, G. Kolff and Co., Java.

Netherlands East Indies Forest Service. 1926. The Forest Service in the Dutch East Indies, Actes du Primer Congres International de Sylviculture (Rome, 29 Avril - 5 Mai 1926). Vol. II. Rapports Presentes a la Primere Section. Imprimerie de l'Institut International d'Agriculture, Rome.

Netherlands East Indies Dept. of Economic Affairs. 1963. Statistical Pocket Book of Indonesia 1941 (with comparative data for 1940 or earlier). Central Bureau of Statistics, De Koninklijke boekhandel en Drukkerijen G. Kolff and Co., Batavia 
Nibbering, J.W. 1988. Forest degradation and reforestation in a highland area in Java, pp. 155-177 In Changing Tropical Forests: Historical Perspectives on Today's Challenges in Asia, Australasia and Oceania, J. Dargavel, K. Dixon, and N. Semple (eds.) Centre for Resource and Environmental Studies, Australian National University, Canberra.

Nirschl, J. 1920. Die Forstwirtschaft in Niederlandish-Indien. Auslandwirtschaft in Einzeldarstellungen Bd. 6. K.F. Koehler, Leipzig.

Nugmho. 1967. Indonesia: Facts and Figures. Terbitan Pertjobaan, Jakarta

Ormeling, F.J. 1956. The Timor Problem: A Geographical Interpretation of an Underdeveloped Island. J.B. Wolters, Groningen. Reprinted 1981 by Martinus Nijhoffs', Gravenhage.

Palte, J.G.L. 1989. Upland Farming on Java, Indonesia: A Socio-Economic Study of Upland Agriculture and Subsistence Under Population Pressure. Nederlandse Geografische Studies 97, Koninklijk Nederlands Aardrijkskundig Genootschap and Geografisch Instituut Rijksuniversiteit Utrecht, Amsterdam/Utrecht.

Pelzer, K.J. 1963. Physical and human resource pattems, pp. 1-23 + 2 maps ("Forests of Indonesia", 1:16,000,000; and "Forest and Sawah: in Java and Madura", 1: 3,800,000), In Indonesia, R.T. McVey (ed.) Yale University Southeast Asia Studies, HRAF Press, New Haven, CT.

Pelzer, K.J. 1963. The agricultural foundation, pp. 118-154, 498-504 In Indonesia, R.T. McVey (ed.) Southeast Asia Studies, Yale University, HRAF Press, New Haven, CT.

Petocz, R.G. 1989. Conservation and Development in Irian Jaya: A Strategy for Rational Resource Utilization. E.J. Brill, Leiden.

Potter, Lesley. 1988. Indigenes and colonizers: Dutch forest policy in South and East Bomeo (Kalimantan) 1900 to 1950, pp. 127-153 In Changing Tropical Forests: Historical Perspectives on Today's Challenges in Asia, Australasia and Oceania, J. Dargavel, K. Dixon, and N. Semple (eds.) Centre for Resource and Environmental Studies, Australian National University, Canberra.

Scholz, U. 1983. The Natural Regions of Sumatra and their Agricultural Production Pattern: A Regional Analysis. Central Research Institute for Food Crops, Bogor, West Java, Indonesia.

Sebire, R.A. 1980. Resource review -the forests and forest industries of Indonesia. Australian Forest Industries J. (June):47-52.

Soemarwoto, O. and I. Soemarwoto. 1984. The Javanese rural ecosystem, pp. 254-287 In An Introduction to Human Ecology Research on Agricultural Systems in Southeast Asia, A.T. Rambo and P.E. Sajise (eds.) University Publications Program, University Philippines at Los Banos, Laguna. 
Soerinagara, I. 1980. The alang-alang (Imperata cylindrica (L.) Beauv.) problem in forestry, pp. 237-242 In Proceedings of the BIOTROP Workshop on Alang-alang (Bogor, July, 1976). BIOTROP Special Publ. No. 5, BIOTROP-SEAMEO Regional Center for Tropical Biology, Bogor.

Soewardi, B. 1983. Indonesia, pp. 83-97 In Swidden Cultivation in Asia, Vol. 1: Current Analysis of the Existing Literature: A Stocktaking Exercise. UNESCO, Bangkok.

Soewardi, B. 1983. Indonesia, pp. 109-155 In Swidden Cultivation in Asia, Vol. 2: Country Profiles: India, Indonesia, Malaysia, Philippines, Thailand. UNESCO, Bangkok.

Steenis, C.G.G.J. 1935. Maleische vegetatieschietsen I. Toelichting bij de plantengeografische kaart van Nederlandsch Oost Indie. Tijdschrift van het Nederlandsch Aardrijkskundig Genootschap Amsterdam, Ser. 2., 52:25-398 + map: "Plantengeografische kaart van Nederlandsch Oost Indie", scale 1:50,000,000. E.J. Brill, Leiden.

Steenis, C.G.G.J. van. 1954. Vegetatie en flora in Niew Guinea. De Ontwikkeling op Ekonomisch, Sociaal en Cultureel Gebied, pp. 218-275 In Nederlands en Australisch Nieuw Guinea, Vol. II, Ir.W.C. Klein (ed.) Hamburg.

Takaya, Y. 1980. Agricultural landscape of the Komering River of South Sumatra, 48 pp. In South Sumatra: Man and Agriculture, Part I, Y. Tsubouchi, N. Iljas, Y. Takaya, and A.R. Hanafiah (eds.) Center for Southeast Asian Studies, Kyoto University, Kyoto, Japan.

van de Graag, Ir.E.A. 1955. De Statistiek in Indonesie (On the Statistics of Indonesia). Uitgeverij W. van Hoeve, Bandung, Indonesia.

Voss, F. 1982. TAD - Report No. 9: Natural Resources Inventory. East Kalimantan Transmigration Area Development Project. Rev. edition, TAD Publications, Hamburg.

White, B. 1973. Demand for labor and population growth in Colonial Java. Human Ecology 1:217-236.

Whitten, A.J. 1987. Indonesia's transmigration program and its role in the loss of tropical rain forests. Conservation Biology 1(3):239-246.

Whitten, A.J., M. Mustafa, and G.S. Henderson. 1987. The Ecology of Sulawesi. Gadjah Mada University Press, Yogyakarta.

Whitten, A.J., S.J. Damanik, Jazanul Anwar, and Nazaruddin Hisyam. 1984. The Ecology of Sumatra. Gadjah Mada University Press, Yogyakarta.

Widjojo Nitisastro. 1970. Population Trends in Indonesia. Comell University Press, Ithaca, NY.

You Poh Seng and Stephen Yeh, 1971. Aspects of population growth and population policy, pp. 447-580 In Southeast Asia's Economy in the 1970's. Asian Development Bank, Praeger Publishers, New York 


\subsubsection{Kampuchea (Cambodia)}

Allouard, P. 1954. La route forestiere en pays tropical (Forest roads in tropical areas). Bois et Forets des Tropiquesi 33:15-36.

Aubreville, A. 1957. Au pays des eaux et des forets: impressions du Cambodge forestier (In the country of waters and forests: impressions of forested Cambodia). Bois et Forets des Tropiques 52:49-56.

Barton, T.R., R.C. Kingsbury, and G.R. Showalter. 1970. Southeast Asia in Maps. Denoyer-Geppert, Chicago, IL.

Burchett, W.G. 1959. Mekong Upstream: A Visit to Laos and Cambodia. Seven Seas Publishers, Berlin.

Caldwell, M. 1979. Kampuchea: Rationale for a Rural Policy. Janata Prachuranalu, Hyderabad.

Cambodge (Etat du) Institut National de la Statistique et des Recherches Economiques. 1970. Bulletin Statistique, Premier Trimestre 1970. Etat du Cambodge, Commissariat General du Plan, Phnom Penh.

Cambodge (Royaume du) Direction de la Statistique et des Etudes Economiques. 1954-1962. Bulletin Mensuel de Statistique. Royaume du Cambodge, Ministere du Plan, Phnom Penh.

Cambodge (Royaume du) Direction de la Statistique et des Etudes Economiques. 1956. Bulletin Economique et Statistique du Cambodge 1953. Royaume du Cambodge, Ministere du Plan, Phnom Penh.

Cambodge (Royaume du) Direction de la Statistique et des Etudes Economiques. 1959. Population du Cambodge en 1958. Royaume du Cambodge, Ministere du Plan, Phnom Penh.

Cambodge (Royaume du) Institut National de la Statistique et des Recherches Economiques. 1964. Bulletin Mensuel de Statistique, Mois d'Octobre 1962 a Juilliet 1964. Royaume du Cambodge, Ministere du Plan, Phnom Penh.

Cambodge (Royaume du) Institut National de la Statistique et des Recherches Economiques. 1965-1967. Bulletin Statistique (quarterly 1965-1967). Royaume du Cambodge, Ministere du Plan, Phnom Penh.

Cambodia (Royaume du) Ministere du plan. 1958. Annuaire statistique retrospectif du Cambodge 1937-1957 (Statistical Yearbook of Cambodia 1937-1957). Entreprise Khmere de Librairie d'Imprimerie et de Papeterie, Phnom Penh. 
Cambodian Authorities. 1968. Conservation in Cambodia, conservation in tropical South East Asia, pp. 456-459 In Proceedings of the Conference on Conservation of Nature and Natural Resources in Tropical South East Asia (Bangkok, Nov. 29-Dec. 4, 1965), L.M. Talbot and M.H. Talbot (eds.) International Union for Conservation of Nature and Natural Resources, Morges, Switzerland.

Champsoloix, R. 1959. A propos de la "foret claire" du Sud-est Asiatique (On the "woodlands" of South-East Asia). Bois et Forets des Tropiques 64:3-11.

Chandler, D.P. 1983. History of Cambodia. Westview Press, Boulder, CO.

Chandler, D.P. 1991. Tragedy of Cambodian History: Politics, War, and Revolution since 1945. Yale University Press, New Haven, CT.

Chamey, J.R. 1987. Appropriate development aid for Kampuchea, pp. 243-266. In Cambodian Agony, D.A. Ablin and M. Hood (eds.) M. E. Sharpe, lnc., London.

Clawson, M., H. Landsberg, M.F. Brewer, P. Crosson, J.V. Krutilla, J. Ingersoll, N. Black, and J. Vaughan. 1971. Agricultural Development in the Mekong Basin: Goals, Priorities and Strategies -A Staff Study. Resources for the Future, Inc., Johns Hopkins Press for Resources for the Future, Inc., Baltimore, MD.

Cosslett, T.L. 1990. The economy, pp. 139-183 In Cambodia: A Country Study, R.R. Ross (ed.) Area Handbook Series, DA Pam. 550-50, Superintendent of Documents, U. S. Govt. Printing Office, Washington, DC.

Delvert, J. 1961. Le Paysan Cambodgen. Mouton and Co. La Haye, Paris.

Dennis, J.V., Jr. 1987. Kampuchea's Ecology and Resource Base: Natural Limitations on Food Production Strategies, pp. 213-242 In Cambodian Agony, D.A. Ablin and M. Hood (eds.) M.E. Sharpe, Inc., London.

Dugros, M. 1937. Le domaine forestier inonde de la Cochinchine. Bulletin Economique de l'Indochine XL:283-314. Gouvernement general de l'Indochine, Direction des Services Economiques, Hanoi.

Ea, M.-T. 1987. Recent population trends in Kampuchea, pp. 3-15 In Cambodian Agony, D.A. Ablin and M. Hood (eds.) M.E. Sharpe, Inc., London.

Ebihara, M. 1987. Revolution and reformulation in Kampuchean village structure, pp. 16-62 In Cambodian Agony, D.A. Ablin and M. Hood (eds.) M.E. Sharpe, Inc., London.

Etcheson, C. 1984. The Rise and Demise of Democratic Kampuchea. Westview Press, Boulder, CO. 
Forest, A. 1980. Le Cambodge et la colonisation francaise: Histoire d' une colonisation sans heurts 1897-1920 (Cambodia and the French Colonization: History of a Colonization without Conflict 1897-1920). Librairie Editions L'Harmattan, Paris.

Foxworthy, F.W. 1932. A forester's trip to Indo-China. Malayan For. 1:8-11.

Galston, A.W. and P.W. Richards. 1984. Terrestrial plant ecology and forestry: An overview, pp. 39-42 In Herbicides in war: The Long-term Ecological and Human Consequences, A.H. Westing (ed.) Taylor and Francis for the Stockholm Intemational Peace Research Institute, London.

Gourou, P. (translated by S.H. Guest and E.A. Clark) 1945. Land Utilization in French Indochina. 3 vols. Institute of Pacific Relations, New York.

Gourou, P. 1954. Vue cavaliere des tropiques pluviuex (Overview of the humid tropics). Bois et Forets des Tropiques 37:3-17.

Great Britain Naval Intelligence Division. 1943. Indo-China. B.R. 510, Geographical Handbook Series, Cambridge University, Cambridge, MA.

Headley, R.K., Jr. 1990. The society and its environment, pp. 73-137 In Cambodia: A Country Study, R.R. Ross (ed.) Area Handbook Series, DA Pam. 550-50, Superintendent of Documents, U.S. Govt. Printing Office, Washington, DC.

Henry, Y. 1932. Economie Agricole de L'Indochine. Gouvemement General de L'Indochine, Hanoi.

Hildebrand, G. and G. Porter. 1976. Cambodia: Starvation and Revolution. Monthly Review Press, New York.

Hood, M. and D.A. Ablin. 1987. The path to Cambodia's present, pp. xv-Ixi In Cambodian Agony, D.A. Ablin and M. Hood (eds.) M.E. Sharpe, Inc., London.

Huguet, L. 1982. Que penser de la "disparition" des forets tropicales? (What are we to think about the "disappearance" of tropical forests?). Bois et Forets des Tropiques 195:7-22.

Indochine (Gouvemement General de l') Direction des Affaires Economiques. 1927. Annuaire Statistique de l'Indochine, Premier Volume: Recueil de Statistiques relatives aux annees 1913 a 1922. Service de la Statistique Generale, Impril. srie d'Extreme-Orient, Hanoi.

Indochine (Gouvernement General de l') Direction des Affaires Economiques. 1931. Annuaire Statistique de l'Indochine, Deuxieme Volume, 1923-1929. Service de la Statistique Generale de l'Indochine, Imprimerie d'Extreme-Orient, Hanoi.

Indochine (Gouvernement General de l') Direction des Affaires Economiques. 1932. Annuaire Statistique de l'Indochine. Troisieme Volume, 1930-1931. Service de la Statistique Generale de l'Indochine, Imprimerie d'Extreme-Orient, Hanoi. 
Indochine (Gouvemement General de 1') Direction des Affaires Economiques et Administratives. 1933. Annuaire Statistique de I'Indochine, Quatrierne Volume, 1931-1932. Bureau de la Statistique Generale. Imprimerie d'Extreme-Orient, Hanoi.

Indochine (Gouvemement General de l') Direction des Affaires Economiques et Administratives. 1935. Annuaire Statistique de l'Indochine, Cinquieme Volume, 1932-1933. Bureau de la Statistique Generale, Imprimerie d'Extreme-Orient, Hanol.

Indochine (Gouvemement General de 1') Direction des Affaires Economiques et Administratives. 1937. Annuaire Statistique de I'Indochine, Sixieme Volume, 1934-1935-1936. Bureau de la Statistique Generale, Imprimerie d'Extreme-Orient. Hanoi.

Indochine (Gouvernement General de l') Direction des Services Economiques. 1938. Annuaire Statistique de l'Indochine, Septieme Volume, 1936-1937. Service de la Statistique Generale, Imprimerie d'Extreme-Orient, Hanoi.

Indochine (Gnuvernement General de l') Direction des Services Economiques. 1939. Annuaire Statistique de l'Indochine. Huitieme Volume, 1937-1938. Service de la Statistique Generale. Imprimerie d'Extreme-Orient, Hanoi.

Indochine (Gouvernement General de l') Direction des Services Economiques. 1942. Annuaire Statistique de l'Indochine, Neuvieme Volume, 1939-1940. Service de la Statistique Generale . Imprimerie d'Extreme-Orient, Hanoi.

Indochine (Gouvemement General de l') Direction des Services Economiques. 1945. Annuaire Statistique de l'Indochine, Dixieme Volume, 1941-1942. Service de la Statistique Generale. Imprimerie d'Extreme-Orient, Hanoi.

Indochine (Statistique Generale de 1'). 1948. Annuaire Statistique de l'Indochine, Onzieme Volume, 1943-1946. Union Francaise, Haut-Commissariat de France pour l'Indochine Affaires Economiques, Statistique Generale de I'Indochine, Saigon.

Indochine (Statistique Generale de l'). 1946. Bulletin Statistique de l'Indochine, 4e Trimestre 1946. Federation Indochinoise, Commissariat Federal aux Affaires Economiques, Statistique Generale de l'Indochine, Saigon.

Indochine (Statistique Generale de 1'). 1946. Bulletin Statistique de l'Indochine, Annee 1947. Union Francaise, Haut Commissariat de France pour l'Indochine Affaires Economiques, Statistique Generale de I'Indochine, Saigon.

Indochine (Statistique Generale de l'). 1949. Bulletin Statistique de l'Indochine, Annee 1948. Union Francaise, Haut-Commissariat de France pour l'Indochine Affaires Economiques, Statistique Generale de I'Indochine, Saigon.

Institut d'Emission des Etats du Cambodge, du Laos et du Vietnam. 1952. Statistiques Economiques et Financieres. No. 1, Direction des Etudes, Imprimerie Francaise d'Outre-Mer, Saigon. 
Institut d'Emission des Etats du Cambodge, du Laos et du Vietnam. 1952. Le probleme du riz. Statistiques Economiques ef Financieres. No. 2:5-18, Service des Etudes Economiques et Financieres, Imprimerie Francaise d'Outre-Mer, Salgon.

Jacob, J.M. 1978. The ecology of Angkor: evidence from the Khmer inscriptions, pp. 109.127 In Nature and Man in South East Asia. P.A. Stott (ed.) School of Oriental and African Studies, University of London, London.

Kiljunen, K. 1984. Kampuchea: Decade of the Genocide: Report of a Finnish Inquiry Commission. Zed Books, London.

Legris, P., F. Blasco., O. Dottin, J. Fontanel, J. Migozzi, and L. Tichit. 1971. Carte internationale du tapis vegetal et des conditions ecologiques a III.000.000 Cambodge. Institut Francais, Pondichery.

Legris, P., F. Blasco., O. Dottin, J. Fontanel, J. Migozzi, and L. Tichit. 1972. Carte internationale du tapis vegetal et des conditions ecologiques a III.000.000. Notice de la Carte Cambodge. Trav. Sec. Sci. Tech. Hors. Serie No. 11, Institut Francais, Pondichery.

Maurand, P. 1938. L'Indochine forestiere. Inst. Rech. Agron. et For. de I'Indochine, Hanoi. McCune, S. 1947. The diversity of Indochina's physical geography. Far Eastern Quarterly 6(4):335-344.

Miller, E.W. 1947. Industrial resources in Indochina. Far Eastern Quarterly 6(4):396-408.

Monney, A. and A. Huber. 1970. Inventaire forestier des terres basses du versant occidental des monis Cardamomes, Cambodge. Exploitation forestiere et plan d'exploitation pour la zone du projet (Forest inventory of lowlands on the west side of the Cardamom Mountains, Cambodia. Forest exploitation and a working plan for exploitation in the project zone.). FO/SF/CAM 6, Rapport technique 4. FAO Programme des Nations Unies pour de Developpement, Rome.

Munson, F.P., K.W. Martindale, D.S. McMorris, K.E. Parachini, W.N. Raiford, and C. Townsend. 1968. Area Handbook for Cambodia. DA Pam 550-50. Superintendent of Documents, U.S. Govt. Printing Office, Washington, DC.

Murray, M.J. 1980. The Development of Capitalism in Colonial Indochina (1870-1940). University of California Press, Berkeley, CA.

Ng Shui Meng. July 1974. The Population of Indochina: Some Preliminary Observations. Field Report Series No. 7, Institute of Southeast Asian Studies, Singapore.

Noble, N. 1955. Agriculture in Cambodia, pp. 249-302 In Area Handbook on Cambodia, M. Zadrozny (ed.) Subcontractor's Monograph HRAF-21, Chicago-14, preliminary edition, University of Chicago for the Human Relations Area Files, Inc., Chicago, IL. 
Nuttonson, M.Y. 1963. Climatological Data of Vietnam, Laos, and Cambodia: A Supplement to the Report of The Physical Environment and Agriculture of Vieinam, Laos and Cambodia. A Study Based on Field Survey Data and on Pertinent Records, Material, and Reports. American Institute of Crop Ecology. Washington, DC.

Nuttonson, M.Y. 1963. The Physical Environment and Agriculture of Vietnam, Laos and Cambodia: A Study Based on Field Survey Data and on Pertinent Records, Matcrial, and Reports. American Institute of Crop Ecology, Washington, DC.

Orans, M. 1955. Tribal peoples of Cambodia, pp. 355-378 In Area Handbook on Cambodia, Zadrozny, M.G. (ed.) Subcontractor's Monograph HRAF-21. Chicago-14, preliminary edition, University of Chicago for the Human Relations Area Files, Chicago, IL.

Osbome, M.E. 1969. The French Presence in Cochinchina and Cambodia. Comell University Press, Ithaca, NY.

Prud'homme, R. 1969. L'economie du Cambodge. Collection 'Tiers Monde', Presses Universitaires de France, Paris.

Republique Khmere Institut National de la Statistique et des Recherches Economiques. 1971. Bulletin Statistique, Troisieme Trimestre 1971. Republique Khmere, Phnom Penh.

Robequain, C. 1944. The Economic Development of French Indo-China. Oxford University Press, London.

Rollet, B. 1953. Note sur les forets claires du sud de l'Indochine (About the open forests of South Indochina). Bois et Forets des Tropiques 31:3-13.

Rollet, B. 1972. La vegetation du Cambodge, premiere partie (Vegetation in Cambodia, part 1). Bois et Forets des Tropiques 144:3-15.

Rollet, B. 1972. La vegetation du Cambodge, deuxieme partie (Vegetation of Cambodia, part 2). Bois et Forets des Tropiques 145:23-38.

Rollet, B. 1972. La vegetation du Cambodge, troisieme partie (Vegetation of Cambodia, part 3). Bois et Forets des Tropiques 146:3-20.

Rollet, B., 1954. Pour un inventaire forestier du Viet-nam, pp. 639-666 In Proceedings of the 4ih World Forestry Congress. General and Special Papers on Tropical Forestry, Vol. III.

Rollet, B., 1960. Emploi de photographes aeriennes au 1/40.000e pour l'interpretation de la vegetation et les inventaires forestiers au Cambodge et au Vietnam (Utilization of aerial photographs, scale 1:40,000, for the interpretation of vegetation and forest inventories in Cambodia and Vietnam). Bois et Forets des Tropiques 74:16-24.

Ross, R. (ed.) 1990. Cambodia: A Country Study. Area Handbook Series, DA Pam 550-50, Superintendent of Documents, U. S. Govt. Printing Office, Washington, DC. 
Rothe, P.-L. 1947a. Foret d'Indochine (premiere partie). Bois el Forets des Tropiques 1:25-30.

Rothe, P.-L. 1947b. Forel d'Indochine. Son passe, son histoire (deuxieme partie). Bois et Forets des Tropiques 2:18-23.

Rothe, P.-L. 1947c. Foret d'Indochine. Ses possibilites son avenir (troisieme partie). Bois et Forets des Tropiques 3:17-23.

Schmid, M. 1977. Some considerations on the edaphic conditions in the tropical forest areas and their implications to land management, pp. 302-324 In Proceedings of a Symposium on Management of Forest Production in Southeast Asia. BIOTROP Special Publication No. 4. BIOTROP-SEAMEO Center for Tropical Blology, Faculty of Forestry, Kasetsan University, Bangkok. Thailand.

Scoville, O.J. 1987. Rebuilding Kampuchea's food supply, pp. 267-290 In Cambodian Agony, D.A. Ablin and M.Hood (eds.) M.E. Shame, Inc., London.

Seekins, D.M. 1990. Historical setting, pp. 1-71 In Cambodia: A Country Study, R.R. Ross (ed.) Area Handbook Series, DA Pam. 550-50, Superintendent of Documents, U. S. Govt. Printing Office, Washington, DC.

Setten, G.G.K. 1969. The pines of Kirirom, Cambodia. Commonwealth Forestry Review 48:238-241.

Siampos, G.S., June 1968. The Population of Cambodia 1945-1980. Formerly classified mimeograph from United Nations Office of Technical Cooperation/UNDP in Cambodia. Phnom Penh.

Thompson, V. 1937. French Indo-China. George Allen and Unwin Ltd, London.

Vickery, M, 1983. Democratic Kampuchea themes and variations, pp. 99.135 In Revolution and its Aftermath in Kampuchea: Eight Essays, D.P. Chandler and B. Kieman (eds.) Monograph Series No. 25, Yale University Southeast Asia Studies, New Haven, CT.

Vickery, M. 1984. Cambodia: 1975-1982. Southend Press, Boston, MA.

Weisberg, B. (ed.) 1970. Ecocide in Indochina: The Ecology of War. Canfield Press, San Francisco, CA.

Westing, A.H. (ed.) 1984. Herbicides in War: The Long-term Ecological and Human Consequences. Taylor and Francis for the Stockholm International Peace Research Institute, London and Philadelphia.

Westing, A.H. 1972. Herticidal damage to Cambodia, pp. 177-205 In Harvest of Death: Chemical Warfare in Vietnam and Cambodia, J.B. Neilands, G.H. Orians, E.W. Pfeiffer, A. Vennema, and A.H. Westing (eds.) The Free Press, New York. 
Whitaker, D.P., J.M. Heimann, J.E. MacDonald, K.W. Martindale, Rinn-Sup Shinn, and C. Townsend. 1973. Area Handbook for the Khmer Republic (Cambodia). DA Pam 550-50, Superintendent of Documents, U.S. Govt. Printing Office, Washington, DC.

Williams, L. 1965. Vegetation of Southeast Asia/Studies of Forest Types, 1963-1965. CR 49-65, U.S. Dept. of Agriculture, Agricultural Research Service, Crops Research Div., Washington, DC.

Williams, L. 1967. Forests of Southeast Asia, Puerto Rico, and Texas. U.S. Dept. of Agriculture, Agricultural Research Service, Crops Research Div., U.S. Dept. of Defense, Advanced Research Projects Agency, Washington, DC.

Wright, M. 1989. Cambodia: A Matter of Survival (Countries in Crisis). St. James Press, Chicago. IL.

Zadrozny, M.G. (ed.) 1955. Area Handbook on Cambodia. Subcontractor's Monograph HRAF-21, Chicago-14, preliminary edition, University of Chicago for the Human Relations Files, Inc., Chicago, Il. 


\subsubsection{Laos}

Adams, N.S. and A.W. McCoy. 1970. Laos: War and Revolution. Harper and Row, New York.

Asian Development Bank Technical Assistance Mission. September 1969. Integrated Agricultural Development Program for the Vientiane Plain, Laos. Asian Development Bank, Vientiane.

Barton, T.R., R.C. Kingsbury, and G.R. Showalter. 1970. Southeast Asia in Maps.

Denoyer-Geppert, Chicago, II.

Batson, W. 1991. After the revolution: ethnic minorities and the New Lao state, pp. 133-158 In Laos: Beyond the Revolution, J.J. Zasloff and L. Unger (eds.) St. Martin's Press, New York.

Borota, J. 1991. Tropical Forests: Some African and Asian Case Studies of Composition and Structure, In Developments in Agricultural and Managed-Forest Ecology 22. Elsevier, Amsterdam.

Branfman, F., J.A. Hafner and J.M. Halpem. 1978. Village of the Deep Pond, Ban Xa Phang Meuk, Laos. Asian Studies Committee, Occasional Papers Series No. 3, Intemational Area Studies Programs, University of Massachusetts at Amherst, Amherst, MA.

Burchett, W.G. 1959. Mekong Upstream: A Visit to Laos and Cambodia. Seven Seas Publishers. Berlin.

Champsoloix, R. 1959. A propos de la "foret claire" du Sud-est Asiatique (On the "woodlands" of South-East Asia). Bois et Forets des Tropiques 64:3-11.

Chanda, Naya. 1982. Economic changes in Laos, 1975-1980, pp. 116-128 In Contemporary Lạs: Studies in the Politics and Society of the Lao People's Democratic Republic, M. Stuart-Fox (ed.) St. Martin's Press, New York.

Chanthepha, S. 1968. Note on the situation of nature and natural resources in Laos, pp. 523-525 in Conservation in Tropical South East Asia: Proceedings of the Conference on Conservation of Nature and Natural Resources in Tropical South East Asia (Bangkok, Nov. 29-Dec. 4, 1965), L.M. Talbot and M.H. Talbot (eds.) Intemational Union for Conservation of Nature and Natural Resources, Morges, Switzerland.

Clawson, M., H. Landsberg, M.F. Brewer, P. Crosson, J.V. Krutilla, J. Ingersoll, N. Black, and J. Vaughan. 1971. Agricultural Development in the Mekong Basin: Goals, Priorities and Strategies A Staff Study. Resources for the Future, Inc., Johns Hopkins Press for Resources for the Future, Inc., Baltimore, MD.

Condominas, G. 1970. The Lao, In Laos: War and Revolution, Adams and A.W. McCoy (eds.) Harper and Row, New York. 
Dommen, A.J. 1964. Conflict in Laos: The Politics of Neutralization. Frederick A. Praeger, New York.

Dommen, A.J. 1985. Laos: Keystone of Indochina. Westview Press, Boulder, CO.

Drilon, J.D., Jr. December 1965. The agricultural development organization and the rice problem in Laos. Report for contract AID L-498, Agricultural Development Organization/U.S. Agency for Intemational Development, Vientiane.

Evans, G. 1990. Lao Peasants Under Socialism. Yale University Press, New Haven, CT.

Evans, G. 1991. Planning problems in peripheral socialism: The case of Laos, pp. 84-130 In Laos: Beyond the Revolution, J.J. Zasloff and L. Unger (eds.) St. Martin's Press, New York.

Foxworthy, F.W. 1932. A forester's trip to Indo-China. Malayan For. 1:8-11.

Galston, A.W. and P.W. Richards. 1984. Terrestrial plant ecology and forestry: An overview, pp. 39-42 In Herbicides in war: The Long-term Ecological and Human Consequences, A.H. Westing (ed.) Taylor and Francis for the Stockholm International Peace Research Institute, London and Philadelphia.

Gourou, P. (translated by S.H. Guest and E.A. Clark) 1945. Land Utilization in French Indochina. 3 vols., Institute of Pacific Relations, New York.

Gourou, P. 1954. Vue cavaliere des tropiques pluviuex (Overview of the humid tropics). Bois et Forets des Tropiques 37:3-17.

Great Britain Naval Intelligence Division. 1943. Indo-China. B.R. 510, Geographical Handbook Series, Cambridge University.

Gupta, V.K., V.N. Asopa, V.K. Gaikwad, and A.H. Kalro. 1990. Planning Rural Development Projects in Laos: A Guide. International Labor Organization, Asian Regional Team for Employment Promotion, Geneva.

Halpem, J.M. 1964. Economy and Society of Laos. Monograph Series No. 5, Yale University Southeast Asia Studies, New Haven, CT.

Hasel, A.A. March 1967. Forest Survey Plan for Laos. USAID-Laos, Vientiane.

Hawkins, R.S.D. 1970. Contours, cultures, and conflict, in Laos: War and Revolution, N.S. Adams and A.W. McCoy (eds.) Harper and Row, New York.

Henry Yves. 1932. Economie agricole de L'Indochine. Gouvernement General de L'Indochine, Hanoi. 
Hickey, G.C. (ed.) 1955. Area Handbook on Laos. Subcontractor's Monograph HRAF-23, Chicago-19, preliminary edition, University of Chicago for the Human Relations Area Files, Chicago, IL.

Huguet, L. 1982. Que penser de la "disparition" des forets tropicales? (What are we to think about the "disappearance" of tropical forests?). Bois et Forets des Tropiques 195:7-22.

Indochine (Gouvernement General de l') Direction des Affaires Economiques. 1927. Annuaire Statistique de l'Indochine, Premier Volume. Service de la Statistique Generale, Recueil de Statistiques relatives aux annees 1913 a 1922, Imprimerie d'Extreme-Orient, Hanoi.

Indochine (Gouvernement General de l') Direction des Affaires Economiques. 1931. Annuaire Statistique de l'Indochine, Deuxieme Volume, 1923-1929. Service de la Statistique Generale de l'Indochine, Imprimerie d'Extreme-Orient, Hanoi.

Indochine (Gouvernement General de l') Direction des Affaires Economiques. 1932. Annuaire Statistique de l'Indochine, Troisieme Volume, 1930-1931. Service de la Statistique Generale de l'Indochine, Imprimerie d'Extreme-Orient, Hanoi.

Indochine (Gouvernement General de l') Direction des Affaires Economiques. 1933. Annuaire Statistique de l'Indochine, Quatrieme Volume, 1931-1932. Bureau de la Statistique Generale, Imprimerie d'Extreme-Orient, Hanoi.

Indochine (Gouvernement General de l') Direction des Affaires Economiques et Administratives. 1935. Annuaire Statistique de l'Indochine, Cinquieme Volume, 1932-1933. Bureau de la Statistique Generale, Imprimerie d'Extreme-Orient, Hanoi.

Indochine (Gouvemement General de l') Direction des Affaires Economiques et Administratives. 1937. Annuaire Statistique de l'Indochine, Sixieme Volume, 1934-1935-1936. Bureau de la Statistique Generale, Imprimerie d'Extreme-Orient, Hanoi.

Indochine (Gouvermement General de l') Direction des Services Economiques. 1938. Annuaire Statistique de l'Indochine, Septieme Volume, 1936-1937. Service de la Statistique Generale, Imprimerie d'Extreme-Orient, Hanoi.

Indochine (Gouvernement General de l') Direction des Services Economiques. 1939. Annuaire Statistique de l'Indochine, Huitieme Volume, 1937-1938. Service de la Statistique Generale, Imprimerie d'Extreme-Orient, Hanoi.

Indochine (Gouvemement General de l') Direction des Services Economiques. 1942. Annuaire Statistique de l'Indochine, Neuvieme Volume, 1939-1940. Service de la Statistique Generale, Imprimerie d'Extreme-Orient, Hanoi.

Indochine (Gouvernement General de l') Direction des Services Economiques. 1945. Annuaire Statistique de l'Indochine, Dixieme Volume, 1941-1942. Service de la Statistique Generale, Imprimerie d'Extreme-Orient, Hanoi. 
Indochine (Statistique Generale de l'). 1946. Bulletin Statistique de l'Indochine, 4e Trimestre 1946. Federation Indochinoise, Commissariat Federal aux Affaires Economiques, Statistique Generale de l'Indochine, Saigon.

Indochine (Statistique Generale de l'). 1946. Bulletin Statistique de l'Indochine, Annee 1947. Union Francaise, Haut Commissariat de France pour l'Indochine Affaires Economiques, Statistique Generale de l'Indochine, Saigon.

Indochine (Statistique Generale de l'). 1948. Annuaire Statistique de l'Indochine, Onzieme Volume, 1943-1946. Union Francaise, Haut-Commissariat de France pour l'Indochine Affaires Economiques, Statistique Generale de l'Indochine, Saigon.

Indochine (Statistique Generale de l'). 1949. Bulletin Statistique de l'Indochine, Annee 1948. Union Francaise, Haut-Commissariat de France pour l'Indochine Affaires Economiques, Statistique Generale de l'Indochine, Saigon.

Institut d'Emission des Etats du Cambodge, du Laos et du Vietnam. 1952. Statistiques economiques et financieres No. 1. Direction des Etudes, Imprimerie Francaise d'Outre-Mer, Saigon.

Institut d'Emission des Etats du Cambodge, du Laos et du Vietnam. 1952. Le probleme du riz. Statistiques economiques et financieres. No. 2:5-18, Service des Etudes Economiques et Financieres, Imprimerie Francaise d'Outre-Mer, Saigon.

James, H.B. July 1965. An Agricultural Development Program for Laos. U.S. Dept. of State, Agency for Intemational Development, Washington, DC.

Laos (Royaume du) Ministere du Plan. 1921. Population du Laos. Service de la Statistique, Royaume du Laos, Vientiane.

Laos (Royaume du) Service National de la Statistique. 1969. Bulletin de Statistiques, 19eme Annee (Statistical Bulletin, 19th year). Royaume du Laos, Ministere du Plan et de la Cooperation, Vientiane.

Larimore, A. 1955. The Laotian economy, pp. 231-269 In Area Handbook on Laos, G.C. Hickey (ed.) Subcontractor's Monograph HRAF-23, Chicago-19, preliminary edition, University of Chicago for the Human Relations Area Files, Chicago, IL.

Larimore, A. 1955. The population characteristics of Laos, pp. 108-136 In Area Handbook on Laos, G.C. Hickey (ed.) Subcontractor's Monograph HRAF-23, Chicago-19, preliminary edition, University of Chicago for the Human Relations Area Files, Chicago, $\mathbb{L}$.

Larimore, A. 1955. The resource base of Laos, pp. 57-86 In Area Handbook on Laos, G.C. Hickey (ed.) Subcontractor's Monograph HRAF-23, Chicago-19, preliminary edition, University of Chicago for the Human Relations Area Files, Chicago, IL. 
LeBar, F.M. and A. Suddard (eds.) 1967. Laos: Its People, Its Society, Its Culture. HRAF Press, New Haven, CT.

Lee, Gary Y. 1982. Minority policies and the Hmong, pp. 201-219 In Contemporary Laos: Studies in the Politics and Society of the Lao People's Democratic Republic, M. Stuart-Fox (ed.) St. Martin's Press, New York.

Maurand, P. 1938. L'Indochine forestiere. Inst. Rech. Agron. et For. de l'Indochine, Hanoi.

McCoy, A.W. 1970. French colonialism in Laos, 1893-1945, pp. 67-99 In Laos: War and Revolution, N.S. Adams and A.W. McCoy (eds.) Harper and Row, New York.

McCune, S. 1947. The diversity of Indochina's physical geography. Far Eastern Quarterly 6(4):335-344.

Miller, E.W. 1947. Industrial resources in Indochina. Far Eastern Quarterly 6(4):396-408.

Morechand, G. 1970. The many languages and cultures of Laos, pp. 29-33 In Laos: War and Revolution, N.S. Adams and A.W. McCoy (eds.) Harper and Row, New York.

Murray, M.J. 1980. The Development of Capitalism in Colonial Indochina (1870-1940). University of Califomia Press, Berkeley, CA.

Ng Shui Meng. July 1974. The Population of Indochina: Some Preliminary Observations. Field Report Series No. 7, Institute of Southeast Asian Studies, Singapore.

Noble, N. 1955. Agriculture, pp. 193-230 In Area Handbook on Laos, G.C. Hickey (ed.) Subcontractor's Monograph HRAF-23, Chicago-19, preliminary edition, University of Chicago for the Human Relations Area Files, Chicago, IL.

Nuttonson, M.Y. 1963. Climatological Data of Vietnam, Laos, and Cambodia: A Supplement to the Report of The Physical Environment and Agriculture of Vietnam, Laos and Cambodia. A Study Based on Field Survey Data and on Pertinent Records, Material, and Reports. American Institute of Crop Ecology, Washington, DC.

Nuttonson, M.Y. 1963. The Physical Environment and Agriculture of Vietnam, Laos and Cambodia: A Study Based on Field Survey Data and on Pertinent Records, Material, and Reports. American Institute of Crop Ecology, Washington, DC.

Paquet, J. (ed.) 1975. Inventory Manual: Reconnaisance Survey of Lowland Forest, Laos. Forest Inventory Manual: Technics and Methods. Royal Lao Govt., Dept. of Water and Forests, Canadian Agency for Intemational Development, U.S. Agency for International Development, Vientiane.

Reinach, L. de. 1911. Le Laos. Librarie Orientale and Americaine, Paris. 
Robequain, C. 1944. The Economic Development of French Indo-China. Oxford University Press, London.

Roberts, T.D., M.E. Carrol, I. Kaplan, J.M. Matthews, D.D. McMorris, and C.Townsend. 1973. Area Handbook for Laos. Superintendent of Documents, U.S. Govt. Printing Office, Washington, DC.

Robinson, W.C. 1991. Laotian refugees in Thailand: the Thai and U.S. response, 1975 to 1988, pp. 215-240 In Laos: Beyond the Revolution, J.J. Zasloff and L. Unger (eds.) St. Martin's Press, New York.

Rcilet, B. 1953. Note sur les forets claires du sud de l'Indochine (About the open forests of South indochina). Bois et Forets des Tropiques 31:3-13.

Rothe, P.-L. 1947a. Foret d'Indochine (premiere partie). Bois et Forets des Tropiques 1:25-30.

Rothe, P.-L. 1947b. Foret d'Indochine. Son passe, son histoire (deuxieme partie). Bois et Forets des Tropiques 2:18-23.

Rothe, P.-L. 1947c. Foret d'Indochine. Ses possibilites son avenir (troisieme partie). Bois et Forets des Tropiques 3:17-23.

Schmid, M. 1977. Some considerations on the edaphic conditions in the tropical forest areas and their implications to land management, pp. 302-324 In Proceedings of the Symposium on Management of Forest Production in Southeast Asia. BIOTROP Special Publication No. 4, BIOTROP-SEAMEO Regional Center for Tropical Biology, Faculty of Forestry, Kasetsart University, Bangkok, Thailand.

Stuart-Fox, M. 1986. Laos: Politics, Economics and Society. Frances Pinters and Lynne Rienner Publishers, Inc., London.

Thompson, V. 1937. French Indo-China. George Allen and Unwin Ltd., London.

Tissot, R. 1959. Geographical and human aspects, pp. 9-15 In Kingdom of Laos: The Land of the Million Elephants and of the White Parasol, R. de Berval (ed.) France-Asie, Saigon.

Tixier, P. 1966. Flore et vegetation orophiles de l'Asie tropicale: les epiphytes du flanc meridional du massif sud Annamitique. Societe d'Edition d'Enseignement Superieur, Paris.

Toye, H. 1968. Laos: Buffer State or Battleground. Oxford University Press, New York.

U.S. Dept. of State. March 1991. Background Notes: Laos. Bureau of Public Affairs, U.S. Govt., Washington, DC.

United Nations Development Program. 1991. The economy of Laos: an overview, pp. 67-81 In Laos: Beyond the Revolution, J.J. Zasloff and L. Unger (eds.) St. Martin's Press, New York. 
United States Mission to Laos. November 1970. Forestry Sector Evaluation for Laos. U.S. Agency for Intemational Development, Vientiane.

Van-es-Beeck, B. 1982. Refugees from Laos, 1975-1979, pp. 324-334 In Contemporary Laos: Studies in the Politics and Society of the Lao People's Democratic Republic, M. Stuart-Fox (ed.) St. Martin's Press, New York.

Vercouttre, C. 1959. Present state of the Laotian economy, pp. 460-468 In Kingdom of Laos: The Land of the Million Elephants and of the White Parasol, R. de Berval (ed.) France-Asie, Saigon.

Vidal, J. 1956. La Vegetation du Laos. 1me partie. Le milieu. Trav. Lab. Forestier de Toulouse, Tome V. Faculte des Sciences, Toulouse.

Vidal, J. 1958. La Vegetation du Laos. 2me. partie. Groupements vegetaux et flore. Trav. Lab. Forestier de Toulouse, Tome V, Faculte des Sciences, Toulouse.

Vidal, J. 1960. Les forets du Laos (Forests of Laos). Bois et Forets des Tropiques 70:5-21.

Viphakone, Keo. 1963. Rural development in Laos, pp. 256-257 In Social Research and Problems of Rural Development in South-East Asia: Proceedings of a Seminar organized by the Viet-Namese National Commission for UNESCO (Saigon, March, 1960), Vu Quoc Thuc (ed.) UNESCO, Brussels.

Weisberg, B.(ed.) 1970. Ecocide in Indochina: The Ecology of War. Canfield Press, San Francisco, CA.

Whitaker, D.P., H.A. Barth, S.M. Berman, J.M. Heimann, J.E. MacDonald, K.W. Martindale, and Rinn-Sup Shinn. 1971. Laos: A Country Study. 2nd edition, DA Pam 550-58, Superintendent of Documents, U.S. Govt. Printing Office, Washington, DC.

Williams, L. 1965. Vegetation of Southeast Asia/Studies of Forest Types, 1963-1965. CR 49-65, U.S. Dept. of Agriculture, Agricultural Research Service, Crops Research Div., Washington, DC.

Williams, L. 1967. Forests of Southeast Asia, Puerto Rico, and Texas. U.S. Dept. of Agriculture, Agricultural Research Service, Crops Research Div./U.S. Dept. of Defense, Advanced Research Projects Agency, Washington, DC.

Zasloff, J.J. 1991. Political constraints on development in Laos, pp. 3-63 In Laos: Beyond the Revolution, J.J. Zasloff and L. Unger (eds.) St. Martin's Press, New York.

Zasloff, J.J. and L. Unger (eds.) 1991. Laos: Beyond the Revolution. St. Martin's Press, New York. 


\subsubsection{Malaysia}

Abdul Latif b. Nordin. 1968. Progress report on forest management and silviculture for the State of Selangor. Malayan For. 31:266-69.

Abdul Majid b. Haji Mohd Shahid. 1968. Report on Forest Administration in West Malaysia for the Year 1965. Jabatan Chetak Kerajaan, Johor Bahru.

Ahmad Zainal b. Mat Isa. 1982. Forest management and development strategies for Negeri Sembilan in the Eighties. Malaysian For. 45:474-84.

Aiken, S.R. and M.R. Moss. 1975. Man's impact on the tropical rainforest of Peninsular Malaysia: a review. Biological Conservation 8:213-29.

Aiken, S.R., C.H. Leigh, T.K. Leinbach, and M.R. Moss. 1982. Development and Environment in Peninsular Malaysia. McGraw-Hill Int. Book Co., Singapore.

Alexander, J.B. 1964. The evolution of land suitability maps in the Federation of Malaya. $J$. Tropical Geography 18:1-6.

Ali Yusop. 1982. The potential for forest industrial development in Sarawak in the Eighties. Malaysian For. 45:460-73.

Allbrook, R.J. 1973. The soils of Pasoh Forest Reserve, Negri Sembilan. Malaysian For. 36:22-33.

Anderson, J.A.R. 1964. The structure and development of the peat swamps of Sarawak and Brunei. J. Tropical Geography 18:7-16.

Anderson, J.A.R. 1983. The tropical peat swamps of Westem Malesia, pp. 181-99 In Mires, Swamp, Bog, Fen and Moor: Regional Studies, ed. A.J.P. Gore (ed.) Ecosystems of the World 4B, Elsevier Scientific Publ. Co., Amsterdam.

Anonymous. 1905. Forest administration in the Federated Malay States in 1904. Indian For. 31:644-47.

Anonymous. 1926. Forestry in Sarawak. Indian For. 52:163-64.

Anonymous. 1928. Forestry in Kelantan and Trengganu: A Note Prepared for the Empire Forestry Conference, Australia and New Zealand, 1928. Authority 4852/28, S.H.C. 364/28, H.M.S.O., London.

Amot, D.B. and J.S. Smith. 1937. Shifting cultivation in Brunei and Trengganu. Malayan For. 6:13-17.

Arshad Ayub. 1979. National agricultural policy and its implications on forest development in the country. Malaysian For. 42:348-53. 
Ashton, P.S. 1964. Ecological Studies in the Mixed Dipterocarp Forests of Brunei State. Oxford For. Mem. No. 25, Clarendon Press. Oxford.

Ashton, P.S. 1976. Mixed dipterocarp forest and its variation with habitat in the Malayan lowlands: a re-evaluation at Pasoh. Malaysian For. 39:56-72.

Ashton, P.S. 1978. Vegetation and soil association in tropical forests. Malayan Nafure J. 30:225-28.

Ashton, P.S. 1982. Dipterocarpaceae, pp. 237-552 In Flora Malesiana, Being an Illustrated Systematic Account of the Malaysian Flora, Including Keys for Determination, Diagnostic Descriptions, References to the Literature, Synonymy, and Distribution, and Notes on the Ecology of Its Wild and Commonly Cultivated Plants, ser. I -Spermatophyta (Flowering Plants). Vol. 9 (Systematic Revisions), Part 2, Martinus Nijhoff, The Hague.

Baharuddin b. Hj. Ghazali, and M.B. Muda. 1968. Effects of economic development on future forest management in Pahang with particular emphasis on land development. Malayan For. $31: 281-83$.

Baring-Gould, S. and C.A. Bampfylde. 1909. A History of Sarawak and Its Two White Rajahs, 1839-1908. Henry Sotheran, London.

Bamard, R.C. 1950. The elements of Malayan silviculture, 1950. Malayan For. 13:122-29.

Beccari, O. 1904. Wanderings in the Great Forests of Borneo. Travels and Researches of a Naturalist in Sarawak. Archibald Constable and Co., Ltd., London.

Beveridge, A.E. 1953. The Menchali Forest Reserve. Malayan For. 16:87-93.

Boswell, A.B.S. 1928. Forestry in Kedah and Perlis. A Statement Prepared for the British Empire Forestry Conference, Australia and New Zealand. H.M.S.O., London.

Brooke. C., Rajah. 1883. Notification of regulations for the disposal of land throughout the State of Sarawak. Sarawak Gazette (Jan. 1, 1883):4-5.

Brooke. C., Rajah. 1900. Order No. X, 1900. Regulations for squatters. Sarawak Gazette (May I, 1900):82.

Brown, S., L. Iverson, and A.E. Lugo. 1993. Land use and hiomass changes of forests in Peninsular Malaysia from 1972 to 1982: a GIS approach, pp 117-143 In Effects of Land Use Change on Atmospheric $\mathrm{CO}_{2}$ Concentrations: South and Southeast Asia as a Case Study, V.H. Dale (ed.) Springer-Verlag, New York.

Browne, F.G. 1949. Storm forest in Kelantan. Malayan For. 12:28-33.

Browne, F.G. 1952. The kerangas lands of Sarawak. Malayan For. 15:61-73. 
Browne, F.G. 1955. Forest Trees of Sarawak and Brunei. Sarawak Govt. Printer, Kuching.

Bruenig, E.F. 1963. The history of forest inventories in Sarawak. Malayan For. 26:141-59.

Bruenig, E.F. 1969. The classification of forest types in Sarawak. Malayan For. 32:143-79.

Brinig. E.F. 1970. Stand structure, physiognomy and environmental factors in some lowland forests in Sarawak. Tropical Ecology 11:26-43.

Brinig. E.F. 1971. On the ecological significance of drought in the equatorial wet evergreen (rain) forest of Sarawak (Bomeo), pp. 66-88 In The Water Relations of Malesian Forests (Transactions of the First Aberdeen-Hull Symposium on Malesian Ecology, Hull, 1970), J.R. Flenley (ed.) Miscellaneous Series No. 11, Dept. Geography, University of Hull, Hull, UK.

Brinig, E.F. 1974. Ecological Studies in the Kerangas Forests of Sarawak and Brunei. Bomeo Literature Bureau, Sarawak Forest Dept., Kuching.

Brunig, E.F. 1989. Use and misuse of tropical rain forests, pp. 611-636 In Tropical Rain Forest Ecosystems: Biogeographical and Ecological Studies, H. Lieth and M.J.A. Werger (eds.) Ecosystems of the World 14B, Elsevier, Amsterdam.

Burgess, P.F. 1968. An ecological study of the hill forests of the Malay Peninsula. Malayan For. 31:314-25.

Burgess, P.F. 1969. Ecological factors in hill and mountain forests of the states of Malaya. Malayan Nature J. 22:119-28.

Burgess, P.F. 1970. An approach towards a silvicultural system for the hill forests of the Malay Peninsula. Malayan For. 33:126-34.

Burgess, P.F. 1971. The effect of logging on hill dipterocarp forests. Malayan Nature J. 24:231-237.

Burgess, P.F. 1973. The impact of commercial forestry on the hill forests of the Malay Peninsula, In Proceedings of the Symprsium on Biological Research and National Development. Suppl. to Malayan Nature $J$.

Burgess, P.F. 1975. Silviculture in the Hill Forests of the Malay Peninsula. Research Pamphlet No. 66, Forest Research Institute, Kepong.

Bum-Murdoch, A.M. 1904. Notes from the Federated Malay States. Indian For. 30:458-63.

Cameron, W. 1885. Exploration of Pahang. J. Straits Branch Royal Asiatic Society 15:155-57.

Carrier, C.L. 1963. The illegal cultivation of forest reserve and state land in Perak. Malayan For. 26:220-25. 
Cerra, N.R. 1967. A note on the forest resources of Kota Tinggi District, Johore. Malayan For. 30:280-84.

Chad Hon-Chan. 1964. The Development of British Malaya 1896-1909. Oxford University Press. Kuala Lumpur.

Chai, P.P.K. 1974. The potential of mangrove forests in Sarawak. Malaysian For, 37:284-88.

Chà, P.P.K. 1975. Mangrove forests of Sarawak. Malaysian For. 38:108-34.

Chad, P.P.K. 1975. The mangrove trees and shrubs of Sarawak. Malaysian For. 38:187-208.

Chapman, V.J. 1977. Wet coastal formations of Indo-Malesia and Papua-New Guinea, pp. 261-70 In Wet Coastal Ecosystems, V.J. Chapman (ed.) Ecosystems of the World 1. Elsevier Scientific Publ. Co., Amsterdam.

Charter, J.R.N. 1928. Forestry in the State of Johore. A Statement Prepared for the British Empire Forestry Conference, Australia and New Zealand, 1928. Govt. Printing Office, Johore Bahru.

Cheah, L.C. 1963. A note on the forest resources of Upper Perak District in Perak. Malayan For. 26:121-24.

Child, H.J. 1896. Timbers in the Straits Settlements. Indian For. 22:408-13.

Chong Peng Wah. 1979. The growing domestic demand for timber and its influence on forest management. Malaysian For. 42:376-89.

Chong Seck-Chim. 1954. The development of Kuala Lumpur district. J. Tropical Geography 3:48-50.

Clarke, E.C. 1968. Silvicultural practice in Sarawak, 1960-68. Malayan For. 31:305-9.

Clifford, H. 1895. Report of Mr. Clifford, Acting British Resident of Pahang, on the expedition recently led into Trengganu and Kelantan on the East Coast of the Malay Peninsula. J. Malayan Branch Royal Asiatic Society 34:1-118.

Clifford, H. 1897. A joumey through the Malay States of Trengganu and Kelantan. Geographical J. 9:1-37.

Cole, R. 1959. Temiar Senoi agriculture: a note on shifting cultivation in Ulu Kelantan, Malaya. Malayan For. 22:191-207. 
Comer, E.J.H. 1951. Wayside Trees of Malaya. 2nd edition, 2 vols., Govt. Printing Office, Singapore.

Courtenay, P.P. 1980. Plantation Agriculture. Rev. edition, Gell and Hyman, London.

Cousens, J.E. 1951. Some notes on the composition of lowland tropical rain forest in Rengam Forest Reserve, Johore. Malayan For. 14:131-39.

Cousens, J.E. 1958. A study of 155 acres of tropical rain forest by complete enumeration of all large trees. Malayan For. 21:155-63.

Cousens, J.E. 1965. Some reflections on the nature of Malayan lowland rainforest. Malayan For. 28:122-28.

Crowther, J. 1982. Ecological observation in a tropical karst terrain, West Malaysia. I. Variations in topography, soils and vegetation. J. Biogeography 9:65-78.

Cubitt, G.E.S. 1920. Forestry in the Malay Peninsula. A Statement Prepared for the British Empire Forestry Conference, London, 1920. Federated Malay States Govt. Printing Office, Kuala Lumpur.

Cubitt, O.E.S. 1924. Forestry in the Malay Peninsula. A Statement Prepared for the British Empire Forestry Conference, Canada, 1923. Federated Malay States Govt. Printing Office, Kuala Lumpur.

Cubitt, G.E.S. and J.G. Watson. 1928. Forestry in the Federated Malay States and Straits Settlements. A Statement Prepared for the British Empire Forestry Conference, Australia and New Zealand, 1928. Federated Malay States Govt. Printing Office, Kuala Lumpur.

Daly, D.D. 1882. Surveys and explorations in the Native States of the Malayan Peninsula, 1875-82. Proceedings of the Royal Geographical Society 4:393-412.

Daniel, J.G. and A. Kulsingam. 1974. Problems arising from large scale forest clearing for agricultural use - the Malaysian experience. Malaysian For. 37:152-60.

Dan Juat Mei. 1977. The prospects of log importation for industrial expansion in Peninsular Malaysia. Malaysian For. 40:85-89.

Davidson, W. 1889. Joumal of a trip to Pahang with H.E. the Govemor. J. Straits Branch Royal Asiatic Society 20:83-90.

Davison, G.W.H. 1982. How much forest is there? Malayan Naturalist 35 (1-2):11-12.

Desch, H.E. 1939. The forests of the Malay Peninsula and their exploitation. Malayan For. 7:169-80. 
Desch, H.E. 1941. The contribution of tropical forests to war economy. Malayan For. 10:123-30.

Devendra, C., Syed Ali b. Syed Abu Bakar, T. Mahendranathan and Encik Lee Chan Lui. 1976. Agriculture in Malaysia, Part I Livestock. Agric. Inst. Malaysia, Kuala Lumpur.

Dew, A.T. 1887. Exploring expedition from Selama, Perak, over the mountains to Pong, Patani, in Nuvember of 1883. J. Straits Branch Royal Asiatic Society 19:111-23.

Dobby, E.H.O. 1939. Settlement and land utilization, Malacca. Geographical J. 94:464-80.

Dobby, E.H.G. 1942. Settlement pattems in Malaya. Geographical Review 32:211-32.

Dobby, E.H.G. 1953. Malaya: rubber and rice. Current History 25:295-300.

Dobby, E.H.G. 1954. Malaya's rice problem. Pacific Affairs 27:58-60.

Dobby, E.H.G. 1955a. Field-studies in the padi-lands of Malaya. Malayan J. Trop. Geog. 6:1-94.

Dobby, E.H.G. 1955b. Padi landscapes of Malaya. Malayan J. Tropical Geography 6:1-95, with atlas.

Donaldson, R.D. 1968. The Present Land Use of Malacca. Land Use Section, Soil Sci. Div., Res. Branch, Div. Agric. and Co-operatives Malaysia, Kuala Lumpur.

Donaldson, R.D. and Siew Kam Yew. 1968. The Present Land Use of Negri Sembilan. Land Use Section, Soil Sci. Div., Res. Branch, Div. Agric. and Co-operatives Malaysia, Kuala Lumpur.

Durant, C.L. 1939. A note on the coastal forests of Kelantan. Malayan For. 8:50-52.

Durgnat, P.A. 1952. Swamp forests in Lower Perak. Malayan For. 15:127-31.

Edwards, J.P. 1951. Forestry in Malaya. Malayan For. 14:33-35.

Edwards, J.P. 1952. Report on Federal Forest Administration in the Federation of Malaya for the Year 1950. Govt. Press, Kuala Lumpur.

Ewel, J.J., Paul Chai, and Lim Meng Tsai. 1983. Biomass and floristics of three young second-growth forests in Sarawak. Malaysian For. 46:347-64.

Federated Malay States. 1898-1919. Annual Report of the Federated Malay States (annual 18961919). British Sessional Papers, H.M.S.O., London. 
Federated Malay States Census Office. 1922. The Census of British Malaya (the Straits Settlements, Federated Malay State and Protected States of Johore, Kedah, Perlis, Kelantan, Trengganu, and Brunei) 1921. Waterlow, London.

Federated Malay States Dept. of Agriculture. 1921. The Agricultural Bulletin of the Federated Malay States. Vol. 9, Fed. Malay States Dept. Agric., Kuala Lumpur.

Federated Malay States Forest Dept. 1919. Report on Forest Administration for the Year 1918. Fed. Malay States Govt. Press, Kuala Lumpur.

Federated Malay States Forest Dept. 1936-1941. Report on Forest Administration in Malaya, Including Brunel, for the Year 1935-1940. Fed. Malay States Govt. Press, Kuala Lumpur.

Federated Malay States Superintendent of the Census. 1932. A Report of the 1931 Malayan Census. Crown Agents for the Colonies, London.

Firth, R. 1943. The coastal people of Kelantan and Trengganu, Malaya. Geograp.ical J. 101:193-205.

Fong Foo-Woon. 1982. Nypa swamps in Peninsular Malaysia, pp. 31-38 In Wetlands Ecology and Management: Proceedings of the First International Wetlands Conference (New Delhi, September, 1980). National Institute of Ecology and Intemational Scientific Publications, Jaipur.

Fox, J.E.D. 1978. The natural vegetation of Sabah, Malaysia. I: The physical environment and classification. Trop. Ecol. 19:218-239.

Foxworthy, F.W. and D.M. Matthews. 1927. Mangrove and Nipah Swamps of British North Borneo. Brit. Govt. North Bomeo Dept. Forestry Bull. No. 3, Govt. Printing Office, B.N.B., Jesselton.

Freeman, J.D. 1955. Iban Agriculture. Colonial Research Studies No. 15, H.M.S.O., London.

Freeman, J.D. 1970. Report on the Iban. London School of Econ. Mon., Social Anthropology No. 41.

Fyfe, A.J. 1964. Forestry in Sabah. Malayan For. 27:82-95.

Garfitt, J.E. 1941. Malayan forest types. Malayan For. 10:136-40.

Geddes, W.R. 1954. The Land Dayaks of Sarawak. Colonial Research Studies No. 14, H.M.S.O., London.

Gillis, M. 1988. Malaysia: public policies and the tropical forest, pp. 115-164 In Public Policies and the Misuse of Forest Resources, R. Repetto and M. Gillis (eds.) Cambridge University Press, Cambridge, MA.

Grant, J.S. 1958. The aborigines of Sarawak. Malayan For. 21:245-50. 
Great Britain Colonial Office. 1934-1955. Economic Survey of the Colonial Empire, 1932, 1933, 1935, 1937, 1951. H.M.S.O., London.

Great Britain Colonial Office. 1953-1963. Sarawak Annual Report, 1951, 1952, $1958,1962$. H.M.S.O., London.

Greenwood, J.M.F. 1964. Rubber-smaltholdings in the Federation of Malaya. J. Tropical Geography 18:81-100.

Grist, D.H. 1932. Malayan Agricultural Statistics 1931. Bulletins, Economic Series No. 1, Straits Settlements and Federated Malay States, Kuala Lumpur.

Grist, D.H. 1933. Nationality of Ownership and Nature of Constitution of Rubber Estates in Malaya. 1933 Economic Series No. 2, Dept. of Agriculture, Straits Settlements and Federated Malay States, Caxton Press, Kuala Lumpur.

Grist, D.H. 1936. An Outline of Malayan Agriculture. Malayan Planting Manual No. 2, Dept. Agric., Straits Settlements and Federated Malay States, Kuala Lumpur.

Gurmit Singh, K.S. 1981. Destroying Malaysian forests, pp. 181-190 In Where Have All the Flowers Gone? Deforestation in the Third World, V.H. Sutlive, N. Altshuler, and M.D. Zamora (eds.) Studies in Third World Societies, Publ. No. 13, Dept. Anthropology, College of William and Mary, Williamsburg, VA.

Harris, G. L. 1956. North Borneo, Brunei, Sarawak. Human Relations Area Files, New Haven, CT.

Hatch, T. 1982. Shifting Cultivation in Sarawak -A Review. Technical Paper No. 8, Soils Div., Res. Branch, Sarawak Dept. of Agriculture, Kuching.

Heaslett, E.A. 1970. Gunong Chabang Tiga: a note on a small area of montane ericaceous forest in Johore. Malayan Nature J. 23:149-54.

Heath, R.G. 1951. Malayan Agricultural Statistics 1949. Bulletins, Economic Series No. 15, Div. Agriculture, Federation of Malaya, Kuala Lumpur.

Hervey, D.F.A. 1879. A trip to Gunong Blumet. J. Straits Branch Royal Asiatic Society 3:85-115.

Hill, R.D. 1967. Agricultural land tenure in West Malaysia. Malayan Economic Review 12:99-116.

Hill, R.D. 1977. Rice in Malaya: A Study in Historical Geography. Oxford University Press, Kuala Lumpur.

Hill, R.D. 1982. Agriculture in the Malaysian Region. Akademi Kiado, Budapest.

Hodgson, D.H. 1939. Working-plans in Malaya. Malayan For. 8:149-54.

Ho, R. 1962. Mixed-farming and multiple-cropping in Malaya. J. Tropical Geography 16:1-17. 
Ho, R. 1965. Land settlement projects in Malaya: an assessment of the role of the Federal Land Development Authority. J. Tropical Geography 20:1-15.

Ho, R. 1968. The evolution of agriculture and land ownership in Saiong Mukim. Malayan Economic Review 13:81-102.

Holbrook, N.M. and F.E. Putz. 1982. Vegetative seaward expansion of Sonneratia alba trees in a Malaysian mangrove forest. Malaysian For. 45:278-81.

Holttum, R.E. 1954. Plant Life in Malaya. Longmans, Green and Co., London.

Homaday, W.T. 1879. Account of a naturalist's visit to the territory of Selangor. J. Straits Branch Royal Asiatic Society 3:124-31.

Hurst, P. 1986. The logger first in first out. SUARA SAM 3(3):8-9.

Ismail b. Haji Ali. 1965. The impact of land development on forest reservation and management in Selangor. Malayan For. 28:264-70.

Jackson, J.C. 1968. Planters and Speculators. University Malaya Press, Kuala Lumpur.

Jackson, J.C. 1968. Sarawak: A Geographic Survey of a Developing State. University Lnndon Press Lid., London

Jacobs, M. 1974. Botanical panorama of the Malesian Archipelago (vascular plants), pp. 263-94 In Natural Resources of Humid Tropical Asia. Natural Resources Research 12, UNESCO, Paris.

John, D.W. 1974. The timber industry and forest administration in Sabah under Chartered Company rule. J. Southeast Asian Stud. 5:55-81.

Johnson, A. 1969. A forest quadrat in the national park: the flora other than trees. Malayan Nature J. 22:152-58.

Johore. 1916-1919. Annual Report of the General Adviser to the Govt. of Johore. 1915-1918. Federated Malay States Govt. Printing Office, Kuala Lumpur. Republished as Papers by Command in Great Britain, Parliament, House of Commons, British Sessional Papers, H.M.S.O., London.

Jones, L.W. 1953. North Borneo Report on the Census of Population held on 4th June, 1951. Crown Agents for the Colonies, London.

Jones, L.W. 1962a. Colony of North Borneo. Report on the Census of Population taken on 10th August 1960. Govt. Printing Office, Kuching.

Jones, L.W. 1962b. Colony of Sarawak. Report on the Census of Population taken on 15th June 1960. Govt. Printing Office, Kuching. 
Jones, L.W. 1966. The Population of Borneo: A Study of the Peoples of Sarawak, Sabah and Brunei. University of London, The Athlone Press, London.

Joseph, K.T. 1964. Sedentary soils of Kedah and their suggested utilization. J. Tropical Geography 18:101-10.

Kato, R., Y. Tadaki, and H. Ogawa. 1978. Plant biomass and growth increment studies in Pasoh Forest. Malayan Nature J. 30:211-24.

Kedah. 1910-1920. Annual Report of the Adviser to the Kedah Government for the Year, 1909-1919. Federated Malay States Govt. Printing Office, Kuala Lumpur. Republished as Papers by Command in Great Britain, Parliament, House of Commons, British Sessional Papers, H.M.S.O., London.

Kelantan. 1912-1941. Administrative Report for the Year, 1910-1939. Malaya Publ. House, Singapore. Republished as Colonial Office Papers in Great Britain, Parliament, House of Commons, British Sessional Papers, H.M.S.O., London.

Kelsall, H.J. and H.N. Ridley. 1891. Account of a trip up the Pahang, Tembeling, and Tahan Rivers, and an attempt to reach Gunong Tahan. J. Straits Branch of the Royal Asiatic Society 23:33-56.

Kira, T. 1978. Community architecture and organic matter dynamics in tropical lowland rain forests of Southeast Asia with special feference to Pasoh Forest, West Malaysia, pp. 561-90 In Tropical Trees as Living Systems: The Proceedings of the Fourth Cabot Symposium Held at Harvard Forest (Petersham, MA, April, 1976), P.B. Tomlinson and M.H. Zimmermann (eds.) Cambridge University Press, Cambridge, MA.

Kirby, S.W. 1928. Johore in 1926. Geographical J. 71:238-60.

Kochummen, K.M. 1966. Natural plant succession after farming in Sg. Kroh. Malayan For. 29:170-81.

Kochummen, K.M. and F.S.P. Ng. 1977. Natural plant succession after farming in Kepong. Malaysian For. 40:61-78.

Kumar, R. 1986. The Forest Resources of Malaysia: Their Economics and Development. Oxford University Press, Oxford.

Lai, K.K. and H.S. Lee. 1977. The potential of agro-forestry in Sarawak and its socio-economic implications, pp. 337-50 In Sixth Malaysian Forestry Conference 1976 Proceedings. Vol. 1, Forest Dept., Sarawak, Kuching.

Lake, H.W. and H.J. Kelsall. 1894. A journey on the Sembrong River. J. of the Straits Branch of the Royal Asiatic Society 26:1-15. 
Lall Singh Gill and Dato Wan Hassan b. Adbul Halim. 1968. Some problems of natural regeneration establishment in the hill dipterocarp corests of Perak. Malayan For. 31:297-304.

Landon, F.H. 1948. Mangrove volume tables for Matang Mangroves in Perak. Malayan For. 11:117-20.

Landon, F.H. 1955. Malayan tropical rain forest. Malayan For. 18:30-38.

Latiff, A. 1982. Notes on the vegetation and flora of Pulau Pemanggil. Malayan Nature J. 35:217-23.

Lau Buong Tiing. 1974. Mixed hardwood forests and the continuity of timber supply in Central Sarawak. Malaysian For. 37:233-40.

Lau Buong Tiing. 1978. Forest resources of Sarawak. Malaysian For. 41:99-103.

Lau Buong Tiing. 1979. The effects of shifting cultivation on sustained yield management for Sarawak National Forests. Malaysian For. 42:418-422.

Leamy, M.L. and W.P. Panton. 1966. Soil Survey Manual for Malayan Conditions. Bulletin No. 119, Malaysia Div. of Agriculture, Ministry of Agriculture and Co-operatives, Kuala Lumpur.

Leech, H.W.C. 1879. About Kinta. J. Straits Branch Royal Asiatic Society 4:21-33.

Leech, H.W.C. 1879. About Slim and Bemam. J. Straits Branch Royal Asiatic Society 4:34-45.

Lee Hua Seng. 1972. The role of silviculture in the management of the peat swamp reserves in Sarawak. Malayan For. 35:260-68.

Lee Hua Seng. 1977. Manipulation and regeneration of the mixed swamp forest in Sarawak. Malayan Nature J. 31:1-9.

Lee Hua Seng. 1982. The development of silvicultural systems in the hill forests of Malaysia. Malaysian For. 45:1-20.

Lee Peng Choong. 1966. The use of aerial photographic interpretation in forest ecology and forest inventory in Malaya. Malayan For. 29:276-81.

Lee Peng Choong. 1973. Multi-use management of West Malaysia's forest resources, pp. 93-101 In Proceedings of the Symposium on Biological Research and National Development. Suppl. to Malayan Nature J.

Lee Peng Choong. 1981. Forest classification in Malaysia, pp. 186-96 In Assessing Tropical Forest Lands, their Suitability for Sustainable Uses: Proceedings of the Conference on Forest Land Assessment and Management for Sustainable Uses (Honolulu, HI, June, 1979), R.A. Carpenter (ed.) International Publ., Ltd., Dublin. 
Lee Yong Leng. 1961. Some aspects of shifting cultivation in British Bomeo. Malayan For. 24:102-110.

Lee Yong Leng. 1965. Agriculture in Sarawak. J. Trop. Geog. 21:21-29.

Lee Yong Leng. 1965. North Borneo (Sabah): A Study in Settlement Geography. Eastem Universities Press, Singapore.

Lee Yong Leng. 1968. Land use in Sarawak. Sarawak Museum J. 16:282-308.

Lee Yong Leng. 1970. Population and Settlement in Sarawak. Donald Moore for Asia Pacific Press, Ltd., Singapore.

Leo Chai and Lee Hua Seng. 1971. The alan (Shorea albida) resources, their properties and utilization. Malayan For. 34:20-35.

Leo Chai. 1979. Forest resource base, policy and legislation of Sarawak. Malaysian For. 42:311-27.

Leong Hing Nin. 1975. Long-term effects of logging in Peninsular Malaysia, pp. 43-55 In Proceedings of a Symposium on the Long-Term Effects of Logging in Southeast Asia (Darmaga, Bogor, Indonesia, June 24-27, 1975), Rahardjo S. Suparto (ed.) BIOTROP Special Publication No. 3, BIOTROP-SEAMEO Regional Center for Tropical Biology, Bogor.

Lim, David D.D. 1973. Economic Growth and Development in West Malaysia: 1947-1970. Oxford University Press, Kuala Lumpur.

Lim Teck Ghee. 1977. Peasants and Their Agricultural Economy in Colonial Malaya 1874-1941. Oxford University Press, Kuala Lumpur.

Lockman b. M. Sirin. 1969. Sustained yield management in West Malaysia. Malayan For. 32:245-51.

MacAndrews, Colin. 1977. Mobility and Modernization: The Federal Land Development Authority and Its Role in Modernizing the Rural Malay. Gadjah Mada University Press, Yogyakarta.

Malaya (Federation) Superintendent of the Census. 1947. A Report on the 1947 Census of Population, Comprising the Federation of Malaya and the Colony of Singapore. Crown Agents for the Colonies, London.

Malaya (Federation). 1950. Draft Development Plan of the Federation of Malaya. Govt. Press, Kuala Lumpur.

Malaya (Federation). 1953. Progress Report on the Development Plan of the Federation of Malaya, 1950-52. Govt. Press, Kuala Lumpur. 
Malaya (Federation). 1953. Malaya Land Utilization Map. Scale 1:760,320. Survey Dept., Federation of Malaya, Kuala Lumpur.

Malaya (Federation). 1954. Malayan Statistics. Govt. Printer, Singapore.

Malaya (Federation) Dept. of Statistics. 1958. Population Census of the Federation of Malaya, 1957. Report No. 1 (Distribution of Population), Govt. Printer, Kuala Lumpur.

Malaya (Federation) Div. of Agriculture. 1962. List of publications of the Dept. of Agriculture, Federation of Malaya, pp. 126-139 In Ministry of Agriculture and Cooperatives, Division of Agriculture, Publications. Div. of Agriculture, Federation of Malaya, Kuala Lumpur.

Malaya (Federation) Forest Dept. 1949. Report on Federal Forest Administration in the Federation of Malaya for the Year 1948. Govt. Press, Kuala Lumpur.

Malaya (Federation) Forest Dept. 1953. Report on Federal Forest Administration in the Federation of Malaya for the Year, 1949-1952. Govt. Press, Kuala Lumpur.

Malaya (Federation) Forest Dept. 1962. Federation of Malaya Report on Forest Administation for the Year, 1960-1962. Penchetak Kerajaan, Kuala Lumpur.

Malaya (Federation) Ministry for Natural Resources and Local Govt. 1955. First Quinquennial Bulletin of Statistics 1951-1955. Govt. Printer, Kuala Lumpur.

Malaya (Federation) Ministry for Natural Resources and Local Govt. 1962. 1961 Annual Supplement to the Second Quinquennial Bulletin. Govt. Printer, Kuala Lumpur.

Malaya (Federation) Ministry of Agriculture and Co-operatives. 1961-1963. Census of Agriculture, 1960. Preliminary Reports: No. 6, Farms Reporting Rubberland; No.6A, Rubberland Area and Production; No. 7, Coconuts; No. 8, Land Use and Tenure of Farms; No. 9, Temporary Crops Area and Production; No. 10, Permanent Crops, Compact Areas, and Scattered Trees; No. 12, Farm Labor; No. 13, Usage of Irrigation, Fertilisers and Chemicals; No. 14, Govt. Farms; No. 15, Estates. Commissioner for Agriculture Census, Kuala Lumpur.

Malaya (Federation) Ministry of Agriculture and Co-operatives. 1962. Census of Agriculture, Federation of Malaya, 1960. Administrative Report 2, Census Documents, Ministry of Agriculture and Cooperatives, Kuala Lumpur.

Malayan Union Forest Dept. 1948. Report on Forest Administration in the Malayan Union for the Year 1946, 1947. Govt. Press, Kuala Lumpur.

Malay States (Federated). 1911. The Chief Secretary's Report for the Year 1910. Crown Agents for the Colonies, London.

Malay States (Federated). 1921-1925. Report of the Chief Secretary for the Year, 1920-1924. Federated Malay States Printing Office, Kuala Lumpur. 
Malay States (Federated) Dept. of Agriculture. 1939. Reports of the Field Branch for the Year 1938. Charles Grenier and Son, Ltd., Kuala Lumpur.

Malaysia. 1971. Second Malaysia Plan, 1971-75. Govt. Press, Kuala Lumpur.

Malaysia Barat Chawangan Ekonomi and Perangkaan (West Malaysia Economics and Statistics Section). 1970. Rumusan Perangkaan (Statistical Digest) 1970. Kementerian Pertanian Dan Perikanan Malaysia Barat, Kuala Lumpur.

Malaysia Forest Dept. 1968. Report on Forest Administration in West Malaysia for the Year 1965. Oleh Mohktar b. Haji Shamsuddin, Penguasa, Johor Bahru.

Malaysia Jabatan Perangkaan (Dept. Statistics). 1965. Annual Bulletin of Statistics Malaysia 1964. Dept. of Statistics, Kuala Lumpur.

Malaysia Jabatan Perangkaan (Dept. Statistics). 1969. Statistical Handbook of Sabah 1968. Dept. of Statistics, Kuala Lumpur.

Malaysia Jabatan Perangkaan (Dept. Statistics). 1971-1973. Banchi Pendudok Dan Perumahan Malaysia, 1970 (1970 Population and Housing Census of Malaysia). Vol. 1, Parts 1-3, 5, 6, 8, 9, 13. Jabatan Perangkaan Malaysia, Kuala Lumpur.

Malaysia Jabatan Perangkaan (Dept. Statistics). 1971. Banchi Pendudok Dan Perumahan Malaysia 1970. Rengkasan Kiraan Luar. (1970 Population and Housing Census of Malaysia. Field Count Summary). Jabatan Perangkaan Malaysia, Kuala Lumpur.

Malaysia Jabatan Perangkaan (Dept. Statistics). 1971. Bilangan Dan Keluasan Lot Dan Hakmilek Kebun Kechil (Dengan Butir Tambahan Fada Lot Estet Lombon, dll.) (Number and Area of Smallholding Lots and Titles (Within Additional Particulars on Lots Under Estates, Mines, etc.)). Jabatan Perangkaan Malaysia, Kuala Lumpur.

Malaysia Jabatan Perangkaan (Dept. Statistics). 1971. Siaran Perangkaan Tahunan (Annual Statistical Bulletin) Malaysia 1970. Jabatan Perangkaan Malaysia, Kuala Lumpur.

Malaysia Jabatan Perangkaan (Dept. Statistics). 1974. Buku Maklumat Perangkaan (Statistical Handbook) Sabah 1973. Jabatan Perangkaan, Kota Kinabalu.

Malaysia Jabatan Perangkaan (Dept. Statistics). 1979. Perangkaan Penting, Semenanjung Malaysia (Vital Statistics, Peninsular Malaysia). Jabatan Perangkaan, Kuala Lumpur.

Malaysia Jabatan Perangkaan (Dept. Statistics). 1980. Siaran Perangkaan Tahunan (Annual Statistical Bulletin) Malaysia 1979. Jabatan Perangkaan Malaysia, Kuala Lumpur.

Malaysia Jabatan Perangkaan (Dept. Statistics). 1981. Siaran Perangkaan Tahunan (Annual Bulletin of Statistics) Sabah 1980. Jabatan Perangkaan, Kota Kinabalu. 
Malaysia Jabatan Perangkaan (Dept. Statistics). 1981. Siaran Perangkaan Tahunan (Annual Statistical Bulletin) Sarawak 1980. Jabatan Perangkaan Malaysia, Kuching.

Malaysia Jabatan Perangkaan (Dept. Statistics). 1987. Buku Tahunan Perangkaan Malaysia (Yearbook of Statistics Malaysia) 1986. Jabatan Perangkaan Malaysia, Kuala Lumpur.

Malaysia Jabatan Pertanian (Dept. Agriculture). 1983. Perangknan Pertanian Sarawak, 1982 (Agricultural Statistics of Sarawak, 1982). Dept. of Agriculture, State of Sarawak, Kuching.

Malaysia Jabatan Pertanian (Dept. Agriculture). 1983. Perangkaan Pertanian Sarawak 1983 (Agricultural Statistics of Sarawak, 1983). Jabatan Pertanian Negeri Sarawak, Kuching.

Malaysia Kementerian Hal Ehwal Tanah dan Galian (Dept. Forestry). 1969. Penyata Tahunan Perhutanan di-Malaysia Barat Tahun 1966 (Annual Report on Forest Administration in West Malaysia for the Year 1966). Jabatan Chetak Kerajaan, Kuala Lumpur.

Malaysia Kementerian Hal Ehwal Tanah dan Galian (Dept. Forestry). 1972-1974. Penyata Tahunan Perhutanan Di-Malaysia Barat (Annual Report of the Forest Administration in West Malaysia) 1968; 1969; 1970. Oleh Mohd, Daud b. Abdul Rahman, Pencetak Kerajaan, Kuala Lumpur.

Malaysia Kementerian Hal Ehwal Tanah dan Galian (Dept. Forestry). 1972. Penyata Tahunan Perhutanan Semenanjung Malaysia Tahun 1971 (Annual Report on Forestry in Peninsular Malaysia, 1971). Ibrahim b. Johari, P.I.S., Timbalan Ketua Pengarah Percetakan, Kuala Lumpur.

Malaysia Kementerian Pertanian Dan Perikanan (Ministry of Agriculture and Fisheries). 1972. Malaysia Barat Rumusan Perangkaan 1970 (West Malaysia Statistical Digest, 1970). Chawangan Ekonomi and Perangkaan (Economics and Statistics Section), Kuala Lumpur.

Malaysia Kementerian Pertanian (Ministry of Agriculture). 1971. Perangkaan Pertanian Sarawak (Agricultural Statistics of Sarawak, 1970). Dept. of Statistics, State of Sarawak, Kuching.

Malaysia Kementerian Pertanian (Ministry of Agriculture). 1981. Buku Maklumat Perangkaan Pertanian (Statistical Handbook of Agriculture, 1981). Kementerian Pertanian, Kuala Lumpur.

Malaysia Kementerian Pertanian (Ministry of Agriculture) 1985. Buku Maklumat Perangkaan Pertanian, Edisi Pindaan (Statistical Handbook of Agriculture). Rev. edition, Kementerian Pertanian Malaysia, Kuala Lumpur.

Malaysia Kementerian Pertanian dan Tanah. 1981. Penyata Tahunan Perhutanan Semenanjung Malaysia Tahun 1979 (Annual Report on Forest Administration in Peninsular Malaysia for the Year 1979). Kementerian Perusahaan Utama, Kuala Lumpur.

Malaysia, State of Sarawak Dept. of Statistics. 1965. Annual Bulletin of Statistics: State of Sarawak 1964. Dept. of Statistics, State of Sarawak, Kuching. 
Malaysia, State of Sarawak Dept. of Statistics. 1971. Annual Bulletin of Statistics: State of Sarawak 1970. Dept. of Statistics, State of Sarawak, Kuching.

Malaysia, State of Sarawak Forest Dept. 1971, 1972, 1981-1984. Annual Report of the Forest Dept., Sarawak, 1970, 1971, 1980-1983. Govt. Printer, Kuching.

Marshall, C. 1952. Land Use and Abuse in Malaya. Malayan For. 15:132-36.

Marshall, C. 1954. Selangor! What of the Future? Malayan For. 17:50-63.

McEwan, R.J. 1970. Notes on the ramin timber industry of Sarawak with particular reference to the Third Division. Malayan For. 33:328-33.

Mead, J.P. 1919. Forest reservation in Sarawak. Sarawak Gazette (December):307-309.

Meijer, W. 1973. Devastation and regeneration of lowland dipterocarp forests in Southeast Asia. Bioscience 23:528-33.

Menon, K.P.V. 1976. History and Development of Forestry and Forest Industries in Malaysia (A Bibliography). F.R.I. Bibliographies No. 4, Forest Res. Inst. Kepong, Selangor.

Mitchell, B.A. 1957. Malayan tin tailings —prospects of rehabilitation. Malayan For. 20:181-86.

Mitchell, B.A. 1963. Forestry and tanah beris. Malayan For. 26:158-70.

Mitchell, B.A. 1964. Periodical cropping of Imperata cylindrica for paper pulp. Malayan For. 27:22-45.

Mohd Alwy b. Haji Suleiman. 1962. Federation of Malaya Report on Forest Administration for the Year 1960. Jabatan Chetak Kerajaan, Kuala Lumpur.

Mohd Basri Hamzah, Kamis Awang and Rusli Mohd. 1983. Issues in Malaysian forestry. Malaysian For. 46:409-24.

Mohd Darus b. Haji Mahmud. 1978. Forest resources of Peninsular Malaysia. Malaysian For. 41:82-93.

Mohd Darus b. Haji Mahmud. 1979. Forest resource base, policy and legislation of Peninsular Malaysia. Malaysian For. 42:328-47.

Mohd Tamin b. Yeop, Aminuddin b. Yusoff, and Tan Swee Lian. 1982. A Special Report on Agricultural Land Use in Peninsular Malaysia. Publications Branch, MARDI, Kuala Lumpur.

Mok, S.T. 1966. A note on the forest resources of Mersing District. Malayan For. 29:102-5.

Mok, S.T. 1966. A note on the forest resources of North Pekan District. Malayan For. 29:26-29. 
Mok, S.T. 1966. A note on the forest resources of South Pekan District. Malayan For. 29:106-11.

Mok, S.T. 1966. A note on the forest resources of Temerloh District. Malayan For. 29:204-8.

Mok, S.T. 1966. Practical aspects of the current forest resources reconnaissance survey. Malayan For. 29:56-63.

Mok, S.T. 1967. A note on the forest resources of Kuantan District. Malayan For. 30:217-21.

Mok, S.T. 1970. Prospects for fuller utilization of Johor's forest resources. Malayan For. 33:356-73.

Mok, S.T. 1984. Forest land use with particular reference to Peninsular Malaysia, pp. 314-329 In Proceedings of the First ASEAN Forestry Congress (Manila, October, 1983). Vol. 2, The Congress Organizing Committee, Bureau of Forest Development, Quezon City.

Morris, H.S. 1953. Report on a Melanau Sago Producing Community in Sarawak. Colonial Research Studies No. 9, H.M.S.O., London.

Moss, M.R. 1981a. An evaluation of some existing biophysical land classification schemes in the context of the FELDA land developments in Malaysia, pp. 197-201 In Assessing Tropical Forest Lands, their Suitability for Sustainable Uses: Proceedings of the Conference on Forest Land Assessment and Management for Sustainable Uses (Honolulu, HI, June, 1979), R.A. Carpenter (ed.) Tycooly Inter. Publ., Ltd., Dublin.

Moss, M.R. 1981b. A process approach to biophysical land classification: some applications to Peninsular Malaysia, pp. 202-207 In Assessing Tropical Forest Lands, their Suitability for Sustainable Uses: Proceedings of the Conference on Forest Land Assessment and Management for Sustainable Uses (Honolulu, HI, June, 1979), R.A. Carpenter (ed.) Tycooly Inter. Publ., Ltd., Dublin.

Murthy, L.S.V. and J. Yong. 1968. Assessment of growing stock in mixed dipterocarp forests of Sarawak. Malayan For. 31:275-80.

Negri Sembilan. 1888-1904. Annual Report, 1887-1902. Published as Papers by Command in Great Britain, Parliament, House of Commons, British Sessional Papers, H.M.S.O., London.

Nieuwolt, S. 1984. The Water balance and agricultural land use in Peninsular Malaysia, pp. 255-74 In Climate and Agricultural Land Use in Monsoon Asia, Masatoshi M. Yoshino (ed.) University of Tokyo Press, Tokyo.

Noakes, D.S.P. 1950. The mangrove charcoal industry of Matang. Malayan For. 13:80-83.

Noakes, D.S.P. 1951. Notes on the silviculture of the mangrove forests of Matang, Perak. Malayan For. 14:183-96. 
Noakes, D.S.P. 1952. A Working Plan of the Matang Mangrove Forest Reserve, Perak. Federation of Malaya Forest Dept., Kuala Lumpur.

Noakes, D.S.P. 1955. Methods of increasing growth and obtaining natural regeneration of the mangrove type in Malaya. Malayan For. 18:23-30.

Noakes, J.L. 1950. Sarawak and Brunei (the Colony of Sarawak and the British Protected State of Brunei), A Report on the 1947 Population Census. Govt. Printing Office. Kuching.

North Bomeo (Colony). 1909. Administration Report for the Year 1908. Microfilm C.0. 648/1. Great Britain Colonial Office, London.

North Bomeo (Colony). 1950. Colony of North Borneo Annual Report 1948. H.M.S.O., London.

North Bomeo (Colony). 1963. Colony of North Borneo Annual Report 1962. H.M.S.O., London.

North Bomeo Agriculture Dept. 1920. Annual Report on Agriculture for 1920. Microfilm C.0. 648/9, Great Britain Colonial Office, London.

North Bomeo Forest Dept. 1953. Annual Report of the Forest Dept. for the Year 1952. Govt. Printer, Jesselton.

North Bomeo Forest Dept. 1963. Annual Report of the Forest Dept. for the Year 1962. Govt. Printer, Jesselton.

North Bomeo Forestry Dept. 1917. Annual Report on the Forestry Dept. for the Year 1916. Microfilm C.O. 648/7, Great Britain Colonial Office, London.

Ooi Jin-Bee. 1960. The nature and distribution of the natural vegetation of Malaya. Pacific Viewpoint 1:183-204.

Ooi Jin-Bee. 1963. Land, People and Economy in Malaya. Longmans, Green and Co., London.

Ooi Jin-bee. 1976. Peninsular Malaysia. Longman, London.

Ormsby-Gore, W.G.A. 1928. Report by the Right Honourable W.G.A. Ormsby-Gore, M.P. (Parliamentary Under-Secretary of State for the Colonies) on his Visit to Malaya, Ceylon, and Java during the Year 1928. Cmd. 3258, Brit. Parl. Sessional Papers, H.M.S.O., London.

Padoch, C. 1982. Migration and Its Alternatives Among the Iban of Sarawak. Verhandelingen van het Koninklijk Instituut voor Taal- Land-end Volkenkunde 98, Martinus Nijhoff, The Hague.

Pahang. 1890-1908. Annual Report of the State of Pahang, 1889-1906. Published as Papers by Command in Great Britain, Parliament, House of Commons, British Sessional Papers, H.M.S.O., London.

Panton, W.P. 1964. The 1962 soil map of Malaya. J. Tropical Geography 18:118-24. 
Perak. 1877-1907. Administration Report for the State of Perak, 1876-1906. Published as Papers by Command in Great Britain, Parliament, House of Commons, British Sessional Papers, H.M.S.O., London.

Perlis. 1910-1920. Annual Report of the Adviser to the Perlis Govt., 1909-1919. Federated Malay States Govt. Printing Office, Kuala Lumpur. Republished as Papers by Command in Oreat Britain, Parliament, House of Commons, British Sessional Papers, H.M.S.O., London.

Poore, M.E.D. 1968. Studies in a Malaysian rain forest. I. The forest on Triassic sediments in Jengka Forest Reserve. J. Ecology 56:143-96.

Pringle, R. 1970. Rajahs and Rebels: The Ibans of Sarawak under Brooke Rule, 1841-1941. Comell University Press, lthaca. NY.

Proctor, J., J.M. Anderson, P. Chai, and H.W. Vallack. Ecological studies in four contrasting lowland rain forests in Gunung Mulu National Park, Sarawak. I. Forest environment, structure and floristics. J. of Ecology 7:237-60.

Proctor, J., J.M. Anderson, and H.W. Vallack. 1983. Comparative studies on forests, soils and litterfall at four altitudes on Gunung Mulu, Sarawak. Malaysian For. 46:60-75.

Ridley, H.N. 1892. Expedition to the Tahan District, Pahang, Malay Peninsula. Proceedings of the Royal Geographical Society 14:533-40.

Ridley, H.N. 1900. A botanical excursion to Gunong Jerai (Kedah Peak). J. Straits Branch Royal Asiatic Society 34:23-30.

Ridley, H.N. 1901. Flora of Mount Ophir. J. Straits Branch Royal Asiatic Society 35:1-28.

Ridley, H.N. 1905. The history of the development of agriculture in the Malay Peninsula. Indian For. 31:658-64.

Ridley, H.N. 1922-1925. The Flora of the Malay Peninsula. 5 vols., L. Reeve and Co., Ltd., London.

Robbins, R.G. and J. Wyatt-Smith. 1964. Dry land forest formations and forest types in the Malayan Peninsula. Malayan For. 27:188-216.

Roe, F.W. The plateau and falls of East Sarawak. Malayan J. Tropical Geography 3:51-65.

Roth, H.L. 1896. The Natives of Sarawak and British North Borneo. 2 vols., Truelove and Hanson, London.

Rutter, O. 1922. British North Borneo: An Account of its History, Resources and Native Tribes. Constable and Co. L.td., London. 
Saad, Abdul Aziz b. Mohd. and Ithnain b. Abdul Hamid. 1980. Problems of sustained yield maintenance in timber deficit states with particular reference to Selangor. Malaysian For. 43:409-17.

Sabah Dept. of Agriculture. 1962. Census of Agriculture, 1961. Dept. Agric., Jesselton.

Sabah Dept. of Agriculture. 1972. Agricultural Statistics of Sabah 1971. Agricultural Information Div., Dept. Agriculture, Kota Kinabalu.

Sabah Dept. of Agriculture. 1982. Agricultural Statistics of Sabah 1976-1980. Agricultural Information Div., Dept. of Agriculture, Kota Kinabalu.

Sabah Forest Dept. 1963. Forest Dept. Annual Report 1962. Govt. Printer, Jesselton.

Sabah Jabatan Hutan. 1983. Annual Report of the Forest Dept. for the Year 1980. Jabatan Cetak Kerajaan (Negeri Sabah, Malaysia), Kota Kinabalu.

Salleh b. Mohd. Nor. 1967. A note on the forest resources of West and South Johore. Malayan For. 30:212-16.

Salleh b. Mohd. Nor. 1968. A note on the forest resources of Segamat District, Johore. Malayan For. 31:28-32.

Salleh b. Mohd. Nor. 1969. Aerial phnto interpretation and the forest resources reconnaisance survey in Malaya. Malayan For. 32:73-79.

Salleh b. Mohd. Nor. 1972. Proposals for a permanent forest estate for West Malaysia. Malayan For. 35:269-84.

Salleh b. Mohd. Nor. 19\%6. Preliminary interpretation of ERTS (Landsat) imagery of Peninsular Malaysia. Malayan For. 39:189-213.

Salleh b. Mohd. Nor and Tang Hong Tat. 1973. Some aspects of the utilization and conservation of the forest resources of West Malaysia, In Proceedings of the Symposium on Biological Research and National Development. Suppl. to Malayan Nature J.

Salleh b. Mohd. Nor. 1988. Forest management, pp. 126-137 In Key Environments: Malaysia, Earl of Cranbrook (ed.) Pergamon Press for Int. Union Conserv. Nature and Nat. Res., Oxford.

Sandhu, K.S. 1964. Emergency resettlement in Malaya. J. Tropical Geography 18:157-83.

Sarawak (Colony). 1936, 1937, 1939. Administration Report for the Year, 1935, 1935, 1936, 1938. Sarawak Govt. Printing Office, Kuching.

Sarawak (Colony). 1952. Sarawak Annual Report 1951. Sarawak Govt. Printing Office, Kuching. 
Sarawak (Colony). 1962. Report on the Census of Population Taken on 15th June 1960. Govt. Printing Office, Kuching.

Sarawak (Colony) Acting Conservator of Forests. 1927. Memorandum by the Acting Conservator of Forests on the forest policy of Sarawak during the period 1919-1926, pp. vi-ix In Sarawak Gazette (Suppl.) (Nov. 1, 1927). Govt. Printing Office, Kuching.

Sarawak (Colony) Dept. of Agriculture. 1961. Sarawak Census of Agriculture 1960. General Report, Sarawak Dept. of Agriculture, Kuching.

Sarawak (Colony) Forest Dept. 1926. Forest Dept. Annual Repon for 1925. Sarawak Govt. Gazette (Sept. 16, 1926):432-444.

Sarawak (Colony) Forest Dept. 1934. Annual Report of the Forest Department for the Year 1933. Sarawak Govt. Printing Office, Kuching.

Sarawak (Colony) Forest Dept. 1947. Annual Report on the Forest Department for the Year 1946. Sarawak Govt. Printing Office, Kuching.

Sarawak (Colony) Forest Dept. 1954. Annual Report on the Forest Department for the Year 1953. Sarawak Govt. Printing Office, Kuching.

Sarawak (Colony) Forest Dept. 1955. Statement of Forest Policy (Approved by the Governor-in-Council, 23rd December, 1954). Sarawak Govt. Printing Office, Kuching.

Sarawak (Colony) Forest Dept. 1956-1963. Annual Report on the Forest Department for the Year (annual, 1955-1962). Govt. Printing Office, Kuching.

Sarawak (Colony) Forest Dept. (no date). Trees and Timbers of Sarawak and Brunei. Leaflets No. 1-45. Published over long period (leaflets not dated), Govt. Printing Office, Kuching.

Sarawak (Colony) Land Committee (C.M. Johnston, S.R. Simpson, and A.J.N. Richards). 1962. Repoit of the Land Committee 1962. Govt. Printing Office, Kuching.

Sarawak (State). 1965. Anmual Bulletin of Statistics, State of Sarawak 1964. Dept. Statistics, State of Sarawak, Kuching.

Sarawak (State) Dept. of Agriculture. 1971. Agricultural Statistics of Sarawak 1970. Dept. Agriculture, Kuching.

Sarawak (State) Forest Dept. 1981. Annual Report of the Forest Dept. Sarawak 1980. Forest Dept., Kuching.

Sarawak (State) Jabatan Pertanian (Dept. Agriculture). 1981. Perangkaan Pertanian Sarawak 1981 (Agricultural Statistics of Sarawak 1981). Jabatan Pertanian, Negeri Sarawak, Kuching. 
Saw Swee-Hock. 1988. The Population of Peninsular Malaysia. Singapore University Press, Nat. University of Singapore, Singapore.

Selangor. 1880-1906. Administration Report for the State of Selangor, 1879-1905. Published as Papers by Command in Great Britain, Parliament, House of Commons, British Sessional Papers, H.M.S.O., London.

Senada, D.A. 1977. The role of forestry in the socio-economic development of rural Sarawak. Malaysian For. 40:2-13.

Setten, G.G.K. 1954. What does Malaya get from the forest? Malayan For. 17:114-28.

Setten, G.G.K. 1960. Article on Temiar Senoi agriculture (letter to the editor). Malayan For. 23:362.

Setten, G.G.K. 1961. A brief note on the history of forest research in Malaya. Malayan For. 24:283-89.

Setten, G.G.K. 1962. The need for a forest estate in Malaya. Malayan For. 25:184-198.

Setten, G.G.K. and J. Wyatt-Smith. 1960. Rural development and the Forest Department. Malayan For. 23:250-54.

Short, D.E. and J.C. Jackson. 1971. The origins of an irrigation policy in Malaya: A review of developments prior to the establishment of the Drainage and Irrigation Department. J. Malaya Branch British Royal Asiatic Society 44:78-103.

Shrubshall, E. 1954. Federation of Malaya Report on the Federal Forest Administration for the Year 1953. G.A. Smith, Govt. Printer, Kuala Lumpur.

Siew Kam Yew. 1969. Land Use Report of Pahang. Land Use Section, Soil Sci. Div., Res. Branch, Div. Agric. and Co-operatives Malaysia, Kuala Lumpur.

Siew Kam Yew. 1969. Land Use Report of Perlis. Land Use Section, Soil Sci. Div., Res. Branch, Div. Agric. and Co-operatives Malaysia, Kuala Lumpur.

Siew Kam Yew. 1969. The Present Land Use of Penang and Province Wellesley. Land Use Section, Soil Sci. Div., Res. Branch, Div. Agric. and Co-operatives Malaysia, Kuala Lumpur.

Smythies, B.E. 1962. Progress Report $1955-60$ by the Forestry Dept. of Sarawak, Prepared for the British Commonwealth Forestry Conference 1962. Sarawak Forestry Dept., Kuching.

Smythies, B.E. 1963. History of forestry in Sarawak. Malayan For. 26:232-253. 
Specht, R.L. and J.S. Womersley. 1979. Heathlands and related shrublands of Malesia (with particular reference to Bomeo and New Guinea), pp. 321-38 In Heathlands and Related Shrublands: Descriptive Studies, R.L. Specht (ed.) Ecosystems of the World 9A, Elsevier Scientific Publ. Co., Amsterdam.

Spurway, J.C. 1937. Shifting cultivation in Sarawak. Malayan For. 26:124-128.

Spurway, J.C. 1946. Annual Report on the Forest Department for the Year 1946. Colony of Sarawak Forest Dept., Kuching.

Steenis, C.G.G.J. van. 1950a. Introduction, pp. x-xli In Flora Malesiana, Being an Illustrated Systematic Account of the Malaysian Flora, Including Keys for Determination, Diagnostic Descriptions, References to the Literature. Synonymy, and Distribution, and Notes on the Ecology of Its Wild and Commonly Cultivated Plants, Series I -Spermatophyta (Flowering Plants). Vol. I, Noordhoff-Kolff N.V., Djakana.

Steenis, C.G.G.J. van. 1950b. The delimitation of Malaysia and its main plant geographical divisions, pp. Ixx-Ixxv In Flora Malesiana, Series I -Spermatophyta (Flowering Plants). Vol. I, Noordhoff-Kolff N.V., Djakarta.

Steenis, C.G.G.J. van. 1954. General considerations, pp. xili-Ixix In Flora Malesiana, Series I -Spermatophyta (Flowering Plants). Vol. IV, Noordhoff-Kolff N.V., Djakarta.

Steenis, C.G.G.J. van. 1958. Flora Malesiana. Vol. V, Noordhoff-Kolff N.V., Djakarta.

Steenis, C.G.G.J. van. 1958. Concise outline of Malaysian vegetation mapping and literature, pp. 68-73 In Study of Tropical Vegetation: Proceedings of the Kandy Symposium. UNESCO, Paris.

Stone, B.C. 1983. Review: Effects of elevation on vegetation on Gunung Jedai, Kedah. Malayan Nature J. 36:289-91.

Straits Settlements and Federated Malay States. 1932-1936. Malayan Agricultural Statistics, 1931-1935. Dept. of Agriculture, Kuala Lumpur.

Straits Settlements. 1892-1920. Annual Report on the Straits Settlements, 1890-1919. Published as Papers by Command in Great Britain, Parliament, House of Commons, British Sessional Papers, H.M.S.O., London.

Straits Settlements. 1902, 1912, 1913, 1920, 1940. Report on the Blue Book of the Straits Settlements, 1901, 1911, 1912, 1919, 1938. Govt. Printing Office, Singapore.

Straits Settlements. 1905, 1914-15, 1931. Annual Departmental Reports, 1903, 1913, 1914, 1930. Govt. Printing Office, Singapore.

Strong, T.A. 1932. The Sakai and shifting cultivation. Malayan For. 2:243-246. 
Sungei Ujong. 1879-1889. Report on the State of Sungei Ujong (annual, 1878-1888). Published as Papers by Command in Great Britain, Parliament, House of Commons, British Sessional Papers, H.M.S.O., London.

Swettenham, F.A. 1880. From Perak to Slim, and down the Slim and Bernam Rivers. J. Straits Branch Royal Asiatic Society 5:51-67.

Swettenham, F.A. 1885. Joumal kept during a joumey across the Malay Peninsula. J. Straits Branch Royal Asiatic Society 15:1-37.

Symington, C.F. 1933. The study of secondary growth on rain forest sites in Malaya. Malayan For. 2:107-17.

Symington, C.F. 1943. Foresters' Manual of Dipterocarps. Malayan Forest Records No. 16. Reprinted 1974 by Penerbit University Malaya, Kuala Lumpur.

Tang Hon Tat, H.A.H. Haron, and E.K. Cheah. 1981. Mangrove forests of Peninsular Malaysia -a review of management and research objectives and priorities. Malaysian For. 44:77-86.

Tang Hon Tat. 1974. A brief assessment of the regeneration systems for Hill Forests in Peninsular Malaysia. Malaysian For. 37:263-70.

Tang Hon Tat. 1980. Factors affecting regeneration methods for tropical high forests in South-East Asia. Malaysian For. 43:469-79.

Tay, T.H. 1969. Distribution, characteristics, uses and potential of peat in West Malaysia. $J$. Tropical Geography 29:57-63.

Tennison-Woods, J.E. 1885. Joumey to the Summit of Gunong Bubu. J. Straits Branch Royal Asiatic Society 14:275-85.

Terengganu. 1911-1940. Annual Report for the Year, 1910-1938. Govt. Printing Office, Singapore. Republished as Colonial Office papers in Great Britain, Parliament, House of Commons, British Sessional Papers, H.M.S.O., London.

Treacher, W.H. 1883. British North Borneo. Report by Governor Treacher, from Ist July to 31 st December, 1882. William Brown and Co., London.

Treacher, W.H. 1890. British Bomeo: sketches of Brunai, Sarawak, Labuan and North Borneo. J. Straits Branch Royal Asiatic Society 21:19-121.

Tregonning, K.G. 1965. A History of Modern Sabah (North Borneo 1881-1963). University Malaya Press for the University of Singapore, Singapore.

Tremeer, R.E. 1910. The early history of rubber planting in Sarawak 1880-1910. The Sarawak Gazette 90:50-52. 
Tufo, M.V. del (Superintendent of the Census, Fed. Malaya). 1949. A Report on the 1947 Census of Population, Comprising the Federation of Malaya and the Colony of Singapore. Crown Agents for the Colonies, London.

Tunku Shamsul Bahrin. 1969. A preliminary study of the fringe alienation schemes in West Malaysia. J. Tropical Geography 28:75-83.

Tunku Shamsul Bahrin. 1973. Land settlement and national development in Malaysia, In Proceedings of the Symposium on Biological Research and National Development. Suppl. to Malayan Nature J.

Valkenburg, S. van. 1935. Agricultural regions of Asia: Part VIII -Malaysia. Economic Geography 11:227-46.

Vincent, A.J. 1963. A Brief introduction to the current forest resources reconnaissance survey in progress in Malaya. Malayan For. 26:226-31.

Walker, F.S. 1938. Regeneration of Klang Mangroves. Malayan For. 7:71-76.

Wallace, Alfred Russel. 1869. The Malay Archipelago: The Land of the Orangutan and the Bird of Paradise, A Narrative of Travel with Studies of Man and Nature. Harper, New York.

Wall, J.R.D. 1964. Topography-soil relationships in lowland Sarawak. J. Tropical Geography 18:192-99.

Walton, A.B. 1951. Land planning and forestry. Malayan For. 14:212-20.

Walton, A.B., R.C. Barnard, and J. Wyatt-Smith. 1952. The silviculture of lowland dipterocarp forest in Malaya. Malayan For. 15:181-97.

Wan Razali Mohd. 1980. Species distribution and sampling tree density: a preliminary investigation using quadrats in a tropical high forest. Malaysian For. 43:432-68.

Watson, J.G. 1927. A note on the exploitation of Damar Penak in the Federated Malay States. Indian For. 53:493-500; 551-60.

Watson, J.G. 1928. Mangrove Forests of the Malay Peninsula. Fraser and Neave, Singapore.

Watson, J.G. 1939. Forestry and tin mining in Malaya. Malayan For. 8:145-49.

Watson, J.G. 1950. Some materials for a forest history of Malaya. Malayan For. 13:63-72.

Wee, Y.C. 1970. Weed succession observations on arable peat land. Malayan For. 33:63-69.

Whitmore, T.C. 1978. The forest ecosystems of Malaysia, Singapore and Brunei: description, functioning and research needs, pp. 641-53 In Tropical Forest Ecosystems: A State-of-Knowledge Report. UNESCO/UNEP/FAO, Paris. 
Whitmore, T.C. 1984. A vegetation map of Malesia at scale 1:5 million. J. Biogeography 11:461-471.

Whitmore, T.C. 1984. Tropical Rain Forests of the Far East. 2nd edition, Clarendon Press, Oxford.

Whitmore, T.C. 1988. Forest types and forest zonation, pp. 20-30 In Key Environments: Malaysia, Earl of Cranbrook (ed.) Pergamon Press, New York.

Whitmore, T.C. and C.P. Bumham. 1969. The altitudinal sequence of forests and soils on granite Near Kuala Lumpur. Malayan Nature J. 22:99-118.

Wiedemann, Alfred M. 1969. A quadrat in the Ulu Gombok Jungle Reserve. Malayan Nature J. 22:159-63.

Winstedt, R.O. (ed.) 1923. Malaya: The Straits Settlements and the Federated and Unfederated Malay States. Constable and Co. Ltd., London.

Wong, I.F.T. 1968. The Present Land Use of Selangor. Land Use Section, Soil Sci. Div., Res. Branch, Div. of Agriculture and Co-operatives, Kuala Lumpur.

Wong, I.F.T. 1969. Land Use Report of Johor. Land Use Section, Soil Sci. Div., Res. Branch, Div. Agriculture and Co-operatives, Kuala Lumpur.

Wong, I.F.T. 1970. Land Use Report of Kedah. Land Use Section, Soil Sci. Div., Res. Branch, Div. Agriculture and Co-operatives, Kuala Lumpur.

Wong, I.F.T. 1970. The Present Land Use of Terengganu. Land Use Section, Soil Sci. Div., Res. Branch, Div. Agriculture and Co-operatives, Kuala Lumpur.

Wong, I.F.T. 1970. The Present Land Use of Kelantan. Land Use Section, Soil Sci. Div., Res. Branch, Div. Agriculture and Co-operatives, Kuala Lumpur.

Wong, I.F.T. 1973. The Present Land Use of Sabah, 1970. Sabah Present Land Use Report No. 5. Div. of Agriculture, Kuala Lumpur.

Wong. I.F.T. 1979. The Present Land Use of Peninsular Malaysia. Ministry of Agriculture, Peninsular Malaysia, Kuala Lumpur.

Wong Yew Kwan and T.C. Whitmore. 1970. On the influence of soil properties on species distribution in a Malayan lowland dipterocarp forest. Malayan For. 33:42-54.

Wray, L. 1890. Joumal of a collecting expedition to the mountain of Batang Padang, Perak. J. Straits Branch Royal Asiatic Society 21:123-65.

Wyatt-Smith, J. 1947. Save the Belukar. Malayan For. 11:24-26. 
Wyatt-Smith, J. 1949. A note on tropical lowland evergreen rain-forest in Malaya. Malayan For. 12:58-64.

Wyatt-Smith, J. 1951a. Forestry, agricultural settlements and land planning. Malayan For. 14:206-12.

Wyatt-Smith, J. 1951b. Forest enumeration surveys. Malayan For. 14:66-74.

Wyatt-Smith, J. 1953a. A note on the vegetation of some islands in the Malacca Straits. Malayan For. 16:191-205.

Wyatt-Smith, J. 1953b. The vegetation of Jarak Island, Straits of Malacca. J. Ecology 41:207-25.

Wyatt-Smith, J. 1954. Forest types in the Federation of Malaya. Malayan For. 17:83-84.

Wyatt-Smith, J. 1955a. Changes in composition in early natural plant succession. Malayan For. 18:44-49.

Wyatt-Smith, J. 1955b. The dipterocarpaceae of Brunei, North Borneo and Sarawak. Malayan For. $18: 70-73 ; 145-56$.

Wyatt-Smith, J. 1957. A note on teak in North-West Malaya. Malayan For. 20:129-39.

Wyatt-Smith, J. 1958. Shifting cultivation in Malaya. Malayan For. 21:139-54.

Wyatt-Smith, J. 1959a. Development of a silvicultural system for the conversion of natural inland lowland evergreen rain forest of Malaya. Malayan For. 22:133-41.

Wyatt-Smith, J. 1959b. Peat swamp forest in Malaya. Malayan For. 22:5-22.

Wyatt-Smith, J. 1961. A note on the fresh-water swamp, lowland and hill forest types of Malaya. Malayan For. 24:110-21.

Wyatt-Smith, J. 1963. Manual of Malayan Silviculture for Inland Forests. 2 Vols., Malayan Forest Records No. 23, Kuala Lumpur.

Wyatt-Smith, J. 1964. A preliminary vegetation map of Malaya with descriptions of the vegetation types. J. Trop. Geog. 18:200-213.

Wyatt-Smith, J. and A.J. Vincent. 1962. Progressive development in the management of tropical lowland evergreen rain forest and mangrove forest in Malaya. Malayan For. 25:199-223.

Yoda, K. 1978. Organic carbon, nitrogen and mineral nutrients stock in the soils of Pasoh Forest. Malayan Nature J. 30:229-51. 


\subsubsection{Myanmar (Burma)}

Adas, M. 1974. The Burma Delta. University of Wisconsin Press, Madison, WI.

Adas, M. 1983. Colonization, commercial agriculture, and the destruction of the deltaic rainforests of British Burma in the late nineteenth century, pp.95-110 and 193-195 In Global Deforestation and the Nineteenth-Century World Economy, R.P. Tucker and J.F. Richards (eds.) Duke Press Policy Studies, Durham, NC.

Ahmad, N. 1971. Economic Resources of the Union of Burma. Tech. Rept. 71-61-ES, Earth Sciences Lab., U. S. Army Natick Lab, Natick, MA.

Andrus, J.R. 1946. The agrarian problem in Burma. Pacific Affairs 19:260-71.

Andrus, J.R. 1948. Burmese Economic Life. Stanford University Press, Stanford, CA.

Anonymous. 1897. The rubber forests of the Hukong Valley. Indian For. 23:110-13.

Anonymous. 1924. The aerial survey of the Irrawaddy Delta forests. Indian For. 50:343-44; 415-17.

Anonymous. 1925. Air reconnaissance of the forests of South Tenasserim Division. Indian For. 51:593-99.

Anonymous, 1927. Air-survey in the Irrawaddy Delta. Indian For. 53:421-23.

Anonymous. 1944. Burma Rice. Burma Pamphlets No. 4, Longmans, Green and Co., Ltd., London.

Arbuthnot, R.E.V. 1917. Burma Season and Crop Report of Burma for the Year Ended the 30th June 1917. Office of the Superintendent, Govt. Printing, Rangoon.

Atkinson, D.J. 1948. Forests and forestry in Burma. J. Royal Society Arts 94:478-91.

Aung Din, U. 1958. Pines for tropical areas. Unasylva 12(3):21-33.

Barbour, Thomas, 1909. Notes on Burma. National Geographic 20:841-66.

Barrington, A.H.M. 1930. Bu. ma forest soils. J. Ecology 18:145-50. Reprinted 1932 in Indian For. 58:547-55.

Barrington, A.H.M. 1931. Forest Soil and Vegetation in the Hlaing Forest Circle, Burma. Burma Forest Bulletin No. 25, Ecology Series No. 1, Superintendent, Govt. Printing and Stationery, Rangoon.

Binns, B.O. 1948. Agricultural Economy in Burma. Superintendent, Govt. Printing and Stationery, Rangoon. 
Biswas, K. 1932. Glimpses of the vegetation of South Burma. J. Bombay Natural History Soc. 36:285-87.

Blanford, H.R. 1924. The aero-photo-survey and mapping of the forests of the Irrawaddy Delta. Indian For. 50:605-16.

Blanford, H.R. 1958. Highlights of one hundred years of forestry in Burma. Emp. For. Rev. $87: 33-42$.

Blower, J. 1985. Conservation priorities in Burma. Oryx 19:79-85.

Brandis, D. 1903. Teak in evergreen forest. Indian For. 29:187-89.

Brant, Charles. 1954. Tadagale: a Burmese village in 1950. Southeast Asia Program Data Paper No. 13, Southeast Asia Program, Comell University, Ithaca, NY.

Bruce, C. 1903. A peculiar type of teak forest. Indian For. 29:20-21.

Burma. 1880, 1881. Report on the Settlement Operations in the Syriam Township, Hanthawaddy District, Season 1879-80; 1880-81. Govt. Press, Rangoon.

Burma. 1882, 1884. Report on the Settlement Operations in the Tharrawaddy District, Season $1880-81 ; 1882-83$. Govt. Press, Rangoon.

Burma. 1884, 1885. Report on the Settlement Operations in the Hanthawaddy and Pegu Districts, Season 1882-83; Season 1883-84. Govt. Press, Rangoon.

Burma. 1885. Report on the Settlement Operations in the Prome District, Season 1884-85. Govt. Press, Rangoon.

Burma. 1885. Report on the Settlement Operations in the Tharrawaddy and Prome Districts, Season 1883-84. Govt. Press, Rangoon.

Burma. 1885. Report on the Settlement of the Karen Hills Subdivision for the Year 1884-85. Govt. Press, Rangoon.

Burma. 1885, 1886. Report on the Settlement Operations in the Bassein and Henzada Districts, Season 1883-84; 1884-85. Govt. Press, Rangoon.

Burma. 1887. Report on the Settlement Operations in the Akyab District, 1885-86. Govt. Press, Rangoon.

Burma. 1887. Report on the Settlement Operations in the Henzada District, Season 1885-86. Govt. Press, Rangoon.

Burma. 1890. Report on the Settlement Operations in the Bassein and Thongwa Districts, Season 1888-89. Govt. Press, Rangoon. 
Burma. 1891, 1892.Report on the Settlement Operations in the Thongwa District, Season 1889-90; 1890-91. Superintendent, Govt. Printing, Rangoon.

Burma. 1892. Report on the Settlement Operations in the Kyaukse District, Season 1890-91, and part of Season 1891-92. Office of the Superintendent, Govt. Printing, Rangoon.

Burma. 1894. Report on the Settlement Operations in the Mandalay District, Season 1892-93. Office of the Superintendent, Govt. Printing, Rangoon.

Burma. 1897. Report on the Assessment of the Agricultural Lands Within the Limits of Moulmein Municipality and of Part of Ngante Kwin, Ngante Circle, 1895-96. Superintendent, Govt. Printing, Rangoon.

Burma. 1898. Report on the Settlement Operations in the Sandoway District, 1897-98. British Burma Press, Rangoon.

Burma. 1898. Report on the Settlement Operations in the Kyaikto Subdivision, Season 1896-97. Superintendent, Govt. Printing, Rangoon.

Burma. 1899. Report on the Garden Classification of Tavoy District During the Years 1897-98 and 1898-99. Superintendent, Govt. Printing, Rangoon.

Burma. 1899. Report on tive Revision Settlement Operations in the Myaungmya District, Season 1897-98. Superintendent, Govt. Press, Rangoon.

Burma. 1900. Report on the Settlement Operations in the Hanthawaddy District, Season 1897-98. Superintendent, Govt. Printing, Rangoon.

Burma. 1900. Report on the Settlement Operations in the Minbu District, Season 1893-97. Superintendent, Govt. Printing, Burma. Rangoon.

Burma. 1900. Report on the Settlement Operations in the Sagaing District, 1899. British Burma Press, Rangoon.

Burma. 1900. Report on the Settlement Operations in the Meiktila District, Season, 1896-98. Superintendent, Govt. Printing, Rangoon.

Burma. 1900. Report on the Revision of Soil Classification and Land Revenue Rates in the Kyaukpyu District, 1898-99. Superintendent, Govt. Printing, Rangoon.

Burma. 1901. Report on the Revision Settlement Operations in the Henzada District, Season 1899-1900. Superintendent, Govt. Printing, Rangoon.

Burma. 1901. Report on the Summary Settlement Operations in the Myingyan District, Season 1899-1901. Superintendent, Govt. Printing, Rangoon. 
Burma. 1902. Report on the Settlement Operations in the Thayetmyo District, Season 1900-1901. British Burma Press, Rangoon.

Burma. 1902. Report on the Settlement Operations in the Bassein and Myaungmya Districts, Season 1901-1902. Govt. Press, Rangoon.

Burma. 1902. Report on the Settlement of Certain Areas in the Henzada District, Season 1900-1901. British Burma Press, Rangoon.

Burma. 1903. Report on the Revision Settlement Operations in the Akyab District, 1902-03. British Burma Press, Rangoon.

Burma. 1905. Report on the Revision Settlement Operations in the Mandalay District, Season 1903-05. British Burma Press, Rangoon.

Burma. 1905. Report on the Summary Settlement Operations in the Kyaukpyu District, 1904-05. British Burma Press, Rangoon.

Burma. 1905. Report on the Settlement Operations in the Magwe District, Season 1897-1903. Superintendent, Govt. Printing, Rangoon.

Burma. 1906. Report on the Settlement Operations in the Shwebo District, 1905. British Burma Press, Rangoon.

Burma. 1906. Report on the Settlement Operations in the Tavoy District, Season 1904-05. British Burma Press, Rangoon.

Burma. 1906. Report on the Revision Settlement Operations in the Maubin District, Season 1904-05. British Burma Press, Rangoon.

Burma. 1907. Report on the Settlement Operations in the Katha District, 1905. 1906. Govt. Printing, Rangoon.

Burma. 1907. Report on the Summary Settlement Operations in the Sandoway District, 1905-06. British Burma Press, Rangoon.

Burma. 1907. Report on the Settlement Operations in the Mergui District, Season 1905-1906. British Burma Press, Rangoon.

Burma. 1908. Report on the Revision Settlement Operations in the Pyapon District, Season 1905-07. Govt. Printing, Rangoon.

Burma. 1927. Final Report on the Revised Settlement Operations in the Pyapon District, Season 1921-25. Superintendent, Govt. Printing and Stationery, Rangoon. 
Burma District Gazetteers. 1910-1935. Burma A Series, by District [Akyab (1917), Amherst (1913, 1935), Arakan Hill District (1910), Bassein (1916), Bhamo (1912), Lower Chindwin (1912), Upper Chindwin (1913), Henzada (1915, Insein (1914), Kyaukse (1925), Mandalay (1928), Maubin (1931), Mergui (1912), Myitkyina (1012), Pakokku (1913), Pegu (1917), Ruby Mines (1915), Salween (1910), Sandoway (1912), Shwebo (1929), Syriam (=Hanthawaddy, 1914), Tharrawaddy, (1920), Thaton (1931), Thayetmyo (1911), Toungoo (1914), Yamethin (1934)]. Superintendent, Govt. Printing and Stationery, Rangoon.

Buma District Gazetteers. 1906-1907. Burma B Series. 36 vols., Govt. Printing, Rangoon.

Burma District Gazetteers. 1912-1913. Burma B Series. 42 vols., Govt. Printing, Rangoon.

Burma District Gazetteers. 1924-1925. Burma B Series. 41 vols., Superintendent, Govt. Printing, Rangoon.

Burma Dept. Land Records and Agriculture. 1941, 1943. Season and Crop Report of Burma for the Year Ending the 30th June (annual, 1941, 1943). Superintendent, Govt. Printing and Stationery, Rangoon.

Burma Forest Dept. 1919. Report on Forest Administration in Burma for the Year Ended the 30th June 1918. Superintendent, Govt. Printing, Rangoon.

Burma Forest Dept. 1926. Report on Forest Administration in Burma for the Year Ending 31st March 1925. Superintendent, Govt. Printing and Stationery, Rangoon.

Burma Forest Dept. 1931. Summary of Information on the Chief Timbers of Burma. Burma Forest Bulletin No. 22, Economic Series No. 4, Superintendent, Govt. Printing and Stationery, Rangoon.

Burma Forest Dept. 1933-1938. Annual Report on Working Plans, Silviculture and Entomology in Burma for the Year (annual, 1932/33-1936/37). Superintendent, Govt. Printing and Stationery, Rangoon.

Burma Forest Dept. 1934-1940. Report on Forest Administration in Burma (Excluding the Federated Shan States) for the Year Ending 31st March (annual 1933-1939). Superintendent, Govt. Printing and Stationery, Rangoon.

Burma Forest Dept. 1935. Review of the Forest Administration in Burma (Including the Federated Shan States) During the Five Years from Ist April 1929 to 31st March 1934. Superintendent, Govt. Printing and Stationery, Rangoon.

Burma Royal Commission on Agriculture. 1927. Agriculture in Burma: A Collection of Papers Written by Govt. Officials for the Royal Commission on Agriculture, 1926-28. Superintendent, Govt. Printing and Stationery, Rangoon.

Burma (Union). 1969. Statistical Year Book: 1969. Central Statistical and Economics Dept., Rangoon. 
Burma (Union). 1973. Agricultural Statistics 1969-70, 1970-71 and 1971-72. Central Press, Rangoon.

Burma (Union). 1980. Agricultural Statistics: 1976-77, 1977-78 ana 1978-79. Printing and Publ. Corp., Rangoon.

Burma (Union). 1984. Agricultural Statistics: 1978-79, 1979-80 and 1980-81. Printing and Publ. Corp., Rangoon.

Burma (Union) Census Division. 1957. First Stage Census 1953. Superintendent, Govt. Printing, Rangoon.

Burma (Union) Central Statistical and Economics Dept. 1961. Quarterly Bulletin of Statistics: First Quarter, 1961. Superintendent, Govt. Printing and Stationery, Rangoon.

Burma (Union) Central Statistical and Economics Dept. 1963. Agricultural Abstract of Burma 1962-63. Superintendent, Govt. Printing and Stationery, Rangoon.

Burma (Union) Central Statistical and Economics Dept. 1966. Statistical Year Book 1963. Central Stat. and Econ. Dept., Rangoon.

Burma (Union) Central Statistical and Economics Dept. 1970. Statistical Year Book 1967. Central Stat. and Econ. Dept., Rangoon.

Burma (Union) Central Statistical Organization. 1976. Statistical Abstract 1974. Central Stat. Org., Rangoon.

Burma (Union) Immigration and Manpower Dept. 1986. 1983 Population Census. Immigration and Manpower Dept., Ministry of Home and Religious Affairs, Socialist Republic of the Union of Burma, Rangoon.

Burma (Union) Ministry of Agriculture and Forests. 1985. Notes on Forestry in Burma. Min. Agriculture and Forests, Rangoon.

Burma (Union) Ministry of Finance and Revenue. 1952. Economic Survey of Burma. Govt. Printing and Stationery, Rangoon.

Burma (Union) Ministry of Finance and Revenue. 1961. Economic Survey of the Union of Burma. Govt. Printing and Stationery, Rangoon.

Burma (Union) Ministry of Livestock Breeding and Fisheries. 1984. Notes on Livestock in Burma. Min. Livestock Breeding and Fisheries, Rangoon.

Burma (Union) Ministry of Planning and Finance. 1971. Report to the People by the Govt. of the Union of Burma on the Financial, Economic and Social Conditions, 1971/72. Central Press, Rangoon. 
Burma (Union) Ministry of Planning and Finance. 1973. Report to the People by the Govt. of the Union of Burma on the Financial, Economic and Social Conditions, 1973-74. Book 1 (Report Relating to the Nation), Min. Planning and Finance, Rangoon.

Burma (Union) Ministry of Planning and Finance. 1978-1982. Report to the People by the Govt. on the Financial, Economic and Social Conditions of the Socialist Republic of the Union of Burma (annual, 1978-79 to 1982-83). Min. Planning and Finance, Rangoon.

Burma (Union) Office of the Commissioner of Settlements and Land Records. 1953. Season and Crop Report of the Union of Burma for the Year Ending the 30th June 1951. Superintendent, Govt. Printing and Stationery, Rangoon.

Burma (Union) Office of the Commissioner of Settlements and Land Records (translation by Thaung). 1961. Season and Crop Report for the Year Ending 30th June 1960. Superintendent, Govt. Printing and Stationery, Rangoon.

Cameron, A.A. 1912. A Note on the Palaungs of the Kodaung Hill Tracts of the Mong Mit State. Superintendent, Govt. Printing, Rangoon.

Champion, H.G. 1936. A preliminary survey of the forest types of India and Burma. Indian For. Rec. 1(1):1-279.

Cheng Siok-Hwa. 1968. The Rice Industry of Burma 1852-1940. University Malaya Press, Kuala Lumpur.

Christian, John LeRoy. 1942. Modern Burma: A Survey of its Political and Economic Development. University Califomia Press, Berkeley, CA.

Couchman, G.H.H. 1893. Notes on the flora and fauna of the Kachin Hills. J. Bombay Natural History Soc. 7:447-51.

Davis, J.H. 1964. The forests of Burma. Sarracenia 8:1-41.

Donnison, F.S.V. 1970. Burma. Emest Benn, Ltd., London.

Edwards, M.V. 1950. Burma forest types (according to Champion's classification). Indian For. Rec. 7(2):135-173.

Erlanger, S. 1990. Burmese teak forest falls to finance a war. New York Times (International) (Dec. 9, 1990), Section L, p. 6.

Fergusson, Bernard. 1946. Upper Burma, 1943-44. Geographical J. 107:1-10.

Ferrars, M.H. 1875. J. of a tour into the Karenee country, east of Toungoo. Indian For. 1:107-23. 
Furer-Haimendorf, Christoph von. 1938. Through the unexplored mountains of the Assam-Burma border. Geographical J. 91:202-19.

Gage, A.T. 1908. The vegetation of the district of Minbu in Upper Burma. Rec. Botanical Survey India 3:1-141.

Griffith, William. 1847. Journals of Travels in Assam, Burma, Bootan, Afghanistan and the Neighboring Countries (Posthumous papers bequeathed to East India Co. and arranged by John M'Clelland). Bishop's College Press, Calcutta.

Hamilton, J.D. 1927. Conclusions based on a geological examination of teak bearing rocks in Burma. Indian For. 53:88-91.

Henderson, J.W. and others. 1971. Area Handbook for Burma. U.S. Govt. Printing Office, Washington, DC.

H.R.B. 1926. The progress of silvicultural work in Burma. Indian For. 51:331-44; 379-92.

Slade, Herbert. 1903. A note from the Myodwin teak plantation. Indian For. 29:458-59.

Slade, Herbert. 1887. Notes on the Chindwin, Upper Burma. Indian For. 13:546-56.

Hundley, H.G. 1961. The forest types of Burma. Trop. Ecol. 2:48-76.

India. 1907-1909. The Imperial Gazetteer of India (new ed.). Vols. 1-26, Clarendon Press, Oxford. India Census Commissioner. 1881. Report on the Census of British Burma. Govt. Press, Rangoon. India Census Commissioner. 1892. Census of India 1891. Vols. 9-10, Burma Superintendent, Govt. Printing, Rangoon.

India Census Commissioner. 1902. Census of India 190I. Vol. 12, Burma Office of the Superintendent of Govt. Printing, Rangoon.

India Census Commissioner. 1912. Census of India 1911. Vol. 9, Burma Office of the Superintendent, Govt. Printing, Rangoon.

India Census Commissioner. 1923. Census of India 1921. Vol. 10, Burma Office of the Superintendent, Govt. Printing, Rangoon.

India Census Commissioner. 1933. Census of India 1931. Vol. 11, Burma Office of the Superintendent, Govt. Printing and Stationery, Rangoon.

India Dept. Revenue and Agriculture. 1902. Agricultural Statistics of India for the Years 1896-97 to 1900-01. 2 vols., Office of the Superintendent of Govt. Printing, Calcutta. 
India Dept. Revenue and Agriculture. 1904. Agricultural Statistics of India for the Years $1898-99$ to 1902-03. 2 vols., Office of the Superintendent of Govt. Printing, Calcutta.

India Dept. Revenue and Agriculture. 1913. Agricultural Statistics of India for the Years 1906-07 to 1910-11. 2 vols., Office of the Superintendent of Govt. Printing, Calcutta.

India Dept. Revenue and Agriculture. 1920. Quinquennial Review of Forest Administration in British India for the Period 1914-15 to 1918-19, to Which is Appended the Annual Return of Forest Statistics for the Year 1918-19. Govt. Monotype Press, Simla.

India Forest Dept. 1921. Annual Return of Statistics Relating 10 Forest Administration in British India for the Year 1919-20. Govt. Monotype Press, Simla.

India Inspector General of Forests. 1906. Review of Forest Administration in British India for the Year 1904-1905. Maps, Office of the Superintendent of Govt. Printing, Calcutta.

India Inspector General of Forests. 1907, 1908. Review of Forest Administration in British India for the Year, 1905-1906, 1906-1907. Superintendent Govt. Printing, Calcutta.

India Inspector General of Forests. 1910. Review of Forest Administration in British India for the Year 1907-1908. Superintendent Govt. Printing, Calcutta.

India Dept. Statistics. 1896. Agricultural Statistics of British India for the Years 1890-91 10 1894-95. Superintendent, Govt. Printing, Calcutta.

India Dept. Statistics. 1921, 1922. Agricultural Statistics of India, 1919-20 and 1920-21. Superintendent, Govt. Printing, Calcutta.

India Dept. Statistics. 1924. Initial Report on the Second Revision of Settlement Operations in the Mandalay District, Season 1922-23. Superintendent, Govt. Printing, Rangoon.

India Forest Dept. 1915. Quinquennial Review of Forest Administration in British India for the Period 1909 to 1914 to which is Appended the Annual Return of Forest Statistics for the year 1913-14. Govt. Monotype Press, Simla.

India Forest Dept. 1922. Annual Return of Statistics Relating to Forest Administration in British India for the Year 1920-1921. Superintendent, Govt. Printing, Calcutta.

India Revenue and Agricultural Dept. 1886-1891. Returns of Agricultural Statistics for British India (annual, 1884/85 to 1889/1890). Superintendent, Govt. Printing, Calcutta.

Ireland, Alieyne. 1907. The Province of Burma. 2 vols., Houghton, Mifflin and Co., Boston, MA.

Keeton, C.L., 3rd. 1974. King Thebaw and the Ecological Rape of Burma: The Political and Commercial Struggle Between British India and French Indo-China in Burma 1878-1886.

Manohar Book Service, Delhi. 
Kingdon-Ward, F. 1920. Alpine meadows of Burma-Yunnan. Gardeners' Chronicle III (67):118.

Kingdon-Ward, F. 1920. Plant collecting on Imaw Bum. Gardeners' Chronicle III (67):168; 228-29; 306-7.

Kingdon-Ward, F. 1921. In Farthest Burma: The Record of an Arduous Journey of Exploration and Research Through the Unknown Frontier Territory of Burma and Tibet. J. B. Lippincott Co., Philadelphia.

Kingdon-Ward, F. 1921. Shrubs on the north-east frontier of Burma. Gardeners' Chronicle III (69):42.

Kingdon-Ward, F. 1921. The botanical exploration of the north-east frontier. Gardeners' Chronicle III (69):114-15.

Kingdon-Ward, F. 1937. Plant Hunter's Paradise. Jonathan Cape, London.

Kingdon-Ward, F. 1939. The Irrawaddy Plateau. Geographical J. 94:293-308.

Kingdon-Ward, F. 1941. The Vemay-Cutting Expedition, November, 1938, to April, 1939: Report on the vegetation and flora of the Hpimaw and Htawgaw Hills, Northerm Burma. Brittonia 4:1-19.

Kingdon-Ward, F. 1944. The Shans and their country. Geographical Magazine 17:364-71.

Kingdon-Ward, F. 1944-1945. A sketch of the botany and geography of North Burma. J. Bombay Nat. Hist. Soc. 44:550-574; 45:16-30; 45:133-148.

Kingdon-Ward, F. 1946. Additional notes on the botany of North Burma. J. Bombay Natural History Soc. 46:381-90.

Kingdon-Ward, F. 1956. Return to the Irrawaddy. Andrew Melrose, London.

Kingdon-Wand, F. 1959. A sketch of the flora and vegetation of Mount Victoria in Burma. Acta Horti Gotoburgensis 22:53-74.

Kingdon-Ward, F. 1960. Pilgrimage for Pla.1ts. George G. Harrap and Co., Ltd., London.

Knappen, Tippetts, Abbett Engineering Co. 1952. Preliminary Report on Economic and Engineering Survey of Burma, for Burma Economic Council. Knappen, Tippetts, Abbett Engineering Co., New York.

Knappen, Tippetts, Abbett and McCarthy Engineering Co. 1953. Economic and Engineering Developmen. of Burma. 2 vols., Comprehensive Report, Prepared for the Union of Burma, Hazell, Watson, and Viney, London.

Kuhn, Delia and Ferdinand. 1962. Borderlands. Knopf, New York. 


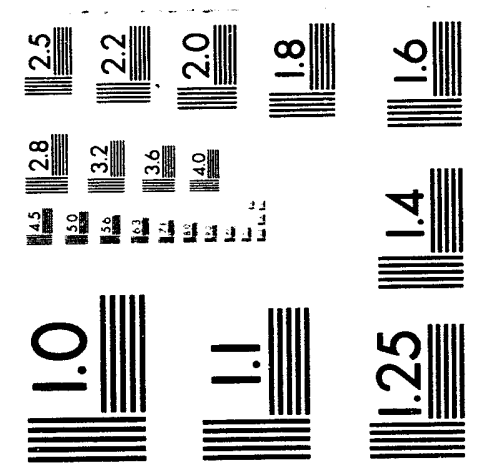



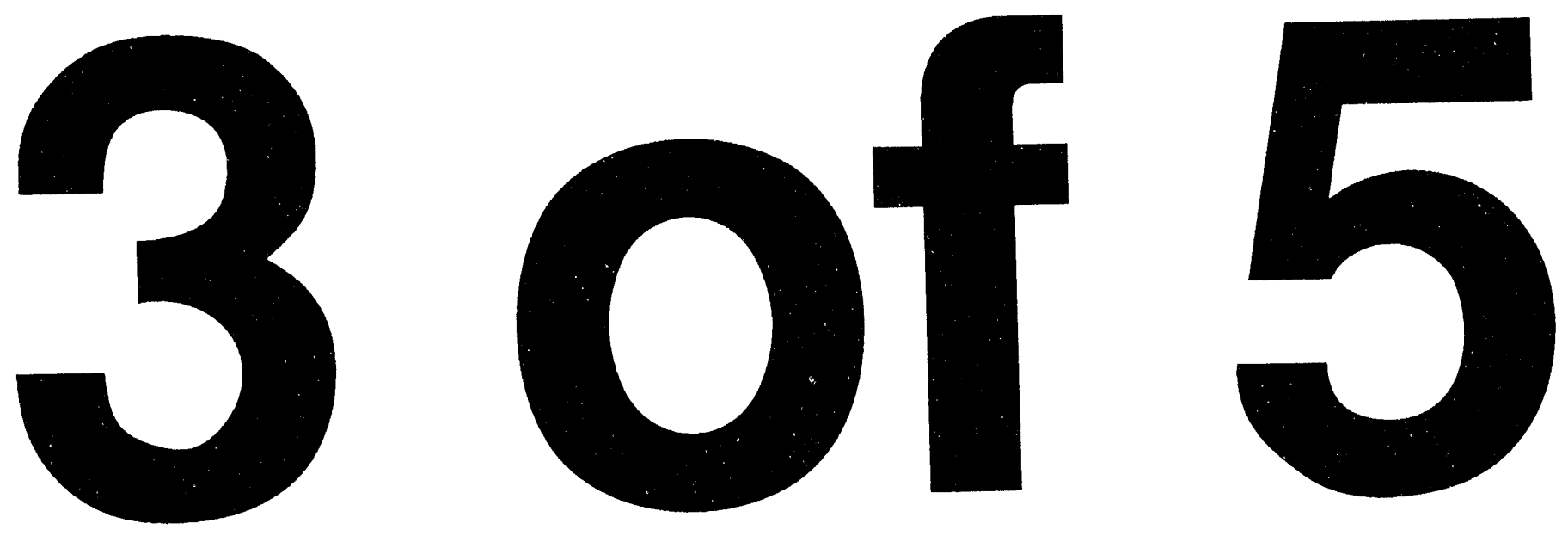
Kurz, S. 1874. Contributions towards a knowledge of the Burmese flora. J. Asiatic Soc. Bengal 43:39-141.

Kurz, S. 1877. Forest Flora of British Burma. Vol. 1. Reprinted in 1974 by M.S. Bishen Singh Mahendra Pal Singh, Dehra Dun.

Kyi, M. 1963. Two critical problems currently facing teak yield regulation and some practical suggestions. Burmese For. 13:6-13.

Kyi Win and Mg Mg Yi. 1982. Some Statistics in Agriculture: Burma. Mimeographed report, Burma Agriculture Corp., Planning Management and Evaluation Div., Rangoon.

Lambert, E.T.D. 1937. From the Brahmaputra to the Chindwin. Geographical J. 89:309-26.

Lanly, J.P. 1979. Personal communication to J. F. Richards concerning FAO-UNEP assessments of land use based on satellite images of Burma between 1973 and 1979, with notes on the interpretive categories used in this classification.

Leach, E.R. 1954. Political Systems of Highland Burma: A Study of Kachin Social Structure. Harvard University Press, Cambridge, MA.

Lehman, F.K. 1963. The Structure of Chin Society: A Tribal People of Burma Adapted to a Non-Western Civilization. Illinois Studies in Anthropology No. 3, University Illinois Press, Urbana, IL.

Long. A. 1953. The forests in the economy of Burma. Burmese For. 3:19-38.

Long, A. 1957. Some aspects of shifting, or taungya cultivation in Burma. Burmese For. 7:115-121.

Long, A. 1968. The forests of Burma. Burmese For. 14:18-35.

Mackenzie, J.M.D. 1917. Fuel and bamboo plantations in the Sittang Delta of the Pegu District, Lower Burma. Indian For. 43:2-5.

Manson, F.B. 1905. The erosion of the hills to the east of the Sittang River, Burma. Indian For. 31:223-27.

Mardon, M. 1991. Maneuvers in the teak wars. Sierra 76(3):30-32.

Maung Gale. 1970. Some problems of forest research and development in Burma. Union of Burma $J$. of Life Sciences 3:227-31.

Maung, M.I.K. 1986. The population of Burma: An analysis of the 1973 Census. Papers of the East-West Population Institute No. 97, Rangoon. 
Maung, K. 1954. The land utilization of Insein District, Burma. Malayan J. Tropical Geography 2:56-61.

McKerral, A. 1927. Climatic tracts; distribution of crops; development of agriculture of the province in recent years, pp. 1-5 In Agriculture in Burma: A Collection of Papers Written by Government Officials for the Royal Commission on Agriculture, 1926-1928. Superintendent, Govt. Printing and Stationery, Rangoon.

Merrill, E.D. 1941. The Upper Burma plants collected by Captain F. Kingdon Ward on the Vemay-Cutting Expedition, 1938-39. Brittonia 4:20-188.

Miedler, K.A. 1953. A contribution to tropical forest utilization: experience with Bumese timbers for housing. Unasylva 7(1):1-9.

Milne, Leslie. 1924. The Home of an Eastern Clan: A Study of the Palaungs of the Shan States. Clarendon Press, Oxford.

Morehead, F.T. 1944. The Forests of Burma. Burma Pamphlets No. 5, Longmans, Green and Co., Ltd., London.

Morehouse, C.H.G. 1946. Burma Facts and Figures. Burma Pamphlets No. 9, Longmans, Green and Co., Ltd., L.ondon.

Myint-Tin and Kyaw-Tint. 1968. Experiments on sampling in forest inventory. Union of Burma J. of Life Sciences 1:46-49.

Nath, Dewan Mohinder. 1961. Botanical survey of the Southern Shan States, with a note on the vegetation of Inle Lake, pp. 157-418 In Burma Research Society Fiftieth Anniversary Publication No. 1. Burma Research Society, Rangoon

Nisbet, John. 1901. Burma Under British Rule -And Before. Archibald Constable, London.

North, C.W. 1947. The new Kachin state. Geographical J. 110:251-54.

Nuttonson, M.Y. 1963a. The Physical Environment and Agriculture of Burma. American Institute of Crop Ecology, Washington, DC.

Nuttonson, M.Y. 1963b. Climate, Soils, and Rice Culture of Burma. Supplementary Information and a Bibliography to the Report of The Physical Environment and Agriculture of Burma. American Institute of Crop Ecology, Washington, DC.

Oliver, J.W. 1905a. Damage done by fires in the Prome Division, Lower Burma. Indian For. 31:296-97.

Oliver, J.W. 1905b. Teak in evergreen forest. Indian For. 31:417.

Parry, N.E. 1932. The Lakhers. Macmillan and Co., Ltd., London. 
Peal, S.E. 1879. Notes on the old Burmese route over Patkai via Nongyang (viewed as the most feasible and direct route from India to China). J. Asiatic Soc. Bengal (Physical Science) 48:69-82.

Peal, S.E. 1881. Report on a visit to the Nongyang Lake, on the Burmese frontier, February 1879. J. Asiatic Soc. Bengal, Part II. -Physical Science (1881) 50:21-30.

Pitchford, V.C. 1937. The Wild Wa States and Lake Nawngkhio. Geographical J. 90:223-32.

Rao, A.S. 1974. The vegetation and phytogeography of Assam-Burma, pp. 204-80 In Ecology and Biogeography in India, M.S. Mani (ed.) Dr. W. Junk Publishers, The Hague.

Richter, H.V. 1969. The Union of Burma, In Agricultural Development in Asia. University Califomia Press, Berkeley, CA.

Robertson, W.A. 1926. Air reconnaissance of the forests of South Tenasserim. Indian For. 52:131-32.

Rodger, A. 1921. A Hand-book of the Forest Products of Burma. Superintendent, Govt. Printing, Rangoon.

Rodger, A. 1923. The biggest teak log ever brought out from the forests of Burma. Indian For. 49:80.

Rogers, C.G. 1918. Big teak in Burma. Indian For. 44:417-19.

Scott, C.W. 1931. Lecture on the forest geography of Burma. Indian For. 57:243-49.

Scott, James G. 1911. Burma: A Handbook of Practical Information. Rev. edition, A. Moring, London.

Shakespear, J. 1912. The Lushei Kuki Clans. Macmillan and Co., Ltd., London.

Silverstein, Josef. 1977. Burma, Military Rule and the Politics of Stagnation. Comell University Press, Ithaca, NY.

Spate, O.H.K. 1945. The Burmese village. Geographical Review 35:523-43.

Spate, O.H.K. and L.W. Trueblood. 1942. Rangoon: a study in urban geograrhy. Geographical Review 32:56-73.

Spearman, H.R. (ed.) 1880. British Burma Gazetteer. 2 vols., Govt. Press, Rangoon. Reprinted 1983 by Gazetteer of Burma, Cultural Publ. House, Delhi.

Stamp, L. Dudley and Leslie Lord. 1923. The ecology of part of the riverine tract of Burma. $J$. Ecology 11:129-59. 
Stamp, L. Dudley. 1930. Burma: an undeveloped monsoon country. Geographical Review 20:86-109.

Stamp. L. Dudley. 1924. Notes on the vegetation of Burma. Geographical J. 64:231-37.

Stamp, L. Dudley. 1925. The aerial survey of the Irrawaddy Delta forests (Burma). J. Ecology 13:262-76.

Stamp, L. Dudley. 1961. The basic land resources of Burma, pp. 435-39 In Burma Research Society Fiftieth Anniversary Publications No. 1. Bunaa Research Society, Rangoon.

Stamp, L. Dudley. 1940. The Irrawaddy River. Geographical J. 95:329-56.

Stamp, L. Dudley. 1924. The Vegetation of Burma, from an Ecological Standpoint. University of Rangoon, Rangoon. Reprinted 1925 by Thacker Spink, Calcutta.

Stebbing, E.P. 1901. A note on the forests of Arrakan. Indian For. 27:67-71.

Stebbing, E.P. 1947. The teak forests of Burma. Nature 160:818-20.

Stevenson, H.N.C. 1943. The Economics of the Central Chin Tribes. The Times of India Press, Bombay. Reprinted 1968 by Gregg Press, Ltd., Famborcugh Hants, UK.

Stevenson, H.N.C. 1944. The Hill Peoples of Burma. Burma Pamphlets No. 6, Longmans, Green and Co., Ltd., London.

Tao Hai. 1913. Some notes on the taungya problem in the Shan States. Indian For. 39:364-71; 399-409.

Thein Han, U. 1951. Forestry in the Union of Burma. Burmese For. 1:5-7.

Thet Tun. 1961. A review of economic planning in Burma, pp. 485-527 In Burma Research Society Fiftieth Anniversary Pullication No. 1. Burma Research Society, Rangoon.

Thien, U. 1959. Fuelwood Situation in Burma. FAO Forestry Occasional Paper No. 6, FAO, Rome.

Tin Htut, U. 1955. A note on "shifting cultivation". Burmese For. 5:108-109.

Tinker, Hugh. 1951. The Union of Burma. Oxford University Press, London.

Troup, R.S. 1911. A note on some statistical and other information regarding the teak forests of Burma. Indian For. Rec. 3(1):1-73.

Tun Wai, U. 1965. Burma, pp, 3-27 In Asian Economic Development, C. Onslow (ed.) Weidenfeld and Nicolson, London. 
Tumbull, J.W., F.B. Armitage, and J. Burley. 1980. Distribution and ecology of the Pinus kesiya complex, pp. 13-45 In Pinus kesiya Royle ex Gordon (Tropical Forestry Papers No. 9), F.B.

Armitage and J. Burley (comp.). Unit of Tropical Silviculture, Commonwealth Forestry Institute, University of Oxford, Oxford.

University of Rangoon Economics Research Project. 1959. Burmese Agriculture 1924-1941.

Economic Paper No. 5, Depts. of Economics, Statistics and Commerce, University of Rangoon, Rangoon.

Unwin, R. 1923. Pioneers of the Forest Department in Burma. Indian For. 49:55-61.

Voon Phin Keong. 1973. The rubber industry of Burma, 1876-1964. J. Southeast Asian Studies 4:216-228.

Watson, H.W.A. 1927. The relation of forestry to agriculture in Burma, pp. 153-157 In Agriculture in Burma: A Collection of Papers Written by Government Officials for the Royal Commission on Agriculture, 1926-1928. Govt. Printing and Stationery, Burma, Rangoon.

Watson, H.W.A. 1927. Forest administration (lecture given to the senior students at Rangoon University). Indian For. 53(1927):131-41; 207-15.

World Bank. 1977. Final Report, Land Use Map Component, Burma. BUR/74/026, Economic Resources Div., Burma Umbrella Project, Agriculture and Rural Development Dept., Washington, DC.

World Bank. 1976. Burma, Land Cover-Land Use Association, Based on Computer Tape Analysis of LANDSAT Data. Map, Agriculture and Rural Development Dept., Washington, DC. 


\subsubsection{Philippines}

Ahem, George P. and W.D. Sterrett. 1909. Conservation of the natural resources of the Philippine Islands. Philippine Agricultural Review 2(9):508-512.

Ahem, G.P. 1906. The Charcoal Industry in the Philippine Islands. Bulletin No. 2, Dept. of the Interior, Bureau of Forestry, Bureau of Printing, Manila.

Alvarez, Jesus. 1978. Grasslands: some issues on their conservation and utilization, pp. 10-18 In Forum on Grasslands and Mangroves: Conservation and Utilization Issues. Philippine Forest Research Soc., Laguna, Philippines.

Alvarez, J.B. 1968. The national park -its concept, standards, and practices, pp. 359-360 In Conservation in Tropical South East Asia: Proceedings of the Conference on Conservation of Nature and Natural Resources in Tropical South East Asia (Bangkok, Nov. 29-Dec. 4, 1965), L.M. Talbot and M.H. Talbot (eds.) IUCN Publications New Series No. 10, Intemational Union for Conservation of Nature and Natural Resources, Morges, Switzerland.

Anderson, J.N. 1982. Rapid rural "development": performance and consequences in the Philippines, pp. 122-171 In Too Rapid Rural Development: Perceptions and Perspectives from Southeast Asia, C. MacAndrews and Chia Lin Sen (eds.) Ohio University Press, Athens, OH.

Anonymous. 1908. Crop reports and statistics. Philippine Agricultural Review 1(1):11-13.

Anonymous. 1909. Crop reporting and statistics. Philippine Agricultural Review 2(1):11-13.

Anonymous. 1909. Statistics on rice in the Philippine Islands. Philippine Agricultural Review 2(2):113.

Antonio, D. 1978. Mangrove resources: some issues on their utilization and conservation, pp. 42-50 In Forum on Grasslands and Mangroves: Conservation and Utilization Issues. Philippine Forest Research Soc., Laguna, Philippines.

Baltasar, L.R. 1959. A report on Philippine forest resources. Philippine Agricultural Situation 1 (3):30-32.

Bautista, G.M. 1990. The forestry crisis in the Philippines: Nature, causes, and issues. The Developing Economies 28(1):67-94.

Bedard, P.W. and T.S. Serevo, 1955. Feasibility of selective logging in dipterocarp forest. Philippine J. Forestry 11:203-209.

Bedard, P.W. 1958. Reconnaissance, classification and mapping of Philippine forests, pp. 49-52 In Study of Tropical Vegetation: Proceedings of the Kandy Symposium. UNESCO, Paris.

Benitez, C. 1926. History of the Philippines: Economic, Social, Political. Ginn and Co., Boston, MA. 
Bina, R.R., R.S. Jara, and C.R. Roque, 1984. Application of multi-level remote sensing survey to mangrove forest resource management in the Philippines, pp. 708-727 In Proceedings of the Asian Symposium on Mangrove Environment Research and Management (Kuala Lumpur, August, 1980), E. Soepadmo, A.N. Rao, and D.J. Maclntosh (eds.) University Malaya and UNESCO, Kuala Lumpur.

Blanche, C.A. 1975. An overview of the effects and implications of Philippine selective logging on the forest ecosystem, pp. 97-109 In Proceedings of a Symposium on the Long-Term Effects of Logging in Southeast Asia, R.S. Suparto, I. Soerianegara, Z. Hamzzah, H. Haeruman Js, S. Hadi, S. Manan, H. Basjarudin, and W. Sukotjo (eds.) BIOTROP Special Publ. No. 3, BIOTROPSEAMEO Regional Center for Tropical Biology, Bogor Agricultural University, Bogor, Indonesia.

Boyce, J.K. 1992. Of coconuts and kings: the political economy of an export crop. Development and Change 4:1-25.

Brown, W.H. 1919. Philippine Fiber Plants. Bulletin No. 19, Dept. of Agriculture and Nat. Res., Bureau of Forestry, Manila.

Brown, W.H. and A.F. Fischer. 1918. Philippine Mangrove Swamps. Bulletin No. 17, Dept. of Agriculture and Nat. Res., Bureau of Forestry, Manila.

Brown, W.H. and A.F. Fischer. 1918. Philippine Bamboos. Bulletin No. 15, Dept. of Agriculture and Nat. Res., Bureau of Forestry, Manila.

Brown, W.H. and E.D. Merrill. 1919. Philippine Palms and Palm Products. Bulletin No. 18, Dept. of Agriculture and Nat. Rer Bureau of Forestry, Manila.

Burley, T.M. 1973. The : ،ilippines: An Economic and Social Geography. G. Bell and Sons Ltd., London.

Camara de Comercio de las Islas Filopinas. 1920. Yearbook of the Philippine Islands 1920. Bureau of Printing, Manila.

Camus, Jose S. 1921. Rice in the Philippines. Philippine Agricultural Review 14:7-86.

Chatfield, G.A. 1961. The Philippines. Our Neighbors series, Donald Moore for Eastem Universities Press Ltd., Singapore.

Chollet, A. 1970. La foret aux Iles Philippines (The forest in the Philippine Islands). Revue Bois et Forests des Tropiques 130:23-29.

Conklin, H.C. 1957. Hanunoo Agriculture. FAO Forestry Development Paper No. 12, FAO, Rome. 
Conklin, H.C. 1969. An ethnological approach to shifting agriculture, pp.221-233 In Environment and Cultural Behavior, A.P. Vayda (ed.) Natural History Press for the American Museum of Natural History, Garden City, NY.

Criag, A. and C. Benitez. 1916. Philippine Progress Prior to 1898. A source book of Philippine history to supply a fairer view of Filipino participation and supplement the defective Spanish accounts. Philippine Education Co., Inc., Manila.

Cruz, E. de la, 1941. The socio-economic significance of the Philippine forest. Philippine $J$. Forestry 4:141-159.

Cruz, W.D. and M.C.J. Cruz. 1990. Population pressure and deforestation in the Philippines. ASEAN Economic Bulletin 7(2):200-212.

Cuzner, Harold, 1910. Com growing in the Philippines. Philippine Agricultural Review 3(5):303-309.

Dano, A. 1990. Effect of buming and reforestation on grassland watershed in the Philippines, pp. 53-61 In Research Needs and Applications to Reduce Erosion and Sedimentation in Tropical Steeplands: Proceedings of the Fiji Symposium (Fiji, June, 1990), R.R. Ziemer, C.L. O'Loughlin, and L.S. Hamilton (eds.) IAHS-AISH Publ. No. 192, IAHS Press, Institute of Hydrology, Wallingford, Oxfordshire, UK.

Dawning, S.L., L.R. Iverson, and S. Brown, 1993. Rates and pattems of deforestation in the Philippines: application of geographic information system analysis. Forest Ecology and Management 57:1-16.

Diaz, Celso P. 1982. Socio-economic thrusts in an integrated forest management system: the Philippine case, pp. 107-122 In Socio-economic Effects and Constraints in Tropical Forest Management, E.G. Hallsworth (ed.) John Wiley and Sons, Chichester.

Eder, J.F. 1988. Batak foraging camps today: a window to the history of a hunting-gathering economy. Human Ecology 16:35-55.

Eder, J.F. 1990. Deforestation and detribalization in the Philippines: the Palawan case. Population and Environment: A Journal of Interdisciplinary Studies 12(2):99-115.

Encamacion, J., Jr. (ed.) 1976. Philippine Economic Problems in Perspective. Institute of Economic Development and Research, School of Economics, University Philippines, Manila.

Everett, H.D. and H.N. Whitford. 1906. A preliminary working plan for the Public Forest Tract of the Insular Lumber Co., Negros Occidental. P.I. Bulletin No. 5, Dept. of the Interior, Bureau of Forestry, Bureau of Printing, Manila.

Fast, J. and J. Richardson. 1979. Roots of Dependency: Political and Economic Revolution in 19th Century Philippines. Foundation for Nationalist Studies, Quezon City, Philippines. 
Flinn, J.C. and P.B.R. Hazell. 1988. Production instability and modem rice technology: a Philippine case study. The Developing Economies 26(1):34-50.

Forbes, W.C. 1928. The Philippine Islands. 2 vols., Riverside Press, Houghton Mifflin Co., New York.

Galang, Z.M. (ed.) 1950. Encyclopedia of the Philippines. Vols. V and VI, Commerce and Industry, Exequiel Floro, Manila.

Golay, F.H. 1961. The Philippines: Public Policy and National Economic Development. Comell University Press, Ithaca, NY.

Gulcur, M.Y. 1968. Renewable natural resources and their problems in the Philippines, pp. 93-99 In Conservation in Tropical South East Asia: Proceedings of a Conference on Conservation of Nature and Natural Resources in Tropical South East Asia (Bangkok, Nov. 29-Dec. 4, 1965), L.M. Talbot and M.H. Talbot (eds.) IUCN Publications New Series No. 10, Intemational Union for Conservation of Nature and Natural Resources, Morges, Switzerland.

Gutierrez, J.S. 1959. Rice production and consumption requirements. Philippine Agricultural Situation 1(4):13-33.

Headland, T.N. 1988. Ecosystemic change in a Philippine tropical rainforest and its effect on a Negrito foraging society. Tropical Ecology 29:121-135.

Hemaez, A. 1954. The root crops in the Philippines with special reference to cassava and camote. Philippine J. Agriculture 19:41-59.

Hicks, G.L. and G. McNicoll. 1971. Trade and Growth in the Philippines: An Open Dual Economy. Comell University Press, Ithaca, NY.

Hobart, W.D. 1911. Statistics regarding com and coconuts growing in the Philippine Islands. Philippine Agricultural Review 4(7):362-365.

Hobart, W.D. 1911. Statistics regarding rice and hemp growing in the Philippine Islands. Philippine Agricultural Review 4(5):248-251.

Hobart, W.D. 1911. Statistics regarding sugar cane and tobacco in the Philippines. Philippine Agricultural Review 4(6):308-311.

Huke, R.E. with J.B. Barcelon, A. Barrera, T. Luna, C. Martin, R.R. Reed, D. Salita, and F. Tamesis. 1963. Shadows on the Land: An Economic Geography of the Philippines. Bookmark, Manila.

Ireland, H.A. 1910. Agricultural conditions in the island of Cebu. Philippine Agricultural Review 3(5):315-320.

Jagor, F. 1875. Travels in the Philippines. Chapman and Hall, London. 
Jara, R.S. 1984. Aquaculture and mangroves in the Philippines, pp. 97-107 In Productivity of the Mangrove Ecosystem, Management Implications: Proceedings of a Workshop held at the University of Sains Malaysia (Penang, October, 1983), Ong Jin-Eong and Gong Wooi-Khoon (eds.) University of Sains Malaysia, Malaysian National Science Reseach and Development Council, Penang, Malaysia.

Kolb, A. 1942. Die Philippinen. K. Koehler Verlag, Leipzig.

Kummer, D.M. 1991. Deforestation in the Postwar Philippines. University Chicago Press. Chicago, IL.

Kummer, D.M. 1992. Measuring forest decline in the Philippines: an exercise in histo-geography. Forest and Conservation History 36:185-189.

Kummer, D.M. 1992. Upland agriculture, the land frontier and forest decline in the Philippines. Agroforestry Systems 18:31-46.

Lillo de Gracia. D.M. 1877. Filipinas, Distrito de Lepanto. Descripcion general acompanada de itinerario y croquis del territorio. Imprenta del Colegio de Santo Tomas, Manila.

Lopez-Gonzaga, V. 1988. The roots of agrarian unrest in Negros, 1850-90. Philippine Studies 36:151-165.

Malcolm, G.A. 1936. The Commonwealth of the Philippines. D. Appleton-Century Co., New York.

Mangahas, M., A.E. Recto, and V.W. Ruttan. 1970. Production and Market Relationship for Rice and Corn in the Philippines. Technical Bulletin No. 9, Intemational Rice Research Institute, Los Banos, Philippines.

Manila Chamber of Commerce. 1909. Philippine hemp statistics, sugar statistics, and tobacco statistics. Philippine Agricultural Review 2(12):461-462; 463; 464.

Maricelo, H.B. and E.T. Tagudar. 1956. Residual stand in selective high-lead logging. Philippine J. Forestry 12:101-115.

McLennan, M.S. 1982. Changing human ecology on the Central Luzon Plain: Nueva Ecija, 1705-1939, pp. 57-90 In Philippine Social History: Global Trade and Local Transformations, A.W. McCoy and E.C. de Jesus (eds.) University Press of Hawaii, Ateneo de Manila University Press, Honolulu, $\mathrm{HI}$.

Melana, D.M. 1982. Research and development status of Philippine mangroves, pp. 127-146 In Proceedings of the Symposium on Mangrove Forest Ecosystem Productivity in Southeast Asia, A.Y. Kostermans and S. Sastroutomo (eds.) BIOTROP Special Publication No. 17, BIOTROPSEAMEO Regional Center for Tropical Biology, Bogor, Indonesia. 
Merritt, M.L. 1908. The Forests of Mindoro. Bulletin No. 8, Dept. of the Interior, Bureau of Forestry, Bureau of Printing, Manila.

Merritt, M.L. and H.N. Whitford. 1906. A preliminary working plan for the Public Forest Tract of the Mindoro Lumber and Logging Co., Bongabon, Mindoro. P.I. Bulletin No. 6, Dept. of the Interior, Bureau of Forestry, Bureau of Printing, Manila.

Miller, E.Y. 1908. Agricultural opportunities in the province of Palawan. Philippine Agricultural Review 1(6):254-256.

Mitra, M. 1973. The Philippines in a botanist's eye. Bull. Botanical Soc. Bengal 27:67-70.

Morris, R.A. and H.G. Zandstra. 1979. Land and climate in relation to cropping pattems, rainfed lowland rice, pp. 255-274 In Selected Papers from the 1978 International Rice Research Conference. International Rice Research Institute, Los Banos, Philippines.

Moya y Jimenez, F.J. de. 1883. Las Islas Filipinas en 1882. Estudios historicos, geograficos, estadisticos y descriptivos. El Correo, Madrid.

Nablo, S.U. 1968. Conservation activities and problems in the Philippines, pp. 481-491 In Conservation in Tropical South East Asia: Proceedings of the Conference on Conservation of Nature and Natural Resources in Tropical South East Asia (Bangkok, Nov. 29-Dec. 4, 1965), L.M. Talbot and M.H. Talbot (eds.) IUCN Publications new series No. 10, International Union for Conservation of Nature and Natural Resources, Morges, Switzerland.

Nagarajan, G., M.A. Quisumbing, and K. Otsuka. 1991. Land pawning in the Philippines: An exploration into the consequences of land reform regulations. The Developing Economies 29(2):125-144.

Nano, J.F. 1939. Kaingin laws and penalties in the Philippines. Philippine J. Forestry 2:87-92.

Nguu, N.V. and E.B. Corpuz. 1980. Resources, production activities and financial status of a kaingin farm, pp. 497-507 In Tropical Ecology and Development: Proceedings of the 5th International Symposium of Tropical Ecology, J.I. Furtado (ed.) International Soc. Tropical Ecology, Kuala Lumpur.

Nieto Aguilar, J. 1894. Mindanao. Su historia y geografia. Imprenta del Cuerpo Administrativo del Ejercito, Madrid.

Oldeman, L.R. 1984. Climate and agricultural land use in the Philippines, pp. 333-352 In Climate and Agricultural Land Use in Monsoon Asia, M.M. Yoshino (ed.) University Tokyo Press, Tokyo.

Owen, Norman G. 1982. Abaca in Kabikolan: prosperity without progress, pp. 191-218 In Philippine Social History: Global Trade and Local Transformations, Alfred W. McCoy and Ed. C. de Jesus (eds.) University Press of Hawaii, Ateneo de Manila University Press, Honolulu, HI. 
Pena, Antonio, 1921. Agricultural conditions in the Philippines, 1920. Philippine Agricultural Review 14(2):129-157.

Philippine Information Society. 1901. The Islands and the People: Facts about the Filipinos. Vol. I, Nos. 1-10, Philippine Information Society, Boston, MA.

Philippines (Commonwealth) Acting Collector of Internal Revenue, 1910. The area of land actually cultivated with sugar cane in 1908 and the area of land adapted to such cultivation, by provinces.

Philippine Agricultural Review 3(5):293.

Philippines (Commonwealth) Bureau of Agriculture, 1911. Live stock and poultry in the Philippine Islands, with Appendices 1-5. Philippine Agricultural Review 4(9) (Live-Stock Number):470-525.

Philippines (Commonwealth) Dept. of Agriculture and Commerce, Division of Statistics. 1933. Statistical Handbook of the Philippine Islands 1932, First Number. Bureau of Printing, Manila.

Philippines (Commonwealth) Commission of the Census. 1943. Census of the Philippines: 1939, Vol. IV: Reports for Economic Census. Chapter I -Forestry. Govt. of the Philippines, Washington, DC.

Philippines (Republic) Bureau of the Census and Statistics. 1947. Yearbook of Philippines Statistics 1946. Bureau of Printing, Manila.

Philippines (Republic) Bureau of the Census and Statistics. 1948. Facts and Figures about Economic and Social Conditions of the Philippines 1946-1947. Bureau of Printing, Manila.

Philippines (Republic) Bureau of the Census and Statistics. 1951. 1948 Census of the Philippines. Population Classified by Province, by City, Municiopality, and Municipal District, and by Barrio. Bureau of Printing, Manila.

Philippines (Republic) Bureau of the Census and Statistics. 1960. Handbook of Philippine Statistics 1903-1959. Bureau of Printing, Manila.

Philippines (Republic) Bureau of the Census and Statistics. 1961. Census of the Philippines: 1960. Population and Housing. Vol. II, Summary Report, Bureau of Printing, Manila.

Philippines (Republic) Bureau of the Census and Statistics. 1970. Philippine Statistics, 1969 Yearbook. Bureau of the Census and Statistics, Manila.

Philippines (Republic) Bureau of the Census and Statistics. 1973. Philippine Statistics, 1971 Yearbook. Bureau of the Census and Statistics, Manila.

Philippines (Republic) Bureau of the Census and Statistics. 1973. 1971 Philippine Yearbook Supplement. Bureau of the Census and Statistics, Manila. 
Philippines (Republic) Bureau of Forest Development. 1983. 1983 Annual Report. Philippines Ministry of Natural Resoruces, Bureau of Forest Development, Manila.

Philippines (Republic) Bureau of Forest Development. 1985. 1985 Philippine Forestry Statistics. Philippines Ministry of Natural Resources, Bureau of Forest Development, Manila.

Philippines (Republic) Bureau of Forest Development. 1986. 1986 Philippine Forestry Statistics. Philippines Ministry of Natural Resources, Bureau of Forest Development, Manila.

Philippines (Republic) National Economic and Development Authority. 1980-1983. Philippine Statistical Yearbook. Bureau of the Census and Statistics, Manila.

Philippines (Republic) National Statistical Coordination Board. 1989-1990. Philippine Statistical Yearbook. Bureau of the Census and Statistics, Manila.

Philippines (Republic) Parks and Wildlife Office. 1968. Status of conservation in the Philippines, pp. 468-480 In Conservation in Tropical South East Asia: Proceedings of the Conference on Conservation of Nature and Natural Resources in Tropical South East Asia (Bangkok, Nov. 29-Dec. 4, 1965), L.M. Talbot and M.H. Talbot (eds.) IUCN Publications new series No. 10, Intemational Union for Conservation of Nature and Natural Resources, Morges, Switzerland.

Philippines (Republic) Secretary of Agriculture and Natural Resources. 1950. Annual Report of the Secretary of Agriculture and Natural Resources for the Fiscal Year Ending June 30, 1949. Bureau of Printing, Manila.

Philippines (Republic) Secretary of Agriculture and Natural Resources. 1964. Annual Report of the Secretary of Agriculture and Natural Resources for the Fiscal Year Ending June 30, 1949. Dept. Agriculture and Natural Resources, Quezon City.

Piper, C.V. 1911. Forage crops and forage conditions in the Philippines. Philippine Agricultural Review 4(8):394-414.

Porter, G., with D.J. Ganapin, Jr. October 1988. Resources, Population, and the Philippines' Future: a Case Study. WRI Paper 4, World Resources Institute, Washington, DC.

Prantilla, E.B. 1982. Regional development planning in the Philippines: issues and prospects, pp. 53-121 In Rural Development and Regional Planning in the '80's: Challenges and Priorities. Asian Institute of Technology, Human Settlements Div., Bangkok.

Prill-Brett, J. 1986. The Bontok: traditional wet-rice and swidden cultivators of the Philippines, pp. 54-83 In Traditional Agriculture in Southeast Asia: A Human Ecology Perspective, G.G. Marten (ed.) Westview Press, Boulder, CO. 
Quisumbing, E. 1965. The vegetation of Batan and Babuyan Islands, pp. 31-38 In Symposium on Ecological Research in Humid Tropics Vegetation. Govt. of Sarawak and UNESCO, Kuching.

Rabor, D.S. 1980. Present status of Philippine ecosystems and the effects of the various changes on wildlife, pp. 267-277 In Tropical Ecology and Development: Proceedings of the 5th International Symposium of Tropical Ecology, J.I. Furtado (ed.) International Soc. Tropical Ecology, Kuala Lumpur.

Revilla, A.V. Jr. 1981. Land assessment and management for sustainable uses in the Philippines, pp. 277-288 In Assessing Tropical Forest Lands: Their Suitability for Sustainable Uses, R.A. Carpenter (ed.) Tycooly International Publ. Ltd, Dublin.

Reyes, M.R. and V.B. Mendoza. 1983. Pantabangan Watershed Management and Erosion Control Project, pp. 485-555 In Forest and Watershed Development and Conservation in Asia and the Pacific, L.S. Hamilton (ed.) Westview Press for East-West Environment and Policy Institute, Boulder, CO.

Reyes, M.R. 1959. Natural regeneration of the Philippine dipterocarp forest. Philippine J. Forestry 15:39-61.

Reyes, M.R. 1978. Philippine forest resources. Malaysian For. 4(2):104-113.

Roth, D. 1983. Philippine forests and forestry: 1565-1920, pp. 33-49 In Global Deforestation and the Nineteenth Century World Economy, Tucker, R. and J.F. Richards (eds.) Policy Studies, Duke Press, Durham, NC.

Roth, D.M. 1982. Church lands in the agrarian history of the Tagalog region, pp. 131-153 In Philippine Social History: Global Trade and Local Transformations, A.W. McCoy and E.C. de Jesus (eds.) University Press of Hawaii, Ateneo de Manila University Press, Honolulu, HI.

Sagrado, M.J. 1972. Debardage par cable dans les regions montagneuses des Philippines. Bois et Forests des Tropiques 144:67-71.

Sajise, P.E. and E.A. Omegan. 1990. The changing upland landscape of the Northem Philippines, pp. 56-68 In Keepers of the Forest: Land Management Alternatives in Southeast Asia, M. Poffenburger (ed.) Kumarian Press, West Hartford, CT.

San Buenaventura, P. 1958. Reforestation of Imperata waste lands in the Philippines. Philippine J. Forestry 14:67-75.

Schlegel, S.A. 1979. Tiruray Subsistence: From Shifting Cultivation to Plow Agriculture. Ateneo de Manila University Press, Quezon City.

Schneider, E.E. 1916. Commercial Woods of the Philippines: Their Preparation and Uses. Bulletin No. 14, Dept. of the Interior, Bureau of Forestry, Bureau of Printing, Manila. 
Scott, W.H. 1982. The Spanish occupation of the Cordillera in the 19th century, pp. 39-55 In Philippine Social History: Global Trade and Local Transformations, A.W. McCoy and E.C. de Jesus (eds). University Press of Hawaii, Ateneo de Manila University Press, Hcnolulu, HI.

Serevo, T.S. 1959. Classification of public forests based on use. Philippine J. Forestry 15:73-84.

Sherard, Sam H. 1911. Agricultural conditions in the province of Nueva Ecija. Philippine Agricultural Review 4(3):130-138.

Smith, I.R. 1980. Traditional fisheries development in the Philippines, pp. 1135-1140 In Tropical Ecology and Development: Proceedings of the 5th International Symposium of Tropical Ecology, J.I. Furtado (ed.) International Soc. of Tropical Ecology, Kuala Lumpur.

Sulit, C. 1959. Brief history of forestry and lumbering in the Philippines. Philippine J. Forestry 15:151-160.

Tamesis, F. 1938. Forestry and its relation to our national development program. Philippine J. Forestry 1:113-123.

Tamesis, F. 1938. Present problems of the lumber industry. Philippine J. Forestry 1:343-346.

Tamesis, F. and V. Sajor, 1953. Forest grazing in the Philippines. Philippine J. Forestry 9:3-8.

Umali, Ricardo M. 1981. Forest land assessment and management for sustainable uses in the Philippines, pp. 289-304 In Assessing Tropical Forest Lands: Their Suitability for Sustainable Uses, R.A. Carpenter (ed.) Tycooly Intemational Publ. Ltd, Dublin.

U.S. Bureau of the Census. 1905. Census of the Philippine Islands Taken Under the Direction of the Philippine Commission in the Year 1903. 4 Vols., Washington, DC.

U.S. Dept. of the Interior. 1939. The Philippines. 2nd edition, National Information Office, Washington, DC.

Utleg, J.L. 1958. Broad land use classification in the Philippines. Philippine J. Forestry 14:33-57.

Utleg, J.L. 1960. Broad land use classification in the Philippines, pp. 91-105 In Proceedings of the 9th Pacific Science Congress of the Pacific Science Association, Vol. 18: Soil and Land Classification. Secretariat, 9th Pacific Science Congress, Bangkok.

Valdepenas Jr., V. and G.M. Bautista. 1977. The Emergence of the Philippine Economy. Papyrus Press, Manila.

Velasco, A.B. 1980. Socio-cultural factors influencing the utilization of mangrove resources in the Philippines: fishpond vs other uses, pp. 1185-1193 In Tropical Ecology and Development: Proceedings of the Sth International Symposium of Tropical Ecology, J.I. Fuitado (ed.) Intemational Soc. Tropical Ecology, Kuala Lumpur. 
Velasco, J.R. and J.V. Santos. 1973. Destruction and renewal of lowland forests in the Philippines, pp. 118-130 In Symposium on Planned Utilization of the Lowland Tropical Forests (Cipayung, Bogor, August, 1971). BIOTROP-SEAMEO Regional Center for Tropical Biology, Bogor, Java.

Viado, J., M.R. Reyes, P.P. Andres, and A.V. Glori. 1975. Country Report: Philippines, pp. 38-53 In The Use of Ecological Guidelines for Development in the Tropical Forest Areas of South East Asia. IUCN Publications new series No. 32, Intermational Union for Conservation of Nature and Natural Resources, Morges, Switzerland.

Viloria, L.A. 1982. Rural development and regional planning in the Philippines, pp. 31-52 In Rural Development and Regional Planning in the '80's: Challenges and Priorities. Asian Institute of Technology, Human Settlements Div., Bangkok.

Volatron, B. 1975. Les industries du bois aux Philippines en 1975 (The timber industries in the Philippines in 1975). Bois et Forests des Tropiques 164:63-74.

Wemstedt, F.L. and J.E. Spencer. 1967. The Philippine Island World: A Physical, Cultural and Regional Geography. University California Press, Berkeley, CA.

Wester, P.J. 1920. A review of Philippine agriculture and Philippine trade opportunities in the United States. Philippine Agricultural Review 13(1):5-24.

Wester, P.J. 1921. The food plants of the Philippines. Philippine Agricultural Review 14:211-384.

Wester, P.J. 1921. Mindanao: some suggestions relative to economic development. Philippine Agricultural Review 14:195-201.

Whitford, H.N. 1911. The Forests of the Philippines. Part I. Forest Types and Products. Bulletin No. 10, Dept. of the Interior, Bureau of Forestry, Bureau of Printing, Manila.

Whitford, H.N. 1909. Studies in the vegetation of the Philippines. I. The composition and volume of the dipterocarp forests of the Philippines. Philippines J. Science, Sec. C-4, pp. 699-725.

Wright, H.M. 1907. A Handbook of the Philippines. A. McClurg and Co., Chicago, IL.

Zamora, P. 1984. Philippine mangroves: assessment of status, environmental problems, conservation and management strategies, pp. 696-707 In Proceedings of the Asian Symposium on Mangrove Environment Research and Management (Kuala Lumpur, August, 1980), E. Soepadmo, A.N. Rao, and D.J. Maclntosh (eds.) University Malaya and UNESCO, Kuala Lumpur. 


\subsubsection{Singapore}

Cameron, J. 1865. Our Tropical Possessions in Malayan India: Being a Descriptive Account of Singapore, Penang, Province Wellesley, and Malacca; Their Peoples, Products, Commerce, and Government Smith Elder and Co. Reprinted 1965 by Oxford University Press, London.

Charter, J.R.N. 1928. Forestry in the State of Johore. A Statement Prepared for the British Empire Forestry Conference, Australia and New Zealand. Govt. Printing Office, Kuala Lumpur.

Chew, E.C.T. and E. Lee (eds.) 1991. A History of Singapore. Oxford Univ. Press, Singapore.

Corlstt, R.T. 1988. Bukit Timah: the history and significance of a small rain-forest reserve. Environmental Conservation 15(1):37-44.

Comer, E.J.H. 1978. The Freshwater Swamp-forest of South Johore and Singapore. Gardens' Bulletin Supplement No. 1, Singapore Botanic Gardens, Parks and Recreation Dept., Singapore.

Cubitt, G.E.S. 1920. Forestry in the Malay Peninsula. A Statement Prepared for the British Empire Forestry Conference, London, 1920. Federated Malay States Govt. Printing Office, Kuala Lumpur.

Cubitt, G.E.S. 1924. Forestry in the Malay Peninsula. A Statement Prepared for the British Empire Forestry Conference, Canada, 1923. Federated Malay States Govt. Printing Office, Kuala Lumpur.

Cubitt, G.E.S. and J.G. Watson. 1928. Forestry in the Federated Malay States and Straits Settlements. A Statement Prepared for the British Empire Forestry Conference, Australia and New Zealand, 1928. Federated Malay States Govt. Printing Office, Kuala Lumpur.

Federated Malay States. 1898-1920. Annual Report of the Federated Malay States (1896 - 1919). British Sessional Papers, H.M.S.O., London.

Federated Malay States. 1911. The Chief Secretary's Report for the Year 1910. Cmd. liii. 301, H.M.S.O., London.

Federated Malay States. 1921-1925. Report of the Chief Secretary for the Year (annual 1920 1924). Federated Malay States Printing Office, Kuala Lumpur.

Federated Malay States Census Office. 1922. The Census of British Malaya (the Straits Settlements, Federated Malay State and Protected States of Johore, Kedah, Perlis, Kelantan, Trengganu, and Brunei) 1921. Waterlow, London.

Federated Malay States Dept. of Agriculture. 1921. The Agricultural Bulletin of the Federated Malay States. Vol. 9, Dept. of Agriculture, Federated Malay States, Kuala Lumpur. 
Federated Malay States Dept. of Agriculture. 1939. Reports of the Field Branch for the Year 1938. Charles Grenier and Son, Ltd., Kuala Lumpur.

Federated Malay States Forest Dept. 1919-1935. Report on Forest Administration for the Year (annual 1918 - 1934). Federated Malay States Govt. Press, Kuala Lumpur.

Federated Malay States Forest Dept. 1936-1941. Report on Forest Administration in Malaya, Including Brunei, for the Year (annual 1935 - 1940). Federated Malay States Govt. Press, Kuala Lumpur.

Federated Malay States Superintendent of the Census. 1932. A Report of the 1931 Malayan Census. Crown Agents for the Colonies, London.

Fryer, D.W. 1970. Malaysia and Singapore, Chapter 6 In Emerging Southeast Asia: A Study in Growth and Stagnation, D. Fryer (ed.) McGraw-Hill Book Company, New York.

Gilliland, H.B. 1961. Progress with Vegetation Studies: Brunei, North Bomeo, Sarawak and Singapore, pp. 12-14 In Proceedings of the Symp. on Humid Tropics Vegetation (Tjiawi, December, 1958). UNESCO Science Cooperation Office for South East Asia, Jakarta.

Graham, W.A. 1914. British possessions in the Malay Peninsula, pp. $371-413$ In The Oxford Survey of the British Empire, Asia, Including the Indian Empire and Dependencies, Ceylon, British Malaya and Far Eastern Possessions, A.J. Herbertson and O.J.R. Howarth (eds.) Clarendon Press, Oxford.

Hamzah b. Sendut 1964. Atlas Menengah Melayu. Siri Buku Sekolah DBP Bill. 94, MarchandPaap-Strooker N.V. for Dewan Bahasa Dan Pustaka, The Hague.

Hanna, W.A. 1973. Singapore success syndrome retested. Part II: space shortages. Southeast Asia Series Vol. XXI, No. 5, American Universities Field Staff Report, Singapore.

Ho, R. 1962. Mixed-farming and multiple-cropping in Malaya. J. Tropical Geography 16:1-17.

Holttum, R.E. 1953. Adinandra belukar: a succession of vegetation from bare ground on Singapore Island. Malayan J. Tropical Geography 3:27-32.

King, A.W. 1939. Plantation and agriculture in Malaya, with notes on the trade of Singapore. Geographical J. 93:136-148.

Macfarlane, H. 1914. Statistics, pp. 463-484 In The Oxford Survey of the British Empire, Asia, Including the Indian Empire and Dependencies, Ceylon, British Malaya and Far Eastern Possessions, A.J. Herbertson and O.J.R. Howarth (eds.) Clarendon Press, Oxford.

Mackenzie, K.E. 1952. Malaya: Economic and Commercial Conditions in the Federation of Malaya and Singapore. Her Majesty's Stationery Office (for Great Britain Board of Trade, Commercial Relations and Exports Dept.), London. 
McGee, T.G. 1964. Population: a preliminary analysis, pp. 67-81 and 411-413 In Malaysia: $a$ Survey, Wang Gungwu (ed.) Frederick A. Praeger Publishers, New York.

Purseglove, J.W. 1958. A note on the vegetation of humid tropics with special reference to Singapore, pp. 84-88 In Study of Tropical Vegetation: Proceedings of the Kandy Symposium. UNESCO, Paris.

Saw Swee-Hock. 1970. Singapore: Population in Transition. Univ. Pennsylvania Press, Philadelphia, PA.

Singapore Chief Statistician. 1967-1970. Yearbook of Statistics Singapore (annual 1967 - 1970). Dept. of Statistics, Singapore.

Singapore Chief Statistician. 1972. Yearbook of Statistics Singapore 1971/72. Dept. of Statistics, Singapore.

Singapore Chief Statistician. 1978. Yearbook of Statistics Singapore 1977/78. Dept. of Statistics, Singapore.

Singapore Chief Statistician. 1982, 1983. Yearbook of Statistics Singapore (annual 1981/82 and 1982/83). Dept. of Statistics, Singapore.

Singapore Dept. of Statistics. 1990, 1991. Yearbook of Statistics Singapore (annual 1990 and 1991). Dept. of Statistics, Singapore.

Straits Settlements and Federated Malay States. 1932-1936. Malayan Agricultural Statistics (annual 1931-1935). Dept. of Agriculture, Caxton Press, Kuala Lumpur.

Straits Settlements. 1892-1920. Annual Report on the Straits Settlements (annual 1890 - 1919). Published as Papers by Command in Great Britain, Parliament, House of Commons, British Sessional Papers, H.M.S.O., London.

Straits Settlements. 1902-1922. Report on the Blue Book of the Straits Settlements (annual 19011921). Govt. Printing Office, Singapore.

Straits Settlements. 1905, 1914-15, 1931. Annual Departmental Reports, 1903, 1913, 1914, 1930. Govt. Printing Office, Singapore.

Straits Settlements. 1940. Report on the Blue Book of the Straits Settlements, 1938. Govt. Printing Office, Singapore.

Tufo, M.V. del. 1949. A Report on the 1947 Census of Population, Comprising the Federation of Malaya and the Colony of Singapore. Superintendent of the Census, Fed. Malaya, Crown Agents for the Colonies, London.

Tumbull, C.M. 1980. A Short History of Malaysia, Singapore and Brunei. Cassell Australia Ltd., Stanmore, Australia. 
Tumbull, C.M. 1989. A History of Singapore 1819-1988. 2nd edition, Oxford Univ. Press, Singapore.

Uhart, E. 1972. Les industries du bois a Singapore (The Timber Industries in Singapore). Bois et Forests des Tropiques 146: 21-30.

Weld, F.A. 1884. The Straits Settlements and British Malaya, pp.43-90 In Honorable Intentions: Talks on the British Empire in South-East Asia (delivered at the Royal Colonial Institute, 1874-1928), P.H. Kratoska (ed.) Republished 1983 by Oxford University Press, Singapore.

Whitmore, T.C. 1978. The forest ecosystems of Malaysia, Singapore and Brunei: description, functioning and research needs, pp. 641-53 In Tropical Forest Ecosystems: A State-of-Knowledge Report. UNESCO/UNEP/FAO, Paris.

Whitmore, T.C. 1984. A vegetation map of Malesia at scale 1:5 million. J. Biogeography $11: 461-471$.

Whitmore, T.C. 1984. Tropical Rain Forests of the Far East. 2nd edition, Clarendon Press, Oxford.

Wray, L. 1874. Settlements on the Straits of Malacca, pp. 19-41 In Honorable Intentions: Talks on the British Empire in South-East Asia (delivered at the Royal Colonial Institute, 1874-1928), P.H. Kratoska (ed.) Republished 1983 by Oxford University Press, Singapore. 


\subsubsection{Sri Lanka}

Abeywickrama, B.A. 1961. The vegetation of the lowlands of Ceylon in relation to soll, pp. 87-92 In Tropical Soils and Vegetation: Proceedings of the Abidjan Symposium. UNESCO, Paris.

Adam, W.G. 1934. Moving swamps in Ceylon. Geographical J. 83:321-323.

Amarasinghe, L. and M.A. Pemadasa. 1982. The ecology of a montane grassland in Sri Lanka. II. The pattem of four major species. J. Ecology 70:17-23.

Amarasinghe, L. and M.A. Pemadasa. 1982. The ecology of a montane grassland in Sri Lanka. IV. Vegetative growth of four major grasses. J. Ecology 70:721-730.

Andrews, J.R.T. 1961. A Forest Inventory of Ceylon, prepared by Hunting Survey Corp. Lid., in co-operation with the Forest Department, Ceylon. Govt. Press, Ceylon Colombo.

Arulchelvam, L. 1968. Mangroves. Ceylon For. 8:59-92.

Baker, J.R. 1937. The Sinharaja rain-forest, Ceylon. Geographical J. 89:539-551.

Bansil, P.C. 1971. Ceylon Agriculture: A Perspective. Dhanpat Rai and Sons, Delhi.

Broun, A.F. 1901. The forests and waste lands of Ceylon. Indian For. 27:199-206.

Ceylon Dept. of Statistics and Office Systems. 1870-1938. The Ceylon Blue Book (annual, 1870-1938). Ceylon Govt. Press, Colombo.

Ceylon Dept. of Census and Statistics. 1951. Census of Ceylon 1946. Vol. I, Part II Statistical Digest, Ceylon Govt. Press, Colombo.

Ceylon Dept. of Census and Statistics. 1949-1966. Statistical Abstract of Ceylon (annual, 1949-1966). Govt. Printing, Ceylon, Colombo.

Ceylon Dept. of Census and Statistics. 1956. Ceylon Census of Agriculture, 1952. Vol. I, Part I Tea Plantations, Govt. Press, Colombo.

Ceylon Dept. of Census and Statistics. 1956. Ceylon Census of Agriculture, 1952. Vol. I, Part II Rubber Plantations, Govt. Press, Colombo.

Ceylon Dept. of Census and Statistics. 1956. Ceylon Census of Agriculture, 1952. Vol. 1, Part III Coconut Plantations, Govt. Press, Colombo.

Ceylon Dept. of Census and Statistics. 1956. Ceylon Census of Agriculiure, 1952. Vol. I, Pant IV Agriculture, Govt. Press, Colombo. 
Ceylon Dept. of Census and Statistics. 1965. Ceylon Census of Agriculture, 1962. Vol. 1, Agricultural Land, Agricultural Operators and Tenure, Govt. Press, Colombo.

Ceylon Dept. of Census and Statistics. 1966. Ceylon Census of Agriculture, 1962. Vol. II, Land Utilization, Govt. Press, Colombo.

Ceylon Dept. of Census and Statistics. 1966. Ceylon Census of Agriculture, 1962. Vol. III, Asweddumized Paddy Lands, Govt. Press, Colombo.

Ceylon Dept. of Census and Statistics. 1968-1972. Statistical Abstract of Ceylon (annual, 1967/68, 1969, 1970/71). Govt. Printing, Colombo.

Ceylon Dept. of Census and Statistics. 1974. The Population of Sri Lanka. Dept. of Census and Statistics, Colombo.

Ceylon Dept. of Commerce and Industries. 1924-1927. Annual General Report on the Economic, Social and General Conditions of the Island (for 1923-1926). Govt. Printer, Colombo.

Ceylon Dept. of Statistics and Office Systems. 1928. Annual General Report on the Economic, Social and General Conditions of the Island for 1927. Govt. Printer, Colombo.

Chapman, V.J. 1947. The application of aerial photography to ecology as exemplified by the natural vegetation of Ceylon. Indian For. 73:287-314.

Comanor, P.L. 1971. An analysis of the woody scrub vegetation of Ruhuna National Park, Ceylon. Tropical Ecology 12:209-222.

Decamps, A. 1953. The forest in relation to man, with special reference to the dry zone of Ceylon. Ceylon For. 1(1):4-5.

de Alwis, K.A. and G.J. Eriyagama. 1969. Some observations on soil-vegetation relationships in the lowland dry zone of Ceylon. Ceylon For. 9:53-76.

de Rosayro, R.A. 1945-1946. The montane grasslands (patanas) of Ceylon: an ecological study with reference to afforestation. Tropical Agriculturist 101:208-213; 102:4-10; 102:81-94; 102:139-147.

de Rosayro, R.A. 1950. Ecological conceptions and vegetation types with special reference to Ceylon. Tropical Agriculturist 106:108-121.

de Rosayro, R.A. 1953. Ecological considerations in the management of wet evergreen forests in Ceylon. Ceylon For. 1:80-90.

de Rosayro, R.A. 1954. A reconnaissance of Sinharaja rain forest. Ceylon For. 1:68-73. 
de Rosayro, R.A. 1955. The silviculture and management of tropical rain forest with special reference to Ceylon. Ceylon For. 1:5-26.

de Rosayro, R.A. 1957. The silviculture and management of tropical rain forest with special reference to Ceylon, pp. 79.100 In Tropical Silviculture, Vol. II. FAO Forestry and Forest Products Studies No. 13, FAO, Rome.

de Rosayro, R.A. 1957. Afforestation for protection and conservation in the up-country patanas. Ceylon For. 3:50-68.

de Rosayro, R.A. 1958a. Tropical ecological studies in Ceylon, pp. 33-39 In Study of Tropical Vegetation: Proceedings of the Kandy Symposium. UNESCO, Paris.

de Rosayro, R.A. 1958b. The climate and vegetation of the Knuckles region of Ceylon. Ceylon For. 3:201-260.

de Rosayro, R.A. 1960. Recent advances in the application of aerial photography to the study of tropical vegetation, pp. 75-117 In Proceedings of the Symposium on Humid Tropics Vegetation (Tjiawl, December, 1958). UNESCO, Bangkok.

de Rosayro, R.A. 1959. The application of aerial photography to stock mapping and inventories on an ecological basis in rain forest in Ceylon. Empire Forestry Review 38:141-174.

de Rosayro, R.A. 1960. The nature and origin of secondary vegetational communities in Ceylon. Ceylon For. 5:23-50.

de Rosayro, R.A. 19in. Recent advances in the application of aerial photography to the study of tropical vegetation, pp. $1 \%-117$ In Proceedings of the Symposium on Humid Tropics Vegetation (Tjiawi, December, 1958). UNESCO, Bangkok.

de Silva, S.F. 1954. A Regional Geography of Ceylon. Rev. edition, Colombo Apothecaries Co., Colombo.

Dittus, W.P.J. 1977. The ecology of a semi-evergreen forest community in Sri Lanka. Biotropica 9:268-286.

Dittus, W.P.J. 198.5. The influence of cyclones on the dry evergreen forest of Sri Lanka. Biotropica 17:1-14.

Dommes, M. 1984. Climate and Agricultural Land Use in Sri Lanka, pp. 203-229 In Climate and Agricultural Land Use in Monsoon Asia, M. Yoshino (ed.) University Tokyo Press, Tokyo.

Eriyagama, G.J. 1961. The semi-arid vegetation in Mannar region: a note on its ecological significance. Ceylon For. 5:66-72.

Farmer, B.H. 1956. Society and the land: with special reference to Ceylon. Ceylon For. 2:102-110. 
Ferguson, A.M. (comp.) 1868. The Ceylon Directory; Calendar; and Compendium of Useful Information for 1866-68. Observer Press, Colombo.

Ferguson, A.M. and J. Ferguson (comp.) 1881. The Ceylon Directory; Calendar; and Compendium of Useful Information for 1880-81. Observer Press, Colombo.

Ferguson, A.M. and J. Ferguson.(comp.) 1886. The Ceylon Directory; Calendar; and Compendium of Useful Information 1885-86 to which is prefixed a Review of the Planting Enterprise and Agriculture of the Colony, with Statistical Information Referring to the Planting Enterprise in Other Countries. A.M. and J. Ferguson, Colombo.

Ferguson's Ceylon Directory. 1923. Directory; Calendar; and Compendium of Useful Information 1923. Compiled and edited by Ceylon Observer Staff, Ceylon Observer Press. Colombo.

Ferguson's Ceylon Directory. 1952. Directory; Calendar; and Compendium of Useful Information 1952. Compiled and edited by Ceylon Observer Staff, Ceylon Observer Press, Colombo.

Ferguson's Ceylon Directory. 1956. Directory; Calendar; and Compendium of Useful Information 1956. Ceylon Observer Press, Colombo.

Ferguson's Ceylon Directory. 1968. Directory; Calendar; and Compendium of Useful Information 1968. Associated Newspapers of Ceylon Ltd., Colombo.

Ferguson's Ceylon Directory. 1969-70. Directory; Calendar; and Compendium of Useful Information 1969-70. Associated Newspapers of Ceylon Ltd., Colombo.

Ferguson's Ceylon Directory. 1979-81. Directory; Calendar; and Compendium of Useful Information 1979-81. Associated Newspapers of Ceylon Ltd., Colombo.

Femando, C.H. and S.S. de Silva. 1984. Man-made lakes: ancient heritage and modem biological resource, pp. 431-447 In Ecology and Biogeography in Sri Lanka, C.H. Fernando (ed.) Dr. W. Junk Publishers, The Hague.

Femando, N.N. 1968. The Natural Vegetation of Ceylon. Swabhasha Printers, Colombo.

Fosberg, F.R. 1987. A living museum of Ceylon trees. Environmental Conservation 14:79.

Galapitage, Vinod. 1987. Conservation and development of natural resources of Sri Lanka, pp. 182-190 In Environmental Education for Conservation and Development, D. Bandhu and G. Berberet (eds.) Indian Environmental Society.

Gaussen, H., P. Legris, M. Viart, and L. Labroue. 1964. Carte internationale du tapis vegetal et des conditions ecologiques a $1 / 1.000 .000$. Ceylon (International Map of the Vegetation and of Environmental Conditions at Scale 1:1,000,000. Ceylon). Institut Francais de Pondichery, Pondichery. 
Geiser, U. and M. Sommer. 1984. Seasonal mapping of productive rice land using remote sensing: an intermediate technology approach in Sri Lanka, pp. 187-201 In Applications of Remote Sensing for Rice Production, A. Deepak and K.R. Rao (eds.) A. Deepak Publ., New York.

Geiser, U., M. Sommer, and A.N.S. Baminiwatte. 1980. Forest cover mapping and monitoring using satellite images (the approach of a Sri Lanka-Swiss Project). Sri Lanka For. 14:131-144.

Greller, A.M. and S. Balasubramaniam. 1980. A preliminary floristic-climate classification of the forests of Sri Lanka. Sri Lanka For. 14:163-169.

Greller, A.M. and S. Balasubramaniam. 1988. Vegetational composition, leaf size, and climatic warmth in an altitudinal sequence of evergreen forests in Sri Lanka (Ceylon). Tropical Ecology 29:121-145.

Greller, A.M., C.V.S. Gunatilleke, I.A.U.N. Gunatilleke, and S. Balasubramaniam. 1980. A phytosociological analysis of three stands of forest in the vicinity of Peradeniya, Kandy District. Sri Lanka For. 14:153-161.

Gunatilleke, C.V.S. and I.A.U.N. Gunatilleke. 1980. The floristic composition of Sinharaja -a rain forest in Sri Lanka with special reference to endemics. Sri Lanka For. 14:171-180.

Gunatilleke, C.V.S. and I.A.U.N. Gunatilleke. 1983. Forestry case study of the Sinharaja Rainforest in Sri Lanka, pp. 289-258 In Forest and Watershed Development and Conservation in Asia and the Pacific, L.S. Hamilton (ed.) Westview Press for the East-West Environment and Policy Institute, Boulder, $\mathrm{CO}$.

Hewawasam, H.T. 1987. Environmental problems and their mitigation through upgrading environmental education in Sri Lanka, pp. 164-181 In Environmental Education for Conservation and Development, D. Bandhu and G. Berberet (eds.) Indian Environmental Society.

Holmes, C.H. 1951. The Grass, Fern and Savannah Lands of Ceylon, their Nature and Ecological Significance. Institute Paper No. 28, Imperial Forestry Institute, Oxford.

Holmes, C.H. 1956-1957. The natural regeneration of the wet and dry evergreen forests of Ceylon. Ceylon For. 2:153-167; 3:15-41; 3:111-127.

Holmes, C.H., 1958. The broad pattern of climate and vegetational distribution in Ceylon, pp. 99-114 In Study of Tropical Vegetation: Proceedings of the Kandy Symposium. UNESCO, Paris.

Jayasuriya, A.H.M. and M.A. Pemadasa. 1983. Factors affecting the distribution of tree species in a dry zone montane forest in Sri Lanka. J. Ecology 71:571-583.

Koelmeyer, K.O. 1957-1958. Climatic classification and the distribution of vegetation in Ceylon. Ceylon For. 3:144-163; 3:265-288.

Koelmeyer, K.O. 1958. Teak plantations in Ceylon. Ceylon For. 3:178-184. 
Legris, P. and M. Viart. 1959. Documentation and method proposed for vegetation mapping at one millionth scale in India and Ceylon. Institut Francais de Pondichery, Travaux de la Section Scientifique et Technique, T. I Fasc. IV, Imprimerie de la Mission, Pondichery.

McCormack, R.J. and A.K. Pillai. 1961. A Forest Inventory of the Kantalai Forest Reserve, Ceylon (Prepared by Hunting Survey Corporation, Toronto, Canada in co-operation with the Ceylon Forest Dept.). Canada-Ceylon Colombo Plan Project, Govt. Press, Colombo.

McCormack, R.J. and A.K. Pillai. 1961. A Forest Inventory of the Kumbukkan Forest Reserve, Ceylon (Prepared by Hunting Survey Corporation, Toronto, Canada in co-operation with the Ceylon Forest Dept.). Canada-Ceylon Colombo Plan Project, Govt. Press, Colombo.

McCormack, R.J. and A.K. Pillai. 1961. A Forest Inventory of the Teravil-Odosuddan Forest Reserve, Ceylon (Prepared by Hunting Survey Corporation, Toronto, Canada in co-operation with the Ceylon Forest Dept.). Canada-Ceylon Colombo Plan Project, Govt. Press, Colombo.

McNeill, W.M. 1937. Jak (Artocarpus integrifolia) plantations in Ceylon. Indian For. 63:380-399.

McNeill, W.M. 1939. Land planning in Ceylon with special reference to the selection and reservation of forest areas. Empire Forestry J. 18:65-76.

Merritt, V.G. and M.S. Ranatunga. 1959 The forests of the Kirindi Oya Basin -a reconnaissance report. Ceylon For. 4:7-38.

Merritt, V.G. and M.S. Ranatunga. 1959 Aerial photographic survey of Sinharaja Forest. Ceylon For. 4:103-156.

Mueller-Dombois, D. 1968. Ecogeographic analysis of a climate map of Ceylon with particular reference to vegetation. Ceylon For. 8:1-20.

Mueller-Dombois, D. 1981. Sri Lanka, pp. 137-175 In Tropical Ecosystems, Fire Regimes and Ecosystem Properties: Proceedings of the Conference, H. A. Mooney, T. M. Bonnicksen, N. L. Christensen, J.E. Lotan, and W.A. Reiners (eds.) General Technical Report WO-26, U.S. Dept. of Agriculture, Washington, DC.

Muttiah, S. 1965. A comparison of three repeated inventories of Sundapola mixed selection working circle and future management. Ceylon For. 7:3-35.

Nisbet, R.H.M. 1961. A Forest Inventory of the Hurulu Forest Reserve, Ceylon (Prepared by Hunting Survey Corporation, Toronto, Canada in co-operation with the Ceylon Forest Dept.). Canada-Ceylon Colombo Plan Project, Govt. Press, Colombo. 
Nisbet, R.H.M. 1961. A Forest Inventory of the Pallekele Forest Reserve, Ceylon (Prepared by Hunting Survey Corporation, Toronto, Canada in co-operation with the Ceylon Forest Dept.). Canada-Ceylon Colombo Plan Project, Govt. Press, Colombo.

Nisbet, R.H.M. 1961. A Forest Inventory of the Peak Wilderness-Agra Boparts Forest Area and Part of the Kelani Valley Forest Area, Ceylon (Prepared by Hunting Survey Corporation, Toronto, Canada in co-operation with the Ceylon Forest Dept.). Canada-Ceylon Colombo Plan Project, Govt. Press, Colombo.

Oudshoom, W. 1961. A Management Inventory of the Delwala-Walankanda Forest Reserve, Ceylon (Prepared by Hunting Survey Corporation, Toronto, Canada in co-operation with the Ceylon Forest Dept.). Canada-Ceylon Colombo Plan Project, Govt. Press, Colombo.

Oudshoom, W. 1961. A Forest Inventory of the Madhu Forest Reserve, Ceylon (Prepared by Hunting Survey Corporation, Toronto, Canada in co-operation with the Ceylon Forest Dept.). Canada-Ceylon Colombo Plan Project, Govt. Press, Colombo.

Panabokke, C.R. 1975. Erosion hazard and farming systems in the humid tropics of South Asia, pp. 213-219 In Soil Conservation and Management in the Humid Tropics, D.J. Greenland and R. Lal (eds.) John Wiley and Sons, New York.

Peebles, P. 1982. Sri Lanka: A Handbook of Historical Statistics. G.K. Hall and Co., Boston, MA.

Pemadasa M.A. 1983. Effects of added nutrients on the vegetation of two coastal grasslands in the dry-zone of Sri Lanka. J. Ecology 71:725-734.

Pemadasa, M.A. and L. Amarasinghe. 1982. The ecology of a montane grassland in Sri Lanka, Part I: Quantitative description of the vegetation. J. Ecology 70:1-15.

Perera, N.P. 1961. An economic study of the up-country forest plantations of Ceylon. Ceylon For. 5:82-100.

Perera, N.P. 1962. The development of forest plantations in Ceylon since the seventeenth century. Ceylon For. 5:142-157.

Perera, N.P. 1969. The ecological status of the montane grasslands (patanas) of Ceylon. Ceylon For. 9:27-45.

Perera, N.P. 1969. The ecological status of the savanna of Ceylon: 1. The upland savanna. Tropical Ecology 10:207-221.

Perera, N.P. 1974. Natural resources, settlements and land use, pp. 453-489 In Ecology and Biogeography in Sri Lanka, C.H. Femando (ed.) Dr. W. Junk Publishers, The Hague.

Perera, N.P. 1975. A physiognomic vegetation map of Sri Lanka (Ceylon). J. Biogeography 2:185-203. 
Perera, N.P. 1977. The development of the forest resources of Sri Lanka. Sri Lanka For. 13:5-8.

Perera, W.R.H. 1981. Forest land assessment and ,anagement for sustainable uses, Sri Lanka -country report, pp. 305-314 In Assessing Tropical Forest Lands: Their Suitability for Sustainable Uses, R.A. Carpenter (ed.) Tycooly Intemational Publ. Ltd., Dublin.

Preu, C. and W. Erdelen. 1992. Geoecological consequences of human impacts on forests in Sri Lanka, pp. 147-164 In Tropical Forests in Transition: Ecology of Natural and Anthropogenic Disturbance Processes, J.G. Goldammer (ed.) BirkhauserVerlag, Basel, Boston, MA.

Senaratna, S.D.J.E. 1958. Regional survey of the grasslands of Ceylon, pp. 175-182 In Study of Tropical Vegetation: Proceedings of the Kandy Symposium. UNESCO, Paris.

Silva, W.P.T. 1972. Tobacco cultivation as an alternative to chena cultivation in the Walapane Division of Ceylon, pp. 758-759 In International Geography, W. Peter Adams and Frederick M. Helleiner (eds.) University of Toronto Press, Toronto.

Soussan, J. and P. O'Keefe. 1985. Sri Lanka: energy, development and resource use. Ambio 14:245-248.

Sridas, S. 1964. Notes on a reconnaissance survey for the integrated development of the Walawe Basin of Ceylon. Ceylon For. 6:121-125

Sri Lanka Dept. of Census and Statistics. 1980. Census of Agriculture 1973 Sri Lanka. General Report, Dept. of Census and Statistics Printing Div., Colombo.

Sri Lanka Dept. of Census and Statistics. 1983-1986. Statistical Abstract of the Democratic Socialist Republic of Sri Lanka (annual, 1982-1985). Dept. of Govt. Printing, Sri Lanka, Colombo.

Sri Lanka Ministry of Agricultural Development and Research. 1981. Agricultural Statistics of Sri Lanka 1951/52 - 1980/81. Ministry of Agricultural Development and Research, Colombo.

Szechowycz, R.W. 1953. Forests in the catchment of the Gal Oya Reservoir. Ceylon For. 1:58-66.

Szechowycz, R.W. 1954. Some observations on climate, soil and forest climax. Ceylon For. 1:131-140.

Szechowycz, R.W. 1956. Some observations on the forests of Ceylon. Ceylon For. 2:192-198.

Szechowycz, R.W. 1961. The savanna forest of the Gal Oya Catchment (Ceylon). Ceylon For. 5:17-22.

Tansley, A.G. and F.E. Fritsch. 1905. Sketches of vegetation at home and abroad: I. The flora of the Ceylon littoral. New Phytologist 4:1-17; 27-55.

Tennent, J.E. 1860. An Account of the Island: Physical, Historical, and Topographical with Notices of its Natural History, Antiquities and Production. Colombo. 
Tisseverasinghe, A.E.K. 1954. Notes on forest law. Ceylon For. 1:112-130.

Tisseverasinghe, A.E.K. and S. Satchithananthan. 1957. The management of Sundapol Plantation. Ceylon For. 3:82-93.

Weeratna, W.G. 1957. Some growth data of teak in Ceylon. Ceylon For. 3:167-170.

Wijesinghe, L.C.A. 1962. Some aspects of land use in the dry montane grasslands. Ceylon For. 5:128-138.

Wijesinghe, L.C.A. de S. 1967. An experiment in the use of improved techniques in dry zone logging. Ceylon For. 8:23-32. 


\subsubsection{Thailand}

Aksomkoae, S. 1979. The energy relationships involved with the use of mangrove forest ecosystem of Thailand for energy and organics, pp. 99-107 In Biological and Sociological Basis for a Rational Use of Forest Resources for Energy and Organics: An International Workshop, S.G. Boyce (ed.) U.S. Dept. Agric., Forest Service, Southeastem Forest Exp. Stn., Asheville, NC.

Aksomkoae, S. and J. Kongsangchai. 1982. Mangrove Forest in Thailand. Royal Forest Dept., Bangkok.

Aksomkoae, S., S. Pribprom, A. Saraya, and J. Kongsangchai. 1986. Mangrove resources and the socio-economics of dwellers in mangrove forests in Thailand, pp. 11-43 In Man in the Mangroves: The Socio-Economic Situation of Human Settlements in Mangrove Forests, P. Kunstadter, E.C.F. Bird, and S. Sabhasri (eds.) United Nations University, Tokyo.

Andrews, J.M. 1935. Siam: 2nd Rural Economic Survey 1934-1935. Bangkok Times Press Ltd., Bangkok.

Arhabirama, A., D. Phantumvanit, J. Elkington, and P. Ingkasuwan. 1988. Thailand: Natural Resources Profile. Oxford University Press, Oxford.

Backer, M. de and K. Openshaw. 1972. Report to the Govt. of Thailand on Present and Future Forest Policy Goals in Thailand. A Timber Trends Study 1970-2000. Report No. TA 3156, United Nations Development Programme, Rome.

Bourgeois-Pichat, J. 1974. An attempt to appraise the accuracy of demographic statistics for an under-developed country: Thailand, pp. 1-31 In Perspective on Thai Population. Repon No. 11, Institute of Population Studies, Chulalongkom University, Bangkok.

Bourke-Borrowes, D.R.S. and Phya Daruphan Pitaks. 1930. Forestry, pp. 120-162 In Siam Nature and Industry. Ministry of Commerce and Communications, Bangkok.

Brown, I. 1988. The Elite and the Economy in Siam c. 1890-1920. Oxford University Press, Singapore.

Caldwell, J.C., 1967. The demographic structure, pp. 27-64 In Thailand: Social and Economic Studies in Development, T.H. Silcock (ed.) Australian National University Press and Duke University Press, Durham, NC.

Chapman, E.C. 1978. Shifting cultivation and economic development in the lowlands of Northem Thailand, pp. 222-235 In Farmers in the Forest: Economic Development and Marginal Agriculture in Northern Thailand, P. Kunstadter, E.C. Chapman, and S. Sabhasri (eds.) University Press Hawaii for East-West Institute, Honolulu, HI. 
Chapman, E.C. 1978. Upland development and prospects for the rural poor: experience in Northem Thailand, pp. 205-216 In Geography and the Environment in Southeast Asia: Proceedings of the Department of Geography and Geology Jubilee Symposium (Hong Kong, June, 1976), R.D. Hill and J.M. Bray (eds). Hong Kong University Press, Hong Kong.

Conservator of Forests, Siam. 1904. Forestry in Siam, pp. 173-181 In The Kingdom of Siam, A.C. Carter (ed). G.P. Putnam's Sons and Knickerbocker Press, New York.

Credner, W. 1935. Siam: Das Land der Tai. Eine Landeskunde auf Grund eigener Reisen und Forschungen. Otto Zeller, Osnabruch.

Das Gupta, A., S. Chotechanapibal, T. Chalothom, and W. Siripak. 1974. Population perspective in Thailand, pp. 33-78 In Perspective on Thai Population. Report No. 11, Institute of Population Studies, Chulalongkom University, Bangkok.

Dilock Prinz von Siam. 1908. Die Landwirtschaft in Siam: Ein Beitrag zur Wirtschaftgeschichte des Konigreichs Siam. C.L. Hirschfeld, Leipzig.

Donner, W. 1977. The Five Faces of Thailand: An Economic Geography. St. Martin's Press, New York.

Drew, W.B., S. Aksomkoae, and W. Kaitpraneet. 1978. An assessment of productivity in successional stages from abandoned swidden (rai) to dry evergreen forest in Nor:heastern Thailand. Forest Research Bull. No. 56, Faculty of Forestry, Kasetsart University, Bangkok.

Drew, W.B., S. Aksomkoae, and W. Kaitpraneet. 1979. The inventory of nutrients in vegetation during secondary successions from swidden to forest in Thailand. Forest Research Bull. No. 61, Faculty of Forestry, Kasetsart University, Bangkok.

Feeny, D. 1982. The Political Economy of Productivity: Thai Agricultural Development, 1880-1975. University British Columbia Press, Vancouver, BC.

Feeny, D. 1988. Agricultural expansion and forest depletion in Thailand, 1900-1975, pp. 112-143 and 281-287 In World Deforestation in the Twentieth Century, J.F. Richards and R.P. Tucker (eds.) Duke University Press, Durham, NC.

Gartner, E.J.G. and G.K. Beuschel. 1963. Report to the Government of Thailand: Forest Inventory of the Northeastern Region. Report No. 1692, FAO Expanded Technical Assistance Program, FAO, Rome.

Geddes, W.R. 1976. Migrants of the Mountains: The Cultural Ecology of the Blue Miao (Hmong Niva) of Thailand. Clarendon Press, Oxford. 
Gibson, T. 1980. Pasture research in alang-alang (Imperata cylindrica (L.) Beauv.) areas in Northem Thailand with notes on the ecology of alang-alang in Northern Thailand, pp. 193-230 In Proceedings of the BIOTROP Workshop on Alang-alang (Bogor, July, 1976). BIOTROP Special Publ. No. 5, BIOTROP-SEAMEO Regional Center for Tropical Biology, Bogor, Indonesia.

Graham, W.A. 1924. Siam. 2 Vols., Alexander Moring Ltd., London.

Grandstaff, T.B. 1980. Shifting Cultivation in Northern Thailand: Possibilities for Development. Resource Systems Theory and Methodology Series No. 3, United Nations University, Tokyo.

Hinton, P. 1978. Declining production among sedentary swidden cultivators: the case of the Pwo Karen, pp. 185-209 In Farmers in the Forest: Economic Development and Marginal Agriculture in Northern Thailand, P. Kunstadter, E.C. Chapman, and S. Sabhasri (eds.) University Press Hawaii for East-West Institute, Honolulu, $\mathrm{HI}$.

Holdridge, L.R., W.C. Grenke, W.H. Hatheway, T. Liang, and J.A. Tosi, Jr. 1971. Forest Environments in Tropical Life Zones: a Pilot Study. Pergamon Press Inc., Oxford.

Ingram, J.C. 1971. Economic Change in Thailand 1850-1970. Stanford University Press, Stanford.

Judd, L.C. 1964. Dry Rice Agriculture in Northern Thailand, Data Paper No. 52, Southeast Asia Program, Dept. of Asian Studies, Comell University, Ithaca, NY.

Kaida, Y. and V. Surarerks. 1984. Climate and agricultural land use in Thailand, pp. 231-254 In Climate and Agricultural Land Use in Monsoon Asia, M.M. Yoshino (ed.) University Tokyo Press, Tokyo.

Kawaguchi, K. and K. Kyuma, 1969. Lowland Rice Soils of Thailand. Reports on Research in Southeast Asia, Natural Science Series N-4, The Center for Southeast Asian Studies, Kyoto University, Kyoto, Japan.

Keen, F.G.B. 1978a. Upland Tenure and Land Use in North Thailand. Tribal Research Centre, Chiangmai, Thailand.

Keen, F.G.B. 1978b. Ecological relationships in a Hmong (Meo) economy, pp. 210-221 In Farmers in the Forest: Economic Development and Marginal Agriculture in Northern Thailand, P. Kunstadter, E.C. Chapman, and S. Sabhasri (eds.) University Press Hawaii for East-West Institute, Honolulu, HI.

KKU-Ford Cropping Systems Project. 1982. An Agroecosystem Analysis of Northeast Thailand. Faculty of Agric., Khon Kaen University, Khon Kaen, Thailand. 
Komkris, T. 1978. Forestry aspects of land use in areas of swidden cultivation, pp. 61-70 In Farmers in the Forest: Economic Development and Marginal Agriculture in Northern Thailand, P. Kunstadter, E.C. Chapman, and S. Sabhasri (eds.) University Press Hawail for East-West Institute, Honolulu, HI.

Kunstadter, P. 1978a. Subsistence agricultural economies of Lua' and Karen hill farmers, Mae Sariang District, Northwestem Thailand, pp. 74-133 In Farmers in the Forest: Economic Development and Marginal Agriculture in Northern Thailand, P. Kunstadter, E.C. Chapman, und S. Sabhasri (eds.) University Press Hawaii for East-West Institute, Honolulu, $\mathrm{Hl}$.

Kunstadter, P. 1978b. Altematives for the development of upland areas, pp. 289-308 In Farmers in the Forest: Economic Development and Marginal Agriculture in Northern Thailand, P. Kunstadter. E.C. Chapman, and S. Sabhasri (eds.) University Press Hawail for East-West Institute, Honolulu, HI.

Kunstadter, P. and E.C. Chapman. 1978. Problems of shifting cultivation and economic development in Northem Thailand. pp. 3-23 In Farmers in the Forest: Economic Development and Marginal Agriculture in Northern Thailand, P. Kunstadter, E.C. Chapman, and S. Sabhasri (eds.) University Press Hawail for East-West Institute, Honolulu, HI.

Kunstadter, P., E.C.F. Bird, and S. Sabhasri. 1986. Man in the Mangroves: The Socio-Economic Situation of Human Settlements in Mangrove Forests. United Nations University. Tokyo.

McCarthy, J. 1902. Surveying and Exploring in Siam (2nd Impression). John Murray Lid., London.

Mungkordin, S. and K. Eadkeo. 1978. Foresiry in Thailand. Occ. Paper (March 1978), Faculty of Forestry, Kasetsant University, Bangkok.

Northem Region Agricultural Development Centre. 1987. Final Reporf: Economics of Producing Crops to Replace Opium-Based Agriculture, Crop Year 1985/86. Contract No. 53-32-U4-5-2, Northem Region Agricultural Development Centre, Chiang Mai, Thailand.

Nuttonson, M.Y. 1963. The Physical Environment and Agriculture of Thailand. American Inst. Crop Ecology, Washington, DC.

Ogawa, H., K. Yoda, and T. Kira. 1961. A preliminary survey on the vegetation of Thailand, pp. 21-157 In Nature and Life in Southeast Asia (Vol. 1), T. Kira and T. Umesao (eds.) Flora and Fauna Res. Soc., Kyoto, Japan.

O'Reilly, R.D. and P.I. McDonald. 1983. Thailand's Agriculture. Geography of World Agriculture 12. Akademiai Kiado Research Institute of Geography, Hungarian Academy of Sciences, Budapest.

Oughton, G.A. 1969. Agriculture development in the hills of Northern Thailand, Appendix $C$ : Second Working Report on Agricultural Activities. Tribal Research Centre, Chiang Mai, Thailand.

Owen, N.G. 1971. The rice industry of mainland southeast Asia: 185()-1914. J. Siam Society 32(2):75-143. 
Pendleton, R.L. 1943. Land use in northeastem Thalland. Geogr. Rev. 33:15-41.

Pendleton, R.L., with T.C. Kingsbury et al. 1962. Thailand: Aspects of Landscape and Life. American Geog. Soc. Handbook, Duell, Sloan and Pearce, New York.

Phenphatanapphong, Prince. 1903. Rai ngan kan pa maj [Report on Forestry] dated I May 1903. Document 2, pp. 4.9 in Socio-economic Institusions and Cultural Change in Siam. 1851-1910: A Documentary Survey, Chatthip Nartupha and Suthy Prasartset (eds.) Southeast Asian Perspectives No. 4, Inst. Southeast Asian Stud., Social Sci. Assoc., Bangkok.

Phillips, T.P. 1973. Cassava (tapioca) in Thalland, pp. 93.105 In Cassava Uillization and Potential Markets, T.P. Phillips (ed.) Intemational Development Research Centre, Ottawa.

Sabhasri, S. 1978. Effects of forest fallow cultivation on forest production and soil, pp. 160-184 In Farmers in the Forest: Economic Development and Marginal Agriculture in Northern Thailand, P. Kunstadter, E.C. Chapman, and S. Sabhasri (eds.) University Press Hawail for East-West Instituic, Honolulu, HI.

Sabhasri, S. 1978. Opium culture in Northem Thailand: social and ecological dilemmas, pp. 206-209 In Farmers in the Forest: Economic Development and Marginal Agriculture in Northern Thailand, P. Kunstadter, E.C. Chapman, and S. Sabhasri (eds.) University Press Hawail for East-West Institute, Honolulu, HI.

Sarnapuddhi, K. 1966. Forestry Development in Thailand. Royal Forest Dept., Bangkok.

Siam Dept. Commerce and Statistics. 1916. Statistical Year Book of the Kingdom of Siam 1916. English edition, Depl. Commerce and Statistics, Ministry of Finance, Bangkok.

Siam Dept. General Statistics. 1921. Statistical Year Book of the Kingdom of Siam 1921. No. 6, English edition, Dept. General Statistics, Ministry of Finance, Bangkok.

Siam Ministry of Agriculture. 1948. Annual Report for the Year 1948 to the Food and Agriculture Organization of the United Nations. Ministry of Agriculture Siam, Bangkok.

Silcock, T.H. 1970. The Economic Development of Thai Agriculture. Comell University Press, Ithaca, NY.

Somboompanya, P. 1984. Thailand, pp. 139-153 In Energy in the ESCAP Region: Policies, Issues and the Potential for Regional Co-operation. Papers No. 4, United Nations Economic and Social Commission for Asia and the Pacific (UN/ESCAP), United Nations, Bangkok. 
Sompherm, K. 1975. Country Repor: Thalland, pp. 53.56 In Proceedings of a Regional Meeting on the Use of Ecological Guidelines for Development in South East Asia. IUCN Publications New Series No. 32, Intemational Union for Conservation of Nature and Natural Resources, Morges, Switzerland.

Sricharatchanya, P. 1989a. Too little, too late. Tha Government finally decides to preserve forests. Far Eastern Econ. Rev. 143(2):40.

Sricharachanya, P. 1989b. Getting lumbered, expensive follow-up to logging ban. Far Eastern Econ. Rev. 143(5):26-28.

Srimongkol, K. and G.G. Marten. 1986. Traditional agriculture in Northem Thailand, pp. 85-102 In Traditional Agriculture in Southeast Asia: A Human Ecology Perspective, O.O. Marten (ed.) Westriew Press, Boulder, CO.

Srisawas, N. 1983a. Thailand, pp. 289.309 In Swidden Cultivation in Asia. Vol. 1: Current Analysis of the Existing Literature: A Stocktaking Exercise. UNESCO, Bangkok.

Srisawas, N. 1983b. Thalland, In Swidden Cultivation in Asia, Vol. 2: Country Profiles: India, Indonesia, Malaysia, Philippines, Thailand. UNESCO, Bangkok.

Srisawas, N. and M. Suwan. 1985. Thalland -Swidden cultivation in the North (White Meo), pp. 269-349 In Swidden Cultivation in Asia. Vol. 3: Empirical Studies in Selecied Swidden Communities: India, Indonesia, Malaysia, Philippines, Thailand. UNESCO, Bangkok.

Stemstein. L. 1974. A critique of Thal population data, pp. 79-98 in Perspective on Thai Population. Report No. 11, Institute of Population Studies Research, Institute of Population Studies, Chulalongkom University, Bangkok.

Sungsawan, S. 1985. A Siudy on the Causes of Deforestation in Northeast Thailand. M.S. Thesis, Faculty of Economics, Thammasan University, Bangkok.

Takaya, Y. (translated by P. Hawkes) 1987. Agricultural Development of a Tropical Delia: A Study of the Chao Phraya Delia. Monographs of the Center for Southeast Asian Studies, Kyoto University No. 17, University Hawail Press, Honolulu., HI.

Thailand Central Statistical Office. 1962. Thailand Population Census, 1960: Whole Kingdom. Central Statistical Office, Office of the Prime Minister, Bangkok.

Thailand Center for Agricultural Statistics. 1980. Agricultural Statistics of Thalland, Crop Year 1979/80. Agricultural Statistics No. 134, Center for Agric. Stat., Off. Agric. Economics, Min. Agric. and Co-operatives, Bangkok.

Thailand Center for Agricultural Statistics. 1989. Agricultural Statistics of Thailand, Crop Year 1988/89. Agricultural Statistics No. 414, Center for Agricultural Statistics, Office of Agricultural Economics, Ministry of Agriculture and Co-operatives, Bangkok. 
Thailand Central Statistical Office, National Economic Development Board. 1962. Thailand Population Census, 1960: Whole KIngdom. Central Statistical Office, Office of the Prime Minister. Bangkok.

Thalland Dept. of Technical and Economic Cooperation 1965. Thailand Facts and Figures 1965. Ministry of National Development, Bangkok.

Thalland Division of Agricultural Economics. 1955. Agricultural Statistics of Thailand, 1955. Div. of Agricultural Economics. Office of the Under-secretary of State, Ministry of Agriculture. Bangkok.

Thailand Division of Agricultural Economics. 1965. Agricultural Statistics of Thailand, 1963. Ministry of Agriculture, Bangkok.

Thailand Division of Agricultural Economics. 1974. Agro-economic Zones for Agricultural Extension and Development. Ministry of Agriculture, Bangkok.

Thailand Ministry of Agriculture. 1949. Annual Report for the Year 1949 10 the Food and Agriculture Organization of the United Nations. Ministry of Agriculture, Bangkok.

Thailand Ministry of Agriculture, 1950a. Annual Report for the Year 1950 to the Food and Agriculture Organization of the United Nations. Ministry of Agriculture, Bangkok.

Thailand Ministry of Agriculture. 1950b. Thalland and her Agricultural Problems. Revised edition. Ministry of Agriculture, Bangkok.

Thailand Ministry of Agriculture. 1957. Agriculture in Thailand. Ministry of Agriculture, Bangkok.

Thailand Ministry of Agriculture. 1959. Annual Report for the Year 1958.59 to the Food and Agriculture Organization of the United Nations. Ministry of Agriculture, Bangkok.

Thailand Ministry of Agriculture. 1964. Periodical Report for the Year 1960-196/-1962 to the Food and Agriculture Organization of the United Nations. Ministry of Agriculture. Bangkok.

Thailand Ministry of Agriculture. 1967. Periodical Report for the Year 1963-1964-1965 to the Food and Agriculture Organization of the United Nations. Ministry of Agriculturc. Bangkok.

Thailand National Economic Council. Central Statistical Office. 1952. Statistical Year Book Thailand (New Series). Vol. 1. Thailand National Economic Council, Central Statistical Office. Bangkok.

Thailand National Statistical Office. 1965-1990. Statistical Yearbook Thailand. No. 26-37 (New Series), National Statistical Office, Office of the Prime Minister, Bangkok.

Thailand National Statistical Office. 1973. 1970 Population and Housing Census, Whole Kingdom Report. Office of the Prime Minister, Bangkok. 
Thailand National Statistical Office. 1974. The Population of Thailand. National Economic and Social Development Boand and Institute of Population Studies, Chulalongkom University Thai Watana Kanich Press, Bangkok.

Thailand National Statistical Office. 1980. Quarterly Bulletin of Statistics. No. 28(1-2), Statistical Reports Div., Bangkok.

van Roy, E. 1971. Economic Systems of Northern Thailand: Structure and Change. Comell University Press, Ithaca, NY.

Wilson, C.M. 1983. Thailand: A Handbook of Historical Statistics. G.K. Hall and Co., Boston, MA.

Zimmermann, C.C. 1931. Siam: Rural Economic Survey 1930-31. Bangkok Times Press Ltd., Bangkok. 


\subsubsection{Vietnam}

Allouard, P. 1954. La route forestiere en pays tropical (Forest roads in tropical areas). Bois et Forets des Tropiques 33:15-30.

Ashton, P.S. 1984. Long-term changes in dense and open inland forests following herbicidal attack, pp. 33-37 In Herbicides in War: The Long-term Ecological and Human Consequences, A.H. Westing (ed.) Taylor and Francis for the Stockholm Intemational Peace Research Institute. London.

Ashton, P.S. 1986. Regeneration in inland lowland forests in South Viet-nam one decade after aerial spraying by Agent Orange as a defoliant. Bois et Forets des Tropiques 211:19-34.

Baker, E.G. S. Moore, A.B. Rendle, H.N. Ridley, and H.F. Wemham. 1921. On plants from South Annam. J. Natural History Society Siam 4(3):111-160.

Banister, J. 1985. The Population of Vietnam. Intermational Population Reports Series P-95, No. 77. U.S. Dept. Commerce, Bureau of the Census, Washington, DC.

Barton, T.R., R.C. Kingsbury, and G.R. Showalter, 1970. Southeast Asia in Maps.

Denoyer-Geppert, Chicago, IL.

Brodrick, A.H. 1942. Little China: the Annamese Lands. Oxford University Press, London.

Buttinger, J. 1961. The ethnic minorities in the Republic of Vietnam, pp. 99-121 In Problems of Freedom: South Vietnam Since Independence, W.R. Fishel (ed.) Free Press of Glencoe (New York) and Bureau of Social and Political Research at Michigan State University, East Lansing, MI.

Chaliand, G. (translated by P. Wiles). 1969. The Peasants of North Vietnam. Penguin Books, Baltimore, MD.

Champsoloix, R. 1955. La foret des pays montagnards du Sud Vietnam et ses produits (Forest areas in the South Vietnam highlands and their products). Bois et Forets des Tropiques 40:3-12.

Champsoloix, R. 1959. A propos de la "foret claire" du Sud-est Asiatique (On the "woodlands" of South-East Asia). Bois et Forets des Tropiques 64:3-11.

Chardin, A. 1950. Le sciage des bois tropicaux dans le Sud Viet-Nam (Tropical Wood Sawing in South Vietnam). Bois et Forets des Tropiques 14:149-162.

Cima, R.J. (ed.) 1989. Vietnam: A Country Study. DA Pam 550-32, Area Handbook Series, Superintendent of Documents, U.S. Govt. Printing Office, Washington, DC. 
Clawson, M., H. Landsberg, M.F. Brewer, P. Crosson, J.V. Krutilla, J. Ingersoll, N. Black, and J. Vaughan. 1971. Agricultural Development in the Mekong Basin: Goals, Priorities and Strategies. A Staff Study, Resources for the Future, Inc., Johns Hopkins Press for Resources for the Future, Baltimore MD.

Condominas, G. 1977. We Have Eaten the Forest: The Story of a Montugnard Village in the Central Highlands of Vietnam. Hill and Wang, New York.

Condominas, Georges, 1980. Agricultural ecology in the Southeast Asian savanna region: the Mnong Gar of Vietnam and their social space, pp. 209-251 In Human Ecology in Savanna Environments, D.R. Harris (ed.) Academic Press, London.

Cosslett, T.L. and W.R. Shaw. 1989. The economy, pp. 141-186 In Vietnam: A Country Study, R. J. Cima (ed.) DA Pam. 550-32, Area Handbook Series, Superintendent of Documents, U.S. Govt. Printing Office, Washington, DC.

Cunningham, A. 1902. The French in Tonkin and South China. Hongkong Daily Press, Hong Kong.

Dinh Hiep. 1984. Long-term changes in dense inland forest following herbicidal attack, pp. 31-32 In Herbicides in War: The Long-term Ecological and Human Consequences, ed. A.H. Westing (ed.) Taylor and Francis for the Stockholm International Peace Research Institute, London.

Dinh Hiep, 1984. Long-term changes in the mangrove habitat following herbicidal attack, pp. 89-90 In Herbicides in War: The Long-term Ecological and Human Consequences, A.H. Westing (ed.) Taylor and Francis for the Stockholm Intemational Peace Research Institute, London.

Fall, B.B. 1964. The Two Viet-Nams: A Political and Military Analysis. Revised edition, Frederick A. Praeger, Publishers, New York.

Fforde, A. and S. Paine. 1987. The Limits of National Liberation (Problems of Economic Management in the Democratic Republic of Vietnam, with a Statistical Appendix). Croom Helm, London.

Foxworthy, F.W. 1932. A forester's trip to Indo-China. Malayan For. 1:8-11.

Galston, A.W. and P.W. Richards. 1984. Terrestrial plant ecology and forestry: An overview, pp. 39-42 In Herbicides in war: The Long-term Ecological and Human Consequences, A.H. Westing (ed.) Taylor and Francis for the Stockholm Intemational Peace Research Institute, London.

Gourou, P. 1931. Le Tonkin. Exposition Coloniale Internationale, Paris.

Gourou, P. (translated by S.H. Guest and E.A. Clark) 1945. Land Utilization in French Indochina. 3 Vols., Institute of Pacific Relations, New York.

Gourou, P. 1954. Vue cavaliere des tropiques pluviuex (Overview of the humid tropics). Bois et Forets des Tropiques 37:3-17. 
Gourou, P. 1955. The Peasants of the Tonkin Delta: A Study of Human Geography. 2 Volumes, Behavior Science Translations, Human Relations Area Flies, New Haven, CT.

Great Britain Naval Intelligence Division, 1943. Indo-China. B.R. 510, Geographical Handbook Series, Cambridge University, Cambridge, MA.

Henderson, W. 1961. Opening of new lands and villages: the Republic of Vietnam Land Development Program, pp. 123-137 In Problems of Freedom: South Vietnam Since Independence, W.R. Fishel (ed.) Free Press of Glencoe (New York) and Bureau of Social and Political Research at Michigan State University, East Lansing, MI.

Henry, Y. 1932. Economie Agricole de L'Indochine. Govt. General de L'Indochine, Hanoi.

Hickey, G.C. 1964. Village in Vietnam. Yale University Press, New Haven, CT.

Hickey, G.C. 1982. Free in the Forest: Ethnohistory of the Vietnamese Central Highlands, 1954-1976. Yale University Press, New Haven, CT.

Hickey, G.C. 1982. Sons of the Mountains: Ethnohistory of the Vietnamese Central Highlands to 1954. Yale University Press, New Haven, CT.

Ho, Pham-Hoang, 1973. L'inventaire de la Flore au Sud Vietnam (Inventory of the South Vietnam Flora), pp. 1-3 In Symposium on Planned Utilization of the Lowland Tropical Forests (Bogor, August, 1971). BIOTROP-SEAMEO Regional Center for Tropical Biology, Bogor, Indonesia.

Huguet, L. 1982. Que penser de la "disparition" des forets tropicales? (What are we to think about the "disappearance" of tropical forests?). Bois et Forets des Tropiques 195:7-22.

Indochine (Gouvernement General de l') Direction des Affaires Economiques. 1927. Annuaire Statistique de l'Indochine, Premier Volume. Recueil de Statistiques relatives aux annees 1913 a 1922. Service de la Statistique Generale, Imprimerie d'Extreme-Orient, Hanoi.

Indochine (Gouvemement General de l') Direction des Affaires Economiques. 1931. Annuaire Statistique de l'Indochine, Deuxieme Volume, 1923-1929. Service de la Statistique Generale de l'Indochine, Imprimerie d'Extreme-Orient, Hanoi.

Indochine (Gouvermement General de l') Direction des Affaires Economiques. 1932. Annuaire Statistique de l'Indochine, Troisieme Volume, 1930-1931. Service de la Statistique Generale de I'Indochine, Imprimerie d'Extreme-Orient, Hanoi.

Indochine (Gouvernement General de l') Direction des Affaires Economiques et Administrative. 1933. Annuaire Statistique de l'Indochine, Quatrieme Volume, 1931-1932. Bureau de la Statistique Generale, Imprimerie d'Extreme-Orient, Hanoi.

Indochine (Gouvernement General de l') Direction des Affaires Economiques et Administrative. 1935. Annuaire Statistique de l'Indochine, Cinquieme Volume, 1932-1933. Bureau de la Statistique Generale, Imprimerie d'Extreme-Orient, Hanoi. 
Indochine (Gouvernement General de l') Direction des Affaires Economiques et Administrative. 1937. Annuaire Statistique de l'Indochine, Sixieme Volume, 1934-1935-1936. Bureau de la Statistique Generale, Imprimerie d'Extreme-Orient, Hanoi.

Indochine (Gouvernement General de l') Direction des Services Economiques. 1938. Annuaire Statistique de l'Indochine, Septieme Volume, 1936-1937. Service de la Statistique Generale, Imprimerie d'Extreme-Orient, Hanoi.

Indochine (Gouvemement General de l') Direction des Services Economiques. 1939. Annuaire Statistique de l'Indochine, Huitieme Volume, 1937-1938. Service de la Statistique Generale, Imprimerie d'Extreme-Orient, Hanoi.

Indochine (Gouvernement General de l') Direction des Services Economiques. 1942. Annuaire Satistique de l'Indochine, Neuvieme Volume, 1939-1940. Service de la Statistique Generale, Imprimerie d'Extreme-Orient, Hanoi.

Indochine (Gouvemement General de l') Direction des Services Economiques. 1945. Annuaire Statistique de l'Indochine, Dixieme Volume, 1941-1942. Service de la Statistique Generale, Imprimerie d'Extreme-Orient, Hanoi.

Indochine (Statistique Generale de 1'). 1948. Annuaire Statistique de l'Indochine, Onzieme Volume, 1943-1946. Union Francaise, Haut-Commissariat de France pour l'Indochine Affaires Economiques, Statistique Generale de l'Indochine, Saigon.

Indochine (Statistique Generale de I'). 1946. Bulletin Statistique de l'Indochine, 4e Trimestre 1946. Federation Indochinoise, Commissariat Federal aux Affaires Economiques, Statistique Generale de l'Indochine, Saigon.

Indochine (Statistique Generale de 1'). 1946. Bulletin Statistique de l'Indochine, Annee 1947. Union Francaise, Haut Commissariat de France pour l'Indochine Affaires Economiques, Statistique Generale de l'Indochine, Saigon.

Indochine (Statistique Generale de l'). 1949. Bulletin Statistique de l'Indochine, Annee 1948. Union Francaise, Haut-Commissariat de France pour l'Indochine Affaires Economiques, Statistique Generale de l'Indochine, Saigon.

Institut d'Emission des Etats du Cambodge, du Laos et du Vietnam. 1952. Statistiques Economiques et Financieres No. I. Direction des Etudes, Imprimerie Francaise d'Outre-Mer, Saigon.

Institut d'Emission des Etats du Cambodge, du Laos et du Vietnam. 1952. Le probleme du riz. Statistiques Economiques et Financieres. No. 2:5-18, Service des Etudes Economiques et Financieres, Imprimerie Francaise d'Outre-Mer, Saigon. 
Joint Development Group, Postwar Planning Group (Saigon), and Development and Resources Corp. (New York). 1970. The Postwar Development of the Republic of Vietnam: Policies and Programs. Praeger Special Studies in Intemational Economics and Development, Praeger Publishers, New York.

Koppes, C.R. 1985. Agent Orange and the official history of Vietnam. Reviews in American History, (March):131-135.

Ladejinsky, W. 1961. Agrarian reform in the Republic of Vietnam, pp. 153-175 In Problems of Freedom: South Vietnam Since Independence, W.R. Fishel (ed.) Free Press of Glencoe (New York) and Bureau of Social and Political Research at Michigan State University, East Lansing, MI.

Le Thanh Khoi. 1955. Le Viet-Nam: Histoire et Civilisation. Le Milieu et l'histoire. Les Editions de Minuit, Paris.

Le Trong Cuc, K. Gillogly, and A.T. Rambo (eds.) 1990. Agroecosystems of the Midlands of Northern Vietnam. Occasional Paper No. 12 of the East-West Environment and Policy Institute, East-West Center, Honolulu, HI.

LePoer, B.L. 1989. Historical setting, pp. 1-79 In Vietnam: A Country Study, R. J. Cima (ed.) Area Handbook Series, DA pam. 550-32, Superintendent of Documents, U.S. Govt. Printing Office, Washington, DC.

Lunet de Lajonquiere, E. 1906. Ethnographie du Tonkin Septentrionale. Ernest Leroux, Editeur, Paris.

Mai Dinh Yen and others. 1984. Coastal, aquatic and marine ecology: Symposium summary, pp. 85-87 In Herbicides in War: The Long-term Ecological and Human Consequences, Westing, A.H. (ed.) Taylor and Francis for the Stockholm Intemational Peace Research Institute, London.

Maurand, P. 1938. L'Indochine Forestiere. Inst. Rech. Agron. et For. de l'Indochine, Hanoi.

McCune, S. 1947. The diversity of Indochina's physical geography. Far Eastern Quarterly 6(4):335-344.

McKinley, T.W., 1957. The Forests of Free Viet-Nam: A Preliminary Study for Organization, Protection, Policy and Production. United States Operations Mission to Vietnam, Saigon.

Miller, E.W. 1947. Industrial resources in Indochina. Far Eastern Quarterly 6(4):396-408.

Mole, R.L. 1970. The Montagnards of South Vietnam: A Study of Nine Tribes. Charles E. Tuttle Co. Publishers, Rutland, VT.

Murray, M.J. 1980. The Development of Capitalism in Colonial Indochina (1870-1940). University of Califormia Press, Berkeley, CA. 
Ng Shui Meng. July 1974. The Population of Indochina: Some Preliminary Observations. Field Report Series No. 7, Institute of Southeast Asian Studies, Singapore.

Nguyen Anh Tuan. 1987. South Vietnam Trial and Experience: A Challenge for Development. Monographs in International Studies, Southeast Asia Series No. 80, Ohio University Center for Intemational Studies, Center for Southeast Asian Studies, Athens, $\mathrm{OH}$.

Nguyen Phuc Sa. 1963. The rural development programme in Viet-Nam, pp. 247-252 In Social Research and Problems of Rural Development in South-East Asia: Proceedings of a Seminar organized by the Viet-Namese national Commission for UNESCO (Saigon, March, 1960), Vu Quoc Thuc (ed.) UNESCO, Brussels.

Nguyen Tien Hung, G. 1977. Economic Development of Socialist Vietnam, 1955-80. Praeger Publishers, New York.

Nguyen Van Hiep and Nguyen Dinh Mo. 1968. The current situation of conservation in Vietnam in 1965, pp. 527-529 In Conservation in Tropical South East Asia: Proceedings of the Conference on Conservation of Nature and Natural Resources in Tropical South East Asia (Bangkok, Nov. 29-Dec. 4, 1965), L.M. Talbot and M.H. Talbot (eds.) Intemational Union for Conservation of Nature and Natural Resources, Morges, Switzerland.

Nguyen Van Phong. 1971. La societe Vietnamienne de 1882 a 1902 d'apres les ecrits des auturs francais. Presses Universitaires de France, Vendome.

Nietschmann, B. 1990. Battlefields of ashes and mud. Natural History (November):34-37.

Norlund, I. 1986. Rice production in colonial Vietnam, 1900-1930: Production, consumption, market relations and social differentiation, pp. 203-229 In Rice Societies: Asian Problems and Prospects, I. Norlund, S. Cederroth, and I. Gerdin (eds.) Scandinavian Institute of Asian Studies, Studies on Asian Topics No. 10, Curzon Press, The Riverdale Co., Riverdale, MD.

Nuttonson, M.Y. 1963. Climatological Data of Vietnam, Laos, and Cambodia: A Supplement to the Report of The Physical Environment and Agriculture of Vietnam, Laos and Cambodia. A Study Based on Field Survey Data and on Pertinent Records, Material, and Reports. American Institute of Crop Ecology, Washington, DC.

Nuttonson, M.Y. 1963. The Physical Environment and Agriculture of Vietnam, Laos and Cambodia: A Study Based on Field Survey Data and on Pertinent Records, Material, and Reports. American Institute of Crop Ecology, Washington, DC.

Osbome, M.E. 1969. The French Presence in Cochinchina and Cambodia. Comell University Press, Ithaca, NY.

Pfeiffer, E.W. 1971. Land War I. Craters, Environment 13(9):3-8.

Pfeiffer, E.W. 1990. Degreening Vietnam. Natural History (November):37-40. 
Pham Hoang Ho. 1968. Plan for the conservation of nature in Vietnam, pp. 407-409 In Conservation in Tropical South East Asia: Proceedings of the Conference on Conservation of Nature and Natural Resources in Tropical South East Asia (Bangkok, Nov. 29-Dec. 4, 1965), L.M. Talbot and M.H. Talbot (eds.) International Union for Conservation of Nature and Natural Resources, Morges, Switzerland.

Phung Trung Ngan. 1968. The status of conservation in South Vietnam, pp. 519-522 In Conservation in Tropical South East Asia: Proceedings of the Conference on Conservation of Nature and Natural Resources in Tropical South East Asia (Bangkok, Nov. 29-Dec. 4, 1965), L.M. Talbot and M.H. Talbot (eds.) International Union for Conservation of Nature and Natural Resources, Morges, Switzerland.

Phung Trung Ngan. 1973. Natural products of the lowland forests in the Republic of Vietnam, pp. 231-237 In Symposium on Planned Utilization of the Lowland Tropical Forests (Bogor, August, 1971). BIOTROP-SEAMEO Regional Center for Tropical Biology, Bogor, Indonesia.

Richards, P.W. 1984. The forests of South Viet Nam in 1971-72: A personal account. Environmental Conservation 11:147-153.

Robequain, C. 1929. Le Thanh Hoa: Etude Geographique d'une Province Annamite (Thanh Hoa: Geographic Study of an Annamite Province). 2 vols., Publications de l'Ecole Francaise d'Extreme-Orient, Les Editions G. Van Oest, Paris.

Robequain, C. 1944. The Economic Development of French Indo-China. Oxford University Press, London.

Rollet, B. 1953. Note sur les forets claires du sud de l'Indochine (About the open forests of South Indochina). Bois et Forets des Tropiques 31:3-13.

Rollet, B. 1954. Pour un inventaire forestier du Viet-nam, pp. 639-666 In Proceedings of the 4th World Forestry Congress, General and Special Papers on Tropical Forestry, Vol. III.

Rothe, P.-L. 1947a. Foret d'Indochine (premiere partie). Bois et Forets des Tropiques 1:25-30.

Rothe, P.-L. 1947b. Foret d'Indochine. Son passe, son histoire (deuxieme partie). Bois et Forets des Tropiques 2:18-23.

Rothe, P.-L. 1947c. Foret d'Indochine. Ses possibilites son avenir (troisieme partie). Bois et Forets des Tropiques 3:17-23.

Sanson, R.L. 1970. The Economics of Insurgency in the Mekong Delta of Vietnam. The M.I.T. Press, Cambridge, MA. 
Schmid, M. 1977. Some considerations on the edaphic conditions in the tropical forest areas and their implications to land management, pp. 302-324 In Proceedings of a Symposium on Management of Forest Production in Southeast Asia. BIOTROP Special Publication No. 4, BIOTROP-SEAMEO Regional Center for Tropical Biology, Faculty of Forestry, Kasetsart University, Bangkok.

Schmid, M. 1958. Note sur les formations vegetales des hauts plataeux du Centre Vietnam et des regions limitrophes (Notes on the vegetation formations of the high plateaux of Central Viet-Nam and its neighbouring regions), pp. 183-194 In Study of Tropical Vegetation: Proceedings of the Kandy Symposium. UNESCO, Paris.

Shinn, Rinn-Sup. 1989. The society and its environment, pp. 81-139 In Vietnam: A Country Study, R.J. Cima (ed.) DA Pam. 550-32, Area Handbook Series, Superintendent of Documents, U.S. Govt. Printing Office, Washington, DC.

Stockholm International Peace Research Institute. 1980. Warfare in a Fragile World: Military Impact on the Human Environment. Taylor and Francis Ltd., London.

Smith, H.H., D.W. Bemier, F.M. Bunge, F.C. Rintz, Rinn-Sup Shinn, and S. Teleki. 1967. Area Handbook for South Vietnam. DA Pam. No. 550-55, Superintendent of Documents, U.S. Govt. Printing, Washington, DC.

Snedaker, S.C. 1984. Coastal, marine and aquatic ecology: An overview, pp. 95-107 In Herbicides in War: The Long-term Ecological and Human Consequences, A.H. Westing (ed.) Taylor and Francis for the Stockholm Intemational Peace Research Institute, London.

Steinberg, D.J. (ed.) 1971. In Search of Southeast Asia: A Modern History. Revised edition, University of Hawaii Press, Honolulu, HI.

Tan Teng Lang. 1985. Economic Debates in Vietnam: Issues and Problems in Reconstruction and Development (1975-84). Research Notes and Discussions Paper No. 55, Institute of Southeast Asian Studies, Singapore.

Thai Cong Tung. 1967. Natural Environment and Land Use in Vietnam. 2nd edition, Vietnam (Republic), Directorate of Agricultural Research, Saigon.

Thai Cong Tung. 1971. Natural Environment and Land Use in Vietnam. 3rd edition, Vietnam (Republic), Ministry of Agriculture, Agricultural Research Institute, Saigon.

Thai Cong Tung. 1972. Agricultural Development Planning and Zoning in South Vietnam. Vietnam (Republic), Ministry of Land Reform, Agriculture, Fishery and Animal Husbandry Development, Agricultural Research Institute, Saigon.

Thai Van Trung and others. 1984. Terrestrial plant ecology and forestry: Symposium summary, pp. 27-29 In Herbicides in War: The Long-term Ecological and Huan Consequences, Westing, A.H. (ed.) Taylor and Francis for the Stockholm International Peace Research Institute, London. 
Thompson, V. 1937. French Indo-China. George Allen and Unwin Ltd., London.

Uhart, E. 1969. Les forets du Sud Viet Nam et la guerre (The forests of South Vietnam and the war). Bois et Forets des Tropiques 125:3-9.

United States Operations Mission to Vietnam, Agriculture Division, July 1964. Report of the Agriculture Division, United States Operations Mission to Vietnam. Printed by Vietnam (Republic), Agricultural Information Service, for United States Agency for Intemational Development, Saigon.

United States Dept. of State. May 1990. Background Notes: Vietnam. Bureau of Public Affairs, Washington, DC.

Viet Nam Central Census Steering Committee. 1990. Vietnam Population Census 1989. Ban Chi Dao Tong Dieu Tra Dan So Trung U'ong, Hanoi.

Viet Nam Cong Hoa xa Hoi Chu Nghia Viet Nam. 1983. Dan So Viet Nam 1-10-1979 (Vietnam Census, 1-10-1979). Ban Chi Dao Tong Dieu Tra Dan So Trugn Uo'ng, Hanoi.

Viet Nam (Tong Cuc Thong Ke). 1985. So Lieu Thong Ke 1984. Nha Xuat Ban Thong Ke, Hanoi.

Viet Nam (Tong Cuc Thong Ke). 1985. So Lieu Thong Ke 1930-1984. Nha Xuat Ban Thong Ke, Hanoi.

Viet Nam (Tong Cuc Thong Ke). 1989. Nien Giam Thong Ke 1987. Nha Xuat Ban Thong Ke, Hanoi.

Vietnamese National Commission for UNESCO. 1966. Thu-Muc Chu-gai ve Van-hoa Viet-nam (Commented Bibliography on Vietnamese Culture). Vietnam National Commission for UNESCO, Saigon.

Vietnam (Etat) Ministere de l'Economie Nationale. 1951. Annuaire Statistique du Vietnam, Premiere Volume, 1949-1950. Institut de la Statistique et des Etudes Economiques du Vietnam, Saigon.

Vietnam (Etat) Ministere de l'Economie Nationale. 1952. Annuaire Statistique du Vietnam, deuxieme volume, 1950-1951. Institut de la Statistion'le et des Etudes Economiques du Vietnam. Saigon.

Vietnam (Etat) Ministere de l'Economie Nationale. 1953. Annuaire Statistique du Vietnam, troisieme volume, 1951-1952. Institut de la Statistique et des Etudes Economiques du Vietnam. Saigon.

Viet-Nam (Republic) Agricultural Economics and Statistics Service. 1961. Viet Nam Thong-ke Canh-nong, 1960 (1960 Vietnam Agricultural Statistics). Agricultural Statistics and Economics Service, Dept. of Rural Affairs, Republic of Viet-Nam, Saigon. 
Viet-Nam (Republic) Agricultural Economics and Statistics Service. 1962. Nien Giam Thong-ke Nong-nghiep, 1961 (1961 Agricultural Statistics Yearbook). Agricultural Statistics and Economics Service, Dept. of Rural Affairs, Republic of Viet-Nam, Saigon.

Viet-Nam (Republic) Agricultural Economics and Statistics Service. 1963. Nien-Giam Thong-ke Nong-nghiep, 1963 (1963 Agriculiural Statistics Yearbook). Agricultural Statistics and Economics Service, Dept. of Rural Affairs, Republic of Viet-Nam, Saigon.

Viet-Nam (Republic) Agricultural Economics and Statistics Service. 1969. Nien-Giam Thong-ke Nong-nghiep, 1968 (Agricultural Statistics Yearbook, 1968). Agricultural Statistics and Economics Service, Ministry of Land Reform and Agriculture and Fishery Development, Republic of Viet-Nam, Saigon.

Viet-Nam (Republic) Agricultural Economics and Statistics Service. 1970. Nien-Giam Thong-ke Nong-nghiep, 1969 (Ayricultural Statistics Yearbook, 1969). Agricultural Statistics and Economics Service, Ministry of Land Reform and Agriculture and Fishery Development, Republic of Viet-Nam, Saigon.

Viet-Nam (Republic) Agricultural Statistics and Economics Service. 1960. Viet Nam Thong-ke Canh-nong, Tai Lieu Suot Nam 1959 (Vietnamese Agricultural Statistics, Data through 1959). Agricultural Statistics and Economics Service, Dept. of Agriculture, Republic of Viet-Nam, Saigon.

Viet-Nam (Republic) Directorate of Agricultural Economics. 1972. Nien-Giam Thong-ke Nong-nghiep, 1971 (Agricultural Statistics Yearbook, 1971). Agricultural Statistics and Economics Service, Ministry of Land Reform, Agriculture, Fishery and Animal Husbandry Development, Republic of Viet-Nam, Saigon.

Viet-Nam (Republique) Institut National de la Statistique. 1958. Enquetes demographiques au Vietnam en 1958 (Demographic Investigations in Vietnam in 1958). Republique du Viet-Nam. Secretariat d'Etat a l'Economic Nationale, Saigon.

Vietnam (Republique) Secretariat d'etat a l'economie nationale. 1955. Annuaire Statistique du Vietnam, Quatrieme volume, 1952-1953. Institut de la Statistique et des Etudes Economiques du Vietnam, Saigon.

Vo Quy. 1990. On the wings of peace. Natural History (November):40-41.

Vu Quoc Thuc (ed.)1963. Social Research and Problems of Rural Development in South-East Asia: Proceedings of a Seminar organized by the Viet-Namese National Commission for UNESCO (Saigon, March, 1960). UNESCO, Brussels.

Vu Quoc Thuc. 1963. The rural problem in the countries of South-east Asia, pp. 61-73 In Social Research and Problems of Rural Development in South-East Asia: Proceedings of a Seminar organized by the Viet-Namese National Commission for UNESCO (Saigon, March, 1960), Vu Quoc Thuc (ed.) UNESCO, Brussels. 
Weisberg. B. (ed.) 1970. Ecocide in Indochina: The Ecology of War. Canfield Press, San Prancisco, CA.

Westing, A.H. 1971. Land war II: leveling the jungle; Land war III: the big bomb. Environment 13(9):8-12 and 13-15.

Westing, A.H. 1974. Postwar forestry in North Vietnam. J. Forestry 72:153-156.

Westing, A.H. (ed.) 1984. Herbicides in War: The Long-lerm Ecological and Human

Consequences. Taylor and Francis for the Stockholm International Peace Research Institute, London.

Westing, A.H, and C.E. Westing. 1981. Endangered species and habitats of Viet Nam.

Environmental Conservation 8(1):59-62.

Williams, L. 1965. Vegetation of Southeast Asia/Studies of Forest Types, 1963-1965. CR 49-65. U.S. Dept. of Agriculture, Agricultural Research Service, Crops Research Div., Washington, DC.

Williams, L. 1967. Forests of Southeast Asia, Puerto Rico, and Texas. U.S. Dept. of Agriculture, Agricultural Research Service, Crops Research Div., U.S. Dept. of Defense, Advanced Research Projects Agency, Washington, DC. 


\section{Common Bibllography}

Adeyoju, S. Kolade. 1976. Land use and tenure in the tropics. Unasylva 28:26-41; 144.

Andreac, B. Farming regions in the tropics: environment, geographical comparisons and socio-economic development, pp. 163-212 in Application of Vegetation Science in Grassland Husbandry (Handbook of Vegetation Science Part XIII), W. Krause (ed.) The Hague.

Angladette. A. 1974. Rice in humid tropical Asia, pp. 415-38 In Natural Resources of Humid Tropical Asia. Natural Resources Research, UNESCO, Parls.

Atal, Y. 1984. Swidden cultivation in Asia: the need for a new approach. Nature and Resources 20:19-26.

Ata, Y. and P.L. Bennagen. 1983a. Introduction, pp. 1-12 In Swidden Cultivation in Asia, Vol. 1: Content Analysis of the Existing Literature: A Stocktaking Exercise. UNESCO Regional Office for Education in Asia and Pacific. Bangkok.

Ata, Y. and P.L. Bennagen. 1983b. Introduction, pp. i-xx In Swidden Cultivation in Asia, Vol. 2: Country Profiles: India, Indonesia, Malaysia, Philippines, Thalland. UNESCO Regional Office for Education in Asia and Pacific, Bangkok.

Bamard, G. and L. Kristoferson. 1985. Agricultural Residues as Fuel in the Third World. Technical Report No. 4, Earthscan. Energy Information Programme, Beijer Institute of the Royal Swedish Academy of Sciences, Intemational Institute for Environment and Development, London.

Bamard, G.W. 1987. Woodfuel in developing countries, pp. 349-366 in Biomass: Regenerable Energy, D.O. Hall and R.P. Overend (eds.) John Wiley and Sons Ltd., Chichester.

Bergsmark, D.R. 1942. Economic Geography of Asia. Prentice-Hall, Inc., New York.

Bor, N. L. 1960. The Grasses of Burma, Ceylon, India and Pakistan (Excluding Bambuseae). Intemational Series of Monographs on Pure and Applied Biology, Vol. 1, Pergamon Press, New York.

Brown, S., A.J.R. Gillespie, and A.E. Lugo. 1989. Biomass estimation methods for tropical forests with applications to forest inventory data. For. Sci. 35:881-902.

Brown, S., A.J.R. Gillespie, and A.E. Lugo. 1991. Biomass of tropical forests of South and Southeast Asia. Can. J. For. Res. 21:111-117.

Brown, S. and A.E. Lugo. 1982. The storage and production of organic matter in tropical forests and their role in the global carton cycle. Biotropica 14:161-187.

Brown, S. and A.E. Lugo. 1984. Biomass of tropical forests: a new estimate based on forest volumes. Science 223:1290-93. 
Brinig. E.F. 1989. Use and misuse of tropical rain forests, pp. 611.636 In Tropical Rain Forest Ecosystems: Blogeographical and Ecological Studies, H. Lieth and M.J. A. Werger (eds.) Ecosystems of the World 14B, Elsevier, Amsterdam.

Brunig, E.F. 1969. Forestry on tmpical podzols and related soils. Tropical Ecology 10:45-58.

Brunsfeld, S.J., L. Ashland, A.L. Merkel, C.R. Hatch, M. Sargent, D.J. Martson, and O.H. Savage. 1982. Biomass Resources in 66 African, Asian and Latin American Countries. Vol. II: Asia. Contribution No. 231, Forest, Wildilfe and Range Experiment Station, University of Idaho. Moscow, ID.

Burke, L.M. and D.A. Lashof, 1990. Greenhouse gas emissions related to agriculture and land-use practices, pp. 27-44 In Impact of Carbon Dioxide, Trace Gases, and Climate Change on Global Agriculture. B.A. Kimball (ed.) ASA Special Publication No. 53, American Society of Agmnomy, Crop Science Society of America, and Soll Science Society of America, Madison, WI.

Burling, R. 1965. Hill Farms and Padi Flelds: Life in Mainland Southeast Asia. Prentice-Hall, Inc., Engelwood Cliffs, NJ.

Buschbacher, R.J. 1986. Tropical deforestation and pasture development. BloScience 36:22-28.

Cappenter, R.A. (ed.) 1981. Assessing Tropical Forest Lands and their Suitability for Sustainable Uses: Proceedings of the Conference on Forest Land Assessment and Management for Sustainable Uses (Honolulu, HI, June, 1979). Tycooly Intemational Publ., Lid., Dublin.

Cecelski, E., J. Dunkerley, W. Ramsey, and E. Mbi. 1979. Household Energy and the Poor in the Third World. RFF Reseanch Paper R-15, Resources for the Future, Washington, DC.

Champion, H.G. 1936. A Preliminary Survey of the Forest Types of India and Burma. Indian Forest Records, Manager of Publications, Delhi.

Champion, H.G. and F.C. Osmaston (eds.) 1962. E. P. Stebbing's 'The Forests of India.' Vol. IV. Being the History from 1925 to 1947 of the Forests now in Burma, India, and Pakistan. Oxford University Press, London.

Champion, H.G. 1969. The effect of human population on the forests of the Indian sub-continent. Jahrb. Sudasien-Instituts Universitat Heidelberg 3:19-28.

Champion, H.G. and S.K. Seth. 1968. A Revised Survey of the Forest Types of India. Manager of Publications, Delhi.

Chapman, E.C. 1975. Shifting agriculture in tropical forest areas of South East Asia, pp. 120-135 In Proceedings of the Regional Meeting on the Use of Ecological Guidelines for Development in South East Asia. IUCN Publications New Series No. 32, Intemational Union for Conservation of Nature and Natural Resources, Morges, Switzerland.

Chapman, V.J. 1976. Mangrove Vegetation. J. Cramer Publ., Vaduz. 
Chatterjec, S.P. 1973. Oeneral sections, pp. 1.30 In World Allas of Agriculture, Vol. 2: Asia and Oceania. Istituto Geografico de Agostini. Novara, Italy.

Cho, L.-J and R.L. Heam (eds.) 1984. Censuses of Asia and the Pacific: 1980. East-West Population Institute, East-West Population Center, Honolulu, HI.

Christanty, L. 1986. Shifting cultivation and tropical solls: pattems, problems, and possible improvements, pp. 226-240 in Traditional Agriculture in Southeast Asia: A Human Ecology Perspective, O.O. Marten (ed.) Westview Press, Boulder, CO.

Clapham, W.B. 1980. Environmental problems, development, and agricultural production systems. Environmental Conservation 7:145-52.

Clarke, C.B. 1898. On the subsubareas of British India, illustrated by the detailed distribution of the Cyperace in that Empire. J. Linnean Soc. (Botany) 34:1-146.

Cobban, J.L. 1968. The Traditional Use of the Forests in Mainland Southeast Asia. Papers in Int. Studies, Southeast Asia Ser. No. 5, Ohio University Center for Int. Studies, Athens, OH.

Collins, N.M., J.A. Sayer and T.C. Whitmore (eds.) 1991. The Conservation Atlas of Tropical Forests: Asia and the Pacific. IUCN, Simon and Schuster, New York.

Committee for the World Atlas of Agriculture. 1969. World Atlas of Agriculture. Land Utilization Maps and Relief Maps prepared by the Committee for the World Allas of Agriculture. Istituto Geografico de Agostini, Novara, Italy.

Conklin, H.C. 1963. The Study of Shifting Cultivation. Studies and Monographs, VI. Tech. Pubs. and Documents, Dept. Social Affairs, Pan American Union, Washington, DC.

Counenay, P.P. 1980. Plantation Agriculture. Rev. edition, Gell and Hyman, London.

Domschke, E. and D.S. Goyer. 1986. The Handbook of National Population Censuses. Africa and Asia. Greenwood Press, New York.

Dale, V.H. (ed.) 1993. Effects of Land Use Change on Atmospheric $\mathrm{CO}_{2}$ Concentrations: South and Southeast Asia as a Case Study. Springer-Verlag, New York.

Dale, V.H. 1993. Terrestrial $\mathrm{CO}_{2}$ flux: the challenge of interdisciplinary research, pp. 1-14 In Effects of Land Use Change on Atmospheric $\mathrm{CO}_{2}$ Concentrations: South and Southeast Asia as a Case Study, Dale, V.H. (ed.) Springer-Verlag, New York.

Dale, V.H., Brown, S., Flint, E.P., Hall, C.A.S., Houghton, R.A., Iverson, L.R., Richards, J.F., and J. Uhlig. 1993. Estimating $\mathrm{CO}_{2}$ flux from tropical forests, pp. 365-378 In Effects of Land Use Change on Atmospheric $\mathrm{CO}_{2}$ Concentrations: South and Southeast Asia as a Case Study, Dale, V.H. (ed.) Springer-Verlag, New York. 
Dargavel, J, and R. Tucker (eds.) 1992. Changing Pacific Forests: Historical Perspective on the Forest Economy of the Pacific Basin. Forest History Society, Durham, NC.

Dargavel, J., Dixon, K., and N. Semple (eds.) 1988. Changing Tropical Forests: Historical Perspectives on Today's Challenges in Asia, Australasia and Oceania. Publications Section, Centre for Resources and Environmental Studies, Canberra, Australia.

Dudal, R. and F.R. Moorman. 1964. Major soils of Southeast Asia. J. Tropical Geography 18:54.80.

Dudal, R., F. Moormann and J. Riquier. 1974. Soils of humid tropical Asia, pp. 159-78 In Natural Resources of Humid Tropical Asia. Natural Resources Research Paper No. 12, UNESCO, Paris.

Dunkerly, J. 1979. Pattems of energy consumption by the rural and urban poor in developing countries. Natural Resources Forum 3:349-373.

Eckholm, E., G. Foley, G. Bamard, and L. Timberlake. 1984. Fuelwood: the Energy Crisis that Won't Go Away. Earthscan, Intermational Institute for Environment and Development, London.

Elahi, K.M. and S, Sultana. 1985. Population redistribution and settlement change in South Asia: a historical evaluation, pp. 15-35 In Population Redistribution and Development in South Asia, L.A. Kosinski and K.M. Elahi (eds.) D. Reidel Publ. Co., Dordrecht.

Emanuel, W.R., G.G. Killough, W.M. Post, and H.H. Shugart. 1984. Modeling terrestrial ecosystems in the global carbon cycle with shifts in carbon storage capacity by land-use change. Ecology 65:970-83.

Emanuel, W.R., H.H. Shugart, and M.P. Stevenson. 1985. Climatic change and the broad-scale distribution of terrestrial ecosystem complexes. Climatic Change 7:29-43.

Emanuel, W.R., H.H. Shugart, and M.P. Stevenson. 1985. Response to comment: climatic change and the broad-scale distribution of terrestrial ecosystem complexes. Climatic Change 7:457-460.

Ewel, J. and L.F. Conde. 1980. Potential Ecological Impact of Increased Intensity of Tropical Forest Utilization. BIOTROP Special Publication No. 11, BIOTROP-SEAMEO Regional Center for Tropical Biology, Bogor.

Fisher, C.A. 1967. South-east Asia: a Social, Economic and Political Geography. 2nd edition, Methuen and Co. Ltd., London.

Flint, E.P. and J.F. Richards. 1989. Bibliography on Tropical Forests and the Global Carbon Cycle. Vol. 2. South Asia. ORNL/CDIAC-24/V2, U.S. Dept. Energy, Oak Ridge National Laboratory, Oak Ridge, TN.

Flint, E.P. and J.F. Richards. 1991. Historical analysis of changes in land use and carton stock of vegetation in south and southeast Asia. Canad. J. For. Res. 21:91-110. 
Flint, E.P. and J.F. Richards. 1993. Trends in carbon content of vegetation in South and Southeast Asia associated with changes in land use, pp. 201-299 In Effects of Land Use Change on Atmospheric $\mathrm{CO}^{2}$ Concentrations: South and Southeast Asia as a Case Study, V.H. Dale (ed.) Springer-Verlag, New York.

Foley, G. 1990. Charcoal Making in Developing Countries. Technical Report No. S, Earthscan, Energy Information Programme, International Institute for Environment and Development, London.

Foley, G., P. Moss, and L. Timberlake. 1984. Stoves and Trees: How Much wood Would a Woodstove Save if a Woodstove Could Save Wood? Earthscan, Intemational Institute for Environment and Development, London.

FAO/ESCAP Regional Workshop. 1984. Wood Energy Development: Report of the FAOIESCAP Regional Workshop (Bangkok, 13-16 December 1983). Regional Office for Asia and the Pacific, FAO, Bangkok.

Food and Agriculture Organization of the United Nations. 1948. Forest Resources of the World. Div. of Forestry and Forest Products, FAO, Washington, DC.

Food and Agriculture Organization of the United Nations. 1963. World Forest Inventory 1963. Forestry and Forest Products Div., FAO, Rome.

Food and Agriculture Organization of the United Nations. 1961-1990. FAO Production Yearbook. Vols. 14-41, FAO, Rome.

Food and Agriculture Organization of the United Nations. 1976. Forest Resources in the Asia and Far East Region. FAO, Rome.

Food and Agriculture Organization of the United Nations. 1977. FAO-UNESCO Soil Map of the World, 1:5,000,000, Vol. VII: South Asia. UNESCO, Paris.

Food and Agriculture Organization of the United Nations. 1979. FAO-UNESCO Soil Map of the World, 1:5,000,000, Vol. IX: Southeast Asia. UNESCO, Paris.

Food and Agriculture Organization of the United Nations. 1980. Report on the Agro-Ecological Zones Project, Vol. 4: Results for Southeast Asia. FAO World Soil Resources Report 48/4, FAO, Rome.

Food and Agriculture Organization of the United Nations. 1982b. Forestry and Forest Products Development in Indonesia. Project Findings and Recommendations. FO/DP/INS/78/054 Terminal Report, United Nations Development Programme, FAO, Rome.

Food and Agriculture Organization of the United Nations. 1989. Classification and Mapping of Vegetation Types in Tropical Asia. FAO, Rome. 
Food and Agriculture Organization of the United Nations. 1976. Forest Resources in the Asia and Far East Region. FAO, Rome.

Food and Agriculture Organization of the United Nations. 1977. FAO-UNESCO Soil Map of the World, 1:5,000,000, Vol. VII: South Asia. UNESCO, Paris.

Food and Agriculture Organization of the United Nations. 1979 FAO-UNESCO Soil Map of the World, 1:5,000,000, Vol. IX: Southeast Asia. UNESCO, Paris.

Food and Agriculture Organization of the United Nations. 1980. Report on the Agro-Ecological Zones Project, Vol. 4: Results for Southeast Asia. FAO World Soil Resources Report 48/4, FAO, Rome.

Food and Agriculture Organization of the United Nations. 1981. Map of the Fuelwood Situation in the Developing Countries at a scale of 1:25,000,000. FAO, Rome.

Food and Agriculture Organization of the United Nations. 1982. Forestry and Forest Products Development Indonesia. Project Findings and Recommendations. FO/DP/INS/78/054 Terminal Report, United Nations Development Programme, FAO, Rome.

Food and Agriculture Organization of the United Nations. 1968. Yearbook of Forest Products 1968. Forestry and Forest Industries Div., FAO, Rome.

Food and Agriculture Organization of the United Nations. 1970-1973. Yearbook of Forest Products (annual, 1969-1971). Forestry Dept., FAO, Rome.

Food and Agriculture Organization of the United Nations. 1974, 1975. Yearbook of Forest Products (Review, 1961-1972 and 1962-1973). Forestry Dept., Forest Economics and Statistics Branch and Trade Div., FAO, Rome.

Food and Agriculture Organization of the United Nations. 1976-1990. Yearbook of Forest Products (annuals, each covering 11-year period; 1963-1974 to 1977-1988). Forestry Dept., Statistics and Economic Analysis Unit, FAO, Rome.

Food and Agriculture Organization of the United Nations. 1981. Forest Resources of Tropical Asia. Tropical Forest Resources Assessment Project (in the framework of GEMS), FAO and United Nations Environment Programme, Rome.

Francois, T. 1953. Grazing and Forest Economy. FAO Forestry and Forest Products Studies No. 4, FAO, Rome.

Gaussen, H. 1954. Geographie des Plantes. 2nd edition, Librairie Armand Colin, Paris.

Goodland, R.J.A, C. Watson, and G. Ledec. 1984. Environmental Management in Tropical Agriculture. Westview Press, Boulder, CO. 
Grainger, A. 1983. Improving the monitoring of deforestation in the humid tropics, pp. 387-95 In Tropical Rain Forest: Ecology and Management, S.L. Sutton, T.C. Whitmore, and A.C. Chadwick (eds.) Special Publication No. 2, British Ecological Society, Blackwell Scientific Publications, Oxford.

Grainger, A. 1984. Quantifying changes in forest cover in the humid tropics: overcoming current limitations. J. World Forest Resource Management 1:3-63.

Green, K.M. 1983. Using Landsat to monitor tropical forest ecosystems: realistic expectations of digital processing technology, pp. 397-409 In Tropical Rain Forest: Ecology and Management, S.L. Sutton, T.C. Whitmore, and A.C. Chadwick (eds.) Special Publication No. 2, British Ecological Society, Blackwell Scientific Publications, Oxford.

Grigg, D.B. 1974. Wet rice cultivation in Asia, In The Agricultural Systems of the World: An Evolutionary Approach, D.B. Grigg (ed.) Cambridge University Press, Cambridge, MA.

Haden-Guest, S., J.K. Wright, and E.M. Teclaff. 1956. A World Geography of Forest Resources. American Geographical Society Special Publication No. 33, Ronald Press Co., New York.

Haig, I.T., M.A. Huberman, and U Aung Din. 1958. Tropical Silviculture. FAO Forestry and Forest Products Studies No. 13, Vol. 1, FAO, Rome.

Hall, C.A.S. and J. Uhlig. 1991. Refining estimates of carbon released from tropical land-use change. Canad. J. For. Res. 21:118-131.

Hall, D.G.E. 1964. Atlas of South-East Asia. Djambatan, Amsterdam.

Hall, D.O., G.W. Bamard, and P.A. Moss. 1982. Biomass for Energy in the Developing Countries: Current Role, Potential, Problems, Prospects. Pergamon Press, Oxford.

Hallsworth, E.G. (ed.) 1982. Socio-Economic Effects and Constraints in Tropical Forest Management. John Wiley and Sons, Ltd., New York.

Hao, W.M., Liu, M.-H., and P.J. Crutzen, 1990. Estimates of annual and regional releases of CO2 and other trace gases to the atmosphere from fires in the tropics, based on the FAO statistics for the period 1975-1980, pp. 440-462 In Fire in the Tropical Biota: Ecosystem Processes and Global Challenges, J.G. Goldammer (ed.) Springer-Verlag, Berlin.

Harper, D.E., Botkin, D.B., Carpenter, R.A., and B.W. Mar. 1987. Applying Ecology to Land Management in Southeast Asia. Occ. Paper No. 2, East-West Environment and Policy Institute, Honolulu, HI.

Harris, D.R. 1980. Tropical savanna environments: definition, distribution, diversity, and development, pp. 3-27 In Human Ecology in Savanna Environments, D.R. Harris (ed.) Academic Press, London. 
Heske, F., J. Weck, E. Otremba, R. Torunsky, and others. 1980. Weltforstatlas (World Forestry Atlas). Maps, Verlag Paul Parey, Hamburg and Berlin.

Holdridge, L.R. 1967. Life Zone Ecology. Rev. edition, Tropical Science Center, San Jose, Costa Rica.

Holdridge, L.R., W.C. Grenke, W.H. Hathaway, T. Liang, and J.A. Tosi, Jr. 1971. Forest Environments in Tropical Life Zones: A Pilot Study. Pergamon Press, Oxford.

Hooker, J.D. 1875-1897. Flora of British India. 7 vols., L. Reeve, London. Reprinted in 1973 by Bishen Singh Mahendra Pal Singh, Dehra Dun.

Houghton, R.A. 1986. Estimating changes in the carbon content of terrestrial ecosystems from historical data, pp. 175-193 In The Changing Carbon Cycle: A Global Analysis, J.R. Trabalka and D.E. Reichle (eds.) Springer-Verlag, New York.

Houghton, R.A., R.D. Boone, J.R. Fruci, J.E. Hobbie, J.M. Melillo, C.A. Palm, B.J. Peterson, G.R. Shaver, and G.M. Woodwell. 1987. The flux of carbon from terrestrial ecosystems to the atmosphere in 1980 due to changes in land use: geographic distribution of the global flux. Tellus 39B:122-139.

Houghton, R.A. and J.L. Hackler. 1993. The net flux of carbon from deforestation and degradation in South and Southeast Asia, pp. 301-327 InEffects of Land Use Change on Atmospheric $\mathrm{CO}_{2}$ Concentrations: South and Southeast Asia as a Case Study, Dale, V.H. (ed.) Springer-Verlag, New York.

Hughart, D. 1979. Prospects for Traditional and Non-conventional Energy Sources in Developing Countries. World Bank Staff Working Paper No. 346, World Bank, Washington, DC.

Huguet, L. 1983. Replenishing the world's forests: the future of the world's tropical forests. Commonwealth Forestry Review 62:195-200.

Hurst. P. 1990. Rainforest Politics: Ecological Destruction in South-East Asia. Zed Books, London.

Hutter, K.L., Rambo, A.T., and G. Lovelace (eds.) 1985. Cultural Values and Human Ecology in Southeast Asia. Michigan Papers on South and Southeast Asia No. 27, Center for South and Southeast Asian Studies, University of Michigan, Ann Arbor, MI.

Imran, M. and P. Barnes. 1990. Energy Demand in Developing Countries: Prospects for the Future. World Bank Staff Commodity Working Paper Number 23, World Bank, Washington, DC.

Intemational Union for Conservation of Nature and Natural Resources. 1974. Flora and fauna conservation, pp. 395-413 In Natural Resources of Humid Tropical Asia. Natural Resources Research Paper No. 12, UNESCO, Paris. 
Iverson, L., S. Brown, A. Prasad, S. Liu, H, Mitasova, A.J.R. Gillespie, and A.E. Lugo. 1993. Use of GIS for estimating potential and actual tropical forest biomass for south and southeast Asia, pp. 67-116 In Effects of Land Use Change on Atmospheric $\mathrm{CO}_{2}$ Concentrations: South and Southeast Asia as a Case Study, V.H. Dale (ed.) Springer-Verlag, New York.

Janaki Ammal, E.K. 1958. Report on the Humid Regions of South Asia, pp. 43-53 In Problems of Humid Tropical Regions. Humid Tropics Research Series, UNESCO, Paris.

Kanno, K. 1985. The five cases: an overview, pp. 350-362 In Swidden Cultivation in Asia, Vol. 3: Empirical Studies in Selected Swidden Communities: India, Indonesia, Malaysia, Philippines, Thailand. UNESCO Regional Office for Education in Asia and Pacific, Bangkok.

Kaufman, Y.J., A. Setzer, C. Justice, C.J. Tucker, M.C. Pereira, and I. Fung. 1990. Remote sensing of biomass buming in the tropics, pp. 371-399 In Fire in the Tropical Biota: Ecosystem Processes and Global Challenges, J.G. Goldammer (ed.) Springer-Verlag, Berlin.

Keane, A.H. 1909. Asia, Southern and Western. Vol 2, Edward Stanford, London.

Kira, T. and H. Ogawa. 1971. Assessment of primary production in tropical and equatorial forests, pp. 309-21 In Productivity of Forest Ecosystems: Proceedings of the Brussels Symposium, 1969, P. Duvigneaud (ed.) UNESCO, Paris.

Koteswaram, P. 1974. Climate and meteorology of humid tropical Asia, pp. 27-86 In Natural Resources of Humid Tropical Asia. Natural Resources Research Paper No. 12, UNESCO, Paris.

Kuchler, A.W. (ed.) 1968. International Bibliography of Vegetation Maps. Vol. 3: U.S.S.R., Asia, and Australia. Library Series No. 29, University Kansas Publications, Lawrence, KS.

Lanly, J.-P. 1976. Tropical moist forest inventories for industrial investment decisions. Unasylva 28:42-51.

Lanly, J.-P. 1982. Tropical Forest Resources. FAO Forestry Paper 30, FAO, Rome.

Lanly, J.-P. 1985. Defining and measuring shifting cultivation. Unasylva 37:17-21.

Lebar, F.M. (ed.) 1972. Ethnic Groups of Insular Southeast Asia. Vol. I: Indonesia, Andaman Islands, and Madagascar. Human Relations Area Files Press, New Haven, CT.

Lebar, F.M., G.C. Hickey, and J.K. Musgrave (eds.) 1964. Ethnic Groups of Mainland Southeast Asia. Human Relations Area Files Press, New Haven, CT.

Leifert, P. 1979. Bangladesh: energy, forestry and the environment, pp. 246-256 In Proceedings of the USAID Asia Bureau Conference on Energy, Forestry and Environment (Manila, November, 1979). U.S. Agency for International Development, Washington, DC.

Lugo, A.E. and S. Brown. 1992. Tropical forests as sinks of atmospheric carbon. Forest Ecology and Management 54:239-255. 
MacKinnon, J. and K. MacKinnon. 1986. Review of the Protected Areas System in the Indo-Malayan Realm. 2 vols. (Vol. I: text; Vol. II: 6 maps), Intemational Union for Conservation of Nature and Natural Resources and the United Nations Environment Programme, Gland, Switzerland.

Makhijani, M. and A. Poole. 1975. Energy and Agriculture in the Third World. Ballinger Publ. Co., Cambridge, MA.

Malingreau, J.-P. 1990. The contribution of remote sensing to the global monitoring of fires in tropical and subtropical ecosystems, pp. 337-370 In Fire in the Tropical Biota: Ecosystem Processes and Global Challenges, J.G. Goldammer (ed.) Springer-Verlag, Berlin.

Matthews, E. 1983. Global vegetation and land use: New high-resolution data bases for climate studies. J. of Climate and Applied Meteorology 22:474-87.

Meijer, Willem. 1980. A new look at the plight of tropical rain-forests. Environmental Conservation 7:203-6.

Mitchell, B.R. 1982. International Historical Statistics: Africa and Asia. New York University Press, New York.

Molofsky, J., C.A.S. Hall, and N. Myers. 1986. A Comparison of Tropical Forest Surveys. Report DOE/NBB-0078, Dist. Category UC-11, prepared for the United States Dept. of Energy, National Technical Information Service, Springfield, MA.

Montalembert, M.R. de and J. Clement. 1983. Fuelwood Supplies in the Developing Countries. FAO Forestry Paper No. 42, FAO, Rome.

Morgan, W.B. and R.P. Moss. 1981. Fuelwood and Rural Energy Production and Supply in the Humid Tropics: A report for the United Nations University with special reference to Tropical Africa and South-East Asia. Tycooly Int. Publ., Ltd., for United Nations University, Dublin.

Mueller-Dombois, D. 1981. The ecological series approach to forest land classification, 105-39 In Assessing Tropical Forest Lands, Their Suitability for Sustainable Uses: Proceedings of the Conference on Forest Land Assessment and Management for Sustainable Uses (Honolulu, HI, June, 1979), R.A. Carpenter (ed.) Tycooly Intemational Publ., Ltd., Dublin.

Myers, N. 1986. Tropical forests: pattems of depletion, pp. 9-22 In Tropical Rain Forests and the World Atmosphere, G.T. Prance (ed.) Westview Press, Inc., Boulder, CO.

Myers, N. 1988. Tropical deforestation and remote sensing. Forest Ecol. and Management 23:215-255.

Myers, N. 1980. Conversion of Tropical Moist Forests. A Report Prepared by Norman Myers for the Committee on Research Priorities in Tropical Biology. National Research Council, National Academy of Sciences, Washington, DC. 
Myers, N. 1980. The present status and future prospects of tropical moist forests. Environmental Conservation 7:101-14.

Myers, Norman. 1983. Tropical moist forests: over-exploited and under-utilized? Forest Ecology and Management 6:59-79.

National Research Council, Assembly of Life Sciences. 1982. Ecological Aspects of Development in the Humid Tropics. Div. of Biological Sciences, Committee on Selected Biological Problems in the Humid Tropics, National Academy Press, Washington, DC.

Nectoux, F. and Y. Kuroda. 1989. Timber from the South Seas: An Analysis of Japan's Tropical Timber Trade and its Environmenial Impact. WWF Intemational, Gland, Switzerland.

Neil, P.E. 1981. Problems and Opportunities in Tropical Rain-Forest Management. C.F.I. Occasional Paper No. 16, Dept. Forestry, Commonwealth Forestry Institute, University of Oxford, Oxford.

$\mathrm{Ng}$, F.S.P. 1983. Ecological principles of tropical lowland rain forest conservation, pp. $359-75$ In Tropical Rain Forest: Ecology and Management, S.L. Sutton, T.C. Whitmore, and A.C. Chadwick (eds.) Special Publication No. 2, British Ecological Society, Blackwell Scientific Publications, Oxford.

Numata, M. 1979. Ecology of Grasslands and Bamboolands in the World. VEB Gustav Fischer Verlag, Jena.

Nye, P.H., and D.J. Greenland. 1960. The Soil Under Shifting Cultivation. Technical Communication No. 51, Commonwealth Bureau of Soils, Commonwealth Agricultural Bureau, Famham Royal.

Oldeman, L.R. and M. Frere. 1982. Technical Report on a Study of the Agroclimatology of the Humid Tropics of Southeast Asia. FAO/UNESCO/WMO Interagency Project on Climatology, Rome.

Olson, J.S. and J.A. Watts. 1983a. Major World Ecosystem Complexes: Ranked by Carbon in Live Vegetation. Map, U.S. Dept. Energy, Office of Energy Research, Carbon Dioxide Res. Div. Washington, DC.

Olson, J.S., J.A. Watts, and L.J. Allison. 1983b. Carbon in Live Vegetation of Major World Ecosystems. TR004, DOE/NBGB-0037, U.S. Dept. Energy, Office of Energy Research, Carbon Dioxide Res. Div., Washington, DC.

Onslow, C. (ed.) 1965. Asian Economic Development. Weidenfeld and Nicolson, London.

Orlich, Leopold von. 1845. Travels in India Including Sinde and the Punjab. 2 Vols., Reprinted 1976 by East and West Publ. Co., Lahore 
Palm, C.A., R.A. Houghton, J.M. Melillo, D. Skole, and G.M. Woodwell. 1986. The effect of tropical deforestation on atmospheric $\mathrm{CO}_{2}$, pp. 181-94 In Land Clearing and Development in the Tropics, R. Lal, P.A. Sanchez, and R.W. Cummings, Jr. (eds.) A.A. Balkema, Rotterdam.

Patterson, M.L.P., with W.J. Alspaugh. 1981. South Asian Civilizations: A Bibliographic Synthesis. University Chicago Press, Chicago, $\mathbb{\Pi}$.

Pelzer, K.J. 1945. Pioneer Settlement in the Asiatic Tropics: Studies in Land Utilization and Agricultural Colonization in Southeastern Asia. Special Publ. No. 29. American Geographical Society, New York.

Pelzer, K.J. 1978. Swidden cultivation in Southeast Asia: historical, ecological, and economic perspectives, pp. 271-285 In Farmers in the Forest: Economic Development and Marginal Agriculture in Northern Thailand, P. Kunstadter, E.C. Chapman, and S. Sabhasri (eds.) University Press Hawail for East-West Institute, Honolulu, HI.

Peters, W.J. and L.F. Neuenschwander. 1988. Slash and Burn: Farming in the Third World Forest. University of Idaho Press, Moscow, ID.

Poffenberger, M. 1989. The deforestation of South Asia: History of management conflicts, pp. 155-172 In Environmental Education and Sustainable Development, Bandhu, D., Singh, H., and A.K. Maitra (eds.) Indian Environmental Society, New Delhi.

Poffenberger, M. 1990. Keepers of the Forest: Land Management Alternatives in Southeast Asia. Kumarian Press, West Hartford, CT.

Poore, D. 1976. The value of tropical moist forest ecosystems and the environmental consequences of their removal. Unasylva 28:127-43; 145-46.

Pringle, S.L. 1978. Quantity and quality of the tropical forests, pp. 51-68 In Proceedings of the Conference on Improved Utilization of Tropical Forests. Forest Products Laboratory, Forest Service, U.S. Dept. Agriculture, Washington, DC.

Pringle, S.L. 1976. Tropical moist forests in world demand, supply and trade. Unasylva 28:106-18, 145.

Rambo, A.T. and P.E. Sajise (eds.) 1984. An Introduction to Human Ecology Research on Agricultural Systems in Southeast Asia. University of the Philippines, Los Banos.

Rambo, A.T., Gillogly, K., and K.L. Hutterer (eds.) 1988. Ethnic Diversity and the Control of Natural Resources in Southeast Asia. Michigan Papers on South and Southeast Asia No. 32. Center for South and Southeast Asian Studies, University of Michigan, Ann Arbor, MI.

Reed, Clyde F. 1969. Bibliography to Floras of Southeast Asia: Burma, Laos, Thailand (Siam), Cambodia, Vietnam (Tonkin, Annam, Cochinchina), Malay Peninsula, and Singapore. Paul M. Harrod Co., Baltimore, MD. 
Repetto, R. 1988. The Forest for the Trees? Government Policies and the Misuse of Forest Resources. World Resources Institute, New York.

Richards, J.F. 1986. World environmental history and economic development, pp. 53.71 In Sustainable Development of the Biosphere, W.C. Clark and R.E. Munn (eds.) Int. Inst. Applied Systems Analysis, Luxembourg.

Richards, J.F. and R. Tucker (eds.) 1988. World Deforestation in the Twentie'h Century. Duke University Press, Durham, NC.

Richards, J.F. and E.P. Flint. 1993. A century of land use change in South and Southeast Asia, 15 66 In Effects of Land Use Change on Atmospheric $\mathrm{CO}_{2}$ Concentrations: South and Southeast Asia as a Case Study, V.H. Dale (ed.) Springer-Verlag, New York.

Richards, J.F., J.S. Olson, and R.M. Rotty. 1983. Development of a Data Base for Carbon Dioxide Releases Resulting from Conversion of Land to Agricultural Uses. Research Memorandum ORAU/IEA-82-10(M), ORNL/TM-8801, Institute for Energy Analysis, Oak Ridge Associated Universities, Oak Ridge, TN.

Richards, P.W. 1952. The Tropical Rain Forest: An Ecological Study. Cambridge University Press, Cambridge, MA.

Richands, P.W. 1977. Tropical forests and woodlands: an overview. Agro-Ecosystems 3:225-38.

Rosayro, R.A. de. 1974. Vegetation of humid tropical Asia, pp. 179-95 In Natural Resources of Humid Tropical Asia. Natural Resources Research Paper No. 12, UNESCO, Paris.

Royle, J.F. 1840. Essay on the Productive Resources of India. Wm. H. Allen and Co., London.

Ruddle, K. and W. Manshard. 1981. Renewable Natural Resources and the Environment: Pressing Problems in the Developing World. Tycooly Intern. Publ. Co. for the United Nations University, Dublin.

Rudloff, W. 1981. World-Climates, with Tables of Climatic Data and Practical Suggestions. Wissenschaftliche Verlags-gesellschaft, Stuttgart.

Schwartzberg, J.E. (ed.) 1978. A Historical Atlas of South Asia. The Association for Asian Studies Reference Series No. 2, University Chicago Press, Chicago, IL.

Schweinfurth, Ulrich. 1957. Die Horizontale und vertikale Verbreitung der Vegetation im Himalaya. Ferdinand Dummlers Verlag, Bonn.

Scott, M. 1986. Southeast Asia's forests: lost for the trees. Far Eastern Economic Review 132(15):89-91.

Shand, R.T. (ed.) 1969. Agricultural Development in Asia. University Califomia Press, Berkeley, CA. 
Singh, J.S., Y. Hanxi, and P.E. Sajise. 1985. Structural and functional aspects of Indian and Southeast Asian savanna ecosystems, pp. 34-51 In Ecology and Mamagement of the World's Savannas, J.C. Tothill and J.J. Mott (eds.) Australian Acad. Sci., Canberra.

Slesser, M., C.W. Lewis, and I. Hounam. 1982. Blomass assessment in Third World villages via a systems methodology. Biomass 2:57-74.

Soemarwoto, O. and A.T. Rambo (eds.) 1987. Impact of Development on Human Activity Systems in Southeast Asia. Institute of Ecology, Padjadjaran University, Jalan Sekeloa, Bandung, Indonesia, and Southeast Asian Universities Agroecosystem Network, Chiang, Mal, Thailand.

Soussan, J. 1988. Primary Resources and Energy in the Third World. Routledge, London.

Soussan, J. 1990. Energy resources, pp. 140-167 In South East Asian Development: Geographical Perspectives, D. Dwyer (ed.) Longman Scientific and Technical, John Wiley and Sons, Essex and New York.

Soussan, J. and P. O'Keefe. 1985. Research policy and review, Part 5: Biomass energy problems and policies in Asia. Environment and Planning A 17:1293-1301.

Spears, J.S. 1979. Can the wet tropical forest survive? Commonwealth Forestry Review 58:165-80.

Spears, J.S. 1983. Replenishing the world's forests. Tropical reforestation: an achievable goal? Commonwealth Forestry Review 62:201-17.

Spencer, J.E. 1966. Shifting Cultivation in Southeastern Asia. University of Califomia Publications in Geography, Vol. 19, University Califomia Press, Berkeley, CA.

Stadelman, R.C. 1966. Forests of Southeast Asia. Wimmer Bros., Memphis TN.

Sukhwal, B.L. 1974. South Asia: A Systematic Geographic Bibliography. Scarecrow Press, Metuchen.

The World Resources Institure and The International Institute for Environment and Development. 1986. World Resources 1986: A Report by The World Resources Institute and The International Institute for Environment and Development. Basic Books, Inc., New York.

Tosi, J.A., Jr. and R.F. Voertman. 1975. Making the best use of the tropics. Unasylva 27:2-10.

Tosi, J. 1980. Life zones, land use, and forest vegetation in the Tropical and Subtropical regions, pp. 44-64 In The Role of Tropical Forests on the World Carbon Cycle, S. Brown, A.E. Lugo, and B. Liegel (eds.) CONF-800350, U.S. Dept. of Energy, Carbon Dioxide Effects Research and Assessment Program, Washington, DC.

Trenbath, B.R. 1984. Decline of soil fertility and the collapse of shifting cultivation systems under intensification, pp. 279-292 In Tropical Rain-Forest: The Leeds Symposium, A.C. Chadwick and S.L. Sutton (eds.) W.S. Maney and Son Ltd., for Leeds Philosophical and Literary Soc., Leeds. 
Troup, R.S. 1921. The Silviculiure of Indian Trees. 3 vols., Clarendon Press, Oxford.

Tucker, R.P. and J.F. Richards (eds). 1988. Global Deforestation and the Nineteenth-Century World Economy. Duke Press Policy Studies, Durham, NC.

Uhlig, J., C.A.S. Hall, and Tun Nyo. 1993. Changing pattems of shifting cultivation in selected countries in southeast Asia and their effect on the global carbon cycle, pp. 145-200 in Effects of Land Use Change on Atmospheric $\mathrm{CO}_{2}$ Concentrations: South and Southeast Asia as a Case Study, V.H. Dale (ed.) Springer-Verlag, New York.

United Nations Economic and Social Commission for Asia and the Pacific. 1982. Proceedings of the ESCAPIFAOIUNEP Expert Group Meeting on Fuelwood and Charcoal. Energy Resources Development Series No. 24, United Nations, New York.

United Nations Economic and Social Commission for Asia and the Pacific. 1984c. Energy in the ESCAP Region: Policies, Issues and the Potential for Regional Co-operation. Development Papers No. 4, United Nations, Bangkok.

United Nations Dept. of Intemational Economic and Social Affairs. 1979. Demographic Yearbook: Historical Supplement. United Nations Publication ST/ESA/STAT/SER.R/8, United Nations, New York.

United Nations Dept. of Intemational Economic and Social Affairs. 1985. Compendium of Human Settlements Statistics. 4th edition, United Nations Statistical Office, New York.

United Nations Dept. of Intemational Economic and Social Affairs. 1986. 1983/84 Statistical Yearbook. 34th issue, United Nations Statistical Office, New York.

United Nations Dept. of Intemational Economic and Social Affairs. 1990. 1988 Demographic Yearbook. 40th issue, United Nations Statistical Office, New York.

United Nations Economic and Social Commission for Asia and the Pacific. 1984. Statistical Yearbook for Asia and the Pacific 1984. UN/ESCAP, Bangkok.

United Nations Economic and Social Commission for Asia and the Pacific. 1985a. Energy Resources Development Problems in the ESCAP Region. Energy Resources Development Series No. 28, United Nations, New York.

United Nations Economic and Social Commission for Asia and the Pacific. 1985b. New and Renewable Sources of Energy for Development. Energy Resources Development Series No. 30. United Nations, New York.

United Nations Economic and Social Commission for Asia and the Pacific. 1990. Economic and Social Survey of Asia and the Pacific 1989. UN/ESCAP, Bangkok.

United Nations Economic Commission for Asia and the Far East. 1956. Survey of Housing and Building Materials in Asia and the Far East, 1956. UN/ESCAP, Bangkok. 
United Nations, UNESCO. 1973. International Classification and Mapping of Vegetation. UNESCO, Paris.

United Nations, UNESCO. 1958. Study of Tropical Vegetation: Proceedings of the Kandy Symposium. UNESCO, Paris.

United Nations, UNESCO. 1978. I ropical Forest Ecosystems, A State-of-Knowledge Report. Natural Resources Research Paper No. 14, UNESCO/UNEP/FAO, Paris.

United Nations, UNESCO. 1979. Tropical Grazing Land Ecosystems, A State-of-Knowledge Report. Natural Resources Research Paper No. 16, UNESCO/UNEP/FAO, Paris.

United States Agency for Intemational Development. 1979. Proceedings of the USAID Asia Bureau Conference on Energy, Forestry and Environment (Manila, November, 1979). U.S. Agency for Intemational Development, Washington, DC.

Walter, H. (translated by D. Mueller-Dombois) 1971. Ecology of Tropical and Subtropical Vegetation. Oliver and Boyd, Edinburgh.

Walter, H. (translated from Sth German edition by O. Muise) 1984. Vegetation of the Earth and Ecological Systems of the Geo-Biosphere. 3rd edition, Springer-Verlag, Berlin.

Whitmore, T.C. 1984. A vegetation map of Malesia at scale 1:5 million. J. Biogeography $11: 461-471$.

Whitmore, T.C. 1984. Tropical Rain Forests of the Far East. 2nd edition, Clarendon Press, Oxford.

Whyte, R.O. 1974. Grasses and grasslands, pp. 239-62 In Natural Resources of Humid Tropical Asia. Natural Resources Research Paper No. 12, UNESCO, Paris.

Whyte, R.O. 1977. Analysis and ecological management of tropical grazing lands, pp. 3-124 In Application of Vegetation Science to Grassland Husbandry (Handbook of Vegetation Science Part XIII), W. Krause (ed.) Dr. W. Junk Publishers, The Hague.

Williams, C.N. and K.T. Joseph. 1970. Climate, Soil and Crop Production in the Humid Tropics. Oxford University Press, Kuala Lumpur.

Williams, L. 1965. Vegetation of Southeast Asia. Studies of Forest Types 1963-1965. U.S. Dept. Agric., Agricultural Research Service, Crops Research Div., Washington, DC.

World Resources Institute. 1990. World Resources 1990-91. U.N. Environment Programme, U.N. Development Programme, Oxford University Press, New York.

Yoshino, M.M. 1984a. Water balance of monsoon Asia, pp. 57-77 In Climate and Agricultural Land Use in Monsoon Asia, M.M. Yoshino (ed.) University Tokyo Press, Tokyo. 
Yoshino, M.M. 1984b. Ecoclimatic systems and agricultural land use in monsoon Asia, pp. 81-108 In Climate and Agricultural Land Use in Monsoon Asia, M.M. Yoshino (ed.) University of Tokyo Press, Tokyo.

Yoshino, M.M. (ed.) 1984. Climate and Agricultural Land Use in Monsoon Asia. University of Tokyo Press, Tokyo.

Zon, Raphael and William N. Sparhawk. 1923. Forest Resources of the World. Maps, Vol. 1, McGraw-Hill Book Co., Inc., New York. 


\subsection{MAPS (ZONE BOUNDARIES)}

Bangladesh Bureau of Statistics. 1981. Statisical Yearbook of Bangladesh, 1981. Statistics Div., Ministry of Planning, Dacca.

Chandler, D.P. 1991. The Tragedy of Cambodian History: Politics, War, and Revolution Since 1945. Yale University Press, New Haven, CT.

Courtenay, P.P. and X.K.Y. Van. 1983. Cartographic Frames for Peninsular Malaysia District Statistics, 1947-1982 (includes the nation of Singapore). Malaysian Dept. of Statistics, Jabatan Perangkaan, Kuala Lumpur.

Dutt, A.K. and M.M. Dutt. 1987. Fully Annotated Atlas of South Asia. Westview Press, Boulder, CO.

Fryer, D.W. 1979. Emerging Southeast Asia: A Study in Growth and Stagnation. 2nd edition, G. Philip, London.

Hickey, G.C. 1982. Sons of the Mountains: Ethnohistory of the Vietnamese Central Highlands to 1954. Yale University Press, New Haven, CT.

Kummer, D.M. 1992. Deforestation in the Postwar Philippines. Geog. Res. Paper No. 234, University of Chicago, Chicago, IL.

Statistik des Auslandes. 1986. Landerbericht, Birma. Statistisches Bundesamt Wiesbaden, W. Kohlhammer GMBH, Stuttgart.

Stemstein, L. 1976. Thailand: the Environment of Modernization. McGraw-Hill Int. Book Co., Singapore.

TT Maps and Publications, Ltd. 1987. A Social and Economic Atlas of India. Sk Mookerjee, Oxford University Press, New Dehli.

Ulack, R., Pauer, G., and others. 1989. Atlas of Southeast Asia. Macmillan Publishers Co., New York.

Wang, G. (ed.) 1964. Malaysia: A Survey (includes the nation of Brunei). Frederick A. Praeger Publishers, New York. 


\section{CONTENTS OF THE COMPUTERIZED DATA FILES}

The following list describes the files distributed on the magnetic media distributed by CDIAC along with this documentation. These files are also available through CDIAC's anonymous file transfer protocol service via the INTERNET.

File number

and

description

$\begin{array}{ll} & \text { Records } \\ \text { Logical } & \text { per } \\ \text { records } & \text { file }\end{array}$

Block

Record

size

length

1. General descriptive

information file

1723

1723

8000

80

2. Land use, $\mathrm{Mg}$ carbon per ha, population, and total carbon data for the 94 zones and 13 countries in South and

Southeast Asia

(FLAT ASCII FILE)

$105 \quad 4725$

6000

60

3. SAS ${ }^{\mathrm{TM}}$ code to read and print

File 2

$95 \quad 95$

8000

80

4. FORTRAN code to read and print File 2

$51 \quad 51$

8000

80

5. Land use accuracy flags

(for file 2) based on the

type and quality of source data

(FLAT ASCII FILE)

$94 \quad 470$

6000

60

6. $\quad S A S^{T M}$ code to read and print

File 5

15

15

8000

80

7. FORTRAN code to read and print File 5

38

38

8000

80 
File number

and

description

\begin{tabular}{|c|c|c|}
\hline $\begin{array}{l}\text { ogical } \\
\text { ecords }\end{array}$ & $\begin{array}{l}\text { Records } \\
\text { per } \\
\text { file }\end{array}$ & $\begin{array}{l}\text { Block } \\
\text { size }\end{array}$ \\
\hline
\end{tabular}

8. Factors (M, E, D, and N) used to calculated the $\mathrm{Mg} \mathrm{C} /$ ha for each land use type, for each time period, and each zone (FLAT ASCII FILE)

$94 \quad 1128$

8000

80

9. $S A S^{\mathrm{TM}}$ code to read and print File 8

$29 \quad 29$

8000

80

10. FORTRAN code to read and print File 8

$50 \quad 50$

8000

80

11. Base map with the Longitude, Latitude coordinates of the 13 countries in South and Southeast Asia (FLAT ASCII FILE) $280^{\mathrm{V}} 21214$

3000 30

12. Base map with the Longitude, Latitude coordinates of the 94 ecological zones in South and Southeast Asia (FLAT ASCII FILE)

$348^{\vee} \quad 34619$

3000

30

13. SAS ${ }^{\text {TM }}$ code to read and print File 11 and 12

$15 \quad 15$

8000

80

14. FORTRAN code to read and print File 11 and 12

$47 \quad 47$

8000

80

15. Land use, $\mathrm{Mg}$ carbon per ha, and total carbon data for Bangladesh

(Lotus $1-2-3^{\text {TM }}$ WK1 FILE)

$x^{N} \quad 537$

1000

100 
File number

and

description

\section{Logical per}

Records

records file

Block

Record

size length

16. Land use, Mg carbon per ha, and total carbon data for

Brunei

(Lotus $1-2 \cdot 3^{\text {TM }}$ WK1 FILE)

$$
x^{N} \quad 96
$$

1000

100

17. Land use, $\mathrm{Mg}$ carbon per ha, and total carbon data for India

(Lotus $1-2-3^{\text {TM }}$ WK1 FILE)

$x^{N} \quad 2335$

1000

100

18. Land use, $\mathrm{Mg}$ carbon per ha, and total carhon data for Indonesia (Lotus $1-2-3^{\mathrm{TM}}$ WK1 FILE)

19. Land use, $\mathrm{Mg}$ carbon per ha, and total carbon data for Kampuchea (Cambodia) (Lotus $1-2-3^{\text {TM }}$ WK1 FILE)

20. Land use, $\mathrm{Mg}$ carbon per ha, and total carbon data for

Laos

(Lotus $1-2-3^{\mathrm{TM}}$ WK1 FILE)

21. Land use, Mg carbon per ha, and total carbon data for Malaysia

(Lotus 1-2-3 ${ }^{\text {TM }}$ WK1 FILE)

22. Land use, $\mathbf{M g}$ carbon per ha, and total carbon data for Myanmar (Burma) (Lotus $1-2-3^{\mathrm{TM}}$ WK1 FILE) 
File number

and

description

Logical

Records

per

Block

Record

records

file

size

length

23. Land use, $\mathrm{Mg}$ carbon per ha, and total carbon data for the Philippines

(Lotus 1-2-3 ${ }^{\text {TM }}$ WK1 FILE)

$x^{N} \quad 438$

1000

100

24. Land use, $\mathrm{Mg}$ carbon per ha, and total carbon data for

Singapore

(Lotus 1-2-3 ${ }^{\text {TM }}$ WK1 FILE)

$x^{N} \quad 96$

1000

100

25. Land use, Mg carbon per ha, and total carbon data for

Sri Lanka

(Lotus 1-2-3 ${ }^{\text {TM }}$ WK1 FILE)

$x^{N} \quad 272$

1000

100

26. Land use, $\mathrm{Mg}$ carbon per ha, and total carbon data for

Thailand

(Lotus 1-2-3 ${ }^{\mathrm{TM}}$ WK1 FILE)

$x^{N} \quad 438$

1000

100

27. Land use, $\mathrm{Mg}$ carbon per ha,

and total carbon data for

Vietnam

(Lotus 1-2-3 ${ }^{\text {TM }}$ WK1 FILE)

$x^{N} \quad 741$

1000

100

28. Land use accuracy flags based on the type and quality of source data for all zones within South and Southeast Asia

(Lotus $1-2-3^{\mathrm{TM}}$ WK1 FILE)

$x^{N} \quad 512$

1000

100 
File number

and

description

Logical per

Block

Record

records file

size

length

29. Factors (M, E, D, and $\mathrm{N}$ ) used

to calculated the $\mathrm{Mg} \mathrm{C} / \mathrm{ha}$ for

each land use type, for each

time period, and each zone within

South and Southeast Asia

(Lotus $1-2-3^{\mathrm{TM}}$ WK1 FILE)

$x^{N} \quad 2098 \quad 1000$

100

30. Land use data for the 94

ecological zones in South

and Southeast Asia

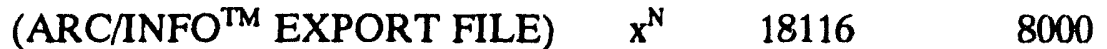

80

31. $\mathrm{Mg} \mathrm{C} / \mathrm{ha}$ data for the 94

ecological zones in South

and Southeast Asia

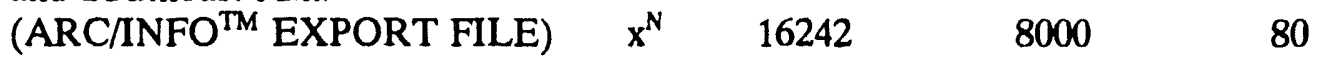

32. Carbon data for the 94

ecological zones in South

and Southeast Asia

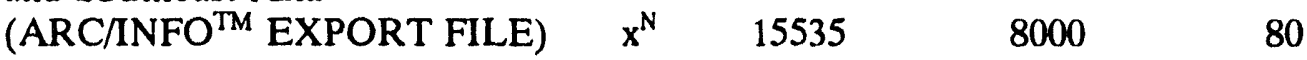

............ Documentation Files Follow -...........

33. Chittagong Hill Tracts

(zone 101) summary file

(Lotus $1-2-3^{\text {TM }}$ WK1 FILE)

$x^{N} \quad 341 \quad 1000$

100

34. Eastern Coast (zone 102)

summary file

(Lotus $1-2-3^{\text {TM }}$ WK1 FILE)

$x^{N} \quad 978$

1000

100

35. Meghna Districts (zone 103)

summary file

(Lotus $1-2-3^{\mathrm{TM}}$ WK1 FILE)

$x^{N} \quad 1674$

1000

100 
File number

and

description

Records

Logical per

Block

Record

records file

size

length

36. Sundarbans (zone 104)

summary file

(Lotus $1-2-3^{\mathrm{TM}}$ WK1 FILE)

$x^{N} \quad 997$

1000

100

37. Western Districts (zone

105) summary file

(Lotus $1-2-3^{\text {TM }}$ WK1 FILE)

$x^{N} \quad 3017$

1000

100

38. Chittagong Hill Tracts

(zone 101) land use

documentation file

(Lotus 1-2-3 ${ }^{\text {TM }}$ WK1 FILE)

$x^{N} \quad 892$

1000

100

39. Eastern Coast (zone 102)

land use documentation

file

(Lotus $1-2-3^{\mathrm{TM}}$ WK1 FILE)

$x^{N} \quad 809$

1000

100

40. Meghna Districts (zone 103)

land use documentation

file

(Lotus 1-2-3 ${ }^{\text {TM }}$ WK1 File)

$x^{N} \quad 839$

1000

100

41. Sundarbans (zone 104)

land use documentation

file

(Lotus $1-2-3^{\text {TM }}$ WK1 File)

$x^{N} \quad 841$

1000

100

42. Western Districts

(zone 105) land use

documentation file

(Lotus $1-2-3^{\text {TM }}$ WK1 File)

$x^{N} \quad 789$

1000

100 
File number

and

description
Records

Logical per

file
Block

size
Record

length

43. Brunei (zone 200) summary and land use documentation file

(Lotus $1-2-3^{\mathrm{TM}}$ WK1 File)

$x^{N} \quad 327$

1000

100

44. India land use (total all zones) documentation file (Lotus $1-2-3^{\text {TM }}$ WK1 File)

$x^{N} \quad 65$

1000

100

45. Andaman/Nicobar Islands (zone 301) summary file (Lotus 1-2-3 ${ }^{\mathrm{TM}}$ WK1 File)

$x^{N} \quad 213$

1000

100

46. Andhra Pradesh (zone 302) summary file (Lotus $1-2-3^{\text {TM }}$ WK1 File)

47. Arunachal Pradesh (zone 303) summary file

(Lotus 1-2-3 ${ }^{\text {tM }}$ WK1 File)

48. Assam (zone 304) summary file

(Lotus $1-2-3^{\mathrm{TM}}$ WK1 File)

$x^{N} \quad 178$

1000

100

49. Bihar (zone 305)

summary file

(Lotus 1-2-3 ${ }^{\text {TM }}$ WK1 File)

$x^{N} \quad 174$

1000

100

50. Delhi (zone 306)

summary file

(Lotus 1-2-3 ${ }^{\text {TM }}$ WK1 File)

$x^{N} \quad 197$

1000

100 
File number

and

description

$\begin{array}{llll} & \text { Records } & \text { Block } & \text { Record } \\ \text { Logical } & \text { per } & \text { size } & \text { length } \\ \text { records } & \text { file } & \text { sile }\end{array}$

51. Part 1 of the Gujarat/

Dadra/Nagar Haveli

(zone 307) summary file

(Lotus 1-2-3 ${ }^{\text {TM }}$ WK1 File)

$x^{N} \quad 189$

1000

100

52. Part 2 of the Gujarat/

Dadra/Nagar Haveli

(zone 307) summary file

(Lotus 1-2-3 ${ }^{\text {TM }}$ WK1 File)

$x^{N} \quad 209$

1000

100

53. Gujarat/Dadra/Nagar H. (zone

307) land use totals from

part 1 and 2 summary files

(Lotus 1-2.3 ${ }^{\mathrm{TM}}$ WK1 File)

$x^{N} \quad 89$

1000

100

54. Part 1 of the Haryana/

Chandigarh (zone 308)

summary file

(Lotus 1-2-3 ${ }^{\mathrm{TM}}$ WK1 File)

$x^{N} \quad 195$

1000

100

55. Part 2 of the Haryana/

Chandigarh (zone 308)

summary file

(Lotus $1-2-3^{\mathrm{TM}}$ WK1 File)

$x^{N} \quad 196$

1000

100

56. Haryana/Chandigarh (zone

308) land use totals from

part 1 and 2 summary files

(Lotus $1-2-3^{\text {TM }}$ WK1 File)

$x^{N} \quad 91$

1000

100

57. Himachal Pradesh (zone 309)

summary file

(Lotus 1-2-3 ${ }^{\text {TM }}$ WK1 File)

$x^{N} \quad 180$

1000

100 
File number

and

description

Logical

records
Records

per

file
Block

size
Record

length

58. Jammu/Kashmir (zone 310) summary file

(Lotus 1.2.3 ${ }^{\mathrm{TM}}$ WK1 File)

$x^{N} \quad 236$

1000

100

59. Karnataka (zone 311)

summary file

(Lotus $1-2-3^{\mathrm{TM}}$ WK1 File)

$x^{N} \quad 237$

1000

100

60. Kerala (zone 312)

summary file

(Lotus $1-2-3^{\mathrm{TM}}$ WK1 File)

$x^{N} \quad 204$

1000

100

61. Lakshadweep Islands

(zone 313) summary file

(Lotus $1-2-3^{\mathrm{TM}}$ WK1 File)

$x^{N} \quad 178$

1000

100

62. Madhya Pradesh (zone 314)

sumrrary file

(Lotus 1-2-3 ${ }^{\mathrm{TM}}$ WK1 File)

$x^{N} \quad 207$

1000

100

63. Part 1 of the Maharashtra/

Goa/Daman/Diu (zone 315) summary file

(Lotus $1-2-3^{\text {TM }}$ WK1 File)

$x^{N} \quad 192$

1000

100

64. Part 2 of the Maharashtra/

Goa/Daman/Diu (zone 315)

summary file

(Lotus $1-2-3^{\mathrm{TM}}$ WK1 File)

$x^{N} \quad 211$

1000

100

65. Maharashtra/Goa/Daman/Diu

(zone 315) land use totals

from part 1 and 2 summary

files

(Lotus $1-2-3^{\mathrm{TM}}$ WK1 File)

$x^{N} \quad 89$

1000

100 
File number

and

description
Records

Logical per

records file
Block

size
Record

length

66. Manipur (zone 316)

summary file

(Lotus 1.2-3 ${ }^{\mathrm{TM}}$ WK1 File)

$x^{N} \quad 175$

1000

100

67. Meghalaya (zone 317)

summary file

(Lotus 1.2-3 ${ }^{\text {TM }}$ WK1 File)

$x^{N} \quad 179$

1000

100

68. Mizoram (zone 318)

summary file

(Lotus 1-2-3 ${ }^{\mathrm{TM}}$ WK1 File)

$x^{N} \quad 178$

1000

100

69. Nagaland (zone 319)

summary file

(Lotus 1-2-3 ${ }^{\text {TM }}$ WK1 File)

$x^{N} \quad 175$

1000

100

70. Orissa (zone 320)

summary file

(Lotus 1-2-3 ${ }^{\mathrm{TM}}$ WK1 File)

$x^{N} \quad 231$

1000

100

71. Punjab (zone 321)

summary file

(Lotus 1-2-3 ${ }^{\mathrm{TM}}$ WK1 File)

$x^{N} \quad 230$

1000

100

72. Rajasthan (zone 322)

summary file

(Lotus $1-2-3^{\mathrm{TM}}$ WK1 File)

$x^{N} \quad 220$

1000

100

73. Sikkim (zone 323)

summary file

(Lotus 1-2-3 ${ }^{\mathrm{TM}}$ WK1 File)

$x^{N} \quad 139$

1000

100

74. Part 1 of the Tamil

Nadu/Pondichery (zone

324) summary file

(Lotus 1-2-3 ${ }^{\text {MM }}$ WK1 File)

$x^{N} \quad 174$

1000

100 
File number

and

description

\section{Records}

Logical

per

file

Block

Record

records

size

length

75. Part 2 of the Tamil

Nadu/Pondichery (zone

324) summary file

(Lotus 1-2.3 ${ }^{\text {mM }}$ WK1 File)

$x^{N} \quad 219$

1000

100

76. Tamil Nadu/Pondichery

(zone 324) land use totals

from part 1 and 2 summary

files

(Lotus 1-2.-3 ${ }^{\text {TM }}$ WK1 File)

$x^{N} \quad 91$

1000

100

77. Tripura (zone 325)

summary file

(Lotus 1-2-3 ${ }^{\text {TM }}$ WK1 File)

$x^{N} \quad 175$

1000

100

78. Uttar Pradesh (zone 326)

summary file

(Lotus 1-2.3 ${ }^{\mathrm{TM}}$ WK1 File)

$x^{N} \quad 167$

1000

100

79. West Bengal (zone 327)

summary file

(Lotus 1-2-3 ${ }^{\text {TM }}$ WK1 File)

$x^{N} \quad 185$

1000

100

80. Indonesia human population

documentation file

(Lotus $1-2-3^{\mathrm{TM}}$ WK1 File)

$x^{N} \quad 234$

1000

100

81. Indonesia livestock

documentation file

(Lotus $1-2-3^{\mathrm{TM}}$ WK1 File)

$x^{N} \quad 417$

1000

100

82. Aceh, North Sumatra, West

Sumatra, Riau, Jambi, South

Sumatra, and Bengkulu/Lampung

(zones 401-7) summary file

(Lotus 1-2-3 ${ }^{\text {TM }}$ WK1 File)

$x^{N} \quad 1103$

1000

100 
File number

and

description

$\begin{array}{ll} & \text { Records } \\ \text { Logical } & \text { per } \\ \text { records } & \text { file }\end{array}$

Block

size

Record

length

83. West, Central, and East Java (zones 408-410) summary file (Lotus 1-2-3 ${ }^{\mathrm{TM}}$ WK1 File)

$x^{N} \quad 537$

1000

100

84. Bali, West Nusa Tenggara, East

Nusa Tenggara, and East Timor (zones 411-414) summary file (Lotus 1-2-3 ${ }^{\text {TM }}$ WK1 File)

$x^{N} \quad 1280$

1000

100

85. West, Central, East, and

South Kalimantan (zones 415.

418) summary file

(Lotus 1.2.3 ${ }^{\text {m }}$ WK1 File)

$x^{N} \quad 1330$

1000

100

86. North/Central and South/

Southeast Sulawesi (zones

419 and 420 ) summary file

(Lotus 1-2-3 ${ }^{\mathrm{TM}}$ WK1 File)

$x^{N} \quad 760$

1000

100

87. Maluku and Irian Jaya (zones

421-422) summary file

(Lotus 1-2-3 ${ }^{\mathrm{TM}}$ WK1 File)

$x^{N} \quad 596$

1000

100

88. Kampuchea (all zones)

summary file

(Lotus 1-2.3 ${ }^{\text {TM }}$ WK1 File)

$x^{N} \quad 358$

1000

100

89. Kampuchea (all zones)

land use documentation

file

(Lotus 1-2-3 ${ }^{\text {TM }}$ WK1 File)

$x^{N} \quad 649$

1000

100

90. Laos (all zones)

summary file

(Lotus 1-2-3 ${ }^{\mathrm{TM}}$ WK1 File)

$x^{N} \quad 376$

1000

100 
File number

and description

$\begin{array}{ll} & \text { Records } \\ \text { Logical } & \text { per } \\ \text { records } & \text { file }\end{array}$

Block

Record

size

length

91. Laos (all zones)

land use documentation

file

(Lotus 1-2.3 ${ }^{\text {MM }}$ WK1 File)

$x^{N} \quad 710$

1000

100

92. Western Peninsular,

Eastern Peninsular, and

Johor (zones 701-703)

summary and land use

documentation file

(Lotus 1-2-3 ${ }^{\mathrm{TM}}$ WK1 File)

$\begin{array}{lll}x^{N} & 674 & 1000\end{array}$

100

93. Western, Central, and

Eastern Sarawak (zones

704-706) summary and

land use documentation

file

(Lotus $1-2-3^{\text {TM }}$ WK1 File)

$x^{N} \quad 348$

1000

100

94. Sabah (zone 707)

summary and land use

documentation file

(Lotus 1-2-3 ${ }^{\text {TM }}$ WK1 File)

$x^{N} \quad 170$

1000

100

95. Chin/Arakan (zone 801)

summary and land use

documentation file

(Lotus 1-2-3 ${ }^{\mathrm{TM}}$ WK1 File)

$x^{N} \quad 1421$

1000

100

96. Northern zone (zone 802)

summary and land use

documentation file

(Lotus $1-2-3^{\mathrm{nM}}$ WK1 File)

$x^{N} \quad 1485$

1000

100 
File number

$$
\text { and }
$$

description

$\begin{array}{ll} & \text { Records } \\ \text { Logical } & \text { per } \\ \text { records } & \text { file }\end{array}$

Block

Record

size

length

97. Dry zone (zone 803) summary and land use documentation file (Lotus $1.2 .3^{\mathrm{TM}}$ WK1 File)

$\begin{array}{ll}x^{N} & 1457 \\ \end{array}$

100

98. Shan/Karen/Kayah (zone

804) summary and land use documentation file (Lotus 1-2-3 ${ }^{\mathrm{TM}}$ WK1 File)

$x^{N} \quad 2352$

1000

100

99. Delta zone (zone 805) summary and land use documentation file (Lotus $1-2-3^{\text {TM }}$ WK1 File)

$\begin{array}{ll}x^{N} & 1996 \quad 1000\end{array}$ 100

100. Peninsular zone (zone 806) summary and land use documentation file (Lotus 1-2.3 ${ }^{\mathrm{TM}}$ WK1 File)

101. Philippines (all zones) summary file (Lotus $1-2-3^{\mathrm{TM}}$ WK1 File)

684

1000

100

102. Philippines (all zones) land use documentation

file (Lotus 1-2.-3 ${ }^{\mathrm{TM}}$ WK1 File)

711

1000

100

103. Singapore summary and land use documentation file (zone 1000)

(Lotus 1-2-3 ${ }^{\mathrm{TM}}$ WK1 File)

$x^{N} \quad 297$

1000

100 
File number

and

description

\begin{tabular}{|c|c|c|}
\hline Logical & $\begin{array}{l}\text { Records } \\
\text { per } \\
\text { file }\end{array}$ & $\begin{array}{l}\text { Block } \\
\text { size }\end{array}$ \\
\hline
\end{tabular}

104. Sri Lanka (all zones)

summary and land use

documentation file

(Lotus 1-2-3 ${ }^{\text {TM }}$ WK1 File)

$x^{N} \quad 468$

1000

100

105. Thailand (all zones)

summary and land use

documentation file

(Lotus 1-2-3 ${ }^{\text {TM }}$ WK1 File)

$x^{N} \quad 396$

1000

100

106. Vietnam (all zones)

summary file

(Lotus 1-2-3 ${ }^{\text {TM }}$ WK1 File)

$x^{N} \quad 411$

1000

100

107. Vietnam (all zones)

land use documentation

file

(Lotus $1-2-3^{\mathrm{TM}}$ WK1 File)

$x^{N} \quad 834$

1000

100

$v_{\text {indicates that the number of records (lines) per logical record varies. }}$

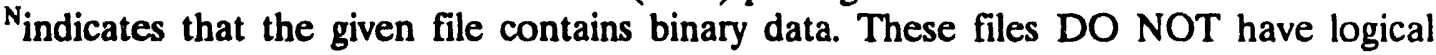
records since these files are in proprietary formats that are usable only by appropriate software packages (e.g., ARC/INFO ${ }^{\mathrm{TM}}$ or Lotus $1-2-3^{\mathrm{TM}}$ ).

1. ARC/INFO ${ }^{\text {TM }}$ export files (Version 6.1) are coverages converted to flat ascii, fixed-block, files for data transfer purposes. The IMPORT command in ARC/NFO ${ }^{\mathrm{TM}}$ must be used to enter these files into your system.

2. ARC/NFFO ${ }^{\mathrm{TM}}$ is a registered trademark of the Environmental Systems Research Institute, Inc., Redlands, CA 92372.

3. $\quad \mathrm{SAS}^{\mathrm{TM}}$ is a registered trademark of the SAS Institute, Inc., Cary, NC 27511-8000.

4. Lotus $1-2-3^{\text {TM }}$ is a registered trademark of Lotus Development Corporation, Cambridge, MA 02142. 


\section{DESCRIPTIVE FILE ON THE MAGNETIC MEDIA}

The following is a listing of the first file provided on the magnetic media distributed by CDIAC. This file provides variable descriptions, formats, units, and other pertinent information about each file associated with this data base.

TITLE OF THE DATA BASE

HISTORIC LAND USE AND CARBON ESTIMATES FOR SOUTH AND SOUTHEAST ASIA: 1880-1980

\section{CONTRIBUTORS}

John F. Richards

Department of History

Duke University

Durham, North Carolina 27708

U.S.A.
Elizabeth P. Flint

Department of History

Duke University

Durham, North Carolina 27708

U.S.A.

\section{SCOPE OF THE DATA}

This data base contains estimates of land use and the carbon content of vegetation for South and Southeast Asia for the years 1880, 1920, 1950, 1970, and 1980. For purposes of this Numeric Data Package (NDP), South and Southeast Asia encompasses the countries of India, Sri Lanka, Bangladesh, Myanmar (Burma), Thailand, Laos, Kampuchea (Cambodia), Vietnam, Malaysia, Brunei, Singapore, Indonesia, and the Philippines.

Information on the population of each country and ecological zone, as well as information on the number of livestock in each country and zone, are included with this NDP. (An ecological zone is made up of one or more contiguous political units (e.g., districts) that have been grouped together based on socio-ecological similarities.] These data may be used by demographers, historians, geographers, or other researchers who are interested in the relationship between land cover change, land degradation, and anthropogenic activities.

The data within this NDP were collected by John Richards and Elizabeth Flint at Duke University, Durham, North Carolina. Data collection was sponsored by the Environmental Sciences Division, U.S. Department of Energy, in support of DOE's Global Carbon Cycle Research Program. The data base was collected to reduce the uncertainty associated with the historic release of carbon into the atmosphere by land use change in South and Southeast Asia. 


\section{DATA FORMATS}

The data distributed with this NDP were initially received as Lotus $1-2-3^{\mathrm{TM}}$ WK1 or WK3 spreadsheets and the base maps were obtained as ARC/INFO ${ }^{\mathrm{TM}}$ export files. The Lotus 1-2-3 ${ }^{\mathrm{TM}}$ spreadsheets have been standardized into the WK1 file format and have been exported into flat ASCII data files to allow for use by a wider audience. The ARC/INFO ${ }^{\mathrm{TM}} \mathrm{EO0}$ files have also been exported (using the UNGENERATE command in $A R C / I_{N F O}{ }^{\mathrm{TM}}$ ) and are formatted in a flat ASCII format. Thus, the data contained in this NDP are available in their entirety in several flat ASCII files (data and base mans) as well as in Lotus $1-2-3^{\mathrm{TM}}$ WK1 and ARC/INFO ${ }^{\mathrm{TM}}$ E00 files.

Seventy-five supporting Lotus 1-2-3 ${ }^{\text {TM }}$ WK1 files have been provided with this NDP to help document how each of the primary data sources were utilized and how the conversion processes were used to transform the original (source) land use categories into the eight standard land use classes used in this data package. Because of the dissimilar and subjective nature of these files, they have not been quality assured by CDIAC. Questions regarding the contents of these files should be directed to the primary investigators.

All land use data values presented in these data files are expressed in units of $10^{3}$ ha. The human and livestock population data are also expressed in thousands. The carbon content estimates for each land use type are expressed in $\mathrm{Mg}$ of carbon per ha (i.e., $1 \mathrm{Mg}$ of carbon = 1 metric ton of carbon). The estimated carbon contents were multiplied by the land use figures to obtain the total amount of carbon sequestered in live vegetation for each land use class, zone, and year in the data set. These total carbon estimates are expressed in $10^{3} \mathrm{Mg}$ of carbon.

\section{FLAT ASCII DATA FILES:}

Five flat ASCII data files are provided with this data package. Four SAS ${ }^{\mathrm{TM}}$ and FORTRAN programs designed to read and print the contents of each data file are also provided. The information within these files will allow the user to ascertain the amount of change in land use, concentration of carbon per ha by land use class, and the change in the amount of carbon sequestered in live vegetation that has occurred in South and Southeast Asia over the last 100 years.

$\overline{\mathrm{ARC} / I N F O^{\mathrm{TM}}}$ is a registered trademark of the Environmental Systems Research Institute, Inc., Redlands, CA 92372.

$\mathrm{SAS}^{\mathrm{TM}}$ is a registered trademark of the SAS Institute, Inc., Cary, NC 27511-8000.

Lotus $1-2-3^{\mathrm{TM}}$ is a registered trademark of Lotus Development Corporation, Cambridge, MA 02142. 


\section{FILE: LANDCARB.ASC}

What follows is a description of the contents and format (variable names, widths, etc.) of the five flat ASCII data files distributed with this data package. The name of the first flat ASCII file is LANDCARB.ASC (File 2). A summary of the FORTRAN format statements used to read File 2 follow.

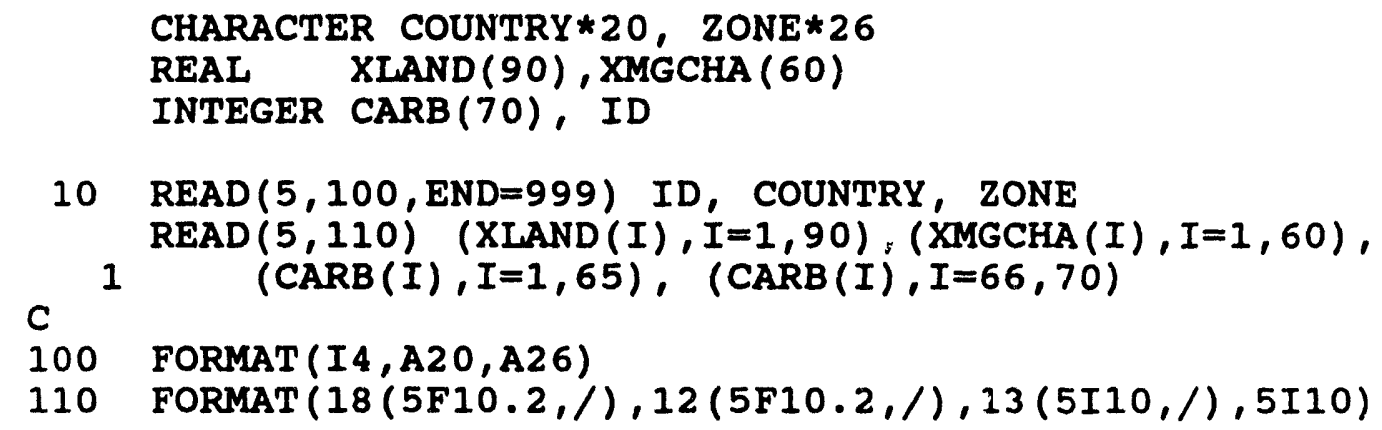

The variables in LANDCARB.ASC, listed in Table 6, are shown in the same order as they appear in File 2.

Table 6. Variable formats for LANDCARB.ASC (File 2).

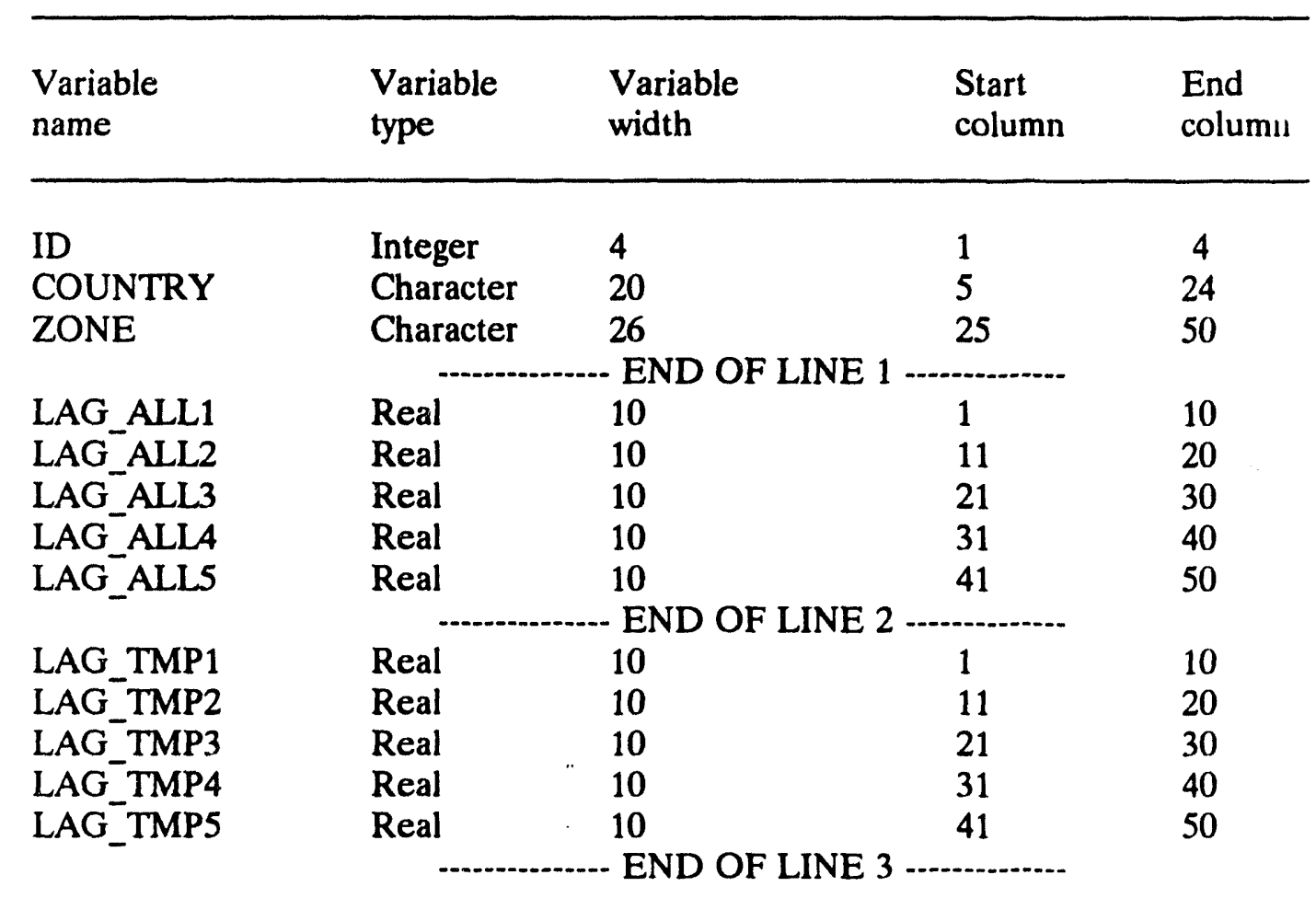


Table 6. (Continued)

\begin{tabular}{|c|c|c|c|c|}
\hline $\begin{array}{l}\text { Variable } \\
\text { name }\end{array}$ & $\begin{array}{l}\text { Variable } \\
\text { type }\end{array}$ & $\begin{array}{l}\text { Variable } \\
\text { width }\end{array}$ & $\begin{array}{l}\text { Start } \\
\text { column }\end{array}$ & $\begin{array}{l}\text { End } \\
\text { column }\end{array}$ \\
\hline LAG_PRM1 & Real & 10 & 1 & 10 \\
\hline LAG_PRM2 & Real & 10 & 11 & 20 \\
\hline LAG_PRM3 & Real & 10 & 21 & 30 \\
\hline LAG_PRM4 & Real & 10 & 31 & 40 \\
\hline LAG_PRM5 & Real & 10 & 41 & 50 \\
\hline LSETTLE1 & Real & 10 & 1 & 10 \\
\hline LSE'TTLE2 & Real & 10 & 11 & 20 \\
\hline LSETTLE3 & Real & 10 & 21 & 30 \\
\hline LSETTLE4 & Real & 10 & 31 & 40 \\
\hline LSETTLE5 & Real & 10 & 41 & 50 \\
\hline LFR CON1 & Real & 10 & 1 & 10 \\
\hline LFR_CON2 & Real & 10 & 11 & 20 \\
\hline LFR_CON3 & Real & 10 & 21 & 30 \\
\hline LFR_CON4 & Real & 10 & 31 & 40 \\
\hline LFR_CON5 & Real & 10 & 41 & 50 \\
\hline LFR INT1 & Real & 10 & 1 & 10 \\
\hline LFR INT2 & Real & 10 & 11 & 20 \\
\hline LFR_INT3 & Real & 10 & 21 & 30 \\
\hline LFR_INT4 & Real & 10 & 31 & 40 \\
\hline \multirow[t]{2}{*}{ LFR_INT5 } & Real & 10 & 41 & 50 \\
\hline & \multicolumn{3}{|c|}{ END OF LINE 7} & \\
\hline LWT_ALL1 & Real & 10 & 1 & 10 \\
\hline LWT_ALL2 & Real & 10 & 11 & 20 \\
\hline LWT_ALL3 & Real & 10 & 21 & 30 \\
\hline LWT_ALLA & Real & 10 & 31 & 40 \\
\hline \multirow{2}{*}{ LWT_ALLS } & Real & 10 & 41 & 50 \\
\hline & \multicolumn{3}{|c|}{ END OF LINE 8} & \\
\hline LWT_FOR1 & Real & 10 & 1 & 10 \\
\hline LWT_FOR2 & Real & 10 & 11 & 20 \\
\hline LWT_FOR3 & Real & 10 & 21 & 30 \\
\hline LWT_FOR4 & Real & 10 & 31 & 40 \\
\hline LWT_FORS & Real & 10 & 41 & 50 \\
\hline
\end{tabular}


Table 6. (Continued)

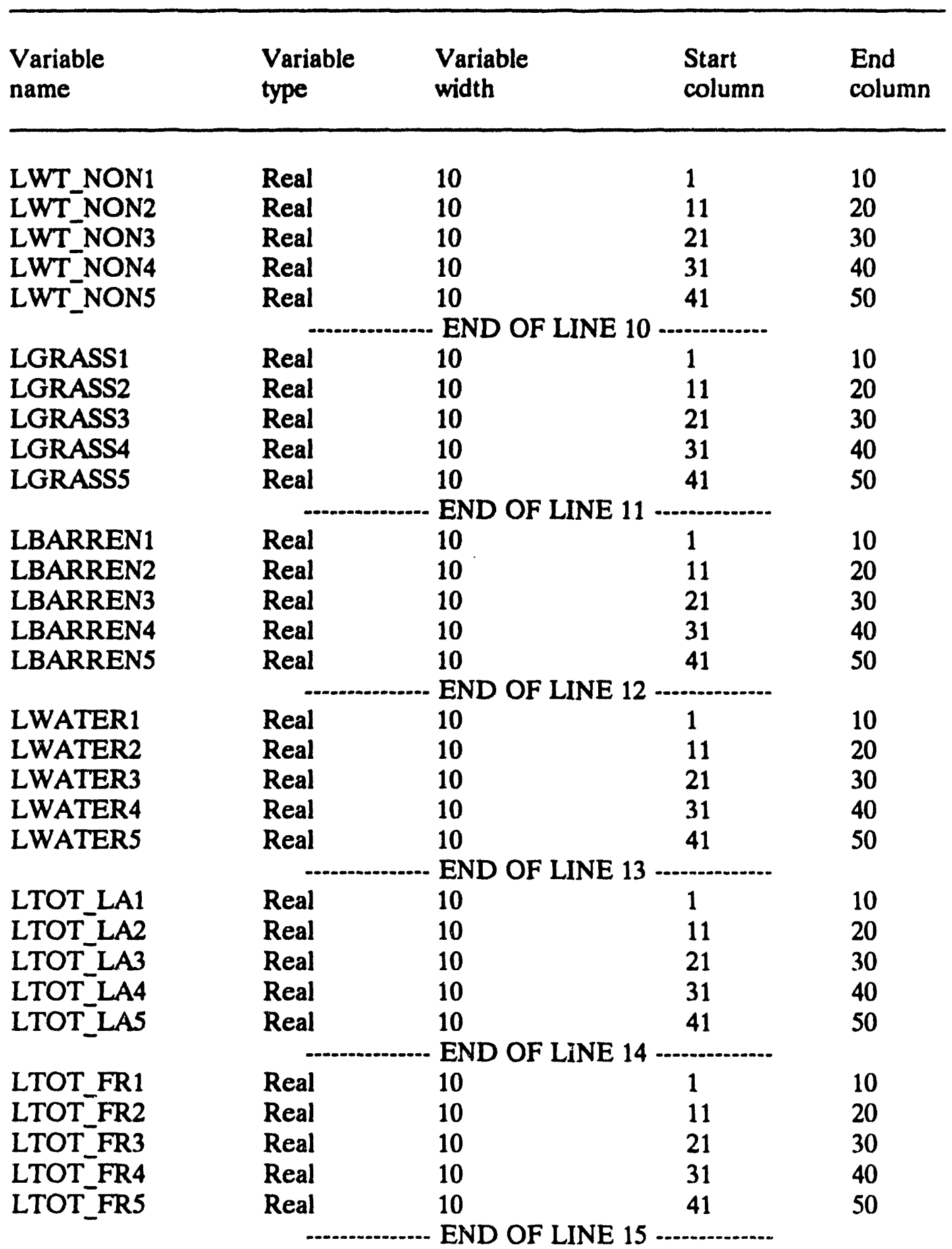


Table 6. (Continued)

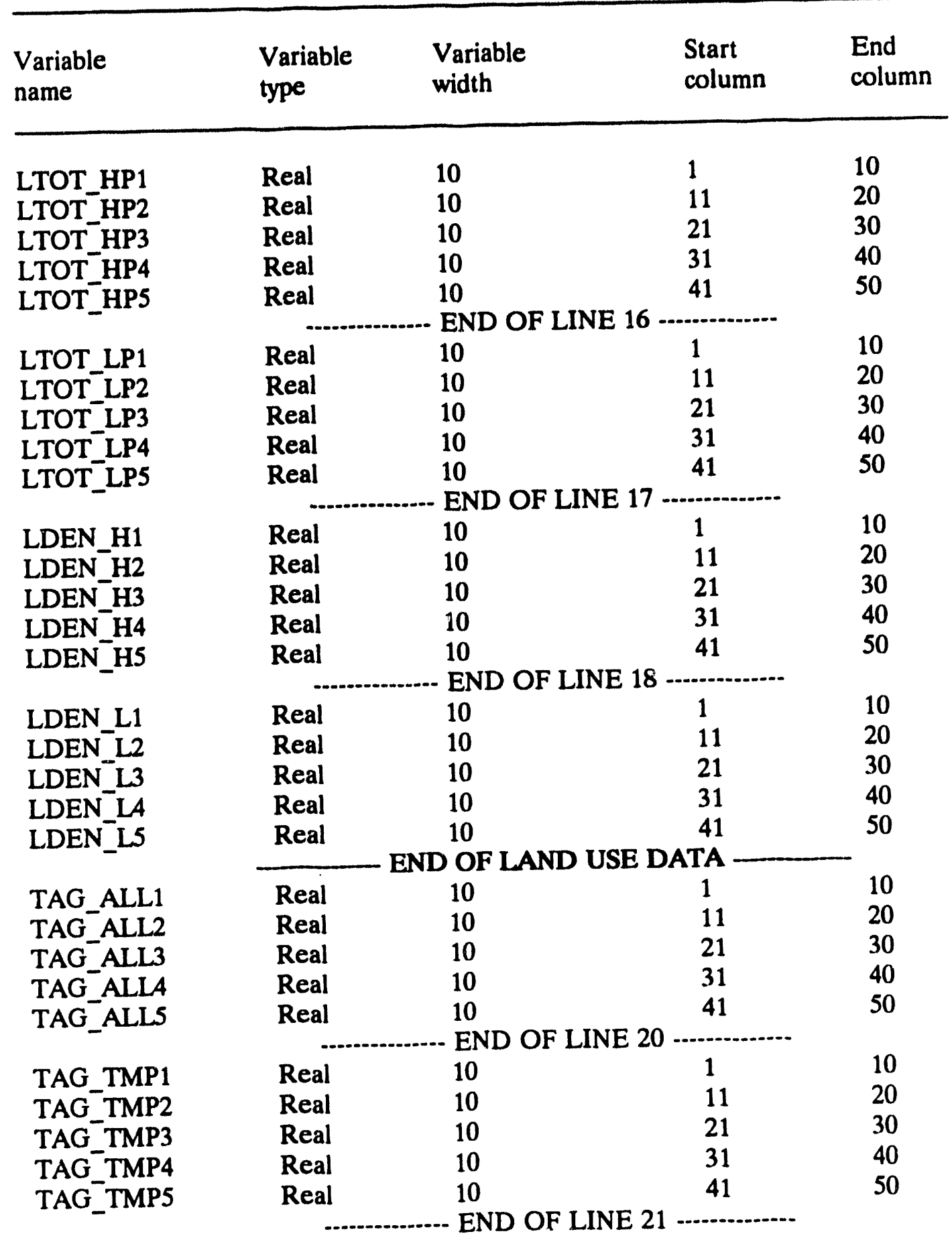


Table 6. (Continued)

\begin{tabular}{|c|c|c|c|c|}
\hline $\begin{array}{l}\text { Variable } \\
\text { name }\end{array}$ & $\begin{array}{l}\text { Variable } \\
\text { type }\end{array}$ & $\begin{array}{l}\text { Variable } \\
\text { width }\end{array}$ & $\begin{array}{l}\text { Start } \\
\text { column }\end{array}$ & $\begin{array}{l}\text { End } \\
\text { column }\end{array}$ \\
\hline TAG PRM1 & Real & 10 & 1 & 10 \\
\hline TAG_PRM2 & Real & 10 & 11 & 20 \\
\hline TAG_PRM3 & Real & 10 & 21 & 30 \\
\hline TAG_PRM4 & Real & 10 & 31 & 40 \\
\hline TAG_PRM5 & Real & 10 & 41 & 50 \\
\hline TSETTLE1 & Real & $\begin{array}{l}\text { END OF } \\
10\end{array}$ & 1 & 10 \\
\hline TSETTLE2 & Real & 10 & 11 & $\begin{array}{l}10 \\
20\end{array}$ \\
\hline TSETTLE3 & Real & 10 & 21 & 30 \\
\hline TSETTLE4 & Real & 10 & 31 & 40 \\
\hline \multirow[t]{2}{*}{ TSETTLES } & Real & 10 & 41 & 50 \\
\hline & Real & $\begin{array}{l}\text { - END OF } \\
10\end{array}$ & 1 & 10 \\
\hline TFR CON2 & Real & 10 & 11 & 20 \\
\hline TFR_CON3 & Real & 10 & 21 & 30 \\
\hline TFR_CON4 & Real & 10 & 31 & 40 \\
\hline TFR_CON5 & Real & 10 & 41 & 50 \\
\hline TFR_INT1 & Real & 10 & 1 & 10 \\
\hline TFR_INT2 & Real & 10 & 11 & 20 \\
\hline TFR_INT3 & Real & 10 & 21 & 30 \\
\hline TFR_INT4 & Real & 10 & 31 & 40 \\
\hline TFR_INT5 & Real & 10 & 41 & 50 \\
\hline TWT_ALL1 & Real & 10 & 1 & 10 \\
\hline TWT ALL2 & Real & 10 & 11 & 20 \\
\hline TWT ALL3 & Real & 10 & 21 & 30 \\
\hline TWT_ALLA & Real & 10 & 31 & 40 \\
\hline \multirow[t]{2}{*}{ TWT_ALLS } & Real & 10 & 41 & 50 \\
\hline & & $\begin{array}{l}- \text { EN } 1 \\
10\end{array}$ & & \\
\hline TWT FOR2 & Real & 10 & 11 & 20 \\
\hline TWT FOR3 & Real & 10 & 21 & 30 \\
\hline TWT_FOR4 & Real & 10 & 31 & 40 \\
\hline TWT_FOR5 & Real & 10 & 41 & 50 \\
\hline
\end{tabular}


Table 6. (Continued)

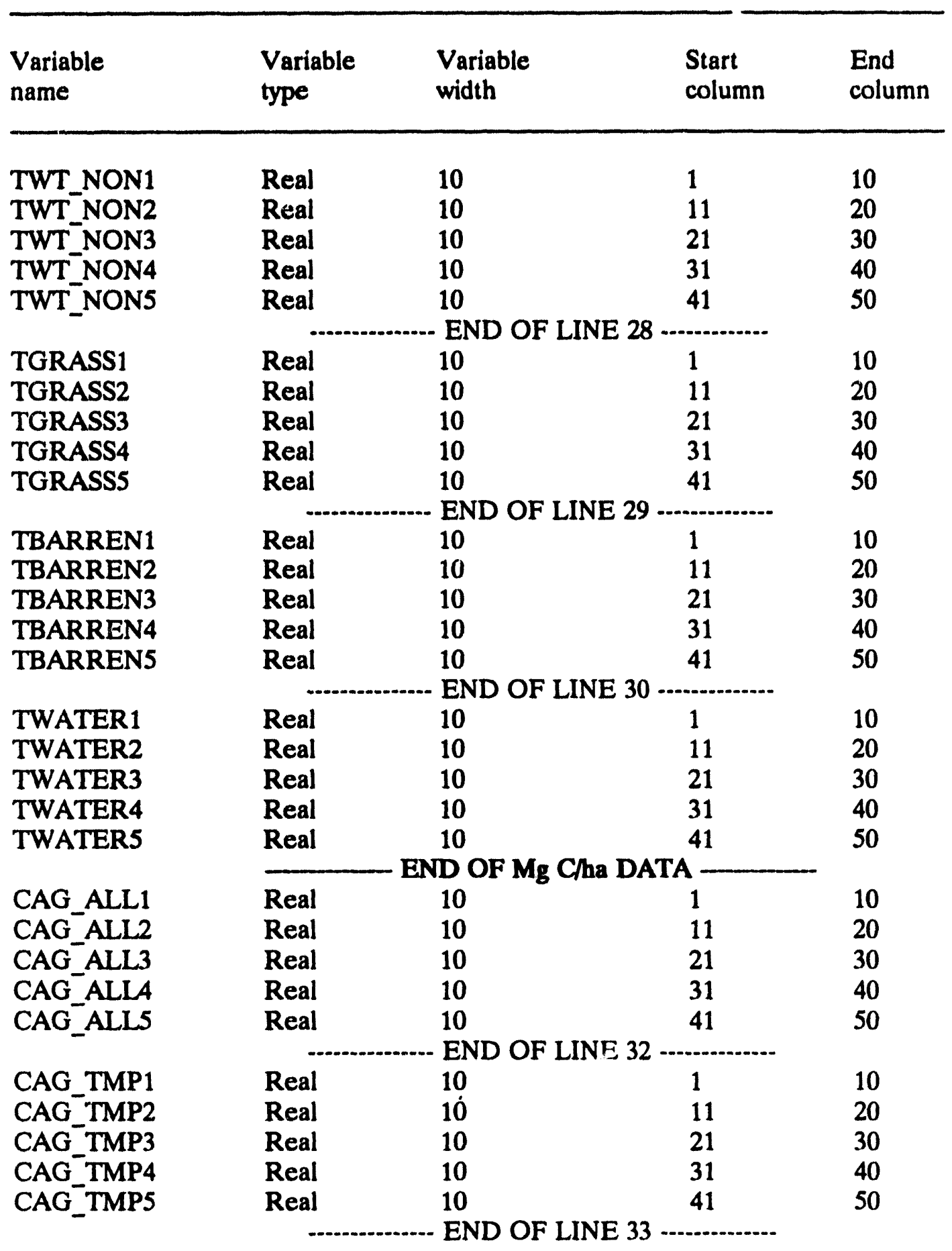


Table 6. (Continued)

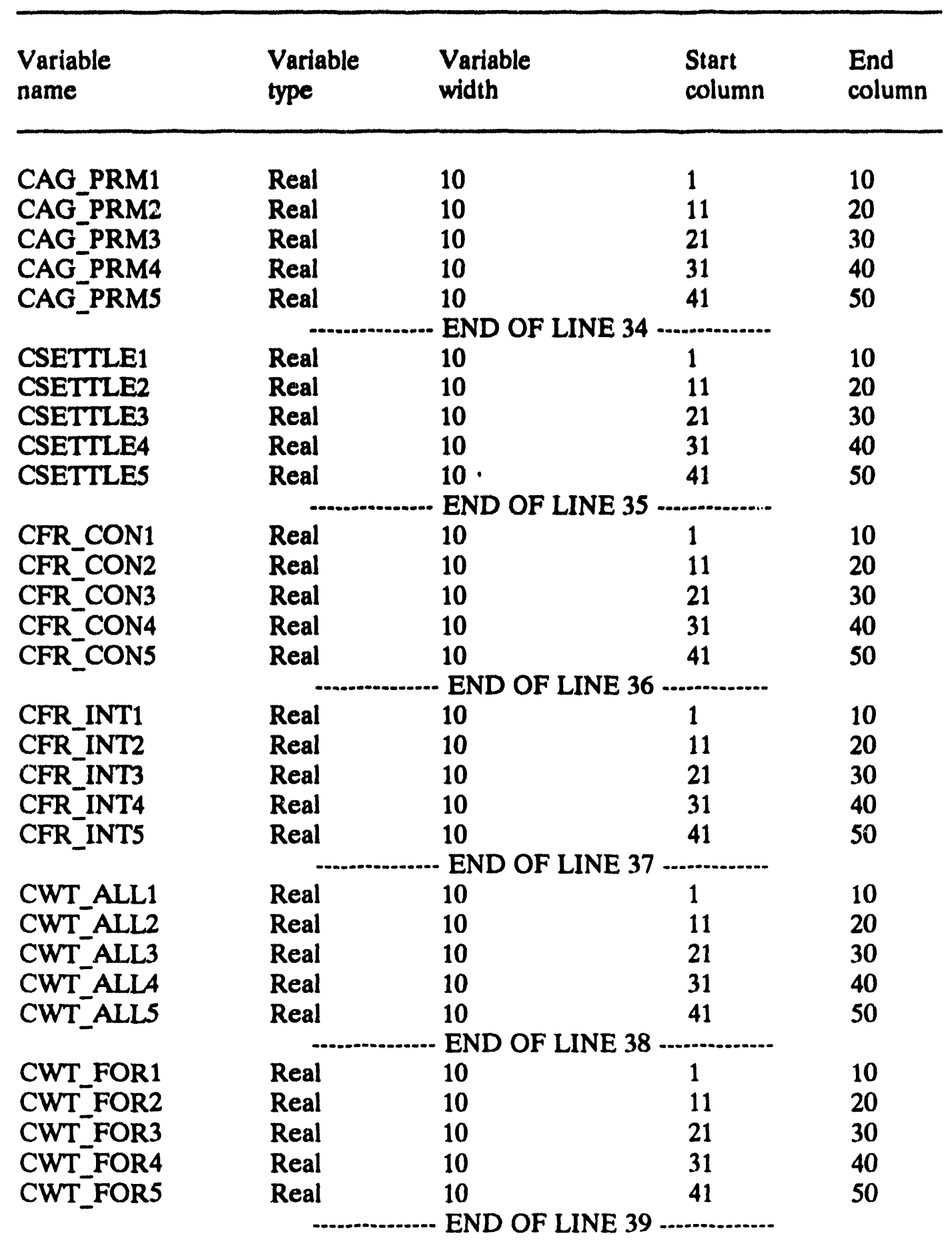


Table 6. (Continued)

\begin{tabular}{|c|c|c|c|c|}
\hline $\begin{array}{l}\text { Variable } \\
\text { name }\end{array}$ & $\begin{array}{l}\text { Variable } \\
\text { type }\end{array}$ & $\begin{array}{l}\text { Variable } \\
\text { width }\end{array}$ & $\begin{array}{l}\text { Start } \\
\text { column }\end{array}$ & $\begin{array}{l}\text { End } \\
\text { column }\end{array}$ \\
\hline $\begin{array}{l}\text { CWT_NON1 } \\
\text { CWT_NON2 } \\
\text { CWT_NON3 } \\
\text { CWT_NON4 } \\
\text { CWT_NON5 }\end{array}$ & $\begin{array}{l}\text { Real } \\
\text { Real } \\
\text { Real } \\
\text { Real } \\
\text { Real }\end{array}$ & $\begin{array}{l}10 \\
10 \\
10 \\
10 \\
10\end{array}$ & $\begin{array}{l}1 \\
11 \\
21 \\
31 \\
41\end{array}$ & $\begin{array}{l}10 \\
20 \\
30 \\
40 \\
50\end{array}$ \\
\hline $\begin{array}{l}\text { CGRASS1 } \\
\text { CGRASS2 } \\
\text { CGRASS3 } \\
\text { CGRASS4 } \\
\text { CGRASS5 }\end{array}$ & $\begin{array}{l}\text { Real } \\
\text { Real } \\
\text { Real } \\
\text { Real } \\
\text { Real }\end{array}$ & $\begin{array}{l}- \text { END O } \\
10 \\
10 \\
10 \\
10 \\
10\end{array}$ & $\begin{array}{l}1 \\
11 \\
21 \\
31 \\
41\end{array}$ & $\begin{array}{l}10 \\
20 \\
30 \\
40 \\
50\end{array}$ \\
\hline $\begin{array}{l}\text { CBARREN1 } \\
\text { CBARREN2 } \\
\text { CBARREN3 } \\
\text { CBARREN4 } \\
\text { CBARREN5 }\end{array}$ & $\begin{array}{l}\text { Real } \\
\text { Real } \\
\text { Real } \\
\text { Real } \\
\text { Real }\end{array}$ & $\begin{array}{l}\text { END OF } \\
10 \\
10 \\
10 \\
10 \\
10\end{array}$ & $\begin{array}{l}1 \\
11 \\
21 \\
31 \\
41\end{array}$ & $\begin{array}{l}10 \\
20 \\
30 \\
40 \\
50\end{array}$ \\
\hline $\begin{array}{l}\text { CWATER1 } \\
\text { CWATER2 } \\
\text { CWATER3 } \\
\text { CWATER4 } \\
\text { CWATER5 }\end{array}$ & $\begin{array}{l}\text { Real } \\
\text { Real } \\
\text { Real } \\
\text { Real } \\
\text { Real }\end{array}$ & $\begin{array}{l}\text { END OF } \\
10 \\
10 \\
10 \\
10 \\
10\end{array}$ & $\begin{array}{l}1 \\
11 \\
21 \\
31 \\
41\end{array}$ & $\begin{array}{l}10 \\
20 \\
30 \\
40 \\
50\end{array}$ \\
\hline $\begin{array}{l}\text { CTOT_LA1 } \\
\text { CTOT_LA2 } \\
\text { CTOT_LA3 } \\
\text { CTOT_LA4 } \\
\text { CTOT_LAS }\end{array}$ & $\begin{array}{l}\text { Real } \\
\text { Real } \\
\text { Real } \\
\text { Real } \\
\text { Real }\end{array}$ & $\begin{array}{l}\text { END OI } \\
10 \\
10 \\
10 \\
10 \\
10\end{array}$ & $\begin{array}{l}1 \\
11 \\
21 \\
31 \\
41\end{array}$ & $\begin{array}{l}10 \\
20 \\
30 \\
40 \\
50\end{array}$ \\
\hline $\begin{array}{l}\text { CTOT_FR1 } \\
\text { CTOT_FR2 } \\
\text { CTOT_FR3 } \\
\text { CTOT_FR4 } \\
\text { CTOT_FR5 }\end{array}$ & $\begin{array}{l}\text { Real } \\
\text { Real } \\
\text { Real } \\
\text { Real } \\
\text { Real }\end{array}$ & $\begin{array}{l}- \text { END OI } \\
10 \\
10 \\
10 \\
10 \\
10\end{array}$ & $\begin{array}{l}1 \\
11 \\
21 \\
31 \\
41\end{array}$ & $\begin{array}{l}10 \\
20 \\
30 \\
40 \\
50\end{array}$ \\
\hline
\end{tabular}


Where:

ID is the identification number.

COUNTRY is the country name.

ZONE is the zone name.

The following variable names have a numeric value from 1 to 5 appended to them and a character ( $\mathrm{L}, \mathrm{T}$, or $\mathrm{C}$ ) prepended. The numeric values indicate the year for which the variable contains data. A values of 1 indicates that the variable holds data for 1880, 2 for 1920,3 for 1950, 4 for 1970 , and 5 for 1980 . The prepended character indicates if the variable contains (L)and use data (in $10^{3} \mathrm{ha}$ ); an estimate of the amount of carbon stored per a ha [in $\mathrm{Mg} / \mathrm{ha}$ or ( $\left.\mathrm{T}\right) / \mathrm{ha}$ ]; or the total amount of (C)arbon sequestered in live vegetation (in $\mathbf{M g}$ ). For example purposes the $\mathrm{L}$ prefix is used to describe the remaining variables.

LAG_ALL is the total amount of land devoted to agriculture in a given year.

LAG_TMP is the amount of agricultural land devoted to temporary annaul crops in a given year.

LAG_PRM is the amount of agricultural land devoted to permanent perennial crops in a given year.

LSETTLE is the amount of land devoted to settled or built-up lands in a given year.

LFR_CON is the amount of land covered with uninterrupted forest (forest lands with greater than $\mathbf{4 0 \%}$ crown closure) in a given year.

LFR_INT is the amount of land covered with interrupted woods (forest lands with less than $40 \%$ crown closure) in a given year.

LWT_ALL is the total amount of land covered by wetlands in a given year.

LWT_FOR is the amount of forested wetland (e.g., mangroves, swamp forest) in a given year.

LWT_NON is the amount of wetland dominated by nonwoody vegetation in a given year.

LGRASS is the amount of land covered by grass or brush lands in a given year.

LBARREN is the amount of barren or sparsely vegetated land (e.g., desert or alpine tundra) in a given year.

LWATER is the amount of land covered by standing water in a given year. The primary cause of changes in this value is the construction of water retention facilities.

LTOT_LA is the total land area of the zone. 
LTOT_FR is the total forest cover in the zone. This variable is the sum of LFR_CON, LFR_INT, and LWT_FOR.

LTOT_HP is the human population in thousands.

LTOT_LP is the livestock population in thousands. Livestock are defined as any four footed domesticated stock animal (e.g., cattle, water buffalo, goats, sheep, pigs, and equines).

LDEN_H is the human population density in persons per ha.

LDEN_L is the livestock population density in head per ha.

\section{FILE: FLAGS.ASC}

The second flat ASCII file provides accuracy flags derived based on the type and quality of the source data used in developing the values contained in LANDCARB.ASC (File 2). This file should be used when individual data values are extracted from this data base to determine the lineage of the data for a given time period in given ecological zone. What follows is a description of the contents and format (variable names, widths, etc.) of the second flat ASCII data file distributed with this data package. The name of the second flat ASCII file is FLAGS.ASC (File 5). A summary of the FORTRAN format statements used to read File 5 follow.

CHARACTER COUNTRY $* 20$, ZONE*26

INTEGER ID, AG_FLG(5), NON_FLG(5), HP_FLG(5)，LP_FLG(5)

$10 \operatorname{READ}(5,100$, END $=999 ;$ ID, COUNTRY, ZONE

$\operatorname{READ}(5,110)$ (AG_FLG (I), I=1,5), (NON_FLG (I), I=1,5),

(HP_FLG $(I), I=1,5),($ LP_FLG $(I), I=1,5)$

C

100 FORMAT (I 4, A20, A26)

110 FORMAT $(3(5 \mathrm{I} 10, /), 5$ I 10$)$

The variables in FLAGS.ASC, listed in Table 7, are shown as they appear in File 5. 


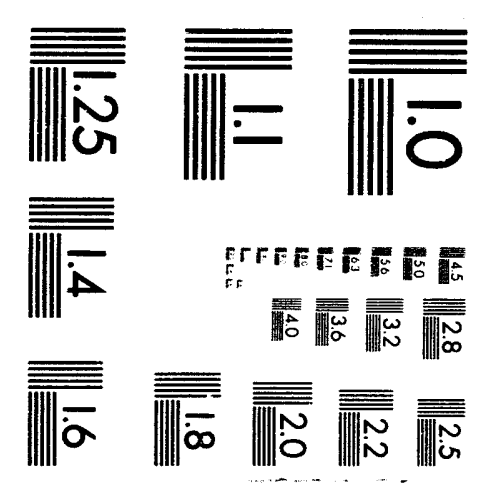



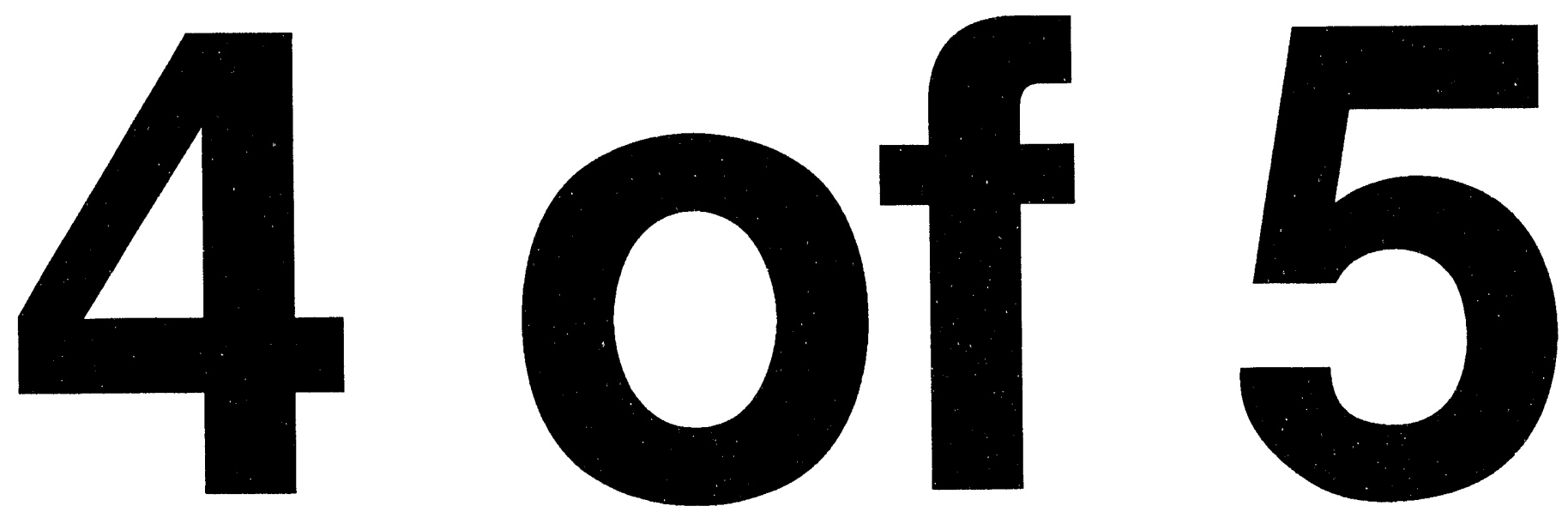
Table 7. Variable formats for FLAGS.ASC (File 5).

\begin{tabular}{|c|c|c|c|c|}
\hline $\begin{array}{l}\text { Variable } \\
\text { name }\end{array}$ & $\begin{array}{l}\text { Variable } \\
\text { type }\end{array}$ & $\begin{array}{l}\text { Variable } \\
\text { width }\end{array}$ & $\begin{array}{l}\text { Start } \\
\text { column }\end{array}$ & $\begin{array}{l}\text { End } \\
\text { column }\end{array}$ \\
\hline ID & Integer & 4 & 1 & 4 \\
\hline COUNTRY & Character & 20 & 5 & 24 \\
\hline \multirow[t]{2}{*}{ ZONE } & Character & 26 & 25 & 50 \\
\hline & \multicolumn{3}{|c|}{ END OF LINE 1} & \\
\hline AG_FLG1 & Real & 10 & 1 & 10 \\
\hline AG_FLG2 & Real & 10 & 11 & 20 \\
\hline AG_FLG3 & Real & 10 & 21 & 30 \\
\hline $\mathrm{AG}_{-} \mathrm{FLG} 4$ & Real & 10 & 31 & 40 \\
\hline \multirow{2}{*}{ AG_FLG5 } & Real & 10 & 41 & 50 \\
\hline & \multicolumn{3}{|c|}{ END OF LINE 2 } & \\
\hline NON_FLG1 & Real & 10 & 1 & 10 \\
\hline NON_FLG2 & Real & 10 & 11 & 20 \\
\hline NON_FLG3 & Real & 10 & 21 & 30 \\
\hline NON_FLG4 & Real & 10 & 31 & 40 \\
\hline \multirow[t]{2}{*}{ NON_FLG5 } & Real & 10 & 41 & 50 \\
\hline & \multicolumn{3}{|c|}{ END OF LINE 3- } & \\
\hline HP_FLG1 & Real & 10 & 1 & 10 \\
\hline HP_FLG2 & Real & 10 & 11 & 20 \\
\hline HP_FLG3 & Real & 10 & 21 & 30 \\
\hline HP_FLG4 & Real & 10 & 31 & 40 \\
\hline \multirow[t]{2}{*}{ HP_FLG5 } & Real & 10 & 41 & 50 \\
\hline & \multicolumn{3}{|c|}{ 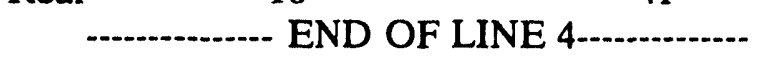 } & \\
\hline LP_FLG1 & Real & 10 & 1 & 10 \\
\hline LP_FLG2 & Real & 10 & 11 & 20 \\
\hline LP_FLG3 & Real & 10 & 21 & 30 \\
\hline LP_FLG4 & Real & 10 & 31 & 40 \\
\hline \multirow[t]{2}{*}{ LP_FLG5 } & Real & 10 & 41 & 50 \\
\hline & \multicolumn{3}{|c|}{ END OF RECORD } & \\
\hline
\end{tabular}

Where:

ID is the zone identification number.

COUNTRY is the country name.

ZONE is the zone name.

The following variable names have a numeric value from 1 to 5 appended to them. The numeric values indicate the year for which the variable contains data. A value of 1 indicates that the variable contains data for 1880,2 for 1920,3 for 1950,4 for 1970, and 5 for 1980 . 
AG_FLG a flag with a value from 0 to 10 that indicates the relative quality and quantity of source data used to estimate the cultivated (agricultural) and settled/built-up land data variables contained in file LANDUSE.ASC (File 2).

NON_FLG a flag with a value from 0 to 10 that indicates the relative quality and quantity of source data used to estimate the nonagricultural and nonsettled/built-up land data variables (e.g., forest cover or barren land) contained in file LANDUSE.ASC (File 2).

HP_FLG a flag with a value from 0 to 10 that indicates the relative quality and quantity of source data used to estimate the human population values contained in file LANDUSE.ASC (File 2).

LP_FLG a flag with a value from 0 to 10 that indicates the relative quality and quantity of source data used to estimate the livestock population values contained in file LANDUSE.ASC (File 2).

Tables $8,9,10$, and 11 define the valid values for each of the four flag variables listed above.

Table 8. System used to rank the quality of the data utilized in determining the amount of cultivated and settled land in each ecological zone. Values range from 0 to 10 , 10 being the best (variable AG_FLG).

Rank Description of minimum data requirements

0 Thin-air extrapolation: no description of land use/agriculture in zone or similar adjoining zone within 20 years of target date.

1 Descriptive information available only for adjacent, similar, or part of zone within 20 years of target date. Minimum: specify whether agriculture is shifting or sedentary and what the major crops are, but no areal estimates nor estimates of the number of agriculturalists are available.

2 Descriptive information for entire zone within 20 years of target date or for significant portions of the zone within 10 years of target date, but no areal estimates are available. Areal estimates are extrapolated from estimates for comparable zones within the same time period.

3 Crude estimate of cultivated area for the zone or a significant part thereof. No specificity as to crops, just overall cultivated or "occupied" area within 10 years of target date. Usually applies to data for 1880 or 1920. 
Table 8. (Continued)

Rank Description of minimum data requirements

4 Plausible estimate of cultivated area in zone within 5 years of target date. Includes official estimates requiring modifications for significant boundary changes ( $>25 \%$ of modern area), general estimates of area in sedentary or swidden crops were found from secondary references. Also includes zones for which conflicting published contemporary estimates exist or official estimates that are believed to be unreliable. Alternative: official estimate for zone, assuming boundary changes $(<25 \%)$ of total area, but between 5 and 10 years from the target date.

5 Documented official or secondary estimates of cultivated area within 5 years of target date from an ongoing series for zones with boundary changes $<25 \%$ of modern area. Minimum data: one estimate of total area in (major) annual crops, where those are dominant or one estimate of total area in (major) perennial crops, where those are dominant. Subdivision into major crops not necessarily available. No multiple-year coverage for annual crops. If swidden agriculture is significant, it is likely to be omitted from official estimates of this quality. Add one point for corroboration by contemporary map or aerial survey (1950-1980 data only).

6 Documented official or secondary estimates of cultivated area within 5 years of target date from an ongoing series. For zones dominated by annual crops, 2 years of coverage within 5 years of the target date are required for most or all of zone, data regarding the percentage of area in major annual crops; no perennial data required. For zones dominated by perennials, separate estimates of area in each major perennial crop, for at least one year within 5 years of target date, plus published estimate (not necessarily official) for annual crops. Includes any reasonable published estimate of swidden area based on population/area ratios and population estimates of swidden groups. No mapped corroboration for estimates of annual crops production, especially from swidden agriculture.

7 Documented official or secondary estimates of cultivated area within 5 years of target date from an ongoing series. Zones dominated by annual crops require 3-5 years of coverage within 5 years of target date for annual crops for most or all of zone, data regarding the percentage of area in major annual crops; no perennial data required. For zones dominated by perennials, separate estimates of area in each major perennial crop, for at least 2 years within 5 years of target date, or a single set of estimates within 2 years of target date, plus at least 1 published estimate of annual crop area as per rank 6. 
Table 8. (Continued)

Rank Description of minimum data requirements

8 Documented official or secondary estimates of cultivated area within 5 years of target date from an ongoing series. Zones dominated by annual crops required 3-5 years of coverage within 5 years of target date for annual crops for most or all of zone, data regarding ihe percentage of area in each major annual crop, and must have at least one estimate of perennial crop area by major crop within 5 years of target date. For zones dominated by perennials, separate estimates of area in each major perennial crop, for at least 2 years within 5 years of target date, or a single set of estimates within 2 years of target date, plus at least two estimates of total annual crop area within 5 years of target date, and percentages of major annual crops (minimum: upland rice/lowland rice/other). Alternative: complete agricultural data based on two exhaustive surveys b-acketing target year with or without major crops or complete agricultural data based on a full-zone survey in date of target year.

9 Documented official or secondary estimates of cultivated area within 5 years of target date from an ongoing series. Zones dominated by annual crops required 4-5 years of coverage within 5 years of target date for annual crops for $90 \%$ or more of zone, data regarding the percentage of area in major annual crops, and must have at least 1 estimate of perennial crop area by major crop within 5 years of target date. Must have percentages of all major perennial crops. For zones dominated by perennials, separate estimates of area in each major perennial crop, for at least 2 years within 5 years of target date, or a single set of estimates within 2 years of target date. Plus at least three estimates of total annual crop area within 5 years of target date and percentages of all major annual crops.

10 Full series of five consecutive years around target date for annual crops, plus the percentage of area in all major annual crops within 1 year of date and equivalent information for all major perennial crops. Published estimate of settled area and information concerning what is in it and official statistics corroborated by full cadastral survey or satellite map. 
Table 9. System used to rank the quality of the data utilized in determining the amount of land in all land use classes except cultivated and built-up/settled land in each ecological zone. Values range from 0 to 10,10 being the best (variable NON_FLG).

Rank Description of minimum data requirements

0 Thin-air extrapolation: no description of zone or similar adjoining district within 20 years of target date.

1 Descriptive information available only for adjacent or similar zone but not for the zone under consideration within 20 years of target date; or descriptive information for significant part of zone under consideration within same time limits.

2 Descriptive information only for a significant part of (but not entire) zone within 10 years of target date, or a full description of entire zone within 20 years of target date.

3 At least one adequate description covering essentially entire zone within 10 years of target date; or two or more texts allowing a composite description of the entire zone to be made (in cases of large boundary change), within same time limits. Example of "adequate description": Early or modern state gazetteer introduction describing "botany" or "vegetation"; brief discussion of vegetation at zone scale within national geography or economic history survey.

Categories 4-10 presuppose at least one description of quality rank (3) as a baseline, plus whatever else is specified. All references meet same time constraints as used for rank (3). If these criteria are not met, one point was subtracted from the rating.

4 Additional descriptive material on vegetation, agriculture, forestry, or land use, which complements and extends (3); or additional descriptive information for parts of the zone or highly site-specific information useful for one but not all categories or parts of zone. Example: highly localized vegetation descriptions, village studies, or detailed coverage of vegetation or land use for zone in national or regional geographies or monographs. No quantitative data.

5 Good descriptive data of rank (4) with plausible estimates of zonal forest area, with descriptive material as backup or more detailed quantitative information on area covered by major vegetation types for part but not all of zone. Examples: forest working plan for significant or characteristic portion of zone; good botanical, ecological, forestry or geographical paper but not covering whole zone. 
Table 9. (Continued)

Rank Description of minimum data requirements

6 Good descriptive data of rank (4) with older vegetation map (partial or complete) in lieu of quantitative data, or a partial vegetation map of zone with partial quantitative data. Little or no quantitative data, or conflict between quantitative and map; or conflicts among multiple quantitative sources or among maps.

$7 \quad$ Good descriptive data of rank (4) with quantitative data for entire zone in only a few categories, or all categories and only part of zone; or tabular and map coverage that when combined cover the full zone.

8 Good descriptive data of rank (4) and either a quantitative estimate of land use/vegetation for entire zone for all major categories or total coverage by a modern map based on cadastral survey, aerial photography, or satellite images.

9 Good descriptive data of rank (4) and both a quantitative estimate of land use/vegetation for entire zone and all major categories and total coverage by modern map based on cadastral survey, aerial photography, or satellite images.

10 Excellent descriptive data of rank (4) with trustworthy, quantitative satellite survey covering entire district in a format easily convertible to our vegetation types with numbers, map, and text all available and data consistent with contemporary vegetation maps. 
Table 10. System used to rank the quality of the human population data in each ecological zone. Values range from 0 to 10, 10 being the best (variable HP_FLG).

Rank Description of minimum data requirements

$0 \quad$ No published estimate of population within 20 years of date for zone and no published estimate of population density for comparable zone at comparable times.

$1 \quad$ Published estimate (unofficial), by 19th century travelers or geographers within 20 years of date for zone. No published census figures and no explanation of published values.

2 Published estimate for population within 20 years of target date by modern author who has reviewed more recent population data (not an official estimate); or partial or seriously flawed census available officially within 20 years of target date, such that significant part of population is undercounted or overcounted. Official census, if involved, is isolated and not easily comparable to later series. Also includes crude national estimates within 20 years of target date that were subdivided to zone based on later census data.

3 Same as rank (2) above, but within 10 years of target date or two estimates within 20 y ars of target date that are reasonably consistent.

4 Ir ated census available within 10 years of target date, with relatively good coverage, but available subdivisions of data obstruct adjustment for boundary changes; or the structure of the census not comparable to later censuses. Other official population data (e.g., estimates based on birth/death records in lieu of formal census) may be considered equivalent; or secondary estimates within 10 years of target date, consistent with later census data.

5 Two censuses available bracketing target date for total period of 30 years or less. Coverage reasonably complete for both. Interpolation using @RATE ${ }^{1}$ function. May be corroborated by secondary estimates.

6 Census within 10 years of target date is part of ongoing regular series, with at least one preceding census and one following, or two preceding. However, significant problems were reported with nearest census to target date. Interpolation using @RATE ${ }^{1}$ function. Wartime censuses would be included here.

7 Census within 3 years of target date, but otherwise equivalent to rank (6). Interpolation using @RATE ${ }^{1}$ function. 
Table 10. (Continued)

Rank Description of minimum data requirements

8 Census within 2 years of target date, part of ongoing series; all values in series have been retrospectively adjusted to modern boundaries (e.g., India 1901-1981), but refer to older values which may have been less accurate or dealt with localities where a significant percentage of population was poorly accessible. Note: For rank (8) or above, subdivision by ethnic groups should be available if swidden agriculture is an important land use.

9 Same as rank (8) above, but after 1950. Quality of census ranked good and adjustments for undercounting or overcounting have been made.

10 Same as rank (9) above, but quality of census ranked excellent. Areas with longterm political stability, accessible topography, and solid census infrastructure.

Note: 1 The @RATE function is a Lotus 1-2-3 ${ }^{\mathrm{TM}}$ procedure that calculates the periodic growth rate necessary for a present value to grow to a future value over a given term. For example, if at least two population values are known then a growth rate in percent can be calculated and used to predict past, intervening, or future populations. 
Table 11. System used to rank the quality of the livestock population data in each ecological zone. Values range from 0 to 10, 10 being the best (variable LP_FLG).

Rank

Description of minimum data requirements

0 No published estimate of even the human population within 20 years of date for zone, and no livestock data.

1 No livestock data for zone within 20 years of target date; livestock population extrapolated from human population data of rank (1) or (2) on the basis of human/livestock ratios outside the 20 year period.

2 No livestock data for zone within 20 years of target date, but livestock population extrapolated from contemporary human census on the basis of human/livestock ratios outside the 20 years period.

3 Partial livestock data within 20 years of target date, permitting extrapolations from contemporary human population if subdivided appropriately. Livestock estimate based on ratios calculated for areas $<50 \%$ or $>150 \%$ of zone.

4 Partial livestock data within 10 years of target date or reasonably full coverage within 20 years of target date. Livestock estimate probably was derived from earlier human/livestock ratio. One or more major species may be excluded.

5 Complete livestock census within 10 years of target date, but district/unit for which censuses were taken has changed considerably (e.g., Bombay/Gujarat/Maharashtra over 1950-1960; or Bengal before versus after partition) or livestock census was separated from target date by major upheaval affecting animal population (migration, war, revolution, famine, etc.).

6 Livestock census within 10 years of target date is preceded or followed by at least one other census of same area. No major species excluded.

7 Livestock census within 5 years of target date for area within $10 \%$ of modern zone boundaries. Preceded or followed by at least one other census of same area.

8 Livestock estimates made annually based on regular censuses supplemented by spot checks or slaughter records, but actual censuses are at intervals of 5 or 10 years. Target date has estimate, but it is not census based.

9 Livestock census of reasonable quality available within 2 years of target date for zone at current boundaries; comparable human census also available. 
Table 11. (Continued)

Rank Description of minimum data requirements

10 Livestock census of excellent quality available within 2 years of target date; must be part of a series of at least three censuses covering zone at its modern boundaries. Comparable human censuses available, and zone is politically stable with a good bureaucratic infrastructure. 


\section{FILE: FACTORS.ASC}

What follows is a description of the contents and format (variable names, widths, etc.) of the third flat ASCII data file distributed with this data package. The name of the third flat ASCII file is FACTORS.ASC (File 8). A summary of the FORTRAN format statements used to read File 8 follow.

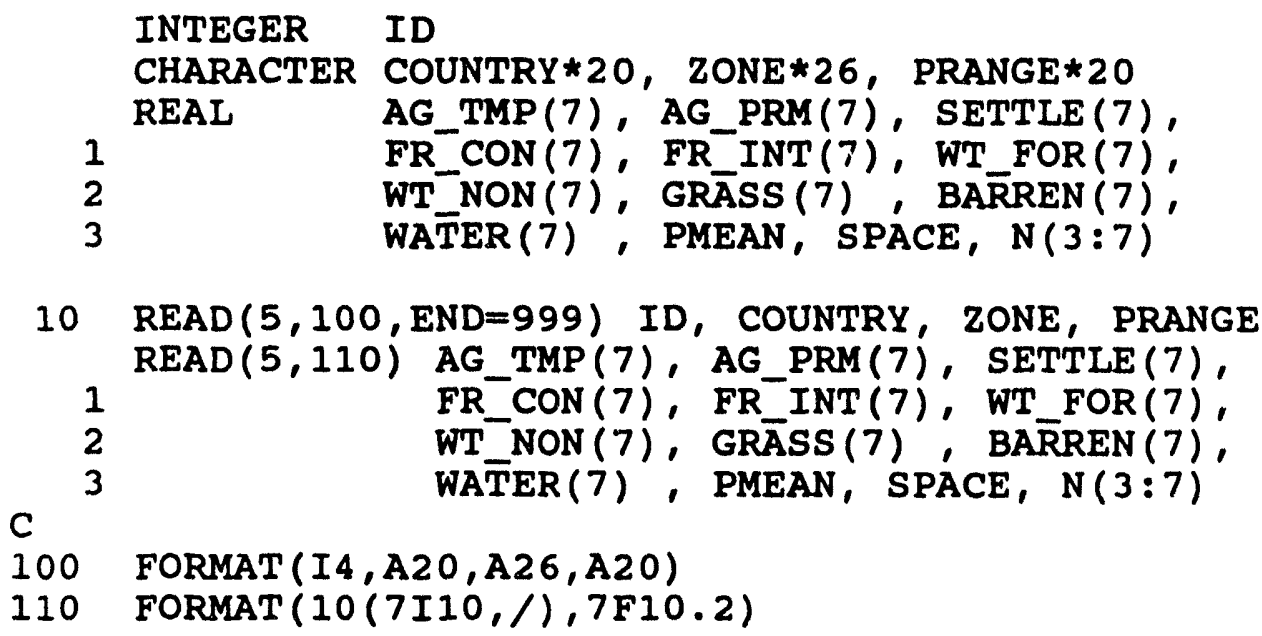

The variables in FACTORS.ASC, listed in Table 12, are shown as they appear in File 8.

Table 12. Variable formats for FACTORS.ASC (File 8).

\begin{tabular}{lllll}
\hline $\begin{array}{l}\text { Variable } \\
\text { name }\end{array}$ & $\begin{array}{l}\text { Variable } \\
\text { type }\end{array}$ & $\begin{array}{l}\text { Variable } \\
\text { width }\end{array}$ & $\begin{array}{l}\text { Start } \\
\text { column }\end{array}$ & $\begin{array}{l}\text { End } \\
\text { column }\end{array}$ \\
\hline ID & Integer & 4 & 1 & 4 \\
COUNTRY & Character & 20 & 5 & 24 \\
ZONE & Character & 26 & 25 & 50 \\
PRANGE & Character & 20 & 51 & 70 \\
& Real & 10 & 1 & 10 \\
AG_TMP1 & Real & 10 & 11 & 20 \\
AG_TMP2 & Real & 10 & 21 & 30 \\
AG_TMP3 & Real & 10 & 31 & 40 \\
AG_TMP4 & Real & 10 & 41 & 50 \\
AG_TMP5 & Real & 10 & 51 & 60 \\
AG_TMP6 & Real & 10 & 61 & 70 \\
AG_TMP7 & & & &
\end{tabular}


Table 12 (Continued)

\begin{tabular}{|c|c|c|c|c|}
\hline $\begin{array}{l}\text { Variable } \\
\text { name }\end{array}$ & $\begin{array}{l}\text { Variable } \\
\text { type }\end{array}$ & $\begin{array}{l}\text { Variable } \\
\text { width }\end{array}$ & $\begin{array}{l}\text { Start } \\
\text { column }\end{array}$ & $\begin{array}{l}\text { End } \\
\text { column }\end{array}$ \\
\hline $\begin{array}{l}\text { AG_PRM1 } \\
\text { AG_PRM2 } \\
\text { AG_PRM3 } \\
\text { AG_PRM4 } \\
\text { AG_PR'55 } \\
\text { AG_PRM6 } \\
\text { AG_PRM7 }\end{array}$ & $\begin{array}{l}\text { Real } \\
\text { Real } \\
\text { Real } \\
\text { Real } \\
\text { Real } \\
\text { Real } \\
\text { Real }\end{array}$ & $\begin{array}{l}10 \\
10 \\
10 \\
10 \\
10 \\
10 \\
10\end{array}$ & $\begin{array}{l}1 \\
11 \\
21 \\
31 \\
41 \\
51 \\
61\end{array}$ & $\begin{array}{l}10 \\
20 \\
30 \\
40 \\
50 \\
60 \\
70\end{array}$ \\
\hline $\begin{array}{l}\text { SETTLE1 } \\
\text { SETTLE2 } \\
\text { SETTLE3 } \\
\text { SETTLE4 } \\
\text { SETTLE5 } \\
\text { SETTLE6 } \\
\text { SETTLE7 }\end{array}$ & $\begin{array}{l}\text { Real } \\
\text { Real } \\
\text { Real } \\
\text { Real } \\
\text { Real } \\
\text { Real } \\
\text { Real }\end{array}$ & $\begin{array}{l}10 \\
10 \\
10 \\
10 \\
10 \\
10 \\
10\end{array}$ & $\begin{array}{l}1 \\
11 \\
21 \\
31 \\
41 \\
51 \\
61\end{array}$ & $\begin{array}{l}10 \\
20 \\
30 \\
40 \\
50 \\
60 \\
70\end{array}$ \\
\hline $\begin{array}{l}\text { FR_CON1 } \\
\text { FR_CON2 } \\
\text { FR_CON3 } \\
\text { FR_CON4 } \\
\text { FR_CON5 } \\
\text { FR_CON6 } \\
\text { FR_CON7 }\end{array}$ & $\begin{array}{l}\text { Real } \\
\text { Real } \\
\text { Real } \\
\text { Real } \\
\text { Real } \\
\text { Real } \\
\text { Real }\end{array}$ & $\begin{array}{l}10 \\
10 \\
10 \\
10 \\
10 \\
10 \\
10\end{array}$ & $\begin{array}{l}1 \\
11 \\
21 \\
31 \\
41 \\
51 \\
61\end{array}$ & $\begin{array}{l}10 \\
20 \\
30 \\
40 \\
50 \\
60 \\
70\end{array}$ \\
\hline $\begin{array}{l}\text { FR_INT1 } \\
\text { FR_INT2 } \\
\text { FR_INT3 } \\
\text { FR_INT4 } \\
\text { FR_INT5 } \\
\text { FR_INT6 } \\
\text { FR_INT7 }\end{array}$ & $\begin{array}{l}\text { Real } \\
\text { Real } \\
\text { Real } \\
\text { Real } \\
\text { Real } \\
\text { Real } \\
\text { Real }\end{array}$ & $\begin{array}{l}10 \\
10 \\
10 \\
10 \\
10 \\
10 \\
10\end{array}$ & $\begin{array}{l}1 \\
11 \\
21 \\
31 \\
41 \\
51 \\
61\end{array}$ & $\begin{array}{l}10 \\
20 \\
30 \\
40 \\
50 \\
60 \\
70\end{array}$ \\
\hline $\begin{array}{l}\text { WT_FOR1 } \\
\text { WT_FOR2 } \\
\text { WT_FOR3 } \\
\text { WT_FOR4 } \\
\text { WT_FOR5 } \\
\text { WT_FOR6 } \\
\text { WT_FOR7 }\end{array}$ & $\begin{array}{l}\text { Real } \\
\text { Real } \\
\text { Real } \\
\text { Real } \\
\text { Real } \\
\text { Real } \\
\text { Real }\end{array}$ & $\begin{array}{l}- \text { END OI } \\
10 \\
10 \\
10 \\
10 \\
10 \\
10 \\
10\end{array}$ & $\begin{array}{l}1 \\
11 \\
21 \\
31 \\
41 \\
51 \\
61\end{array}$ & $\begin{array}{l}10 \\
20 \\
30 \\
40 \\
50 \\
60 \\
70\end{array}$ \\
\hline
\end{tabular}


Table 12 (Continued)

\begin{tabular}{|c|c|c|c|c|}
\hline $\begin{array}{l}\text { Variable } \\
\text { name }\end{array}$ & $\begin{array}{l}\text { Variable } \\
\text { type }\end{array}$ & $\begin{array}{l}\text { Variable } \\
\text { width }\end{array}$ & $\begin{array}{l}\text { Start } \\
\text { column }\end{array}$ & $\begin{array}{l}\text { End } \\
\text { column }\end{array}$ \\
\hline WT_NON1 & Real & 10 & 1 & 10 \\
\hline WT_NON2 & Real & 10 & 11 & 20 \\
\hline WT_NON3 & Real & 10 & 21 & 30 \\
\hline WT NON4 & Real & 10 & 31 & 40 \\
\hline WT_NON5 & Real & 10 & 41 & 50 \\
\hline WT_NON6 & Real & 10 & 51 & 60 \\
\hline \multirow{2}{*}{ WT_NON7 } & Real & 10 & 61 & 70 \\
\hline & \multicolumn{3}{|c|}{ END OF LINE 8} & \\
\hline GRASS1 & Real & 10 & 1 & 10 \\
\hline GRASS2 & Real & 10 & 11 & 20 \\
\hline GRASS3 & Real & 10 & 21 & 30 \\
\hline GRASS4 & Real & 10 & 31 & 40 \\
\hline GRASS5 & Real & 10 & 41 & 50 \\
\hline GRASS6 & Real & 10 & 51 & 60 \\
\hline \multirow[t]{2}{*}{ GRASS7 } & Real & 10 & 61 & 70 \\
\hline & \multicolumn{3}{|c|}{ END OF LINE 9} & \\
\hline BARREN1 & Real & 10 & 1 & 10 \\
\hline BARREN2 & Real & 10 & 11 & 20 \\
\hline BARREN3 & Real & 10 & 21 & 30 \\
\hline BARREN4 & Real & 10 & 31 & 40 \\
\hline BARREN5 & Real & 10 & 41 & 50 \\
\hline BARREN6 & Real & 10 & 51 & 60 \\
\hline \multirow[t]{2}{*}{ BARREN7 } & Real & 10 & 61 & 70 \\
\hline & \multicolumn{3}{|c|}{ END OF LINE 10} & \\
\hline WATER1 & Real & 10 & 1 & 10 \\
\hline WATER2 & Rea! & 10 & 11 & 20 \\
\hline WATER3 & Real & 10 & 21 & 30 \\
\hline WATER4 & Real & 10 & 31 & 40 \\
\hline WATER5 & Real & 10 & 41 & 50 \\
\hline WATER6 & Real & 10 & 51 & 60 \\
\hline \multirow[t]{2}{*}{ WATER7 } & Real & 10 & 61 & 70 \\
\hline & \multicolumn{3}{|c|}{ END OF LINE 11} & \\
\hline PMEAN & Real & 10 & 1 & 10 \\
\hline SPACE & Real & 10 & 11 & 20 \\
\hline N3 & Real & 10 & 21 & 30 \\
\hline N4 & Real & 10 & 31 & 40 \\
\hline N5 & Real & 10 & 41 & 50 \\
\hline N6 & Real & 10 & 51 & 60 \\
\hline \multirow[t]{2}{*}{ N7 } & Real & 10 & 61 & 70 \\
\hline & \multicolumn{3}{|c|}{ END OF RECORD } & \\
\hline
\end{tabular}


Where:

ID is the zone identification number.

COUNTRY is the country name.

ZONE is the zone name.

PRANGE is the annual precipitation range for the ecological zone in mm/year. A range of 999-999 indicates that these data were not readily available from published data sources.

The following variable names have a numeric value $1,2,3,4,5,6$, or 7 appended to them. The variables with the number 1 contain the maximum potential carbon content for the given land use class in $\mathrm{Mg} / \mathrm{ha}$; variables with the number 2 contain the environmental limitation factor (determined based on PRANGE, soil characteristics, slope, etc.); and variables with numeric postfixes from 3-7 contain the degradation factor, with the numeric value indicating the year for which the variable contains data. A value of 3 indicates the variable contains data for 1880,4 for 1920, 5 for 1950, 6 for 1970, and 7 for 1980 .

AG_TMP are data values for annual or semiannual crops (e.g., rice).

AG_PRM are data values for permanent crops (e.g., rubber plantation).

SETTLE are data values for settled/built-up land.

FR_CON are data for continuously forested land (forests with crown closure of $40 \%$ or greater).

FR_INT are data values for interrupted woodland.

WT_FOR are data values for forested wetland.

WT_NON are data values for nonforested wetland.

GRASS are data values for grass/shrub lands.

BARREN are data values for barren or sparsely vegetated land.

WATER are data values for water (hydrophytes).

PMEAN is the mean annual rainfall for the given ecological zone in mm/year. If these data were not available the data file will contain a value of 999.00 .

SPACE is a space holding variable that never contains actual data, should contain a value of 999.00 .

$\mathrm{N}$

is the $\mathbf{N}$ calculated using the $\mathrm{S}, \mathrm{F}$, and $\mathrm{A}$ values shown in Appendix $\mathrm{B}$. This variable was utilized with the human population data (in LANDCARB.ASC -File 2) of each zone to calculated the degradation factors for the woody vegetation land use classes. 


\section{FILE: SEA_CTRY.ASC AND SEA_ZONEASC}

The fourth and fifth flat ASCII files - SEA_CTRY.ASC (File 11) and SEA_ZONE.ASC (File 12), respectively, contain digitized base maps of South and Southeast Asia. The national boundaries were obtained at a scale of 1:2,000,000, while internal zone boundaries were obtained from several different publications. Thus, the accuracy of the zone boundaries varies between countries based on the scale and detail of each source map. To reduce edge matching problems that occurred when several maps were combined, the zone and nation boundaries were smoothed (in $\mathrm{ARC} / \mathrm{INFO}^{\mathrm{TM}}$ ) to a nominal map scale of $1: 4,000,000$ with a minimal resolution of one point per $4 \mathrm{~km}$. File 11 contains boundaries for the 13 countries within the study region and File 12 contains boundaries for the 94 ecological zones. These digital data are included to allow the land use/carbon data contained in the other flat ASCII data files distributed with this data base to be mapped. The "key" that links the polygons described in these two files to the land use/carbon data contained in Files 2, 5, and 8 is the zone identification number (for a complete listing of these identification numbers see Table 1). This number is contained in each record (of each file) and should be used to cross-reference the files.

Unlike the other data files within this data base, these files contain line segments that describe the polygon boundaries of each country or ecological zone. These polygons have no attribute data associated with each polygon (beyond the polygon name). Commands such as RELATE in ARC/INFO ${ }^{\mathrm{TM}}$ (or similar commands in other geographic information systems) may be used to associate the land use/carbon data with the appropriate polygon.

What follows is a description of the contents and format of the fourth and fifth flat ASCII data file distributed with this data package. A summary of the FORTRAN format statements used to read these files follows:

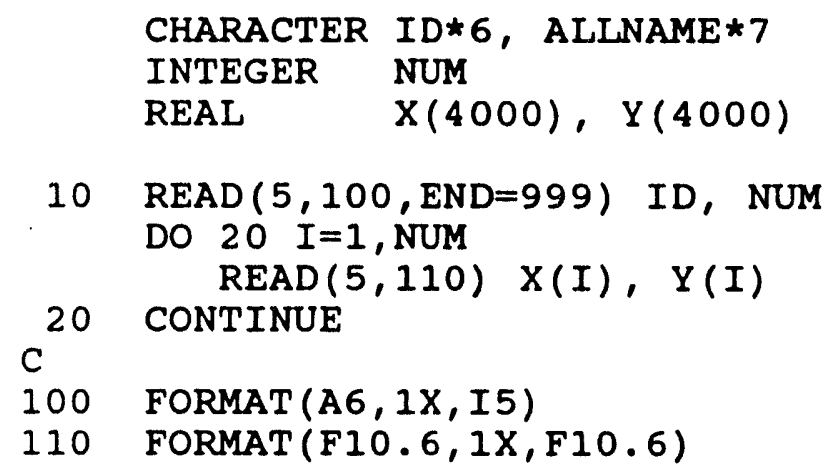

An example of the file format used in SEA_CTRY.ASC and SEA_ZONE.ASC is shown in Table 13. 
Table 13. Sample of the vector format used for SEA_CTRY.ASC (File 11) and SEA_ZONEASC (File 12).

Zone Number of code points

" 400", 13

$121.859993,-10.610300$

$121.795998,-10.600261$

$121.734795,-10.600780$

$121.696365,-10.561336$

$121.753677,-10.531301$

$121.811150,-10.502058$

$121.847893,-10.452695$

$121.902847,-10.419775$

$121.960655,-10.441310$

$122.001862,-10.467175$

$121.987274,-10.528060$

$121.933311,-10.562428$

$121.859993,-10.610300$

" 400", 123

$122.478599,-10.768567$

...
-Polygon 400 uses 13 points to describe the region -Starts at $121.86^{\circ} \mathrm{E}, 10.61^{\circ} \mathrm{S}$

-Ends at $121.86^{\circ} \mathrm{E}, 10.61^{\circ} \mathrm{S}$

-Continued

Note that the two example polygons in Table 13 have the same name (i.e., "400"). This is intentional since in this case $\mathbf{4 0 0}$ is the zone identification number for Indonesia, a country that is made up of several islands. The polygon names may repeat, depending on the number of polygons it takes to describe the boundaries of each country or ecological zone. Along with the polygons that describe the different countries and ecological zones are two special polygon types that are identified by the following polygon identification numbers;

0 indicates that the given polygon is not within any of the defined ecological zones or countries, and

9999 indicates that the given polygon is a "island" or "lake" within another polygon.

The following is a short listing of the ecological zone identification numbers used throughout this data base as the primary sort key. This information is presented here in a condensed form, Table 1 in Part 1 of this document should be consulted for more detailed information. 


\begin{tabular}{|c|c|c|c|}
\hline $\begin{array}{l}\text { Place } \\
\text { name }\end{array}$ & $\begin{array}{l}\text { Zone } \\
\text { ID }\end{array}$ & $\begin{array}{l}\text { Place } \\
\text { name }\end{array}$ & $\begin{array}{l}\text { Zone } \\
\text { ID }\end{array}$ \\
\hline $\begin{array}{l}\text { BANGLADESH } \\
\text { Eastern Coast } \\
\text { Sundarbans } \\
\end{array}$ & $\begin{array}{l}100 \\
102 \\
104 \\
\end{array}$ & $\begin{array}{l}\text { Chittagong Hills Tracts } \\
\text { Meghna } \\
\text { Western Districts }\end{array}$ & $\begin{array}{l}101 \\
103 \\
105 \\
\end{array}$ \\
\hline BRUNEI & 200 & Total & 201 \\
\hline $\begin{array}{l}\text { INDIA } \\
\text { Andhra Pradesh } \\
\text { Assam } \\
\text { Delhi } \\
\text { Haryana/Chandigarh } \\
\text { Jammu/Kashmir } \\
\text { Kerala } \\
\text { Madhya Pradesh } \\
\text { Manipur } \\
\text { Mizoram } \\
\text { Orissa } \\
\text { Rajasthan } \\
\text { Tamil Nadu/Pondichery } \\
\text { Uttar Pradesh } \\
\end{array}$ & $\begin{array}{l}300 \\
302 \\
304 \\
306 \\
308 \\
310 \\
312 \\
314 \\
316 \\
318 \\
320 \\
322 \\
324 \\
326 \\
\end{array}$ & $\begin{array}{l}\text { Andaman/Nicobar Islands } \\
\text { Arunachal Pradesh } \\
\text { Bihar } \\
\text { Gujarat/Dadra/Nagar H. } \\
\text { Himachal Pradesh } \\
\text { Karnataka } \\
\text { Lakshadweep Islands } \\
\text { Maharashtra/Goa/Daman/Diu } \\
\text { Meghalaya } \\
\text { Nagaland } \\
\text { Punjab } \\
\text { Sikkim } \\
\text { Tripura } \\
\text { West Bengal }\end{array}$ & $\begin{array}{l}301 \\
303 \\
305 \\
307 \\
309 \\
311 \\
313 \\
315 \\
317 \\
319 \\
321 \\
323 \\
325 \\
327 \\
\end{array}$ \\
\hline $\begin{array}{l}\text { INDONESIA } \\
\text { North Sumatra } \\
\text { Riau } \\
\text { South Sumatra } \\
\text { West Java } \\
\text { East Java } \\
\text { West Nusa Tenggara } \\
\text { East Timor } \\
\text { Central Kalimantan } \\
\text { South Kalimantan } \\
\text { South/Southeast Sulawesi } \\
\text { Irian Jaya }\end{array}$ & $\begin{array}{l}400 \\
402 \\
404 \\
406 \\
408 \\
410 \\
412 \\
414 \\
416 \\
418 \\
420 \\
422 \\
\end{array}$ & $\begin{array}{l}\text { Aceh } \\
\text { West Sumatra } \\
\text { Jambi } \\
\text { Bengkulu/Lampung } \\
\text { Central Java } \\
\text { Bali } \\
\text { East Nusa Tenggara } \\
\text { West Kalimantan } \\
\text { East Kalimantan } \\
\text { North/Central Sulawesi } \\
\text { Maluku }\end{array}$ & $\begin{array}{l}401 \\
403 \\
405 \\
407 \\
409 \\
411 \\
413 \\
415 \\
417 \\
419 \\
421\end{array}$ \\
\hline $\begin{array}{l}\text { KAMPUCHEA } \\
\text { Northeast Region } \\
\text { Southwest Highlands }\end{array}$ & $\begin{array}{l}500 \\
502 \\
504 \\
\end{array}$ & $\begin{array}{l}\text { Northwest Region } \\
\text { Southeast Lowlands }\end{array}$ & $\begin{array}{l}501 \\
503\end{array}$ \\
\hline $\begin{array}{l}\text { LAOS } \\
\text { Louang Phrabang } \\
\text { Annamite Chain }\end{array}$ & $\begin{array}{l}600 \\
602 \\
604\end{array}$ & $\begin{array}{l}\text { Northwest Laos } \\
\text { Central Laos } \\
\text { Champasak }\end{array}$ & $\begin{array}{l}601 \\
603 \\
605\end{array}$ \\
\hline
\end{tabular}




\begin{tabular}{|c|c|c|c|}
\hline $\begin{array}{l}\text { Place } \\
\text { name }\end{array}$ & $\begin{array}{l}\text { Zone } \\
\text { ID }\end{array}$ & $\begin{array}{l}\text { Place } \\
\text { name }\end{array}$ & $\begin{array}{l}\text { Zone } \\
\text { ID }\end{array}$ \\
\hline $\begin{array}{l}\text { MALAYSIA } \\
\text { Eastern Peninsular } \\
\text { Western Sarawak } \\
\text { Eastern Sarawak }\end{array}$ & $\begin{array}{l}700 \\
702 \\
704 \\
706 \\
\end{array}$ & $\begin{array}{l}\text { Western Peninsular } \\
\text { Johor } \\
\text { Central Sarawak } \\
\text { Sabah }\end{array}$ & $\begin{array}{l}701 \\
703 \\
705 \\
707 \\
\end{array}$ \\
\hline $\begin{array}{l}\text { MYANMAR } \\
\text { Northern Myanmar } \\
\text { Shan/Karen/Kayah } \\
\text { Peninsular }\end{array}$ & $\begin{array}{l}800 \\
802 \\
804 \\
805\end{array}$ & $\begin{array}{l}\text { Chin/Arakan } \\
\text { Dry Zone } \\
\text { Delta }\end{array}$ & $\begin{array}{l}801 \\
803 \\
805\end{array}$ \\
\hline $\begin{array}{l}\text { PHILIPPINES } \\
\text { Palawan } \\
\text { Mindanao }\end{array}$ & $\begin{array}{l}900 \\
902 \\
904\end{array}$ & $\begin{array}{l}\text { Luzon } \\
\text { Visayas }\end{array}$ & $\begin{array}{l}901 \\
903\end{array}$ \\
\hline SINGAPORE & 1000 & Total & 1001 \\
\hline $\begin{array}{l}\text { SRI LANKA } \\
\text { Dry Zone }\end{array}$ & $\begin{array}{l}1100 \\
1102 \\
\end{array}$ & Wet Zone & 1101 \\
\hline $\begin{array}{l}\text { THAILAND } \\
\text { Northeastern Region } \\
\text { Southern Region }\end{array}$ & $\begin{array}{l}1200 \\
1202 \\
1204 \\
\end{array}$ & $\begin{array}{l}\text { Northern Region } \\
\text { Central Plain }\end{array}$ & $\begin{array}{l}1201 \\
1203\end{array}$ \\
\hline $\begin{array}{l}\text { VIETNAM } \\
\text { Tonkin Delta } \\
\text { Central Highlands } \\
\text { Mekong Delta }\end{array}$ & $\begin{array}{l}1300 \\
1302 \\
1304 \\
1306\end{array}$ & $\begin{array}{l}\text { Northwest Highlands } \\
\text { North Central Coast } \\
\text { South Central Coast }\end{array}$ & $\begin{array}{l}1301 \\
1303 \\
1305\end{array}$ \\
\hline
\end{tabular}




\section{LOTUS $1-2.3^{\text {TM }}$ WK1 SPREADSHEET FILES}

Ninety Lotus $1-2-3^{\mathrm{TM}}$ WK1 spreadsheet files are provided with this NDP. The first 13 of these files contain the same data as is contained in File 2 (LANDCARB.ASC). The names of the these thirteen spreadsheets (Files 15 to 27) are 100LUC.WK1, 200LUC.WK1, 300LUC.WK1, 400LUC.WK1, 500LUC.WK1, 600LUC.WK1, 700LUC.WK1, 800LUC.WK1, 900LUC.WK1, 1000LUC.WK1, 1100LUC.WK1, 1200LUC.WK1, and 1300LUC.WK1. The numeric part of the filename is the zone identification number of the country for which the file contains data (e.g., $100=$ Bangladesh). Each file contains data for all ecological zones that occur within the given country plus national totals. The 14th spreadsheet file, FLAGS.WK1 (File 28), contains the data accuracy flags found in File 5 (FLAGS.ASC). The 15th spreadsheet file, FACTORS.WK1 (File 29), contains the $M, E$, and $D$ factors [i.e., the maximum potential carbon factor $(M)$, environmental limitation factor (E), and the degradation factor (D)] that are contained in File 8 (FACTORS.ASC).

The remaining 75 spreadsheet files (Files 33-107) contain background documentation on the procedures used to obtain the land use data contained in this NDP. These files have been provided to help document the land use data contained in Files 1-32. Because of the wide variation in the format and content of these spreadsheets, CDIAC is distributing these files on an "as is" basis and any questions regarding the contents of these files should be directed to the primary investigators. Refer to Appendix D to obtain a summary of the contents of these files.

The primary advantages of the Lotus $1-2-3^{\mathrm{TM}}$ files over the flat ASCII data is that the data values have been separated by country, are maintained within Lotus $1-2-3^{\mathrm{TM}}$ to the 14 th decimal place (reducing problems with rounding errors). In addition, the Lotus $1-2-3^{\mathrm{TM}}$ files contain the formulas that were used to calculate the total carbon portion of the spreadsheets. The formulas allow the total carbon estimates to be recalculated automatically if the user wishes to change the estimated carbon values for one of the land use classes.

The general format of the Lotus $1-2-3^{\mathrm{TM}}$ data files are depicted in Tables 14, 15, and 16 for portions of spreadsheet 100LUC.WK1 (File 15), FLAGS.WK1 (File 28), and FACTORS.WK1 (File 29), respectively.

Table 14. Display of a portion of the land use and carbon data in spreadshect 100LUC.WK1.

\begin{tabular}{|c|c|c|c|c|c|c|}
\hline$\cdot 100$ & & & & & & \\
\hline "BANGLADESH" & Tour & 182000 & 1920.00 & 1950.00 & 1970.00 & 1980.00 \\
\hline "Landuse $\left(10^{\wedge} 3 \mathrm{ba}\right)^{\circ}$ & "NET CULTIVATED AREA" & 7191.02 & 749.88 & 8373.9 & 846874 & 841878 \\
\hline • & - Temporary crope" & 605294 & 718437 & 8121.55 & 8215.76 & 8161.55 \\
\hline - & - Permanent crope" & 238.07 & 203.52 & 22243 & 25298 & 257.23 \\
\hline$\cdot$ & SETTLED/BUILT.UP & 307.14 & 405.85 & 4922 & 824.18 & 982.43 \\
\hline$\cdot$ & "FOREST/WOODLAND" & 654.83 & 54.39 & 456.46 & 355.17 & 307.41 \\
\hline$\cdot$ & "INTERRUPTED WOODS & 78622 & 04.22 & $\operatorname{sog} 13$ & 457.02 & 431.59 \\
\hline • & WETLANDS" & 1739.20 & 168088 & 1290.17 & 1115.16 & geass \\
\hline$\cdot$ & - Poresced wellands" & 930.05 & 816.03 & 6) 35 & 545.53 & 510.82 \\
\hline - & - Nonforealed wetlands" & 809.15 & 864.85 & 651.81 & 569.63 & 475.73 \\
\hline
\end{tabular}




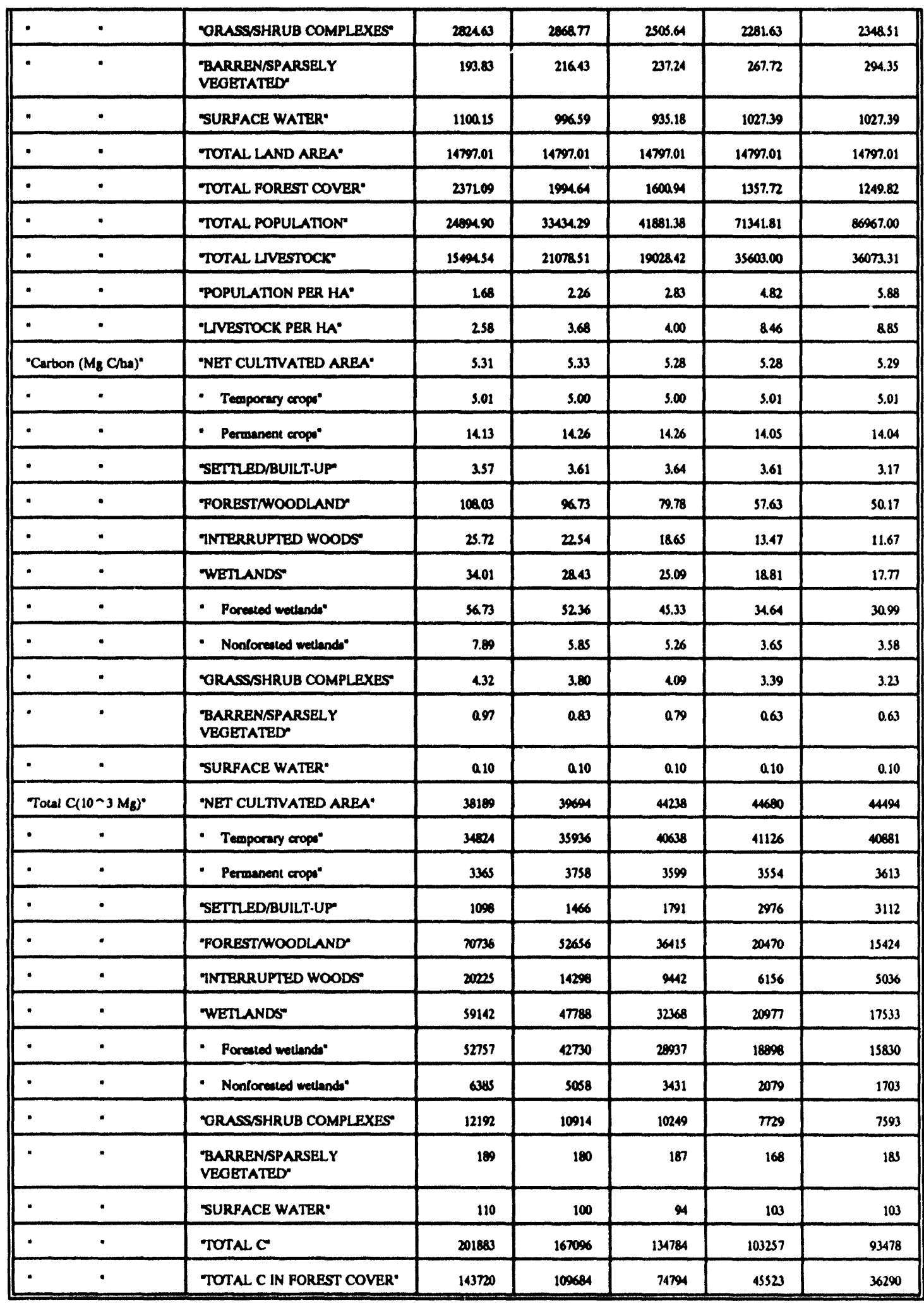


Table 15. Display of a portion of the data accuracy flags in spreadsheet FLAGS.WK1.

\begin{tabular}{|c|c|c|c|c|c|c|}
\hline${ }^{\circ} 101^{\circ}$ & & & & & & \\
\hline "BANGLADESH" & Chiluagong Hill Truces" & 1860 & 1920 & 1950 & 1970 & 1900 \\
\hline - $\quad$ - & Net Sown" & 2 & 6 & 6 & 7 & 7 \\
\hline$\cdot$ & "Non-As Lendure" & 2 & 4 & s & 6 & 8 \\
\hline - $\quad$ - & "Population" & s & 6 & 8 & 6 & 8 \\
\hline$\cdot$ & Unveloct" & 0 & s & s & 6 & 7 \\
\hline
\end{tabular}

Table 16. Display of a portion of the M, E, D, and N data in spreadsheet FACTORS.WK1.

\begin{tabular}{|c|c|c|c|c|c|c|c|c|c|}
\hline \multicolumn{10}{|c|}{$" 101^{*}$} \\
\hline & ADESH & "Cbluseng Hit Traces" & $M$ & $\mathbf{E}$ & Dies & DI9: & Disso & D1970 & "D1980 \\
\hline . & : & 'NET CULTIVATED AREA & 99.00 & 99.00 & 999.00 & 99.00 & 99.00 & 99.00 & 999.00 \\
\hline - & - & - Teaporary Crope" & 480 & 1.00 & 1.00 & 100 & 1.00 & 1.00 & 1.00 \\
\hline$\bullet$ & - & - Permanent Cropo" & 10000 & 1.00 & a.1s & a.1s & a.15 & Q.1s & 0.15 \\
\hline - & - & SETTLEDBUUL.T-UP & 400 & 1.00 & 1.00 & 1.00 & 1.00 & 1.00 & 1.00 \\
\hline - & - & TOREST/WOODLAND & 35000 & Q.71 & aso & 0.44 & 0.34 & 0.26 & 0.22 \\
\hline - & $\cdot$ & TNTERRUPTED WOODS" & 87.50 & $a .71$ & a.so & 0.44 & a.34 & 0.26 & 0.22 \\
\hline . & - & WETLANDS" & 99.00 & 999.00 & 99.00 & 999.00 & 999.00 & 99.00 & 99.00 \\
\hline - & - & - Porneled Wetinds" & 203.00 & a.71 & aso & $a+4$ & 0.34 & 0.26 & 0.22 \\
\hline - & - & - Nonlorvat Wetande & 3000 & 100 & $a \infty$ & 0.80 & $a n$ & 0.64 & 0.61 \\
\hline - & - & ORASSSHRUB COMPLEXES & 1200 & 1.00 & a.89 & 0.83 & $a \pi n$ & 0.64 & 0.61 \\
\hline • & - & $\begin{array}{l}\text { BARREN/SPARSELY } \\
\text { VEOETATED }\end{array}$ & 2.40 & 1.00 & 0.69 & $\mathbf{0 . 8 3}$ & $0 . n$ & 0.64 & 0.61 \\
\hline - & - & SURPACE WATER & 0.10 & 1.00 & 100 & 1.00 & 1.00 & 1.00 & 1.00 \\
\hline & & RengenMean RainlallN" & 250000 & 999.00 & 10,00 & 9.00 & 9.00 & 800 & 800 \\
\hline
\end{tabular}




\section{ARC/INFO $^{\text {TM }}$ (Version 6.1) EXPORT FILES}

Three ARC/INFO ${ }^{\text {TM }}$ E00 export files are provided with this NDP to allow mapping of the land use and carbon data and comparisons to be made between this and other geographic data sets. These files contain the same data as File 2 (LANDCARB.ASC). The names of files 30, 31, and 32 are SEA_LAND.E00, SEA_TCHA.E00, and SEA_CARB.E00, respectively. Each file contains data for all 94 ecological zones that occur within the study region. File SEA_LAND contains land use data and human and livestock population data by year (all values are given in thousands). File SEA_TCHA contains the estimated carbon contents per ha for each of the eight land use class in $\mathrm{Mg} /$ ha by time period. File SEA_CARB contains the total carbon sequestered in live vegetation by land use class, zone, and time period in $10^{3} \mathrm{Mg}$ of carbon (i.e., this file is the product of SEA_LAND and SEA_TCHA).

The ARC/INFO ${ }^{\mathrm{TM}}$ EO0 export files were produced using the EXPORT command with the NONE option in ARC/INFO ${ }^{\mathrm{TM}}$ Version 6.1. These files are in an uncompressed, fixed block format that can be moved across computer systems. The coverages are in a GEOGRAPHIC projection, a spherical reference system that locates positions using latitude and longitude coordinates that are stored in decimal degrees. As a result of this, the reference system in which the data are stored is not uniform in size or area.

After these files are loaded onto your system and imported into $\mathrm{ARC} / \mathrm{INFO}{ }^{\mathrm{TM}}$, data from any of the three coverages may be accessed directly (e.g., in INFO) or a RELATE may be created that links the coverages based on a common variable. If this is done we suggest that the "relate item" used be the zone identification number (variable ZONE). A listing of the variable names and data formats for these E00 files are depicted in Tables 17, 18, and 19. Variable names are similar to those used in LANDCARB.ASC (File 2), with the primary difference being that prefix letters have been dropped because the data in LANDCARB.ASC have been split into three E00 files, the numeric postfixes have also been replaced by the actual year they represent (e.g., the variable name LAG_ALL1 in LANDCARB.ASC has been replaced by AG_ALL_1880).

Table 17. Variable formats for SEA_LAND.EOO (File 30).

\begin{tabular}{llllll}
\hline $\begin{array}{l}\text { Start } \\
\text { column }\end{array}$ & $\begin{array}{l}\text { Item } \\
\text { name }\end{array}$ & $\begin{array}{l}\text { Data } \\
\text { width }\end{array}$ & $\begin{array}{l}\text { Display } \\
\text { width }\end{array}$ & $\begin{array}{l}\text { Data } \\
\text { type }\end{array}$ & $\begin{array}{l}\text { Decimal } \\
\text { places }\end{array}$ \\
\hline 1 & AREA & 4 & 12 & $\mathrm{~F}$ & 3 \\
5 & PERIMETER & 4 & 12 & $\mathrm{~F}$ & 3 \\
9 & SEA_LAND & 4 & 5 & $\mathrm{~B}$ & - \\
13 & SEA_LAND-ID & 4 & 5 & $\mathrm{~B}$ & - \\
17 & CTRY & 4 & 4 & $\mathrm{I}$ & - \\
21 & CTRY-NAME & 20 & 20 & $\mathrm{C}$ & - \\
41 & ZONE & 4 & 4 & 1 & - \\
45 & ZONE-NAME & 26 & 26 & $\mathrm{C}$ & -
\end{tabular}


Table 17. (Continued)

\begin{tabular}{|c|c|c|c|c|c|}
\hline $\begin{array}{l}\text { Start } \\
\text { column }\end{array}$ & $\begin{array}{l}\text { Item } \\
\text { name }\end{array}$ & $\begin{array}{l}\text { Data } \\
\text { width }\end{array}$ & $\begin{array}{l}\text { Display } \\
\text { width }\end{array}$ & $\begin{array}{l}\text { Data } \\
\text { type }\end{array}$ & $\begin{array}{l}\text { Decimal } \\
\text { places }\end{array}$ \\
\hline 71 & AG_ALL_1880 & 10 & 10 & $\mathbf{N}$ & 2 \\
\hline 81 & $A^{-}{ }_{-}^{-} L_{L}^{-} 1920$ & 10 & 10 & $\mathrm{~N}$ & 2 \\
\hline 91 & $A^{-} A L L_{-}^{-} 1950$ & 10 & 10 & $\mathbf{N}$ & 2 \\
\hline 101 & AG_ALL_1970 $^{-}$ & 10 & 10 & $\mathbf{N}$ & 2 \\
\hline 111 & $A G^{-} A L L 1980$ & 10 & 10 & $\mathrm{~N}$ & 2 \\
\hline 121 & AG TEMP 1880 & 10 & 10 & $\mathrm{~N}$ & 2 \\
\hline 131 & $\mathrm{AG}^{-}$TEMP 1920 & 10 & 10 & $\mathrm{~N}$ & 2 \\
\hline 141 & AG_TEMP_1950 & 10 & 10 & $\mathrm{~N}$ & 2 \\
\hline 151 & AG_TEMP_1970 & 10 & 10 & $\mathrm{~N}$ & 2 \\
\hline 161 & AG TEMP 1980 & 10 & 10 & $\mathrm{~N}$ & 2 \\
\hline 171 & AG PERM 1880 & 10 & 10 & $\mathrm{~N}$ & 2 \\
\hline 181 & AG PERM 1920 & 10 & 10 & $\mathrm{~N}$ & 2 \\
\hline 191 & AG_PERM_1950 & 10 & 10 & $\mathbf{N}$ & 2 \\
\hline 201 & AG_PERM_1970 & 10 & 10 & $\mathrm{~N}$ & 2 \\
\hline 211 & AG PERM 1980 & 10 & 10 & $\mathrm{~N}$ & 2 \\
\hline 221 & SETTLED 1880 & 10 & 10 & N & 2 \\
\hline 231 & SETTLED_1920 & 10 & 10 & $\mathrm{~N}$ & 2 \\
\hline 241 & SETTLED 1950 & 10 & 10 & $\mathrm{~N}$ & 2 \\
\hline 251 & SETTLED_1970 & 10 & 10 & $\mathbf{N}$ & 2 \\
\hline 261 & SETTLED_1980 & 10 & 10 & $\mathbf{N}$ & 2 \\
\hline 271 & FOR_CON_1880 & 10 & 10 & $\mathrm{~N}$ & 2 \\
\hline 281 & FOR $C O N$ & 10 & 10 & $\mathrm{~N}$ & 2 \\
\hline 291 & FOR $\mathrm{CON} 1950$ & 10 & 10 & $\mathrm{~N}$ & 2 \\
\hline 301 & FOR_CON_1970 & 10 & 10 & $\mathrm{~N}$ & 2 \\
\hline 311 & FOR_CON_1980 & 10 & 10 & $\mathbf{N}$ & 2 \\
\hline 321 & FOR_INT_1880 & 10 & 10 & $\mathbf{N}$ & 2 \\
\hline 331 & FOR INT 1920 & 10 & 10 & $\mathrm{~N}$ & 2 \\
\hline 341 & FOR INT 1950 & 10 & 10 & $\mathrm{~N}$ & 2 \\
\hline 351 & FOR_INT_1970 & 10 & 10 & $\mathrm{~N}$ & 2 \\
\hline 361 & FOR_INT 1980 & 10 & 10 & $\mathrm{~N}$ & 2 \\
\hline 371 & WET ALI 1880 & 10 & 10 & $\mathrm{~N}$ & 2 \\
\hline 381 & WET_ALL 1920 & 10 & 10 & $\mathrm{~N}$ & 2 \\
\hline 391 & WET_ALL_1950 & 10 & 10 & $\mathrm{~N}$ & 2 \\
\hline 401 & WET_ALL_1970 & 10 & 10 & $\mathbf{N}$ & 2 \\
\hline 411 & WET ALL 1980 & 10 & 10 & $\mathbf{N}$ & 2 \\
\hline 421 & WET FOR 1880 & 10 & 10 & $\mathbf{N}$ & 2 \\
\hline 431 & WET FOR 1920 & 10 & 10 & $\mathrm{~N}$ & 2 \\
\hline 441 & WET FOR 1950 & 10 & 10 & $\mathrm{~N}$ & 2 \\
\hline 451 & WET_FOR_1970 & 10 & 10 & $\mathrm{~N}$ & 2 \\
\hline 461 & WET FOR 1980 & 10 & 10 & $\mathrm{~N}$ & 2 \\
\hline
\end{tabular}


Table 17. (Continued)

\begin{tabular}{|c|c|c|c|c|c|}
\hline $\begin{array}{l}\text { Start } \\
\text { column }\end{array}$ & $\begin{array}{l}\text { Item } \\
\text { name }\end{array}$ & $\begin{array}{l}\text { Data } \\
\text { width }\end{array}$ & $\begin{array}{l}\text { Display } \\
\text { width }\end{array}$ & $\begin{array}{l}\text { Data } \\
\text { type }\end{array}$ & $\begin{array}{l}\text { Decimal } \\
\text { places }\end{array}$ \\
\hline 471 & WET_NON_1880 & 10 & 10 & $\mathbf{N}$ & 2 \\
\hline 481 & WET_NON_1920 & 10 & 10 & $\mathrm{~N}$ & 2 \\
\hline 491 & WET_NON_1950 & 10 & 10 & $\mathbf{N}$ & 2 \\
\hline 501 & WET NON 1970 & 10 & 10 & $\mathrm{~N}$ & 2 \\
\hline 511 & WET_NON_1980 & 10 & 10 & $\mathrm{~N}$ & 2 \\
\hline 521 & 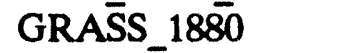 & 10 & 10 & $\mathbf{N}$ & 2 \\
\hline 531 & GRASS_1920 & 10 & 10 & $\mathrm{~N}$ & 2 \\
\hline 541 & GRASS 1950 & 10 & 10 & $\mathrm{~N}$ & 2 \\
\hline 551 & GRASS 1970 & 10 & 10 & $\mathrm{~N}$ & 2 \\
\hline 561 & GRASS_1980 & 10 & 10 & $\mathrm{~N}$ & 2 \\
\hline 571 & BARREN_1880 & 10 & 10 & $\mathrm{~N}$ & 2 \\
\hline 581 & BARREN_1920 & 10 & 10 & $\mathrm{~N}$ & 2 \\
\hline 591 & BARREN_1950 & 10 & 10 & $\mathrm{~N}$ & 2 \\
\hline 601 & BARREN_1970 & 10 & 10 & $\mathbf{N}$ & 2 \\
\hline 611 & BARREN 1980 & 10 & 10 & $\mathrm{~N}$ & 2 \\
\hline 621 & WATER 1880 & 10 & 10 & $\mathrm{~N}$ & 2 \\
\hline 631 & WATER_-1920 & 10 & 10 & $\mathrm{~N}$ & 2 \\
\hline 641 & WATER_1950 & 10 & 10 & $\mathrm{~N}$ & 2 \\
\hline 651 & WATER_1970 & 10 & 10 & $\mathrm{~N}$ & 2 \\
\hline 661 & WATER 1980 & 10 & 10 & $\mathrm{~N}$ & 2 \\
\hline 671 & TOT_LĀND_1880 & 10 & 10 & $\mathrm{~N}$ & 2 \\
\hline 681 & TOT_LAND_1920 & 10 & 10 & $\mathrm{~N}$ & 2 \\
\hline 691 & TOT LAND 1950 & 10 & 10 & $\mathbf{N}$ & 2 \\
\hline 701 & TOT LAND 1970 & 10 & 10 & $\mathrm{~N}$ & 2 \\
\hline 711 & TOT LAND 1980 & 10 & 10 & $\mathrm{~N}$ & 2 \\
\hline 721 & TOT_FOR_1-1880 & 10 & 10 & $\mathrm{~N}$ & 2 \\
\hline 731 & TOT_FOR_1920 & 10 & 10 & $\mathrm{~N}$ & 2 \\
\hline 741 & TOT FOR 1950 & 10 & 10 & $\mathrm{~N}$ & 2 \\
\hline 751 & TOT FOR 1970 & 10 & 10 & $\mathrm{~N}$ & 2 \\
\hline 761 & TOT_FOR_1980 & 10 & 10 & $\mathrm{~N}$ & 2 \\
\hline 771 & TOT_HPOP__1880 & 10 & 10 & $\mathrm{~N}$ & 2 \\
\hline 781 & TOT HPOP 1920 & 10 & 10 & $\mathrm{~N}$ & 2 \\
\hline 791 & TOT HPOP 1950 & 10 & 10 & $\mathrm{~N}$ & 2 \\
\hline 801 & TOT HPOP 1970 & 10 & 10 & $\mathrm{~N}$ & 2 \\
\hline 811 & TOT_HPOP_1980 & 10 & 10 & $\mathrm{~N}$ & 2 \\
\hline 821 & TOT_LPOP_1880 & 10 & 10 & $\mathrm{~N}$ & 2 \\
\hline 831 & TOT LPOP 1920 & 10 & 10 & $\mathrm{~N}$ & 2 \\
\hline 841 & TOT_LPOP_1950 & 10 & 10 & $\mathrm{~N}$ & 2 \\
\hline 851 & TOT LPOP 1970 & 10 & 10 & $\mathrm{~N}$ & 2 \\
\hline 861 & TOT_LPOP_1980 & 10 & 10 & $\mathrm{~N}$ & 2 \\
\hline
\end{tabular}


Table 17. (Continued)

\begin{tabular}{llllll}
\hline $\begin{array}{l}\text { Start } \\
\text { column }\end{array}$ & $\begin{array}{l}\text { Item } \\
\text { name }\end{array}$ & $\begin{array}{l}\text { Data } \\
\text { width }\end{array}$ & $\begin{array}{l}\text { Display } \\
\text { width }\end{array}$ & $\begin{array}{l}\text { Data } \\
\text { type }\end{array}$ & $\begin{array}{l}\text { Decimal } \\
\text { places }\end{array}$ \\
\hline 871 & DEN_H_1880 & 10 & 10 & $\mathrm{~N}$ & 2 \\
881 & DEN_H_1920 & 10 & 10 & $\mathrm{~N}$ & 2 \\
891 & DEN_H_1950 & 10 & 10 & $\mathrm{~N}$ & 2 \\
901 & DEN_H_1970 & 10 & 10 & $\mathrm{~N}$ & 2 \\
911 & DEN_H_1980 & 10 & 10 & $\mathrm{~N}$ & 2 \\
921 & DEN_L_1880 & 10 & 10 & $\mathrm{~N}$ & 2 \\
931 & DEN_L_1920 & 10 & 10 & $\mathrm{~N}$ & 2 \\
941 & DEN_L_1950 & 10 & 10 & $\mathrm{~N}$ & 2 \\
951 & DEN_L_1970 & 10 & 10 & $\mathrm{~N}$ & 2 \\
961 & DEN_L_1980 & 10 & 10 & $\mathrm{~N}$ & 2 \\
\hline
\end{tabular}

"Data types are B-binary, C-character, F-float, I-integer, and $\mathrm{N}$-numeric. $\mathrm{F}$ and $\mathrm{N}$ data types are real numbers with different precisions (precision is system dependent). 
Table 18. Variable formats for SEA_TCHA.EOO (File 31).

\begin{tabular}{|c|c|c|c|c|c|}
\hline $\begin{array}{l}\text { Start } \\
\text { Column }\end{array}$ & $\begin{array}{l}\text { Item } \\
\text { Name }\end{array}$ & $\begin{array}{l}\text { Data } \\
\text { Width }\end{array}$ & $\begin{array}{l}\text { Display } \\
\text { Width }\end{array}$ & $\begin{array}{l}\text { Data } \\
\text { Type }\end{array}$ & $\begin{array}{l}\text { Decimal } \\
\text { Places }\end{array}$ \\
\hline 1 & AREA & 4 & 12 & $\mathrm{~F}$ & 3 \\
\hline 5 & PERIMETER & 4 & 12 & $\mathbf{F}$ & 3 \\
\hline 9 & SEA TCHA & 4 & 5 & B & - \\
\hline 13 & SEA_TCHA-ID & 4 & 5 & $\mathbf{B}$ & - \\
\hline 17 & CTRY & 4 & 4 & $\bar{I}$ & - \\
\hline 21 & CTRY-NAME & 20 & 20 & $\mathrm{C}$ & - \\
\hline 41 & ZONE & 4 & 4 & I & - \\
\hline 45 & ZONE-NAME & 26 & 26 & $\mathrm{C}$ & - \\
\hline 71 & AG_ALL_1880 & 10 & 10 & $\mathbf{N}$ & 2 \\
\hline 81 & $\mathrm{AG}^{-} \mathrm{ALL} 1920$ & 10 & 10 & $\mathbf{N}$ & 2 \\
\hline 91 & $\mathrm{AG}^{-} \mathrm{ALL}^{-} 1950$ & 10 & 10 & $\mathbf{N}$ & 2 \\
\hline 101 & $\mathrm{AG}_{-}^{-} \mathrm{ALL}_{-1970}^{-}$ & 10 & 10 & $\mathbf{N}$ & 2 \\
\hline 111 & AG_ALL_1980 & 10 & 10 & $\mathbf{N}$ & 2 \\
\hline 121 & AG_TEMP 1880 & 10 & 10 & $\mathbf{N}$ & 2 \\
\hline 131 & AG_TEMP_1920 & 10 & 10 & $\mathbf{N}$ & 2 \\
\hline 141 & AG_TEMP_1950 & 10 & 10 & $\mathbf{N}$ & 2 \\
\hline 151 & AG_TEMP $^{-} 1970$ & 10 & 10 & $\mathbf{N}$ & 2 \\
\hline 161 & AG_TEMP_1980 & 10 & 10 & $\mathbf{N}$ & 2 \\
\hline 171 & AG_PERM 1880 & 10 & 10 & $\mathbf{N}$ & 2 \\
\hline 181 & AG_PERM_1920 & 10 & 10 & $\mathrm{~N}$ & 2 \\
\hline 191 & AG PERM 1950 & 10 & 10 & $\mathrm{~N}$ & 2 \\
\hline 201 & AG_PERM_1970 & 10 & 10 & $\mathbf{N}$ & 2 \\
\hline 211 & AG_PERM_1980 & 10 & 10 & $\mathbf{N}$ & 2 \\
\hline 221 & SETTLED_-1 880 & 10 & 10 & $N$ & 2 \\
\hline 231 & SETTLED_1920 & 10 & 10 & $\mathbf{N}$ & 2 \\
\hline 241 & SETTLED_1950 & 10 & 10 & $\mathbf{N}$ & 2 \\
\hline 251 & SETTLED_1970 & 10 & 10 & $\mathbf{N}$ & 2 \\
\hline 261 & SETTLED 1980 & 10 & 10 & $\mathbf{N}$ & 2 \\
\hline 271 & FOR_CON_1880 & 10 & 10 & $\mathbf{N}$ & 2 \\
\hline 281 & FOR CON 1920 & 10 & 10 & $\mathbf{N}$ & 2 \\
\hline 291 & FOR_CON_1950 & 10 & 10 & $\mathbf{N}$ & 2 \\
\hline 301 & FOR CON 1970 & 10 & 10 & $\mathrm{~N}$ & 2 \\
\hline 311 & FOR_CON_1980 & 10 & 10 & $\mathbf{N}$ & 2 \\
\hline 321 & FOR_INT_1880 & 10 & 10 & $\mathbf{N}$ & 2 \\
\hline 331 & FOR INT 1920 & 10 & 10 & $\mathbf{N}$ & 2 \\
\hline 341 & FOR_INT_1950 & 10 & 10 & $\mathrm{~N}$ & 2 \\
\hline 351 & FOR INT 1970 & 10 & 10 & $N$ & 2 \\
\hline 361 & FOR_INT_1980 & 10 & 10 & $\mathbf{N}$ & 2 \\
\hline
\end{tabular}


Table 18. (Continued)

\begin{tabular}{|c|c|c|c|c|c|}
\hline $\begin{array}{l}\text { Start } \\
\text { Column }\end{array}$ & $\begin{array}{l}\text { Item } \\
\text { Name }\end{array}$ & $\begin{array}{l}\text { Data } \\
\text { Width }\end{array}$ & $\begin{array}{l}\text { Display } \\
\text { Width }\end{array}$ & $\begin{array}{l}\text { Data } \\
\text { Type }\end{array}$ & $\begin{array}{l}\text { Decimal } \\
\text { Places }\end{array}$ \\
\hline 371 & WET_ALL_1880 & 10 & 10 & $\mathbf{N}$ & 2 \\
\hline 381 & WET_ALL_1920 & 10 & 10 & $\mathbf{N}$ & 2 \\
\hline 391 & WET_ALL_1950 & 10 & 10 & $\mathbf{N}$ & 2 \\
\hline 401 & WET_ALL_1970 & 10 & 10 & $\mathrm{~N}$ & 2 \\
\hline 411 & WET_ALL_1980 & 10 & 10 & $\mathrm{~N}$ & 2 \\
\hline 421 & WET_FOR_1880 & 10 & 10 & $\mathbf{N}$ & 2 \\
\hline 431 & WET_FOR_1920 & 10 & 10 & $\mathbf{N}$ & 2 \\
\hline 441 & WET_FOR_1950 & 10 & 10 & $\mathbf{N}$ & 2 \\
\hline 451 & WET_FOR_1970 & 10 & 10 & $\mathrm{~N}$ & 2 \\
\hline 461 & WET_FOR_1980 & 10 & 10 & $\mathrm{~N}$ & 2 \\
\hline 471 & WET_NON_1880 & 10 & 10 & $\mathrm{~N}$ & 2 \\
\hline 481 & WET_NON_1920 & 10 & 10 & $\mathbf{N}$ & 2 \\
\hline 491 & WET_NON_1950 & 10 & 10 & $\mathbf{N}$ & 2 \\
\hline 501 & WET_NON_1970 & 10 & 10 & $\mathrm{~N}$ & 2 \\
\hline 511 & WET_NON_1980 & 10 & 10 & $\mathbf{N}$ & 2 \\
\hline 521 & GRAS̄S_1880 & 10 & 10 & $\mathrm{~N}$ & 2 \\
\hline 531 & GRASS_1920 & 10 & 10 & $\mathbf{N}$ & 2 \\
\hline 541 & GRASS_1950 & 10 & 10 & $\mathbf{N}$ & 2 \\
\hline 551 & GRASS_1970 & 10 & 10 & $\mathbf{N}$ & 2 \\
\hline 561 & GRASS_1980 & 10 & 10 & $\mathbf{N}$ & 2 \\
\hline 571 & BARREN 1880 & 10 & 10 & $\mathbf{N}$ & 2 \\
\hline 581 & BARREN_1920 & 10 & 10 & $\mathbf{N}$ & 2 \\
\hline 591 & BARREN_1950 & 10 & 10 & $\mathbf{N}$ & 2 \\
\hline 601 & BARREN_1970 & 10 & 10 & $\mathrm{~N}$ & 2 \\
\hline 611 & BARREN_1980 & 10 & 10 & $\mathrm{~N}$ & 2 \\
\hline 621 & WATER_1̄880 & 10 & 10 & $\mathbf{N}$ & 2 \\
\hline 631 & WATER_1920 & 10 & 10 & $N$ & 2 \\
\hline 641 & WATER_1950 & 10 & 10 & $\mathbf{N}$ & 2 \\
\hline 651 & WATER_1970 & 10 & 10 & $\mathrm{~N}$ & 2 \\
\hline 661 & WATER_1980 & 10 & 10 & $\mathrm{~N}$ & 2 \\
\hline
\end{tabular}

"Data types are B-binary, C-character, F-float, I-integer, and N-numeric. F and $\mathrm{N}$ data types are real numbers with different precisions (precision is system dependent). 
Table 19. Variable formats for SEA_CARB.E00 (File 32).

\begin{tabular}{|c|c|c|c|c|c|}
\hline $\begin{array}{l}\text { Start } \\
\text { Column }\end{array}$ & $\begin{array}{l}\text { Item } \\
\text { Name }\end{array}$ & $\begin{array}{l}\text { Data } \\
\text { Width }\end{array}$ & $\begin{array}{l}\text { Display } \\
\text { Width }\end{array}$ & $\begin{array}{l}\text { Data } \\
\text { Type }\end{array}$ & $\begin{array}{l}\text { Decimal } \\
\text { Places }\end{array}$ \\
\hline 1 & AREA & 4 & 12 & $\mathrm{~F}$ & 3 \\
\hline 5 & PERIMETER & 4 & 12 & $\mathrm{~F}$ & 3 \\
\hline 9 & SEA_CARB & 4 & 5 & B & - \\
\hline 13 & SEA_CARB-ID & 4 & 5 & B & - \\
\hline 17 & CTR'Y & 4 & 4 & I & - \\
\hline 21 & CTRY-NAME & 20 & 20 & $\mathrm{C}$ & - \\
\hline 41 & ZONE & 4 & 4 & I & - \\
\hline 45 & ZONE-NAME & 26 & 26 & $\mathrm{C}$ & - \\
\hline 71 & AG_ALL_1880 & 10 & 10 & I & - \\
\hline 81 & $A^{-} G_{-}{ }^{-} L_{L}{ }_{-1} 1920$ & 10 & 10 & I & - \\
\hline 91 & $\mathrm{AG}_{-}^{-} \mathrm{ALL}_{-} 1950$ & 10 & 10 & I & - \\
\hline 101 & AG_ALL_1970 & 10 & 10 & I & - \\
\hline 111 & AG_ALL_1980 & 10 & 10 & I & - \\
\hline 121 & AG_TEMP_1880 & 10 & 10 & I & - \\
\hline 131 & AG_TEMP_1920 & 10 & 10 & I & - \\
\hline 141 & AG_TEMP_1950 & 10 & 10 & I & - \\
\hline 151 & AG_TEMP_1970 & 10 & 10 & I & - \\
\hline 161 & AG_TEMP_1980 & 10 & 10 & I & - \\
\hline 171 & AG_PERM_1880 & 10 & 10 & I & - \\
\hline 181 & AG_PERM_1920 & 10 & 10 & I & - \\
\hline 191 & AG_PERM_1950 & 10 & 10 & I & - \\
\hline 201 & AG_PERM_1970 & 10 & 10 & I & - \\
\hline 211 & AG_PERM_1980 & 10 & 10 & I & - \\
\hline 221 & SETTTLED_-1880 & 10 & 10 & I & - \\
\hline 231 & SETTLED_1920 & 10 & 10 & I & - \\
\hline 241 & SETTLED_1950 & 10 & 10 & I & - \\
\hline 251 & SETTLED_1970 & 10 & 10 & I & - \\
\hline 261 & SETTLED_1980 & 10 & 10 & I & - \\
\hline 271 & FOR_CON_1880 & 10 & 10 & I & - \\
\hline 281 & FOR_CON_1920 & 10 & 10 & I & - \\
\hline 291 & FOR_CON_1950 & 10 & 10 & I & - \\
\hline 301 & FOR_CON_1970 & 10 & 10 & I & - \\
\hline 311 & FOR_CON_1980 & 10 & 10 & I & - \\
\hline 321 & FOR_INT_1880 & 10 & 10 & I & - \\
\hline 331 & FOR_INT_1920 & 10 & 10 & I & - \\
\hline 341 & FOR_INT_1950 & 10 & 10 & I & - \\
\hline 351 & FOR_INT_1970 & 10 & 10 & I & - \\
\hline 361 & FOR_INT_1980 & 10 & 10 & I & - \\
\hline
\end{tabular}


Table $19 . \quad$ (Continued)

\begin{tabular}{|c|c|c|c|c|c|}
\hline $\begin{array}{l}\text { Start } \\
\text { Column }\end{array}$ & $\begin{array}{l}\text { Item } \\
\text { Name }\end{array}$ & $\begin{array}{l}\text { Data } \\
\text { Width }\end{array}$ & $\begin{array}{l}\text { Display } \\
\text { Width }\end{array}$ & $\begin{array}{l}\text { Data } \\
\text { Type }\end{array}$ & $\begin{array}{l}\text { Decimal } \\
\text { Places }\end{array}$ \\
\hline 371 & WET_ALL_1880 & 10 & 10 & I & - \\
\hline 381 & WET_ALL_1920 & 10 & 10 & I & - \\
\hline 391 & WET_ALL_1950 & 10 & 10 & I & - \\
\hline 401 & WET_ALL_1970 & 10 & 10 & I & - \\
\hline 411 & WET_ALL_1980 & 10 & 10 & I & - \\
\hline 421 & WET_FOR_1880 & 10 & 10 & I & - \\
\hline 431 & WET_FOR_1920 & 10 & 10 & I & - \\
\hline 441 & WET_FOR_1950 & 10 & 10 & I & - \\
\hline 451 & WET_FOR_1970 & 10 & 10 & I & - \\
\hline 461 & WET_FOR_1980 & 10 & 10 & I & - \\
\hline 471 & WET_NON_1880 & 10 & 10 & I & - \\
\hline 481 & WET_NON_1920 & 10 & 10 & I & - \\
\hline 491 & WET_NON_1950 & 10 & 10 & I & - \\
\hline 501 & WET_NON_1970 & 10 & 10 & I & - \\
\hline 511 & WET_NON_1980 & 10 & 10 & I & - \\
\hline 521 & GRAS̄S_1880 & 10 & 10 & I & - \\
\hline 531 & GRASS_1920 & 10 & 10 & $I$ & - \\
\hline 541 & GRASS_1950 & 10 & 10 & I & - \\
\hline 551 & GRASS_1970 & 10 & 10 & I & - \\
\hline 561 & GRASS_1980 & 10 & 10 & I & - \\
\hline 571 & BARREN_1880 & 10 & 10 & I & - \\
\hline 581 & BARREN_1920 & 10 & 10 & I & - \\
\hline 591 & BARREN_1950 & 10 & 10 & I & - \\
\hline 601 & BARREN_1970 & 10 & 10 & I & - \\
\hline 611 & BARREN_1980 & 10 & 10 & I & - \\
\hline 621 & WATER_'̄ 880 & 10 & 10 & I & - \\
\hline 631 & WATER_1920 & 10 & 10 & I & - \\
\hline 641 & WATER_1950 & 10 & 10 & I & - \\
\hline 651 & WATER_1970 & 10 & 10 & I & - \\
\hline 661 & WATER_1980 & 10 & 10 & I & - \\
\hline 671 & TOT_LANND_1880 & 10 & 10 & I & - \\
\hline 681 & TOT_LAND_1920 & 10 & 10 & I & - \\
\hline 691 & TOT_LAND_1950 & 10 & 10 & I & - \\
\hline 701 & TOT_LAND 1970 & 10 & 10 & I & - \\
\hline 711 & TOT_LAND_1980 & 10 & 10 & I & - \\
\hline
\end{tabular}


Table 19. (Continued)

\begin{tabular}{llllll}
\hline $\begin{array}{l}\text { Start } \\
\text { Column }\end{array}$ & $\begin{array}{l}\text { Item } \\
\text { Name }\end{array}$ & $\begin{array}{l}\text { Data } \\
\text { Width }\end{array}$ & $\begin{array}{l}\text { Display } \\
\text { Width }\end{array}$ & $\begin{array}{l}\text { Data } \\
\text { Type }\end{array}$ & $\begin{array}{l}\text { Decimal } \\
\text { Places }\end{array}$ \\
\hline 721 & TOT_FOR_1880 & 10 & 10 & I & - \\
731 & TOT_FOR_1920 & 10 & 10 & I & - \\
741 & TOT_FOR_1950 & 10 & 10 & I & - \\
751 & TOT_FOR_1970 & 10 & 10 & I & - \\
761 & TOT_FOR_1980 & 10 & 10 & I & - \\
\hline
\end{tabular}

"Data types are B-binary, C-character, F-float, I-integer, and $\mathrm{N}$-numeric. $\mathrm{F}$ and $\mathrm{N}$ data types are real numbers with different precisions (precision is system dependent). 


\section{LISTING OF THE FORTRAN DATA RETRIEVAL PROGRAMS}

What follows is a listing of the four FORTRAN data retrieval programs provided by CDIAC with this data base. Each program is designed to read and write the contents of one or more of the five flat ASCII data files.

The first FORTRAN program (File 4 on the magnetic tape) is designed to read and print the file LANDCARB.ASC (File 2).

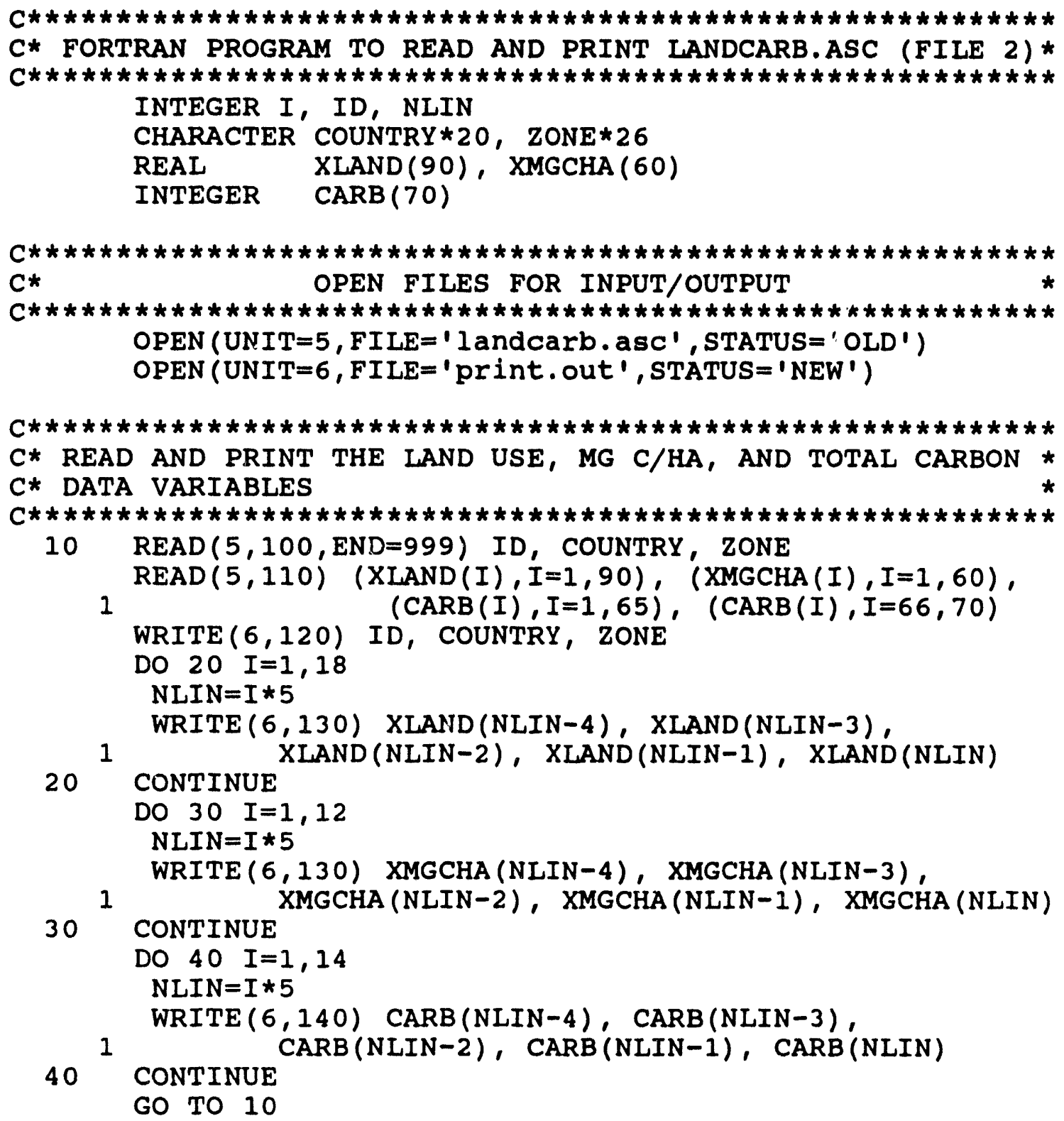




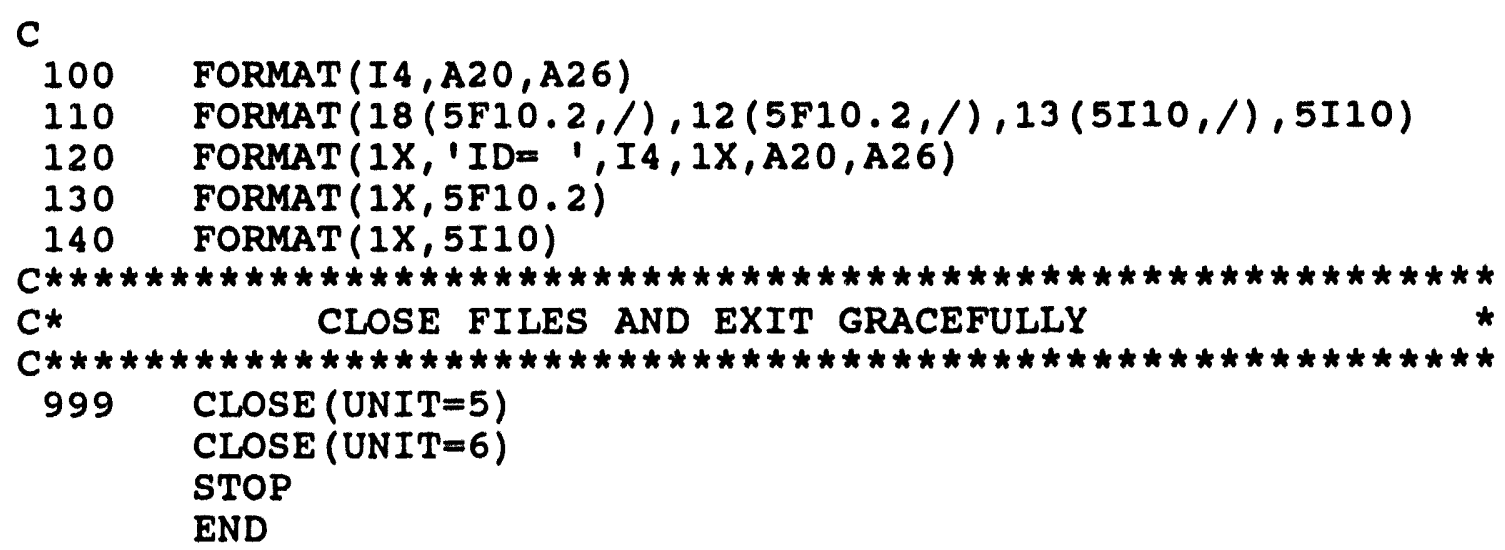

The second FORTRAN program (File 7 on the magnetic tape) is designed to read and print the file FLAGS.ASC (File 5).

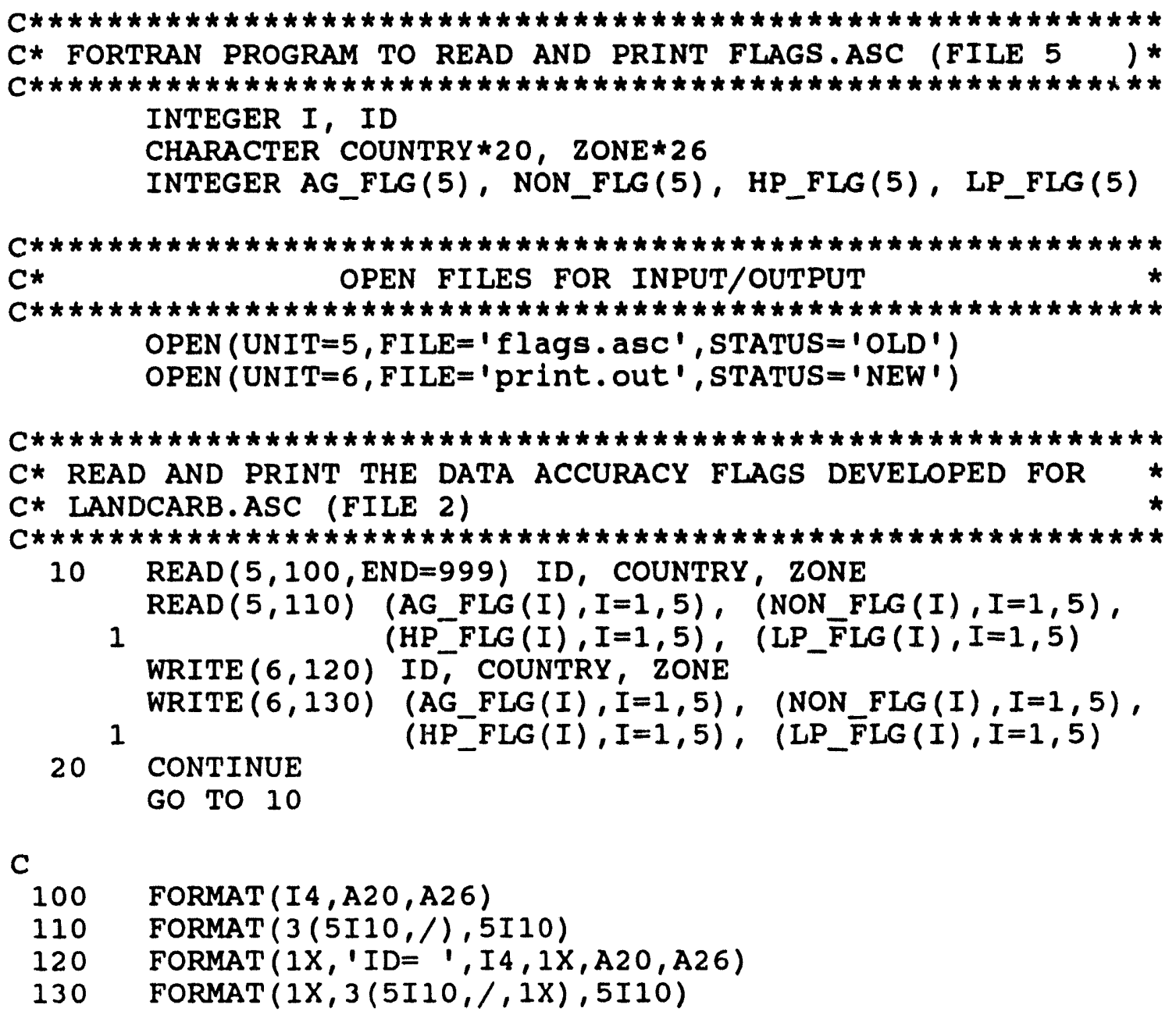




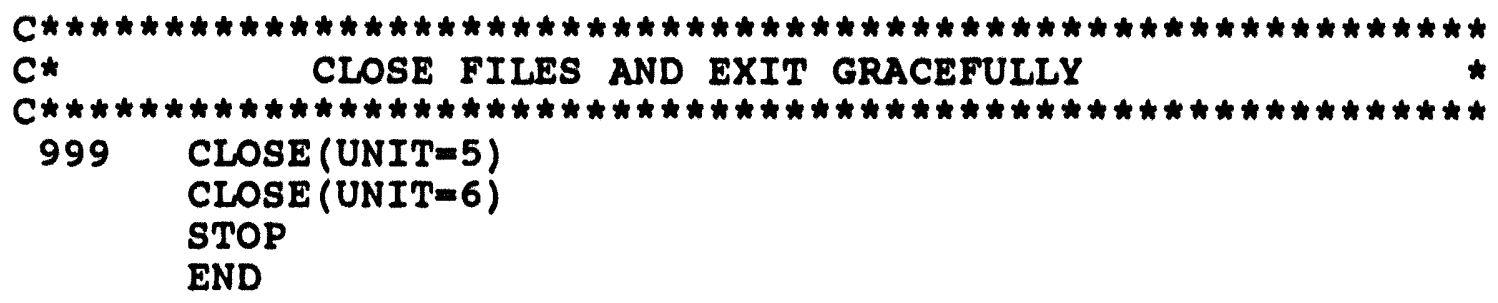

The third FORTRAN program (File 10 on the magnetic tape) is designed to read and print the file FACTORS.ASC (File 8).

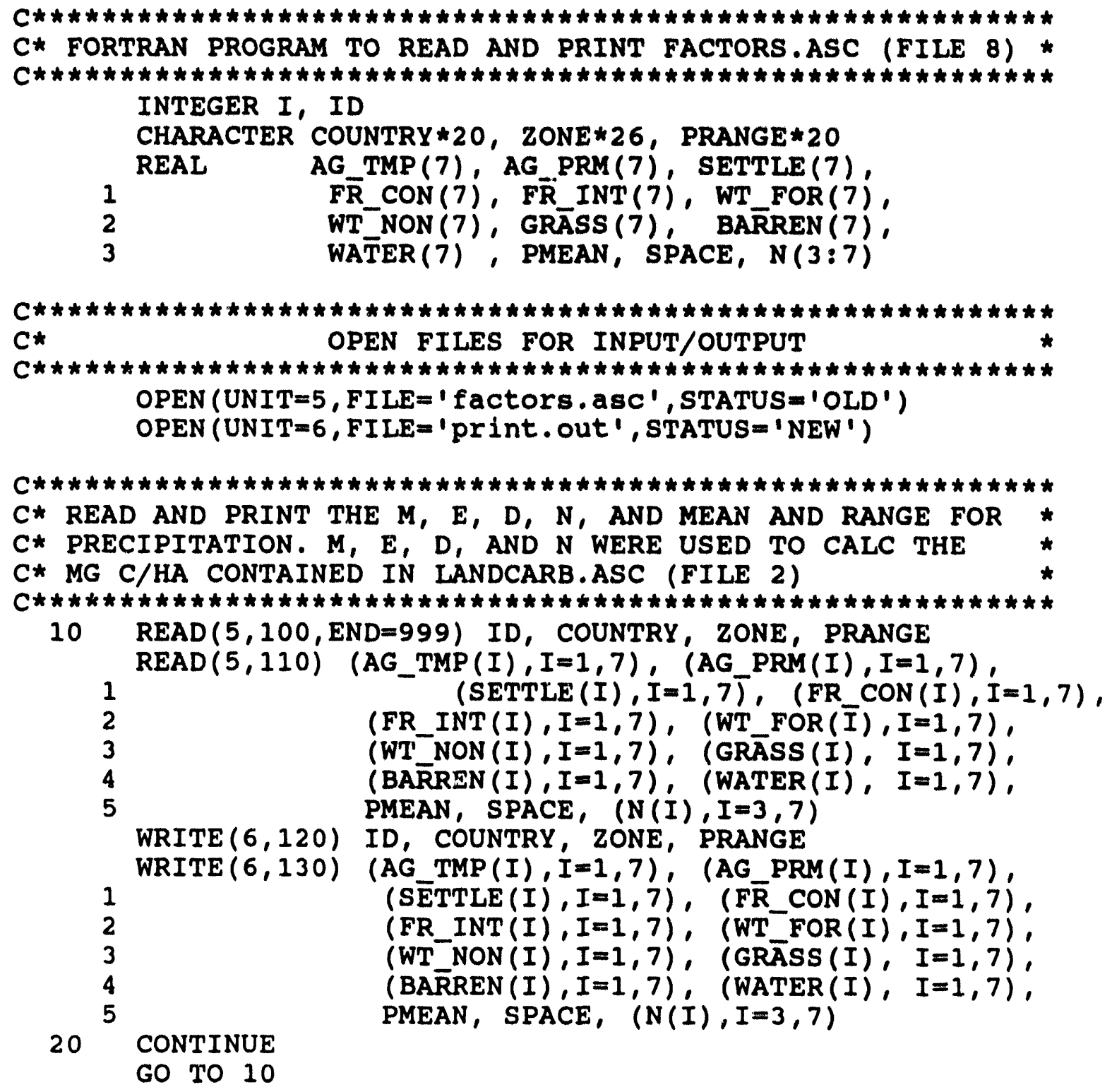


C

100 FORMAT (I4,A20,A26,A20)

110 FORMAT $(10(7 F 10.2, /), 7$ F10.2)

120 FORMAT ( $1 X$, I ID $=1, I 4,1 X, A 20, A 26, /, 1 X$,

1

'Prec1p. Range= ',A20)

130 FORMAT (1X, 10 (7F10.2,/,1X), 7F10.2)

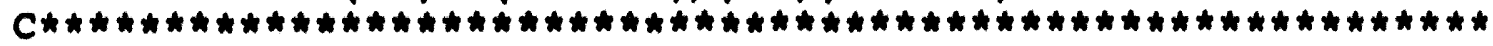

$C \star$

CLOSE FILES AND EXIT GRACEFULLY

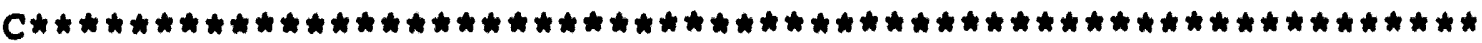

999 CLOSE (UNIT $=5$ )

CLOSE (UNIT $=6$ )

STOP

END

The last FORTRAN program (File 14 on the magnetic tape) is designed to read and print the files SEA_CTRY.ASC (File 11) and SEA_ZONE.ASC (File 12).

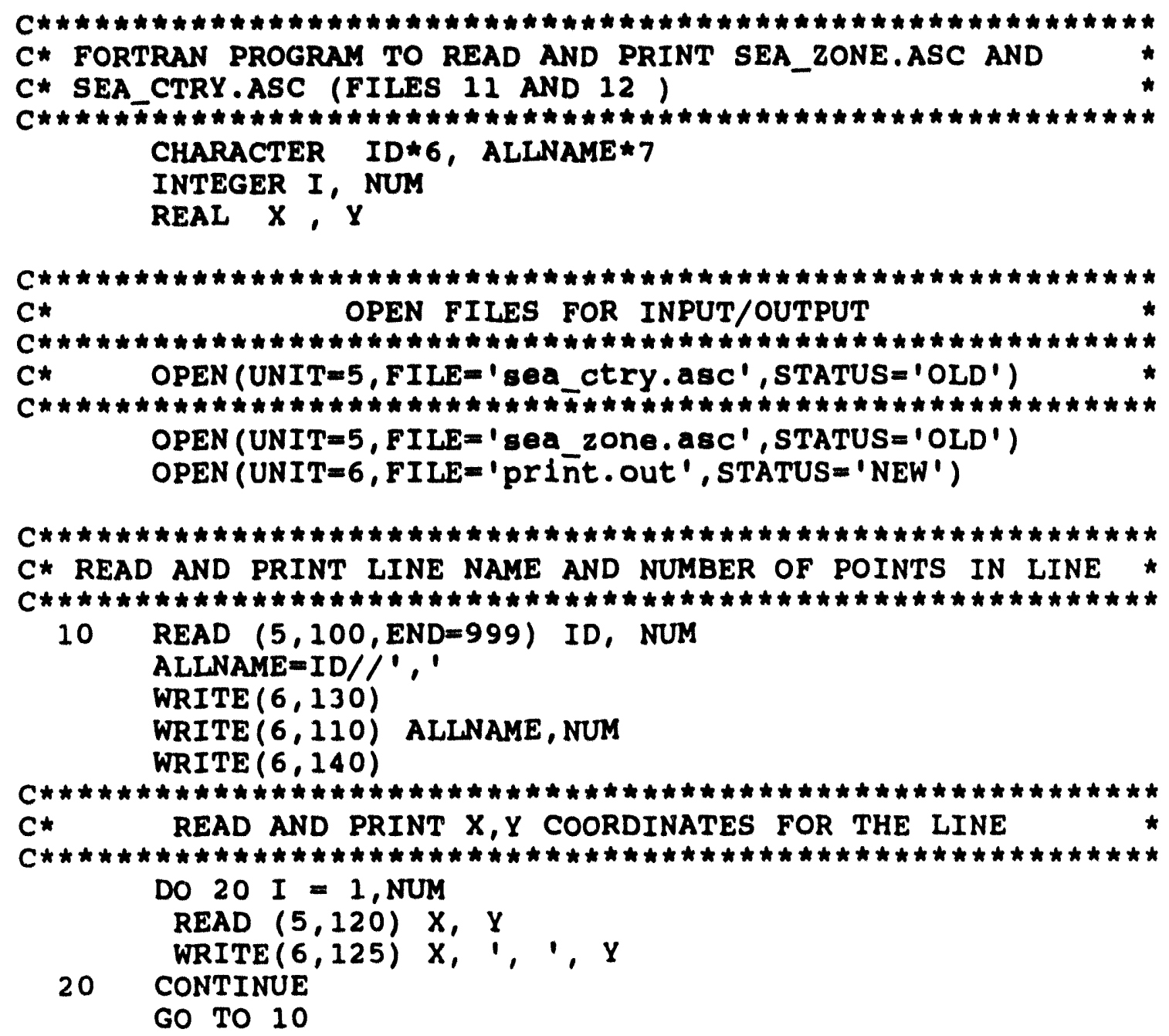


C

100 FORMAT $(A 6,1 X, I 5)$

110 FORYAT $(1 X, A 7, I 6)$

120 FORMAT (F10.6, 1X, F10.6)

125 FORUAT (1X, F10.6,A2, F10.6)

130 FORMAT (1X, 'NAME , NUMBER')

140 FORYAT ( $1 X,{ }^{\prime} X$, $Y$ ' $)$

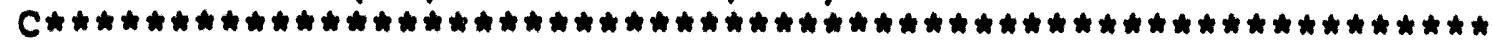

$C *$

CLOSE FILES AND EXIT GRACEFULLY

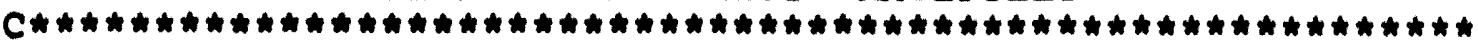

999 CLOSE (UNIT $=5$ )

CLOSE (UNIT $=6$ )

STOP

END 


\section{LISTING OF THE SAS ${ }^{\text {m }}$ DATA RETRIEVAL PROGRAMS}

The following pages list the four SAS ${ }^{\text {TM }}$ data retrieval programs provided by CDIAC with this data base. Each program is designed to read and write the contents of one or more of the five flat ASCIl data filea.

The first program (File 3 on the magnetic tape) is designed to read and print the file LANDCARB.ASC (File 2).

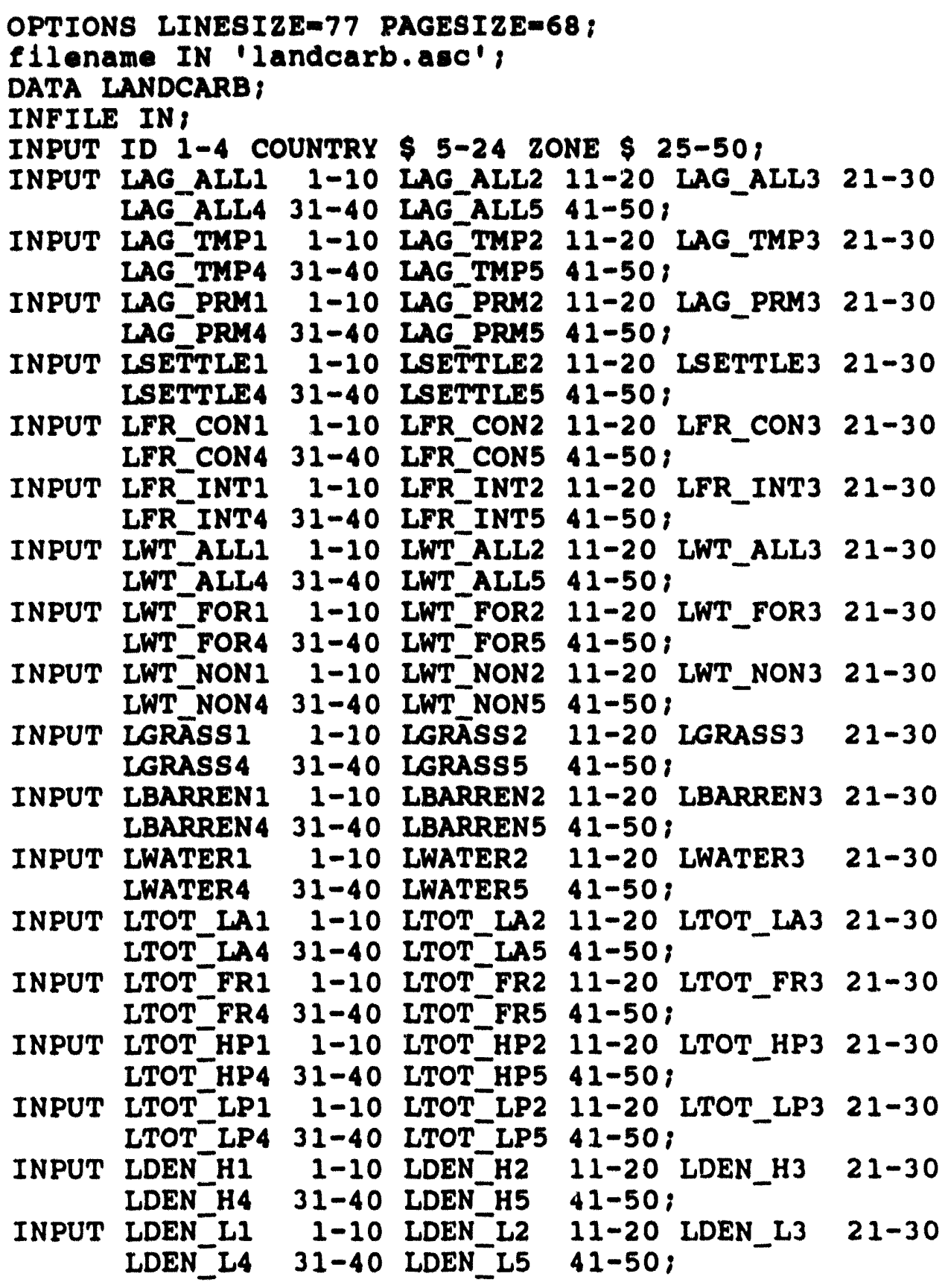




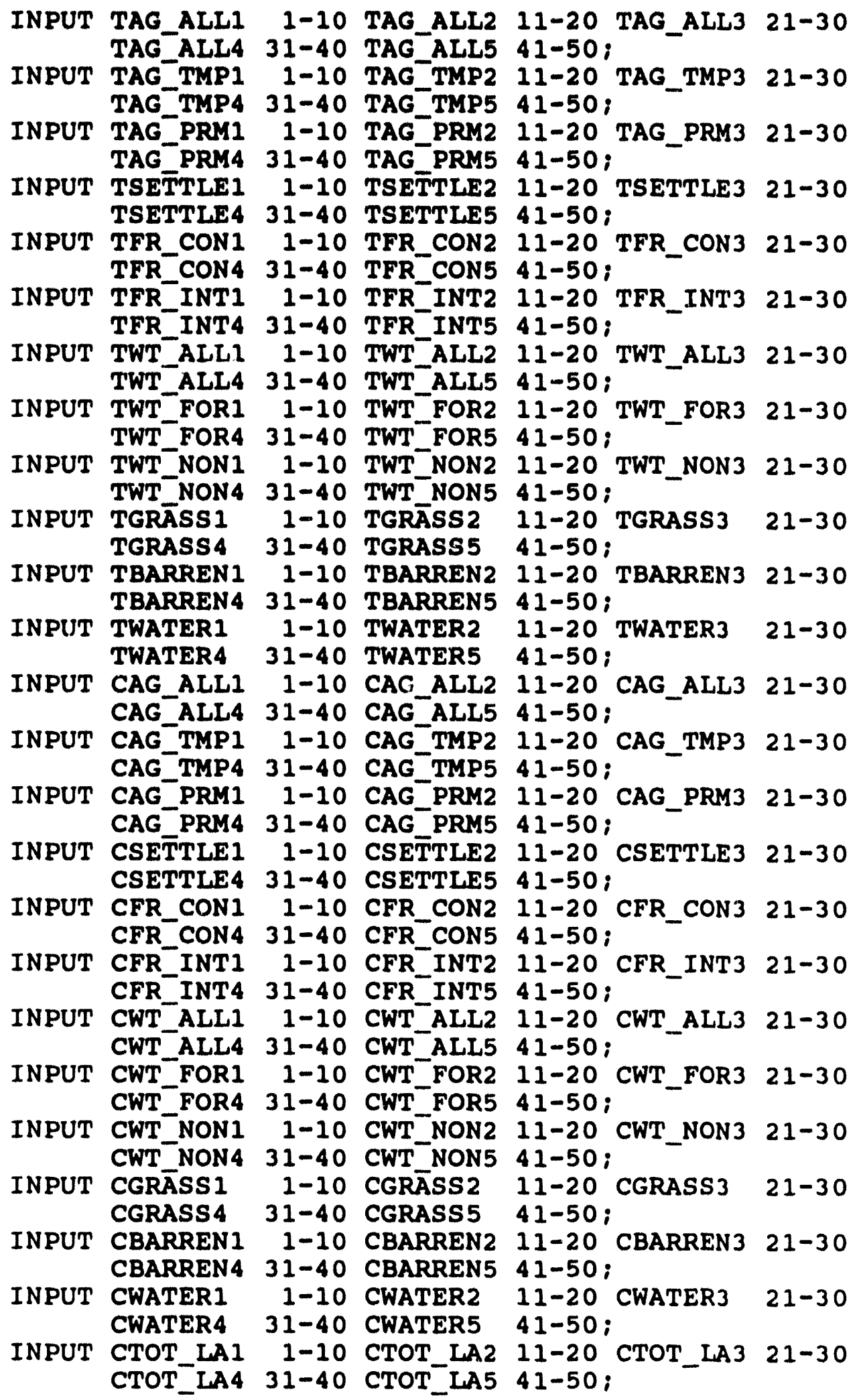


INPUT CTOT_FR1 1-10 CTOT_FR2 11-20 CTOT_FR3 21-30

PROC PRINT;

CTOT_FR4 31-40 CTOT_FR5 41-50;

RUN ;

The second SAS ${ }^{\mathrm{TM}}$ program (File 6 on the magnetic tape) is designed to read and print the file FLAGS.ASC (File 5).

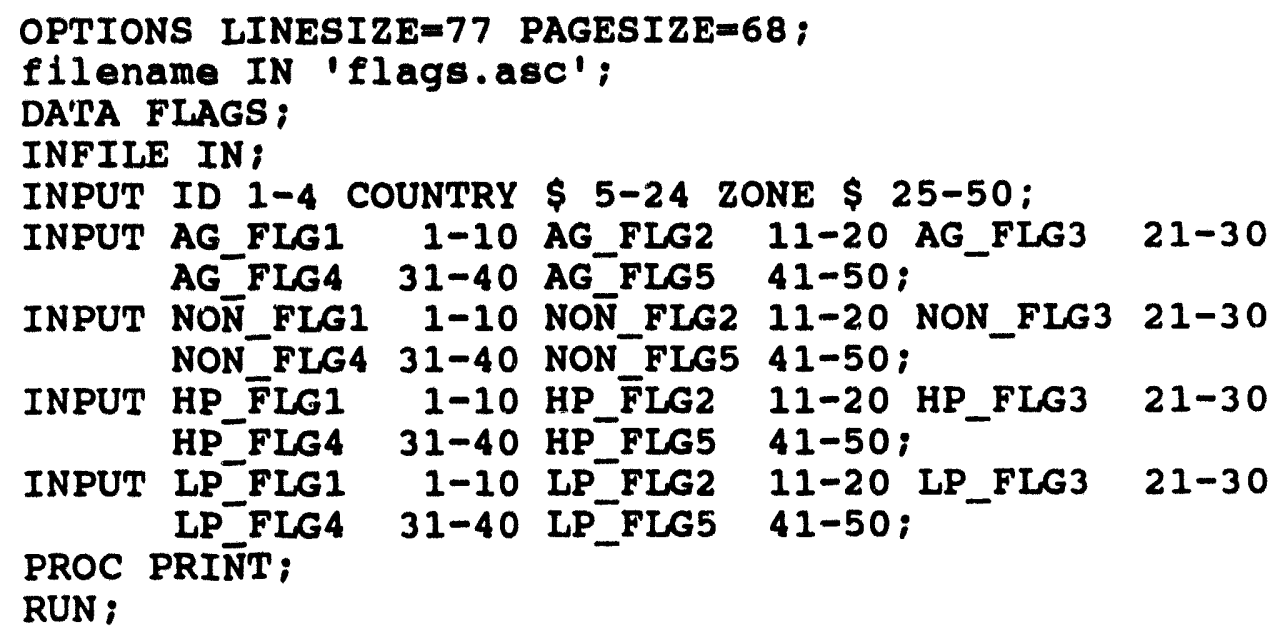

The third SAS ${ }^{\mathrm{TM}}$ program (File 9 on the magnetic tape) is designed to read and print the file FACTORS.ASC (File 8).

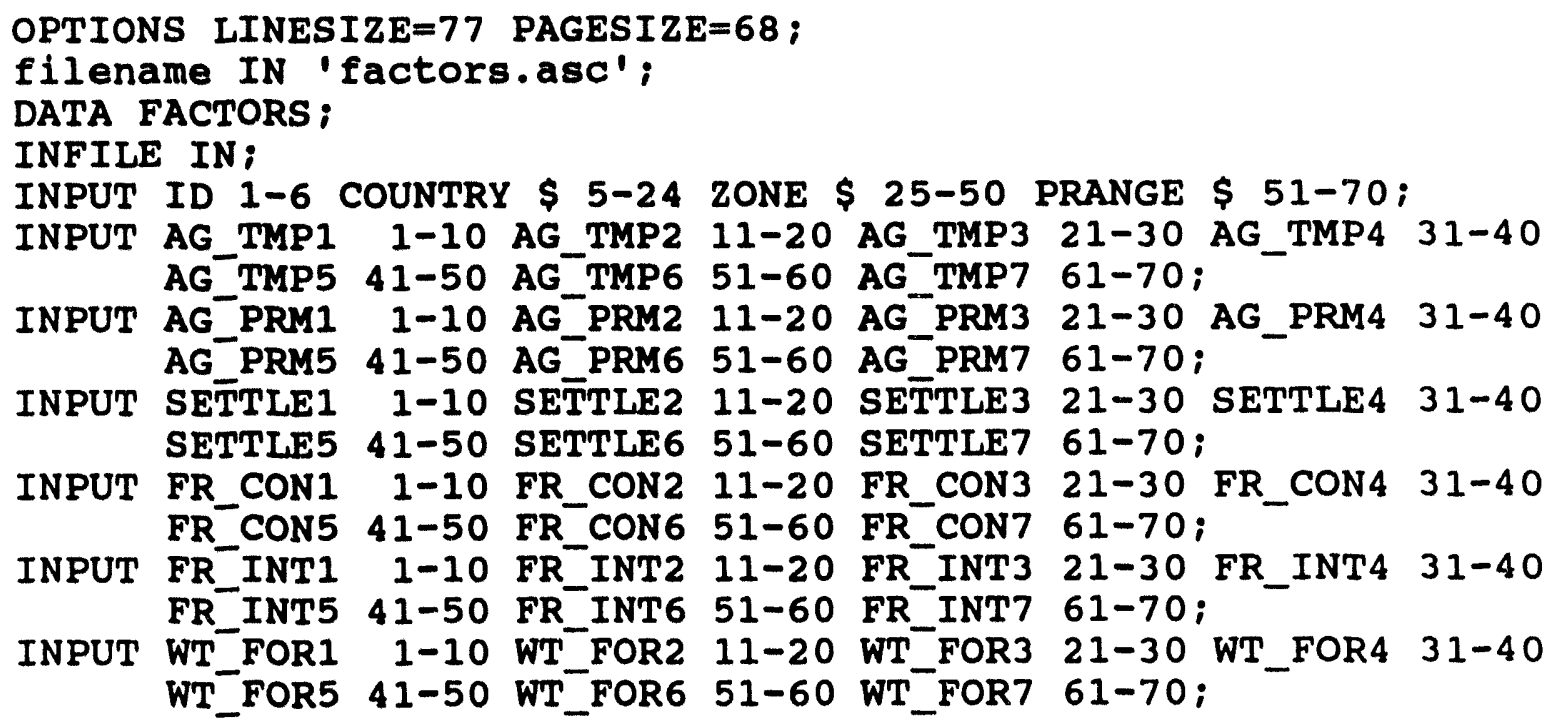




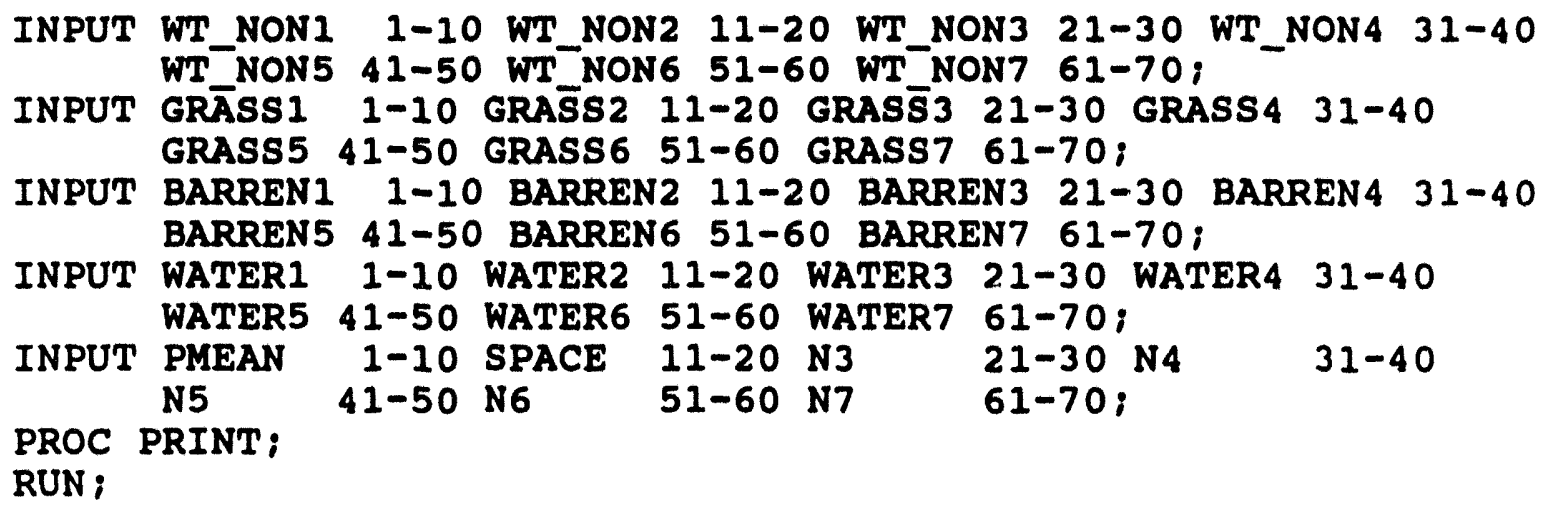

The last SAS ${ }^{\mathrm{TM}}$ program (File 13 on the magnetic tape) is designed to read and print the files SEA_CTRY.ASC (File 11), or SEA_ZONE.ASC (File 12) with modification.

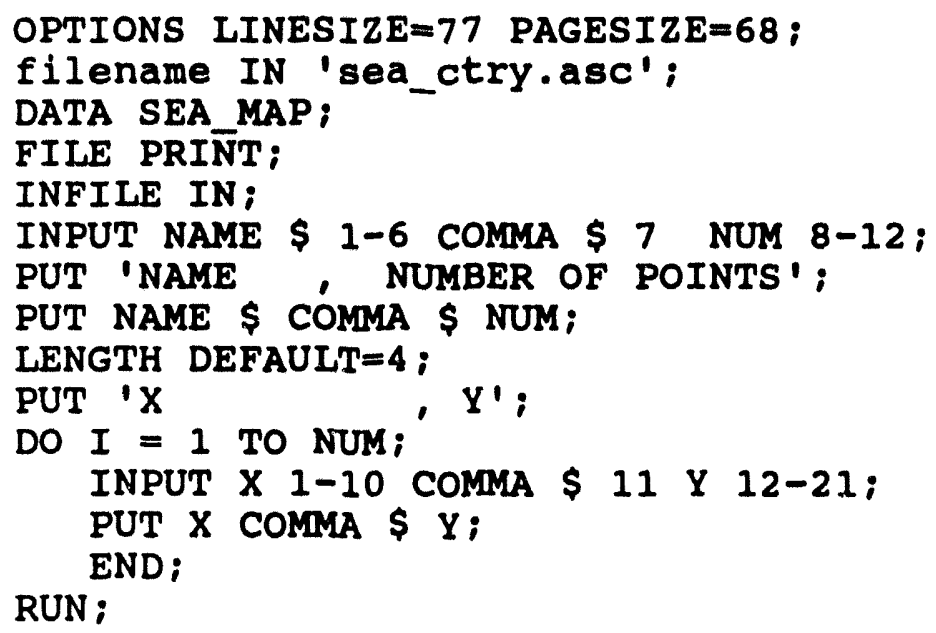




\section{PARTIAL LISTINGS OF THE FLAT ASCII DATA FILES}

What follows is a sample listing of the first 15 lines in each of the flat ASCII data files provided with this data base.

Sample listing of LANDCARB.ASC (File 2).

\begin{tabular}{rrrrr}
\hline \multicolumn{7}{c}{ "BANGLADESH" } & \multicolumn{1}{c}{ "Total" } \\
7191.02 & $\mathbf{7 4 4 9 . 8 8}$ & $\mathbf{8 3 7 3 . 9 8}$ & $\mathbf{8 4 6 8 . 7 4}$ & $\mathbf{8 4 1 8 . 7 8}$ \\
6952.94 & $\mathbf{7 1 8 6 . 3 7}$ & $\mathbf{8 1 2 1 . 5 5}$ & $\mathbf{8 2 1 5 . 7 6}$ & $\mathbf{8 1 6 1 . 5 5}$ \\
238.07 & 263.52 & 252.43 & 252.98 & 257.23 \\
307.14 & 405.85 & $\mathbf{4 9 2 . 2 2}$ & $\mathbf{8 2 4 . 1 8}$ & 982.43 \\
654.83 & 544.39 & 456.46 & 355.17 & 307.41 \\
786.22 & 634.22 & 506.13 & 457.02 & 431.59 \\
1739.20 & 1680.88 & 1290.17 & 1115.16 & 986.55 \\
930.05 & 816.03 & 638.35 & 545.53 & 510.82 \\
809.15 & 864.85 & 651.81 & 569.63 & 475.73 \\
2824.63 & 2868.77 & 2505.64 & 2281.63 & 2348.51 \\
193.83 & 216.43 & 237.24 & 267.72 & 294.35 \\
1100.15 & 996.59 & 935.18 & 1027.39 & 1027.39 \\
14797.01 & 14797.01 & 14797.01 & 14797.01 & 14797.01 \\
2371.09 & 1994.64 & 1600.94 & 1357.72 & 1249.82 \\
\hline
\end{tabular}

Sample listing of FLAGS.ASC (File 5).

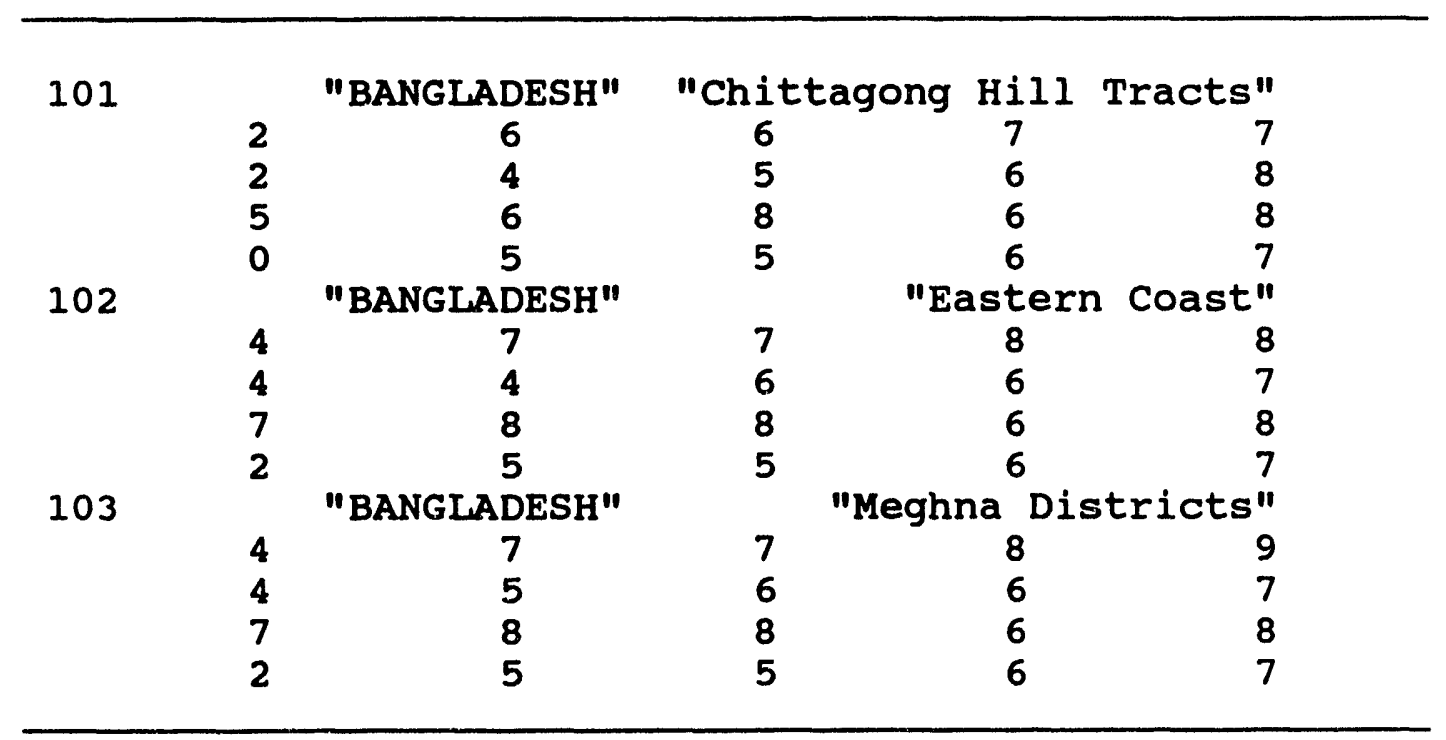


Sample listing of FACTORS.ASC (File 8).

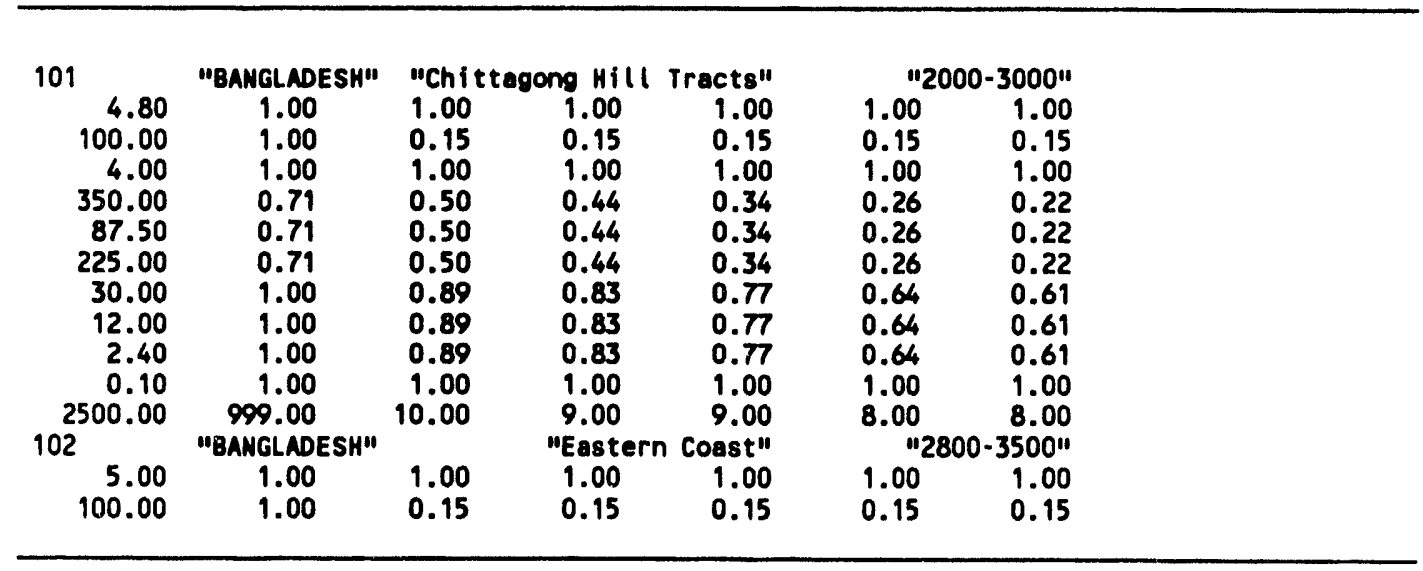

Sample listing of SEA_CTRY.ASC (File 11).

" 300", 3363

$73.851997,30.079775$

$73.890816,30.114367$

$73.927193,30.142658$

$73.967690,30.167334$

$74.010643,30.191696$

$73.963776,30.214712$

$73.959106,30.280006$

$73.921059,30.307379$

$73.886314,30.338505$

$73.886917,30.372524$

$73.915848,30.407366$

$73.946342,30.440830$

$73.979813,30.471676$

$73.977806,30.533745$
Sample listing of SEA_ZONE.ASC (File 12).

"310", 487
$75.384109,32.220661$
$75.380653,32.304546$
$75.333771,32.321987$
$75.292931,32.346195$
$75.257011,32.375904$
$75.225777,32.410862$
$75.158730,32.405712$
$75.121193,32.433640$
$75.077171,32.454288$
$75.023506,32.465755$
$74.994484,32.430923$
$74.953201,32.455288$
$74.892960,32.457699$
$74.861343,32.492290$




\section{VERIFICATION OF DATA TRANSPORT: FLAT ASCII DATA FILES}

After the flat ASCII data files have been loaded onto your system, verify that the files have not been corrupted during transport. To do this, some or all of the characteristics presented in the following tables should be checked by using operating system commands (e.g., ls -1). This information is presented as a tool to ensure proper reading of the flat ASCII data files.

Table 20. File characteristics of the five flat ASCII data files provided with this numeric data package.

\begin{tabular}{|c|c|c|c|c|}
\hline $\begin{array}{l}\text { File } \\
\text { name }\end{array}$ & $\begin{array}{l}\text { File } \\
\text { contents }\end{array}$ & $\begin{array}{l}\text { File } \\
\text { number }\end{array}$ & $\begin{array}{c}\text { File } \\
\text { size } \\
\text { (bytes) }\end{array}$ & $\begin{array}{l}\text { File } \\
\text { length } \\
\text { (lines) }\end{array}$ \\
\hline LANDCARB.ASC & $\begin{array}{l}\text { Land use, } \mathrm{Mg} \mathrm{C} / \mathrm{ha} \text {, } \\
\text { total carbon, and } \\
\text { population estimates } \\
\text { for all } 94 \text { zones and } \\
13 \text { countries }\end{array}$ & 2 & 283,500 & 4,725 \\
\hline FLAGS.ASC & $\begin{array}{l}\text { Accuracy flags for } \\
\text { the land use and } \\
\text { population data for } \\
\text { all } 94 \text { zones }\end{array}$ & 5 & 28,200 & 470 \\
\hline FACTORS.ASC & $\begin{array}{l}\text { Listing of the } M, E \text {, } \\
\mathrm{D} \text {, and } \mathrm{N} \text { factors used } \\
\text { in calculating the } \\
\mathrm{Mg} \mathrm{C} / \mathrm{ha} \text { for each land } \\
\text { use class for all } 94 \\
\text { zones }\end{array}$ & 8 & 90,240 & 1,128 \\
\hline SEA_CTRY.ASC & Country boundaries & 11 & 636,420 & 21,214 \\
\hline SEA_ZONE.ASC & $\begin{array}{l}\text { Ecological zone } \\
\text { boundaries }\end{array}$ & 12 & $1,038,570$ & 34,619 \\
\hline
\end{tabular}




\section{VERIFICATION OF DATA TRANSPORT: LOTUS $1-2-3^{\mathrm{TM}}$ SPREADSHEET FILES}

After the Lotus $1-2-3^{\mathrm{TM}}$ WK1 files have been loaded onto your system, verify that the files have not been corrupted during transport. To do this, the size of the files should be checked by using operating system commands (e.g., Is -1 ), and after loading the data into Lotus $1-2-3^{\mathrm{TM}}$, the total number of rows in each spreadsheet should be compared with those presented in Table 21. If the file sizes differ from those presented by $>1$ byte or the number of rows in the spreadsheet do not match, the file may have been corrupted in transport.

Table 21. File characteristics of the 90 Lotus $1-2-3^{\mathrm{TM}}$ WK1 spreadsheets provided with this numeric data package.

\begin{tabular}{|c|c|c|c|c|}
\hline $\begin{array}{l}\text { File } \\
\text { name }\end{array}$ & $\begin{array}{l}\text { File } \\
\text { contents }\end{array}$ & $\begin{array}{l}\text { File } \\
\text { number }\end{array}$ & $\begin{array}{l}\text { File } \\
\text { size } \\
\text { (bytes) }\end{array}$ & $\begin{array}{l}\text { File } \\
\text { length } \\
\text { (rows) }\end{array}$ \\
\hline 100LUC.WK1 & $\begin{array}{l}\text { Land use, } \mathrm{Mg} \mathrm{C} / \mathrm{ha} \text {, total } \\
\text { carbon, and population } \\
\text { estimates for Bangladesh } \\
\text { (total) and all zones }\end{array}$ & 15 & 53,700 & 276 \\
\hline 200LUC.WK1 & Brunei & 16 & 9,600 & 46 \\
\hline 300LUC.WK1 & India & 17 & 233,500 & 1288 \\
\hline 400LUC.WK1 & Indonesia & 18 & 192,900 & 966 \\
\hline 500LUC.WK1 & Kampuchea & 19 & 43,400 & 230 \\
\hline 600LUC.WK1 & Laos & 20 & 52,000 & 276 \\
\hline 700LUC.WK1 & Malaysia & 21 & 67,200 & 368 \\
\hline 800LUC.WK1 & Myanmar & 22 & 60,300 & 322 \\
\hline 900LUC.WK1 & Philippines & 23 & 43,800 & 230 \\
\hline 1000LUC.WK1 & Singapore & 24 & 9,600 & 46 \\
\hline 1100LUC.WK1 & Sri Lanka & 25 & 27,200 & 138 \\
\hline 1200LUC.WK1 & Thailand & 26 & 43,800 & 230 \\
\hline
\end{tabular}


Table 21. (Continued)

\begin{tabular}{|c|c|c|c|c|}
\hline $\begin{array}{l}\text { File } \\
\text { name }\end{array}$ & $\begin{array}{l}\text { File } \\
\text { contents }\end{array}$ & $\begin{array}{l}\text { File } \\
\text { number }\end{array}$ & $\begin{array}{c}\text { File } \\
\text { size } \\
\text { (bytes) }\end{array}$ & $\begin{array}{l}\text { File } \\
\text { length } \\
\text { (rows) }\end{array}$ \\
\hline 1300LUC.WK1 & Vietnam & 27 & 74,100 & 322 \\
\hline FLAGS.WK1 & $\begin{array}{l}\text { Accuracy flags for } \\
\text { the land use and } \\
\text { population data }\end{array}$ & 28 & 51,200 & 564 \\
\hline FACTORS.WK1 & $\begin{array}{l}\text { Listing of the } M, E \text {, } \\
D \text {, and } N \text { factors used } \\
\text { in calculating the } \\
\text { Mg C/ha for each land } \\
\text { use class }\end{array}$ & 29 & 209,800 & 1410 \\
\hline
\end{tabular}

THE FOLLOWING WK1 FILES CONTAIN EXPLANATORY AND DOCUMENTATION INFORMATION ON THE DATA SOURCES AND PROCEDURES USED TO OBTAIN THE LAND USE DATA CONTAINED IN FILES 2, 15-27, AND 30-32. FOR A DESCRIPTION OF THE CONTENTS OF THESE FILES REFER TO APPENDIX D.

$\begin{array}{llll}\text { D101S.WK1 } & \text { Bangladesh } & 33 & 34,100 \\ \text { D102S.WK1 } & n & 34 & 97,800 \\ \text { D103S.WK1 } & " & 35 & 167,400 \\ \text { D104S.WK1 } & " & 36 & 99,700 \\ \text { D105S.WK1 } & " & 37 & 301,700 \\ \text { D101L.WK1 } & " & 38 & 89,200 \\ \text { D102L.WK1 } & " & 39 & 80,900 \\ \text { D103L.WK1 } & " & 40 & 83,900 \\ \text { D104L.WK1 } & " & 41 & 84,100 \\ \text { D105L.WK1 } & " & 42 & 78,900 \\ \text { D200A.WK1 } & \text { Brunei } & 43 & 32,700 \\ \text { D300T.WK1 } & \text { India } & 44 & 6,500 \\ \text { D301S.WK1 } & " & 45 & 21,300 \\ \text { D302S.WK1 } & " & 46 & 21,700 \\ \text { D303S.WK1 } & " & 47 & 18,200 \\ \text { D304S.WK1 } & " & 48 & 17,800 \\ \text { D305S.WK1 } & " & 49 & 17,400 \\ \text { D306S.WK1 } & " & 50 & 19,700 \\ \text { D307P1S.WK1 } & " & 51 & 18,900 \\ \text { D307P2S.WK1 } & " & 52 & 20,900 \\ \text { D307T.WK1 } & " & 53 & 8,900 \\ \text { D308P1S.WK1 } & " & 54 & 19,500\end{array}$


Table 21. (Continued)

\begin{tabular}{|c|c|c|c|}
\hline $\begin{array}{l}\text { File } \\
\text { name }\end{array}$ & $\begin{array}{l}\text { File } \\
\text { contents }\end{array}$ & $\begin{array}{l}\text { File } \\
\text { number }\end{array}$ & $\begin{array}{c}\text { File } \\
\text { size } \\
\text { (bytes) }\end{array}$ \\
\hline D308P2S.WK1 & India (Continued) & 55 & 19,600 \\
\hline D308T.WK1 & " & 56 & 9,100 \\
\hline D309S.WK1 & $"$ & 57 & 18,000 \\
\hline D310S.WK1 & $"$ & 58 & 23,600 \\
\hline D311S.WK1 & $"$ & 59 & 23,700 \\
\hline D312S.WK1 & $"$ & 60 & 20,400 \\
\hline D313S.WK1 & $"$ & 61 & 17,800 \\
\hline D314S.WK1 & $"$ & 62 & 20,700 \\
\hline D315P1S.WK1 & $"$ & 63 & 19,200 \\
\hline D315P2S.WK1 & $"$ & 64 & 21,100 \\
\hline D315T.WK1 & $"$ & 65 & 8,900 \\
\hline D316S.WK1 & $"$ & 66 & 17,500 \\
\hline D317S.WK1 & $"$ & 67 & 17,900 \\
\hline D318S.WK1 & $"$ & 68 & 17,800 \\
\hline D319S.WK1 & $"$ & 69 & 17,500 \\
\hline D320S.WK1 & $"$ & 70 & 23,100 \\
\hline D321S.WK1 & $"$ & 71 & 23,000 \\
\hline D322S.WK1 & $"$ & 72 & 22,000 \\
\hline D323S.WK1 & $"$ & 73 & 13,900 \\
\hline D324P1S.WK1 & $n$ & 74 & 17,400 \\
\hline D324P2S.WK1 & $"$ & 75 & 21,900 \\
\hline D324T.WK1 & $"$ & 76 & 9,100 \\
\hline D325S.WK1 & $"$ & 77 & 17,500 \\
\hline D326S.WK1 & $"$ & 78 & 16,700 \\
\hline D327S.WK1 & $"$ & 79 & 18,500 \\
\hline D400HP.WK1 & Indonesia & 80 & 23,400 \\
\hline D400LP.WK1 & $"$ & 81 & 41,700 \\
\hline D401-7S.WK1 & $"$ & 82 & 110,300 \\
\hline D408-10S.WK1 & $n$ & 83 & 53,700 \\
\hline D411-14S.WK1 & $n$ & 84 & 128,000 \\
\hline D415-18S.WK1 & $"$ & 85 & 133,000 \\
\hline D419-20S.WK1 & $"$ & 86 & 76,000 \\
\hline D421-22S.WK1 & $n$ & 87 & 59,600 \\
\hline D500S.WK1 & Kampuchea & 88 & 35,800 \\
\hline D500L.WK1 & $"$ & 89 & 64,900 \\
\hline D600S.WK1 & Laos & 90 & 37,600 \\
\hline D600L.WK1 & " & 91 & 71,000 \\
\hline
\end{tabular}


Table 21. (Continued)

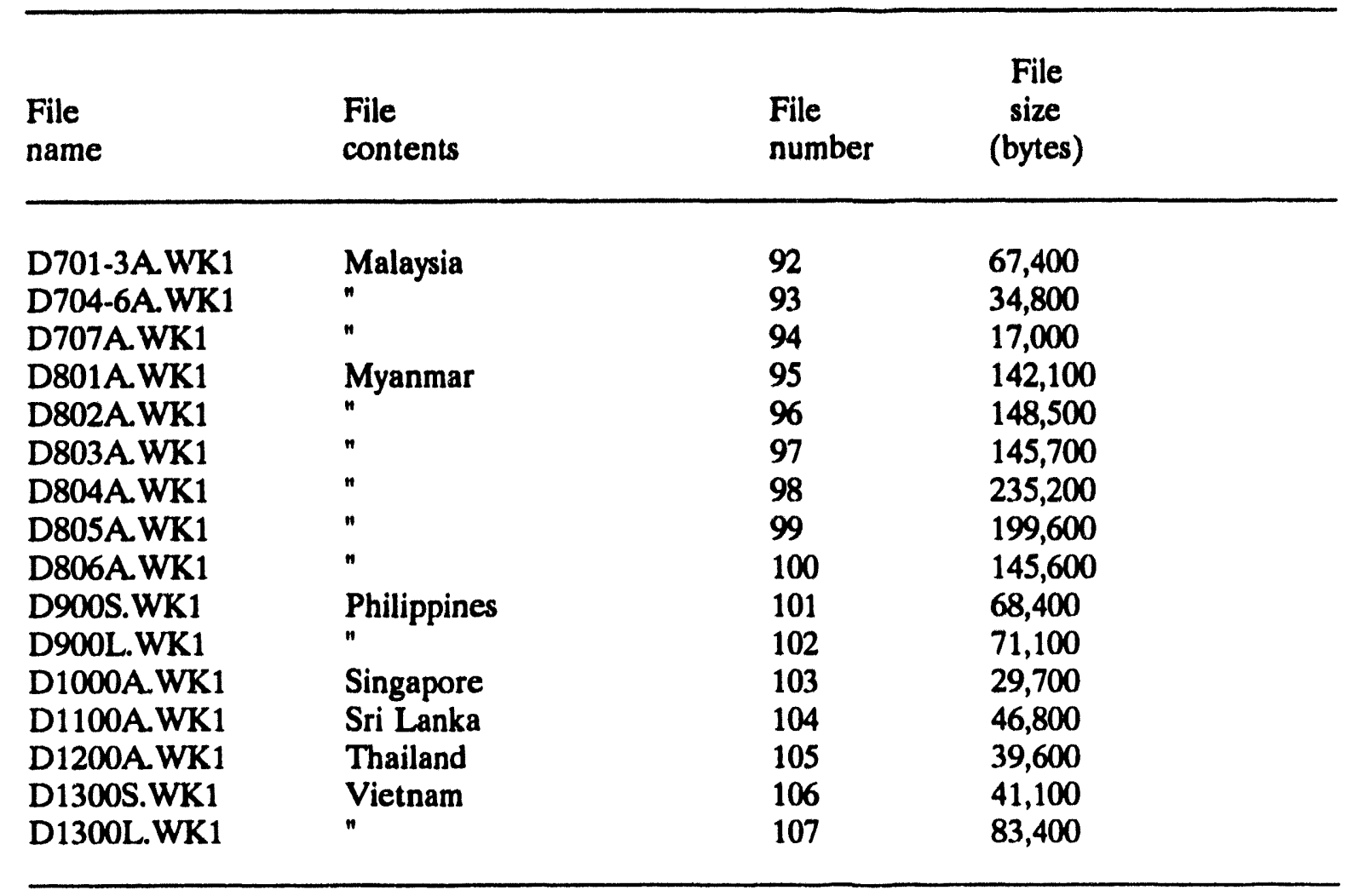




\section{VERIFICATION OF DATA TRANSPORT: ARCINFO ${ }^{\text {TM }}$ EXPORT FILES}

The three ARC/NFO ${ }^{\text {TM }}$ export files provided with this NDP were created in ARC/INFO ${ }^{\text {TM }}$, Version 6.1, using the EXPORT command with the COVER and NONE options. Each export file contains an entire coverage and its associated INFO data files in a fixed-length, uncompressed format.

The exported coverages are in a GEOGRAPHIC projection, which is a spherical reference system that locates positions by using latitude and longitude coordinates that are stored in decimal degrees. As a result of this, the reference grids in which the data are stored are not uniform in size or area. The source maps from which these coverages were obtained varied widely in scale and detail. National boundaries were obtained at a scale of 1:2,000,000, while internal zone boundaries were obtained from several different publications (with scales varying from $1: 1,000,000$ to $1: 20,000,000$ ). To reduce edge matching problems that occurred when these data sources were combined, the zone and nation boundaries were smoothed (in $A R C / I N F O{ }^{\mathrm{TM}}$ ) to a nominal map scale of $1: 4,000,000$ with a minimum resolution of one point per $4 \mathrm{~km}$.

After loading the ARC/NFO ${ }^{\text {TM }}$ export files onto a system, the user should verify that the files have been correctly transported. To verify the integrity of the files, the size of the export files and (after importing the data into ARC/INFO ${ }^{\mathrm{TM}}$ ) the total number of INFO data records in each coverage should be compared with those presented in Table 22. If the file sizes differ from those presented by $>1$ byte or the number of INFO data records do not match those shown in Table 22, the coverage may have been corrupted in transport. Importation of the $A R C / I N F O^{T M} E 00$ files into the user's $A R C /{ }^{2}{ }^{2} O^{T M}$ system can be accomplished by using the IMPORT command with the COVER option. The IMPORT command will automatically recognize that the export file is in an uncompressed format (files should be EXTERNALED after being imported [e.g., ARC> external SEA_ZONE ]).

Table 22. File characteristics of the three ARC/INFO ${ }^{\text {MM }}$ EO0 export files provided with this numeric data package.

\begin{tabular}{llllll}
\hline $\begin{array}{l}\text { Export } \\
\text { file } \\
\text { name }\end{array}$ & $\begin{array}{l}\text { File } \\
\text { number }\end{array}$ & $\begin{array}{l}\text { File } \\
\text { size } \\
\text { (bytes) }\end{array}$ & $\begin{array}{l}\text { File } \\
\text { size } \\
\text { (blocks) }\end{array}$ & $\begin{array}{l}\text { ARC/NFO } \\
\text { data } \\
\text { type }\end{array}$ & $\begin{array}{l}\text { Number } \\
\text { of ARC/INFOTM } \\
\text { records }\end{array}$ \\
\hline SEA_LAND.E00 & 30 & $1,449,200$ & 2,831 & PAT & 347 \\
SEA_TCHAE00 & 31 & $1,299,280$ & 2,538 & PAT & 347 \\
SEA_CARB.E00 & 32 & $1,242,640$ & 2,428 & PAT & 347 \\
\hline
\end{tabular}

one block equals 512 bytes. 


\section{APPENDIX A}

PRINTOUTS OF THE STEP 2 (LAND USE)

LOTUS 1-2-3 ${ }^{\mathrm{m}}$ SPREADSHEETS FOR 13 COUNTRIES (TOTALS) 


\section{PRINTOUTS OF THE STEP 2 (LAND USE) \\ LOTUS 1-2-3 ${ }^{\mathrm{TM}}$ SPREADSHEETS FOR 13 COUNTRIES (TOTALS)}

What follows is a listing of the land use change spreadsheets compiled for each country. The data were obtained by aggregating the data values from all ecological zones located within the given country. These data, along with the data for each of the 94 ecological zones, are contained within the digital data files included with this NDP. Data values are in thousands of hectares, with the first two lines in each country listing containing the country identification code (zone code), country name, zone name (i.e., "Total"), and a listing of the years for which data was obtained.

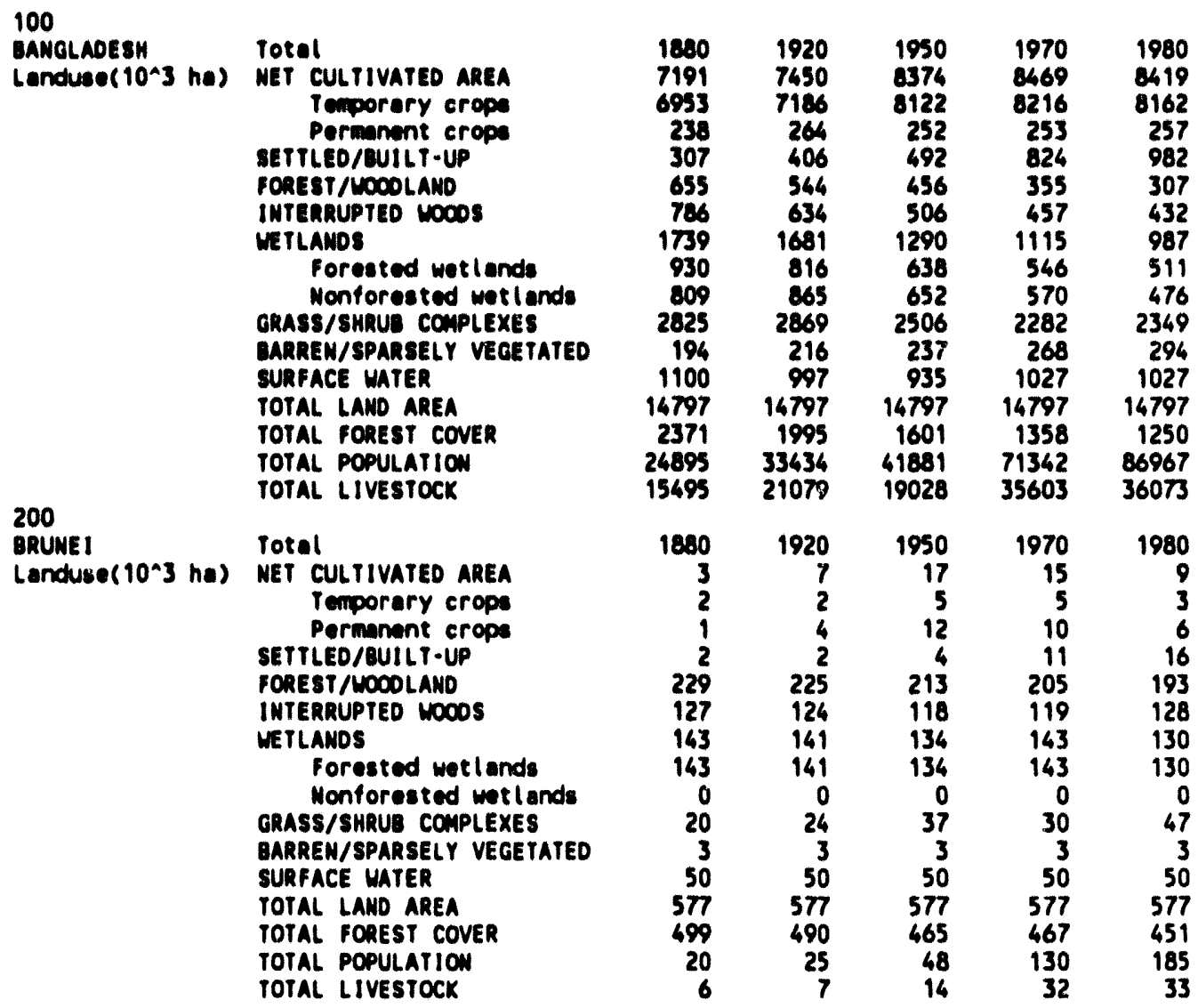


300

INOIA

Totel

Landuage(10^3 ho) Met CULTIVATto AREA

remporary cropa

Permenent crope

SETTLEO/EUILT-UP

POnEST/LOOOLAND

IMTERRUPTED voos

MTLAMDS

Forested wotl ands

Monforested wetlands

CRASS/SHEUS COMPLEXES

BARREN/SPARSELY VECETATEO

SURFACE MATER

TOTAL LAND AREA

TOTAL POAEST COVER

TOTAL POPULATION

TOTAL LIVESTOCK

400

INDONESIA Total

Landuse (10A3 ha) MEI CULIIVATED AREA

Temporary cropa

Permanent crope

SETTLED/UUILT-UP

ponest/Mocolano

INTERRUPTEO WOOOS

METLANDS

Forested metl ende

Monforested wetlands

GRASS/SHRUE COAPLEXES

GARREW/BPARSELY VECETATEO

GURBACE MATEA

TOTAL LAND AREA

TOTAL FOAEST COVER

TOTAL POPULATION

500

TOTAL LIVESTOCK

KAMPUCHEA

Total

Landuse (10^3 ha)
NET CULTIVATED AREA

Temporary crope

Permanent crope

SETTLED/BUILT-UP

FORE ST/LOOOLAND

INTERRUPTED UOOOS

METLANDS

Forested wetlands

Nonforested wetlands

GRASS/SHRUB COAPLEXES

BARREN/SPARSELY VEGETATED

SURFACE WATER

TOTAL LAND AREA

TOTAL FOREST COVER

TOTAL POPULATION

TOTAL LIVESTOCK

\begin{tabular}{|c|c|c|c|c|}
\hline $\begin{array}{r}1890 \\
100809 \\
96119 \\
6734 \\
3742 \\
65071 \\
35228 \\
6346 \\
2303 \\
3963 \\
63698 \\
36159 \\
8649 \\
319703 \\
102682 \\
225439 \\
184319\end{array}$ & $\begin{array}{r}1920 \\
106733 \\
101891 \\
4919 \\
6317 \\
38971 \\
33746 \\
5833 \\
2076 \\
3757 \\
66566 \\
34858 \\
8659 \\
319703 \\
94793 \\
251647 \\
212395\end{array}$ & $\begin{array}{r}1950 \\
123234 \\
117460 \\
5841 \\
5981 \\
51352 \\
29664 \\
4912 \\
1522 \\
3390 \\
62877 \\
33055 \\
8630 \\
319703 \\
82537 \\
356844 \\
282591\end{array}$ & $\begin{array}{r}1970 \\
140886 \\
135878 \\
5008 \\
8162 \\
44498 \\
28590 \\
4393 \\
1217 \\
3176 \\
54698 \\
30060 \\
8646 \\
319703 \\
74305 \\
536125 \\
342718\end{array}$ & $\begin{array}{r}1980 \\
142644 \\
137483 \\
5057 \\
10080 \\
39227 \\
24335 \\
4057 \\
1030 \\
3027 \\
60528 \\
30349 \\
8683 \\
319703 \\
64591 \\
670037 \\
377025\end{array}$ \\
\hline $\begin{array}{r}1880 \\
5471 \\
4629 \\
842 \\
165 \\
112258 \\
17514 \\
29647 \\
29473 \\
174 \\
22331 \\
1905 \\
3494 \\
192805 \\
159245 \\
26009 \\
8246\end{array}$ & $\begin{array}{r}1920 \\
11891 \\
9647 \\
2244 \\
363 \\
107208 \\
15563 \\
28426 \\
28252 \\
172 \\
23774 \\
2088 \\
3496 \\
192805 \\
151023 \\
50100 \\
11190\end{array}$ & $\begin{array}{r}1950 \\
16561 \\
12504 \\
4057 \\
622 \\
99438 \\
18236 \\
26428 \\
26259 \\
169 \\
25762 \\
2265 \\
3494 \\
192805 \\
143932 \\
78369 \\
18518\end{array}$ & $\begin{array}{r}1970 \\
22237 \\
15642 \\
6634 \\
989 \\
90946 \\
15321 \\
24639 \\
24475 \\
164 \\
32723 \\
2656 \\
3494 \\
192805 \\
130743 \\
117365 \\
25470\end{array}$ & $\begin{array}{r}1 \\
29 \\
19 \\
10 \\
1 \\
84 \\
15 \\
22 \\
22 \\
34 \\
2 \\
3 \\
192 \\
121 \\
147 \\
28\end{array}$ \\
\hline $\begin{array}{r}9467 \\
4640 \\
1280 \\
721 \\
559 \\
1698 \\
91 \\
452 \\
18104 \\
14829 \\
1685 \\
1329\end{array}$ & $\begin{array}{r}9305 \\
4517 \\
1204 \\
678 \\
525 \\
1794 \\
109 \\
452 \\
18104 \\
14500 \\
2562 \\
2020\end{array}$ & $\begin{array}{r}8653 \\
4293 \\
902 \\
498 \\
404 \\
1965 \\
145 \\
452 \\
18104 \\
13444 \\
4289 \\
1630\end{array}$ & $\begin{array}{r}1970 \\
2412 \\
2261 \\
152 \\
69 \\
7355 \\
4695 \\
690 \\
398 \\
292 \\
2268 \\
163 \\
452 \\
18104 \\
12447 \\
6938 \\
4314\end{array}$ & $\begin{array}{l}18 \\
12\end{array}$ \\
\hline
\end{tabular}

A -4 


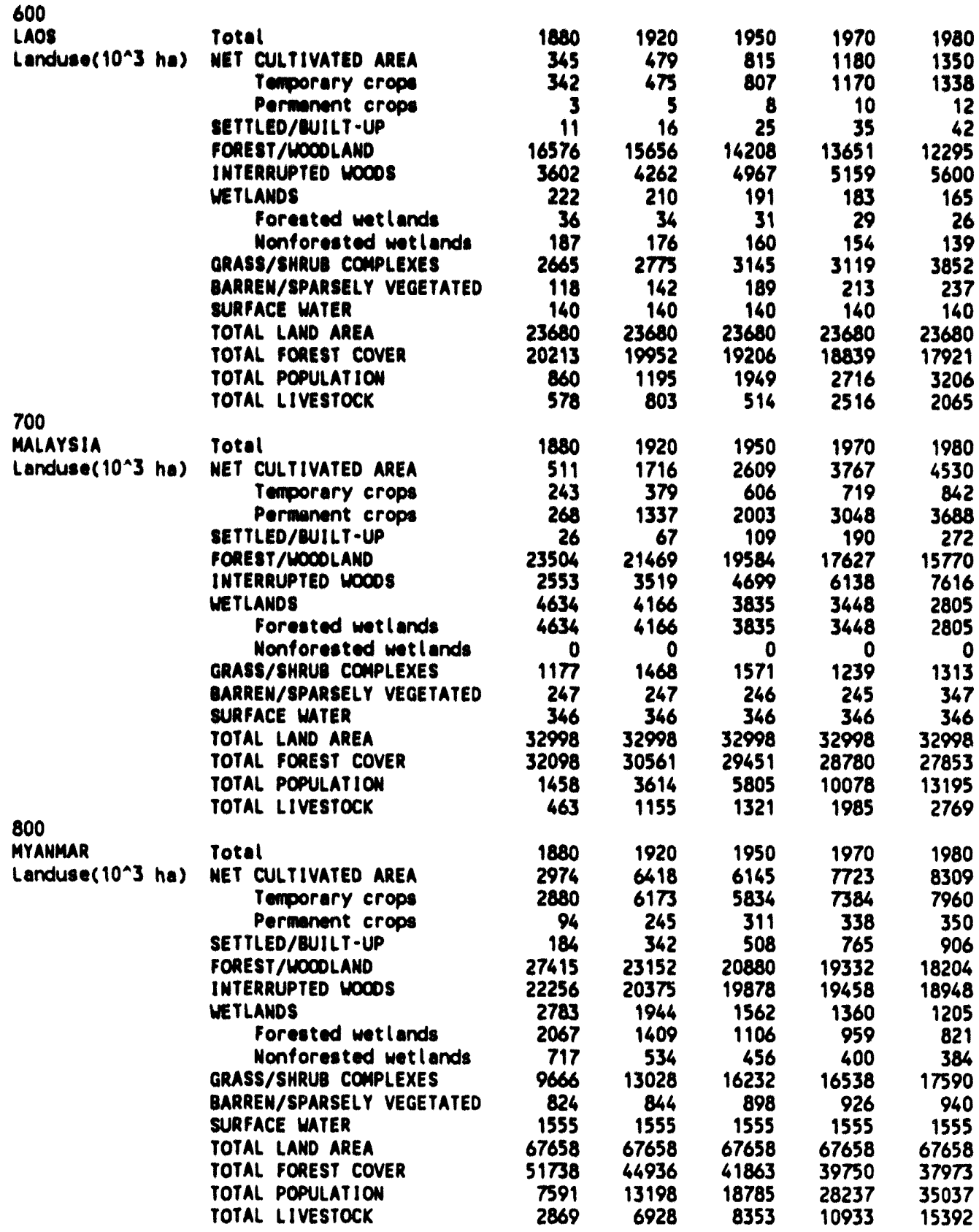


900

\begin{tabular}{|c|c|c|c|c|c|c|}
\hline $\begin{array}{l}\text { PHILIPPINES } \\
\text { Landuse }\left(10^{\wedge} 3 \text { ha }\right)\end{array}$ & 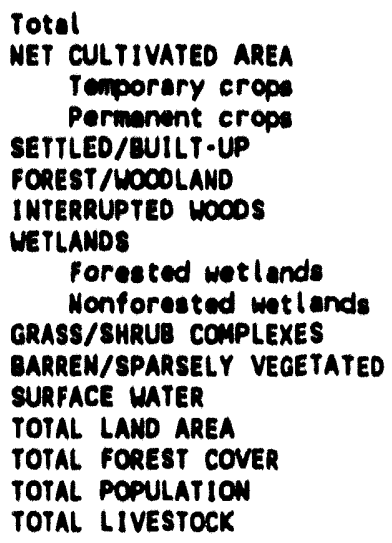 & $\begin{array}{r}1880 \\
2010 \\
1335 \\
675 \\
105 \\
17538 \\
2962 \\
681 \\
500 \\
181 \\
6274 \\
318 \\
112 \\
30000 \\
21000 \\
6000 \\
3545\end{array}$ & $\begin{array}{r}1920 \\
3494 \\
2321 \\
1173 \\
187 \\
16120 \\
2723 \\
613 \\
450 \\
163 \\
6413 \\
338 \\
112 \\
30000 \\
19293 \\
10750 \\
6352\end{array}$ & $\begin{array}{r}1950 \\
4745 \\
3233 \\
1512 \\
355 \\
14276 \\
1599 \\
613 \\
401 \\
212 \\
7943 \\
358 \\
112 \\
30000 \\
16276 \\
20335 \\
7088\end{array}$ & $\begin{array}{r}1970 \\
6437 \\
3892 \\
2546 \\
640 \\
9933 \\
3581 \\
503 \\
288 \\
215 \\
8353 \\
378 \\
175 \\
30000 \\
13802 \\
36684 \\
13632\end{array}$ & $\begin{array}{r}1980 \\
9725 \\
5683 \\
4042 \\
846 \\
7902 \\
2161 \\
356 \\
241 \\
115 \\
8431 \\
398 \\
183 \\
30000 \\
10304 \\
48098 \\
13977\end{array}$ \\
\hline $\begin{array}{l}1000 \\
\text { SINGAPORE } \\
\text { Landise }\left(10^{\wedge} 3 \mathrm{ha}\right)\end{array}$ & 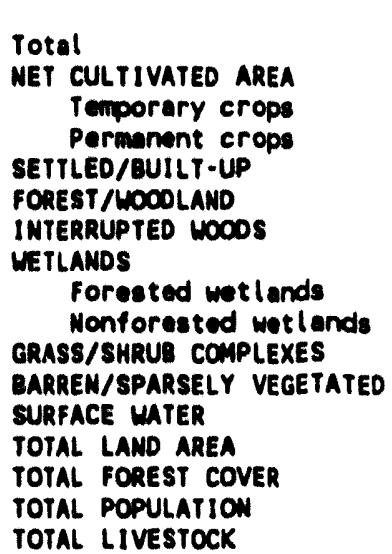 & $\begin{array}{r}1880 \\
31 \\
2 \\
29 \\
1 \\
6 \\
6 \\
6 \\
6 \\
1 \\
7 \\
0 \\
4 \\
62 \\
18 \\
139 \\
64\end{array}$ & $\begin{array}{r}1920 \\
30 \\
1 \\
24 \\
4 \\
6 \\
6 \\
5 \\
4 \\
0 \\
7 \\
0 \\
4 \\
62 \\
16 \\
431 \\
197\end{array}$ & $\begin{array}{r}1950 \\
17 \\
3 \\
14 \\
10 \\
1 \\
3 \\
5 \\
4 \\
0 \\
22 \\
0 \\
4 \\
62 \\
8 \\
1022 \\
119\end{array}$ & $\begin{array}{r}1970 \\
17 \\
6 \\
11 \\
19 \\
3 \\
1 \\
3 \\
2 \\
1 \\
16 \\
0 \\
3 \\
62 \\
5 \\
2075 \\
1008\end{array}$ & $\begin{array}{r}1980 \\
11 \\
5 \\
6 \\
28 \\
3 \\
3 \\
3 \\
2 \\
1 \\
14 \\
0 \\
2 \\
62 \\
8 \\
2414 \\
1203\end{array}$ \\
\hline $\begin{array}{l}1100 \\
\text { SRI LANKA } \\
\text { Landuse }\left(10^{\wedge} 3 \text { has }\right)\end{array}$ & 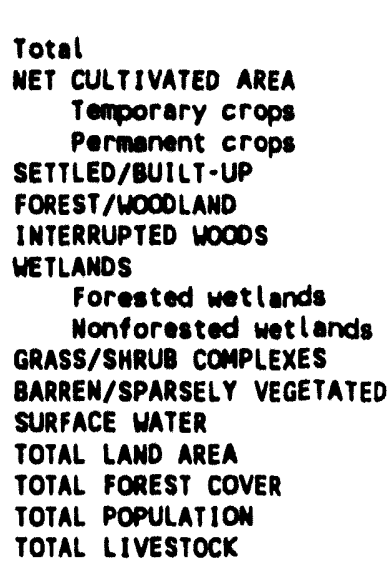 & $\begin{array}{r}1880 \\
679 \\
283 \\
395 \\
7 \\
3703 \\
1174 \\
70 \\
14 \\
56 \\
688 \\
37 \\
202 \\
6561 \\
4892 \\
2760 \\
1100\end{array}$ & $\begin{array}{r}1920 \\
1133 \\
388 \\
744 \\
11 \\
3474 \\
945 \\
64 \\
13 \\
51 \\
690 \\
41 \\
202 \\
6561 \\
4432 \\
4498 \\
1874\end{array}$ & $\begin{array}{r}1950 \\
1462 \\
425 \\
1038 \\
20 \\
3170 \\
746 \\
58 \\
12 \\
46 \\
858 \\
46 \\
202 \\
6561 \\
3927 \\
7678 \\
2233\end{array}$ & $\begin{array}{r}1970 \\
1979 \\
895 \\
1084 \\
32 \\
2011 \\
1169 \\
55 \\
11 \\
44 \\
1051 \\
62 \\
202 \\
6561 \\
3190 \\
12690 \\
3025\end{array}$ & $\begin{array}{r}1980 \\
2147 \\
1025 \\
1122 \\
90 \\
1680 \\
866 \\
53 \\
11 \\
42 \\
1455 \\
68 \\
202 \\
6561 \\
2556 \\
14847 \\
3079\end{array}$ \\
\hline
\end{tabular}

A. 6 


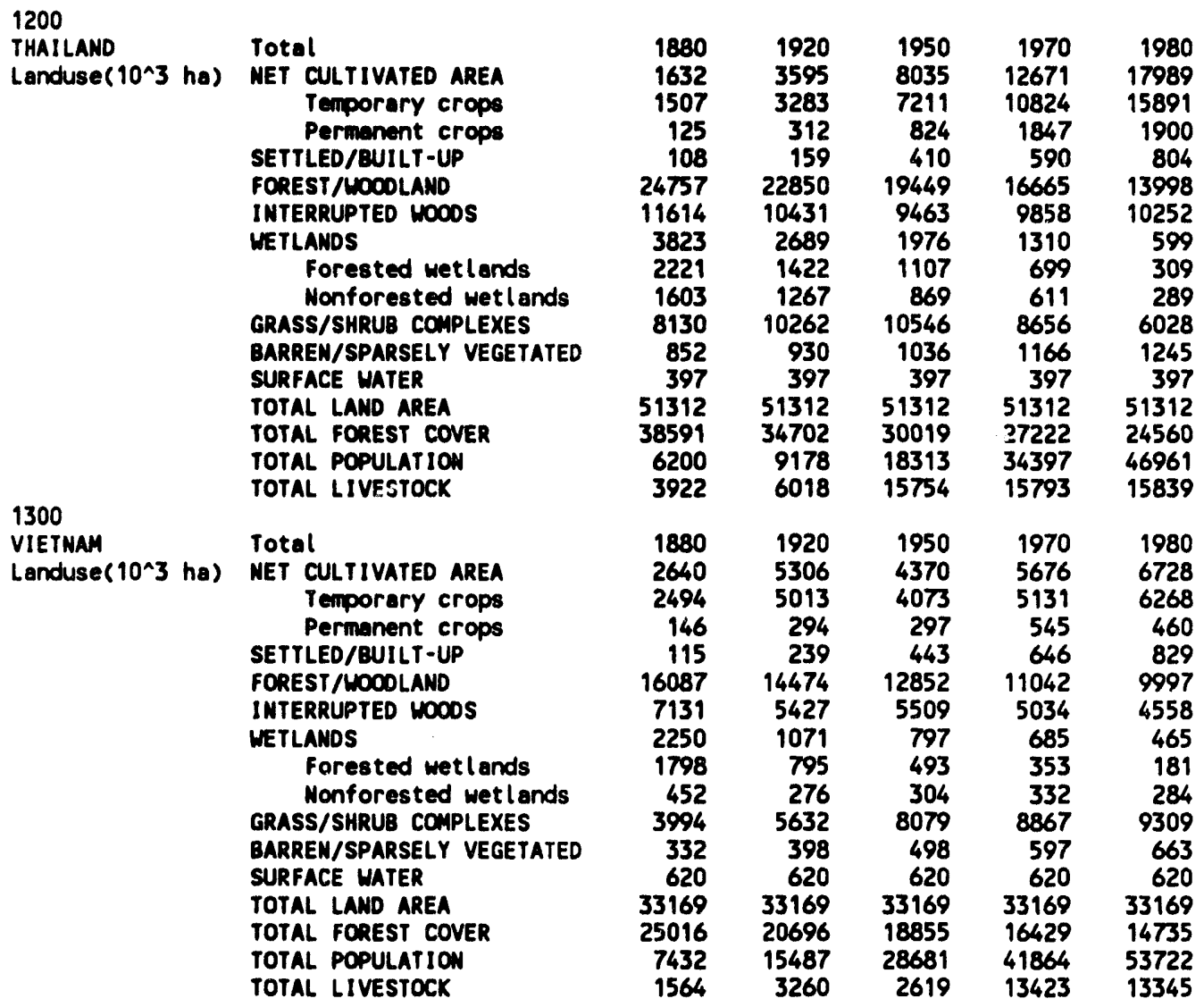




\section{APPENDIX B}

LISTING OF THE FACTORS (S, F, AND A) USED IN CALCULATING THE DEGRADATION (D) MULTIPLIER 


\section{LISTING OF THE FACTORS (S, F, AND A) USED IN CALCULATING THE DEGRADATION (D) MULTIPLIER}

The $S, F$, and $A$ factors were used by the primary investigators to estimate $N$, where $S$ represents the degree to which the agricultural system of a zone is dominated by shifting versus sedentary cultivation; $F$ represents the degree to which a zone is a net exporter or importer of forest products; and A represents the degree to which a zone is a net exporter or importer of agricultural products. (See Sect. 8.2.5 for a description of the methods used in determining S, F, and $A)$. The calculated $N(N=S \times F \times A)$ values were used in conjunction with the human population density data (in people per ha) to calculate the degradation (D) multiplier for the forested/woodland, interrupted woods, and forested wetland land use classes. The maximum potential biomass $(M)$ was then multiplied by the environmental limitation $(E)$, and $D$ factors to obtain the mean carbon content per ha (in $\mathrm{Mg}$ ) for the woody land use classes, and each zone and year. These carbon estimates were then multiplied by the land use data to obtain the total carbon estimates for each year and ecological zone.

The values assigned to each of the three factors was highly subjective. Due to this, the factors have not been provided in a digital file. These factors are listed by zone in this appendix to assist the user in understanding how the $\mathrm{S}, \mathrm{F}$, and $\mathrm{A}$ factors determined $\mathrm{N}$, and influenced $\mathrm{D}$. The factors in this list have been rounded to the nearest tenth. Because of this, the $N$ values shown here may vary slightly from those contained in the flat ASCII data file FACTORS.ASC (File 8).

\begin{tabular}{lllllll}
$\begin{array}{l}\text { Zone } \\
\text { name }\end{array}$ & $\begin{array}{l}\text { Zone } \\
\text { code }\end{array}$ & Year & S & F & A & N \\
& & & & & & \\
\hline & & & & & & \\
BANGLADESH & 101 & 1880 & 10.0 & 1.0 & 1.0 & 10.0 \\
Chittagong Hill Tracts & & 1920 & 9.0 & 1.0 & 1.0 & 9.0 \\
& & 1950 & 7.5 & 1.2 & 1.0 & 9.0 \\
& & 1970 & 6.0 & 1.3 & 1.0 & 7.8 \\
& & 1980 & 6.0 & 1.3 & 1.0 & 7.8 \\
Eastern Coast & & & & & & \\
& 102 & 1880 & 1.0 & 1.0 & 1.0 & 1.0 \\
& & 1920 & 1.0 & 1.0 & 0.8 & 0.8 \\
& & 1950 & 1.0 & 1.0 & 0.8 & 0.8 \\
& & 1970 & 1.0 & 1.0 & 0.8 & 0.8 \\
& & 1980 & 1.0 & 1.0 & 0.8 & 0.8 \\
Meghna Districts & & & & & \\
& 103 & 1880 & 1.1 & 1.1 & 0.8 & 1.0 \\
& & 1920 & 1.0 & 1.0 & 0.8 & 0.8 \\
& & 1950 & 1.0 & 1.0 & 0.7 & 0.7 \\
& & 1970 & 1.0 & 0.9 & 0.7 & 0.6 \\
& & 1980 & 1.0 & 0.9 & 0.7 & 0.6
\end{tabular}




\begin{tabular}{|c|c|c|c|c|c|c|}
\hline $\begin{array}{l}\text { Zone } \\
\text { name }\end{array}$ & $\begin{array}{l}\text { Zone } \\
\text { code }\end{array}$ & Year & $\mathbf{S}$ & F & $\mathbf{A}$ & $\mathbf{N}$ \\
\hline Sundarbans & 104 & $\begin{array}{l}1880 \\
1920 \\
1950 \\
1970 \\
1980\end{array}$ & $\begin{array}{l}1.0 \\
1.0 \\
1.0 \\
1.0 \\
1.0\end{array}$ & $\begin{array}{l}1.5 \\
1.3 \\
1.3 \\
1.2 \\
1.1\end{array}$ & $\begin{array}{l}0.8 \\
0.8 \\
0.8 \\
0.8 \\
0.8\end{array}$ & $\begin{array}{l}1.2 \\
1.0 \\
1.0 \\
1.0 \\
0.9\end{array}$ \\
\hline Western Districts & 105 & $\begin{array}{l}1880 \\
1920 \\
1950 \\
1970 \\
1980\end{array}$ & $\begin{array}{l}1.0 \\
1.0 \\
1.0 \\
1.0 \\
1.0\end{array}$ & $\begin{array}{l}1.0 \\
1.0 \\
1.0 \\
0.9 \\
0.9\end{array}$ & $\begin{array}{l}1.0 \\
1.0 \\
1.0 \\
0.9 \\
0.9\end{array}$ & $\begin{array}{l}1.0 \\
1.0 \\
1.0 \\
0.8 \\
0.8\end{array}$ \\
\hline $\begin{array}{l}\text { BRUNEI } \\
\text { Total }\end{array}$ & 201 & $\begin{array}{l}1880 \\
1920 \\
1950 \\
1970 \\
1980\end{array}$ & $\begin{array}{l}8.0 \\
6.0 \\
4.0 \\
3.0 \\
2.0\end{array}$ & $\begin{array}{l}1.0 \\
1.3 \\
1.5 \\
1.0 \\
1.0\end{array}$ & $\begin{array}{l}1.0 \\
1.0 \\
1.0 \\
1.0 \\
1.0\end{array}$ & $\begin{array}{l}8.0 \\
8.0 \\
6.0 \\
3.0 \\
2.0\end{array}$ \\
\hline $\begin{array}{l}\text { INDIA } \\
\text { Andaman/Nicobar Islands }\end{array}$ & 301 & $\begin{array}{l}1880 \\
1920 \\
1950 \\
1970 \\
1980\end{array}$ & $\begin{array}{l}10.0 \\
10.0 \\
10.0 \\
6.0 \\
6.0\end{array}$ & $\begin{array}{l}2.0 \\
2.0 \\
2.0 \\
2.0 \\
2.0\end{array}$ & $\begin{array}{l}0.5 \\
0.5 \\
0.5 \\
0.5 \\
0.5\end{array}$ & $\begin{array}{l}10.0 \\
10.0 \\
10.0 \\
6.0 \\
6.0\end{array}$ \\
\hline Andhra Pradesh & 302 & $\begin{array}{l}1880 \\
1920 \\
1950 \\
1970 \\
1980\end{array}$ & $\begin{array}{l}1.5 \\
1.5 \\
1.2 \\
1.0 \\
1.0\end{array}$ & $\begin{array}{l}0.8 \\
0.8 \\
0.8 \\
0.8 \\
0.7\end{array}$ & $\begin{array}{l}0.9 \\
0.9 \\
0.9 \\
0.9 \\
0.9\end{array}$ & $\begin{array}{l}1.0 \\
1.0 \\
0.8 \\
0.7 \\
0.6\end{array}$ \\
\hline Arunachal Pradesh & 303 & $\begin{array}{l}1880 \\
1920 \\
1950 \\
1970 \\
1980\end{array}$ & $\begin{array}{l}10.0 \\
9.0 \\
7.5 \\
6.0 \\
5.0\end{array}$ & $\begin{array}{l}1.0 \\
1.0 \\
1.0 \\
1.0 \\
1.5\end{array}$ & $\begin{array}{l}1.0 \\
1.0 \\
1.0 \\
1.0 \\
1.0\end{array}$ & $\begin{array}{l}10.0 \\
9.0 \\
7.5 \\
6.0 \\
7.5\end{array}$ \\
\hline Assam & 304 & $\begin{array}{l}1880 \\
1920 \\
1950 \\
1970 \\
1980\end{array}$ & $\begin{array}{l}1.5 \\
1.5 \\
1.3 \\
1.2 \\
1.2\end{array}$ & $\begin{array}{l}1.5 \\
1.3 \\
1.3 \\
1.2 \\
1.2\end{array}$ & $\begin{array}{l}1.5 \\
1.5 \\
1.3 \\
1.1 \\
1.0\end{array}$ & $\begin{array}{l}3.4 \\
2.9 \\
1.7 \\
1.6 \\
1.4\end{array}$ \\
\hline
\end{tabular}




\begin{tabular}{|c|c|c|c|c|c|c|}
\hline $\begin{array}{l}\text { Zone } \\
\text { name }\end{array}$ & $\begin{array}{l}\text { Zone } \\
\text { code }\end{array}$ & Year & $\mathbf{S}$ & $\mathbf{F}$ & $\mathbf{A}$ & $\mathrm{N}$ \\
\hline Bihar & 305 & $\begin{array}{l}1880 \\
1920 \\
1950 \\
1970 \\
1980\end{array}$ & $\begin{array}{l}1.0 \\
1.0 \\
1.0 \\
1.0 \\
1.0\end{array}$ & $\begin{array}{l}1.0 \\
1.0 \\
1.0 \\
1.0 \\
1.0\end{array}$ & $\begin{array}{l}1.0 \\
1.0 \\
1.0 \\
1.0 \\
1.0\end{array}$ & $\begin{array}{l}1.0 \\
1.0 \\
1.0 \\
1.0 \\
1.0\end{array}$ \\
\hline Delhi & 306 & $\begin{array}{l}1880 \\
1920 \\
1950 \\
1970 \\
1980\end{array}$ & $\begin{array}{l}1.0 \\
1.0 \\
1.0 \\
1.0 \\
1.0\end{array}$ & $\begin{array}{l}0.8 \\
0.8 \\
0.6 \\
0.5 \\
0.5\end{array}$ & $\begin{array}{l}0.9 \\
0.9 \\
0.5 \\
0.4 \\
0.4\end{array}$ & $\begin{array}{l}0.7 \\
0.7 \\
0.3 \\
0.2 \\
0.2\end{array}$ \\
\hline Gujarat/Dadra/Nagar Haveli & 307 & $\begin{array}{l}1880 \\
1920 \\
1950 \\
1970 \\
1980\end{array}$ & $\begin{array}{l}1.0 \\
1.0 \\
1.0 \\
1.0 \\
1.0\end{array}$ & $\begin{array}{l}1.0 \\
1.0 \\
1.0 \\
1.0 \\
1.0\end{array}$ & $\begin{array}{l}1.0 \\
1.0 \\
1.0 \\
1.0 \\
1.0\end{array}$ & $\begin{array}{l}1.0 \\
1.0 \\
1.0 \\
1.0 \\
1.0\end{array}$ \\
\hline Haryana/Chandigarh & 308 & $\begin{array}{l}1880 \\
1920 \\
1950 \\
1970 \\
1980\end{array}$ & $\begin{array}{l}1.0 \\
1.0 \\
1.0 \\
1.0 \\
1.0\end{array}$ & $\begin{array}{l}0.9 \\
0.9 \\
0.9 \\
0.8 \\
0.7\end{array}$ & $\begin{array}{l}1.4 \\
1.4 \\
1.4 \\
1.5 \\
1.5\end{array}$ & $\begin{array}{l}1.3 \\
1.3 \\
1.3 \\
1.2 \\
1.0\end{array}$ \\
\hline Himachal Pradesh & 309 & $\begin{array}{l}1880 \\
1920 \\
1950 \\
1970 \\
1980\end{array}$ & $\begin{array}{l}1.0 \\
1.0 \\
1.0 \\
1.0 \\
1.0\end{array}$ & $\begin{array}{l}1.8 \\
1.8 \\
1.8 \\
1.6 \\
1.6\end{array}$ & $\begin{array}{l}1.0 \\
1.0 \\
1.0 \\
1.0 \\
1.0\end{array}$ & $\begin{array}{l}1.8 \\
1.8 \\
1.8 \\
1.6 \\
1.6\end{array}$ \\
\hline Jammu/Kashmir & 310 & $\begin{array}{l}1880 \\
1920 \\
1950 \\
1970 \\
1980\end{array}$ & $\begin{array}{l}1.0 \\
1.0 \\
1.0 \\
1.0 \\
1.0\end{array}$ & $\begin{array}{l}1.5 \\
1.5 \\
1.5 \\
1.5 \\
1.5\end{array}$ & $\begin{array}{l}0.7 \\
0.7 \\
0.7 \\
0.7 \\
0.7\end{array}$ & $\begin{array}{l}1.0 \\
1.0 \\
1.0 \\
1.0 \\
1.0\end{array}$ \\
\hline Karnataka & 311 & $\begin{array}{l}1880 \\
1920 \\
1950 \\
1970 \\
1980\end{array}$ & $\begin{array}{l}1.0 \\
1.0 \\
1.0 \\
1.0 \\
1.0\end{array}$ & $\begin{array}{l}1.2 \\
1.2 \\
1.0 \\
1.0 \\
1.0\end{array}$ & $\begin{array}{l}1.0 \\
1.0 \\
1.0 \\
1.0 \\
1.0\end{array}$ & $\begin{array}{l}1.2 \\
1.2 \\
1.0 \\
1.0 \\
1.0\end{array}$ \\
\hline
\end{tabular}




\begin{tabular}{|c|c|c|c|c|c|c|}
\hline $\begin{array}{l}\text { Zone } \\
\text { name }\end{array}$ & $\begin{array}{l}\text { Zone } \\
\text { code }\end{array}$ & Year & $\mathbf{S}$ & $\mathbf{F}$ & $\mathbf{A}$ & $\mathbf{N}$ \\
\hline Kerala & 312 & $\begin{array}{l}1880 \\
1920 \\
1950 \\
1970 \\
1980\end{array}$ & $\begin{array}{l}1.0 \\
1.0 \\
1.0 \\
1.0 \\
1.0\end{array}$ & $\begin{array}{l}0.8 \\
0.8 \\
0.8 \\
0.8 \\
0.8\end{array}$ & $\begin{array}{l}0.7 \\
0.7 \\
0.6 \\
0.6 \\
0.6\end{array}$ & $\begin{array}{l}0.6 \\
0.6 \\
0.5 \\
0.5 \\
0.5\end{array}$ \\
\hline Lakshadweep Islands & 313 & $\begin{array}{l}1880 \\
1920 \\
1950 \\
1970 \\
1980\end{array}$ & $\begin{array}{l}1.0 \\
1.0 \\
1.0 \\
1.0 \\
1.0\end{array}$ & $\begin{array}{l}0.5 \\
0.5 \\
0.5 \\
0.5 \\
0.5\end{array}$ & $\begin{array}{l}0.4 \\
0.4 \\
0.4 \\
0.4 \\
0.4\end{array}$ & $\begin{array}{l}0.2 \\
0.2 \\
0.2 \\
0.2 \\
0.2\end{array}$ \\
\hline Madhya Pradesh & 314 & $\begin{array}{l}1880 \\
1920 \\
1950 \\
1970 \\
1980\end{array}$ & $\begin{array}{l}2.0 \\
2.0 \\
1.8 \\
1.5 \\
1.5\end{array}$ & $\begin{array}{l}1.3 \\
1.3 \\
1.3 \\
1.1 \\
1.1\end{array}$ & $\begin{array}{l}1.0 \\
1.0 \\
1.0 \\
1.0 \\
1.0\end{array}$ & $\begin{array}{l}2.6 \\
2.6 \\
2.3 \\
1.7 \\
1.7\end{array}$ \\
\hline Maharashtra/Goa/Daman/Diu & 315 & $\begin{array}{l}1880 \\
1920 \\
1950 \\
1970 \\
1980\end{array}$ & $\begin{array}{l}1.0 \\
1.0 \\
1.0 \\
1.0 \\
1.0\end{array}$ & $\begin{array}{l}1.0 \\
1.0 \\
1.0 \\
1.0 \\
1.0\end{array}$ & $\begin{array}{l}1.0 \\
1.0 \\
1.0 \\
1.0 \\
1.0\end{array}$ & $\begin{array}{l}1.0 \\
1.0 \\
1.0 \\
1.0 \\
1.0\end{array}$ \\
\hline Manipur & 316 & $\begin{array}{l}1880 \\
1920 \\
1950 \\
1970 \\
1980\end{array}$ & $\begin{array}{l}6.0 \\
5.0 \\
5.0 \\
4.0 \\
4.0\end{array}$ & $\begin{array}{l}2.0 \\
2.0 \\
1.3 \\
1.2 \\
1.2\end{array}$ & $\begin{array}{l}1.0 \\
1.0 \\
1.0 \\
1.0 \\
1.0\end{array}$ & $\begin{array}{l}12.0 \\
10.0 \\
6.5 \\
4.8 \\
4.8\end{array}$ \\
\hline Meghalaya & 317 & $\begin{array}{l}1880 \\
1920 \\
1950 \\
1970 \\
1980\end{array}$ & $\begin{array}{l}7.5 \\
6.0 \\
5.5 \\
4.5 \\
4.0\end{array}$ & $\begin{array}{l}1.0 \\
1.0 \\
1.0 \\
1.0 \\
1.0\end{array}$ & $\begin{array}{l}1.0 \\
1.0 \\
1.0 \\
1.0 \\
1.0\end{array}$ & $\begin{array}{l}7.5 \\
6.0 \\
5.5 \\
4.5 \\
4.0\end{array}$ \\
\hline Mizoram & 318 & $\begin{array}{l}1880 \\
1920 \\
1950 \\
1970 \\
1980\end{array}$ & $\begin{array}{l}10.0 \\
10.0 \\
10.0 \\
8.0 \\
6.0\end{array}$ & $\begin{array}{l}1.0 \\
1.0 \\
1.0 \\
1.0 \\
1.3\end{array}$ & $\begin{array}{l}1.0 \\
1.0 \\
1.0 \\
1.0 \\
1.0\end{array}$ & $\begin{array}{l}10.0 \\
10.0 \\
10.0 \\
8.0 \\
7.8\end{array}$ \\
\hline
\end{tabular}




\begin{tabular}{|c|c|c|c|c|c|c|}
\hline $\begin{array}{l}\text { Zone } \\
\text { name }\end{array}$ & $\begin{array}{l}\text { Zone } \\
\text { code }\end{array}$ & Year & $\mathbf{s}$ & $\mathbf{F}$ & A & $\mathbf{N}$ \\
\hline Nagaland & 319 & $\begin{array}{l}1880 \\
1920 \\
1950 \\
1970 \\
1980\end{array}$ & $\begin{array}{l}10.0 \\
10.0 \\
10.0 \\
6.0 \\
5.0\end{array}$ & $\begin{array}{l}1.0 \\
1.0 \\
1.0 \\
1.0 \\
1.0\end{array}$ & $\begin{array}{l}1.0 \\
1.0 \\
1.0 \\
1.0 \\
1.0\end{array}$ & $\begin{array}{l}10.0 \\
10.0 \\
10.0 \\
6.0 \\
5.0\end{array}$ \\
\hline Orissa & 320 & $\begin{array}{l}1880 \\
1920 \\
1950 \\
1970 \\
1980\end{array}$ & $\begin{array}{l}2.0 \\
1.5 \\
1.3 \\
1.3 \\
1.2\end{array}$ & $\begin{array}{l}1.3 \\
1.3 \\
1.3 \\
1.2 \\
1.0\end{array}$ & $\begin{array}{l}1.0 \\
1.0 \\
1.0 \\
1.0 \\
1.0\end{array}$ & $\begin{array}{l}2.6 \\
2.0 \\
1.7 \\
1.6 \\
1.2\end{array}$ \\
\hline Punjab & 321 & $\begin{array}{l}1880 \\
1920 \\
1950 \\
1970 \\
1980\end{array}$ & $\begin{array}{l}1.0 \\
1.0 \\
1.0 \\
1.0 \\
1.0\end{array}$ & $\begin{array}{l}0.8 \\
0.8 \\
0.8 \\
0.7 \\
0.5\end{array}$ & $\begin{array}{l}1.3 \\
1.3 \\
1.3 \\
1.5 \\
2.0\end{array}$ & $\begin{array}{l}1.0 \\
1.0 \\
1.0 \\
1.0 \\
1.0\end{array}$ \\
\hline Rajasthan & 322 & $\begin{array}{l}1880 \\
1920 \\
1950 \\
1970 \\
1980\end{array}$ & $\begin{array}{l}1.0 \\
1.0 \\
1.0 \\
1.0 \\
1.0\end{array}$ & $\begin{array}{l}1.0 \\
1.0 \\
1.0 \\
1.0 \\
1.0\end{array}$ & $\begin{array}{l}1.0 \\
1.0 \\
1.0 \\
1.0 \\
1.0\end{array}$ & $\begin{array}{l}1.0 \\
1.0 \\
1.0 \\
1.0 \\
1.0\end{array}$ \\
\hline Sikkim & 323 & $\begin{array}{l}1880 \\
1920 \\
1950 \\
1970 \\
1980\end{array}$ & $\begin{array}{l}2.0 \\
1.3 \\
1.0 \\
1.0 \\
1.0\end{array}$ & $\begin{array}{l}2.5 \\
2.0 \\
2.0 \\
2.0 \\
2.0\end{array}$ & $\begin{array}{l}1.5 \\
1.0 \\
1.0 \\
1.0 \\
1.0\end{array}$ & $\begin{array}{l}7.5 \\
2.6 \\
2.0 \\
2.0 \\
2.0\end{array}$ \\
\hline Tamil Nadu/Pondichery & 324 & $\begin{array}{l}1880 \\
1920 \\
1950 \\
1970 \\
1980\end{array}$ & $\begin{array}{l}1.0 \\
1.0 \\
1.0 \\
1.0 \\
1.0\end{array}$ & $\begin{array}{l}0.9 \\
0.9 \\
0.9 \\
0.8 \\
0.8\end{array}$ & $\begin{array}{l}0.9 \\
0.9 \\
0.9 \\
0.8 \\
0.8\end{array}$ & $\begin{array}{l}0.8 \\
0.8 \\
0.8 \\
0.6 \\
0.6\end{array}$ \\
\hline Tripura & 325 & $\begin{array}{l}1880 \\
1920 \\
1950 \\
1970 \\
1980\end{array}$ & $\begin{array}{l}8.0 \\
5.0 \\
4.0 \\
2.0 \\
1.5\end{array}$ & $\begin{array}{l}1.3 \\
1.0 \\
1.0 \\
1.0 \\
1.3\end{array}$ & $\begin{array}{l}1.0 \\
1.0 \\
1.0 \\
1.0 \\
1.0\end{array}$ & $\begin{array}{l}10.4 \\
5.0 \\
4.0 \\
2.0 \\
2.0\end{array}$ \\
\hline
\end{tabular}




\begin{tabular}{lllllll}
\hline $\begin{array}{l}\text { Zone } \\
\text { name }\end{array}$ & $\begin{array}{c}\text { Zone } \\
\text { code }\end{array}$ & Year & S & F & A & N \\
\hline Uttar Pradesh & 326 & 1880 & 1.0 & 0.9 & 0.9 & 0.8 \\
& & 1920 & 1.0 & 0.9 & 0.9 & 0.8 \\
& 1950 & 1.0 & 0.9 & 0.8 & 0.7 \\
& & 1970 & 1.0 & 0.8 & 0.6 & 0.5 \\
West Bengal & & 1980 & 1.0 & 0.8 & 0.6 & 0.5 \\
& & & & & & \\
& 327 & 1880 & 1.0 & 0.9 & 0.9 & 0.8 \\
& & 1920 & 1.0 & 0.9 & 0.9 & 0.8 \\
& & 1950 & 1.0 & 0.8 & 0.8 & 0.6 \\
& & 1970 & 1.0 & 0.7 & 0.6 & 0.4 \\
& & 1980 & 1.0 & 0.7 & 0.6 & 0.4
\end{tabular}

Note: Most logging in India is limited to mountain areas (Himalayas or Western Ghats). Some states which export timber to other states are not shown as net exporters because their internal fuelwood demand is much greater than their roundwood output. Most "export" of wood products in Indian zones is to other Indian zones. On the whole, India has not been a net exporter of wood during the $1880-1980$ period.

Note: Some values of $\mathrm{N}$ have been rounded to nearest integer or 0.5 when transferred to carbon calculation spreadsheets.

INDONESIA

Aceh

$\begin{array}{llllll}401 & 1880 & 7.5 & 1.0 & 1.0 & 7.5 \\ & 1920 & 5.0 & 1.0 & 1.0 & 5.0 \\ & 1950 & 4.0 & 1.3 & 1.0 & 5.2 \\ & 1970 & 3.0 & 1.7 & 1.0 & 5.1 \\ & 1980 & 3.0 & 1.7 & 1.0 & 5.1\end{array}$

North Sumatra

402

$\begin{array}{lllll}1880 & 3.0 & 1.0 & 1.3 & 3.9 \\ 1920 & 2.5 & 1.0 & 1.2 & 3.0 \\ 1950 & 1.5 & 1.0 & 1.7 & 2.5 \\ 1970 & 1.2 & 1.0 & 1.9 & 2.3 \\ 1980 & 1.0 & 1.0 & 2.0 & 2.0\end{array}$

West Sumatra

$\begin{array}{llllll}403 & 1880 & 3.0 & 1.0 & 1.3 & 3.9 \\ & 1920 & 2.5 & 1.0 & 1.2 & 3.0 \\ & 1950 & 1.5 & 1.0 & 1.7 & 2.5 \\ & 1970 & 1.2 & 1.0 & 1.9 & 2.3 \\ & 1980 & 1.0 & 1.0 & 2.0 & 2.0\end{array}$

B - 8 


\begin{tabular}{|c|c|c|c|c|c|c|}
\hline $\begin{array}{l}\text { Zone } \\
\text { name }\end{array}$ & $\begin{array}{l}\text { Zone } \\
\text { code }\end{array}$ & Year & $\mathbf{S}$ & $\mathbf{F}$ & $\mathbf{A}$ & $\mathbf{N}$ \\
\hline Riau & 404 & $\begin{array}{l}1880 \\
1920 \\
1950 \\
1970 \\
1980\end{array}$ & $\begin{array}{l}8.0 \\
8.0 \\
5.0 \\
3.0 \\
3.0\end{array}$ & $\begin{array}{l}1.3 \\
1.3 \\
1.2 \\
1.3 \\
1.3\end{array}$ & $\begin{array}{l}1.0 \\
1.0 \\
1.0 \\
1.0 \\
1.0\end{array}$ & $\begin{array}{l}10.4 \\
10.4 \\
6.0 \\
3.9 \\
3.9\end{array}$ \\
\hline Jambi & 405 & $\begin{array}{l}1880 \\
1920 \\
1950 \\
1970 \\
1980\end{array}$ & $\begin{array}{l}8.0 \\
6.0 \\
4.0 \\
3.0 \\
3.0\end{array}$ & $\begin{array}{l}1.0 \\
1.0 \\
1.3 \\
1.3 \\
1.3\end{array}$ & $\begin{array}{l}1.0 \\
1.0 \\
1.0 \\
1.0 \\
1.0\end{array}$ & $\begin{array}{l}8.0 \\
6.0 \\
5.2 \\
3.9 \\
3.9\end{array}$ \\
\hline South Sumatra & 406 & $\begin{array}{l}1880 \\
1920 \\
1950 \\
1970 \\
1980\end{array}$ & $\begin{array}{l}8.0 \\
5.0 \\
4.0 \\
3.0 \\
3.0\end{array}$ & $\begin{array}{l}1.3 \\
1.5 \\
1.3 \\
1.3 \\
1.3\end{array}$ & $\begin{array}{l}1.0 \\
1.0 \\
1.0 \\
1.3 \\
1.3\end{array}$ & $\begin{array}{l}10.4 \\
7.5 \\
5.2 \\
5.0 \\
5.0\end{array}$ \\
\hline Bengkulu/Lampung & 407 & $\begin{array}{l}1880 \\
1920 \\
1950 \\
1970 \\
1980\end{array}$ & $\begin{array}{l}8.0 \\
4.0 \\
3.0 \\
2.0 \\
1.5\end{array}$ & $\begin{array}{l}1.3 \\
1.5 \\
1.3 \\
1.3 \\
1.3\end{array}$ & $\begin{array}{l}1.0 \\
1.0 \\
1.0 \\
1.0 \\
1.0\end{array}$ & $\begin{array}{l}10.4 \\
6.0 \\
3.9 \\
2.6 \\
2.0\end{array}$ \\
\hline West Java & 408 & $\begin{array}{l}1880 \\
1920 \\
1950 \\
1970 \\
1980\end{array}$ & $\begin{array}{l}1.5 \\
1.0 \\
1.0 \\
1.0 \\
1.0\end{array}$ & $\begin{array}{l}0.8 \\
0.8 \\
0.7 \\
0.7 \\
0.7\end{array}$ & $\begin{array}{l}0.8 \\
0.8 \\
0.7 \\
0.6 \\
0.6\end{array}$ & $\begin{array}{l}1.0 \\
0.6 \\
0.5 \\
0.4 \\
0.4\end{array}$ \\
\hline Central Java & 409 & $\begin{array}{l}1880 \\
1920 \\
1950 \\
1970 \\
1980\end{array}$ & $\begin{array}{l}1.0 \\
1.0 \\
1.0 \\
1.0 \\
1.0\end{array}$ & $\begin{array}{l}0.8 \\
0.7 \\
0.7 \\
0.7 \\
0.7\end{array}$ & $\begin{array}{l}0.8 \\
0.7 \\
0.7 \\
0.6 \\
0.6\end{array}$ & $\begin{array}{l}0.6 \\
0.5 \\
0.5 \\
0.4 \\
0.4\end{array}$ \\
\hline East Java & 410 & $\begin{array}{l}1880 \\
1920 \\
1950 \\
1970 \\
1980\end{array}$ & $\begin{array}{l}1.0 \\
1.0 \\
1.0 \\
1.0 \\
1.0\end{array}$ & $\begin{array}{l}0.9 \\
0.8 \\
0.7 \\
0.7 \\
0.7\end{array}$ & $\begin{array}{l}0.9 \\
0.8 \\
0.7 \\
0.6 \\
0.6\end{array}$ & $\begin{array}{l}0.8 \\
0.6 \\
0.5 \\
0.4 \\
0.4\end{array}$ \\
\hline
\end{tabular}




\begin{tabular}{|c|c|c|c|c|c|c|}
\hline $\begin{array}{l}\text { Zone } \\
\text { name }\end{array}$ & $\begin{array}{l}\text { Zone } \\
\text { code }\end{array}$ & Year & $\mathbf{S}$ & $\mathbf{F}$ & $\mathbf{A}$ & $\mathbf{N}$ \\
\hline Bali & 411 & $\begin{array}{l}1880 \\
1920 \\
1950 \\
1970 \\
1980\end{array}$ & $\begin{array}{l}1.2 \\
1.0 \\
1.0 \\
1.0 \\
1.0\end{array}$ & $\begin{array}{l}1.0 \\
1.0 \\
0.9 \\
0.8 \\
0.7\end{array}$ & $\begin{array}{l}1.0 \\
1.0 \\
0.9 \\
0.8 \\
0.7\end{array}$ & $\begin{array}{l}1.2 \\
1.0 \\
0.8 \\
0.6 \\
0.5\end{array}$ \\
\hline West Nusa Tenggara & 412 & $\begin{array}{l}1880 \\
1920 \\
1950 \\
1970 \\
1980\end{array}$ & $\begin{array}{l}3.0 \\
2.0 \\
1.8 \\
1.5 \\
1.5\end{array}$ & $\begin{array}{l}1.0 \\
1.0 \\
1.0 \\
1.0 \\
1.0\end{array}$ & $\begin{array}{l}1.0 \\
1.0 \\
1.0 \\
1.0 \\
1.0\end{array}$ & $\begin{array}{l}3.0 \\
2.0 \\
1.8 \\
1.5 \\
1.5\end{array}$ \\
\hline East Nusa Tenggara & 413 & $\begin{array}{l}1880 \\
1920 \\
1950 \\
1970 \\
1980\end{array}$ & $\begin{array}{l}5.0 \\
4.0 \\
3.0 \\
3.0 \\
3.0\end{array}$ & $\begin{array}{l}1.0 \\
1.0 \\
1.0 \\
1.0 \\
1.0\end{array}$ & $\begin{array}{l}1.0 \\
1.0 \\
1.0 \\
1.0 \\
1.0\end{array}$ & $\begin{array}{l}5.0 \\
4.0 \\
3.0 \\
3.0 \\
3.0\end{array}$ \\
\hline East Timor & 414 & $\begin{array}{l}1880 \\
1920 \\
1950 \\
1970 \\
1980\end{array}$ & $\begin{array}{l}4.0 \\
4.0 \\
4.0 \\
4.0 \\
4.0\end{array}$ & $\begin{array}{l}1.0 \\
1.0 \\
1.0 \\
1.0 \\
1.3\end{array}$ & $\begin{array}{l}1.0 \\
1.0 \\
1.0 \\
1.0 \\
1.0\end{array}$ & $\begin{array}{l}4.0 \\
4.0 \\
4.0 \\
4.0 \\
5.2\end{array}$ \\
\hline West Kalimantan & 415 & $\begin{array}{l}1880 \\
1920 \\
1950 \\
1970 \\
1980\end{array}$ & $\begin{array}{l}10.0 \\
10.0 \\
7.5 \\
6.0 \\
6.0\end{array}$ & $\begin{array}{l}1.5 \\
1.5 \\
2.0 \\
2.0 \\
2.0\end{array}$ & $\begin{array}{l}1.0 \\
1.0 \\
1.0 \\
1.0 \\
1.0\end{array}$ & $\begin{array}{l}15.0 \\
15.0 \\
15.0 \\
12.0 \\
12.0\end{array}$ \\
\hline Central Kalimantan & 416 & $\begin{array}{l}1880 \\
1920 \\
1950 \\
1970 \\
1980\end{array}$ & $\begin{array}{l}10.0 \\
10.0 \\
10.0 \\
8.0 \\
8.0\end{array}$ & $\begin{array}{l}2.0 \\
2.0 \\
2.0 \\
2.5 \\
2.5\end{array}$ & $\begin{array}{l}1.0 \\
1.0 \\
1.0 \\
1.0 \\
1.0\end{array}$ & $\begin{array}{l}20.0 \\
20.0 \\
20.0 \\
20.0 \\
20.0\end{array}$ \\
\hline East Kalimantan* & 417 & $\begin{array}{l}1880 \\
1920 \\
1950 \\
1970 \\
1980\end{array}$ & $\begin{array}{l}10.0 \\
10.0 \\
10.0 \\
10.0 \\
8.0\end{array}$ & $\begin{array}{l}2.0 \\
2.0 \\
2.0 \\
2.0 \\
2.5\end{array}$ & $\begin{array}{l}1.0 \\
1.0 \\
1.0 \\
1.0 \\
1.0\end{array}$ & $\begin{array}{l}20.0 \\
20.0 \\
20.0 \\
20.0 \\
20.0\end{array}$ \\
\hline
\end{tabular}




\begin{tabular}{|c|c|c|c|c|c|c|}
\hline $\begin{array}{l}\text { Zone } \\
\text { name }\end{array}$ & $\begin{array}{l}\text { Zone } \\
\text { code }\end{array}$ & Year & $\mathbf{S}$ & $\mathbf{F}$ & A & $\mathbf{N}$ \\
\hline South Kalimantan & 418 & $\begin{array}{l}1880 \\
1920 \\
1950 \\
1970 \\
1980\end{array}$ & $\begin{array}{l}4.0 \\
4.0 \\
3.5 \\
3.0 \\
3.0\end{array}$ & $\begin{array}{l}1.3 \\
1.3 \\
1.3 \\
1.3 \\
1.3\end{array}$ & $\begin{array}{l}1.0 \\
1.0 \\
1.0 \\
1.0 \\
1.0\end{array}$ & $\begin{array}{l}5.2 \\
5.2 \\
4.5 \\
3.9 \\
3.9\end{array}$ \\
\hline North/Central Sulawesi & 419 & $\begin{array}{l}1880 \\
1920 \\
1950 \\
1970 \\
1980\end{array}$ & $\begin{array}{l}10.0 \\
8.0 \\
5.0 \\
4.0 \\
3.5\end{array}$ & $\begin{array}{l}1.0 \\
1.0 \\
1.2 \\
1.3 \\
1.3\end{array}$ & $\begin{array}{l}1.0 \\
1.0 \\
1.0 \\
1.0 \\
1.0\end{array}$ & $\begin{array}{l}10.0 \\
8.0 \\
6.0 \\
5.2 \\
4.5\end{array}$ \\
\hline South/Southeast Sulawesi & 420 & $\begin{array}{l}1880 \\
1920 \\
1950 \\
1970 \\
1980\end{array}$ & $\begin{array}{l}8.0 \\
5.0 \\
3.0 \\
2.4 \\
2.0\end{array}$ & $\begin{array}{l}1.0 \\
1.0 \\
1.3 \\
1.3 \\
1.5\end{array}$ & $\begin{array}{l}1.0 \\
1.0 \\
1.0 \\
1.0 \\
1.0\end{array}$ & $\begin{array}{l}8.0 \\
5.0 \\
3.9 \\
3.1 \\
3.0\end{array}$ \\
\hline Maluku & 421 & $\begin{array}{l}1880 \\
1920 \\
1950 \\
1970 \\
1980\end{array}$ & $\begin{array}{l}9.0 \\
9.0 \\
6.0 \\
5.0 \\
5.0\end{array}$ & $\begin{array}{l}1.3 \\
1.3 \\
1.5 \\
2.0 \\
2.0\end{array}$ & $\begin{array}{l}1.3 \\
1.3 \\
1.3 \\
1.0 \\
1.0\end{array}$ & $\begin{array}{l}15.2 \\
15.2 \\
11.7 \\
10.0 \\
10.0\end{array}$ \\
\hline Irian Jaya & 422 & $\begin{array}{l}1880 \\
1920 \\
1950 \\
1970 \\
1980\end{array}$ & $\begin{array}{l}10.0 \\
10.0 \\
10.0 \\
10.0 \\
10.0\end{array}$ & $\begin{array}{l}1.5 \\
1.5 \\
1.2 \\
1.2 \\
1.2\end{array}$ & $\begin{array}{l}1.0 \\
1.0 \\
1.0 \\
1.0 \\
1.0\end{array}$ & $\begin{array}{l}15.0 \\
15.0 \\
12.0 \\
12.0 \\
12.0\end{array}$ \\
\hline
\end{tabular}

Note: Some values of $\mathrm{N}$ have been rounded to nearest integer or 0.5 when transferred to carbon calculation spreadsheets.

Note: Values of $S, F$, and $A$ initially chosen generated a set of $N$ values which did not correspond optimally with carbon content estimates generated from provincial forest volume data. Some $S, F$, and $A$ values were adjusted to generate a set of $N$ values consistent with biomass extrapolations from provincial data.

Note: Irian Jaya did not export forest products during this period, but $\mathrm{F}$ has been artifically increased to account for extra loss of forest biomass associated with the agricultural practices required to maintain locally dense populations at high elevations for long periods of time.

$$
\text { B - } 11
$$




\begin{tabular}{|c|c|c|c|c|c|c|}
\hline $\begin{array}{l}\text { Zone } \\
\text { name }\end{array}$ & $\begin{array}{l}\text { Zone } \\
\text { code }\end{array}$ & Year & $\mathbf{S}$ & $\mathbf{F}$ & $\mathbf{A}$ & $\mathbf{N}$ \\
\hline $\begin{array}{l}\text { KAMPUCHEA (Cambodia) } \\
\text { Northwestern Region }\end{array}$ & 501 & $\begin{array}{l}1880 \\
1920 \\
1950 \\
1970 \\
1980\end{array}$ & $\begin{array}{l}5.0 \\
5.0 \\
3.0 \\
2.0 \\
3.0\end{array}$ & $\begin{array}{l}1.0 \\
1.0 \\
1.0 \\
1.0 \\
1.0\end{array}$ & $\begin{array}{l}1.0 \\
1.0 \\
1.0 \\
1.0 \\
1.0\end{array}$ & $\begin{array}{l}5.0 \\
5.0 \\
3.0 \\
2.0 \\
3.0\end{array}$ \\
\hline Northeast Region & 502 & $\begin{array}{l}1880 \\
1920 \\
1950 \\
1970 \\
1980\end{array}$ & $\begin{array}{l}8.0 \\
8.0 \\
3.0 \\
2.7 \\
3.0\end{array}$ & $\begin{array}{l}1.5 \\
1.5 \\
1.2 \\
1.2 \\
1.3\end{array}$ & $\begin{array}{l}1.0 \\
1.0 \\
1.0 \\
1.0 \\
1.0\end{array}$ & $\begin{array}{l}12.0 \\
12.0 \\
3.6 \\
3.2 \\
3.9\end{array}$ \\
\hline Southeast Lowlands & 503 & $\begin{array}{l}1880 \\
1920 \\
1950 \\
1970 \\
1980\end{array}$ & $\begin{array}{l}1.5 \\
1.3 \\
1.3 \\
1.0 \\
1.0\end{array}$ & $\begin{array}{l}1.0 \\
1.0 \\
1.0 \\
1.0 \\
1.2\end{array}$ & $\begin{array}{l}1.0 \\
1.0 \\
1.0 \\
1.0 \\
1.0\end{array}$ & $\begin{array}{l}1.5 \\
1.3 \\
1.3 \\
1.0 \\
1.2\end{array}$ \\
\hline Southwest Highlands & 504 & $\begin{array}{l}1880 \\
1920 \\
1950 \\
1970 \\
1980\end{array}$ & $\begin{array}{l}5.0 \\
5.0 \\
3.6 \\
2.8 \\
3.6\end{array}$ & $\begin{array}{l}1.0 \\
1.0 \\
1.0 \\
1.0 \\
1.0\end{array}$ & $\begin{array}{l}1.0 \\
1.0 \\
1.0 \\
1.0 \\
1.0\end{array}$ & $\begin{array}{l}5.0 \\
5.0 \\
3.6 \\
2.8 \\
3.6\end{array}$ \\
\hline
\end{tabular}

Note: Some values of $\mathrm{N}$ have been rounded to nearest integer when transferred to carbon calculation spreadsheets.

LAOS

Northwestern Laos

$\begin{array}{llllll}601 & 1880 & 10.0 & 1.0 & 1.0 & 10.0 \\ & 1920 & 10.0 & 1.0 & 1.0 & 10.0 \\ & 1950 & 10.0 & 1.0 & 1.0 & 10.0 \\ & 1970 & 10.0 & 1.0 & 1.0 & 10.0 \\ & 1980 & 8.0 & 1.3 & 1.0 & 10.4\end{array}$

Louang Phrabang

$\begin{array}{rlllll}602 & 1880 & 8.0 & 1.6 & 1.0 & 12.8 \\ & 1920 & 8.0 & 1.6 & 1.0 & 12.8 \\ 1950 & 7.0 & 1.6 & 1.0 & 11.2 \\ & 1970 & 7.0 & 1.6 & 1.0 & 11.2 \\ & 1980 & 7.0 & 1.6 & 1.0 & 11.2\end{array}$




\begin{tabular}{lllllll}
\hline Zone & Zone & & & & & \\
name & code & Year & S & F & A & N \\
\hline \multirow{2}{*}{ Central Laos } & 603 & 1880 & 7.5 & 2.0 & 1.0 & 15.0 \\
& & 1920 & 6.0 & 2.0 & 1.0 & 12.0 \\
& 1950 & 5.0 & 2.0 & 1.0 & 10.0 \\
& & 1970 & 4.0 & 2.0 & 1.0 & 8.0 \\
& & 1980 & 4.0 & 2.0 & 1.0 & 8.0 \\
Annamite Chain & 604 & 1880 & 10.0 & 1.0 & 1.0 & 10.0 \\
& & 1920 & 10.0 & 1.0 & 1.0 & 10.0 \\
& & 1950 & 10.0 & 1.0 & 1.0 & 10.0 \\
& & 1970 & 8.0 & 1.0 & 1.0 & 8.0 \\
Champasak & 1980 & 8.0 & 1.1 & 1.0 & 8.8 \\
& & & & & & \\
& 605 & 1880 & 5.0 & 1.0 & 1.0 & 5.0 \\
& & 1920 & 4.0 & 1.0 & 1.0 & 4.0 \\
& & 1950 & 4.0 & 1.0 & 1.0 & 4.0 \\
& & 1970 & 4.0 & 1.0 & 1.0 & 4.0 \\
& & 1980 & 4.0 & 1.1 & 1.0 & 4.4
\end{tabular}

Note: Some values of $\mathrm{N}$ have been rounded to nearest integer or 0.5 when transferred to carbon calculation spreadsheets.

MALAYSIA

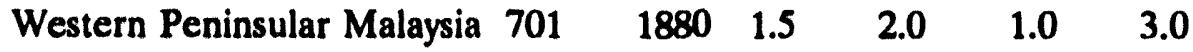

$\begin{array}{lllll}1920 & 1.0 & 2.0 & 1.0 & 2.0\end{array}$

$\begin{array}{lllll}1950 & 1.0 & 1.5 & 1.0 & 1.5\end{array}$

$\begin{array}{lllll}1970 & 1.0 & 1.2 & 1.3 & 1.6\end{array}$

$\begin{array}{lllll}1980 & 1.0 & 1.0 & 1.5 & 1.5\end{array}$

$\begin{array}{lllllll}\text { Eastern Peninsular Malaysia } & 702 & 1880 & 3.0 & 1.3 & 1.0 & 3.9\end{array}$

$\begin{array}{lllll}1920 & 2.0 & 1.8 & 1.0 & 3.6\end{array}$

$\begin{array}{lllll}1950 & 1.5 & 1.8 & 1.2 & 3.2\end{array}$

$\begin{array}{lllll}1970 & 1.0 & 2.0 & 1.5 & 3.0\end{array}$

$\begin{array}{lllll}1980 & 1.0 & 1.5 & 2.0 & 3.0\end{array}$

$\begin{array}{lllllll}\text { Johore } & 703 & 1880 & 1.5 & 2.0 & 1.0 & 3.0\end{array}$

$\begin{array}{lllll}1920 & 1.0 & 2.0 & 1.0 & 2.0\end{array}$

$\begin{array}{lllll}1950 & 1.0 & 1.5 & 1.0 & 1.5\end{array}$

$\begin{array}{lllll}1970 & 1.0 & 1.5 & 1.0 & 1.5\end{array}$

$\begin{array}{lllll}1980 & 1.0 & 1.0 & 1.0 & 1.0\end{array}$

B $\cdot 13$ 


\begin{tabular}{|c|c|c|c|c|c|c|}
\hline $\begin{array}{l}\text { Zone } \\
\text { name }\end{array}$ & $\begin{array}{l}\text { Zone } \\
\text { code }\end{array}$ & Year & $\mathbf{S}$ & $\mathbf{F}$ & $\mathbf{A}$ & $\mathbf{N}$ \\
\hline Western Sarawak & 704 & $\begin{array}{l}1880 \\
1920 \\
1950 \\
1970 \\
1980\end{array}$ & $\begin{array}{l}8.0 \\
8.0 \\
6.0 \\
4.0 \\
4.0\end{array}$ & $\begin{array}{l}1.0 \\
1.0 \\
1.3 \\
2.0 \\
2.0\end{array}$ & $\begin{array}{l}1.0 \\
1.0 \\
1.0 \\
1.0 \\
1.0\end{array}$ & $\begin{array}{l}8.0 \\
8.0 \\
7.8 \\
8.0 \\
8.0\end{array}$ \\
\hline Central Sarawak & 705 & $\begin{array}{l}1880 \\
1920 \\
1950 \\
1970 \\
1980\end{array}$ & $\begin{array}{l}10.0 \\
10.0 \\
10.0 \\
8.0 \\
7.5\end{array}$ & $\begin{array}{l}1.0 \\
1.0 \\
1.2 \\
1.5 \\
2.0\end{array}$ & $\begin{array}{l}1.0 \\
1.0 \\
1.0 \\
1.0 \\
1.0\end{array}$ & $\begin{array}{l}10.0 \\
10.0 \\
12.0 \\
12.0 \\
15.0\end{array}$ \\
\hline Eastern Sarawak & 706 & $\begin{array}{l}1880 \\
1920 \\
1950 \\
1970 \\
1980\end{array}$ & $\begin{array}{l}10.0 \\
10.0 \\
8.0 \\
6.0 \\
6.0\end{array}$ & $\begin{array}{l}1.0 \\
1.0 \\
1.6 \\
2.5 \\
2.5\end{array}$ & $\begin{array}{l}1.0 \\
1.0 \\
1.0 \\
1.0 \\
1.0\end{array}$ & $\begin{array}{l}10.0 \\
10.0 \\
12.8 \\
15.0 \\
15.0\end{array}$ \\
\hline Sabah & 707 & $\begin{array}{l}1880 \\
1920 \\
1950 \\
1970 \\
1980\end{array}$ & $\begin{array}{l}8.0 \\
6.0 \\
4.3 \\
4.0 \\
4.0\end{array}$ & $\begin{array}{l}1.5 \\
1.7 \\
3.0 \\
3.0 \\
3.0\end{array}$ & $\begin{array}{l}1.0 \\
1.0 \\
1.0 \\
1.0 \\
1.0\end{array}$ & $\begin{array}{l}12.0 \\
10.2 \\
12.9 \\
12.0 \\
12.0\end{array}$ \\
\hline
\end{tabular}

Note: Some values of $\mathrm{N}$ have been rounded to nearest integer or 0.5 when transferred to carbon calculation spreadsheets.

MYANMAR (Burma)

Chin/Arakan States

$\begin{array}{llllll}801 & 1880 & 9.0 & 1.7 & 1.0 & 15.3 \\ & 1920 & 8.0 & 1.5 & 1.0 & 12.0 \\ & 1950 & 6.0 & 1.5 & 1.0 & 9.0 \\ & 1970 & 6.0 & 1.5 & 1.0 & 9.0 \\ & 1980 & 6.0 & 1.5 & 1.0 & 9.0\end{array}$

Northern Myanmar

$\begin{array}{llllll}802 & 1880 & 8.0 & 1.8 & 1.3 & 18.7 \\ & 1920 & 8.0 & 1.5 & 1.3 & 15.6 \\ & 1950 & 6.0 & 2.0 & 1.3 & 15.6 \\ & 1970 & 4.0 & 2.0 & 1.5 & 12.0 \\ & 1980 & 4.0 & 2.0 & 1.5 & 12.0\end{array}$




\begin{tabular}{|c|c|c|c|c|c|c|}
\hline $\begin{array}{l}\text { Zone } \\
\text { name }\end{array}$ & $\begin{array}{l}\text { Zone } \\
\text { code }\end{array}$ & Year & $\mathbf{S}$ & $\mathbf{F}$ & $\mathbf{A}$ & $\mathbf{N}$ \\
\hline Dry Zone & 803 & $\begin{array}{l}1880 \\
1920 \\
1950 \\
1970 \\
1980\end{array}$ & $\begin{array}{l}6.0 \\
5.0 \\
4.5 \\
4.0 \\
4.0\end{array}$ & $\begin{array}{l}1.0 \\
1.0 \\
1.0 \\
1.0 \\
1.0\end{array}$ & $\begin{array}{l}1.0 \\
1.0 \\
1.0 \\
1.0 \\
1.0\end{array}$ & $\begin{array}{l}6.0 \\
5.0 \\
4.5 \\
4.0 \\
4.0\end{array}$ \\
\hline Shan/Karen/Kayah & 804 & $\begin{array}{l}1880 \\
1920 \\
1950 \\
1970 \\
1980\end{array}$ & $\begin{array}{l}7.0 \\
6.0 \\
6.0 \\
4.5 \\
4.5\end{array}$ & $\begin{array}{l}2.0 \\
2.0 \\
2.0 \\
2.0 \\
2.0\end{array}$ & $\begin{array}{l}1.0 \\
1.0 \\
1.0 \\
1.0 \\
1.0\end{array}$ & $\begin{array}{l}14.0 \\
12.0 \\
12.0 \\
9.0 \\
9.0\end{array}$ \\
\hline Delta & 805 & $\begin{array}{l}1880 \\
1920 \\
1950 \\
1970 \\
1980\end{array}$ & $\begin{array}{l}2.0 \\
1.3 \\
1.0 \\
1.0 \\
1.0\end{array}$ & $\begin{array}{l}2.3 \\
2.0 \\
2.0 \\
2.0 \\
2.0\end{array}$ & $\begin{array}{l}1.0 \\
1.2 \\
1.2 \\
1.2 \\
1.0\end{array}$ & $\begin{array}{l}4.6 \\
3.1 \\
2.4 \\
2.4 \\
2.0\end{array}$ \\
\hline Peninsular & 806 & $\begin{array}{l}1880 \\
1920 \\
1950 \\
1970 \\
1980\end{array}$ & $\begin{array}{l}8.0 \\
4.5 \\
3.5 \\
3.0 \\
3.0\end{array}$ & $\begin{array}{l}2.5 \\
2.0 \\
2.0 \\
1.8 \\
1.7\end{array}$ & $\begin{array}{l}1.0 \\
1.0 \\
1.0 \\
1.0 \\
1.0\end{array}$ & $\begin{array}{l}20.0 \\
9.0 \\
7.0 \\
5.4 \\
5.1\end{array}$ \\
\hline
\end{tabular}

Note: Some values of $\mathrm{N}$ have been rounded to nearest integer or 0.5 when transferred to carbon calculation spreadsheets.

\section{PHILIPPINES}

$\begin{array}{lllllll}\text { Luzon } & 901 & 1880 & 3.0 & 1.3 & 0.8 & 3.1 \\ & & 1920 & 2.0 & 1.3 & 0.8 & 2.1 \\ & & 1950 & 2.0 & 1.3 & 0.8 & 2.1 \\ & & 1970 & 1.5 & 1.5 & 0.8 & 1.8 \\ & & 1980 & 1.5 & 1.5 & 0.8 & 1.8 \\ \text { Palawan } & & & & & & \\ & 902 & 1880 & 8.0 & 1.0 & 1.0 & 8.0 \\ & & 1920 & 7.0 & 1.0 & 1.0 & 7.0 \\ & & 1950 & 7.0 & 1.0 & 1.0 & 7.0 \\ & & 1970 & 5.0 & 1.2 & 1.0 & 6.0 \\ & & 1980 & 3.0 & 1.7 & 1.0 & 5.1\end{array}$




\begin{tabular}{lcccccc}
\hline Zone & Zone & & & & & \\
name & code & Year & S & F & A & N \\
& & & & & & \\
\hline \multirow{2}{*}{ Visayas } & 903 & 1880 & 3.0 & 1.3 & 0.8 & 3.1 \\
& & 1920 & 2.0 & 1.3 & 0.8 & 2.1 \\
& & 1950 & 1.5 & 1.5 & 0.8 & 1.8 \\
& & 1970 & 1.5 & 1.5 & 0.8 & 1.8 \\
& & 1980 & 1.5 & 1.5 & 0.8 & 1.8 \\
Mindanao & & & & & & \\
& 904 & 1880 & 4.0 & 1.3 & 1.0 & 5.2 \\
& & 1920 & 3.0 & 1.3 & 1.0 & 3.9 \\
& & 1950 & 1.5 & 1.5 & 0.9 & 2.0 \\
& & 1970 & 1.3 & 1.5 & 0.8 & 1.6 \\
& & 1980 & 1.2 & 1.5 & 0.8 & 1.4
\end{tabular}

Note: These estimates were revised after the mean forest biomass values calculated for 1980 were compared with independent forest biomass estimates by S. Brown and colleagues from national inventory data. (Initial estimates of $\mathrm{S}, \mathrm{F}$, and $\mathrm{A}$ generated values of $\mathrm{N}$ which were not compatible with the inventory-based biomass data.)

SINGAPORE

Total

$\begin{array}{rrrrrr}1001 & 1880 & 2.0 & 0.5 & 0.5 & 0.5 \\ & 1920 & 1.2 & 0.5 & 0.5 & 0.3 \\ & 1950 & 1.0 & 0.5 & 0.3 & 0.2 \\ & 1970 & 1.0 & 0.3 & 0.3 & 0.1 \\ & 1980 & 1.0 & 0.3 & 0.3 & 0.1\end{array}$

SRI LANKA

Wet Zone

$\begin{array}{llllll}1101 & 1880 & 1.5 & 1.0 & 0.7 & 1.0 \\ & 1920 & 1.3 & 1.0 & 0.6 & 0.8 \\ & 1950 & 1.2 & 0.9 & 0.6 & 0.6 \\ & 1970 & 1.1 & 0.8 & 0.5 & 0.4 \\ & 1980 & 1.1 & 0.8 & 0.5 & 0.4\end{array}$

Dry Zone

$\begin{array}{rlllll}1102 & 1880 & 7.0 & 0.9 & 0.8 & 5.0 \\ & 1920 & 5.5 & 0.9 & 0.8 & 4.0 \\ 1950 & 4.0 & 0.9 & 0.7 & 2.5 \\ & 1970 & 3.5 & 0.8 & 0.7 & 2.0 \\ & 1980 & 3.0 & 0.8 & 0.6 & 1.4\end{array}$

Note: These estimates were revised after the mean forest biomass values calculated for 1980 were compared with independent forest biomass estimates by S. Brown and colleagues from national inventory data. (Initial estimates of $\mathrm{S}, \mathrm{F}$, and $\mathrm{A}$ generated values of $\mathrm{N}$ which were not compatible with the inventory-based biomass data.) 


\begin{tabular}{lcccccc}
\hline $\begin{array}{l}\text { Zone } \\
\text { name }\end{array}$ & $\begin{array}{c}\text { Zone } \\
\text { code }\end{array}$ & Year & S & F & A & N \\
& & & & & & \\
\hline & & & & & & \\
THAILAND & 1201 & 1880 & 5.0 & 2.0 & 1.2 & 12.0 \\
Northern Region & & 1920 & 4.0 & 2.0 & 1.3 & 10.4 \\
& & 1950 & 3.5 & 1.8 & 1.3 & 8.9 \\
& & 1970 & 3.0 & 1.8 & 1.3 & 7.0 \\
& & 1980 & 3.0 & 1.8 & 1.3 & 7.0 \\
Northeastern Region & 1202 & 1880 & 2.5 & 2.0 & 1.0 & 5.0 \\
& & 1920 & 2.0 & 2.0 & 1.0 & 4.0 \\
& & 1950 & 2.0 & 1.8 & 1.0 & 3.6 \\
& & 1970 & 2.0 & 1.5 & 1.0 & 3.0 \\
& & 1980 & 2.0 & 1.5 & 1.0 & 3.0 \\
Central Plain & 1203 & 1880 & 2.0 & 3.0 & 1.0 & 6.0 \\
& & 1920 & 1.3 & 2.5 & 1.5 & 4.9 \\
& & 1950 & 1.1 & 2.5 & 1.5 & 4.1 \\
& & 1970 & 1.1 & 1.5 & 1.5 & 2.5 \\
& & 1980 & 1.1 & 1.2 & 1.5 & 2.0 \\
Southern Region & & & & & \\
& & 1880 & 3.0 & 1.7 & 1.0 & 5.1 \\
& & 1920 & 3.0 & 1.7 & 1.0 & 5.1 \\
& & 1950 & 2.5 & 1.5 & 1.1 & 4.1 \\
& & 1970 & 2.0 & 1.3 & 1.2 & 3.1 \\
& & 1980 & 1.5 & 1.3 & 1.5 & 2.9
\end{tabular}

Note: Some values of $\mathrm{N}$ have been rounded to nearest integer when transferred to carbon calculation spreadsheets.

VIETNAM

Northwest Highlands

$\begin{array}{llllll}1301 & 1880 & 10.0 & 1.5 & 1.0 & 15.0 \\ & 1920 & 8.0 & 1.3 & 1.0 & 10.4 \\ & 1950 & 5.0 & 1.0 & 1.0 & 5.0 \\ & 1970 & 3.5 & 1.0 & 1.0 & 3.5 \\ & 1980 & 3.0 & 1.0 & 1.0 & 3.0\end{array}$

Tonkin Delta

$\begin{array}{rlllll}1302 & 1880 & 1.5 & 1.0 & 1.0 & 1.5 \\ 1920 & 1.2 & 1.0 & 1.0 & 1.2 \\ 1950 & 1.0 & 1.0 & 0.8 & 0.8 \\ 1970 & 1.0 & 1.0 & 0.8 & 0.8 \\ 1980 & 1.0 & 1.0 & 0.8 & 0.8\end{array}$




\begin{tabular}{|c|c|c|c|c|c|c|}
\hline $\begin{array}{l}\text { Zone } \\
\text { name }\end{array}$ & $\begin{array}{l}\text { Zone } \\
\text { code }\end{array}$ & Year & $\mathbf{S}$ & $\mathbf{F}$ & A & $\mathbf{N}$ \\
\hline North Central Coast & 1303 & $\begin{array}{l}1880 \\
1920 \\
1950 \\
1970 \\
1980\end{array}$ & $\begin{array}{l}4.0 \\
2.5 \\
1.8 \\
1.2 \\
1.0\end{array}$ & $\begin{array}{l}1.0 \\
1.0 \\
1.0 \\
1.5 \\
1.5\end{array}$ & $\begin{array}{l}1.0 \\
1.0 \\
1.0 \\
1.0 \\
1.0\end{array}$ & $\begin{array}{l}4.0 \\
2.5 \\
1.8 \\
1.8 \\
1.5\end{array}$ \\
\hline Central Highlands & 1304 & $\begin{array}{l}1880 \\
1920 \\
1950 \\
1970 \\
1980\end{array}$ & $\begin{array}{l}8.0 \\
6.0 \\
5.0 \\
3.0 \\
2.5\end{array}$ & $\begin{array}{l}2.0 \\
1.5 \\
1.5 \\
2.0 \\
2.0\end{array}$ & $\begin{array}{l}1.0 \\
1.1 \\
1.2 \\
1.0 \\
1.0\end{array}$ & $\begin{array}{l}16.0 \\
9.9 \\
9.0 \\
6.0 \\
5.0\end{array}$ \\
\hline South Central Coast & 1305 & $\begin{array}{l}1880 \\
1920 \\
1950 \\
1970 \\
1980\end{array}$ & $\begin{array}{l}4.0 \\
3.0 \\
2.4 \\
1.5 \\
1.0\end{array}$ & $\begin{array}{l}1.0 \\
1.0 \\
1.0 \\
1.1 \\
1.1\end{array}$ & $\begin{array}{l}1.0 \\
1.0 \\
1.0 \\
0.7 \\
1.0\end{array}$ & $\begin{array}{l}4.0 \\
3.0 \\
2.4 \\
1.2 \\
1.1\end{array}$ \\
\hline Mekong Delta & 1306 & $\begin{array}{l}1880 \\
1920 \\
1950 \\
1970 \\
1980\end{array}$ & $\begin{array}{l}2.0 \\
1.5 \\
1.5 \\
1.0 \\
1.0\end{array}$ & $\begin{array}{l}1.0 \\
1.0 \\
1.0 \\
1.3 \\
1.2\end{array}$ & $\begin{array}{l}1.0 \\
1.2 \\
1.2 \\
1.0 \\
1.0\end{array}$ & $\begin{array}{l}2.0 \\
1.8 \\
1.8 \\
1.3 \\
1.2\end{array}$ \\
\hline
\end{tabular}

Note: Some values of $\mathrm{N}$ have been rounded to nearest integer when transferred to carbon calculation spreadsheets.

Note: Some 1970 and 1980 values of S, F, and A incorporate assessment of wartime effects on farming patterns and resource consumption. 


\section{APPENDIX C}

PRINTOUTS OF THE STEP 3 (CARBON)

LOTUS $1-23^{\text {TM }}$ SPREADSHEETS FOR 13 COUNTRIES (TOTALS) 


\section{PRINTOUTS OF THE STEP 3 (CARBON) LOTUS 1-2-3 ${ }^{\text {TM }}$ SPREADSHEETS FOR 13 COUNTRIES (TOTALS)}

What follows is a listing of the total carbon spreadsheets compiled for each country. The data were obtained by aggregating the data values from all the ecological zones present within the given country. These data, along with the data for each of the 94 ecological zones, are contained within the digital data files included with this NDP. Data values are expressed in thousands of $\mathrm{Mg}$, with the first two lines in each country listing containing the country identification code (zone code), country name, zone name (i.e., "Total"), and a listing of the years for which data were obtained.

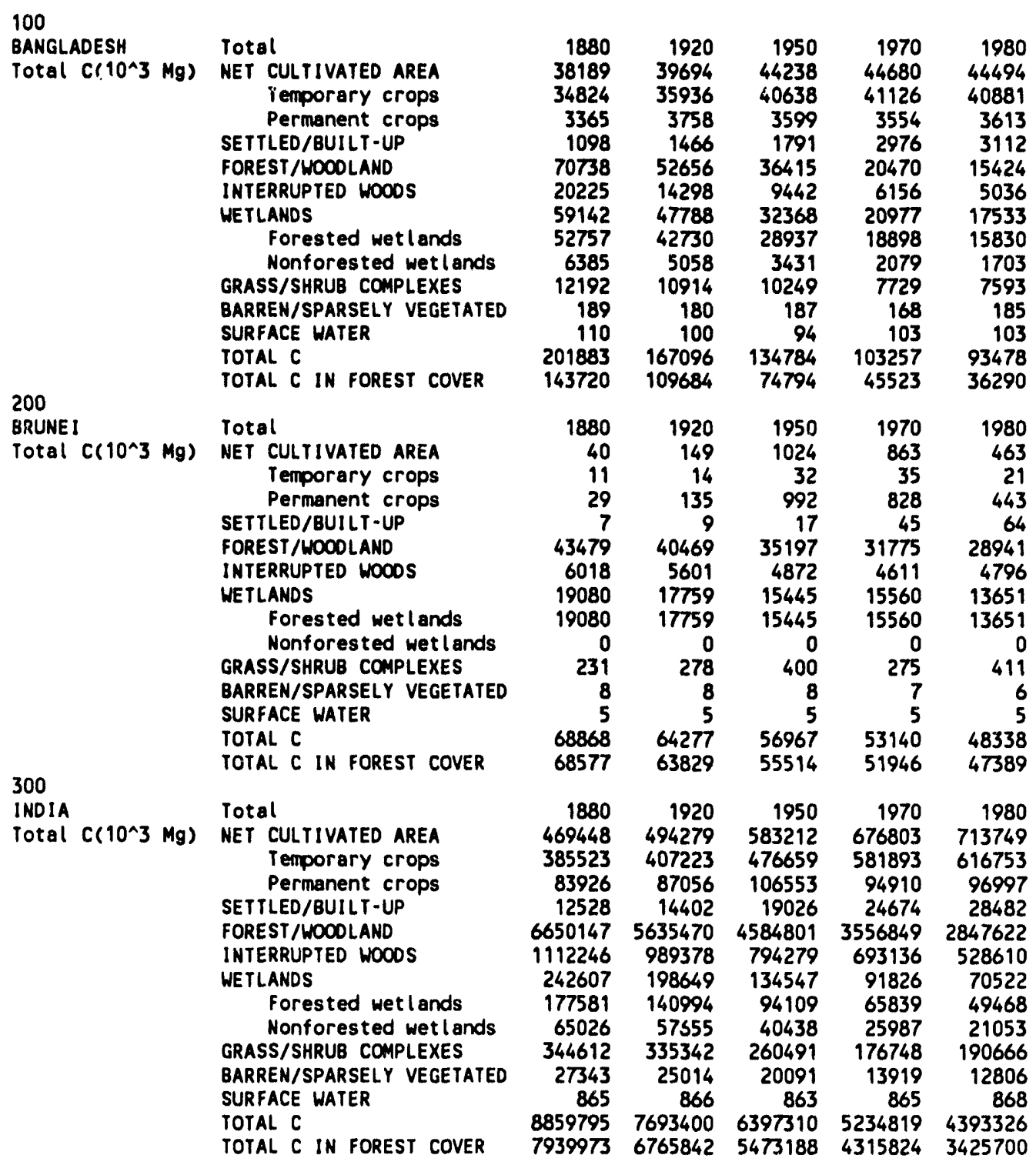




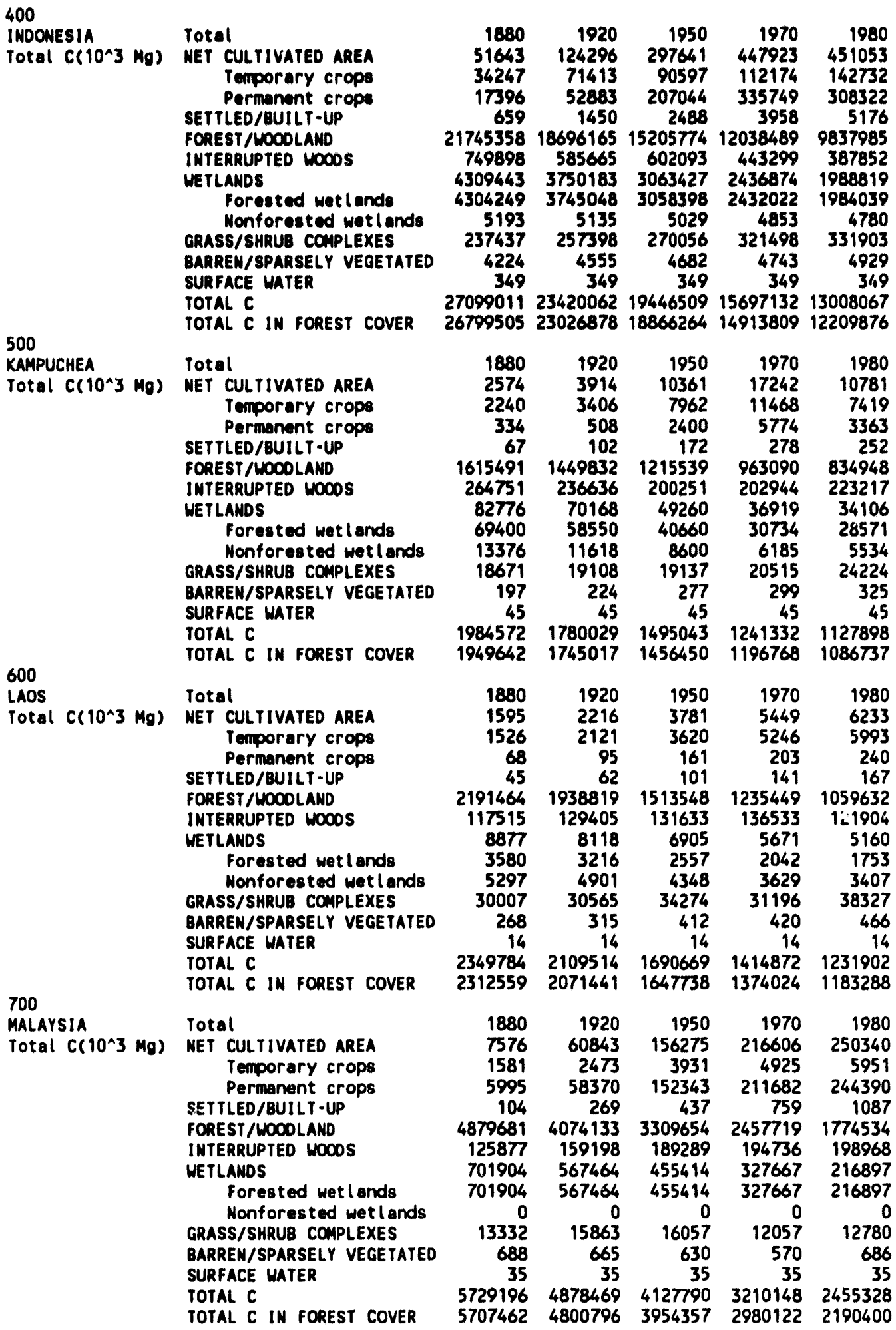


800

MYANMAR

Total $\mathrm{C}\left(10^{\wedge} 3 \mathrm{Mg}\right)$

900

$\begin{array}{ll}\text { PHILIPPINES } & \text { TOtal } \\ \text { Total C(10^3 Mg) } & \text { NET }\end{array}$

Total C(10^3 $\mathrm{Mg})$ NET CULTIVATED AREA

Temporary crops

Permanent crops

SETTLED/BUILT-UP

FOREST/LOOOLAND

INTERRUPTED WOOOS

METLANDS

Forested wetl ands

Monforested wet lands

GRASS/SHRUB COMPLEXES

BARREN/SPARSELY VEGETATED

SURFACE WATER

TOTAL C

TOTAL C IN FOREST COVER

1000

SINGAPORE TOtal

Total C(10^3 Mg) NET CULTIVATED AREA

Temporary crops

Permanent crops

SETTLED/BUILT - UP

FOREST/MOOOLANO

INTERRUPTED WOOOS

WETLANDS

Forested wet lands

Nonfores ted wet lands

GRASS/SHRUB COMPLEXES

BARREN/SPARSELY VEGETATED

SURFACE WATER

TOTAL C

TOTAL C IN FOREST COVER

1100

SR! LANKA

Total

Total $\mathrm{C}\left(10^{\wedge} 3 \mathrm{Mg}\right)$

NET

Temporary crops

Permanent crops

SETYLEO/BUILT -UP

FOREST/MOODLAND

INTERRUPTED WOOOS

METLANDS

Forested wetlands

Nonfores ted wet lands

GRASS/SHRUB COMPLEXES

BARREN/SPARSELY VEGETATEO

SURFACE WATER

TOTAL C

TOTAL C IN FOREST COVER

$\begin{array}{rr}1880 & 1920 \\ 20291 & 45737 \\ 17151 & 37230 \\ 3140 & 8527 \\ 647 & 1234 \\ 2704394 & 1947302 \\ 537332 & 436575 \\ 171787 & 105703 \\ 152997 & 92795 \\ 18790 & 12908 \\ 100897 & 122697 \\ 1695 & 1539 \\ 156 & 156 \\ 3537198 & 2660962 \\ 3394723 & 2476672\end{array}$

1950

46660

34816

11844

1854

1484388

359125

73888

63274

10613

141792

1531

156

2089393

3394723

2476672

1880
28306
8057
20249

1920

49151

13955

35196

419

3025476

159846

41613

37812

3802

55911

583

3312165

3223134

750

2525366
136965

33810

31039

2771

48524

525

2795102

2693369

1950

64945

19588

45357

1498

1878768

65679

27351

24113

3238

52183

478

2090834

1968560

$1880 \quad 1920$

$745 \quad 862$

11

734

711

711
237

237
455

448

8

46
0

2199

2199
1395

;880

9888

1728

8160

28

389774
44861

44861

2388

1049

1339

5745

75

20
52779

435684

\section{0}

$$
646
$$

24
622

852

17

440

165

253

249

4
28

28
0
0

1765

854

622
41

39
63

63
176

173

3

66

1031

275

1920

17968

2324

15644

46

340195

32802

1924

889

1035

4879

71

397905

1950

27440

2545

24895

262057

262057

22079

1970

58076

44218

13858

2787

1163288

$57958 \quad 46937$

$49157 \quad 39053$

88017884

$134033 \quad 132484$

$1416 \quad 1306$

$156 \quad 156$

$1721350 \quad 1499810$

$1516084 \quad 1292319$

1970

100726

1980

$24361 \quad 39760$

$76365 \quad 121254$

$2559 \quad 3376$

$965996 \quad 668501$

$104622 \quad 52733$

$15696 \quad 11332$

$13509 \quad 10342$

$2187 \quad 990$

$36481 \quad 33538$

$340 \quad 305$

$\begin{array}{rr}17 & 18 \\ 1226438 & 930818\end{array}$

1084127731576

$\begin{array}{rr}1970 & 1980 \\ 557 & 335 \\ 43 & 35 \\ 513 & 300 \\ 76 & 110 \\ 142 & 140 \\ 12 & 55 \\ 75 & 60 \\ 70 & 57 \\ 5 & 3 \\ 28 & 20 \\ 0 & 0 \\ 0 & 0 \\ 890 & 721 \\ 224 & 252\end{array}$

$1970 \quad 1980$

$38509 \quad 38866$

$5118 \quad 6157$

$33391 \quad 32708$

$129 \quad 361$

$156020 \quad 128924$

$31983 \quad 23189$

$\begin{array}{lll}1569 & 1287 & 1207\end{array}$

$\begin{array}{lll}695 & 616 & 579\end{array}$

$670 \quad 628$

$\begin{array}{lll}5562 & 5522 & 7487\end{array}$

$\begin{array}{lll}75 & 80 & 87\end{array}$

$\begin{array}{lll}318881 & 233550 \quad 200142\end{array}$

$\begin{array}{lll}284832 & 188619 & 152693\end{array}$

C. 5 


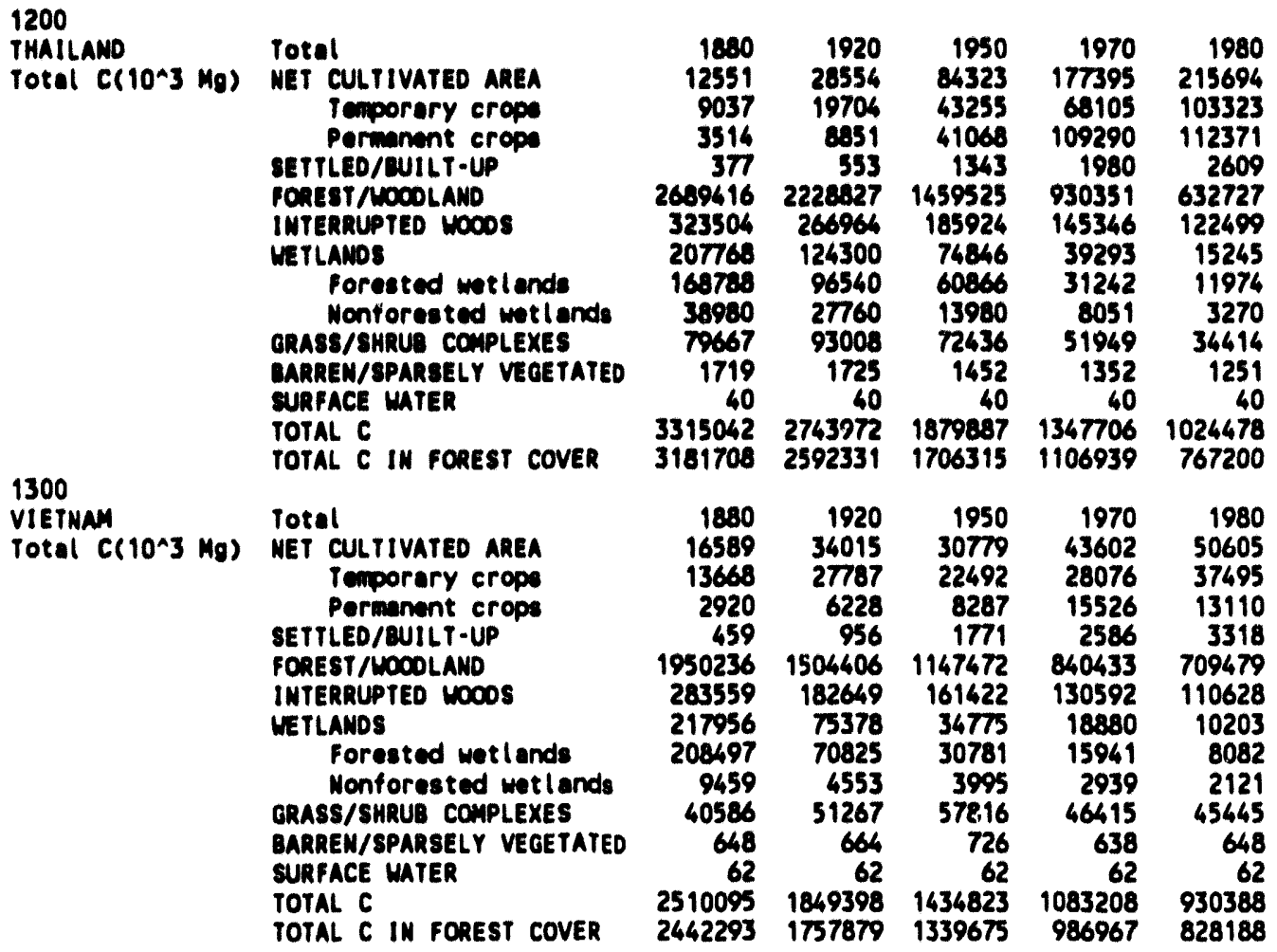




\section{APPENDIX D \\ EXPLANATORY LOTUS 1-2-3 ${ }^{\text {m }}$ SPREADSHEETS PROVIDED BY THE PRIMARY INVESTIGATORS}





\section{EXPLANATORY LOTUS $1-23^{\text {TM }}$ SPREADSHEETS PROVIDED BY THE PRIMARY INVESTIGATORS}

This appendix provides a short description for each of the 75 Lotus $1.2-3^{7 \mathrm{M}}$ WK1 files provided for documentation purposes with this NDP. These files document when and how each of the primary data sources were used to obtain the land use estimates contained in this data package. In most cases these files also describe the data sources used to obtain the livestock and human population values.

Due to the subjective nature of selecting, interpreting, and utilizing historical data, CDIAC has only conducted a cursory review of these files. Because of this, these files are being provided by CDIAC on an "as is" basis, and any questions regarding the validity of the assumptions used in these files should be directed to the primary investigators.

To allow the user to rapidly identify the documentation files, they have been named on the basis of the zone numbering system defined in Table 1, Part 1, of this document. The name

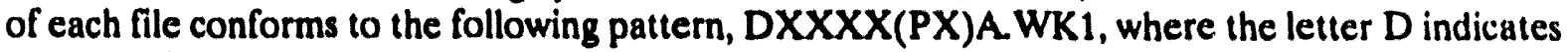
that the file is a documentation file, XXXX is the ecological zone code(s) for which the file contains data, PX is an optional postfix that is used when more than one file contains data for the same zone, and the final letter is one of the following: $S$-summary of sources, $L$-derivation of land use data, A -a union of $S$ and L, HP -summary of sources for human population data, LP -summary of sources for livestock data, and $T$-union of all summaries that fall within or below the given zone code (i.e., a national summary). For example, file D308P1S.WK1 is a summary documentation file that contains data for zone $\underline{308}$, and the file is part 1 of several files that contain information for this zone.

The following table provides a short description of each file. This description includes the file number, file name, and a short summary of the files contents. The textual description is included to assist the user in selecting pertinent files from which to obtain information on the methods and sources used in estimating the land use and population data for a given ecological zone.

File

File

File

number

name

description

33.

D101S.WK1

34. D102S.WK1
Data source listing, decadal agricultural statistics from 1880-1980, and population and settled/built-up area data for the Chittagong Hill Tracts zone and subdivisions thereof in Bangladesh.

Same as File 33, but data are for the Eastern Coast zone and subdivisions thereof in Bangladesh. 
File

File

number

name

File

description

35.

D103S.WK1

36.

D104S.WK1

37.

D105S.WK1

38.

D101L.WK1

39.

D102L.WK1

40.

41.

42.

43.
Same as File 33, but data are for the Meghna Districts zone and subdivisions thereof in Bangladesh.

Same as File 33, but data are for the Sundarbans zone and subdivisions thereof in Bangladesh.

Same as File 33, but data are for the Western Districts zone and subdivisions thereof in Bangladesh.

History of boundary changes in the zone, allocation of national land use data into the 8 land use classes used in this data base, record of modifications made to data based on secondary sources (listed) for the Chittagong Hill Tracts zone in Bangladesh.

History of boundary changes in the zone, allocation of national land use data into the 8 land use classes used in this data base for the Eastern Coast zone in Bangladesh

Same as File 39, but data are for the Meghna Districts zone in Bangladesh

Same as File 39, but data are for the Sundarbans zone in Bangladesh

Same as File 39, but data are for the Western Districts zone in Bangladesh

Data source listing for livestock, human population, and land use data; discussion of data limitations; allocation of national land use data into the 8 land use classes used in this data base for the country of Brunei. 
File

number

File

name
File

description
44.

D300T.WK1

45.

D301S.WK1

46.

D302S.WK1

47.

D303S.WK1

48.

D304S.WK1

49.

D305S.WK1

50.

D306S.WK1

51.

D307P1S.WK1

52.

D307P2S.WK1

53.

D307T.WK1
Total land use, livestock, and human population data for India as aggregated from this data base; comparison of these totals with alternate totals available from the FAO.

Data source listing for land use data; listing of livestock data by species; listing of modification assumptions used to revise official data; allocation of national land use data into the $\mathbf{8}$ land use classes used in this data base for the Andaman and Nicobar Islands zone in India (limited human population data).

Same as File 45, but data are for the Andhra Pradesh zone in India.

Same as File 45, but data are for the Arunachal Pradesh zone in India.

Same as File 45, but data are for the Assam zone in India.

Same as File 45, but data are for the Bihar zone in India.

Same as File 45, but data are for the Delhi zone in India.

Same as File 45, but data are for the Dadra and Nagar Haveli subdivisions of the Gujarat/Dadra/Nagar H. zone in India.

Same as File 45, but data are for the Gujarat subdivision of the Gujarat/Dadra/Nagar H. zone in India.

Total of the land use and population data in Files $\mathbf{5 1}$ and $\mathbf{5 2}$ for the Gujarat/ Dadra/Nagar H. zone in India. 
File File

File

number name

description

54.

D308P1S.WK1

55.

D308P2S.WK1

56.

D308T.WK1

57.

D309S.WK1

58.

D310S.WK1

59.

60.

61.

62.

63.

D315P1S.WK1

64.

D315P2S.WK1
Same as File 45, but data are for the

Chandigarh subdivision of the

Haryana/Chandigarh zone in India.

Same as File 45, but data are for the Haryana subdivision of the

Haryana/Chandigarh zone in India.

Total of the land use and population data in Files 54 and 55 for the

Haryana/Chandigarh zone in India.

Same as File 45, but data are for the Himachal Pradesh zone in India.

Same as File 45, but data are for the Jammu/Kashmir zone in India.

Same as File 45, but data are for the Karnataka zone in India.

Same as File 45 , but data are for the Kerala zone in India.

Same as File 45, but data are for the Lakshadweep Islands zone in India.

Same as File 45, but data are for the Madhya Pradesh zone in India.

Same as File 45, but data are for the Goa, Daman, and Diu subdivisions of the Maharashtra/Goa/Daman/Diu zone in India.

Same as File 45, but data are for the Maharashtra subdivision of the Maharashtra/Goa/Daman/Diu zone in India. 
File

65.

D315T.WK1

66

D316S.WK1

67.

D317S.WK1

68.

D318S.WK1

69.

70.

71.

72.

73.

74.

D324P1S.WK1

75.

D324P2S.WK1

76.

D324T.WK1
Total of the land use and population data in Files 63 and 64 for the Maharashtra/ Goa/Daman/Diu zone in India.

Same as File 45, but data are for the Manipur zone in India.

Same as File 45, but data are for the Meghalaya zone in India.

Same as File 45, but data are for the Mizoram zone in India.

Same as File 45, but data are for the Nagaland zone in India.

Same as File 45, but data are for the Orissa zone in India.

Same as File 45, but data are for the Punjab zone in India.

Same as File 45, but data are for the Rajasthan zone in India.

Same as File 45, but data are for the Sikkim zone in India.

Same as File 45, but data are for the Pondichery subdivision of the Tamil Nadu/Pondichery zone in India.

Same as File 45, but data are for the Tamil Nadu subdivision of the Tamil Nadu/Pondichery zone in India.

Total of the land use and population data in Files 74 and 75 for the Tamil Nadu/Pondichery zone in India. 
File

number
File

name
File

description
77.

D325S.WK1

78.

D326S.WK1

79.

D327S.WK1

80.

D400HP.WK1

81.

D400LP.WK1

82.

D401-7S.WK1

83.

D408-10S.WK1
Same as File 45, but data are for the Tripura zone in India.

Same as File 45, but data are for the Uttar Pradesh zone in India.

Same as File 45, but data are for the West Bengal zone in India.

Data source listing for human population data, data are presented by province when available and are then aggregated by ecological zone for the country of Indonesia.

Data source listing for livestock population data, data are presented by province when available and are then aggregated by ecological zone for the country of Indonesia.

Data source listing for land use data, listing of modification assumptions used to revise official data; allocation of national land use data into the 8 land use classes used in this data base for Aceh, North Sumatra, West Sumatra, Riau, Jambi, South Sumatra, and Bengkulu/Lampung zones in Indonesia (this file refers to several spreadsheets not distributed with this data package, when the referenced files pertain to human or livestock populations, Files 80 and 81 may be consulted to obtain equivalent background information).

Same as File 82, but data are for the West Java, Central Java, and East Java zones in Indonesia. 


$\begin{array}{llc}\text { File } & \text { File } & \text { File } \\ \text { number } & \text { name } & \begin{array}{c}\text { description } \\ \text { descion }\end{array}\end{array}$

84.

D411-14S.WK1

85.

D415-18S.WK1

86.

D419-20S.WK1

87.

D421-22S.WK1

88.

D500S.WK1

89.

D500L.WK1

90.

D600S.WK1
Same as File 82 except discussion of data sources is separated by zone due to the diversity of sources; the land use data for all zones have been summed for error checking (data are separated by zone in the primary data files); data are for the Bali, West Nusa Tenggara, East Nusa Tenggara, and East Timor zones in Indonesia.

Same as File 82, but data are for the West, Central, East, and South

Kalimantan zones in Indonesia.

Same as File 82, but data are for the North/Central and South/Southeast Sulawesi zones in Indonesia.

Same as File 82, but data are for the Maluku and Irian Jaya zones in Indonesia.

Data source listing for land use, livestock, and human population data; listing of modification assumptions used to revise official data; discussion of why population values may vary significantly by period; calculation of land use/population ratios to allow estimation of missing data for individual zones within the country of Kampuchea (Cambodia).

Allocation of national land use data into the 8 land use classes used in this data base for each ecological zone; land use allocations for each zone are based on percent ratios calculated in File 88.

Same as File 88 , but data are for the country of Laos. 
File

number
File

name
File

description
91.

D600L.WK1

92.

D701-3A.WK1

93.

D704-6A.WK1

94.

D707A.WK1

95.

D801A.WK1

96.

D802A.WK1

97.

D803A.WK1

98.

D804A.WK1
Same as File 89, but data are for the country of Laos.

Data source listing for land use data; listing of modification assumptions used to revise official data; allocation of national land use data into the 8 land use classes used in this data base for the Western Peninsular, Eastern Peninsular, and Johor zones in Malaysia.

Same as File 92, except several land use values are estimated based on human population/land use class ratios; data are for the Western, Central, and Eastern Sarawak zones in Malaysia.

Same as File 92, except a listing of the data sources used in determining human populations is included, data are for the Sabah zone in Malaysia.

Data source listing; decadal agricultural statistics for 1880-1980; and population and settled/built-up area data for the Chin/Arakan zone and subdivisions thereof in Myanmar.

Same as File 95, but data are for the Northern zone and subdivisions thereof in Myanmar.

Same as File 95, but data are for the Dry zone and subdivisions thereof in Myanmar.

Same as File 95, but data are for the Shan/Karen/Kayah zone and subdivisions thereof in Myanmar. 
File

99.

D805A.WK1

100.

D806A.WK1

101.

D900S.WK1

102.

D900L.WK1

103.

D1000A.WK1

104.

D1100A.WK1
Same as File 95, but data are for the Delta zone and subdivisions thereof in Myanmar.

Same as File 95, but data are for the Peninsular zone and subdivisions thereof in Myanmar.

Data source listing for land use, livestock, and human population data; listing of modification assumptions used to revise official data, discussion of why livestock values vary significantly by period; calculation of land use/population ratios to allow estimation of missing data for individual zones within the country of the Philippines.

Allocation of national land use data into the 8 land use classes used in this data base for each ecological zone (land use allocation for each zone is based on percent ratios calculated in File 101).

Data source listing for livestock, human population, and land use data; conversion of English to metric units; allocation of national land use data into the 8 land use classes used in this data base for the country of Singapore.

Same as Files 101 and 102, but data are for the country of Sri Lanka and subdivisions thereof. 
File

number
File

name
File

description
105.

D1200A.WK1

106.

D1300S.WK1

107.

D1300L.WK1
Data source listing for livestock, human population, and land use data (data were obtained based on the physiographic region), allocation of land use data into the 8 land use classes used in this data base for the country of Thailand and subdivisions thereof.

Data source listing for land use, livestock, and human population data, listing of assumptions used to revise official data, calculation of land use/population ratios used to estimate missing data for individual zones within the country of Vietnam.

Allocation of national land use data into the 8 land use classes used in this data base for each ecological zone; listing of assumptions used to revise the allocation of land area (allocation for each zone is based on percent ratios calculated in File 106). 
APPENDIX E

REPRINT OF PERTINENT LTERATURE 
Reprinted with permission from Canadian Journal of Forest Research

Volume 21, Number 1, January 1991

Note: The carbon and land use values shown in this article have been revised. The revised data are contained with the digital data distributed with this documentation. 


\title{
Historical analysis of changes in land use and carbon stock of vegetation in south and southeast Asia
}

\author{
Elizabeth P. Flint' \\ Deparıment of Hislory, Duke University, Durham, NC 27708, U.S.A. \\ and \\ Department of Botany, Duke University, Durham, NC 27706, U.S.A. \\ AND \\ JOHN F. RICHARDS \\ Department of History, Duke University Durham, NC 27708, U.S.A.
}

FLINT, E. P., and RICHARDS, J. F. 1991. Historical analysis of changes in land use and carbon stock of vegetation in south and southeast Asia. Can. J. For. Res. 21: 91-110.

A time series (1880, 1920, 1950, 1980) of estimates of land use and carbon content of veretation is presented for a contiguous ares of $1.7 \times 10^{6} \mathrm{~km}^{2}$ in northern India, Bangladesh, and Burma. This was developed using sequential bookkeeping models, which systematically incorporate official agricultural and forest statistics with ecological, botanical, historical, geographical, and demographic data. For 149 administrative units, aggregated into 39 ecclogical zones, we estimated area and carbon content for each of the following land-use categories: net cultivated area, settled-built-up area, forest-woodland, interrupted woods, grass-shrub complexes, barren - sparsely vegetated areas, wetlands, and surface water. Dominant patterns of land-use change were deforestation, agricultural expansion, and wetland clearance, but significant regional and temporal disparities were observed. For the entire study region, the estimated standing stock of carbon in biomass declined by $2.62 \mathrm{Gt}$ over the century. Release by periods was $911 \mathrm{Mt}$ for $1880-1920,750 \mathrm{Mt}$ for 1920-1950, and $964 \mathrm{Mt}$ for 1950-1980. Forest-woodland and interrupted woods vegetation released carbon equivalent to over $90 \%$ of the total release. Both conversion of forest to other vegetation types and reduction over time of biomass within vegetation types contributed significantly to decreases in total standing carbon stock during the period.

FLINT, E. P., et RIChards, J. F. 1991. Historical analysis of changes in land use and carbon stock of vegetation in south and southeast Asia. Can. J. For. Res. $21: 91-110$.

Les auteurs présentent une série chronologique $(1880,1920,1950,1980)$ d'estimés de l'utilisation des terres et de la teneur en carbone de la végettation pour une superficie contiguë de $1,7 \times 10^{6} \mathrm{~km}^{2}$ située dans le nord de l'Inde, au Bangla Desh et en Birmanie. Ils ont utilise pour cela des modeles sequentiels de la tenue des livies qui incorporaient systématiquement des statistiques officielles agricoles et forestieres et des donnetes ecologiques, botaniques, historiques. geographiques et démographiques. Pour les 149 unites administratives, reqrouptes en 39 zones teologiques, ils ont estimé la superficie et la teneur en carbone pour chacune des catégories d'utilisation des terres suivantes : cultures, urbanisa. tion, forêt et forêt claire, bois discontinus, herbaçaies et arbustaies, terrains sans vegetation, terrains humides et eaux libres. Les patrons dominants de changement de l'utilisation des terres étaient le déboisement, l'expansion de l'agriculture et le defrichement des terrains humides bien qu'on ait observé de fortes disparités régionales et temporelles. Pour l'ensemble de la région étudié, le contenu estimé en carbone dans la biomasse a diminué, au cours du siecle, de $2,62 \mathrm{Gt}$ La perte, par periodes, a ete de 911 Mi de 1880 a 1920 , de 750 Mi entre 1920 et 1950 et de 964 Mit entre 1950 et 1980 Les categories forèt et forèt claire et bois discontinus ont contribué à plus de $9: 0$ de la perte totale. Durant la période étudiee, ce sont et la conversion de la forèt en autres types de végétation et la réduction, dans le temps, de la biomasse des types de végétation qui ont contribué, de façon significative, a diminuet le stock total sur pied du carbone.

[Traduit par la Rédaction]

Introduction

Importance of land-use change as a contributory factor to global carbon release

The potential political and economic dislocations that may result from anthropogenic climate change lend some urgency to the task of developing a global model that can predict the timing and magnitude of future increases in global atmospheric carbon dioxide concentration (as well as changes in concentrations of other radiatively active gases, such as methane). Development of a carbon cycle model with predictive value requires an understanding of all major processes leading to the release or storage of carbon. Uncertainty concerning the magnitude, time course, causal factors, geographical localization (and in some cases the sign) of nux due to some processes still exists. A case in point is the release of carbon from biotic systems as a result of human activities. Various methods of estimating biotic carbon release have generated a total flux of the same order of

\footnotetext{
'Author to whom all correspondence should be addressed.
}

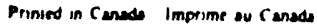

magnitude as that due to fossil-fuel combustion, but the time courses of estimated releases vary widely (91). Further information on the causes and components of carbon release from biotic systems is therefore highly desirable, particularly for tropical regions (91). It is known that transformations of land between forest and nonforest vegetation categories are responsible for a major proportion of changes in terrestrial carbon stocks, but the effects of degradation over time on carbon content within vegetation categories are also important (92). This paper presents the results of a detailed study of a century of changes in land use in south and southeast Asia and an analysis of changes in the standing stock of carbon in the vegetation of these systems from 1880 to 1980. It includes an assessment of the relative contributions of both transformation of land from one category to another and degradation within categories.

\section{The study region}

The area under consideration includes the nations of Burma and Bangladesh and the following states in northern India: Himachal Pradesh, Uttar Pradesh, Bihar, West 


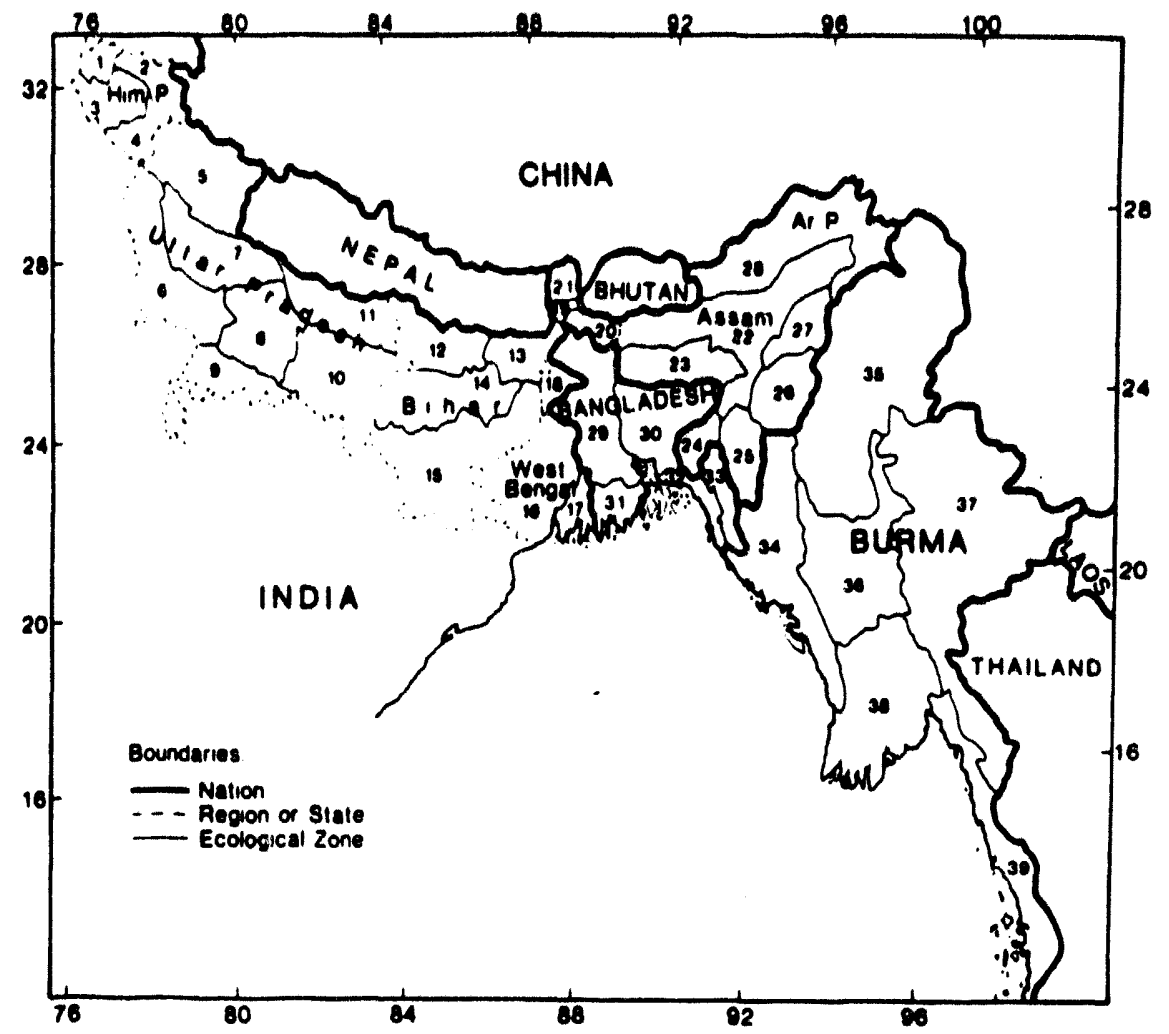

FIG. 1. Map of study area (northern India, Bangladesh, and Burma), showing relevant national boundaries, state or regional boundaries within northern India, and boundaries of the 39 ecological zones. National names are indicated in capital letrers. The larger northern Indian states (Uttar Pradesh, Bihar, West Bengal, Assam, Himachal Pradesh (Him P), and Arunachal Pradesh (Ar P)) are also identified. Each ecological zone is identified by a number; refer to Table 1 for a key to these map location numbers. The map is drawn on the same conic projection used in the physiographic and administrative south Asian maps of Schwartzberg (176).

Bengal, Sikkim, Assam, Meghalaya, Tripura, Mizoram, Manipur, Nagaland, and Arunachal Pradesh (Fig. 1, Table 1). Total area of the region is $1695 \times 10^{6} \mathrm{~km}^{2}$, amounting to $1.3 \sigma_{0}$ of the world's land surface. The study covers the cen. tury from 1880 through 1980.

The topography of this region is enormously diverse, encompassing the range from coastal lowlands to high Himalayan peaks (176). Climate in south and southeast Asia is monsoonal, dominated by moisture-laden southwesterly winds in summer and dry northeasterly winds in winter; thus precipitation in the study region is strongly seasonal (162). Mean annual precipitation ranges from below $500 \mathrm{~mm}$ in parts of Himachal Pradesh (132) to over $10000 \mathrm{~mm}$ in parts of Meghalaya $(160,216)$. Mean annual temperature varies strongly with elevation and latitude, ranging from $27^{\circ} \mathrm{C}$ (in parts of Burma, West Bengal, and Bangladesh) to below $0^{\circ} \mathrm{C}$ (above the snow line throughout the Himalayas), and there is a wide range of amplitudes of diurnal and seasonal temperature variation (175, 120, 142, 143). A wide variety of life zones (89) is represented in the region, including such extreme types as tropical rain forest, subtropical thorn woodland, and nival $(60)$. Soil types of the region include Inceptisols, Ultisols, Alfisols, Entisols, Vertisols, Aridisols, Mollisols, and Histosols (55, 32, 168, 4).

The wide range of natural vegetation types occurring in the region reflects this environmental heterogeneity (Fig. 2). Vegetation formations represented include tropical forest types (ranging from evergreen rain forest to thorn forest) and a continuum of wet to dry subtropical and temperate montane forest types, including both broad-leaved and coniferous associations. In addition, high-elevation sites support subalpine vegetation, krummholz, and wet and dry alpine tundra $(85,169,177)$.

In some portions of the study region, notably parts of Arunachal Pradesh $(114,116,185)$ and the high mountains of Burma $(119,192)$, forests still dominate the land-use pattern, and human disturbance has been limited to the operations of relatively small populations of shifting cultivators. In contrast, archaeological evidence indicates (165) that some Gangetic Plain sites in Uttar Pradesh and Bihar supported sedentary agriculture as early as the Harappan period (ca. 2500-1500 B.C.). Vegetation maps of south Asia constructed from historical sources (10) indicate that cropland had displaced forest in core areas of settlement in the Gangetic Plain before A.D. 650. Records of the Mughal period indicate further expansion of agriculture in the Gangetic Plain at the expense of tropical forest before A.D. 1600. (137). Maps reconstructed from the Ain-i-Akbari (ca. 1561-1595) indicate that at this time the extent of deforestation was considerably greater in the relatively dry upper Gangetic Plain than downriver $(10,86)$. Rice cultivation was well established at this time in the lower Gangetic Plain (corresponding to modern Bihar, West Bengal, and Bangladesh) but had not yet completely displaced the 
TABle I. List of ecological zones in study region, including key to location on map. zone area, and number of districts or divisions in zone

\begin{tabular}{|c|c|c|c|}
\hline $\begin{array}{l}\text { Key to map } \\
\text { location } \\
\text { (Fig. I) }\end{array}$ & $\begin{array}{l}\text { Ecological zone. } \\
\text { state, nation }\end{array}$ & $\begin{array}{c}\text { Area } \\
\left(10^{6} \mathrm{ha}\right)\end{array}$ & $\begin{array}{c}\text { Number of } \\
\text { districts of } \\
\text { divisions }\end{array}$ \\
\hline $\begin{array}{l}1 \\
2 \\
3 \\
4\end{array}$ & $\begin{array}{l}\text { Chamba } \\
\text { Trans-Himalaya } \\
\text { Greater Kangra } \\
\text { Greater Simia } \\
\text { Total Himachal Pradesh, India }\end{array}$ & $\begin{array}{l}0.652 \\
1.876 \\
1.860 \\
0.989 \\
5.377\end{array}$ & $\begin{array}{r}1 \\
2 \\
4 \\
3 \\
10\end{array}$ \\
\hline $\begin{array}{r}5 \\
6 \\
7 \\
8 \\
9 \\
10 \\
11\end{array}$ & $\begin{array}{l}\text { Himalayan Uttar Pradesh } \\
\text { Western Uttar Pradesh } \\
\text { West Central Ullar Pradesh } \\
\text { Central Uttar Pradesh } \\
\text { Bundelkhand } \\
\text { Southeastern Uttar Pradesh } \\
\text { Eastern Terai } \\
\text { Total Uttar Pradesh. India }\end{array}$ & $\begin{array}{r}3.337 \\
4.728 \\
3.823 \\
3.818 \\
2.946 \\
3.258 \\
3.323 \\
29.231\end{array}$ & $\begin{array}{r}8 \\
11 \\
8 \\
8 \\
4 \\
10 \\
9 \\
94\end{array}$ \\
\hline $\begin{array}{l}12 \\
13 \\
14 \\
15\end{array}$ & $\begin{array}{l}\text { Mithila Plain } \\
\text { Kosi Plain } \\
\text { Magadh-Shahabad } \\
\text { Chota Nagpur } \\
\text { Total Bihar, India }\end{array}$ & $\begin{array}{r}3.267 \\
1.690 \\
4.468 \\
7.964 \\
17.388\end{array}$ & $\begin{array}{r}4 \\
2 \\
5 \\
6 \\
17\end{array}$ \\
\hline $\begin{array}{l}16 \\
17 \\
18 \\
19 \\
20\end{array}$ & $\begin{array}{l}\text { Alluvial Plain } \\
24 \text { Parganas-Calcutta } \\
\text { Malda-W. Dinajpur } \\
\text { Darjeelins } \\
\text { West Bengal Terai } \\
\text { Total West Bengal, India }\end{array}$ & $\begin{array}{l}5.233 \\
1.471 \\
0.892 \\
0.308 \\
0.963 \\
8.866\end{array}$ & $\begin{array}{r}9 \\
1 \\
2 \\
1 \\
2 \\
15\end{array}$ \\
\hline $\begin{array}{l}21 \\
22\end{array}$ & $\begin{array}{l}\text { Sikkim, India } \\
\text { Assam, India }\end{array}$ & $\begin{array}{l}0.730 \\
7.852\end{array}$ & $\begin{array}{r}1 \\
10\end{array}$ \\
\hline $\begin{array}{l}23 \\
24 \\
25 \\
26 \\
27\end{array}$ & $\begin{array}{l}\text { Meghalaya } \\
\text { Tripura } \\
\text { Mizoram } \\
\text { Manipur } \\
\text { Nagaland } \\
\text { Total NE Hill States, India }\end{array}$ & $\begin{array}{l}2.249 \\
1.048 \\
2.109 \\
2.236 \\
1.653 \\
9.294\end{array}$ & $\begin{array}{l}1 \\
1 \\
1 \\
1 \\
1 \\
5\end{array}$ \\
\hline \multirow[t]{2}{*}{28} & Arunachal Pradesh, India & 8.358 & 5 \\
\hline & Total northern India & 87.095 & 117 \\
\hline \multirow[t]{2}{*}{$\begin{array}{l}29 \\
30 \\
31 \\
32 \\
33\end{array}$} & $\begin{array}{l}\text { Western Districts } \\
\text { Meghna Districts } \\
\text { Sundarbans } \\
\text { Coastal Bangladesh } \\
\text { Chittagong Hill Tracts }\end{array}$ & $\begin{array}{l}5.279 \\
4.441 \\
2.362 \\
1.396 \\
1.319\end{array}$ & $\begin{array}{l}8 \\
4 \\
2 \\
2 \\
1\end{array}$ \\
\hline & Total Bangladesh & 14.797 & 17 \\
\hline \multirow[t]{3}{*}{$\begin{array}{l}34 \\
35 \\
36 \\
37 \\
38 \\
39\end{array}$} & $\begin{array}{l}\text { Chin-Arakan Divisions } \\
\text { Northern Burma } \\
\text { Dry Zone } \\
\text { Shan-Karen-Kayah } \\
\text { Burma Delia } \\
\text { Tenasserim-Mon - }\end{array}$ & $\begin{array}{r}7.280 \\
18.367 \\
8.184 \\
19.791 \\
8.471 \\
5.364\end{array}$ & $\begin{array}{l}2 \\
2 \\
2 \\
4 \\
3 \\
2\end{array}$ \\
\hline & Total Burma & 67.657 & 15 \\
\hline & Total study region & 169.545 & 149 \\
\hline
\end{tabular}

Nort Zones are grouped by wate or larger region within India and we aso aseregated for each nation in the sudy region

tropical moist forest vegetation (3, 86, 166). Early Burmese records ( 11 th- 13 th centuries) indicate that population and agriculture, as in India, were concentrated in relatively dry parts of the country (205). As recently as the 19h century, some of the lowland moist forests of the Gangetic and Brahmaputra plains $(136,181,182,26)$ and the Irrawaddy

E - 5 


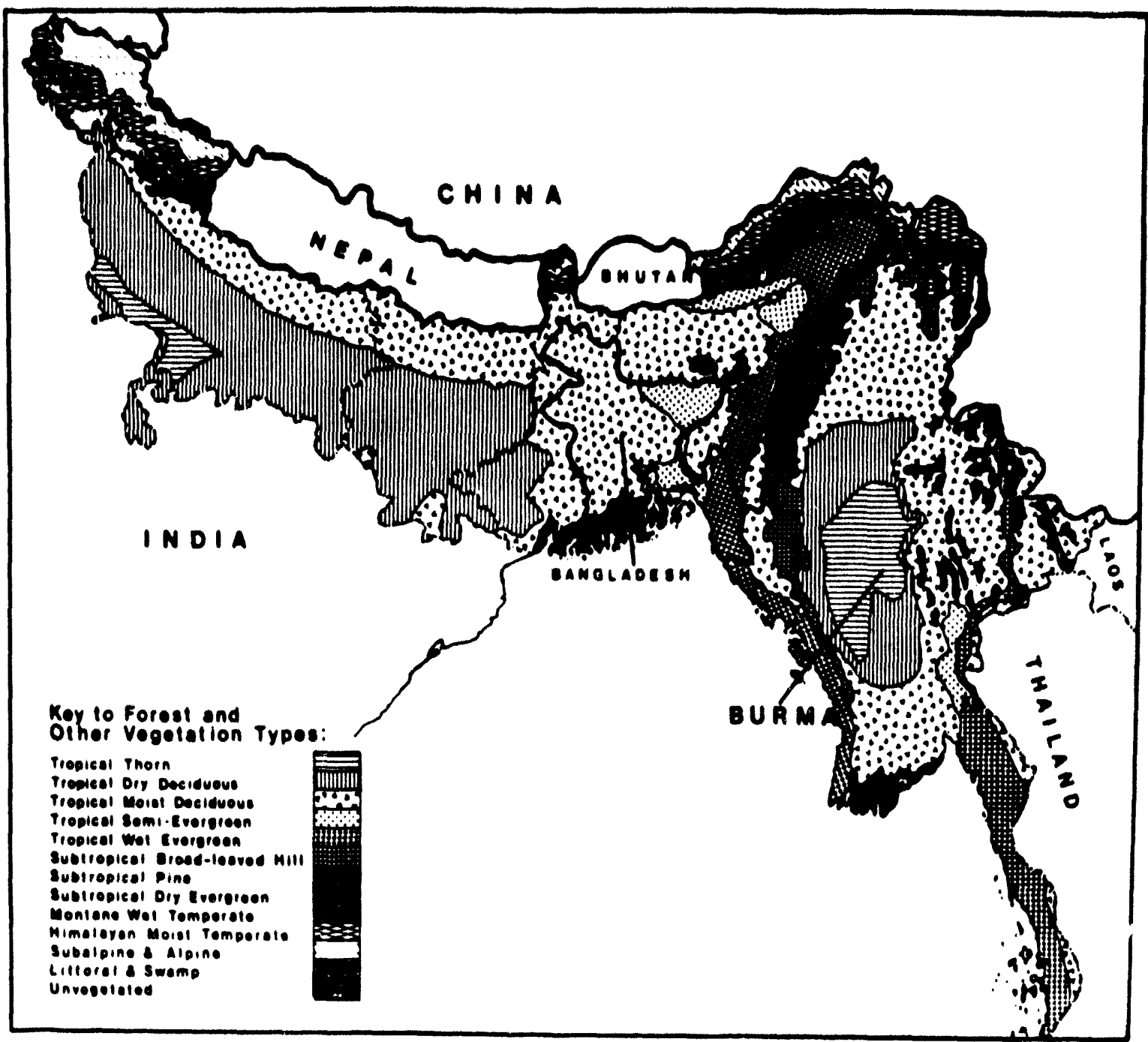

FIG 2. Map of stud: area showing its expected natural vegetation under current climalic conditions. This map uses the vegelation classification of Champion and $\operatorname{Seth}(45)$, but includes information from a number of other sources $(42,46,56,59,123,130,139,159,193)$.

Delta $(1,61)$ still represented an open frontier for the expan. sion of agriculture. Thus, our study region reflects a wide range of intensity of human use and historical experience $(4,195,5,126)$. Considerable variations in population den. sity from 1880 to 1980 at the national level can be seen in Table 2, and a much greater spread (from 0.02 to 2.82 persons/ha in 1880 and 0.05 to 9.55 persons/ha in 1980) is noted in smaller, more ecologically homogenous zones. Over the entire study region, the human population increased by $19 \%$ from 1880 to 1920 , by $38 \%$ from 1920 to 1950 , and by $93 \%$ from 1950 to 1980 .

\section{Methodology: historical sources}

The entire study area fell within the sphere of influence of the British Empire through the end of the second world war. Most of modern-day India, Bangladesh, and Burma was under direct colonial management; the remainder con. sisted of princely states subject to indirect British political control. The colonial governments, and those of the adja. cent semi-independent states, both relied on taxation of land as a major source of revenue. Careful revenue records were

$$
\text { E - } 6
$$

maintained for agricultural land, which was taxed annually at a rate proportional to its economic productivity $(7,23$, 167, 170).

Colonial governments also asserted ownership over most forest land and hired professional foresters to manage if for maximum long-term yields of timber and other forest resources $(28,171,44,212)$. During the colonial period, foresters throughout the region followed a common tradi. tion established by European foresters transplanted to south and southeast Asia in the mid $19 \mathrm{~h}$ century $(140,196-198$, 118, 21). Management practices and classification systems developed within this tradition are important components of current forest policy, not only in India (121) and Bangladesh (118), but also in social:st Burma (33). Throughout the region, the state (whether colonial or inde. pendent) has faced a conflict in land-use policy between two needs: foresi clearance for agriculture a versus foresi pres. ervation to ensure a sustained future supply of wood prod. ucts and to protect watersheds $(173,209)$.

State economic interests thus provided strong incentives for frequent cadastral and forest surveys of all but the least. 
TAale 2. Total human population and density, from 1880101980 , for each nation in the study recion

\begin{tabular}{|c|c|c|c|c|c|c|c|c|}
\hline & \multicolumn{4}{|c|}{ Total human population (millions) } & \multicolumn{4}{|c|}{$\begin{array}{l}\text { Population density } \\
\text { (persons/ha) }\end{array}$} \\
\hline & 1880 & 1920 & 1950 & 1980 & 1880 & 1920 & 1950 & 1980 \\
\hline $\begin{array}{l}\text { N. India } \\
\text { Bangladesh } \\
\text { Burma }\end{array}$ & $\begin{array}{r}90.03 \\
24.89 \\
7.59\end{array}$ & $\begin{array}{l}99.57 \\
33.43 \\
13.20\end{array}$ & $\begin{array}{r}141.30 \\
41.88 \\
18.79\end{array}$ & $\begin{array}{r}267.34 \\
86.97 \\
35.04\end{array}$ & $\begin{array}{l}1.03 \\
1.68 \\
0.11\end{array}$ & $\begin{array}{l}1.14 \\
2.26 \\
0.20\end{array}$ & $\begin{array}{l}1.62 \\
2.83 \\
0.28\end{array}$ & $\begin{array}{l}3.07 \\
3.88 \\
0.52\end{array}$ \\
\hline Total study region & 122.51 & 146.20 & 201.97 & 389.35 & 0.72 & 0.86 & 1.19 & 2.30 \\
\hline
\end{tabular}

accessible territory. Beginning in 1884, the land-use data gen. erated by such surveys were published as part of the Agricultural Statistics of British India (100). As the statistics were annually updated, increasingly large percentages of the colonial territory and the princely states were included within the reportins network $(7,101,96,97)$. This system continued throughout the colonial period for all parts of British India (16) and was maintained after independence by the newly formed governments of India, Bangladesh, and Burma (106-108, 146, 11, 13, 35, 36, 37). Thus, continuous lonsterm series of systematically collected annual land-use data are available for most of the study region.

The lowest level of resolution for these data (and therefore in our work) is the district in India and Bangladesh and the division (an asgregation of several districts) in Burma. Our data represent 134 districts (mean area $0.70 \times 10^{6} \mathrm{ha}$ ) in northern India and Bangladesh, plus is Burmese divisions (mean area $4.51 \times 10^{6} \mathrm{ha}$ ). Official land-use statistics for the entire region used the same classification system throughout the century. The total area was officially divided (16) into five major land-use categories: Net Sown (including all land in temporary or permanent crops); Fallow land; Culturable Waste (including pasture and all other land judged potentially useful for agriculture); Forest (all lands classed or administered as forest, whether state owned or private); and Not Available for Cultivation (land environmentally unsuitable for crops, like desert or tundra, land underwater, plus settled and built-up areas). Some temporal and regional variations in definitions of categories occur (e.g., adjustments of the legal definition of forest and changes in the number of years of abandonment required to shift Fallow land into the Culturable Waste class), but overall the system is surprisingly consistent.

\section{Methodology: choice of land-use categories}

The categories used for official land-use statistics were developed for administrative use and so do not accurately represent vegetation cover and carbon content of a given land area. They are not directly comparable to land-use classifications used in other parts of the world. Therefore, we developed a set of globally applicable, ecologically based, land-use classes and a system for translating information from its original format to these ecological classes. Our classification was adapted from that used by Olson et a. (144) to map carbon in world ecosystem complexes at the half-degree scale. We used eight major classes: $(i)$ net cultivated area, which is subdivided into temporary and permanent crops; (ii) settled-built-up area, which includes land under settlements, roads and railways, mines, etc; (iii) forest-woodland, which inciudes all forms of natural and plantation forest with $30 \%$ or greater crown cover (to increase the accuracy of carbon eatimates, we compiled local information on the areas of land in four subcategories: tropical moist forest, tropical dry forest, temperate broad. leaved forest, and coniferous forest); (iv) interrupted woods, which is vegetation with some arboreal component, but mean crown cover below 30\% (this category includes thorn woodland, degraded or scrub forest, bamboo, tree savanna, and related vesetation types with biumass signifi. cantly lower than that of forest-woodland; it is derived from, but not identical with, the category of the same name as defined by Olson et al. (144)); ( $v$ ) grass-shrub complexes, which include grasslands, forb communities, and shrub land; (vi) barren - sparsely vezetated class, which includes tundra, desert, semidesert scrub, and all unvegetated land (rock, sand, ice); (vii) the wetlands class, which comprises all vegetation subject to inundation by either fresh or salt water (we compile data separately within this category for herba. ceous wetlands, freshwater swamp forest, and tidal (mostly mangrove) forest); (viii) the surface water class, which comprises areas permanently underwater (rivers, estuaries, canals, lakes, irrigation tanks, etc.).

\section{Methodology: spreadsheet operation}

The logic involved in developing our time series of land. use data and carbon-stock estimates is embodied in a sequential series of modular Lotus $1.2 \cdot 3^{2}$ spreadsheets. The nowchart in Fig. 3 summarizes the construction and aggregation of spreadsheets used to evaluate land use and carbon content. Our analysis involves three sequential spread. sheets. Spreadsheet A compiles data for administrative units that represent the lowest level of ageregation. Output from one or more A spreadsheets is then fed into spreadsheet B for further analysis at a higher level of aggregation. The combination of A and B embodies our bookkeeping nodel of land use. Output of B becomes the initial input for spread.

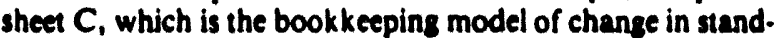
ing stock of carbon in live vegetation. Our system design allows alteration of input data at any point in the process. (The operation of the spreadsheets, briefly described in the following section, is documented in detail in a technical manuscript, forthcoming from Oak Ridge National Labo. ratories (Oak Ridze TN) in 1990.)

\section{Land-use spreadsheets}

The first step in preparation of a time series of land-use data is entry of input data into the A spreadsheet for a given district or division. Data for areas of land in each official category are drawn from the agricultural statistics series

\footnotetext{
MA.

${ }^{2}$ Registered trademark of Lotus Development Corp., Cambridge,
} 


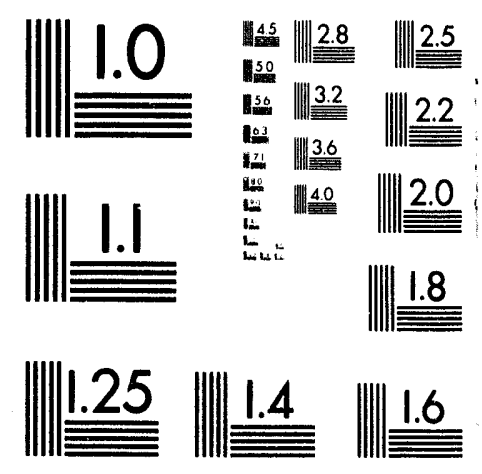



METHODOLOGY:

SEQUENCE OF 3 MODULAR SPREADSHEETS

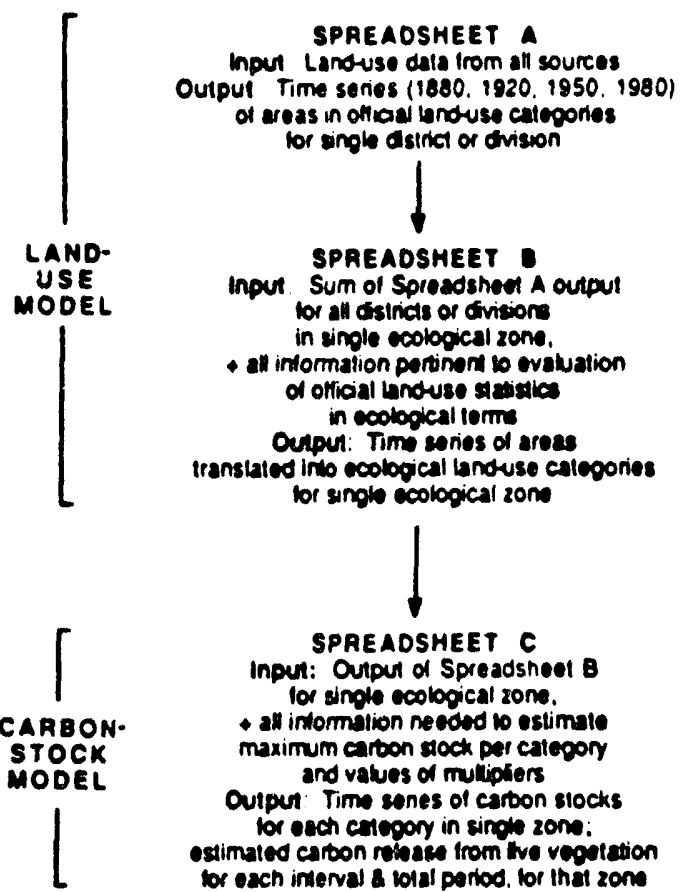

Fic. 3. Flow sheet illustrating spreadsheet methodology used in analysis of changes in land use and carbon stocks in study area.

described earlier. Missing data are supplemented by consulting revenue records, particularly settlement survey reports (e.8., 48, 113), and from regional and local gazetteers $(15,95,178)$. Typically these sources contain both landuse statistics and detailed descriptions of land in each official category. Additional information on the extent of forest cover, the condition and legal status of forests, and local vegetation types is taken from forest administration reports (18, 58, 98, 99, 115), working plans $(78,191)$, and other forestry publications $(20,33,88,102,105,125,141,210)$. Data are also drawn from a geographically indexed bibliography of over 4200 botanical, agricultural, ecological, seographical, and historical studies pertaining to land use in south Asia (62), which was prepared in conjunction with this study. We evaluate all available vegetation maps, particularly those from older forestry sources $(52,71)$ and those that indicate both vegetation types and land use $(200,22$, 73-77, 131). We also examine all available forest coverdata sets developed using remote sensing sources $(63,67,109$, 174, 214). We consult census data to determine the human population of each administrative unit at each date. Censuses in India, published decennially from 1872 through 1981 (16, 112,145 ), included Burma until 1931 and Bangladesh until 1941. (Modern population data for Burma were compiled from references 3438; for Bangladesh, from 12,14,15, and 147.) Livestock censuses $(103,104)$ and other sources $(13$, $37,213)$ provide information on livestock numbers.

Spreadsheet A automatically adjusts for missing data and boundary changes, allows manual overrides for unusual circumstances, and provides a section for documentation of these adjustments. The final spreadsheet output is a data set that allocates, for each date, 100\% of the Jistrict area to the five official administrative categories mentioned earlier. When all of the A spreadsheets for a nation are com. pleted, we aggregate the output for contiguous and ecolog. ically similar districts or divisions at the highes level of the ecological zone. Here, we aggregate data from 149 smalles administrative units into the 39 ecological zones listed in Table 1. Some zones include only a single district; others include as many as 11 . Mean areas of our ecological zones in India. Bangladesh, and Burma are $3.11 \times 10^{6}$. $2.96 \times 10^{6}$, and $11.28 \times 10^{6}$ ha, respectively.

The aggregated land-use data for an ecological zone constitute the input to spreadsheet $B$. The primary purpose of spreadsheet B is translation of the land-use data from the official categories used in spreadsheet $A$ to the ecological classes that form the basis for our estimation of carbon content. One class at a time, we allocate all land area in each administrative class to ecological categories. This conversion is made in the context of the full multidisciplinary range of sources for all districts or division in the zone. Land areas are finally summed for each ecological calegory to produce the output data set of spreadsheet B: a time series for the zone showing the areas in each ecological land-use category, for the dates 1880, 1920, 1950 and 1980.

\section{Carbon spreadsheet}

As shown in the flowchart (Fig. 3), the output of B forms the initial input for spreadsheet $C$, which embodies our carbon bookkeeping model. Operating at the level of the ecological zone, spreadsheet $C$ standardizes the process of estimation of carbon content in live vezetation in each ecological category at each date. Use of this spreadsheet requires examination of all biomass data applicable to each ecologi. cal category for vegetation from all locations comparable to the ecolezical zone under consideration. In addition to the global forest biomass reviews of Cannell $(39,40)$, which contain considerable quantities of south and southeast Asian data, we found the following south and southeast Asian sources particularly useful: $54,158,164,189$, and 202 for forests; $33,187,188$, and 215 for grasslands and savanna; 79 and 80 for wetlands; 133, 160, 203, and 204 for successional vegetation in tropical moist forests; 64,65 , and 135 for cropland. (Additional literature on biomass of south Asian vegetation used in developing our analyses, 100 extensive to cite in this publication, can be accessed using the indexed bibliography (62) of Flint and Richards.) Carbon values are used directly when available (e.8., 190), but generally must be calculated from biomass, using a $50 \%$ conversion factor (29).

Almost all direct measurements of vegetation biomass and carbon content are modern. Thesefore, estimation of carbon content of vegetation at earlier dates requires systematic evaluation of all quantitative and descriptive information relevant to assessment of factors that influenced the actual carbon stock at each date within the zone. (Particularly important is time-specific information pertaining to forest volume.) Formulas built into spreadsheet $\mathrm{C}$ standardize the procedure for estimation of carbon content (t/ha) for each ecological land-use category at each date. Then the land area of each category (ha) is multiplied by the carbon content (t/ha) to calculate total carbon stock for the category. Output of spreadsheet $C$ includes both the area and the estimated carbon content for each land-use category as of 
1880, 1920, 1950, and 1980. Spreadsheet $C$ also calculates carbon release or uptake, for each category and for the total area, for intervals between each successive pair of dates, and for the entire century.

We estimate carbon release from live vegetation in this model as the difference in total carbon content between two given dates. Our bookkeeping model does not assess the partitioning of carbon into various decay pools, and therefore does not directly address the time course of the release. It calculates carbon stuck at each point in time for each ecological category in the zone, using [1].

Method for time-specific estimation of carbon content in vegetation of each ecological category

To estimate the actual carbon stock per hectare (CPH) for a single category at one point in time, we use the formula

\section{[1] $\mathrm{CPH}=M(E D)$}

where $M$ is the maximum carbon stock (t/ha) in live vegetation theoretically possible under optimal conditions and $E$ and $D$ are fractional multipliers that quantify the estimated reduction of $M$ by abiotic and biotic factors, respectively.

$\boldsymbol{M}$ is estimated for each ecological category, for a relatively large area (often several ecological zones), after compiling all applicable biomass data for undisturbed vegetation in the class. It represents the maximum carbon content (t/ha) of undisturbed live vegetation in that class, under optimal conditions, that would be expected for a substantial area. $M$ values for forest-woodland are generally consistent in magnitude with biomass extrapolated from volume data from mature, undisturbed stands of major commercial species on top-quality sites. Although all published forest biomass data are considered in the estimation of forestwoodland $M$ values, we avoid overreliance on isolated instances of extremely high biomass representing extreme outliers of the total forested area.

$E$, the environmental limitation multiplier, expresses the degree to which abiotic factors (climate, soil chemistry and structure, topography, etc.) reduce carbon content below the maximum value, $M$. For woody vegetation, we developed a set of multipliers based on the strong correlations between forest site quality and yield. Site quality was an important variable used by south Asian foresters in their construction of yield tables that predict crop volume from top height of trees at given stand ages $(196-198,121)$. Their procedures applied the traditional European methods (8) to tropical forests and involved similar assumptions concerning the strong dependency of crop volume in even-aged stands upon site quality. For each species of commercial value, site-quality curves were constructed that allowed professional foresters to assess site quality of local stands on a relative scale from I (the best) to $V$ (the worst, generally not commercially exploitable) and therefort to predict the merchantable volume of those stands without immediate harvest. Using the methodology of Brown et al. (29-31), we developed tables quantifying the relationship between site quality and predicted biomass of mature stands for most of the major commercial species (broadleaf and conifer) in the region. To prepare these, we used volume data in yield and stand tables published for commercial species of the study region by S. H. Howard (1921-1926), H. G. Champion et al. (1929-1934), I. D. Mahendru (1932-1933), S. K. Seth et al. (1957-1960), S. N. Dabral et al. (1960-1969), A. N.
Chaturvedi et al. (1971-1980), R. P. Sharma et al. (1977-1981), and S. P. Singh et al. (1979-1985). (Refer to Flint and Richards (62) for citations.) We then applied data on specific gravity of each species $(49,50,69,124,152,156$ $157,163)$ and information on biomass partitioning and expansion factors $(29-31,39,40,54,117,134,189)$ to extrapolate biomass from volume. A survey of our completed tables indicated that estimated stand biomass of each site quality, expressed as percentages of the quality I biomass, ranged from $70-80 \%$ for quality II; $40-60 \%$ (generally about $50 \%$ ) for quality III; $30-40 \%$ for quality IV; and $20 \%$ or less for quality $V$. The ranges of percentages indicate the extent of interspecific and regional variation in the relative volumes expected from the lower site quality classes.

Especially for early dates, location-specific site-quality estimates (e.g., 41, 207) are our best surrogate for firsthand measurements of forest biomass. For common and gregarious species like sal (Shorea robusta Gaertn. f.) and chir pine (Pinus longifolia Roxb.), site-quality estimates based on performance of single speries are often applicable to relatively large areas. Some forestry sources also assign overall sitequality ratings to mixed-species forests. In either situation, the site-quality rating effectively integrates the abiotic environmental factors that affect biomass accumulation. We estimate site quality for forests lacking such data by comparing all forest vegetation descriptions (particularly those including height, girth, and density estimates) and environmental data (precipitation, temperature, soil type, etc.) with equivalent information available for the nearest comparable sites for which site quality has been officially assessed. A wide selection of such descriptions is available (e.8., 17, 24, $25,81,154,180,183,206$; see 62 for further references).

Data from working plans indicate the mean site quality, even in the best state-controlled forests, seldom exceeds quality III, and top-quality forest rarely exceeds 1 or $2 \% 0$ of the total (191). As a result, our environmental limitation multiplier for the forest of an entire zone typically reduces estimated carbon content to $50 \%$ or less of the regional maximum, $M$, even before factoring in the degradation multiplier.

Site-quality classes are not applicable to nonwoody vegetation, so our environmental limitation multiplier for other vegetation is based primarily on relationships between mean annual rainfall and biomass of herbaceous communities, as documented in the regional literature $(187,53,215)$.

$D$, the degradation multiplier, expresses the extent of reduction in carbon content due to biomass removal by humans and livestock. For each zone, degradation multipliers for woody vegetation are based on the density of humans, who are directly responsible for most wood removal. (It is of interest here to note that one authority estimates that $90 \%$ of the wood taken from Indian forests ca. 1980 is firewood (27), with all other uses relegated to the remaining 10\%.) Magnitude of multipliers was empirically derived from published comparisons of biomass in undisturbed forest and forest degraded by human activity of various types and intensities $(63,67,189,204)$. Our overall biomass estimates at the regional scale were cross-checked against published local (e.8., 83), regional $(20,210,68,185)$, and national estimates of commercial and noncommercial volume of various forest types $(66,67)$.

For nonwocidy vegetation, virtually all of which is grazed, our degradation multipliers reflect livestock density per hect- 
TABLE 3. Area of each major land-use calegory, from 1880 to 1980. for the study region (northern India, Bangladesh, and Burma)

\begin{tabular}{|c|c|c|c|c|}
\hline \multirow[b]{2}{*}{ Land-use category } & \multicolumn{4}{|c|}{ Area $\left(10^{6}\right.$ ha $)$ of each category } \\
\hline & 1880 & 1920 & 1950 & 1980 \\
\hline $\begin{array}{l}\text { Net cultivated area } \\
\text { Temporary crops } \\
\text { Permanent crops } \\
\text { Settled-buile-up area } \\
\text { Forest-woodland } \\
\text { Interrupted woods } \\
\text { Grass-shrub complexes } \\
\text { Barren - sparsely vegetated } \\
\text { Wetlands } \\
\text { Surface water }\end{array}$ & $\begin{array}{r}38.72 \\
1.62 \\
1.81 \\
47.30 \\
34.06 \\
25.67 \\
7.76 \\
6.75 \\
5.86\end{array}$ & $\begin{array}{r}42.97 \\
41.03 \\
1.94 \\
2.26 \\
40.99 \\
31.88 \\
31.97 \\
7.99 \\
5.72 \\
5.76\end{array}$ & $\begin{array}{r}47.77 \\
45.55 \\
2.22 \\
3.03 \\
36.34 \\
30.70 \\
33.47 \\
8.00 \\
4.58 \\
5.64\end{array}$ & $\begin{array}{r}53.55 \\
51.05 \\
2.50 \\
5.29 \\
30.00 \\
28.41 \\
34.89 \\
7.81 \\
3.40 \\
5.73\end{array}$ \\
\hline Total area & 169.95 & 169.55 & 169.55 & 169.55 \\
\hline
\end{tabular}

are of natural vegetation. Their magnitude is based or regional literature relating vegetation biomass to grazing pressure $(53,188)$.

The system ersployed here to analyze land use and carbon stock of vegetation in south and southeast Asia can be extended to other world regions. The ecological categories are globally applicable. The bookkeeping approach adjusts readily to any choice of time periods or divisions of area. Context-sensitive use of both statistical and narrative data from many sources is facilitated by the procedures for systematic input and translation of data. Most importantly, the hierarchical, summed data sets lend themselves to a continuing process of refinement and correction.

\section{Results and discussion}

\section{Changes in land use}

Table 3 summarizes the area of land in each major ecological category in 1880,1920,1950, and 1980, for the entire study region. In terms of the area affected, the most important change in land use was deforestation, i.e., the conversion of land originally classified as either forest-woodland or interrupted woods to categories of lower biomass. Over $37 \%$ of the area bearing forest-woodland vegetation in 1880 (equivalent to $10 \%$ of the entire study area), plus $17 \%$ of the interrupted woods, was converted to vegetation types of lower biomass. Much, but not all, of this loss was associated with a second imfrortart trend, the 33\% expansion of net cultivateo area. Also notable was a $50 \%$ reduction in the area occupied by vegetation in the wetland categories. Forest not replaced by cropland or settled area (which increased by $193 \%$ ) tended to degrade to the category of grass-shrub complexes, which increased in area by $36 \%$. The area classified as barren - sparsely vegetated showed little change.

The rates of these changes were not constant among the three intervals 1880-1920,1920-1950, and 1950-1980. For examp 'e, reduction in forest-woodland occurred at an average rat of $15000-16000 \mathrm{~km}^{2} /$ decade through 1950 , accelerating thereafter to $21100 \mathrm{~km}^{2} /$ decade. Cultivated area increased relatively slowly $\left(6600 \mathrm{~km}^{2} /\right.$ decade) before 1920 and more rapidly thereafter (16 000 and $19300 \mathrm{~km}^{2} /$ decade for the intervals 1920-1950 and 1950-1980, respectively). However, arable expansion cannot be maintained at these rates, because most of the available land that can support agriculture is already in crops. The wetlands depletion rate. which averaged $2100 \mathrm{~km}^{2} /$ decade in the first interval, rose to 3800 and then $3900 \mathrm{~km}^{2} /$ decade during the nexi two intervals.

\section{Changes in carbon content of vegetation at the level of the entire study region}

Table 4 shows changes in the total carbon stock of the study area from 1880 to 1980 . Carbon content of live vegetation dropped progressively throughout the century. From 1880 to 1980, for the entire $1.7 \times 10^{6} \mathrm{~km}^{2}$ study area, we estimate that carbon release from live vegetation totaled $2.63 \mathrm{Gt}$. This represents a $43 \%$ depletion of the estimated 1880 carbon stock. Carbon release in each interval was considerable: $911 \mathrm{Mt}$ from 1880 to $1920,750 \mathrm{Mt}$ from 1920 to 1950, and $964 \mathrm{Mi}$ from 1950 to 1980. The rate of release, expressed in average values per decade, increased in each succeeding interval: from 228 to 250 to $321 \mathrm{Mt} /$ decade.

The forest-woodland class contained more carbon than all other categories combined, but the proportion of total carbon in this class progressively declined throughout the century, from $73 \%$ in 1880 to $63 \%$ in 1980 (Table 5). This was due to both contraction of forest-woodland area (from 28 to $18 \%$ of the regional total) and reduction of its mean carbon stock (from 94 to $74 \mathrm{t} / \mathrm{ha}$ ). The percentage of total carbon in wetlands also decreased. Proportions of the total carbon in the cultivated, interrupted woods, and grass-shrub categories increased.

The overall carbon release had two major components: (i) transfer of area from classes of high to classes of lower biomass and (ii) reduction in the mean biomass of vegetation within classes (carbon content of course directly followed the biomass $t r$.nds). We compared the relative importance of changes between and within categories in the carbon release estimates by running the carbon-stock bookkeeping model at the level of the study area with two different assumptions

If we assume that carbon content per hectare remained stable within each ecological category at the 1880 value, and the degradation multiplier is held constant, the estimated total carbon release from 1880 to 1980 is $1.8 \mathrm{Gt}$. But when we assume that reduction of carbon content within categories occurred in synchrony with increases in human or livestock density and we apply successively smaller degradation multipliers at later dates, the estimated carbon release rises to $2.6 \mathrm{G}$ t for the century. Thus, the adjustments associated with degradation within categories increased our estimated carbon release by $49 \%$.

Figure 4 illustrates, for the entire study area, the pattern of carbon release and uptake by category. In every inter$\mathrm{val}$, the forest-woodland class lost the most carbon. Carbon lost from this class (Table 6) equaled $85 \%$ of the total release for the century. Smaller, but still significant, quantities of carbon were released from vegetation in the interrupted woods and wetland categories. There was little net change in carbon stock of grass-shrub vegetation, as early uptake was offiset by later release. Change in carbon content of the barren - sparsely vegetated category was minimal. The limited carbon uptake that occurred was concentrated in cultivated and settled classes, and three-quarters of it was associated with expansion of the area in temporary crops.

It is important to recognize that even by 1880 human activ-

$$
\text { E - } 10
$$


TABLE 4. Estimated carbon content of vegetation in each land-use category, from 1880 to 1980 , for the study region

\begin{tabular}{lrrrr}
\hline & \multicolumn{4}{c}{ Estimated carbon content of vegetation (Mt) } \\
\cline { 2 - 5 } \multicolumn{1}{c}{ Land-use category } & \multicolumn{1}{c}{1880} & 1920 & \multicolumn{1}{c}{1950} & \multicolumn{1}{c}{1980} \\
\hline Net cultivated area & 252.9 & 286.2 & 320.2 & 365.4 \\
Temporary crops & 227.0 & 253.5 & $28 C .9$ & 319.7 \\
Permanent crops & 25.9 & 32.7 & 39.3 & 45.7 \\
Setlled-buili-up area & 4.6 & 6.0 & 8.3 & 14.0 \\
Forest-woodland & 4435.4 & 3654.8 & 3021.4 & 2209.6 \\
Interrupted woods & 839.5 & 729.9 & 657.5 & 546.2 \\
Grass-shrub complexes & 221.1 & 258.3 & 253.5 & 232.3 \\
Barren - sparsely vegetated & 8.7 & 8.1 & 7.0 & 5.9 \\
Wetlands & 354.4 & 257.6 & 182.7 & 112.8 \\
Surface water & 0.6 & 0.6 & 0.6 & 0.6 \\
Total all categories & 6113.1 & 5201.6 & 4451.1 & 3486.8 \\
\hline
\end{tabular}

TABLE S. Changes in percentages of total carbon in vegetation of each land-use category, from 1880 to 1980 , for the study region

\begin{tabular}{lrrrr}
\hline & \multicolumn{4}{c}{ Percentage of total carbon } \\
\cline { 2 - 5 } \multicolumn{1}{c}{ Land-use category } & \multicolumn{1}{c}{1880} & \multicolumn{1}{c}{1920} & 1950 & 1980 \\
\hline Net cultivated area & 4.1 & 5.5 & 7.2 & 10.5 \\
Temporary crops & 3.7 & 4.9 & 6.3 & 9.2 \\
Permanent crops & 0.4 & 0.6 & 0.9 & 1.3 \\
Settled-built-up area & 0.1 & 0.1 & 0.2 & 0.4 \\
Forest-woodland & 72.6 & 70.3 & 67.9 & 63.4 \\
Interrupted woods & 13.7 & 14.0 & 14.8 & 15.7 \\
Grass-shrub complexes & 3.6 & 5.0 & 5.7 & 6.7 \\
Barren - sparsely vegetated & 0.1 & 0.2 & 0.2 & 0.2 \\
Wetlands & 5.8 & 5.0 & 4.1 & 3.2 \\
Surface water & 0.0 & 0.0 & 0.0 & 0.0 \\
Total all categories & 100.0 & 100.0 & 100.0 & 100.0 \\
\hline
\end{tabular}

ity had reduced both forest cover and biomass in the study region. Even at this point in time the proportion of the region bearing forest-woodland vegetation was clearly lower than the total area potentially capable (Fig. 2) of supporting climax forest vegetation in the absence of human activ. ity. Many forests had been converted to agricultural land. In addition, much land still officially described as forest as of 1880 bore vegetation in which the arboreal component was discontinuous, depauperate, or absent. We allocated such land to the interrupted woods and even grass-shrub complexes. Thus, our 1880 estimate of forest-woodland cover for the region does not represent a predisturbance state. Furthermore, careful scrutiny of a wide variety of historical sources indicates that much of the vegetation that met our criteria for classification as forest-woodland in 1880 was also significantly degraded. This is reflected in the relatively low estimate of initial carbon content of the vegetation in the forest-woodland class. For most of south and southeast Asia, a predisturbance or pristine landscape did not exist in the 19 th century. Therefore, assumptions that preindustrial forests bore climax vegetation of high carbon content should be modified for south and southeast Asia, and reevaluated for every world region.

Regional comparisons

At present, $51 \%$ of the study area is in northern India, $9 \%$ in Bangladesh, and $40 \%$ in Burma. Neither the present

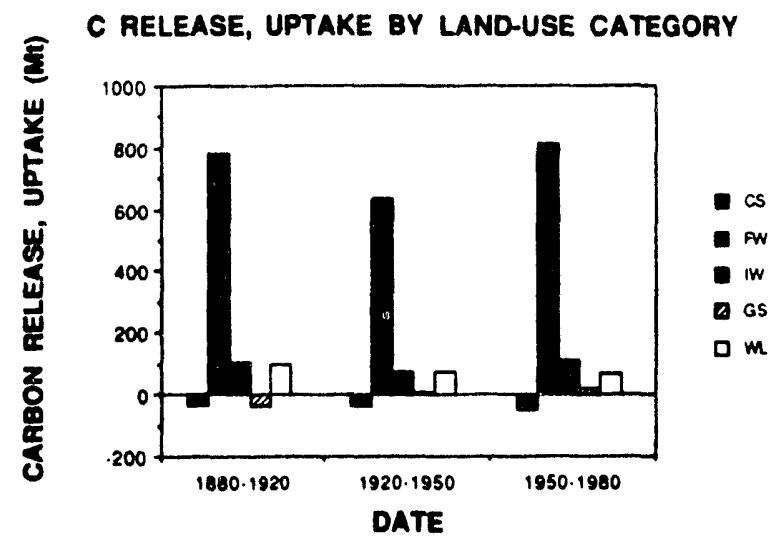

Fig. 4. Graph illustrating carbon release and uptake in the study area, during each of three time intervals, for five land-use categories. Each bar represents carbon release or uptake $(M t)$ in one land-use category during one interval. Bars extending above the zero line represent carton release: bars extending belou it shnu uptake. Key 10 bars: CS, cultivated or settled; FW, torestwoodland; iW: interrupted woods; GS, grass-shrub complexes; WL, wellands. Net changes in the barren - sparsely vegetated and surface water categories were too small to register on the graph, so they have been omitied.

nor the past distributions of the various land-use categories among the three nations are directly proportional to their overall areal representation in the study area. Most categories are very disproportionately distributed among nations. For example, throughout the century, close to $60 \%$ of the total forest-woodland (Table 7) was in Burma, and less than $2 \%$ in Bangladesh. In contrast, $29 \%$ of total wetland area occurs in Bangladesh. Differences in proportions of total cultivated and settled area among the three nations reflect their differing national histories and population densities. Population density (persons/ha) in 1980 for Bangladesh was 5.9; for northern India, 3.1; for Burma, 0.5. As of 1980, the area of cultivated land in Bangladesh was still slightly higher than that of Burma, which is more than four times its size.

Accordingly, total carbon stocks of the three nations have never been proportional to their share of the area (Table 8). Over the entire century, about half the total carbon content of veretation in the study area has been located in

$$
\text { E - } 11
$$


TABLE 6. Estimated carbon release (negative values) and uptake (positive values) for each land-use category during three intervals, and for total period, for the study region

\begin{tabular}{|c|c|c|c|c|c|c|c|c|}
\hline \multirow[b]{2}{*}{ Land-use category } & \multicolumn{4}{|c|}{ Total carbon release and uptake $(\mathrm{M})$} & \multicolumn{4}{|c|}{ \% carbon release and uptake* } \\
\hline & $\begin{array}{l}1880 \\
1920\end{array}$ & $\begin{array}{l}1920 \\
1950\end{array}$ & $\begin{array}{l}1950- \\
1980\end{array}$ & $\begin{array}{c}1880- \\
1980\end{array}$ & $\begin{array}{c}1880- \\
1920\end{array}$ & $\begin{array}{c}1920- \\
1950\end{array}$ & $\begin{array}{l}1950- \\
1980\end{array}$ & $\begin{array}{c}1880- \\
1980\end{array}$ \\
\hline $\begin{array}{l}\text { Net cultivated area } \\
\text { Temporary crops } \\
\text { Permanent crops } \\
\text { Settled, built-up area } \\
\text { Forest-woodland } \\
\text { Interrupted woods } \\
\text { Grass-shrub complexes } \\
\text { Barren - sparsely vegetated } \\
\text { Wetlands } \\
\text { Surface water }\end{array}$ & $\begin{array}{r}33.4 \\
26.6 \\
6.8 \\
1.5 \\
-780.6 \\
-105.6 \\
37.2 \\
-0.5 \\
-96.9 \\
0.0\end{array}$ & $\begin{array}{r}34.0 \\
27.3 \\
6.6 \\
2.3 \\
-633.5 \\
-72.4 \\
-4.8 \\
-1.2 \\
-74.9 \\
0.0\end{array}$ & $\begin{array}{r}45.1 \\
38.8 \\
6.3 \\
3.7 \\
-811.8 \\
-111.3 \\
-21.2 \\
-1.0 \\
-69.9 \\
0.0\end{array}$ & $\begin{array}{r}112.5 \\
92.7 \\
19.8 \\
9.4 \\
-2225.8 \\
-289.3 \\
11.2 \\
-2.7 \\
-241.6 \\
0.0\end{array}$ & $\begin{array}{r}3.7 \\
2.9 \\
0.7 \\
0.2 \\
-85.6 \\
-11.6 \\
4.1 \\
-0.1 \\
-10.6 \\
0.0\end{array}$ & $\begin{array}{r}4.5 \\
3.6 \\
0.9 \\
0.3 \\
-84.4 \\
-9.7 \\
-0.6 \\
-0.2 \\
-10.0 \\
0.0\end{array}$ & $\begin{array}{r}4.7 \\
4.0 \\
0.7 \\
0.6 \\
-84.2 \\
-11.5 \\
-2.2 \\
-0.1 \\
-7.2 \\
0.0\end{array}$ & $\begin{array}{r}4.3 \\
3.5 \\
0.8 \\
0.4 \\
-84.8 \\
-11.0 \\
0.4 \\
-0.1 \\
-9.2 \\
0.0\end{array}$ \\
\hline Total all calegories & -911.5 & -750.5 & -964.4 & -2626.3 & -100.0 & -100.0 & -100.0 & -100.0 \\
\hline
\end{tabular}

TABLE 7. Percentages of total area in selected land-use categories, from 1880 10 1980, in each nation in the study region, compared with percentage of the rotal study region represented by each nation

\begin{tabular}{|c|c|c|c|c|c|c|c|c|c|c|c|c|c|}
\hline & \multirow{2}{*}{$\begin{array}{l}\text { Area of } \\
\text { nation as \% of } \\
\text { regional total }\end{array}$} & \multicolumn{4}{|c|}{$\begin{array}{l}\% \text { of total forest-woodland } \\
\text { area }\end{array}$} & \multicolumn{4}{|c|}{$\begin{array}{l}\text { \% of tota! cultivated + } \\
\text { setiled area }\end{array}$} & \multicolumn{4}{|c|}{$\%$ of total wetland area } \\
\hline & & 1880 & 1920 & 1950 & 1980 & 1880 & 1920 & 1950 & 1980 & 1880 & 1920 & 1950 & 1980 \\
\hline $\begin{array}{l}\text { N. India } \\
\text { Bangladesh } \\
\text { Burma }\end{array}$ & $\begin{array}{r}51.4 \\
8.7 \\
39.9\end{array}$ & $\begin{array}{r}40.6 \\
1.4 \\
58.0\end{array}$ & $\begin{array}{r}42.2 \\
1.3 \\
56.5\end{array}$ & $\begin{array}{r}41.3 \\
1.3 \\
57.4\end{array}$ & $\begin{array}{r}38.3 \\
1.0 \\
60.7\end{array}$ & $\begin{array}{r}74.8 \\
17.8 \\
7.4\end{array}$ & $\begin{array}{l}67.8 \\
17.3 \\
14.9\end{array}$ & $\begin{array}{l}69.6 \\
17.5 \\
12.9\end{array}$ & $\begin{array}{l}68.8 \\
15.7 \\
15.5\end{array}$ & $\begin{array}{l}33.0 \\
25.8 \\
41.2\end{array}$ & $\begin{array}{l}36.6 \\
29.4 \\
34.0\end{array}$ & $\begin{array}{l}37.7 \\
28.2 \\
34.1\end{array}$ & $\begin{array}{l}35.6 \\
29.0 \\
35.4\end{array}$ \\
\hline Total study region & 100.0 & 100.0 & 100.0 & 100.0 & 100.0 & 100.0 & 100.0 & 100.0 & 100.0 & 100.0 & 100.0 & 100.0 & 100.0 \\
\hline
\end{tabular}

Burma. This is consistent with the high representation of forest-woodland (the category with highest mean carbon content) in that country. India has been slightly under. represented, and Bangladesh deficient in carbon stock.

Each nation's paltern of carbon release and uptake over time has been distinctive (Table 9). In Burma, the highest rate of carbon release occurred in the first interval, with a drop-off after 1920. Carbon released from the forestwoodland class amounted $1087 \%$ of the total. Two factors contributed to the release: a $33 \%$ reduction in forestwoodland area and reduction of carbon content within the category from an estimated $84 \mathrm{t} / \mathrm{ha}$ in 1880 to $66 \mathrm{t} / \mathrm{ha}$ in 1980. These estimates may seem low, but the zones in Burma with rainfall sufficient to support high rain forest were significantly degraded before 1880 . The Tenasserim dipterocarp forests (93) were significantly damaged by commercial extraction of teak before $1850(196)$; while those of Arakan include much secondary growth due to long-term shifting cultivation $(179,193)$. The remainder of the carbon release in Burma came from interrupted woods and wetlands vegetation, both of which also showed significant reductions in area and carbon content per hectare. The modest carbon uptake was limited to the cultivated and grass-shrub classes. Total carbon release from Burma for the century is estimated as $1.28 \mathrm{Gt}$. A recent estimate (92) of the 1980 release from Burma suggests that the rate of carbon release from this nation continues to increase.

Bangladesh, with carbon release less than a tenth of Burma's $(0.10 \mathrm{Gt})$, showed a different pattern of carbon stock dynamics. The mean rate of release per decade increased in each succeeding interval. Wetland vegetation accounted for $47 \%$ of the total release, almost all of it from the Sundarbans mangrove and tidal forest $(66,180)$. Contributing to this release were a $43 \%$ reduction in welland area and an estimated decline in its carbon content from 40 $1022 \mathrm{t} /$ ha over the course of the century. Another $35 \%$ of the total release came from forest-woodland vegetation, primarily due to the effects of logging, shifting cultivation, and dam construction on the tropical humid forests in the Chittagong Hill Tracts and Coastal zones $(6,199)$. Much of the rest of Bangladesh was deforested before 1880 (110) and, thus, contributed little to the forest-woodland release. However, carbon was also released from vegetation in the interrupted woods and even the grass-shrub complex categories. The effects of degradation within land-use categories are particularly severe in this nation (6) because of the extremely high densities of both people (Table 1) and livestock (Table 10). Bangladesh is disproportionately over. endowed, and Burma underendowed, with both two- and four-legged consumers. The limited carbon uptake that occurred in the cultivated sector was due to expansion of the area in that class, rather than to changes in mean carbon content of temporary crops. Current carbon release from Bangladesh is relarively low (92), because most of its area had already been transformed from high-carbon forested to low-carbon nonforested systems before 1880 .

In northern India, the rate of carbon release rose with each succeeding interval $(78,123$, and $183 \mathrm{Mt} /$ decade). Total release for the century $(1.23 \mathrm{Gt}$ ) was comparable to that of Burma. By one recent calculation (92), the annual carbon

$$
\text { E - } 12
$$


TABle 8. Area and total carbon in vegetation, from 1880 to 1980 , for each nation in the study region

\begin{tabular}{|c|c|c|c|c|c|c|c|c|c|c|}
\hline & \multirow{2}{*}{$\begin{array}{c}\text { Area } \\
\left(10^{6} \mathrm{ha}\right)\end{array}$} & \multicolumn{4}{|c|}{$\begin{array}{l}\text { Total carbon content } \\
\text { in vegetation }(\mathrm{Mt})\end{array}$} & \multirow{2}{*}{$\begin{array}{l}\text { Area of } \\
\text { nation as } \\
\% \text { of } \\
\text { regional } \\
\text { lotal }\end{array}$} & \multicolumn{4}{|c|}{$\%$ of totai carbon in vegetation } \\
\hline & & 1880 & 1920 & 1950 & 1980 & & 1880 & 1920 & 1950 & 1980 \\
\hline $\begin{array}{l}\text { N. India } \\
\text { Bangladesh } \\
\text { Burma }\end{array}$ & $\begin{array}{l}87.10 \\
14.80 \\
67.66\end{array}$ & $\begin{array}{r}2736 \\
212 \\
3158\end{array}$ & $\begin{array}{r}2423 \\
177 \\
2592\end{array}$ & $\begin{array}{r}2054 \\
148 \\
2244\end{array}$ & $\begin{array}{r}1504 \\
109 \\
1872\end{array}$ & $\begin{array}{r}51.4 \\
8.7 \\
39.9\end{array}$ & $\begin{array}{r}44.8 \\
3.5 \\
51.7\end{array}$ & $\begin{array}{r}46.7 \\
3.4 \\
49.9\end{array}$ & $\begin{array}{r}46.2 \\
3.3 \\
50.5\end{array}$ & $\begin{array}{r}43.3 \\
3.1 \\
53.7\end{array}$ \\
\hline Total study region & 169.55 & 6104 & 5193 & 4446 & 3485 & 100.0 & 100.0 & 100.0 & 100.0 & 100.0 \\
\hline
\end{tabular}

release from Burma now exceeds that of the entire nation of India, a trend consistent with the comparative time courses of carbon release observed here. Carbon release in northern India was particularly concentrated in the forest-woodland class, which lost carbon equivalent to $89 \%$ of the total release. As elsewhere, reduction in both area $(52 \%)$ and mean carbon content per hectare of forest (from 108 to $88 \mathrm{t} / \mathrm{ha}$ ) contributed to this release. Mean carbon content of northern Indian forests is somewhat higher than that of Burma because a relatively high proportion of the surviving forest-woodland in the former consists of highbiomass forest types (in relatively inaccessible Arunachal Pradesh and the reserved forests of the Himalayan districts of Uttar Pradesh). Interrupted woods, wetlands, and grassshrub vegetation were the other sources of carbon release in northern India. Overgrazing has significantly reduced the carbon content per hectare of nonforest vesjetation. The number of livestock doubled from 1880 to $19 / 30$ (Table 10), while that of people almost tripled (Table 1). Carbon uptake in cultivated land, associated with increased area in this category, was minimal in context of the total release.

Table 11 compares the relative contributions of seven states or aggregations of states to the total northern Indian area and carbon stock. With less than $10 \%$ of the total area, Arunachal Pradesh contained an estimated $31 \%$ of the carbon stock in 1880 , and $42 \sigma_{0}$ in 1980 . Its relative inacces. sibility, rugged mountain terrain, and sparse population prevented rapid deforestation (201). Uttar Pradesh, with one-third of the total area, has accounted for about $20 \%$ of the carbon stock. This is concentrated in the forests of the Himalayan districts $(85,185)$. Most of the carbon in the other zones of Uttar Pradesh in contained in the vegetation of the cultivated land, which has dominated their land-use patterns throughout the century $(43,57,127,148)$. The carbon contents of the Northeast Hill States, Assam, Sikkim. and Himachal Pradesh, are roughly proportional to their area. Heavily agricultural Bihar (2) and West Bengal (136, 181) have been proportionally underrepresented in carbon terms throughout the century.

\section{Case studies of deforestation}

The regional and temporal heterogeneity in our carbonstock estimates results from juxtaposition of many different patterns of land use at smaller spatial scales. In each zone we see complex and localized interactions of environmental and historical factors. We will examine three case studies at the level of the ecological zone that illustrate different processes of deforestation.

Case study 1: agricultural expansion in the Burme Delta A classic case of deforestation driven largely by agricul- tural expansion occurred in the Burma Delta zone (Fig. 2. zone 38, comprising the modern Irrawaddy and Pegu divisions and Rangoon) following its annexation by the British in 1852. Rice cultivation was already established in parts of the upper Irrawaddy River delta. Colonial administrators valued the remaining forest vegetation, because these mixed tropical moist deciduous forests contained economically significant quantities of teak ( Tectona grandis L. f.), pyinkado (Xylia dolabriformis Benth.), and other desirable trees (196). Government controls to prevent depletion of these species by commercial loggers were applied as early as 1858, and much of the remaining forest land of this type had been legally reserved by $1880(17,21)$.

However, the extensive tidal and mangrove forests of the lower delta, which were relatively untouched before the advent of the British, were not regarded as worthy of conservation. As late as 1948 , one British authority dismissed the tidal forests as "horrible places fit only for the snakes and crabs that inhabit them, feet deep in mud" $(9$, p. 480). Colonial administrators rewrote old trade laws, structured new land tenure and taxation systems to favor forest clearance and rice planting ty peasant migrants, subsidized embankment construction to protect the paddy crep, and built roads to provide market access, all with the intint of establishing a rice export economy $(1,172)$. When the Suez Canal was opened in 1869, the foreign market became even stronger (129), and the influx of land-hungry peasants to the lower Irrawaddy Delta increased.

The initial phase of agricultural expansion was concentrated in fallow land, secondary vegetation, and herbaceous wetlands dominated by kaing grass (Saccharum spontaneum L.), which immigrants found relatively easy to clear. Such land was in short supply by 1880 . Thereafter, the virgin wetland forests of lower Burma were preferentially sacrificed to provide more land for commercial cultivation of rice (1). Inland tidal forests dominated by large kanazo (Heritiera Jomes Buch.) trees were particularly attractive to cultivators because they were less saline and less vulnerable to severe floods. Soon, however, even the most frequently flooded and salt-tolerant mangrove swamps were being converted to rice paddies, and dense stands of Rhizophora, Sonneratia, and Ceriops spp. were destroyed.

Table 12 illustrates the changes in land use and carbon content in the Burma Delta zone. From 1880 to 1920, the net sown area increased by $142 \%$, at the expense of $47 \%$ of the 1880 wetland forest area. As a result, the Delta, with only $12.5 \%$ of the area in Burma, accounted for $32 \%$ of its total carbon release from 1880 to 1920 . The magnitude of this release is explained by the large areas cleared and the relatively high biomass of the vegetation that was 


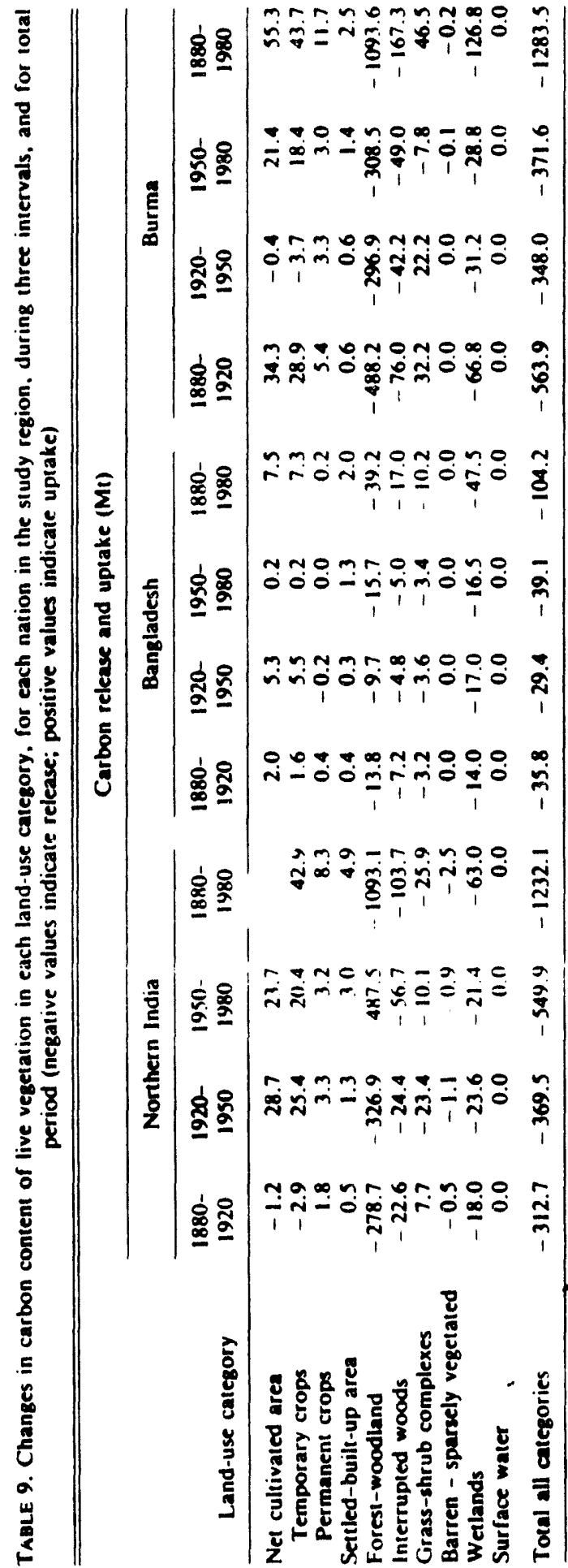

E - 14 replaced by nice: kanazo trees in the tidal forests uere knoun 10 reach heights of $45 \mathrm{~m}$, and shorter stands were characterized by high stem density (194). Additional carbon release occurred when unprotected lowland stands of tropical moist forests were converted to rice land and logging depleted the biomass in teak-bearing reserved forests (197). but the enormous expansion of cultivaled area was clearly the major cause of carbon release in this zone before 1920. It was recognized that by this time most of the area suitable for rice production was occupied (129). From 1920 to 1950, both the net cultivated area and the forest-woodland area declined (by 15 and 16\%, respectively). The primary causal factor here was the Japanese invasion of Burma during the second world war (44). The area in wetlands also declined. Further reductions of $13 \%$ in forest-woodland area and $28 \%$ in wetland area between 1950 and 1980 were probably linked to both a $38 \%$ expansion of the cultivated area and new techniques for commercial exploitation of woody species in both the tropical moist and tidal forests. Overall, however, the primary factor driving deforestation in this area has clearly been conversion to arable land.

\section{Case study 2: commercial overfelling in Chamba, Himachal} Pradesh

A contrasting pattern is seen in the mountainous Chamba ecological zone in the Indian Himalayas (Fig. 2, zone 1). Here, throughout the century, the primary agent of deforestation was commercial extraction of timber from forests, with subsistence use of wood as an aggravating factor after 1950. Extant 10h century deeds suggest that sedentary agriculture was well established in Chamba valleys at that time, and human settlement in the area apparently dates back to the Ist century A.D. (47). However, until the British gained political control over the northwestern Himalayas in the early $19 \mathrm{th}$ century, the mountain forests of Chamba were relatively undisturbed $(208,209)$. During that period, travelers to this Himalayan state (coextensive with the modern district and our ecological zone) described supposedly inexhaustible forests of deodar (Cedrus deodara L.) (196). This conifer was particularly valuable because of its great size (trees over $70 \mathrm{~m}$ tall were still standing in the western Himalayas in 1920) and the resistance of its wood to rot and insect attack $(207,208)$. It is believed that some trees were cut as building timber for export to the Lahore market before the $19 \mathrm{rh}$ century (78).

However, the recorded history of deodar exploitation in Chamba begins after 1850. By this daie, the accessible north. ern Indian forests of sal (Shorea robusta), the only other species north of the Ganges equally desirable for construction and railway sleepers (15i), had been depleted (189). Private timber contractors aware of the needs of the colonial government then turned their attentions to the forest estate of the Rajah of Chamba, which was known to contain stands of quality I deodar. They did so with such energy that this resource was reported as near exhaustion by 1864 (51). The actual proportion of deodar in these forests was considerably lower than that initially estimated, since deodar is limited in its elevational range and it often grows intermixed with other species, notably blue pine (Pinus excelsa Wall.) and ban oak (Quercus incana Roxb.) (72, 81, 128 , 138, 161). The Rajah, who had effectively lost control of his reserved forests, leased them to the British Forest Department, and forest conservancy was introduced $(78,196,197)$. 
An official program of forest management slowed but did not halt the contraction of the forest area, because railway expansion generated an enormous demand (209) throughout the rest of the 19th century, rendering economically feasible the exploitation of formerly remote deodar stands. By 1905. technological changes made commercial logging of blue pine economically remunerative (78). Formerly uncommercial forests dominated by this species now came under the axe, as deodar became increasingly scarce, so the forest area of Chamba continued to contract. As wood preservation technology improved, the remaining coniferous species of the Himalayas were gradually reclassified as economically useful. Many of these were overfelled during both the first and second world wars $(198,44)$ in response to military demands for wood. When the princely state of Chamba was integrated into Himachal Pradesh after independence, the Indian Forest Service took full control of forests (138), which were by now badly depleted. Commercial logging, although subjected to some controls, continued at tvels exceeding maximum sustained yield.

After 1950, accelerated subsistence use of oaks for firewood and browse by an exploding farm population (189) deforested large areas of temperate broad-leaved irees that had hitherto been relatively unmolested. Sedentary agriculture as practiced in the western and central Indian Himalayas requires such extensive energy subsidies from forests (150) that adjacent forests of up to four times the cultivated area are needed to maintain the system (111). As elsewhere in the Himachal Pradesh and Uttar Pradesh Himalayas (149), the depredations of itinerant pastoralists (19) further degraded the forests.

Table 13 illustrates the process of deforestation in Chamba. In 1 century, this zone lost $64 \%$ of its forestwoodland area. Some land went into permanent cultivation and now bears temporary crops or orchards (186), but this amounted to less than $15 \%$ of the deforested area. Most of the remainder was degraded to scrub or pasture. Because over $90 \%$ of the 1880 carbon stock of Chamba was in the forest-woodland class, almost all of the carbon release in this zone came from the forest vegetation. Reduction in forest area was the primary factor, but depletion of biomass in the remaining forests was also involved; estimated carbon content of the Chamba forest-woodland declined from 127 to $94 \mathrm{t} / \mathrm{ha}$, primarily as a result of selective commercial removal of the largest trees.

\section{Case study 3: shifting cultivation in Meghalaya}

A very different process of deforestation is represented by the indigenous practice of shifting cultivation iii the humid hill country of northeastern India and adjacent parts of Burma. Tribal peoples have developed a variety of agricultural subsistence strategies, collectively known as jhum (211). Typically, a family of five or six members clear-cuts a forest plot of 2 to 2.5 ha on sloping land, allows the slash to dry during the winter season, burns it in March or April, and plants a mixture of up to 30 species of cereals, legumes, tuber crops, vegetables, and fruits $(70,159)$. The plot is abandoned after 1 or 2 years of cultivation and (under optimal conditions) left fallow for 25-35 years to allow forest regrowth $(70,203,204)$. Considerable information on the ecology of jhum $(133,159,160,203,204)$ is available from the northeast Indian state of Meghalaya (Fig. 2, zone 23), where tribesmen have practiced it for generations
TAale 10. Livestock populations, from 1880 to 1980, for each nation in the study region

\begin{tabular}{lrrrr}
\hline & \multicolumn{4}{c}{ Livestock population (millions) } \\
\cline { 2 - 5 } & 1880 & 1920 & 1950 & 1980 \\
\hline N. India & 67.29 & 78.81 & 109.77 & 134.71 \\
Bangladesh & 15.49 & 21.38 & 19.03 & 36.07 \\
Burma & 2.69 & 6.93 & 8.35 & 15.39 \\
Total study region & 85.47 & 107.11 & 137.15 & 186.18 \\
\hline
\end{tabular}

TABLE 11. Area and total carbon content of vegetation, from 1880 to 1980, for state or aggregations of states in northern India. expressed as percentages of the total northern India area and carbon content, respectively

\begin{tabular}{|c|c|c|c|c|c|}
\hline \multirow{2}{*}{$\begin{array}{c}\text { State or } \\
\text { aggregation of } \\
\text { states }\end{array}$} & \multirow{2}{*}{$\begin{array}{l}\text { Area, as } \\
\% \% \text { of } \\
\text { total area }\end{array}$} & \multicolumn{4}{|c|}{$\begin{array}{l}\text { Carbon content, as } \% \text { of } \\
\text { total northern India carbon }\end{array}$} \\
\hline & & 1880 & 1920 & 1950 & 1980 \\
\hline Himachal Pradesh & 6.2 & 7.6 & 7.3 & 6.8 & 5.2 \\
\hline Uttar Pradesh & 33.6 & 21.7 & 20.8 & 20.0 & 18.2 \\
\hline Bihar & 20.0 & 8.4 & 7.5 & 6.9 & 7.0 \\
\hline West Bengal & 10.2 & 4.9 & 4.8 & 4.0 & 3.7 \\
\hline Sikkim & 0.8 & 0.9 & 0.9 & 1.0 & 0.9 \\
\hline Assam & 9.0 & 10.6 & 9.6 & 9.6 & 9.3 \\
\hline Arunachal Pradesh & 9.6 & 31.0 & 34.6 & 38.0 & 41.9 \\
\hline Northeast Hill States & 10.7 & 15.0 & 14.4 & 13.7 & 13.8 \\
\hline Total & 100.0 & 100.0 & 100.0 & 100.0 & 100.0 \\
\hline
\end{tabular}

(84, 153). In the absence of human intervention, the natural vegetation of the Meghalaya hills (87) would be dominated by tropical evergreen forest (Mesua ferrea L., Castanopsis indica A.DC.; Dysoxylum, Terminalia, and Elaeocarpus spp., etc.), tropical semievergreen forest (characterized by species of Eloeocarpus and Dillenia, among others), moist temperate forests (Quercus and Castanopsis spp., Schıma khasiana Dyer, etc.), and islands of subtropical coniferous (Pinus khasya Royle) forest.

Colonial foresters and botanists working not only in Meghalaya but also throughout northeastern India, the Bangladesh Chittagong Hills, and Burma, deplored shifting agriculture as wasteful of timber. Dietrich Brandis, the founder of the Indian Forest Service did adapt it in Burma to develop the taungya method of regenerating teak (28). But as a rule the Forest Service strongly discouraged shifting cultivation in reserved forests. Meghalaya was included in this policy, although significant areas of deciduous forest (which in some ways are more economically desirable than the evergreen types) appear to have been established in the past as a result of jhum fires (87). Indeed, at low population densities, shifting-cultivation systems theoretically possess long-term sustainability (159). This is particularly true where tribes (as is customary in Meghalaya) avoid old. growth tropical forest and concentrate their slash and burn operations on the more manageable secondary forest (159. 203). However, the critical variable determining sustainability is the length of time allowed for regrowth of arboreal vegetation. A stable system can only be maintained if the ratio of persons to land permits a fallow interval of at least 20 years, and optimally 30 years after each planting. Early 
TABLE 12. Changes in land use and carbon content in the Burma Delta zone from 1880 to 1980

\begin{tabular}{|c|c|c|c|c|c|c|c|c|}
\hline \multirow[b]{2}{*}{ Land-use calegory } & \multicolumn{4}{|c|}{ Area $\left(10^{3} \mathrm{ha}\right)$} & \multicolumn{4}{|c|}{ Estimated carbon content $(k t)$} \\
\hline & 1880 & 1920 & 1950 & 1980 & 1880 & 1920 & 1950 & 1980 \\
\hline $\begin{array}{l}\text { Net cultivaled area } \\
\text { Temporary crops } \\
\text { Permanent crops } \\
\text { Setlled-buili-up area } \\
\text { Forest-woodland } \\
\text { Interrupted woods } \\
\text { Grass-shrub complexes } \\
\text { Barren - sparsely vegetated } \\
\text { Wetlands } \\
\text { Surface water }\end{array}$ & $\begin{array}{r}1147 \\
1111 \\
36 \\
36 \\
3314 \\
1758 \\
636 \\
61 \\
1101 \\
398\end{array}$ & $\begin{array}{r}2777 \\
2669 \\
108 \\
108 \\
2344 \\
1279 \\
916 \\
65 \\
585 \\
398\end{array}$ & $\begin{array}{r}2363 \\
2229 \\
133 \\
160 \\
1975 \\
1103 \\
2002 \\
70 \\
400 \\
398\end{array}$ & $\begin{array}{r}3255 \\
3147 \\
108 \\
291 \\
1720 \\
1011 \\
1428 \\
78 \\
290 \\
398\end{array}$ & $\begin{array}{r}12014 \\
11110 \\
904 \\
224 \\
347998 \\
55369 \\
8903 \\
214 \\
82227 \\
40\end{array}$ & $\begin{array}{r}29385 \\
26 \quad 687 \\
2698 \\
434 \\
210919 \\
34528 \\
10987 \\
196 \\
37426 \\
40\end{array}$ & $\begin{array}{r}25630 \\
22295 \\
3335 \\
639 \\
162954 \\
27304 \\
24019 \\
210 \\
23713 \\
40\end{array}$ & $\begin{array}{rr}34 & 165 \\
31 & 472 \\
2 & 693 \\
1 & 165 \\
116 & 118 \\
20 & 466 \\
12 & 850 \\
175 \\
13 & 929 \\
40\end{array}$ \\
\hline Tocal ares & 8471 & 8471 & 8471 & 8471 & 506988 & 323915 & 264509 & 198910 \\
\hline
\end{tabular}

TABLE 13. Changes in land use and carbon content in the Chamba zone from 1880101980

\begin{tabular}{|c|c|c|c|c|c|c|c|c|}
\hline \multirow[b]{2}{*}{ Land-use category } & \multicolumn{4}{|c|}{ Area $\left(10^{3} \mathrm{ha}\right)$} & \multicolumn{4}{|c|}{ Estimated carbon content (kt) } \\
\hline & 1880 & 1920 & 1950 & 1980 & 1880 & 1920 & 1950 & 1980 \\
\hline $\begin{array}{l}\text { Net cultivated area } \\
\text { Temporary crops } \\
\text { Permanent crops } \\
\text { Setlled-built-up area } \\
\text { Forest-woodland } \\
\text { Interrupted woods } \\
\text { Grass-shrub complexes } \\
\text { Barren - sparsely vegetated } \\
\text { Wetlands } \\
\text { Surface water }\end{array}$ & $\begin{array}{r}29.9 \\
29.7 \\
0.2 \\
1.7 \\
125.6 \\
11.8 \\
202.3 \\
273.3 \\
0.0 \\
6.9\end{array}$ & $\begin{array}{r}34.7 \\
34.5 \\
0.2 \\
2.0 \\
104.6 \\
13.4 \\
216.2 \\
273.8 \\
0.0 \\
6.9\end{array}$ & $\begin{array}{r}33.2 \\
33.0 \\
0.2 \\
2.8 \\
82.7 \\
15.3 \\
236.3 \\
274.3 \\
0.0 \\
6.9\end{array}$ & $\begin{array}{r}40.9 \\
38.6 \\
2.3 \\
3.6 \\
45.9 \\
8.8 \\
267.2 \\
278.2 \\
0.0 \\
6.9\end{array}$ & $\begin{array}{r}196 \\
193 \\
3 \\
9 \\
16010 \\
452 \\
667 \\
150 \\
0 \\
1\end{array}$ & $\begin{array}{r}228 \\
224 \\
4 \\
6 \\
62045 \\
462 \\
648 \\
137 \\
0 \\
1\end{array}$ & $\begin{array}{r}218 \\
215 \\
3 \\
9 \\
8370 \\
464 \\
638 \\
123 \\
0 \\
1\end{array}$ & $\begin{array}{r}286 \\
251 \\
35 \\
11 \\
4341 \\
249 \\
641 \\
111 \\
0 \\
1\end{array}$ \\
\hline Total area & 651.5 & 651.5 & 651.5 & 651.5 & 17483 & 13527 & 9823 & 5641 \\
\hline
\end{tabular}

descriptions of agricultural practices and vegetation $(94,122$, 153) suggest that population density in parts of the northeastern Himalayas locally exceeded this limit well before the 20 h century. Travelers' descriptions of Cherrapunji station in the wettest part of Meghalaya $(82,90)$ indicate that considerable areas of rain forest had been permanently converted to grassland before 1850 .

What was once only a local problem is now regional; explosive growth of population since 1950 (119\% in Meghalaya) has forced virtually all northeast Indian shifting cultivators to progressively shorten the length of the fallow period between cycles of clearing and burning from 30 years to as little as 5 years (204). Ten-and 15-year cycles allow some forest regrowth, but repeated short cycles cause exotic herbaceous weeds such as Eupatorium adenophohum Spreng. and Imperata cylindrica (L.) Beauv. to permanently replace the forest. Infestations of these species were observed in northeastern India before 1920 (184). Land infested with these species cannot be economically returned to cultivation and is permanently relegated to the grass-shrub category. In extreme cases, shortened jhum cycles can cause erosion and total loss of vegetation (160).

Our data for Meghalaya state (Table 14) indicate a $56 \%$ reduction in the forest-woodland vegetation between 1880 and 1980. The deforestation rale increased in each successive interval. Cultivated area increased by $168 \%$, but this accounted for only a quarter of the lost forest area. Some land has been converted to sedentary agriculture, and much remains in jhum fields. But most of the deforested land has been degraded to the grass-shrub complex category, the typical end point of degradation induced by excessively shon jhum cycles (70). Overall, the carbon content of live vegetation in this zone decreased by $52 \%$, with the greatest rate of loss occurring in the final interval. Forest-woodland systems lost carbon equivalent to $62 \%$ of the total release. Reduction in area and degradation within category were both significant components of the release. Estimated carbon content per hectare for forest-woodland in Meghalaya dropped from 88 to $68 \mathrm{t} / \mathrm{ha}$. Interrupted woods vegetation also released a significant amount of carbon. The carbon content of the grass-shrub calegory increased because the area in this category rose by over $250 \%$.

\section{Implications of comparison of the case studies}

The three case studies described show that in each ecological zone the single concept of deforestation is underlain by a unique mosaic of land-use changes. Remarkably different economic activities caused dramatic transformations on the land, and large reductions in the carbon content of vegetation, in the three case studies. In some cases (c.8.. Meghalaya) these processes were driven primarily by local events, but in others (notably the Burma Delta), global economic and political factors significantly affected the patterns of land-use change. Such diversity is characteristics of human activity in every part of the world during the past 2 centuries (172). Attempts to model past land-use

$$
\text { E - } 16
$$


TABLE 14. Changes in land use and carbon content in the Meghalaya zone from 1880 to 1980

\begin{tabular}{|c|c|c|c|c|c|c|c|c|}
\hline \multirow[b]{2}{*}{ Land-use category } & \multicolumn{4}{|c|}{ Area $\left(10^{3} \mathrm{ha}\right)$} & \multicolumn{4}{|c|}{ Estimaled carbon content ( $k t)$} \\
\hline & 1880 & 1920 & 1950 & 1980 & 1880 & 1920 & 1950 & 1980 \\
\hline $\begin{array}{l}\text { Net cultivated area } \\
\text { Temporary crops } \\
\text { Permanent crops } \\
\text { Settled-built-up area } \\
\text { Forest-woodland } \\
\text { Interrupted woods } \\
\text { Grass-shrub complexes } \\
\text { Barren - sparsely vegetated } \\
\text { Wetlands } \\
\text { Surface water }\end{array}$ & $\begin{array}{r}72 \\
68 \\
4 \\
4 \\
852 \\
1119 \\
166 \\
11 \\
22 \\
2\end{array}$ & $\begin{array}{r}92 \\
85 \\
7 \\
6 \\
687 \\
1185 \\
244 \\
11 \\
20 \\
2\end{array}$ & $\begin{array}{r}138 \\
126 \\
13 \\
9 \\
529 \\
1188 \\
353 \\
11 \\
18 \\
2\end{array}$ & $\begin{array}{r}193 \\
181 \\
12 \\
20 \\
378 \\
1028 \\
595 \\
22 \\
11 \\
2\end{array}$ & $\begin{array}{r}674 \\
612 \\
62 \\
17 \\
74763 \\
29456 \\
1660 \\
28 \\
1359 \\
0\end{array}$ & $\begin{array}{r}874 \\
767 \\
107 \\
25 \\
55666 \\
28799 \\
2199 \\
25 \\
1117 \\
0\end{array}$ & $\begin{array}{rr}1 & 321 \\
1 & 130 \\
191 \\
36 \\
39 \\
3925 \\
26474 \\
3178 \\
25 \\
946 \\
0\end{array}$ & $\begin{array}{r}1809 \\
1629 \\
180 \\
80 \\
25488 \\
20813 \\
4759 \\
45 \\
532 \\
0\end{array}$ \\
\hline Total area & 2249 & 2249 & 2249 & 2249 & 107956 & 88706 & 71232 & 53526 \\
\hline
\end{tabular}

change must recognize and consider the variability of these processes among different time periods and societies.

\section{General conclusions}

Our study, based on a surprising depth of source material for what are today considered Third World nations, has generated time series of land-use data and carbon stock estimates for $1.7 \times 10^{6} \mathrm{~km}^{2}$ of south and southeast Asia. During the century under review, major shifts in the area covered by major land-use classes have occurred. Forests and woodlands declined by $17.3 \times 10^{6}$ ha $(37 \%)$; net cultivated area grew by $13.2 \times 10^{6}$ ha $(33 \%)$. Human numbers in this region more than tripled between 1880 and 1980. Lands in this region have become more productive from the standpoint of certain human needs (in particular, food production). But, at the same time, much of their vegetative cover has been converted from categories of high biomass to categories of low biomass. Such conversions, particularly the felling and clearing of forests and woodlands, have released an estimated $1.8 \mathrm{Gt}$ of carbon into the atmosphere.

Since 1880 , recurring human exploitation of the land has depleted the vegetation within each land-use category. Intensifying human pressures have reduced the standing stock $o$ ? live vegetation at an accelerating rate. This process of depletion must be quantified to arrive at a credible value for carbon releases. By our calculations, degradation within land-use categories contributed an additional $47 \%(0.8 \mathrm{Gt})$ to the regional carbon release between 1880 and 1980 .

In summary, our data reveal a dynamic picture of dramatic changes in land use and the carbon content of live vegetation over the century in this tropical and subtropical region. Intensified forest clearance for both permanent and swidden agriculture, timber extraction, and exploitation of fodder and other forest produce have all contributed to deforestation and consequent release of carbon to the atmosphere. Similar documentation of long-term land-use change in other world regions can reduce uncertainties in estimates of biotic release as a component of the global carbon cycle.

\section{Acknowledgements}

We thank Dr. S. Brown for providing unpublished biomass and volume data from south and southeast Asian forests, which were used in preparation of some of the carbon estimates; Dr. J. Olson for assistance in the development of the ecological categorization; Ms. J. Dillon for map preparation; Dr. J. Arlinghaus, Mr. S. Kumar, and Ms. A. Kumar for data entry; Dr. V. Dale, Dr. W. D. Billings, and an anonymous reviewer for reviewing the manuscript; and Dr. B. Dancik and Dr. G.L. Baskerville for editorial assistance. This research was performed under subcontract No. 19X-SB828C (No. 1) with John F. Richards, under Martin Marietta Energy Systems Inc., of contract DE-ACOS840R21400 with the United States Department of Energy.

1. ADAS, M. 1983. Colonization, commercial agriculture, and the destruction of the deltaic rainforests of British Burma in the late nineteenth century. In Global deforestation and the nineteenth-century world economy. Edited by R.P. Tucker and J.F. Richards. Duke Press Policy Studies, Durham NC. pp. 95-110, 193-195.

2. AHMAD, E. 1965. Bihar: a physical, economic and regional geography. Ranchi University, Ranchi, Bihar.

3. AHMAD, N. 1958. An economic geography of East Pakistan Oxford University Press, London.

4. AHMIAD, N. 1971. Economic resources of the Union of Burma. Earth Sciences Laboratory, U.S. Army Natich Lab. oratory, Natick, MA. Tech. Rep. No. 71-61-ES.

5. AHMAD, N. 1976. A new economic geography of Bangladesh. Vikas Publishing House, New Delhi.

6. AhmED, M. 1987. Bangladesh: how forest exploitation is leading to disaster. Ecologist, 17: 168-169.

7. Asthana, B.N., and SRIvastava, S.S. 1965. Applied statistics of India. Chaitanya Publishing House, Allahabad.

8. AsSMANN, E. 1970. The principles of forest yield study: studies in the organic production, structure, increment and yield of foresi stands. Edired by P.W. Davis. Pergamon Press, Oxford.

9. ATKINSON, D.J. 1948. Forests and forestry in Burma. J. R. Soc. Arts, 94: 478-491.

10. BANERJEE, A. 1966. Indian forests through the ages. In West Bengal forests: centenary commemoration volume 1964 . West Bengal Directorate of Forests, W. B. Divisional Forest Officer, Planning and Statistical Cell, Calcutta. pp. 29-52.

11. BANGLADESH MINISTRY OF AGRICULTURE, AGRO-ECONOMIC RESEARCH SECTION. 1973. Bangladesh agriculture in statistics. Bangladesh Ministry of Agriculture, Dacca.

12. B/NGladesh Bureau of Statistics. 1976. Population rensus of Bangladesh 19\%4. District census reports series. Bangladesh Bureau of Statistics, Dacca.

13. Bangladesh Bureau of Statistics. 1980. The yearbook of agricultural statistics of Bangladesh 1979-80. Bangladesh Bureau of Statistics, Dacca. 
14. Bangladesh Bureal of Statistics 1983. District statistics 1983 series. Bangladesh Bureau of Statistics, Dacca.

15. Bangladesh Ministry of Cabinet Aftalrs. 1971-1981. Bangiadesh District Gazelteers series (continuation of series begun in 1970 by East Pakistan Government). Government Press, Dacca.

16. BANSIL, P.C. 1984. Agricultural statistics in India: a guide. 3rd ed. Oxford \& IBH Publishing Co., New Delhi.

17. BARRINGTON, A.H.M. 1931. Forest soil and vegetation in the Hlaine Forest Circle, Burma. Burma For. Bull. 25. Ecol Ser. No. 1 .

18. Bengal Forest Department. 1932. Annual progress report on forest administration in the Presidency of Bengal for the year 1931-32. Bengal Secretariat Book Depot, Calcuita.

19. BhASIN, V. 1988. Himalayan ecology, Iranshumance and social organisation. Kamla-Raj Enterprises, Delhi.

20. Bihar Forest Department. 1967. Statistical glimpses of Bihar forests 1964-1963. Forest Research Division, Bihar. Superintendent of the Secretariat Press of Bihar. Patna.

21. BLANFORD, H.R. 1958. Highlights of one hundred years of forestry in Burma. Emp. For. Rev. 87: 33-42.

22. BlasCo, F. 1988. The international vegetation map (Toulouse, France). In Vegetation mapping. Ediled by A.W. Kuchler and I.S. Zonneveld. Handbook of vegetation science. Vol. 10. Kluwer Academic Publishers, Dordrechi, Netherlands. pp. $443-460$

23. BLYN, G. 1966. Agricultural trends in India, 1891-1947: out. put, availability, and productivity. University of Pennsylvania Press, Philadelphia

24. BOR, N.L. 1938. A sketch of the vegetation of the Aka Hills, Assam. A synecological study. Indian For. Rec. Bot. (New Ser.), 1(4): $\mid-221$.

25. BOR, N.L. 1942. The relict vegetation of the Shillong Plateau-Assam. Indian For. Rec. Bot. (New Ser.), 3(6): 152-195.

26. BORA, A.K. 1986. Pattern of land utilization in Assam Manas Publications, Delhi.

27. Bowonder, B. 1982. Deforestation in India: Int J. Environ. Stud. 18: 223-236.

28. BrandIS, D. 1897. Indian forestry. Oriental University Institute. Woking.

29. Brown, S., and LUGO, A.E 1982. The slorage and production of organic matter in tropical forests and their role in the global carbon cycle. Biotropica, 14: 161-187.

30. BrowN, S., and LUCO, A.E. 1984. Biomass of tropical forests: a new estimate based on forest volumes. Science (Washington, D.C.), 223: 1290-1293.

31. Brown, S., Gillespie, A.J.R., and LUCO, A.E. 1989 Biomass estimation methods for tropical forests with applica. tions to forest inventory data. For. Sci. 35: 881-902.

32. BUOL, S.W., HOLE, F.D., and MCCRACKEN, R.J. 1980. Soil zenesis and classification. 2nd ed. lowa State University Press, Ames.

33. Burma Ministry of AGRICULTURE AND Forests. 19́8s. Notes on forestry in Burma. Ministry of Agriculture and Forests, Rangoon.

34. Burma Census Division. 1957. First stage census, 1953. Superintendent of Government Printing \& Stationery. Rangoon.

35. Burma Central Statistical and economics Depart. MENT. 1963. Agricultural abstract of Burma 1962-63. Superintendent of Government Printing Stationery, Rangoon.

36. Burma. Goverment OF. 1973. Agricultural statistics 1969-70, 1970-71 and 1971-72. Central Press, Rangoon.

37. BURMa, GOVERnMent OF. 1984. Agricultural statistics 1978-79, 1979-80 and 1980-81. Printing \& Publishing Corp., Rangoon.
38. Blrma Ministry of Planning and Finance. 1982. Repori to the Pyithu Hluttaw on the financial, economic and social conditions of the Socialist Republic of the Union of Burma. 1981-82. Burma Ministry of Planning and Finance, Rangoon

39. CANNELL, M.G.R. 1982. World forest biomass and primary production data. Academic Press. London.

40. CANNELL, M.G.R. 1984. Woody biomass of forest stands For. Ecol. Manage. 8: 299-312.

41. ChAMPION, H.G. 1983. Regeneration and management of sal (Shorea robusta) Gaertn. f. Indian For. Rec. Silvic. 19x(3): 1-159.

42. Champion, H.G. 1936. A preliminary survey of the forest types of India and Burma. Indian For. Rec. Silvic. (New Ser.) I(I): $1-279$

43. Champion, H.G. 1969. The effect of human population on the forests of the Indian sub-continent. Jahrb. Sudasien-Inst. Univ. Heidelb. 3: 19-28.

44. Champion, H.G., and OSmaston, F.C. 1962 . E.P. Stebbing's "The Forests of India." Vol. 4. The history from 1925101947 of the forests now in Burma, India, and Paxistan. Oxford University Press, London.

45. Champion, H.G., and SETh, S.K. 1968. A revised survey of the forest types of India. Manager of Publications, Delhi.

46. Champion, H.G., Seth, S.K., and Khattak. G.M. 1965. Forest types of Pakistan. Pakistan Forest Institute. Peshaway

47. Charak, S.S. 1978. History and culture of Himalayan states. Vol. 1. Himachal Pradesh. Pan 1. Light \& Life Publishers, New Delhi.

48. Chaudhuri, H.N. IM3. The Cooch Behar State and its land revenue settlements. Cooch Behar State Press, Cooch Behar

49. CHOWDHURY, K A., and GHOSH, S.S. 1958. Indian woods: their identification, properties and uses. Vol. 1. Dilleniaceae to Elaeocarpaceae. Manager of Publications, Delhi.

50. Chudnoff, M. 1984. Tropical timbers of the world. U.S. Dep. Agric. Agric. Handb. No. 607.

51. CleGhorN, H. 1864. Report upon the forests of the Punjab and the Western Himalaya. Thomason Civil Engineering Col. lege, Roorkee.

52. Cou AN, J.M. 1929. The forests of Kalimpong: an ecological account. Rec. Bol. Surv. India, 12(1): 1-74.

53. Dabadghao, P.M., and Shankarnarayan, K.A. 1973. The grass cover of India. Indian Council of Agriculiural Researich. Neu Delhi.

54. DAS, A.K., and RAmakrishnav, P.S. 1987. Above-ground biomass and nutrient contents in an age series of Khasi pine (Pinus kesiya). For. Ecol. Manage. 18: 61-72.

55. DASGUPTA. S.P. (Editor). 1980. Atlas of agricultural resources of India. India Department of Science and Tech. nology, National Atlas and Thematic Mapping Organization, New Delhi.

56. DAvIS, J.H 1964. The forests of Burma. Sarracenia, 8 : $1-4 \mid$.

57. DUDGEON, W. 1920. A contribution to the ecology of the Upper Gangetic Plain. J. Indian Bot. Soc. 1: 296-324.

58. EARDLEY-WILMOT, S. 1906. Review of forest administration in British India for the year 1903-1904 with a quinquennial summary. Orfice of the Superintendent of Government Printing, Calcutta.

59. EDWARDS, M.V. 1950. Burma forest types (according to Champion's classification). Indian For. Rec. Silvic. (New Ser.], 7(2): 135-173.

60. Emanuel, W.R., Shugart, H.H., and Stevenson, M.P. 1985. Climatic change and the broad-scale distribution of terrestrial ecosystem complexes. Clim. Change, 7: 29-43.

61. FisHer, C.A. 1967. South-east Asia: a social, economic and political geography. 2nd ed. Methuen \& Co. Lid., London.

62. FLINT, E.P., and RICHARDS, J.F. 1989. Bibliography on tropical foresis and the global carbon cycle. Vol. 2. South Asia. Oak Ridge National Laboratory, Oak Ridge. TN. 
ORNL/CDIAC.24/V2.

63. FOOd AND AGRICULITURE ORganization OF the UNITED NATIONS. 1976. Forest resources in the Asia and Far East region. Food and Agriculiural Organization of the United Nations, Rome.

64. FoOd and agriculture Organization of the United NATIONS. 1978. Report on the agro-ecological zones project. Vol. 1. Methodology and results for Africa. Food and Agriculture Organization of the United Nations, Rome. FAO World Soil Resour. Rep. 48/1.

65. FoOd and Agriculture Organization of the UNITED NATIONS. 1980 Peport on the agro-ecological zones project. Vol. 4. Results $\uparrow$ southeast Asia. Food and Agriculture Organization of the United Nations, Rome. FAO World Soil Resour. Rep. $48 / 4$.

66. FoOd AND AGRICULtURE ORganization OF the United NATIONS. 1982. Management and utilization of mangroves in Asia and the Pacific. Food and Agriculture Organization of the United Nation: Rome. FAO Environ. Pap. No. 3.

67. FOOd AND AGRICULTURE ORGANIzATION OF THE UNITED Nations. Tropical Forest AsSessment ProJect. 1981. Forest Resources of tropical Asia. Food and Agriculture Organization of the United Nations, Rome.

68. Forest RESEARCh INSTITUTE OF INDIA, EdITORIAL COMMIT. TEE for Forest CENTENARY PUblications. 1961. 100 years of Indian forestry, 1861-1961. Vols. 1 and 2. Manager of Publications, Civil Lines, Delhi.

69. Forest RESEARCh InSTITUTE OF India, WOOd ANatomy BraNCH. 1963. Indian woods: their identification, properties and uses. Vol. 2. Linaceae to Moringaceae. Manager of Publications, Delhi.

70. Gangwar, A.K., and Ramakrishnan, P.S. 1987. Cropping and yield patterns under different land use systems at higher elevations of Meghalaya in North-eastern India. Int. J. Ecol. Environ. Sci. 13: 73-86.

71. GAMBlE, J.S. 1875. The Darjeeling forests. Indian For. 1: 73-99.

72. GAMmie, G.A. 1898. A botanical tour in Chamba and Kangra. Rec. Bot. Surv, India, 1: 183-214.

73. Gaussen, H., Legris, P., Blasco, F., Delacourt, A.. MEHER-HOMJI, V.M., and TrOY, J.P. 1971. Carte internationale du tapis vegetal el des conditions ecologiques. International map of the vegetation and of environmental condi. tions. Wainganga. Indian Council of Agricultural Research. Pondichery.

74. Gaussen, H., Legris, P., Meher-Homji, V.M., Fontanel, J., Pascal, J.-P., Chandrahasan, K., DelaCOURT, A., and TroY, J.P. 1975. Notice de la feuille Orissa. Trav. Sect. Sci. Tech. Inst. Fr. Pondichery [Hors. Ser.] No. 14.

75. Gaussen, H., Meher-Homi, V.M., Blasco, F., Delacourt, A., Fontanel, J., Legris, P., and Troy, J.P. 1973. Carte internationale du tapis végétal et des conditions écologiques a $1 / 1,000,000$. Orissa. Institut Français and Indian Council of Agricultural Research. Pondichéry.

76. Gaussen, H., Meher-Homji, V.M., Fontanel, J., Legris, P., and PASCAL, J.-P. 1978. Carte internationale du tapis végétal et des conditions écologiques a $1 / 1,000,000$. Allahabad. Institut Français and Indian Council of Agricultural Research, Pondichery, India.

77. Gaussen, H., Meher-Homj, V.M., Legris, P., Delacourt, A., Troy, J.P., Blasco, F., and Fontanel, J. 1974. Notice de la feuille Wainganga. Trav. Sect. Sci. Tech. Inst. Fr. Pondichery [Hors. Ser.] No. 13.

78. GLOVER, H.M. 1928. Two modern working plans for coniferous forests of the Punjab Himalayas. Indian For. 54: 790-793.

79. GOPAL, B. 1982. Ecology and management of freshwater wetlands in India. In Proceedings of the International Scien- tific Workshop on Ecosystem Dynamics in Freshwater Wetlands and Shallow Water Bodies, 12-26 July 1981, MinskPinsk-Tskhaltoubo. Vol. !. Centre of International Projects GKNT, Moscow. pp. 127-162.

80. GOPAL, B., and ShARMA, K.P. 1982. Studies of wetlands in India with emphasis on structure, primary production, and management. Aquat. Bot. 12: 81-91.

81. GORRIE, R.L. 1933. The Sutlej deodar: its ecology and timber production. Indian For. Rec. Silvic. 17(4): 1-140.

82. GRIFFITH, W. 1847. Journals of travels in Assam, Burma, Bootan, Afghanistan and the neighbouring countries. Bishop's College Press, Calcutta.

83. GUHATHAKURTA, P. 1974. A study of the forest resources of Kalimpong Forest Division. Planning \& Statistical Cell, Office of Chief Conservator of Forests, West Bengal, Calcutta. Bull. No. 58.

84. GURDON, P.R.T. 1914. The Khasis. 2nd ed. MacMillan \& Co. Ltd., London.

85. GUPTA, R.K. 1983. The living Himalayas. Vol. 1. Aspects of environment and resource ecology of Garhwal. Today \& Tomorrow's Printers \& Publishers, New Delhi.

86. H... I. 1982. An at'as of the Mughal Empire: political and econot nc waps with detailed notes, bibliography' and index. Oxford University Press, Delhi.

87. HARIDAiAN, K., and RAO, R.R. 1985. Forest flora of Meghalaya. Vol. I. Ranunculaceae to Cornaceae. Bishen Singh Mithendra Pal Singh, Dehra Dun.

88. Himacha: Pradesh Department of Forest Farming AND EnVIRONMEntal Conservation. 1980. H.P. Forest statistics 1980. Himachal Pradesh Department of Forest Farming \& Environmental Conservation, Simla.

89. Holdridge, L.R., Grenke, W.C., Hatheway, W.H., LIANG, T., and TOSI, J.A., JR. 1971. Forest environments in tropical life zones: a pilot study. Pergamon Press Inc. Oxford.

90. HOOKER, J.D. 1854. Himalayan journals; or, notes of a naturalist in Bengal, the Sikkim and Nepal Himalayas, the Khasia Mountains, ec. Revised edition published in 1891 by Ward. Lock. Bowden \& Co., London.

91. Houghton, R.A. 1986. Estimating changes in the carbon content of terrestrial ecosystems from historical data. In The changing carbon cucle: a global analysis. Edited by J.R Trabalka and D.E. Reichle. Springer-Verlag. New York. pp. 175-193.

92. HOUGHTON, R.A., BOONE, R.D., FRUCI, J.R., HObBIF, J.E., Melillo, J.M., Palm, C.A., Peterson, B.J., Shaver, G.R., and WOODWELL, G.M. 1987. The flux of carbon from terrestrial ecosystems to the atmosphere in 1980 due to changes in land use: geographic distribution of the global flux. Tellus, 398: 122-139.

93. HuNDLEY, H.G. 1961. The forest types of Burma. Trop. Ecol. 2: 48-76.

94. HutChinson, R.H.S. 1906. An account of the Chittagong Hill tracts. Bengal Secretariat Book Depot, Calcutta.

95. GOVERNMENT Of INDIA. 1907-1909. The Imperial Gazetteer of India. New ed. Vols. 1-26. Clarendon Press, Oxford.

96. INDIA DEPARTMENT OF COMMERCIAL. INTELLIGENCE AND STATISTICS. 1945. Agricultural statistics of India for the year 1938-1939. Manager of Publications, Delhi.

97. INDIA DEPARTMENT OF STATISTICS. 1922. Agricultural statistics of India, 1919-20. Superintendent of Government Printing, Calcutta.

98. INDIA FOREST DEPARTMENT. 1915. Quinquennial review of forest administration in British lildia for the period 1909 to 1914 to which is appended the annual return of forest statistics for the year 1913-14. Government Monotype Press, Simia.

99. INDIA FOREST DEPARTMENT. 1922. Annual return of statistics relating to forest administration in British India for the year 1920-1921. Superintendent of Government Printing, 
Calcutta.

100. India Revenue and Acricultural Department. 1886 Returns of agricultural statistics for British India for 1884-85. Superintendent of Government Printing. Calculta.

101. India Statistical Department. 1896. Agricultural statistics of British India for the years 1890-91 to 1894-95. Superintendent of Government Printing, Calcutta.

102. India Central. Forestry Commission. 1976. Forest statistics. F.R.I. Press, Dehra Dun.

103. India Directorate of Economics And Statistics. 1972. Indian livestock census 1966. Manager of Publications, Civil Lines, Delhi.

104. India Directorate of Economics AND Statistics. 1977. Indian livestock census 1972. Manager of Publications, Civil Lines, Delhi.

105. India ECONOMIC \& Statistical AdVISER to the Govern. MENT OF INDIA. 1960. Indian forest statistics 1956-57 and 1957-58. Manager of Publications, Civil Lines, Delhi.

106. India Ministry of Agriculture, Directorate of ECONOMICS AND STATISTICS. 1970. Indian Agricultural Statistics, 1961-62 and 1962-63. Manager of Publications, Delhi.

107. India Ministry of Agriculture. Directorate of ECONOMICS AND STATISTICS. 1985. Indian Agricultural Statistics, 1974-75 to 1976-77. Controller of Publications, Civil Lines, Delhi.

108. India Ministry of FoOd and AGRICUlture, Directorate OF ECONOMICS AND STATISTICS. 1952. Indian Agricultural Statistics, 1949-50. Manager of Publications, Delhi.

109. India National Remote Sensing Agency, Department OF SPACE. 1983. Mapping of forest cover in India from satellite imagery, 1972-75 and 1980-82. Summary report. India National Remote Sensing Agency, Hyderabad.

110. ISHAQUe, H.S.M. 1946. Agricultural statistics by plot to plot enumeration in Bengal 1944-45. Superintendent of Govern. ment Printing, Bengal Government Press, Alipore.

111. IVES, J.D., and MESSERLI, B. 1989. The Himalayan dilemma: reconciling development and conservation. Routledge, London and New York.

112. Jahdal, C.G. Singh, C. Prakash, A., and RoY BURMAN, B.K. 1972. Bibliography of census publications in India. Nanager of Publications, Delhi.

113. JACK, J.C. 1915. Final report on the survey and settlement operations in the Bakarganj district. 1900 10 1908. Bengal Secretariat Book Depot, Calcutta.

114. JHA, S.D. 1986. Arunachal Pradesh (rich land and poor people). Omsons Publications, New Delhi.

115. KaUl, O.N., and Sharma, D.C. 1971. Forest types statistics. Indian For. 97: 435-436.

116. KawOSA, M.A. 1988. Remote sensing of the Himalaya. Natraj Publishers, Dehra Dun, India.

117. Kawosa, M.A., Aselmann, I., and Lieth, H. 1984. Production relations of a coniferous forest of Kashmir Valley. Prog. Biometeorol. 3: 158-170.

118. KHATTAK, G.M. 1979. History of forest management in Bangladesh. Pak. J. For. 29: 121-128.

119. KINGDON-WARD, F. 1944-1945. A sketch of the botany and geography of North Burma. J. Bombay Nat. Hist Soc. 44: 550-574; 45: 16-30, 133-148.

120. LABROUE, L., LeGRIS, P., and VIART, M. 1965. Bioclimats du sous-continent Indien. Trav. Sect. Sci. Tech. Inst. Fr. Pondichery T.3. Fasc. 3

121. LAL, J.B. 1989. India's forests: myth and reality. Natraj Publishers, Dehra Dun, India.

122. LEACH, E.R. 1954. Political systems of highland Burma: a study of Kachin social structure. Harvard Unjversity Press, Cambridge.

123. LEGRIS, P. 1963. La végétation de I'Inde : écologie et nore. Trav. Sect. Sci. Tech. Inst. Fr. Pondichery. T.6.
124. LimaYe, V.D.. and SeAMAN, L.N. 1933. The physical and mechanical properties of woods grown in India: third interim report on project I. Indian For. Rec. Economy, 18(10): 1-70.

125. LONC, A. 1968. The forests of Burma. Burmese For. 14: 18-35.

126. MamoriA, C.B. 1975. Geography of India lagricultural geography\}. Shiva Lal Agarwal \& Co., Agra, India.

127. MANI, M.S. 1974. Biogeography of the Indo-Gangetic Plain. In Ecology and biogeography in Indie. Edited by M.S. Mani. Dr. W. Junk Publishers, The Hague. pp. 247-280.

128. MCDONELL, J.C. 1882-1883. A trip through Chamba Indian For. 8: 35-38, 168-171, 272-274: 9: 18-20, 287-291

129. MCKERRAL, A. 1927. Climatic tracts; distribution of crops; development of agriculture of the province in recent years. In Agriculture in Burme: collection of papers written by government officials for the Royal Commission on Agriculture, 1926-1928. Superintendent of Covernment Printing \& Stationery, Rangoon, Burma. pp. 1-5.

130. MEHER-HOMJI, V.M. 1984. A new classification of the phytogeographic zones of India. Indian J. Bot. 7: 224-233.

131. Meher-HomJI, V.M., Fontanel, J., PASCal, J.-P., Chandrahasan, K., and Delacourt, A. 1978. Noles on the sheet Allahabad. Trav. Sect. Sci. Tech. Inst. Fr. Pondichery [Hors Ser.] No. 15.

132. Melkania, N.P., and Melkania, U. 1987. Man and environment in Himachal Pradesh, India. In Himachal Himalaya ecology and environment. Edited by S.K. Chadha. Today \& Tomorrow's Printers \& Publishers, New Delhi. pp. 81-99.

133. Mishra, B.K.. and RAmakrishnan, P.S. 1983. Secondary succession subsequent to slash and burn agriculture at higher elevations of north east India. I. Species diversity, biomass and litter production. Acta Oecol. Oecol. Appl. 4: 95-107.

134. MiSRA, R., SiNGH, J.S., and SINGH, K.P. 1967. Preliminary observations on the production of dry matter by sal (Shored robuste Gaertn. f.) Trop. Ecol. 8: 94-104.

135. MITCHELL, R. 1979. The analysis of Indian agro-ecosystems. Interprint, New Delhi

136. Mitra, A. 1953. An account of land management in West Bengal 1870-1950. Census 1951 West Bengal, Land Land Revenue Department. Superintendent of Government Printing. West Bengal Government Press, Alipore.

137. Moosvi, S. 198\%. The economy of the Mughal Empire : 1595: a statistical study. Oxford University Press. Delhi.

138. Negi, T.S. 1963. Himachal Pradesh District gazetteers: Chamba. Roshan Lal Datra, Batala.

139. National COUNCIL OF APPLIED ECONOMIC RESEARCh OF INDIA. 1968. Techno-economic survey of Nagaland. National Council of Applied Economic Research. New Delhi.

140. NEIL, P.E. 1981. Problems and opportunities in tropical rain-forest management. CFI (Commonw. For. Inst.) Occas. Pap. No. 16.

141. NiCHOLSON, J.W. 1926. The forests within Bihar and Orissa. Superintendent of Government Printine of Bihar \& Orissa. Paina.

142. NUtTONSON, M.Y. 1963. The physical environment and agriculture of Burma. American Institute of Crop Ecology, Washington, DC.

143. NUTTONSON, M.Y. 1963. Climate, soils, and rice culture of Burma. Supplementary information and a bibliography to the repon of the physical environment and agriculture of Burma. American Institute of Crop Ecolosy, Washington, DC.

144. OLSON, J.S., WATTS, J.A., and ALLISON, L.J. 1983. Carbon in live vegetation of major world ecosystems. U.S. Department of Energy, Office of Energy Research, Carbon Dioxide Research Division, Washington, DC. TR004, DOE/NBGB-0037.

145. Padmanabha, P. 1982. Final population totals. Census of India 1981. Ser. 1. Pap. No. I of 1982. Controller of Publications. Civil Lines. Delhi. 
146. Pakistan Department of agricultural Economics and Statistics. 1962. Land and crop statistics of Pakistan. Manager of Publications, Karachi.

147. Pakistan Office of Census Commissioner. 1964. Population census of Pakistan 1961. District Census Reports. Vols. 1-17. Pakistan Office of Census Commissioner, Karashi.

148. Pandey, V.K., and TeWARI, S.K. 1987. Some ecological implications of land use dynamics in Uttar Pradesh. Indian J. Agric. Econ. 42: 388-394.

149. PATIL, B.D., and PATHAK, P.S. 1978. Grassland development in the Himalayas. In National seminar on resources development and the environment in the Himalayan region. India Department of Science and Technology, National Com. mittee on Environmental Planning \& Co-ordination, New Delhi. pp. 204-215.

150. Pandey, U., and Singh, J.S. 1984. Energy-flow relationships between agro- and forest ecosystems in Central Himalaya. Environ. Conserv. 2: 45-53.

151. Pearson, R.S. 1913. On the economic value of Shorea robusto (sal). Indian For. Mem. Econ. Ser. 2(2): 1-79.

152. Pearson. R.S., and Brown, H.P. 1932. Commercial timbers of India: their distribution, supplies, anatomical struc ture, physical and mechanical properties, and uses. Vols. I and 2. Government of India Central Publication Branch, Calcutta.

153. Playfair, A. 1909. The Garos. (Reprinted in 1975 by United Publishers, Gauhati, Assam.]

154. PURI, G.S. 1960. Indian forest ecology. Vols. 1 and 2. Oxford Book \& Stationery Co., New Delhi.

155. PUR, G.S., MEHER.HOMI, V.M., GUPTA, R.K., and PUR, S. 1983. Forest ecology. 2nd ed. Vol. I. Phytogeography and forest conservation. Oxford \& IBH Publishing Co., New Delhi.

156. Puryakastha, S.K. 1982. Indian woods: their identification, properties and uses. Vol. 4. Myrtaceac to Symplocaceae. Controller of Publications. Delhi.

157. Puryakastha, S.K. 1985. Indian woods: their identification, properties and uses. Vol. S. Oleaceae to Santalaceae. Controller of Publications, Delhi.

158. RAM, J., SiNGH, J.S., and SiNGH, S.P. 1989. Plant biomass, species diversity and net primary production in a central Himalayan high altitude grassland. J. Ecol. 77: 456-468

159. RamakRISHNAN, P.S. 1985. Tribal man in the humid tropics of the North-east. Man India, 65: 1-32.

160. RAMAKRISHNAN, P.S., and RAM, S.C. 1988. Vegetation, biomass and productivity of seral grasslands of Cherrapunji in north-east India. Vegetatio, 74: 47-53.

161. RAMAM, S.S., and ShARMA, B.M. 1978. Ecology and management of conifer forests of Western Himalaya with special reference to Cedrus deodara. In Glimpses of ecology (Prof. R. Misra commemorative volume). Edited by J.S. Singh and B. Gopal. International Scientific Publications, Jaipur, Rajasthan. pp. 155-166.

162. RAMDAS, L.A. 1974. Weather and climatic patterns. In Ecology and biogeography in India. Edited by M.S. Mani, Dr. W. Junk Publishers, The Hague. pp. 99-134.

163. RAMESh RAO, K., and Puryakastha, S.K. 1972. Indian woods: their identification, properties and uses. Vol. 3. Leguminosae to Combretaceac. Manager of Publications, Delhi.

164. RANA, B.S., SINGH, S.P., and SINGH, R.P. 1989. Biomass and net primary productivity in Central Himalayan forests along an altitudinal gradient. For. Ecol. Manage. 27: 199-218.

165. RANDHAWA, M.S. 1980. A history of agriculture in India. Vol. I. Beginning to 12th century. Indian Council of Agricultural Research, New Delhi.

166. RANDHAWA, M.S. 1982. A history of agriculture in India. Vol. 2. Eighth to eighteenth century. Indian Council of Agricultural Research. New Delhi.
167. RANDHAWA, M.S. 1983. A history of agriculture in India. Vol. 3. 1575-1947. Indian Council of Agricultural Research, New Delhi.

168. RASHID, H. 1977. Geography of Bangladesh. University Press, Dacca.

169. RAU, M.A. 1974. Vegetation and phytogeography of the Himalaya. In Ecology and biogeography in India. Edited by M.S. Mani. Dr. W. Junk Publishers, The Hague. pp. 247-280.

170. REYNOLDS, H.O. 1927. Land records and agricultural statistics. In Agriculture in Burma: a collection of papers written by government officials for the Royal Commission on Agriculture, 1926-1928. Superintendent of Government Printing \& Stationery, Burma, Rangoon. pp. 12-15.

171. RIBbentrop, B. 1900. Forestry in India. Office of the Superintendent of Government Printing, Calcutta.

172. RICHARDS, J.F. 1986. World environmental history and economic development. In Sustainable development of the biosphere. Edited by W.C. Clark and R.E. Munn. International Institute of Applied Systems Analysis, Luxembourg. pp. 53-71.

173. Richards, J.F., Haynes, E.S., and Hagen, J.R. 1985. Changes in the land and human productivity in northern India, 1870-1970. Agric. Hist. 59: 523-547.

174. RoY, P.S., and UNNI, N.V.M. 1980. The forest type classification and mapping of shifting cultivation areas using Landsat data in Mizoram. In Proceedings of the Seminar on Application of Photo-Interpretation and Remote Sensing Techniques for Natural Resources Survey and Environmental Analysis, 8-10 Oct. 1980, Dehra Dun. Indian Society of Photo-Interpretation \& Remote Sensing, Dehra Dun. pp. 246-251.

175. RUDLOFF, W. 1981. World-climates, with tables of climatic data and practical sugzestions. Wissenschaftliche Verlagsgesellschaft mbH, Stuttgart.

176. SCHWARTZBERG, J. (Editor). 1978. A historical atlas of south Asia. University of Chicago Press, Chicago.

177. SCHWEINFURTH, U. 1957. Die horizontale und vertikale Verbreitung der Vegetation im Himalaya. Ferd. Dummlers Verlag, Bonn.

178. SCHOLBERG, H. 1970. The district gazetteers of British India: a bibliography. Biblictheca Asiatica 3. Inter Documentation Co. AG, Zug. Switzerland.

179. SCotT, C.W. 1931. Lecture on the forest geography of Burma. Indian For. 57: 243-249.

180. SEIDENSTICKER, J., and HAI, M.A. 1983. The Sundarbans wildlife management plan: conservation in the Bangladesh coastal zone. International Union for Conservation of Nature \& Natural Resources, Gland, Switzerland.

181. SEN, J. 1988. Land utilization and population distribution: a case study of West Bengal (1850-1985). Daya Publishing House, Delhi.

182. SEN, S.K. 1979. Agrarian relations in India (1793-1947). People's Publishing House, New Delhi.

- 183. SEN GUPTA, J.N. 1939. Dipterocarpus (gurjan) forests in India and their regeneration. Indiar, For. Rec. Silvic. [New Ser.], 3(4): 61-164.

184. SEN GUPTA, J.N. 1949. The growing menace of assam-lota (Eupatorium spp.) and how to combat it. Indian For. 75: 351-393.

185. SETH, S.K. 1978. Forests and forestry in the Himalayan region. In National seminar on resources development and environment in the Himalayan region, 10-13 Apr. 1978, New Delhi. India Department of Science and Technology, National Committee on Environmental Planning \& Co-ordination, New Delhi. pp. 70-97.

186. Sharma, J.P. 1972. Problems of land utilization in the Himalayan Ravi-Chenab Doab. Geogr. Rev. India, 34: 354-368. 
187. SINGH, J.S., HANXI, Y., and SAJISE, P.E. 1985. Structural and functional aspects of Indian and southeast Asian savanna ecosystems. In Ecology and management of the world's savannas. Edited by J.C. Tothill and J.J. Moll. Ausiralian Academy of Science, Canberra. pp. 34-51.

188. SINCH, J.S., and SAXENA, A.K. 1978. The grass cover in the Himalayan region. In National seminar on resources devel. opment and the environment in the Himalayan region. India Department of Science and Technology, National Committee on Environmental Planning \& Co-ordination. New Delhi. pp. 164-203.

189. SINGH, J.S., and SINGH, S.P. 1986. Forest vegetation of the Himalaya. Bot. Rev. SJ: 80-195.

190. Singh, J.S., TIWARI, A.K., and SAXENA, A.K. 1985. Himalayan forests: a net source of carbon for the atmosphere. Environ. Conserv. 12: 67-69.

191. SinHA, J.N. 1962. Fourth revised working plan for the reserved and protected forests of Saranda Division, Bihas, 1956-57 to 1975-76. Superintendent of the Secretariat Press of Bihar, Paina.

192. StADELMAN, R.C. 1966. Forests of southeast Asia. Wimmer Bros., Memphis.

193. Stamp, L.D. 1924. The vegetation of Qurma from an ecological standpoint. University of Rangoon, Rangoon. Burma.

194. STAMP, L.D. 1925. The aerial survey of the Irrawaddy Delta Forests (Burma). J. Ecol. 13: 262-276.

195. STAMP, L.D. 1930. Burma: an undeveloped monsoon country. Geogr. Rev. 20: 86-109.

196. Stebbinc, E.P. 1922. The forests of India. Vol. I. John Lane. The Bodley Head Lid., London.

197. Stebbing, E.P. 1923. The forests of India. Vol. 2. The development of the Indian forest service. John Lane, The Bodley Head Lid., London.

198. Stebiinc, E.P. 1926. The forests of India. Vol. 3. The progress of conservancy and the development of research in forestry 1901-1925. John Lane. The Bodley Head Lid., London.

199. Task Force Bangladesh (Hossain, M., Jahangir, B.E.K., Chowdhury, F.I., Sarkar, A.U., Rahman, S. et al.). 1979. Population in forestry communities practising shifting cultivation: a case study of Bangladesh. Bangladesh Institute of Development Studies, Dacca

200. TEKARL, A.K. 1966. Land utilization in Jaunsar Bewar. Deccan Geogr. 3/4: 1-128.

201. Thangam, E.S. 1979. Forest development programme in Arunachal Pradesh-development strategy. In Man and forest (a new dimension in the Himalaya). Edited by K.M. Gupta and D. Bandhu. Today \& Tomorrow's Printers \& Publishers, New Delhi. pp. 215-222.

202. TIWARI, A.K., SAXENA, A.K., and SINGH, J.S. 1985. Inventory of forest biomass for Indian central Himalaya. In Environmental regeneration in Himalaya: concepts and strategies
Edired by J.S. Singh. Central Himalaya Envitonment Association and Gyanodaya Prakashan. Naini Tal. Pp. 236-247.

203. Toky, O.P., and RAMAKRISHNAN, P.S. 1981. Cropping and yields in agricultural systems of the north-eastern hill region of India. Agro-Ecosystems, 7: 11-25.

204. TOKY, O.P., and Ramakrishnan, P.S. 1983. Secondary succession following slash and burn agriculture in north. eastern India. I. Biomass, litterfall, and productivity. J. Ecol. 71: $735-745$.

205. TraGer, F.N., and KoeniG, W.J. 1979. Butmese sit-tans, 1764-1826: records of rural life and administration. Association of Asian Studies. Monogr. No. 36. University of Arizona Press, Tucson.

206. Troup, R.S. 1911. A note on some statistical and other information regarding the teak forests of Burma. Indian For. Rec. 3(1): 1-73.

207. Troup, R.S. 1921. The silviculture of Indian trees. Vols. 1-3. Clarendon Press, Oxford.

208. TUCKER, R.P. 1982. The forests of the Western Himalayas: the legacy of British colonial administration. J. For. Hist. 26: $112-123$.

209. TUCKER, R.P. 1983. The British colonial system and the forests of the Western Himalayas, 1815-1914. In Global deforestation and the nineteenth-century world economy. Edited by R. Tucker and J.F. Richards. Duke Press Policy Studies, Durham, NC. pp. 146-166, 199-202.

210. UTTAR PRADESH FOREST DEPARTMENT. 1961. The centenary of forest administration in Uttar Pradesh 1861-1961. Souvenir. United Block Printers. Lucknow, India.

211. WADIA, F.K. 1980. Control of shifting cultivation in the north eastern region. In Tribal economy of the north-eastern region. Edited by T. Mathew. Spectrum Publications, Gauhati, Assam. pp. 40-47.

212. WATSON, H.W.A. 1927. The relation of forestry to agriculture in Burma. In Agriculture in Burma: collection of papers written by government officials for the Royal Commission on Agriculture, 1926-1928. Superintendent of Government Printing \& Stationery, Rangoon, Burma. pp. 153-157.

213. WHYTE, R.O. 1957. The grassland and fodder resources of India. Indian Council of Agricultural Research. New Delhi. Sci. Monogr. No. 22.

214. World Baik. AGricllture aid Rl'ral DEIELOPNENT Department, ECONOAIC P.ESOL'RCes Division. 1977. Final report, land use map component, Burma. (BUR/74/026 Burma Umbrella Project.]

21S. YADAVA, P.S., and SINGH, J.S. 1975. Grassland vegetation: its structure, function, utilization and management. Progress in ecology. Vol. 2. Today \& Tomorrow's Printers \& Publishers, New Delhi.

216. ZIMBA, D.T. 1978. Geography of Meghalaya. 2nd ed. Zimba \& Sons, Shillong, Meghalaya. 


\section{INTERNAL DISTRIBUTION}

1. L. D. Bates

2. T. A. Boden

3. H. L. Boston

4. J. B. Cannon

5. J. H. Cushman

6. R. M. Cushman

7. V. H. Dale

8. R. C. Daniels

9. W. R. Emanuel

10. M. P. Farrell

11. D. E. Fowler

12. C. W. Gehrs

13. S. G. Hildebrand

14. P. Kanciruk

15. D. Kaiser

16. D. E. Reichle

17. F. E. Sharples

18. D. S. Shriner

19. S. H. Stow

20-220. CDIAC

221. Central Research Library

222-223. ESD Library

224. Information Analysis Library

225-226. Laboratory Records Department

227. Laboratory Records, RC

228. ORNL Patent Office

229. ORNL Y-12 Technical Library
MS-7169

MS-6335

MS-6402

MS-6189

MS-6352

MS-6335

MS-6038

MS-6335

MS-6335

MS-6038

MS-6035

MS-6036

MS-6037

MS-6490

MS-6335

MS-6253

MS-6036

MS-6038

MS-6038

MS-6335

\section{EXTERNAL DISTRIBUTION}

230. Oekan Abdoellah, Institute of Ecology, Padjadjaran University, Jl. Sekeloa, Bandung, INDONESIA

231. S. S. Alexander, Pennsylvania State University, Department of Geosciences, 503 Deike Building, University Park, PA 16802

232. Ralph J. Alig, USDA Forest Service, Pacific Northwest Research Station, Forestry Science Laboratory, 3200 Jefferson Way, Corvallis, OR 97331

233. J. H. Allen, National Oceanic and Atmospheric Administration, National Geophysical Data Center Code E/GC2, 325 Broadway, Boulder, CO 80303 
234. D. Alvic, EERC/UT, Pellissippi Office, Ste. 100, 10521 Research Drive, Knoxville, TN 37932

235. Masahiro Amano, Forestry and Forest Products Research Institute, Department of Forest Management, Matsunosato 1, Kukisaki, Inashiki-gun, Ibaraki 302, JAPAN

236. Vladimir V. Annenkov, Institute of Geography of Russia, Academy of Sciences, Starometny 29, Moscow 109017, RUSSIA

237. Willaim Ascher, Professor, Public Policy Studies, 211 Old Chemistry Bldg., Box 90237, Duke University, Durham, NC 27706

238. B.C. Barah, Department of Economics, University of Hyderabad, Central University Hyderabad 500 134, Andhra Pradesh, INDIA

239. R. C. Barry, University of Colorado, World Data Center A, Glaciology, CIRES, Campus Box 449, Boulder, CO 80309-0449

240. Kamla Barwa, Department of Biology, University of Massachusetts-Boston, 100 Morrissey Blvd., Boston, MA 02125

241. Francine Berkowitz, S. Dillon Ripley Center 3123, Smithsonian Institution, 1100 Jefferson Drive, Washington, DC 20560

242. W. Dwight Billings, Department of Botany, 142 Biological Sciences Bldg., Duke University, Durham, NC 27706

243. Peter Boomgaard, Royal Tropical Institute, Amsterdam, THE NETHERLANDS

244. Harold C. Brookfield, Department of Human Geography, Australian National Universily, G.P.O. Box 4, Canberra, ACT 2601, AUSTRALIA

245. C.R. Broome, National Agricultural Library, 10301 Baltimore Blvd., Beltsville, MD 20705-2351

246. Peter Brosius, Department of Anthropology, University of Michigan, 1054 L.S.A. Bldg., Ann Arbor, MI 48109

247. Sandra Brown, US-EPA, Environmental Research Laboratory, $200 \mathrm{SW} 35$ th St., Corvallis, OR 97333

248. William H. Chafe, 226 Carr Bldg., Chair, Dept. of History, Duke University, Durham, NC 27706

249. Ranabir Chakravarti, 18/32. Dover Lane, Calcutta 700 029, INDIA

250. A.N. Chaturvedi, Tata Energy Research Institute, 101 Jor Bagh, New Delhi 110003 , INDIA 
251. Robert Chen, Interdisciplinary Research, CIESIN, Bay City, MI 48710

252. M. A. Chinnery, National Oceanic and Atmospheric Administration, National Geophysical Data Center Code E/GC2, 325 Broadway, Boulder, CO 80303

253. N.L. Christenson, Dean, School of the Environment, 216 Biological Sciences Bldg., Box 90329, Duke University, Durham, NC 27706

254. William Clark, Kennedy School of Government, P-28, Harvard University, 79 Kennedy St., Cambridge, MA 02138

255. N. Mark Collins, World Conservation Monitoring Centre, 219 Huntingdon Road, Cambridge CB3 ODL, U.K.

256. Joseph Cornell, State University of New York, College of Environmental Sciences and Forestry, 301 Illick Hall, 1 Forestry Drive, Syracuse, NY 13210

257. V.K. Dadhwal, Land Resources Division, Space Applications Centre, Indian Space Research Organisation, SAC P.O., Ahmedabad 380 053, INDIA

258. Roger C. Dahlman, Global Change Research Program, Environmental Sciences Division, Office of Health and Environmental Research, ER-74, U.S. Department of Energy, Washington, DC 20585

259. John Dargavel, Centre for Resource and Environmental Studies, Australian National University, Canberra, ACT 2601, AUSTRALIA

260. Michael R. Dove, Senior Fellow, Program on Environment, East-West Center, 1777 East-West Road, Honolulu, HI 96848

261. W. Draeger, EROS Data Center, U.S. Geological Survey, Sioux Falls, SD 57198

262. M. Dryer, National Oceanic and Atmospheric Administration, Space Environmental Lab., ERL/OAR, R/E/SE, 320 Broadway, Boulder, CO 80303

263. M. Edwards, Global Change Information Programme, ARIDC, Department of Environmental and Geographical Sciences, Manchester Metropolitan University, Chester St., Manchester M1 5GD, U.K.

264. Ong Jin Eong, Center for Marine and Coastal Studies, Universiti Sains Malaysia, 11800 Penang, MALAYSIA

265. Jin Qi Fang, Department of Geography, Queen's University, Kingston, Ontario, K7L 3N6, CANADA

266. J. F. Farvolden, Professor, Department of Earth Sciences, University of Waterloo, Waterloo, Ontario N2L 3G1 Canada 
267. J. Filson, National Earthquake Information Center, U.S. Geological Survey, Denver Federal Center, P.O. Box 20546, Denver, CO 80225

268-270. E. P. Flint, Department of History, 226 Carr Bldg., Duke University, Durham, NC 27708

271. J. M. Fox, Fellow, Program on Environment, East-West Center, 1777 East-West Road, Honolulu, HI 96848

272. Jerry F. Franklin, Bloedel Professor of Ecosystem Analysis, College of Forest Resources, University of Washington, Anderson Hall (AR-10), Seattle, WA 98195

273. Dr. Diana W. Freckman, Director, College of Natural Resources, 101 Natural Resources Building, Colorado State University, Fort Collins, CO 80523

274. I. Fung, School of Earth and Ocean Sciences, University of Victoria, P.O. Box 1700, Victoria, BC V8W 2Y2, CANADA

275. Mahdav Gadgil, Centre for Ecological Sciences, Indian Institute of Science, Bangalore 560012 , INDIA

276. David J. Galas, Office of Health and Environmental Research, ER-70, U.S. Department of Energy, Washington, DC 20585

277. C. Geron, Air and Engineering Research Laboratory, U. S. Environmental Protection Agency, Mail Drop \#62, Research Triangle Park, NC 27711

278. Kees Klein Goldewijk, Environmental Forescasting Office, RIVM, Antonie van Leeuwenhoeklaan 9, P.O. Box 1, 3720 BA Bilthoven, THE NETHERLANDS

279. Hans-Friedrich Graf, Max-Planck-Institut Fuer Meteorologie, Bundesstrasse 55, D-20146 Hamburg, GERMANY

280. S. Graves, National Aeronautics and Space Administration Headquarters Code SED, 600 Independence Avenue, Washington, DC 20546

281. J. L. Green, National Space Science Data Center, NASA Goddard Space Flight Center, Code 630.2, Greenbelt, MD 20771

282. Thomas J. Gross, Global Change Research Program, Environmental Sciences Division, Office of Health and Environmental Research, ER-74, U.S. Department of Energy, Washington, DC 20585

283. K. D. Hadeen, National Oceanic and Atmospheric Administration, NESDIS/NCDC, Federal Building MC E/CC, Asheville, NC 28801

284. C. A. S. Hall, State University of New York, College of Environmental Sciences and Forestry, 301 Illick Hall, 1 Forestry Drive, Syracuse, NY 13210 
285. D. Hall, Division of Life Sciences, King's College, London, University of London, Campden Hill Road, London W8 7AH, U.K.

286. J. R. E. Harger, UNESCO/ROSTSEA, Regional Office for Science \& Technology for South East Asia, Jalan M.H. Thamrin 14, Tromolpos 1273, Jakarta, INDONESIA

287. S. Hartnett, Department of Geography, University of Wisconsin-Eau Claire, Eau Claire, WI 54701

288. R. C. Harriss, Institute for the Study of Earth, Oceans, and Space, Science and Engineering Research Building, University of New Hampshire, Durham, NH 03824

289. W. W. Heck, USDA/ARS/NCSU, 1509 Varsity Drive, Raleigh, NC 27606

290. R. J. Herring, Department of Government, Cornell University, Ithaca, NY 14853

291. W. J. Hinze, Purdue University, Department of Earth and Atmospheric Sciences, West Lafayette, IN 47907

292. R.A. Houghton, Code YSE, NASA Headquarters, 300 E Street S.W., Washington, DC 20546-0001

293. L. Iverson, Northeastern Forest Experiment Station, USDA Forest Service, 359 Main Road, Delaware, OH 43105

294. G. Y. Jordy, Director, Office of Program Analysis, Office of Energy Research, ER-30, G-226, U.S. Department of Energy, Washington, DC 20585

295. Veena Joshi, Dean, Energy Policy, 9 Jor Bagh, New Delhi 110 003, INDIA

296. D. M. Kammen, Woodrow Wilson School of Public and International Affairs, Princeton University, Princeton, NJ 08544

297. Kuswata Kartawinata, UNESCO Regional Office for Science Technology for Southeast Asia, Jl. M.H. Thamrin 14, P.O. Box 1273/JKT, Jakarta 10012. INDONESIA

298. Dr. Thomas R. Karl, National Climatic Data Center, Federal Building, 37 Battery Park Avenue, Asheville, NC 28801

299. M. S. Kasana, Department of Biological Sciences, Lancaster University, Lancaster LA1 4YQ, U.K.

300. Omkar N. Kaul, Tata Energy Research Institute, 9 Jor Bagh, New Delhi 110 (0)3, INDIA 
301. M. A. K. Khalil, Director, Global Change Research Center, Oregon Graduate Institute of Science and Technology, 19600 N.W. von Neumann Drive, Beaverton, OR 97006-1999

302. T. N. Khoshoo, Tata Energy Research Institute, 101 Jor Bagh, New Delhi 110 003, INDIA

303. Pankaj Khullar, Director, Silviculture Research, Forest Research Institute, Dehra Dun 248 006, INDIA

304. H. S. Kingra, Associate Professor, Indira Gandhi National Forest Academy, Dehra Dun 248 006, INDIA

305. J. Klink, Department of Geography, Miami University, Oxford, OH 45056

306. Deepak Kumar, National Institute of Science, Technology and Development Studies, Dr. K.S. Krishnan Road, New Delhi 110 012, INDIA

307. J. Laarman, School of Forest Resources, Department of Forestry, North Carolina State University, Box 5488, Raleigh, NC 27607

308. Abubakar M. Lahjie, Faculty of Forestry, Mulawarman University, Samarinda, East Kalimantan, INDONESIA

309. D. Lauer, EROS Data Center, U.S. Geological Survey, Sioux Falls, SD 57198

310. S. Levitus, NOAA/National Oceanographic Data Center, 1825 Connecticut Avenue, NW, Washington, DC 20235

311. Librarian, South and Southeast Asian Library, Cornell University, Ithaca, NY 14853

312. Librarian, IUCN Conservation Monitoring, 219 Huntingdon Road, Cambridgc CB3 ODL, U.K.

313. L. Loennstedt, Dept. of Forestry, College of Forest Resources, Box 8008-Jordan Hall, North Carolina State University, Raleigh, NC 27695-8008

314. M. S. Loughridge, National Oceanic and Atmospheric Administration, National Geophysical Data Center, Code E/GC3, 325 Broadway, Boulder, CO 80303

315. D. Ludden, Department of History, University of Pennsylvania, Philadelphia, PA 19104

316. A. E. Lugo, Institute of Trupical Forestry, USDA Forest Service, Rio Piedras, Puerto Rico 00928

317. R. Luxmoore, Head, Habitats Unit, World Conservation Monitoring Centre, 219 Huntingdon Road, Cambridge CB3 ODL, U.K. 
318. C. Mackie, Program Manager -Indonesia, Conservation International, $101518 \mathrm{th} \mathrm{St.,}$ N.W., Washington, DC 20036

319. K. Mackinnon, WWF Indonesia Programme, P.O. Box 133, Bogor, West Java, INDONESIA

320. A. Maheshwary, South Asia Bibliographer, 0017A Perkins Library, P.O. Box 90195, Duke University, Durham, NC 27706

321. D. Major, Committee for Research on Global Environmental Change, Social Science Research Council, 605 Third Avenue, New York, NY 10158

322. M. Mann, FernUniversitat, Gesamthochschule - Feithstr. 140/AVZ Il 5800 Hagen, GERMANY

323. Y. Matsuoka, Associate Professor, Environmental and Sanitary Engineering, Kyoto University, Kyoto 606-01, JAPAN

324. H. M. McCammon, Acting Deputy Director, Environmental Sciences Division, Office of Health and Environmental Research, Office of Energy Research, ER-74, U.S. Department of Energy, Washington, DC 20585

325. J. McNeill, Department of History, Goergetown University, Washington, DC 20057-1058

326. Pradeep Mehendiratta, American Institute of Indian Studies, D-31 Defence Colony, New Delhi 110 024, INDIA

327. V. M. Meher-Homji, Institut Francais de Pondicherry, 10 St. Louis Street, P.B. 33, Pondichery 605001 , INDIA

328. N. P. Melkania, Faculty of Ecosystem Management, Indian Institute of Forest Management, Indira Hills, Nehru Nagar, Bhopal 462 003, INDIA

329. J. C. Menaut, Laboratoire d'Ecologie de l'Ecole Normale Superieure, 46 rue d'Ulm, 752.30 Paris Cedex 05, FRANCE

330. B. Moore, Complex Systems Research Center, University of New Hampshire, Durham, NH 03824-3535

331. D. Murdiyarso, Environmental Research Centre, Institut Pertanian Bogor (PPLH-IPB), P.O. Box 145, Bogor, INDONESIA

332. R. R. Navalgund, Head, Land Resources Division, Space Applications Centre, Indian Space Research Organisation, SAC P.O., Ahmedabad 380 053, INDIA

333. J. D. S. Negi, Division of Ecology, Forest Research Institute, Dehra Dun 248 006, INDIA 
334. Office for Interdisciplinary Earth Studies, University Corporation for Atmospheric Research, P.O. Box 3000, Boulder, CO 80307-3000

335. S. O'Hara, Professor, Department of Geography, The University of Sheffield, Western Bank, Sheffield S10 2TN, U.K.

336. J. S. Olson, Global Patterns Company, Box 361A Rt. 2, Eblen Cave Road, Lenoir City, TN 37771-9424

337. R. H. Olsen, Vice President for Research, University of Michigan, Medical Science Building II, \#5605, 1301 East Catherine Street, Ann Arbor, MI 48109-0620

338. J. T. Overpeck, National Oceanic and Atmospheric Administration, National Geophysical Data Center, Paleoclimatology Program, 325 Broadway E/EC, Boulder, CO 80303

339. G. Pacheco, 3128 Jordan Hall, North Carolina State University, Raleigh, NC 27695-8008

340. C. Padoch, The New York Botanical Garden, Bronx, NY 10458-5126

341. E. Painter, 2101 Chapala, Santa Barbara, CA 93105

342. P. Parks, Department of Agricultural Economics and Marketing, Rutgers, New Brunswick, NJ 08901

343. M. Parry, Environmental Change Unit, 1-A Mansfield Road, University of Oxford, Oxford, OX1 3TV, U.K.

344. J. P. Pascal, Institut Francais de Pondicherry, 10 St. Louis Street, P.B. 33, Pondichery 605001 , INDIA

345. Ari Patrinos, Director, Environmental Sciences Division, Office of Health and Environmental Research, ER-74, U.S. Department of Energy, Washington, DC 20585

346. N. L. Peluso, Energy \& Resources Group, University of California, Berkeley, CA 94270

347. Dr. Thomas C. Peterson, national Climatic Data Center, Federal Building, 37 Battery Park Avenue, Asheville, NC 28801

348. M. Poffenberger, c/o Program on Environment, East-West Center, 1777 East-West Road, Honolulu, HI 96848

349. K. Polenske, Department of Economics, Building 9, Room 535, MIT, Cambridge, MA 02139

350. M. Pomeroy, Department of Biology, 2 Cummington St., Boston, MA 02215 
351. R. Pontius, Jr., State University of New York, College of Environmental Sciences and Forestry, 301 Illick Hall, 1 Forestry Drive, Syracuse, NY 13210

352. C. Potter, Iohnson Controls World Services, Global Biogeochemistry Modeling Laboratory, Ecosystem Science \& Technology Branch, NASA-Ames Research Center, MS 239-20, Moffell Field, CA 94035

353. L. Potter, Department of Geography, University of Adelaide, P.O. Box 498, South Australia 5001, AUSTRALIA

354. Jacques Pouchepadass, Department of Social Sciences, Institut Francais de Pondicherry, 10 St. Louis Street, P.B. 33, Pondichery 605 001, INDIA

355. Jean-Philippe Puyreveaud, Institut Francais de Pondicherry, 10 St. Louis Street, P.B. 33, Pondichery 605001 , INDIA

356. S. J. Pyne, American Studies Program, Arizona State University West, 4701 West Thunderbird Road, P.O. Box 37100, Phoenix, AZ 85068-7100

357. Ye Qi, State University of New York, College of Environmental Sciences and Forestry, 301 Illick Hall, 1 Forestry Drive, Syracuse, NY 13210

358. T. V. Rama-Chandra, Centre for Ecological Sciences, Indian Institute of Science, Bangalore 560 012, INDIA

359. P. S. Ramakrishnan, School of Environmental Sciences, Jawaharlal Nehru University, New Delhi 110 067, INDIA

360. A. T. Rambo, Director, Program on Environment, East-West Center, 1777 East-West Road, Honolulu, HI 96848

361. W. Ravenscroft, State University of New York, College of Environmental Sciences and Forestry, 301 Illick Hall, 1 Forestry Drive, Syracuse, NY 13210

362. Ajay S. Rawat, C 2B/32C Janakpuri, New Delhi 110 058, INDIA

363. J. K. Rawat, Conservator of Forests, Forest Research Institute, Dehra Dun 248006 , INDIA

364. S. Ichtiaque Rasool, IGBP Data and Information System Office, Universite Paris, Tour 26, 4 Etage, Aile 26-16, 4 Place Jussieu, 75230 Paris, Cedex 06, FRANCE

365. Robert Repetto, World Resources Institute, 1735 New York Avenue, N.W., Washington, DC 20006

366-368. J.F. Richards, Department of History, 226 Carr Bldg., Duke University, Durham, NC 27708 
369. Michael R. Riches, Global Change Research Program, Environmental Sciences Division, Office of Health and Environmental Research, ER-74, U.S. Department of Energy, Washington, DC 20585

370. A. Robock, Department of Meteorology, University of Maryland, College Park, MD 20742

371. R. C. Rockwell, Executive Director, International Univ. Consortium for Political and Social Research, P.O. Box 1248, University of Michigan, Ann Arbor, MI 48106

372. M. Rosenzweig, Department of Geography, 378 Locust Walk, University of Pennsylvania, Philadelphia, PA 19104-6297

373. S. Ruttenberg, Univ. Corporation for Atmospheric Research, CSNET, P. O. Box 3000, Boulder, CO 80307-3000

374. Satpal Sangwan, National Institute of Science, Technology and Development Studies, Dr. K.S. Krishnan Road, New Delhi 110 012, INDIA

375. W. H. Schlesinger, Department of Botany, 139 Biological Sciences Bldg., Box 90340, Duke University, Durham, NC 27706

376. R. A. Sedjo, Resources for the Future, Forest Economic and Policy Program, 1616 P Street, N.W., Washington, DC 20036

377. Ashok Sharma, Assistant Silviculturist, Forest Research Institute, Dehra Dun 248 006, INDIA

378. S. C. Sharma, Division of Ecology, Forest Research Institute, Dehra Dun 248 006, INDIA

379. A. L. Shumbera, National Oceanic and Atmospheric Administration, WDC-A for Meteorology, National Climatic Data Center, Federal Building MC E/CC, Asheville, NC 28801

380. T. Siddiqi, Senior Fellow, Program on Environment, East-West Center, 1777 East-West Road, Honolulu, HI 96848

381. J. S. Singh, Centre of Advanced Study in Botany, Banaras Hindu University, Varanasi 221005 , Uttar Pradesh, INDIA

382. K. D. Singh, Forest Resources Assessment and Monitoring, Food and Agriculture Organization, Via delle Terme di Caracalla, Rome 01000, ITALY

383. K. P. Singh, Centre of Advanced Study in Botany, Banaras Hindu University, Varanasi 221 005, Uttar Pradesh, INDIA 
384. D. Skole, Complex Systems Research Center, University of New Hampshire, Durham, NH 03824-3535

385. K R. Smith, Senior Fellow, Program on Environment, East-West Center, 1777 East-West Road, Honolulu, HI 96848

386. Mr. Peter M. Steurer, National Climatic Data Center, Federal Building, 37 Battery Park Avenue, Asheville, NC 28801

387. A. Soegiarto, Indonesian Institute of Sciences, LIPI, Jalan Gatot Subroto 10, Jakarta, INDONESIA

388. E. Soepadmo, Department of Botany, University of Malaya, 59100 Kuala Lumpur, MALAYSIA

389. O. Soemarwoto, Institute of Ecology, Padjadjaran University, Jl. Sekeloa, Bandung, INDONESIA

390. K. W. Sorensen, UNESCO/ROSTSEA, Regional Office for Science \& Technology for South East Asia, Jalan M.H. Thamrin 14, Jakarta, INDONESIA

391. H. K. Steen, Executive Director, Forest History Society, 701 Vickers Ave., Durham, NC 27701

392. J. E. de Steiger, Southern Global Change Program, USDA Forest Service, 1509 Varsity Drive, Raleigh, NC 27606

393. D. E. Stone, Director, Organization for Tropical Studies, 410 Swift Avenue, Durham, NC 27705

394. B. R. Strain, Department of Botany, 139 Biological Sciences Bldg., Duke University, Durham, NC 27706

395. S. Subak, Research Fellow, Harvard University, 177 River St., Cambridge, MA 02139

396. P. Tabusa, Research Information Services, East-West Center, Honolulu, HI 96848

397. J. W. Terborgh, Director, Center for Tropical Conservation, Box 90381, 3705C Erwin Rd., Durham, NC 27705

398. Han-Qin Tien, State University of New York, College of Environmental Sciences and Forestry, 301 Illick Hall, 1 Forestry Drive, Syracuse, NY 13210

399. A. Tsing, Anthropology Board of Studies, Kerr Hall, University of California, Santa Cruz, CA 95064

400. R. Tucker, 909 Loyola Drive, Ann Arbor, MI 48103 
401. B. L. Turner II, Graduate School of Geography, Clark University, 950 Main St., Worcester, MA 01610-1477

402. A. P. Vayda, Department of Human Ecology, Cook College, P.O. Box 231, Rutgers University, New Brunswick, NJ 08903

403. Patma Vityakon, Department of Soil Science, Faculty of Agriculture, Khon Kaen University, Khon Kaen 4002, THAILAND

404. D. Wear, USDA Forest Service, Southeastern Forest Experiment Station, Forest Sciences Laboratory, 3041 Cornwallis Road, P.O. Box 12254, Research Triangle Park, NC 27711

405. F. Webster, University of Delaware, College of Marine Studies, Lewes, DE 19958

406. J. Wescoat, Department of Geography, University of Colorado, Boulder, CO 80301

407. T. M. L. Wigley, School of Environmental Sciences, University of East Anglia, Norwich NR4 7TJ, U.K.

408. M. Williams, School of Geography, Oxford University, Mansfield Rd., Oxford OX1 3TB, U.K.

409. Dr. Cort J. Willmott, Chair, Department of Geography, University of Delaware, Newark, DE 19716

410. Wisconsin Land Tenure Center, University of Wisconsin, Madison, WI 53706

411. F. J. Wobber, Environmental Sciences Division, Office of Health and Environmental Research, Office of Energy Research, ER-74, U.S. Department of Energy, Washington, DC 20585

412. L. W. Wolf, National Research Council, Commission on Geosciences, Environment, and Resources, 2101 Constitution Avenue, Washington, DC 20418

413. D. Woodcock, Department of Geography, University of Hawaii at Manoa, 2424 Maile Way, Porteus Hall, Honolulu, HI 96822

414. P. Xenos, Senior Fellow, Program on Environment, East-West Center, 1777 East-West Road, Honolulu, HI 96848

415. Ms. Hengchun Ye, Department of Geography, University of Delaware, Newark, DE 19716

416. Roman I. Zlotin, Institute of Geography of Russia, Academy of Sciences, Starometny 29, Moscow 109017, RUSSIA 
417. Office of Assistant Manager for Energy Research and Development, U.S. Department of Energy Oak Ridge Field Office, P. O. Box 2001, Oak Ridge, TN 37831-8600

418-420. Office of Scientific and Technical Information, P. O. Box 62, Oak Ridge, TN 37831 

11
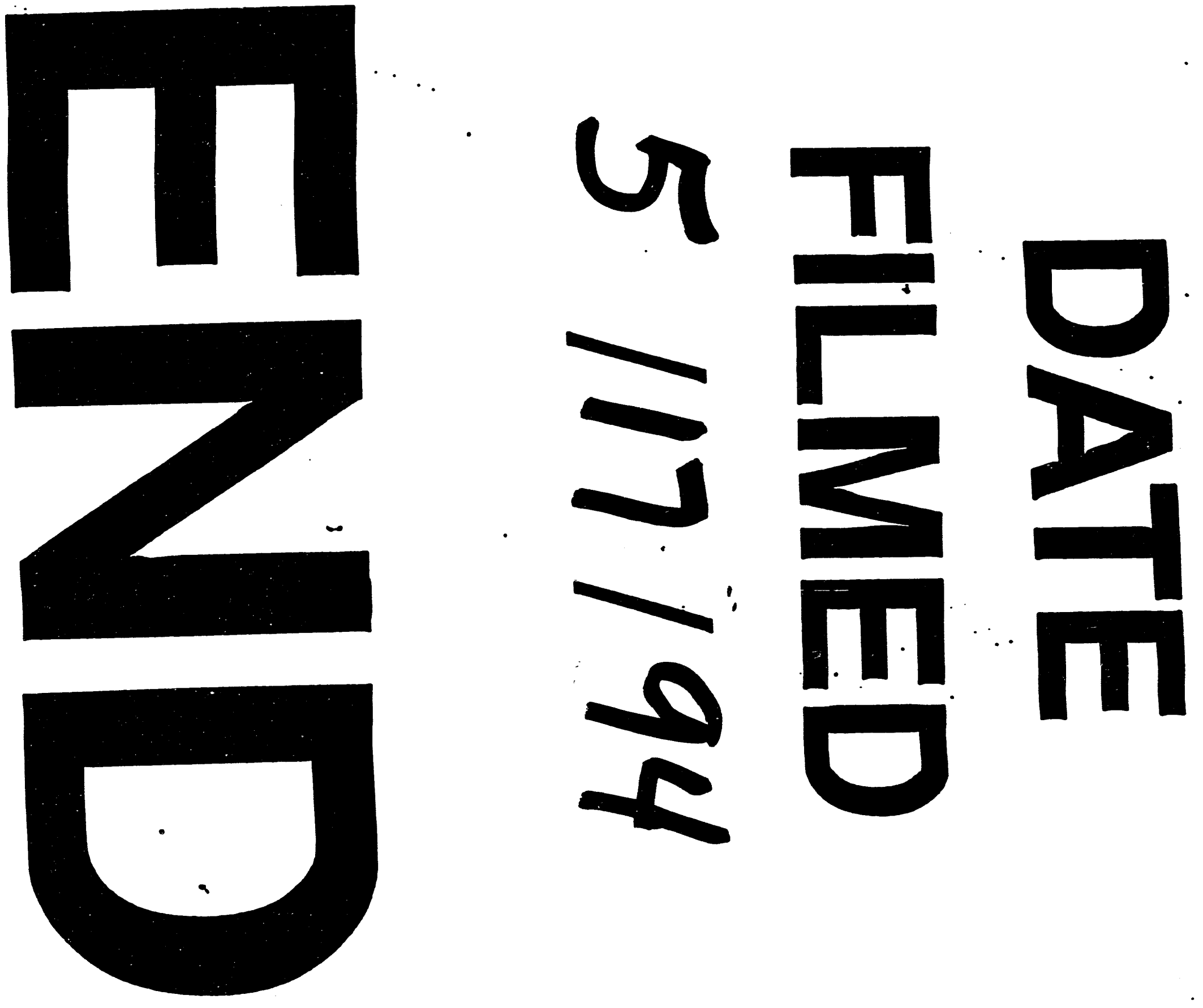


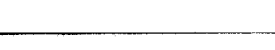

